
Am. ?nil. Nax.

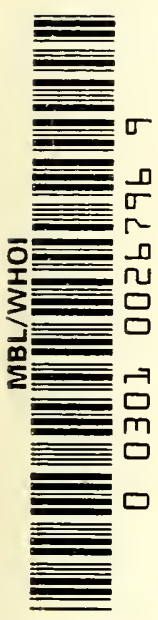

Marine Biological Laboratory

II 3 F A R Y

FEE 2? 1952

WOODS HOLE, MASS. 

THE REPTILES OF OHIO 


\section{EDITORIAL STAFF}

John D. Mizelle ....................................................................................... Zoology

Editor, University of Notre Dame, Notre Dame, Ind.

EDWARD A. Chapin

Entomology

U. S. National Museum, Washington, D. C.

Albert A. Delisle

Plant Morphology

University of Notre Dame, Notre Dame, Ind.

Carroll lane Fenton

Invertebrate Paleoniology

404 Livingston Ave., New Brunswick, N. J.

John Hobart Hoskins

Paleobolany

University of Cincinnati, Cincinnati, Ohio

George Neville Jones Plant Taxonomy

University of Illinois, Urbana, III.

Remington Kellogc

Mammalogy

U. S. National Museum, Washington, D. C.

Jean Myron Linsdale

Ornithology

Hastings Reservation, Monterey, Calif.

George Willard Martin Mucology

State University of lowa, lowa City, lowa

Hugh M. Raup Plant Ecology

Harvard Forest, Harvard University, Petersham, Mass.

Karl Patterson Schmidt

Ichthyology and Herpetology

Chicago Natural History Museum, Chicago, III.

Harley Jones Van Cleave Invertebrate Zoology

University of Illinois, Urbana, Ill. 


\section{THE REPTILES OF OHIO}

by

\section{ROGER CONANT}

Curator of Reptiles

Philadelphia Zoological Garden

Zoological Society of Philadelphia

Second Edition

( ith revisionary addenda)

University of Notre Dame Press

Notre Dame, Indiana

Copyright, 1951 by The American Midland Naturalist,

University of Notre Dame, Notre Dame, Indiana 


\section{EDITOR's NOTE}

The Reptiles of Ohio by Roger Conant,* published several years ago in The American Midland Naturalist, has enjoyed the distinction of being continually requested by zoologists from the date of its appearance until the present time. This continued demand was such that several months ago it was considered sufficient to warrant republication of this valuable contribution. Obviously, the best method to be followed in accomplishing a task of this type would entail a sweeping revision-an expensive venture in these days of inflation and high printing costs. After consultation with Mr. Conant, there evolved a plan whose principal results may be outlined as follows:

1. Reproduction of the major portion of the original text, after correction of typographical errors, by the relatively inexpensive photo-offset process.

2. Reproduction of the plates from the original engravings.

3. Inclusion of revisionary addenda (prepared by Mr. Conant) which incorporate new data, notes on taxoriomic changes, and comments on the progress of the study of reptiles in Ohio during the past decade. Cross references, provided in the addenda for each species, are very valuable since they refer to the plates, distribution maps, and detailed discussions in the original report.

4. Preparation of a supplementary list of references.

5. Preparation of a new set of maps, showing all known localities for each species. These maps are grouped together at the end of the addenda.

6. Preparation of a new index which includes references to both the old text and the new.

The second edition of The Reptiles of Ohio, in effect, includes two separate but closely allied papers - the longer one, which originally appeared in 1938, and the supplement, which brings the information up to date--JoHn D. Mizelle, Editor.

* Conant, Roger 1938-The Reptiles of Ohio. Amer. Midl. Nat. 20(1) : 1-200. 


\section{CONTENTS}

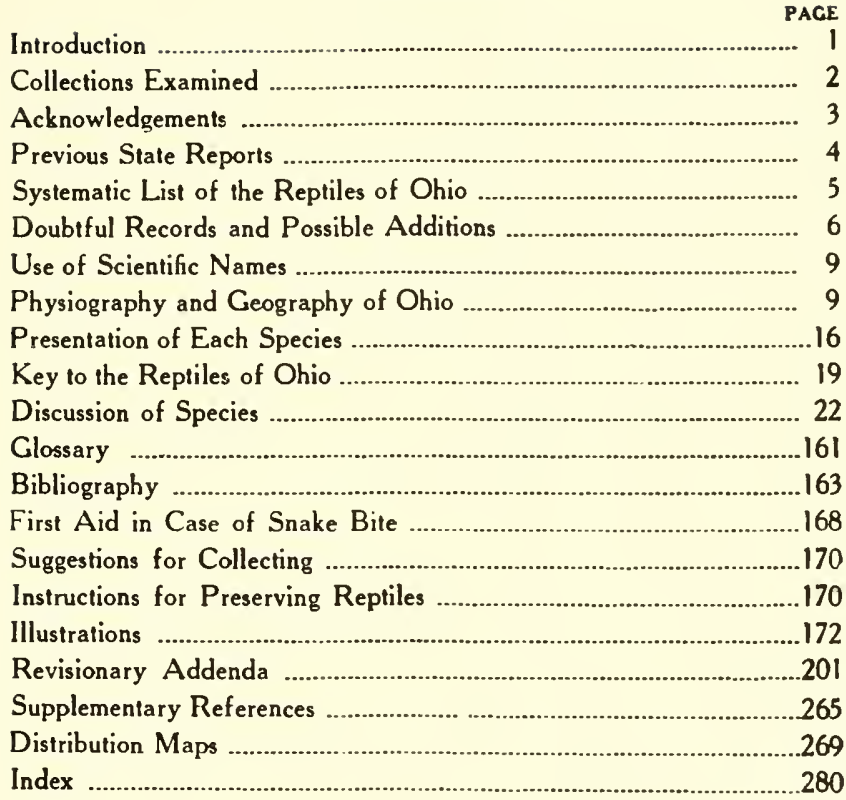





\title{
The American Midland Naturalist
}

Published Bi-Monthly by The University of Notre Dame, Notre Dame, Indiana

\begin{tabular}{lll}
\hline Vol. 20 & JULY, 1938 & No. 1 \\
\hline
\end{tabular}

\section{The Reptiles of Ohio}

\author{
Roger Conant
}

\section{Introduction}

A century has passed since the publication of the first report on the reptiles of Ohio (Kirtland, 1838). During that time rapid strides have been made in the field of herpetology in general, but the reptiles of Ohio have not been studied as thoroughly or as intensively as in other and particularly some of the adjacent states. Two extensive papers on the herpetology of Ohio (Smith, 1882, and Morse, 1904) brought the available information up to their respective dates, but it has remained for the enormous development in methods of communication and transportation to present an opportunity for a more comprehensive survey. The modern rail and highway networks have opened many areas difficult or impossible of access to our predecessors, and by motor car the farthest corners of the state are now only four or five hours distant from the capital.

While the progress and prosperity of the commonwealth have been a boon to field work they have also resulted in the destruction of many habitats and the possible elimination of one or more species from the fauna of the state. The expansion of agriculture and industry has upset original conditions to a great degree, since it has caused the destruction of forests and prairies, the draining of bogs and ponds and the pollution of many streams.

The present work was undertaken with the desire in mind to study the reptiles of the state in as many different ways as possible although the subject of distribution has received somewhat the greatest attention.

A brief resume of the work which has been done should be of interest. Early in 1929 the literature was searched and the leading museums canvassed in an effort to ascertain how much information might be at hand. The decided paucity of specimens from Ohio and the need for extensive freld work became immediately evident. Only the Ohio State Museum possessed a representative collection. Field trips were begun on a small scale in 1930, became more numerous the following year and reached a high in 1932. Travel was almost exclusively by automobile and an examination of the mileage records reveals that the writer drove approximately 41,000 miles in the state during the years 1930 to 1935 inclusive. Personal collections were made in 80 and visits were 
paid to 87 of the 88 counties of Ohio; locality records are available from every county.

Most of the field work was accomplished week ends and with Toledo (the writer's residence) as the base. It was customary to leave Friday evenings, drive the greater part of the night, collect from dawn to dark Saturdays and Sundays and return home Sunday nights. Vacation periods, holidays, and such business as attending meetings of the Ohio Academy of Science provided additional opportunities for collecting. Many of the localities were visited on numerous occasions and at different seasons and from the more productive ones considerable information has accrued. A number of representative local collections were made by interested persons in various parts of the state who either presented their material to the writer or made it available to him for study.

In the course of the work many more specimens came to hand than it was possible or practical to preserve. Surplus material was liberated, placed on exhibition in the Toledo Zoological Park or traded to other zoos. However, all rare or unusual specimens and the great majority of those representing new localities were preserved, the bulk of them in the collection of the Toledo Zoological Society.

In addition to making studies upon the specimens found in the field an effort was made to examine Ohio reptiles in the leading museums of the country, and to visit as many of the college museums and private collections in the state as time and circumstances permitted. A list of the institutions and individuals from whom material was borrowed and studied is given immediately below. The initials in parentheses are those used to designate the various collections in the lists of locality records published in the present text. DOR signifies that the specimen was found dead on the road but for some reason was not preserved.

\section{Collections Examined}

(AMNH)-American Museum of Natural History, New York City. (ANSP)-Academy of Natural Sciences of Philadelphia, Pennsylvania. (AS)-Arthur Stupka, Columbus, Ohio.

(BU) - Baylor University, Waco, Texas.

(BGSU)-Bowling Green State University, Bowling Green, Ohio.

(BHFM) - Baker-Hunt Foundation Museum, Covington, Kentucky.

(CAS) - Chicago Academy of Sciences, Chicago, Illinois.

(CM) - Carnegie Museum, Pittsburgh, Pennsylvania.

(CMNH) - Cleveland Museum of Natural History, Cleveland, Ohio.

(CSNH) - Cincinnati Society of Natural History, Cincinnati, Ohio.

(CU) - Cornell University, Ithaca, New York.

(DOR) - Specimen found dead upon the road but not preserved.

(FMNH)-Field Museum of Natural History, Chicago, Illinois.

(LMK) - L. M. Klauber, San Diego, California.

(MC) - Marietta College, Marietta, Ohio.

(MCZ)-Museum of Comparative Zoology, Cambridge, Massachusetts.

(MU)-Miami University, Oxford, Ohio.

(NU)-Park Collection, Northwestern University, Chicago, Illinois.

(OC)-Oberlin College, Oberlin, Ohio.

(OEE) - O. E. Ehrhart, Antwerp, Ohio. 
(OSM) - Ohio State Museum, Columbus, Ohio.

(OU)-Ohio University, Athens, Ohio.

(SHS)-Sandusky High School, Sandusky, Ohio.

(SL)-Stone Laboratory, Put-in-Bay, Ohio.

(TZS)-Toledo Zoological Society, Toledo, Ohio.

(UMMZ)-University of Michigan Museum of Zoology, Ann Arbor, Michigan.

(USNM) - United States National Museum, Washington, D. C.

(WC) - College of Wooster. Wooster, Ohio.

(WRU) - Western Reserve University, Cleveland, Ohio.

\section{ACKNOWLEDGEMENTS}

The writer is indebted to a large number of persons who have assisted him during the course of the present work. Naturally, these fall into a variety of classifications. First are his professional colleagues whose keen interest in herpetology largely has been responsible for keeping him at a task which at times seemed endless and full of discouragement. To Dr. Charles F. Walker, formerly of the Ohio State Museum, but now with the Soil Conservation Service at Dayton, he is profoundly indebted. Dr. Walker's work on the amphibians of Ohio and his extraordinary knowledge of the natural history, geography and geology of the stafe have placed him in the unique position of serving as a fountain head of information and as a propelling stimulus in the present work.

Other members of the American Society of lchthyologists and Herpetologists have been most helpful by acting as critics and advisers, by lending specimens, and by participating in the field work. To them the writer wishes to express his sincere thanks. These include the late Dr. Frank N. Blanchard, of the Zoology Department of the University of Michigan; Mrs. Helen T. Gaige, Dr. Norman E. Hartweg, Milton B. Trautman, Reeve M. Bailey and Joseph R. Bailey, of the University of Michigan Museum of Zoology; Dr. Howard K. Cloyd, Walter L. Necker, and Dr. Hobart M. Smith, of the Chicago Academy of Sciences; Dr. Leonhard Stejneger and Dr. Doris M. Cochran, of the United States National Museum; M. Graham Netting, of the Carnegie Museum; Karl P. Schmidt, of the Field Museum of Natural History; Dr. E. R. Dunn, of Haverford College; Dr. Thomas Barbour, and Arthur Loveridge, of the Museum of Comparative Zoology; Dr. Edward H. Taylor, of the University of Kansas; Dr. A. H. Wright, of Cornell University; Dr. William M. Clay, of the University of Louisville; Henry W. Fowler, of the Academy of Natural Sciences of Philadelphia; Arthur Greenhall, of New York City.

Dr. J. Percy Moore, Professor of Zoology of the University of Pennsylvania, has read the manuscript and offered several suggestions for its improvement.

The directors, curators and professors in charge of the various Ohio museum and college collections have kindly assisted by making specimens available for study, and many of them have further aided by increasing their collections of reptiles on their own time and at their own expense. Among these especially must be mentioned Edward S. Thomas, Curator of Natural History of the Ohio State Museum, and Ralph Dury, Director of the Museum of the Cincinnati Society of Natural History. Others who have aided in this way are Professor E. L. Moseley of the Bowling Creen State University, Professor Lynds Jones of Oberlin College, Dr. John W. Aldrich of the Cleveland Museum of Natural History, Dr. J. Paul Visscher and Dr. A. H. Hersh of the Western Reserve University, Dr. Robert A. Hefner of Miami University, Dr. H. Ray Eggleston of Marietta College, Dr. W. A. Matheny of Ohio University, Dr. M. Lelyn Branin of John Carroll University and Dr. Ralph V. Bangham and Dr. W. P. Spencer of the College of Wooster.

The writer is also indebted to the following who have made local collections of reptiles near their homes or in the districts in which they were working: Arthur Stupka, formerly resident at Columbus and Laurelville but now with the National Park Service; O. E. Ehrhart of Antwerp; R. L. Pope of Hillsboro; Dr. Lawrence E. Hicks of Columbus; Clarence James of Williamstown; J. R. Kelso of Burton; Wm. 
Rofkar of Port Clinton; B. J. Skinner of Westchester; E. A. Doolittle of Painesville; Karl Maslowski, Woodrow Goodpaster and Wm. Gessing, all of Cincinnati.

The writer is indebted to the Zoological Board of Management of the Toledo Zoological Park and especially to Percy C. Jones, President, and Frank L. Skeldon, Secretary, for their cooperation. He likewise is obligated to Leo Higgins, his assistant while at Toledo, for much help.

The Zoological Society of Philadelphia has extended much encouragement and assistance and for financial help in borrowing specimens for examination, and for permission to spend some little time on the completion of this report the writer wishes to express his profound thanks.

To many of his lay friends and acquaintances the author is at a loss properly to convey his appreciation. Four persons in particular participated in far more field trips than any others and without their financial assistance it would have been impossible to carry on much of the field work. They are M. K. Murphy, Homer Percival, David Delzell and Byron Gardner, Jr., all of Toledo. Many others helped with field work, some to quite an extensive degree. Among these are included Charles L. Burris, Louis W. Campbell, Robert Mattlin, Cecil Murphy, James Kitzmiller, Jr., James Friauf, Robert Lampton, Russell Schunk, Richard Tallman, Bernard Campbell and the late John Search, all members at one time or another of the Toledo Naturalists' Association.

Lawrence W. Hiett, Fred R. Flickinger and Mack Newkirk, all of Toledo, have aided materially in the preparation of photographs as well as by doing work in the field. Edward S. Thomas and Dr. Howard K. Gloyd, previously mentioned, have very kindly loaned several photographs. W. Stuart Cramer, of Reading, Pa., has prepared the plates illustrating scale characters.

E. L. Wickliff, Chief of the Bureau of Scientific Research, Conservation Division, Ohio State Department of Agriculture, has been most cooperative at all times. Edith N. Swanson and Mark Mooney, Jr., have aided materially with the clerical work attendant to preparing the manuscript.

\section{Previous State Reports}

Three lists of Ohio reptiles have been published. The first of these, by Kirtland (1838), records three lizards, nine turtles and fifteen snakes. Considering the early day at which he collected and the fact that most of his field work appears to have been done in northeastern and southwestern Ohio, his list of twenty-seven reptiles is remarkable. Smith (1882) prepared a report on the reptiles and amphibians in which he gives three lizards, thirteen turtles and twenty-four snakes as being native to Ohio. Since his work was based chiefly upon the writings of other herpetologists and upon material sent to him from Ohio its accuracy and completeness are much open to question. Apparently he did little collecting in the state.

The most complete report published to date is by Morse (1904). He did considerable field work and a number of his specimens are still preserved in the Ohio State Museum. His records include three lizards, eight turtles and twenty-nine snakes. 


\section{Systematic List of the Reptiles of Ohio*}

After a careful study of records available from all sources the list given below has been prepared. It is believed that it includes all of the species and subspecies known definitely to occur in Ohio.

\section{Class Reptilita \\ Subclass Diapsida \\ Order Squamata}

\section{Suborder SAURIA}

Family Iguanidae

1. Sceloporus undulatus (Latreille)

\section{Family Scincidae}

2. Leiolopisma unicolor (Harlan)

3. Eumeces fasciatus (Linné)

4. Eumeces laticeps Schneider

\section{Suborder Serpentes \\ Family Colubridae}

5. Carphophis amoena helenae (Kennicott)

6. Diadophis punctatus edwardsii (Merrem)

7. Heterodon contortrix (Linné)

8. Opheodrys aestivus (Linné)

9. Opheodrys vernalis (Harlan)

10. Coluber constrictor constrictor Linné

11. Coluber constrictor flaviventris Say

12. Elaphe obsoleta obsoleta (Say)

13. Elaphe vulpina (Baird and Girard)

14. Lampropeltis getulus nigra (Yarrow)

15. Lampropeltis triangulum triangulum (Lacépède)

16. Natrix erythrogaster erythrogaster (Forster)

17. Natrix kirtlandii (Kennicott)

18. Natrix septemvittata (Say)

19. Natrix sipedon sipedon (Linné)

20. Natrix sipedon insularum Conant and Clay

21. Storeria dekayi (Holbrook)

22. Storeria occipito-maculata (Storer)

23. Virginia valeriae valeriae Baird and Girard

24. Thamnophis butleri (Cope)

25. Thamnophis sauritus sauritus (Linné)

26. Thamnophis sirtalis sirtalis (Linné)

\section{Family Crotalidae}

27. Agkistrodon mokasen mokasen Beauvois

\footnotetext{
* For use of names see page 9.
} 
28. Sistrurus catenatus catenatus (Rafinesque)

29. Crotalus horridus horridus Linné

Subclass Synapsida

Order Testudinata

Family Kinosternidae

30. Sternotherus odoratus (Latreille)

31. Chelydra serpentina (Linné)

\section{Family Chelydridae}

\section{Family Testudinidae}

32. Clemmys guttata (Schneider)

33. Emys blandingii (Holbrook)

34. Terrapene carolina (Linné)

35. Graptemys geographica (Le Sueur)

36. Chrysemys bellii marginata Agassiz

37. Pseudemys scripta troostii (Holbrook)

Family Trionychidae

38. Amyda mutica (Le Sueur)

39. Amyda spinifera (Le Sueur)

In all probability it will be remarked that the writer has been too conservative in preparing the above list, and that he has been too critical in his treatment of the records appearing in the literature. Every area of any size in which biological work has been done, however, possesses a collection of records which are doubtful and which many revisers do not have the courage to discard. Many unfortunately are based upon misidentifications and others upon obvious escapes. Reptiles, particularly turtles, are being transported constantly by human agency, and such extraneous species as the horned toads, Phrynosoma cornutum and $P$. solare, the bull snake, Pituophis sayi sayi, the python, Python molurus bivittatus, the alligator, Alligator mississipiensis, and the tortoise, Gopherus agassizii, etc., were collected in Ohio and reported to the writer during the course of the present survey.

It has been the policy to discount all records concerning which there appears to be the least doubt. It is fully realized, of course, that the amount of field work done in the state, while fairly extensive, falls far short of making available a complete understanding of the reptiles of Ohio, and it is expected that other species will be added to the list from time to time. Likewise some of the species here considered as doubtful may be shown by new material to be actually a part of the Ohio fauna. It is recognized that it is much more difficult to prove a species does not occur in a certain area than to prove it does.

\section{Doubtful Records and Possible Additions}

In the discussion immediately following, a list of species is presented which are not included in the main listing of Ohio reptiles. In this are given many records which the writer considers doubtful. Mention also is made of species known to occur in adjacent states and which eventually may be found in Ohio. The list follows: 
Ophisaurus ventralis (Linné), Glass Lizard.-A specimen preserved in the Ohio State Museum (No. 163) was found by Dr. Townshend on September 17, 1891, on the Ohio State University Farm adjacent to the university campus in Columbus. It was killed in a hay field and the mark of the pitch-fork tine (?) which pierced it in capture is quite evident. It is felt wisest to eliminate this species from the state list on the supposition that this lone Ohio specimen, in such a locality, had a very good chance of being introduced accidently. Search was made for the glass "snake" in many places in western Ohio but without success. It is well known in northwestern Indiana.

Cnemidophorus sexlineatus sexlinenlus (Linné), SiX-LiNED LiZARD.-There are no Ohio records for this species but it occurs in western and southern Indiana (Burt, 1931. 86 ). It was sought in southern Ohio, particularly in some of the dry prairies.

Eumeces anthracinus (Baird), COAL SKINK.- There are no Ohio records, but this lizard is known from the mountains in Pennsylvania. It may occur in eastern and southern Ohio.

Diadophis punctatus arnyi (Kennicott), Arny's Ring-Necked Snake.-A single individual preserved in the United States National Museum is catalogued as follows: "No. 10086, Hughes, (Butler County), Ohio, April, 1879, by R. T. Shepherd." There are two reasons. however, which make the presence in Ohio of this more western race of Diadophis highly doubtful. The first of these is that none of the several Diadophis seen from southern and southwestern Ohio show any evidence of approach toward the well-spotted under surface of arnyi.

The second reason is that other specimens with adjacent catalogue numbers, and which were received from Shepherd at the same time as the specimen of arnyi, also probably are from farther west than Ohio. These are Tropidoclonion lincatum (USNM No. 10088) and Lampropeltis triangulum syspila (USNM No. 10084 2 specimens). Mr. Shepherd, who recently died, was consulted in 1934 with a view to shedding light upon the origin of these specimens. He failed to recall them but made the general statement that "probably" any material he sent to the National Museum came from the vicinity of Hughes, where he was schoolmaster in 1879. However, he was unable to remember whether he received any specimens from the west which he may have forwarded to $\mathrm{W} /$ ashington from Hughes.

An inquiry was addressed to Dr. Doris M. Cochran at the National Museum and she replied that specimens catalogued before and after the doubtful ones are all from localities east of Ohio. This eliminates the possibility that a collection from Hughes and one from farther west arrived at the museum at the same time and the data for the two were accidently transposed. However, since the specimens are all so obviously of more western forms and since they constitute the only records of their kind for either Ohio or southeastern Indiana, it is felt iustifiable to presume that some error has been made. They are thus removed from the Ohio list until such time as they may be substantiated by additional records. Recent collecting in the vicinity of Hughes has yielded only the forms known to be common in southwestern Ohio.

Pituophis sayi sayi (Schlegel), Bull SNAKE.-The shed skin in the collection of the United States National Museum (No. 12739) from Circleville probably is from an escaped or captive specimen.

Lampropelits calligaster (Harlan), Prairie King SNAKE.-Smith (1882.689) and Morse $(1904,130)$ both included this species in their lists on the basis of a specimen collected by Professor Tuttle at Lancaster in Fairfield County and which was deposited in the Ohio State (University) Museum. The specimen is no longer extant, but Blanchard $(1921,122)$ has called attention to the fact, that from the description given by Smith, the identification is obviously incorrect.

Lampropeltis triangulum syspila (Cope), RED MILK SNAKE.-Recorded only from the doubtful Hughes locality (see discussion of Diadophis punctatus arnyi above).

Cemophora coccinea (Blumenbach), Scarlet Snake.-The locality "Ohio" on U. S. National Museum specimen No. 9267 is probably in error.

Natrix cyclopion cyclopion (Duméril and Bibron), Green Water SNake.-Two specimens in the Museum of Comparative Zoology (No. 163) are catalogued as "Ohio." 
It is possible this locality refers to the Ohio River and that the specimens may have been collected in western Kentucky or southern Illinois.

Nalrix rhombifera (Hallowell), Diamond-Backed Water SNAKe.-Two specimens in the Museum of Comparative Zoology (No. 144) are labelled "Ohio." The same applies to these as to the Natrix c. cyclopion above.

Natrix sipedon fasciala (Linné), Banded Water SNAKe.-Morse $(1904,130)$ records a single specimen of this water snake from Warren County. The specimen (OSM 44) was examined, but the writer failed to find it exhibiting any characters other than those which would identify it as Natrix sipedon sipedon.

Tropidoclonion linealum (Hallowell), LINED SNAKE.-Recorded only from the doubtful Hughes locality. This specimen (USNM 10088) has been examined and is definitely Tropidoclonion although Hay (1892a, 592) states, "It (Tropidoclonion) has been reported from Hughes, Ohio by Dr. Yarrow (1882, 131), but I am informed by Dr. L. Steineger, of the National Museum, that the specimen so determined is a Storeria." Hay (loc. cit.) knows of no Indiana localities and gives Urbana, Illinois, as the point nearest to Indiana where it has been collected. More recent writers (Myers, 1926 and 1927 and Piatt, 1931) likewise do not include it in the fauna of Indiana.

Micrurus fulvius fulvius (Linné), CoRAl SNAKE.-A specimen, (CSNH 23!) bears the following data: "North Bend, Hamilton County, Ohio." Some doubt as to the accuracy of this locality is indicated in the statement of Butler (1892, 178-9). This author mentions that the specimen was presented to the Cincinnati Society of Natural History by Dr. John A. Warder and then goes on to say, "The record shows it to be from Ohio. Dr. Warder's home was at North Bend and possibly the specimen came from there."

Even though the locality may be correct it is felt that the chances of this specimen having been transported and accidently introduced were good, especially at a time when its dangerous nature was not so well known. Even such a competent authority as Cope (1900, 1119) assumed that this species was "innocuous to man and the larger animals." Butler (loc. cit.) reports a specimen from Milan, Ripley County, Indiana.

It seems strange that no further specimens of this species have been found since 1892 in a region which is so well settled, which has so many campers and hikers and where in recent years the Junior Society of Natural Sciences of Cincinnati has been so active. For the above reasuns and in view of the fact that there are no other localities in the Ohio River basin for this species (other than the two mentioned above) it is felt wisest to discount the single Ohio record.

Kinosternon subrubrum subrubrum (Lacépède), MUd TURTLE.-This species is known from Indiana (Hay, 1892a and Grant, 1935) and from western Pennsylvania (specimens in the Carnegie Museum from Warrendale). There are no Ohio records but it is entirely possible it may occur in the southern part of the state.

Clemmys insculpla (Le Conte). Wood TurTLE.-This turtle is known from several localities in western Pennsylvania, some of them close to the Ohio border. It may occur in northeastern Ohio but frequent search in that part of the state failed to reveal it. There are a few specimens in the museum at Adelbert College, Western Reserve University in Cleveland, which are reputed to be, at least in part, from the Kirtland collection. None of these bear collecling data, however, except some marked "Pennsylvania."

Clemmys muhlenbergii (Schoepf), Muhlenberc's Turtle.-Netting (1927) has recorded this species from the Pymatuning swamp near Linesville, Pennsylvania, and since the publication of his paper the Carnegie Museum has acquired three additional specimens from counties bordering eastern Ohio. It is probable that this species may occur in tamarack bogs or in small clear streams in northeastern Ohio.

Graptemys pseudogeographica pseudogeographica (Gray), FAlse MAP TURTLE.There is a single specimen (USNM 775i) from Columbus. This is a small individual with a carapace length of $86 \mathrm{~mm}$. Since great numbers of juveniles are sold in pet stores this specimen may have been an escape. The false map turtle was kept in mind 
while field work was pursued in southwestern Ohio but no specimens were found. It may occur in the Ohio River or in some of its tributaries. Hay $(1892 a, 573)$ records it from southern Indiana.

\section{Use of Scientific Names}

The scientific names employed in the above list and in the systematic list of reptiles of Ohio are the same as those of Stejneger and Barbour (1933) with the following exceptions:

Leiolopisma unicolor (Harlan) replaces Leiolopisma laterale (Say). See Stejneger $(1934,182)$.

Eumeces laticeps Schneider, not recognized by Stejneger and Barbour, is here considered as distinct from Eumeces fasciatus (Linné).

Opheodrys vernalis (Harlan). The smooth green snake is referred to the genus Opheodrys instead of to Liopeltis. See Schmidt and Necker (1936).

Natrix erythrogaster erythrogaster (Forster), not recognized by Stejneger and Barbour, is considered as specifically distinct from Natrix sipedon sipedon (Linné).

Natrix sipedon insularum Conant and Clay has been described only recently. (Conant and Clay, 1937).

Agkistrodon mokasen mokasen Beauvois is changed to subspecific status. See Gloyd and Conant (1934).

Crotalus horridus horridus Linné becomes a trinominal. See Gloyd (1935).

Pseudemys scripta troostii (Holbrook). Viosca (1933) has shown that Pseudemys elegans (Wied) is conspecific with Pseudemys troostii (Holbrook) and Carr (1937) has further shown that Pseudemys scripta (Schoepff) intergrades with troostii in the Gulf coastal plain.

\section{Physiography and Geography of Ohio}

As numerous authors have shown, the distribution of animals frequently is correlated with physiography. Thus a species may occur abundantly in one region and be lacking in another, even though the two are adjacent geographically. In Ohio certain species of reptiles find their most suitable habitats in limited portions of the state. In such cases it has been found that the species in question is more or less confined to one or more of the physiographic areas of Ohio. These areas are described in detail below and comment is made upon the species inhabiting each of them.

Portions of five physiographic areas are found within the limits of Ohio. These are (1) the lake plains, (2) the till plains, (3) the glaciated Allegheny plateau, (4) the unglaciated Allegheny plateau, and (5) the blue grass region (see Map 1). Each of these areas is characterized by distinctive features which are summarized below.

1. The lake plains are bounded by old beach lines marking the maximum limits of Lake Maumee in postglacial times. These plains cover a wide portion of northwestern Ohio from Lake Erie to and beyond the Indiana boun- 
dary. To the east they parallel the shore of Lake Erie, although here they are very narrow. For the most part they are monotonously level and are relieved only by the valleys of the streams which pass through them; drainage is entirely to Lake Erie.

They are intensely cultivated, particularly in the western portions, and to the east, along the lake, they are utilized in addition for factory sites, summer resorts and real estate developments. Except for the extensive lake marshes

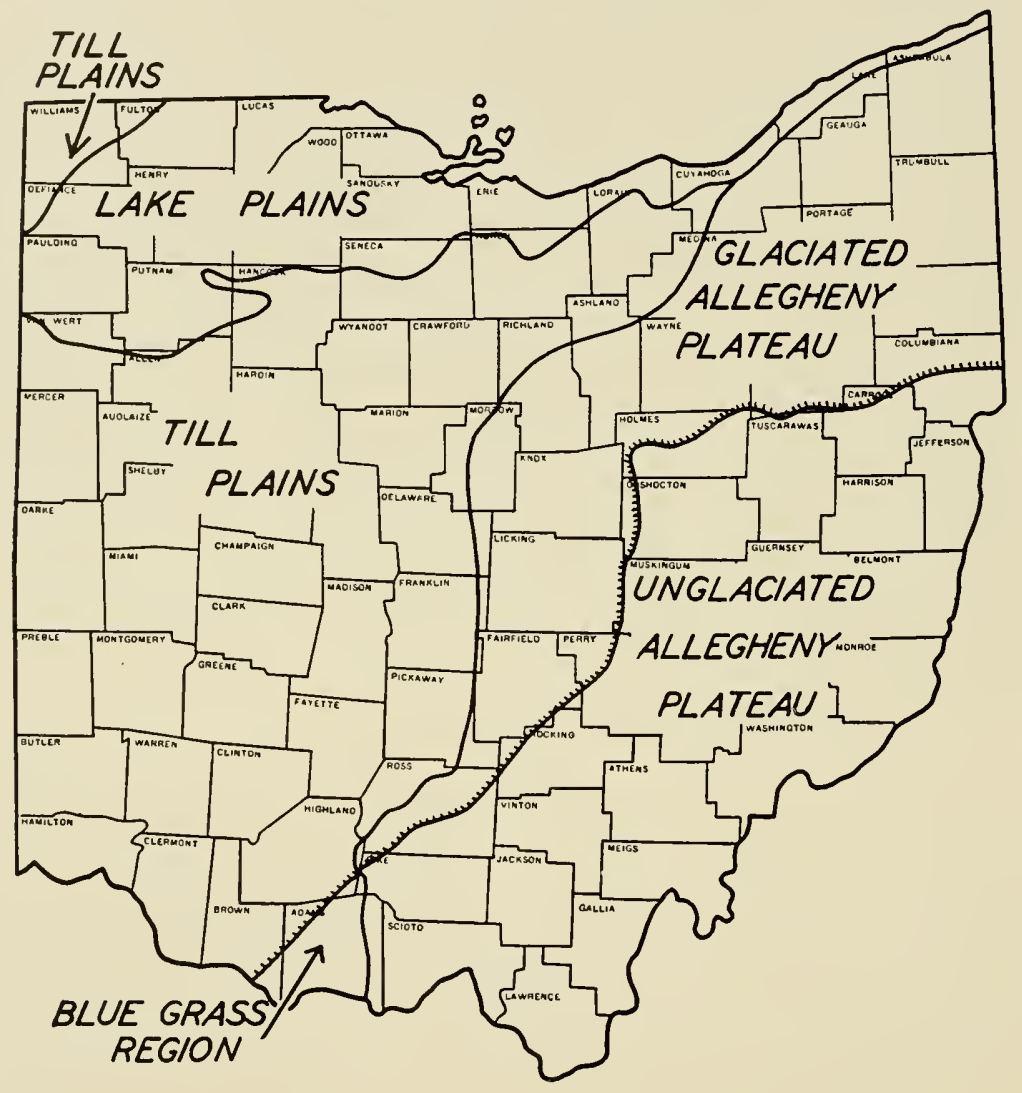

Map 1. The Physiographic Areas of Ohio (After Peattie). The Lake Plains are characteristically level and are bounded by old beach lines marking the maximum extent of Lake Maumee in postglacial times. Low rolling hills cover much of the Till Plains area which is terminated on the east by the eastern limit of the Upper Devonian shales. The Allegheny Plateau is more deeply dissected, especially in the unglaciated portion. and the bed rock is chiefly sandstone, shale and conglomerate. The western half of the state rests upon the limestone of the Cincinnati geanticline. The Blue Grass Region is the only limestone country in the state which escaped glaciation. The glacial boundary is indicated by the cross-hatched line. 
lying largely between Toledo and Sandusky, very little of the lake plains remain in anything approaching their original condition.

A few areas of special interest are found within the boundaries of the lake plains. West and southwest of Toledo is a sandy tract known as the "Oak Openings" which covers approximately 150 square miles. The soil is unsuited for many crops and the district has been somewhat less disturbed than others. It supports a growth of deciduous trees of a dwarfed and scrubby nature, and in it two species of reptiles are common which otherwise exhibit a rather limited distribution in northwestern Ohio. These are Heterodon contortrix and Terrapene carolina. The same two species also occur, however, in and near the sandy portions of fossil and modern beaches such as are found near Portage, Wood County, and on Cedar Point, Erie County, respectively.

The Catawba and Marblehead peninsulas in Ottawa County and the islands adjacent to them in Lake Erie are also of interest. Here the limestone, which underlies much of western Ohio, outcrops and provides excellent hiding places for snakes. Crotalus horridus horridus still maintains itself here, although it appears to have been exterminated elsewhere in Ohio, save in the wilder portions of the southern counties. Diadophis punctatus edwardsii is numerous in the area and the common water snakes of the islands are subspecifically distinct from those of the mainland.

Comment on the lake marshes has been made above. East of Sandusky, Lake Erie is bordered to a large extent by low rock cliffs or clay banks, but the mouths of some of the rivers are marshy. In Lake County is found the sizable Mentor Marsh. Much of the Maumee River valley was originally the "Great Black Swamp" of pioneer days. Although the latter region has long since been cleared and drained, many of the more terrestrial species of reptiles such as Coluber constrictor flaviventris and Lampropeltis triangulum triangulum apparently are not yet common in it.

Collecting in the lake plains was good in many localities and certain of the aquatic and semi-aquatic reptiles were present in abundance. Of the one species of lizard, seventeen of snakes and eight of turtles known from the lake plains all were found to be common in at least one or two localities. In Ohio only three forms occur exclusively or almost exclusively in the lake plains. These are Natrix sipedon insularum, Elaphe vulpina and Emys blandingii. The first appears to be peculiar to the Lake Erie islands and the second has been taken only in and near the lake marshes. Blanding's turtle, while it enters the till plains in the extreme northwestern corner of the state, seems to be otherwise confined to the lake plains. It is common in most of the counties bordering Lake Erie and those lying north of the Maumee River.

2. The till plains cover the major part of western Ohio. They are bounded on the east by the eastern limit of the Upper Devonian shales and rest upon the limestone bedrock of the Cincinnati geanticline. The entire area has been glaciated and in many places the till reaches a considerable thickness. Drainage is chiefly to the Ohio River but a few of the streams flow northward into Lake Erie or into rivers emptying into it. The headwaters of the Wabash 
River are in west central Ohio. Along the Lake Erie-Ohio River drainage divide, swampy forests and boggy tracts were once common.

Points of interest within the area include the reservoirs for the now abandoned Miami and Erie Canal which are known as Indian Lake, Lake St. Mary's and the Loramie Reservoir. All of these are well populated with turtles. The highest and lowest points in Ohio are both in the till plains, the former being at the summit of Campbell Hill in Logan County, which attains an elevation of 1550 feet, and the latter being at Cincinnati where the low water level of the Ohio River is 428 feet above sea level.

Centered in Logan and Champaign Counties are a number of large moraines among which lie several bogs of small size. Drainage from this area is rapid and gives rise to such streams as the Mad River, one of the very few clear streams of large size in Ohio. Near Urbana, Champaign County, is a small arbor vitae bog, apparently the only one of its kind in the state. In it Clemmys guttata is common and at one time Sistrurus catenatus catenatus was numerous about its borders.

In the extreme northwestern part of Ohio the till plains are characterized by small lakes and tamarack-sphagnum bogs, such as are common in the adjacent parts of Indiana and Michigan. This is the only portion of the till plains in which Emys blandingii is indigenous.

In the counties bordering the Ohio River are many deep, rocky, well wooded ravines. In, and near these, several species occur in numbers which are also common in the unglaciated plateau, but which are either rare or absent in other parts of the till plains. These include Sceloporus undulatus, Eumeces laticeps, Heterodon contortrix, Opheodrys aestivus, Coluber constrictor constrictor and Agkistrodon mokasen mokasen.

Almost the entire till plains area is extensively cultivated or has been at some time. The original forest has disappeared and ditching and tiling have lowered the water table considerably. Collecting, except in a few areas, was poor, and field activities, on the whole, were less successful in the till plains than in any of the other physiographic areas. Natrix sipedon sipedon and Natrix septemvittata, however, are almost universally common along the streams.

Despite the comparative scarcity of reptiles the till plains is the richest area in number of species recorded, but this is due in a large measure to the proximity of more favorable habitats near the edges of the adjacent regions. Three species of lizards, twenty-one snakes and ten turtles, or a total of thirtyfour forms were taken in the till plains. Of this number, however, no less than thirteen barely enter its borders or are confined to more or less limited areas. In addition to Emys, Sceloporus, Heterodon, Agkistrodon, etc. mentioned above, the following species show such a limited distribution in the till plains: Carphophis amoena helenae, Storeria occipito-maculata, Virginia valeriae valeriae, Pseudemys scripta troostii and Amyda mutica.

Natrix erythrogaster erythrogaster is the only Ohio species collected exclu- 
sively in the till plains, but since it is known from only two localities no significance can be attached to this fact.

3. The glaciated Allegheny plateau differs from the till plains, and the greater part of the lake plains, in that the underlying rocks are largely shale, sandstone and conglomerate rather than limestone. Hence the water, in general, is softer and the $\mathrm{pH}$ is lower. The unglaciated plateau area also shares these characteristics.

The glaciated plateau lies chiefly in northeastern Ohio although a long narrow portion of it extends to the southwest almost to the Ohio River. The topography of the area is varied; in some portions there are low rolling hills while in others the relief is more marked. Near Lake Erie there are several broad valleys, formed by postglacial rivers, in which the streams occupying them at present appear trivial. In the northeastern counties small bogs, ponds and lakes are numerous. Some of the streams of the area empty into Lake Erie but drainage is largely to the Ohio River; along the eastern boundary of Ashtabula County the Lake Erie-Ohio River divide approaches to within twenty miles of the Lake.

Cultivation is less extensive in the glaciated plateau than in the plains areas to the west. The valleys of stronger relief are for the most part well covered with trees, and wood lots are numerous in many places, especially in Geauga County which is noted for its maple syrup production. The area is well settled, however, and contains many large manufacturing centers such as Akron, Canton and Youngstown.

Particular points of interest include Buckeye Lake, which served as a reservoir for the Ohio and Erie Canal, and the Pymatuning swamp, a small portion of which entered Ohio near Andover, Ashtabula County. This swamp came closer to being a wilderness than any other place in the state, and it was the mecca of Ohio naturalists until the promotion of the Pymatuning Reservoir caused the complete destruction of the Ohio portion of it.

The extreme northeastern corner of the state is the only part of Ohio lying in the Transition Zone. Here many northern plants were once numerous and some are recorded from nowhere else in the state. Hemlock is common in many places and small stands of white pine and tamarack are still to be found.

In this corner of the state Storeria occipito-maculata is common, although elsewhere in Ohio it appears to be rare. Probably Clemmys insculpta and Clemmys mublenbergii occur in this region; they have been found in the adjacent part of Pennsylvania but repeated search for them in Lake, Geauga and Ashtabula Counties has resulted in failure.

Eighteen snakes, two lizards and seven turtles, or a total of twenty-seven species, are known from the glaciated plateau. Of this number, however, Sceloporus undulatus, Carphophis amoena helenae, Heterodon contortrix, Natrix kirtlandii, Thamnophis butleri and Agkistrodon mokasen mokasen barely enter the area or are restricted to habitats closely resembling the adjacent region. Of these, Sceloporus, Heterodon and Agkistrodon, which are 
widely distributed in unglaciated Ohio, follow up such streams as the Mohican River for a considerable distance into glaciated territory.

4. The unglaciated plateau, occupying the southeastern part of Ohio, is composed essentially of two or more old peneplains now deeply dissected. Relief is strong and in many places a difference in elevation of 600 feet or more may be seen between the tops of the hills and the bottoms of the nearby river valleys. Drainage, which is entirely to the Ohio River, is rapid, and ponds and bogs are scarce. Surface erosion is well marked in many places where the forest has been removed.

Rocks of several formations outcrop in many areas; sandstone, shale and conglomerate predominate but there is occasional limestone. Numerous hillsides are covered with loose rocks, and cliffs of moderate height are found in many localities. Of the latter, the most spectacular are of the Sharon and Black Hand conglomerates. In several ravines in Hocking County the last named formation is weathered in such a way as to form cliffs with deep concave faces, known locally as "caves."

Cultivation, except in some of the broader river valleys, is not extensive and much of the unglaciated plateau is covered with trees. Oak and hickory predominate on many of the hills while pine is most abundant on others; hemlock is common in a number of the moister ravines. In the state forests in Lawrence and Scioto Counties, trees almost completely cover many thousands of acres.

The lower Scioto River valley together with the portions of Pike and Scioto Counties lying to the west of the river might well be characterized as one of the most productive areas for reptiles in the state. Along the river; and the abandoned Ohio and Erie Canal which parallels it, turtles and aquatic snakes are common, and in the valleys and hills which lie to the west, snakes and lizards are numerous. Several species, such as Carphophis amoena helenae and Crotalus horridus horridus are common in this small area, although elsewhere in the state they are rather rare.

Coal mining is a major industry in eastern Ohio and in many places its development has caused marked changes in the appearance of the country. The timber requirements of the mines have resulted in the nearby hills being completely denuded. Waste from some of the diggings keeps many streams in a chronic state of pollution. Such unnatural conditions as these cannot help but have a profoundly adverse effect upon many of the reptiles.

Collecting in the heavily mined areas was poor, but elsewhere in the unglaciated plateau field trips were for the most part successful. A total of thirty species including four lizards, eighteen snakes and eight turtles was obtained in this part of Ohio. Of this number, however, no less than eleven were taken exclusively in this area, or here appeared to reach their maximum abundance in the state. These are Sceloporus undulatus, Leiolopisma unicolor, Eumeces laticeps, Carphophis amoena helenae, Opheodrys aestivus, Coluber constrictor constrictor, Lampropeltis gctulus nigra, Virginia valeriae 
TABLE 1

Distribution of Reptiles in Ohio

Species

Physiographic Area

$\mathrm{X}=\mathrm{O}$ wide distribution within the area

$/=$ Rare or restricted within the area

Sceloporus undulatus

Leiolopisma unicolor

Eumeces fasciatus

Eumeces laticeps

Carphophis amoena helenae

Diadophis punctatus edwardsii

Heterodon conlortrix

Opheodrys aestivus

Opheodrys vernalis

Coluber constrictor constrictor

Coluber constrictor flaviventris

Elaphe obsoleta obsoleta

Elaphe vulpina

Lampropellis getulus nigra

Lampropeltis triangulum triangulum

Nalrix erythrogaster erythrogaster

Nalrix Rirllandii

Natrix septemvittata

Natrix sipedon sipedon

Natrix sipedon insularum

Storeria dehayi

Storeria occipilo-maculata

Virginia valeriae valeriae

Thamnophis bulleri

Thannophis sauritus sauritus

Thamnophis sirtalis sirtalis

Aghistrodon mokasen mokasen

Sistrurus catenatus calenatus

Crotalus horridus horridus

Sternotherus odoralus

Chelydra serpentina

Clemmys gullata

Emys blandingii

Terrapene carolina

Graptemys geographica

Chrysemys bellii marginata

Pseudemys scripta troostii

Amyda mulica

Amyda spinifera

Total species

\begin{tabular}{|c|c|}
\hline 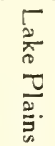 & 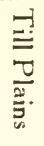 \\
\hline & 1 \\
\hline
\end{tabular}

\begin{tabular}{|c|c|c|}
\hline 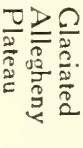 & 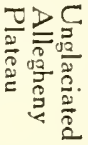 & 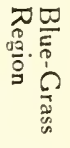 \\
\hline
\end{tabular}

X

$\mathrm{x}$

1

\begin{tabular}{l|l}
$\mathrm{X}$ & $\mathrm{X}$ \\
\hline
\end{tabular}

\begin{tabular}{|c|c|c|c|c|}
\hline \multirow[t]{2}{*}{$\mathrm{X}$} & $\mathrm{X}$ & $Y$ & $X$ & \\
\hline & 7 & & $x$ & $x$ \\
\hline & 7 & 1 & $x$ & \\
\hline
\end{tabular}

\begin{tabular}{|c|c|c|c|c|c} 
& $\mathrm{x}$ & $\mathrm{X}$ & $\mathrm{X}$ & $\mathrm{X}$ & \\
\hline $\mathrm{X}$ & $/$ & $/$ & $\mathrm{X}$ & \\
\hline & $/$ & $\mathrm{X}$ & $\mathrm{X}$ & & \\
\hline & & $/$ & $\mathrm{X}$ & $\mathrm{X}$ & $\mathrm{X}$ \\
\hline $\mathrm{X}$ & $\mathrm{X}$ & $/$ & & \\
\hline $\mathrm{X}$ & $\mathrm{X}$ & $\mathrm{X}$ & $\mathrm{X}$ & $\mathrm{X}$ \\
\hline $\mathrm{X}$ & & & &
\end{tabular}

\begin{tabular}{l|l|l|l|l|l}
\hline & & & & $/$ & $/$ \\
\hline & $x$ & $x$ & $X$ & $x$ & $X$ \\
\hline
\end{tabular}


valeriae, Agkistrodon mokasen mokasen, Crotalus horridus horridus and Amyda mutica.

5. The blue grass region, which lies almost entirely in Adams County in south central Ohio, occupies a much smaller area than any of the other physiographic areas which enter Ohio. Like the till plains, its bed rock is limestone, but it differs from the latter in that it escaped glaciation. It is more rugged and the limestone outcrops in many places, especially in the stream valleys.

A large part of the surface is under cultivation and it cannot be said that collecting is good. Owing to this fact and to its small size, it is only natural that but few species are recorded. Only two lizards, eight snakes and four turtles are known from within its borders, but undoubtedly a resident working over a period of years, would be able to find most of the species known from the adjacent parts of the unglaciated plateau and till plains areas.

Of particular interest are the small dry prairies such as the one at Lynx, Adams County, and in which Sceloporus undulatus is abundant.

\section{Presentation of Each Species}

Presented in the following pages are detailed accounts of each of the species of reptiles known to occur in Ohio. In these are embodied the observations made in the field, supplemented by divers notes on feeding and breeding activities in captivity. Of necessity the manner of presentation of each species varies, but it adheres more or less to a general plan which may be summarized and commented upon as follows:

First appears a detailed description of the species based entirely, unless otherwise noted, upon Ohio specimens. Such description is composite and was prepared from a study of a series of individuals. It is intended to apply to the Ohio population of each form as a whole and consequently takes into consideration such things as the range of variation in scale counts, color, pattern, etc. It also calls attention to specimens found to exhibit unusual or aberrant conditions.

Measurements and studies of squamation, pattern, etc. follow the standards indicated below. All measurements were originally taken in the more facile and accurate metric system, but to make the work more useful to those who are not accustomed to thinking in terms of millimeters, all gross measurements are expressed in the English system. Smaller ones demanding greater accuracy, such as the length and width of eggs, are given in the metric system.

The total length of snakes and lizards is from the tip of the snout to the tip of the tail. Tail lengths are from the middle of the anal plate to the tip of the tail. Measurements of turtles such as "length of carapace," "length of plastron," etc., are straight line dimensions obtained by using calipers. Tail measurements of turtles are from the center of the anus to the tip.

Scale counts of snakes are according to the accustomed fashion. The num- 
ber of rows of scales shows the reduction or addition of rows beginning on the neck and ending just anterior to the anus. Ventral counts are from the first transversely enlarged scale under the throat to, and including, the anal plate. The number of subcaudals includes the terminal spine or scale on the end of the tail.

Oculars are expressed in the text as 2-3, 1-2, etc., in which the first figure refers to the number of preoculars and the second to the number of postoculars. Temporals are expressed as 1-1-2, 2-3-2, etc., in which the first figure refers to the number of temporals in the first row, the second figure those in the second row, and the third figure those in the third row.

The Ohio material of each species available for study is indicated at the end of the descriptions under three headings, namely "Specimens Examined," "Specimens Preserved," and "Specimens Studied." Under the first of these is given the total number of Ohio specimens which passed through the hands of the writer, including all preserved material, live individuals, those found dead upon the road, etc. Under the second heading is given the total of museum specimens seen during the course of the work. Under the last is stated the number upon which scale counts and pattern studies were made and hence the number of specimens which form the basis of the description.

Next in order appears a statement of the general range of the species. Following this is given the range within the borders of the state and if such is of particular or unusual interest, attention is directed to the fact. Next is presented a list of Ohio localities arranged alphabetically by counties.

The preparation of the locality lists required much time and effort. No map was found which shows all the localities given by divers collectors and noted in the catalogues of the various museums. Some few ambiguous localities were impossible to locate and all such are religiously excluded as are also those which give the locality merely as "Ohio." Others were ascertained only after making careful inquiry concerning local names, checking misspellings, etc. The topographical maps of the United States Geological Survey, which fortunately are complete for Ohio, are the most detailed and accurate which have appeared and they have been used as the standard for plotting and listing the localities. In cases where a locality was traced only with difficulty, the writer has appended the name of a nearby town or the township in which the locality is situated.

The topographical maps are much too bulky for general use and in their stead, when too great detail was not required, it was found convenient to utilize Rand McNally's Pocket Map of Ohio. This map shows the township boundary lines and is accompanied by a gazeteer of cities and towns. The official road map of Ohio, published by the State Department of Highways, was also found useful in locating the state parks and other points of public interest.

Certain policies have been maintained in the preparation of the locality lists. No hearsay evidence has been accepted and only those specimens which 
have been personally examined by the writer are included.* Definite records in the literature, however, are also listed but only a certain few of them. The bulk of the material upon which the Ohio records of such authors as Raird and Girard (1853); Smith (1882), Yarrow (1882), Cope (1900) and Morse (1904) were based, has been seen by the present writer, and since all of these specimens are listed under the locality records for each species it is superfluous to repeat the many published records. Consequently, of the latter, only those are given where the specimens have been lost or where the writer has failed to examine them. If there is any doubt as to the accuracy of the locality, or of the identification of any of these, they are not included.

In the case of all preserved specimens the collection to which they belong and the museum number, if any, is indicated immediately following the locality. The letters used to denote the various collections are the initials of the institutions or of the private owners. A list of these begins on page 2 . Localities not followed by any designation refer to specimens examined by the writer but which were not preserved.

The distribution maps of the various species have been prepared from the lists of locality records and here again certain policies have been followed. Specimens recorded with no more detailed locality than just the county are plotted on the maps near the center of the county in question and are accompanied by a capital letter "C." In cases where a more definite record from within the borders of the same county is available, the unqualified county record is not plotted upon the map. Likewise in the case of township records if a definite locality from within the borders of the township is available, another locality stated merely as the township is not plotted.

The spots have been placed upon the maps with as much accuracy as possible. Solid symbols indicate localities from which the writer has seen specimens; hollow ones show additional localities reported in the literature. The dark lines crossing the maps show the boundaries of the physiographic regions.

The small inset maps of the United States accompanying each of the Ohio distribution maps indicate, by means of a solid dark area, the general range of the species or subspecies concerned. Several of the forms occurring in Ohio have ranges extending beyond the borders of the United States. In these cases the advantage of using a United States map, as against a map of North America of the same size, is felt to be sufficient to outweigh showing the complete ranges. The latter are stated in the text for each form.

It should be remembered that the inset maps are merely indicative of the ranges and must not be relied upon for exactness. Detailed locality maps showing the complete ranges of the various reptiles occurring in Ohio are very few. Except for those appearing in Blanchard (1921 \& 1923), Ortenburger (1928), Ruthven (1908), etc., they are non-existent. In most cases the ranges are still too poorly known to be shown with accuracy.

* A few records of common species, made chiefly in 1935, are included even though the specimens have not been seen by the writer. This material is now in museums and has been identified by competent herpetologists. 
In the text, following the statement of the range and the presentation of the locality records, an account is given of the habits and habitat of the species in question. Unless otherwise noted the detailed observations and generalized statements in this section are based entirely upon Ohio specimens which were studied either in the field or in the laboratory. These are supplemented by statements in the literature to which reference is made in the text. While the varying quantity and quality of information which is available for each species prevents an entirely uniform treatment, the order indicated below has been followed as closely as possible:

A statement as to relative abundance; a discussion of habitat preferences and specific places in which specimens have been found; unusual or characteristic habits and comment upon popular superstitions; seasonal variation; association with other species; food in nature and in captivity; notes on eggs and young.

The photographs illustrate all of the species and subspecies of reptiles known from Ohio; the captions state the locality in which the specimen shown was collected and also its measured or approximate length.

\section{Key to the Reptiles of Ohio*}

1. Body elongate and covered with small scales. Anus a cross-slit.-Order SQuAMaTA (Lizards and Snakes)

Body short and broad and enclosed between two (upper and lower) shields or shells. Anus rounded or a longitudinal slit.--Order TESTUdinata (Turtles)

2. Limbs present; eyelids movable; an external ear opening.-Suborder SAUR1A (Lizards)

Limbs absent; no external ear openings or movable eyelids.--Suborder SERPENTES (Snakes)

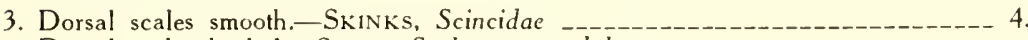

Dorsal scales keeled.-Swift, Sceloporus undulatus.

4. Center of lower eyelid transparent and without scales; the adpressed limbs lack considerably of meeting.-BROWN-BACKED SKINK, Leiolopisma unicolor.

Lower eyelid without a transparent center; the adpressed limbs meet or overlap

5. Seven upper labials, four usually preceding the subocular. Maximum length 3.15 inches from snout to vent.-BLUE-TAllED SKINK, Eumeces fasciatus.

Eight upper labials, five usually preceding the subocular. Maximum length greater than 3.15 inches from snout to vent.-LARGE-HEAdED SKINK. Eumeces laticeps.

6. A deep facial pit present about midway between each eye and nostril _------_31.

No facial pit present _-_-_-_-_-_- 7.

7. Some or all of dorsal scales keeled _-_- 8 .

Dorsal scales smooth _-_- 23.

* Key adapted in part from Blanchard (1925a) and Ruthven, Thompson and Gaige (1928). 
8. Anal plate single.-Garter Snakes, Thamnophis -...-_-_- 9.

Anal plate divided -..-_- 11.

9. Lateral stripes normally not involving the second row of scales. Tail $28 \%$ or more of total length. - RIBBON SNAKE, Thamnophis sauritus sauritus. Lateral stripes normally involving all or part of the second row of scales. Tail less than $28 \%$ of total length

10. Lateral stripes normally on the second and third rows of scales. Labials usually 7 upper and 10 lower.-Common Garter SNAKE, Thamnophis sirtalis sirtalis.

Lateral stripes on the third and adjacent halves of the second and fourth rows of scales. Labials usually 6 upper and 8 lower.-ButLer's GarTer SNAKE, Thamnophis butleri.

11. Rostral turned up in front and keeled above.-Hog-Nosed SNAKE, Heterodon contortrix.

Rostral normal

12. Loreal present -

Loreal absent.-Brown SNAKes, Storeria

13. Scale rows 15; belly red, rarely black.-STORER's SNAKE, Storeria occipitomaculata.

Scale rows 17; belly white or pinkish.-DekaY's SNAKE, Storeria dekayi.

14. Loreal separated from the eye by one or more preoculars

Loreal in contact with the eye.-Ground SNAKE, Virginia valeriae valeriae.

15. Two nasals

One nasal; the nostril in its center; uniform light green in color above.Keeled Green Snake, Opheodrys aestivus.

16. First three to seven rows of scales smooth, the rest weakly keeled.-RAT SNAKES, Elaphe

Scales strongly keeled except occasionally the first row.-WATER SNAKES, Natrix

17. Color above, uniform black or with obscure blotches; ventrals 228 to 242 ; juveniles conspicuously spotted.-PILOT BLACK SNAKE, Elaphe absoleta obsoleta.

Color above, yellowish to light brown with prominent dark brown or black blotches; ventrals 195 to 212; juveniles similar to adults.-FoX SNAKE, Elaphe vulpina.

18. Scale rows $19-17$ 19.

Scale rows 21 or more

19. Light lateral stripes on the first and second rows of scales; no dorsal blotches. - QueEn SNAKE, Natrix septemvittata.

No light lateral stripes; dorsal blotches present - KIRTLAND's WATER SNAKE, Natrix hirtlandii.

20. A pattern of dorsal and lateral blotches more or less evident throughout the length of the body and tail

Pattern of dorsal and lateral blotches obsolete or lacking

21. Lateral blotches alternating with dorsal blotches to or almost forward to the head. Belly uniform red or orange.-RED-BELlied WATER SNAKE, Natrix erythrogaster erythrogaster (juvenile).

Lateral blotches fused with dorsal blotches to form dark cross bands anteriorly. Belly mottled.-Common Water SNaKe, Natrix sipedon sipedon. 
22. Uniform black or blackish brown above and uniform reddish below.Red-Bellied Water SNake, Natrix erythrogaster erythrogaster.

Uniform grey, greenish or light brown above and uniform white, yellow or orange below.-IsLand Water SNAke, Natrix sipedon insularum.*

23. Anal plate divided -

Anal plate single.-KING SNAKES, Lampropeltis -

24. A pattern of large reddish or brownish blotches on a lighter ground.-Milk SNAKE, Lampropeltis triangulum triangulum.

Ground color blackish and crossed by rows of small yellow dots.-Bt_AcK Kinc SNAKE, Lampropeltis getulus nigra.

25. One or more preoculars present

No preocular; loreal in contact with the eye

26. Scale rows 13; 5 upper labials; 1 nasal.-WORM SNAKE, Carphophis amoena helenae.

Scale rows 15; 6 upper labials; 2 nasals.-Ground SNAKE, Virginia valeriae valeriae.

27. Two nasals

One nasal; the nostril in its center; uniform light green in color above. Smooth Green Snake, Opheodrys vernalis.

28. Dorsal scale rows 17 or 15

Dorsal scale rows 23 or more.-RAT SNakes, Elaphe

29. No neck ring; usually two anterior temporals

A light colored neck ring; one anterior temporal.-RING-NECKED SNAKE, Diadophis punctatus edwardsii.

30. Black above, grey below; throat and chin whitish, heavily spotted with blackish. Subcaudals average 94 . Juveniles patterned with dorsal saddles. - Black Racer. Coluber constrictor constrictor.

Bluish, greenish or greyish above, yellowish below; throat and chin white, unspotted. Subcaudals average 87 . Juveniles patterned with dorsal saddles. - Blue Racer, Coluber constrictor flaviventris.

31. Tail terminating in a rattle or a button

No rattle; tail tapering to a point.-COPPERHEAD, Agkistrodon mokasen mokasen.

32. Plates on top of head large and arranged symmetrically. A pattern of large spots on the back with smaller alternating spots on the sides; some specimens entirely black.-MASSASAUGA, Sistrurus catenatus catenalus.

Top of head covered with small unsymmetrical scales. A pattern of transverse zig-zag, or chevron-shaped bands.-Timber Rattlesnake, Crotalus horridus horridus.

33. Carapace with a leathery skin and with no horny plates.-SofT-SHELLED Turtles, $A$ muda

Carapace rigid and with horny plates

34. Carapace with tubercles or spines especially along the anterior margin; a longitudinal ridge projecting into each nostril from the septum.-SPINY Soft-Shelled Turtle, Amyda spinifera.

Carapace without tubercles or spines; no longitudinal ridge projecting into the nostrils.-Brown Soft-Shelled Turtle, Amyda mutica.

* The key will not function for all specimens of Natrix sipedon insularum. See detailed discussion of this subspecies beginning on page 86 . 
35. Plastron small and covering only a small portion of the ventral fleshy parts -

Plastron nearly or completely covering the ventral fleshy parts -

36. Tail long and covered above with a median row of large tubercles. Marginal scutes 25.- SNAPPING TURTLE, Chelydra serpentina.

Tail short and without a median row of tubercles. Marginal scutes usually 23.-Musk TURTLE, Sternotherus odoratus.

37. Plastron hinged and movable

Plastron rigid and immovable

38. Carapace long and depressed; upper jaw notched in front.-BLANDinc's TURTLE, Emys blandingii.*

Carapace short and high; forward part of upper jaw hook-like and projected downward.-Box TuRTLE, Terrapene carolina.*

39. A prominent red band extending backward from the eye on either side of the head.-Cumberland Terrapin, Pseudemys scripla troostii.

No prominent red band on sides of head

40. Upper jaw notched in front

Upper jaw not notched in front.-MAP TURTLE, Graplemys geographica.

41. A tooth-like projection at either side of the notch; carapace not spotted with yellow.-PAinted TURTLE, Chrysemys bellii marginala.

No tooth-like projections at sides of notch; carapace marked with bright yellow dots.--SPOTTED TURTLE, Clemmys guttata.

\section{Discussion of Species}

\section{Sceloporus undulatus (Latreille)}

Swift; Fence Lizard; Pine Lizard

Description.-A small lizard attaining a length of about 7 inches. Largest perfect** Ohio specimen ( 9 ), $71 / 8$ inches in length; smallest newly hatched young, $2 \mathrm{I} / 8$ inches. Head small but somewhat wider than neck; eye small. Limbs well developed; five toes and claws on each foot. Body moderately slender in juveniles, stouter in adults. Tail long and slender and from 1.15 to 1.50 times the length from snout to vent.

Scales around middle of body 40 to 51 , average 45 . Dorsal scales from parietal to a point directly above the anus 35 to 48 , average 42.5 . Dorsal scales keeled; ventral scales smooth. Upper labials 5, occasionally 6, rarely 4 ; lower labials 6 , occasionally 7 , rarely 5 . Supraoculars 5 , commonly 6 , rarely 7 or 4 . Femoral pores most commonly 13,14 or 15 (18 on one side in one specimen), average 14.4 .

Ground color variable but usually some shade of grey. Individuals capable of changing their colors to a certain degree; they may be light grey at one time

* In very young specimens the hinge is not readily apparent. Juvenile Blanding's turtles may be distinguished from other juvenile hard-shelled Ohio turtles by the uniform yellow throat, and box turtles may be known by the hook-like downward projection of the forward part of the upper jaw.

** This species, in common with the other lizards inhabiting Ohio, loses its tail if seized by that appendage. The tail is regenerated in time but the new one is not as long or as perfect as the original. 
and a very dark grey, brownish, greenish or bronzed at another. Dorsal surface crossed by 6 to 10 , average 9 , more or less complete wavy crossbands varying from a fraction of one, to two full scales in width. Similar, but less distinct markings on the tail.

Ground color of ventral surface light grey or yellowish and often marked with a few small dark spots or streaks. A band of blue across the throat and a similar band of blue on either side of the midventral line. Blue areas usually pale and rarely suffused with black in females. In males, the blue more intense, occupying a greater area and usually heavily marked with black; latter color sometimes extending backward from blue throat band on to shoulders. Intensity of dark areas varies from time to time as in the dorsal coloration.

Juveniles similar to adults but usually paler and with the blue areas little developed.

Specimens examined, 153; specimens preserved, 124; specimens studied, 43.

Range.-Southeastern New York to Florida and west to Nebraska, Kansas, Oklahoma and Texas.

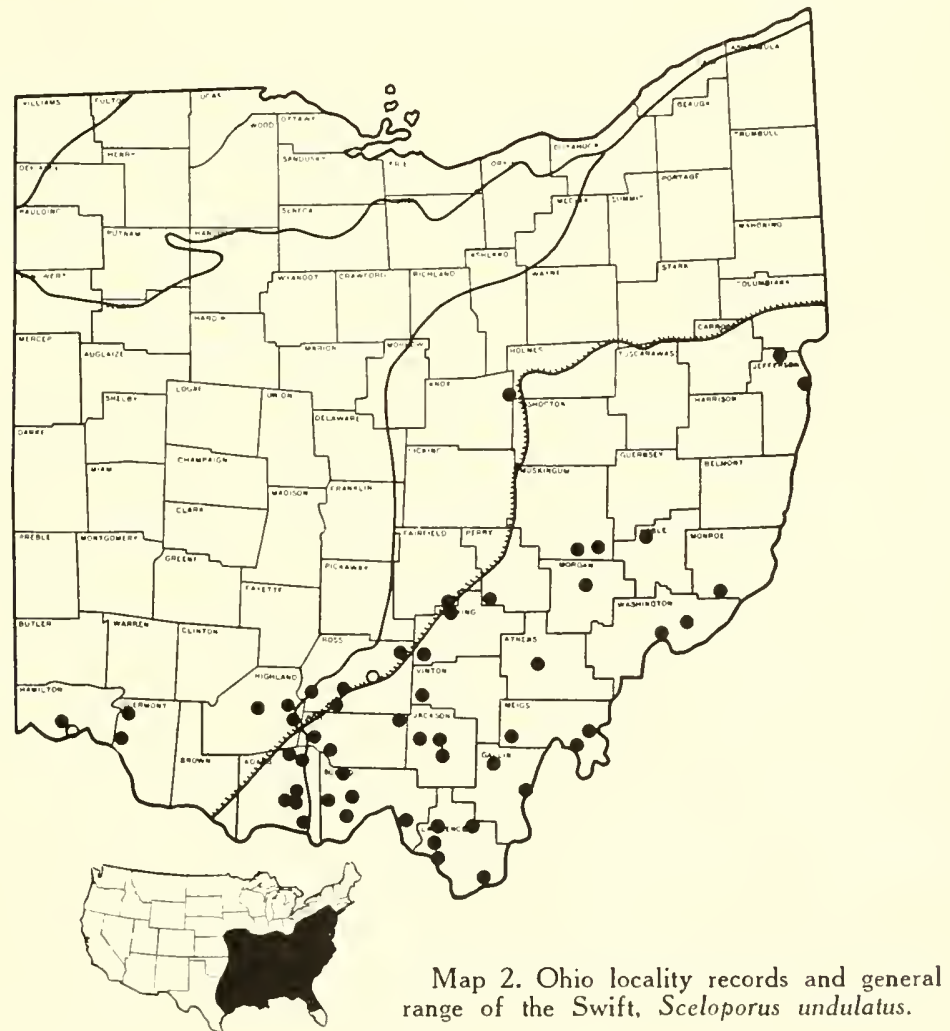


The range of the swift in Ohio is restricted to the unglaciated area, its immediate vicinity and the counties to the west lying just north of the Ohio River (see Map 2). Locality records are:

Adams County: Buzzard's Rock. Jefferson Twp. (OSM 226); Cedar Mills (TZS 714); Green Twp. (OSM 168); Jefferson Twp. (TZS 713); E of Locust Grove (OSM 388); Lynx Prairie, near Lynx (TZS 710); Serpent Mound, Bratton Twp. (AS). Athens County: Near Athens (OU; TZS 1052). Clermont CounTY: Miami Twp. (OSM 377.1-.2); Union Twp. (CSNH 1836). Fairfield County: (Morse, 1904); Sugar Grove (OSM 159, 160.1-.12). Gallia CountY: Near Blazer, Gallipolis (TZS 1829); Vinton (OSM 269.1-.2). Hamilton CountY: Cincinnati (Morse, 1904); Westwood (CSNH 1167). Higilland CountY: Beaver Mill, Paint Twp. (TZS 427); Carmel; Hillsboro (TZS 761). Hockıng Countr: Clear Creek, Good Hope Twp. (OSM 161, 209.2, 361 ; TZS 416-7, 1534-5); Salt Creek Twp. (AS; TZS 988). JACKson CounTY: Franklin Twp. (TZS 1075); Jackson (TZS 1258-9); White's Gorge, Liberty Twp. Jefrerson County: Brush Creek Twp. (CM 4220); near Irondale, Brush Creek Twp. (TZS 1561); New Somerset, Toronto (OSM 271.1). KNoX County: Brinkhaven (OSM 178, 368; TZS 1864-5). Lawrence County: Near Arabia, Aid Twp. (TZS 419); Dean Forest, Elizabeth Twp. (OSM 162.1-.2); Ironton (TZS 2301-8); Union Twp. (OSM 217.1-.2); Vesuvius Furnace, Elizabeth Twp. Meics County: near Bashan (OSM 403); Salem Twp. (OSM 381.1-.2); Sutton Twp. (TZS 415). Monroe CountY: Near Cline, Washington Twp. (TZS 1993). Morgan County: Malta (AS). MusK1NGUM CounTY: High Hill (OSM 476); Poverty Ridge, Blue Rock Twp. (TZS 2409-11). Noble County: Buffalo Twp. (TZS 1260). Perry County: Monday Creek Twp. (OSM 227). Pike CountY: Chimney Rocks, Jackson Twp. (OSM 234); Laurel Ridge, Sunfish Twp. (TZS 1080); Mifflin Twp. (TZS 579). Ross County: Big Round Top Mountain, Paint Twp. (CSNH 1866A-J); Bourneville (OSM 222.1-.2); Chillicothe (Morse, 1904); Colerain Twp. (TZS 391); Copperas Mountain, Twin Twp. (TZS 1278-80). Scıoto CountY: Brush Creek Twp. (TZS 712); Franklin Furnace (TZS 1819-20); 5 mi. SW of Otway (TZS 1882); Roosevelt Game Preserve, Nile Twp. (TZS 696-709, 1495); near Sedan; Union Twp. (OSM 179). Vinton County: Harrison Twp. (TZS 1270, 1276); Pigeon Creek, Harrison Twp. (TZS 711). WAshington CounTY: Lawrence Twp. (OSM 219); Marietta (MC).

Habitat and Habits.-In some localities swifts may be characterized as abundant. They frequently were seen on field trips and it was unusual not to take at least one specimen on each excursion to unglaciated Ohio. In some localities as many as a dozen were collected in a few hours, and often a like or greater number escaped as a result. of their agility or the inaccessibility of the places in which they were observed. In general, it may be said that the swift is common in the more southern unglaciated counties and rarer to the north and west.

Individuals were found in a variety of habitats but there appeared to be a preference for the drier woods and hillsides. A few were collected in such moist places as on the banks of streams or in damp ravines, but by far the greater number were in much drier situations. They were seldom seen far from woods but if they were in the open, a brush pile, a heap of rocks or other cover was usually near into which they could dart when alarmed.

Specimens often had their own individual resting places and most of these were well exposed to the sun and in the vicinity of an adequate food supply in the form of ants, beetles, etc. Favorite spots were rotting logs or stumps, the trunks of dead trees, large rocks, the edges of cliffs, etc. When 
perched on such objects, they were conspicuous and often could be seen from some distance away.

Swifts can move with considerable speed, but they seldom run far. When approached, they dart to cover or to the opposite side of their perch. There they remain at rest but on the alert. If they are on a tree or stump they endeavor to keep the trunk between themselves and their pursuer, but each time they move they go higher or lower until they are ultimately out of reach.

The collector who has had experience with these lizards can often catch them with little trouble. By cautiously peering around the bole and stepping back out of sight as soon as the location of the specimen has been noted, one may thrust his hand around the tree very quickly and gently press the lizard against the bark until it can be grasped with the other hand. Care must be exercised, however, not to hold the tail alone for it will become detached and the lizard will run to safety.

Individuals soon become tame, as a rule, although at first they struggle to escape and may pinch the fingers of their captors between their jaws. They can be taken readily with a fine wire or horse hair noose fastened to the end of a pole. Specimens which live near farm buildings and cabins, and which have become accustomed to human beings, often will dart out and seize insects at the feet of the observer, providing the latter remains motionless. A particularly tame specimen which lived in and about the foundations of a cabin in Hocking County was once offered a small grasshopper on the end of a string. It swallowed the insect and when the string was pulled the lizard was lifted nearly a foot from the ground before it disgorged.

Swifts appear to be strictly diurnal. They retire to a convenient hiding place under a stone, the loose bark of a stump, etc., at twilight, and on cool or rainy days they seldom venture forth. Sawdust piles are another favorite retreat. The blue areas on the under surface are usually brightest when the lizard is in the sun and palest when it is hiding.

Specimens were collected in every month from April to October, inclusive, but many more were taken in May and September than in any other months. The swift was found at one time or another with almost all of the species of snakes which are common in southeastern Ohio and it even was discovered under the same shelter with a copperhead and a ring-necked snake. It was rarely found in the same habitat with the blue-tailed skink since the latter prefers a damper environment. However, in several of the localities in Ohio where the large-headed skink (Eumeces laticeps) was collected, swifts were also in evidence.

The food of this lizard consists very largely of insects but according to Surface $(1907,257)$ it also eats snails, "sow-bugs" and spiders. Captives ate ants, honey bees, meal worms, wax worms, caterpillars of various species, flies, small beetles, may-flies, grasshoppers, crickets, bugs and in fact almost any insect offered to them which was small enough for them to overpower and swallow. With such a decided appetite for insects it is obvious that the swift is an animal of considerable economic value. 
Unfortunately no eggs of this lizard were secured during the course of the present work. A female collected June 7, 1931, contained eggs which were nearly ready to be laid (to judge by their size). Another female collected in southern Ohio in the spring of 1933 escaped from captivity and took up its abode in the garden of its owner who lived in Toledo. It was allowed to remain at liberty and apparently deposited eggs, for 5 specimens, 21/8 inches in length, and which had obviously just hatched, were discovered in a large crack in the side-walk on August 31, 1933. Ditmars $(1936,57)$ states that the eggs are from $3 / 8$ to $\mathrm{I} / 2$ inch in length, are oval and are covered with a thin papery shell. He gives the incubation period as from six to eight weeks.

\section{Leiolopisma unicolor (Harlan)}

\section{Brown-Backed SKink}

Description.-A small lizard which occasionally may reach a length of 5 or $5 \mathrm{r} / 2$ inches. The only specimen extant from Ohio measures $23 / 8$ inches, but a portion of its tail is lacking. Head small and scarcely distinct from neck; eye small. Legs small; five toes on each foot; the adpressed limbs lack considerably of meeting. Body slender. Scales around middle of body 26*; the scales smooth. Upper labials 7, lower labials 6. Lower eyelid with a transparent disc.

The ground color of the dorsum is yellowish to golden brown and is usually marked with two or more irregular longitudinal rows of small dark streaks. A dark line, $1 \mathrm{I} / 2$ to 2 scales wide, extends backward from the nostril through the eye, runs the length of the body and fades on the distal portion of the tail. Below this dark line the sides are flecked or streaked with black or dark brown on a ground of grey. The under surface is uniform yellowish or whitish. The limbs are dark above and light below.

This species bears a striking resemblance in pattern to the two-lined salamander (Eurycea bislineata bislineata) which is common in southern and eastern Ohio.

Range.-New Jersey to Florida and west to the Great Plains in Kansas, Oklahoma and Texas.

The brown-backed skink has been taken in only one place in Ohio, viz., Hocking County: Salt Creek Twp. (OSM 435). In this locality, and under the circumstances in which it was taken, it is felt that the chances of its having been accidentally introduced are slight. Stupka $(1933,43)$ found the specimen October 2, 1932, as he was notching a chestnut tree preparatory to cutting it down; the lizard ran down the tree following one of the furrows in the bark.

The locality is among the wildest in Ohio. It is well wooded and hilly, farms are far apart and it is relatively inaccessible to picnic parties and tourists. Although the specimen extends the range of the species considerably to

* Statistics given are from the lone Ohio specimen. The color and pattern description is based on a study of specimens from several parts of the range. 


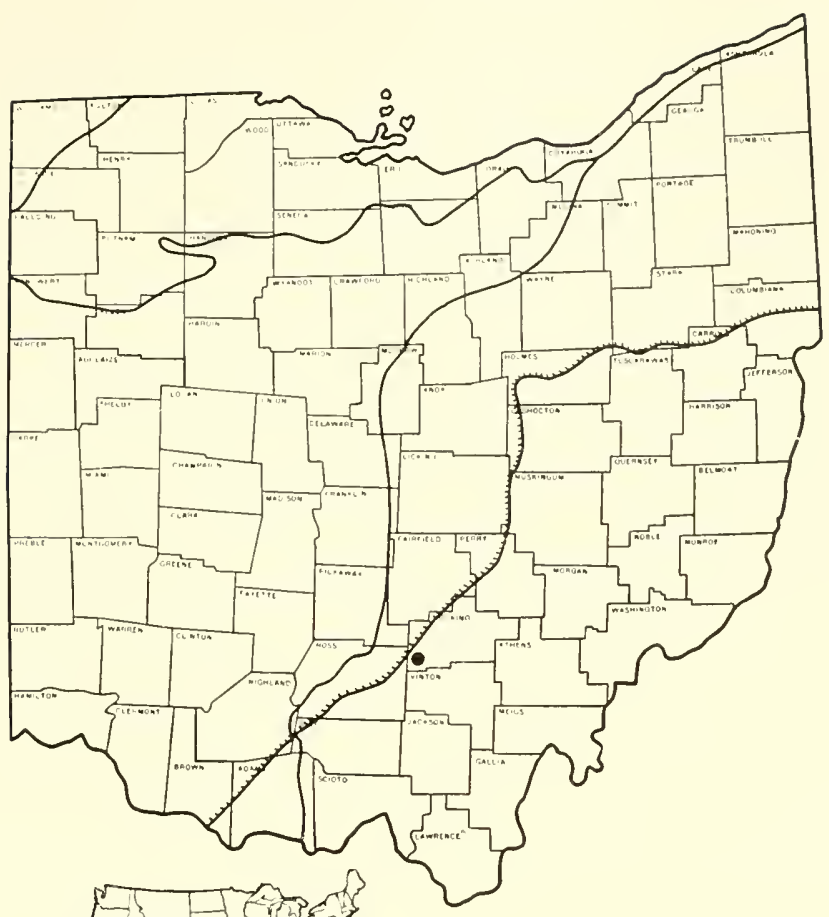

Map 3. Ohio locality record and general range of the Brown-backed Skink, Leiolopisma unicolor.

the north of its previously known range, no doubts are held as to the accuracy of the record. This lizard is probably rare in Ohio and its small size makes it an inconspicuous animal and one easily overlooked. Kirtland (1838, 188 ) states that "S. quinquelineatus and S. lateralis (unicolor) were shown to me by Mr. Dorfeuille as inhabitants of Ohio." As Stupka (loc. cit.) mentions, the Dorfeuille collection at Cincinnati has long since been destroyed and this record cannot be checked.

Habitat and Habits.-Gloyd $(1928,120)$ has summarized his observations on this lizard in Franklin County, Kansas, as follows:-

This little skink was abundant in wooded country near Ottawa. It frequented wooded bluffs, both limestone and sandstone, although it seemed to be found in somewhat greater numbers near the latter. Almost every specimen was secured among leaves on or near the ground. A few were dug out of crevices in dead logs or between rocks. A gravid female which died June 9 contained five eggs. Two other females deposited eggs on June 9 and June 27 respectively. The first set numbered four eggs, three of which hatched August 21. At time of hatching the young skinks measured 40, 44 and $48 \mathrm{~mm}$. (1 $9 / 16$ to $17 / 8$ inches) in length. There were only two eggs in the second set. When laid their dimensions were $7.8 \times 5.5 \mathrm{~mm}$. and $7.5 \times 5.5 \mathrm{~mm}$. 


\section{Eumeces fasciatus (Linné)}

Blue-Tailed Skink; Scorpion

Description.-A small lizard reaching a length of 7 inches or more. Largest perfect Ohio specimen ( 8 ), $7 \mathrm{r} / 2$ inches; smallest newly hatched individual, $21 / 16$ inches. Head small and usually little, if at all, distinct from neck; eye small. Limbs well developed; five toes and claws on each foot. Body moderately slender in young specimens; stouter in large adults. Tail long and slender and from 1.19 to 1.66 , average 1.42, times the length from snout to vent.

Scales around middle of body 27 to 30, average 29. Scales smooth. Upper labials usually 7 (in $87.5 \%$ of the cases), of which 4 precede the subocular labial. In several specimens there are 8 upper labials (of which 5 precede the subocular labial) but this number ordinarily occurs on only one side of the head, the other side bearing the customary 7 . Only $6 \%$ of the specimens examined have 8 upper labials on both sides. Lower labials 7 , rarely 6 or 8 .

Last upper labial followed by two small scales of nearly equal size and shape and lying one above the other. Occasionally these scales may be unequal in size or misshapen, but departures from the normal occur in only $10 \%$ of the cases. Prefrontals broadly in contact with each other in $50 \%$ of the specimens, narrowly in contact in $20 \%$ and not in contact in $30 \%$.

Color pattern above consisting of five light stripes, each about the width of a scale, on a darker ground. In small specimens the stripes are bright yellow and the ground color is black, but with increasing size and age the contrast lessens. The stripes become brownish or olive and the areas between them lighten. The two contrasting colors approach each other in tone until eventually the pattern may be discerned only with difficulty and the lizard may appear nearly uniform olive or olive brown. The change is most complete in large adult males and is accompanied by an increase in size of the temporal region and the appearance of reddish pigment on the head. Adult females have the last two characters little developed and always exhibit the striped pattern to a greater or lesser degree. One of the last portions of the pattern to lose its identity is the dark area between the first and second light stripes on either side.

Legs similar in color to the darker dorsal areas and occasionally with indications of light stripes. Under surface uniform yellow, the scales sometimes edged with darker. Tail in juveniles bright blue but with the striping of the dorsum continued on a third or more of its anterior end. The tail becomes greyish as the lizard grows and soon blends in color with the dorsal surface.

Specimens examined, 140; specimens preserved, 104; specimens studied, 140.

Range.-Southern New England to Florida and west to the Great Plains in South Dakota and Texas. The blue-tailed skink has been collected in a number of widely separated localities in Ohio (Map 4). Specific records are:

Adams County: Green Twp. (OSM 247). Ashtabula County: Eagleville (CMNH); Pymatuning Swamp, near Andover (TZS 1043, 1795). Auglaize CounTY: 3 mi. SW of St. Mary's (ANSP 20604; TZS 2460). Butler CountY: Near Oxford (TZS 392). Clermont County: (CSNH 1983); Union Twp. (TZS 
1997). Crawford County: $3 \mathrm{mi}$. N of Bucyrus (TZS 475); 4 mi. NW of Sulphur Springs (TZS 453). Franklin County: Columbus (OSM 156); Truro Twp. (OSM 155). Fulton County: 2 mi. S of Treadway, Amboy Twp. (TZS 1056). Geauga County: Near Burton (CSNH 2018). Hancock County: Cass Twp. (TZS 623-6). Hardin County: Dudley Twp. (TZS 1300-2); 3 mi. E. of Mt. Victory (OSM 380.2; TZS 63-72, 1159-62, 1313-6, 1385-93, 1428-38, 1747). HighLAND County: $1 / 2$ mi. E of Ft. Hill, Brush Creek Twp. (TZS 545). Hocking County: Clear Creek, Good Hope Twp. (OSM 209.1, 354); Salt Creek Twp. (OSM 401.1). Knox County: Mt. Vernon (OC). Logan County: Indian Lake (OSM 448). Lucas County: East Toledo; Reno, Jerusalem Twp. (TZS 1924); Richfield Twp. (TZS 1055, 1146-58A, 1167); Spencer Twp. (TZS 1325-31); Toledo (TZS 443). Paulding County: $4 \mathrm{mi}$. NE of Antwerp (OSM 262.1). Pike County: Mifflin Twp. (TZS 546). Putnam County: $3 \mathrm{mi}$. WSW of Ottawa (TZS 442). RichLAND County: Plymouth Twp. (TZS 1281). Scioto County: Brush Creek Twp. (TZS 717-8); 5 mi. SW of Otway (TZS 1887); $12 \mathrm{mi}$. SW of Portsmouth (TZS 1817-8); Roosevelt Game Preserve, Nile Twp. (TZS 1494); Shawnee Forest, Union Twp. (OSM 154); Sunshine, Harrison Twp. (TZS 1096A). Union CounTY: Washington Twp. (TZS 513). Wood County: E of Bowling Green (BGSU); Ross Twp. (TZS 1658); Opposite Waterville (TZS 1925).

Morse (1904) also gives the localities Chillicothe and Franklin County but since the specimens on which these were based have been lost it is impossible to determine whether they were E. fasciatus or E. laticeps.

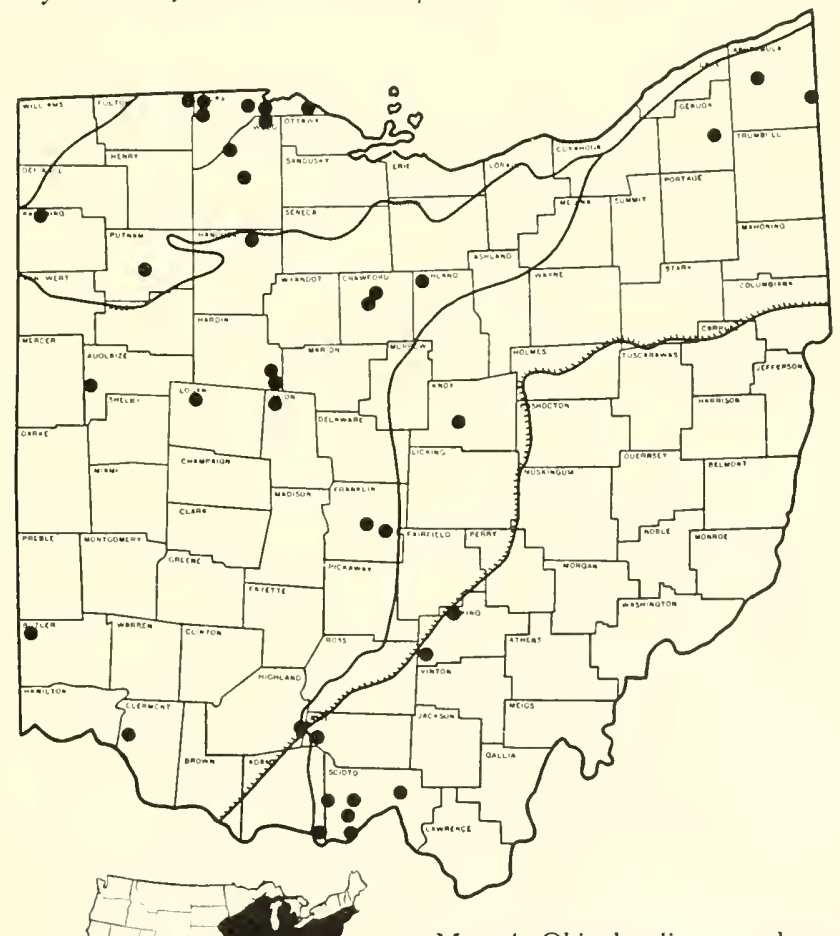

Map 4. Ohio locality records and general range of the Blue-tailed Skink, Eumeces fascialus. 
Habitat and Habits.-The blue-tailed skink is a common lizard in many parts of Ohio. In general, it might be said it is most abundant in some of the northwestern counties where former patches of swamp forest are now in evidence solely as rotting stumps and logs. It appears to be least common in eastern Ohio, especially in the dry hills and the counties in which coal mining is a major industry.

Practically every specimen collected was in a moist environment. None were found in swamps or in areas which are subject to severe spring floodings, but nearly every one taken was in or under some damp object. A favorite hiding place was under the bark of decaying logs or stumps; rotting sawdust piles were often well populated with them. When exposed to the light, as a result of their shelter being opened or pulled away, these lizards either scampered rapidly away or sought to burrow into the wood pulp or loose earth upon which they were resting. Individuals driven from cover, and those which were discovered in the open, almost invariably tried to hide under nearby objects, even the collector's feet. Some individuals appeared to have specific retreats, from which they foraged when the coast was clear, but to which they speedily returned when frightened. Thus a specimen living in a tangled mass of bark slabs on an old sawdust pile in Hardin County darted over the same route to its refuge each time some one passed. The instinct to return to a certain spot appears to be well developed, for skinks several times darted directly toward or past a collector in order to reach their abodes.

Specimens were rarely found far from the ground. They sometimes climbed upon the objects which formed their homes but when pursued they almost invariably dashed down from them. Even in southern Ohio where the many trees and rocks offer excellent opportunities for climbing, skinks of this species were found only on or near the ground. While far too few specimens were collected in this area to warrant the making of definite statements, it can at least be said that all the individuals found were in the ravines and none were on the hilltops. None were seen in trees or on cliffs such as were inhabited by swifts and large-headed skinks.

Individuals almost always tried to bite when they were seized, but their teeth are so small that they did not break the skin. Their smooth, shiny scales make them difficult objects to hold and their quick, almost machine-like movements require the collector to be agile and alert. The tail is easily broken and must often be detached by natural enemies judging from the many specimens which were found with broken or partially regenerated tails.

Skinks appear to be strictly diurnal; specimens were seen abroad only on warm, sunny days. When it was cloudy or cool, or if it were early morning or twilight, they were found only in their various hiding places. Specimens were collected from April to September and the seasonal distribution through the summer months was fairly even. A small individual was discovered near Mt. Victory, Hardin County, on January 22, 1933, under a log. The surrounding area was covered with several inches of water and the under surface of the $\log$ was decidedly soggy. The temperature was about $60^{\circ} \mathrm{F}$. at the time. Garter snakes (Thamnophis butleri, T. s. sauritus and T. s. sirtalis), milk 
snakes, red-bellied water snakes and massasaugas often were collected at the same times and places as blue-tailed skinks.

The food of this lizard consists largely of insects. Examinations of the the stomach contents of a few Ohio specimens revealed the presence of grasshopper nymphs and small beetles. Specimens kept in captivity ate meal worms, crickets, grasshoppers, spiders, roaches and newborn mice. A few individuals would lap egg from a mixture of chopped meat and eggs, and one large male killed and ate a small common swift which it swallowed head first.

Several clutches of eggs were found in the field and a number of young were hatched in captivity. In every case a brooding female was discovered with the eggs. Unless she was badly frightened she would remain with them, although she usually tried to conceal herself beneath the wood pulp or sawdust which formed the hatching medium. Females were always close to the eggs and if not actually upon them usually were touching at least one or two.

Noble and Mason (1933) have studied the brooding habits of this and other species of lizards and have shown that females will drive away small lizards, snakes and mice which might harm their eggs. They have also shown that the female, in leaving her nest and basking or running about in the sun, will have her temperature raised, and that this additional heat may aid in incubation when she returns to lie against or upon her eggs.

The eggs which were found in the field were an inch to six inches beneath the upper surface of the log or stump which sheltered them. They were oval in shape with thin leathery shells which were not easily indented by the fingers when handled. They were whitish in color but were usually stained buff by the hatching medium. Information concerning five clutches of eggs collected near Mt. Victory is giver in Table 2.

TABLE 2

Eggs and Young of Eumeces fascialus

\begin{tabular}{c|c|c|c|c|c|c}
\hline $\begin{array}{c}\text { Date } \\
\text { collected }\end{array}$ & Date hatched & $\begin{array}{c}\text { No. } \\
\text { of } \\
\text { eggs }\end{array}$ & $\begin{array}{c}\text { Average } \\
\text { dimensions of } \\
\text { eggs when found }\end{array}$ & $\begin{array}{c}\text { Maximum } \\
\text { \& minimum } \\
\text { length of eggs } \\
\text { when found }\end{array}$ & $\begin{array}{c}\text { Maximum } \\
\text { \& minimum } \\
\text { width of eggs } \\
\text { when found }\end{array}$ & $\begin{array}{c}\text { Av. } \\
\text { length } \\
\text { of } \\
\text { young }\end{array}$ \\
\hline $7 / 27 / 30 \mid$ hatching when found & 7 & $13.1 \times 9.7 \mathrm{~mm}$. & $14-12 \mathrm{~mm}$. & $10-9 \mathrm{~mm}$. & $21 / 4 \mathrm{in}$. \\
\hline $7 / 27 / 30 \mid$ hatching when found & 10 & $13.2 \times 10 \mathrm{~mm}$. & $14-12 \mathrm{~mm}$. & $11-9 \mathrm{~mm}$. & $21 / 4 \mathrm{in}$. \\
\hline $7 / 16 / 32$ & August 9.1932 & 9 & $14.4 \times 11.6 \mathrm{~mm}$. & $16-13 \mathrm{~mm}$. & $12-11 \mathrm{~mm}$. & $23 / 8 \mathrm{in}$. \\
\hline $7 / 16 / 32 \mid$ & did not hatch & 13 & $14.3 \times 11.2 \mathrm{~mm}$. & $16-13 \mathrm{~mm}$. & $12-11 \mathrm{~mm}$. & \\
\hline $7 / 23 / 32$ & did not hatch & 11 & $13.8 \times 11.2 \mathrm{~mm}$. & $15-13 \mathrm{~mm}$. & $12-10 \mathrm{~mm}$. & \\
\hline
\end{tabular}

In the laboratory the eggs were placed in the same material in which they were found. Two clutches collected July 27, 1930, were hatching when they were discovered and another group hatched in the laboratory August 9, 1932. The number of eggs in a clutch varied from 7 to 13 and the newly hatched young ranged from $21 / 4$ to $29 / 16$ inches in length. Juveniles shed their skins within a few hours after hatching.

The number of eggs has been variously reported in the literature as from 2 to 15 but since Eumeces inexpectatus (Taylor, 1932a) and E. laticeps (Tay- 
lor, 1932b) have been but recently recognized as distinct from the blue-tailed skink, there is often little way of telling to which of these three species the various authors refer. In Michigan, however, where only fasciatus occurs, Ruthven $(1911,264)$ found the number of eggs in various clutches to be 6 , $6,8,8,9,11,13$ and 14 . In the laboratory Noble and Mason $(1933,2)$ had six specimens of fasciatus which laid from 5 to 8 eggs each and one laid only 2. The latter authors give the incubation period in the laboratory as from 27 to 47 days.

\section{Eumeces laticeps Schneider \\ Large-Headed Skink; Scorpion}

Description.-The largest lizard occurring in the state. Longest adult Ohio specimen ( $\hat{o}$ ), $9 \mathrm{r} / 2$ inches, but minus a small portion of its tail. The smallest perfect specimen examined measured $43 / 4$ inches. Head small and but little distinct from neck except in large males in which the posterior portion of the head is swollen and widened laterally to a considerable extent. Limbs well developed; five toes and claws on each foot. Body moderately slender in juveniles; stout in adults. Tail long and slender and from 1.19 to 1.68 , average 1.47 , times the length from snout to vent.

Scales around middle of body 30 to 32, average 30.6. Scales smooth. Upper labials usually 8 , of which 5 precede the subocular labial. In $28 \%$ of the cases the number of upper labials is 7 , of which 4 precede the sub. ocular labial. This condition may occur on both sides of the head or on only one. Lower labials 7 , rarely 8 .

Last upper labial usually followed by a single postlabial with a small scale situated above its posterior end. The lower secondary temporal very frequently enters the auricular opening or is only narrowly separated from it. Prefrontals broadly in contact with each other in every specimen examined.

Color pattern above consisting of five light stripes, each about the width of a scale, on a darker ground. In juveniles the stripes are bright yellow on black but with increasing size and age the contrast lessens. The two contrasting colors approach each other in tone, the one darkening and the other lightening, until the pattern may be discerned only with difficulty. Adult females retain some indication of the striped pattern, but large males become uniform olive or olive brown, show considerable reddish on the head and have the posterior portion of the head considerably swollen and widened laterally.

Legs similar in color to darker dorsal areas. Under surface uniform yellowish, the scales occasionally edged with darker. Tail in juveniles bright blue but with the striping continued from the dorsum onto its anterior third or more. Tail in adults uniformly the same as the dorsal coloration.

The change from juvenile to adult coloration occurs at a greater size in Eumeces laticeps than in Eumeces fasciatus. A specimen of laticeps, 53/4 inches in length, shows no indication of change while numerous specimens of fasciatus of similar length exhibit considerable darkenings of the stripes and lightening of the areas between them. The reddish on the head and the swollen temporal region in adult males is usually much more pronounced in laticeps. 
Specimens examined, 23; specimens preserved, 23; specimens studied, 19.

Range.-Oklahoma and Texas, east to Florida and the South Atlantic States and north to the southern parts of Missouri, Illinois, Indiana, Ohio, Virginia and extreme southeastern Pennsylvania. The range of the largeheaded skink in Ohio has been found to be in the southern counties, especially in the unglaciated area and the counties bordering the Ohio River (Map 5). Localities are:

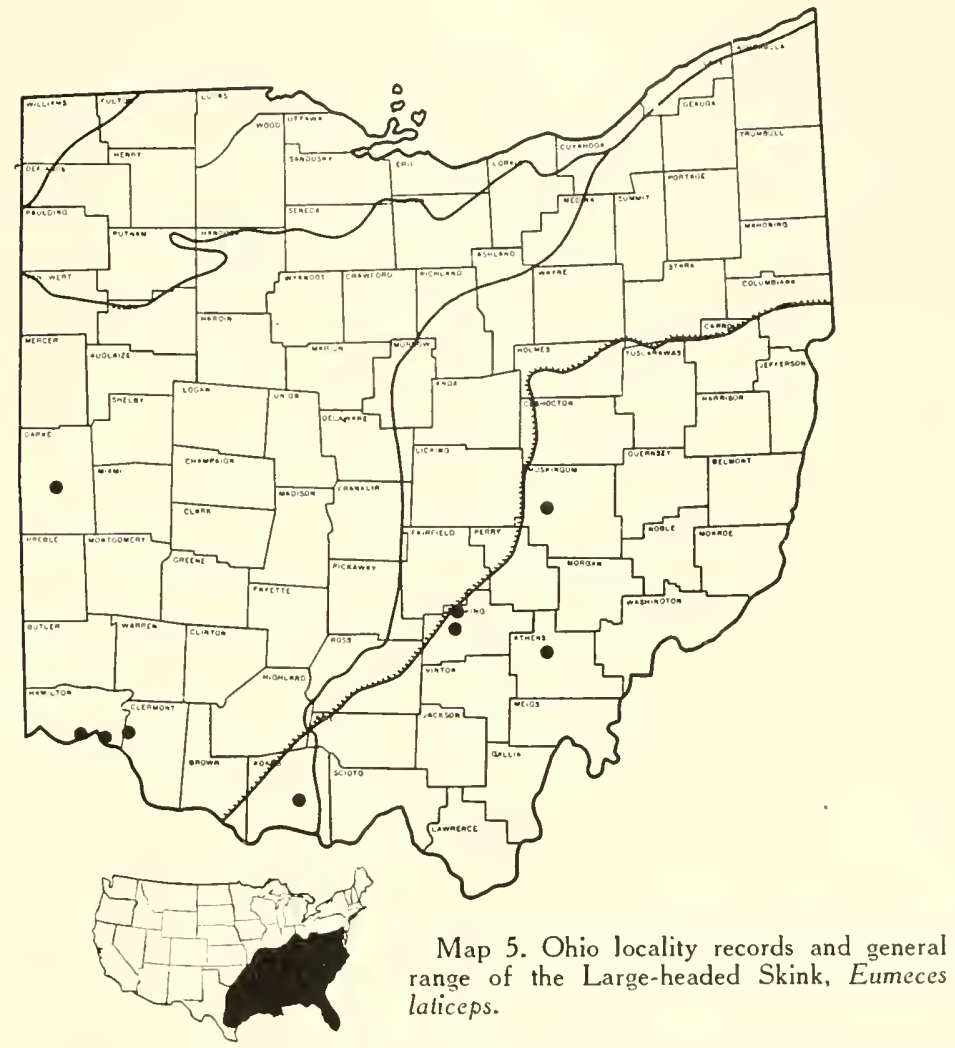

Adams County: Ohio Brush Creek, E of West Union (OSM 400). Athens County: $21 / 2 \mathrm{mi}$. N of Athens (OU). Clermont County: Near Mt. Carmel (CSNH 1942A-C); Union Twp. (TZS 1964). DARKe County: Greenville (CU 7050). Hamilton County: (CSNH 144-5; TZS 2420); Cincinnati (CSNH 149); Riverside, Cincinnati (CSNH 150A-B); Union Levee, Cincinnati (CSNH 1666). Hocking County: Crane Hollow, Laurel Twp. (OSM 463); Good Hope Twp. (OSM 191.1, 412.1, 417.1; TZS 292, 1554-6). Muskingum County: Dillon Falls, Licking River, Falls Twp. (OSM 475).

Habitat and Habits.-Apparently the large-headed skink prefers a dry habitat. All those taken were on bare rocks, cliffs, on dry hillsides, or in trees, except for three small ones discovered in a sawdust pile. Large speci- 
mens were decidedly arboreal; an adult male shaken out of a tree in Hocking County promptly ran up another. Specimens are very quick and it requires considerable agility and often much perseverance to catch them. They resist capture by biting, and while their teeth are short, their jaws are so strong that they pinch hard and are apt to break the skin.

\section{Holbrook (1842, II, 119) in writing about this large skink says,}

He chooses his residence in deep forests, and is commonly found about hollow trees, often at a height of thirty or forty feet from the ground; sometimes taking up his abode in a last year's nest of a woodpecker, out of which he thrusts his bright red head in a threatening manner to those who disturb his home. He never makes his habitat on or near the ground, and, in fact seldom descends from his elevation unless in search of food or water.

Swifts were in evidence in every Ohio locality in which large-headed skinks were collected. It is probable that the habitats of the present species and the blue-tailed skink may overlap, and especially in such artificial places as sawdust piles. However, they were clearly differentiated in the case of the relatively few specimens of both species which were collected within the range of laticeps in the state. Fasciatus appears to be essentially terrestrial, to prefer a moist environment and to be at home in the ravines in southern Ohio. Laticeps, on the other hand, is largely arboreal (particularly adults), prefers dry cliffs, sunny hillsides and hilltops and lives in general above the habitat of fasciatus.

It is probable that the food consists largely of insects although specimens are large and powerful enough to overcome young rodents as well. Captives ate a wide variety of insects and lapped egg with their tongues.

Noble and Mason (1933) have found that females brood their eggs as do the females of the blue-tailed skink. Two females which they had in captivity laid 6 eggs each and another laid 7; the incubation period was 39, 48 and 56 days in the case of these three clutches. When laid the eggs were 15 and 18.5 $\mathrm{mm} . \times 9 \mathrm{~mm}$. and were distinctly larger than the eggs of blue-tailed skinks which were laid at the same time. At the time of hatching, however, the eggs of the two species were nearly the same size but the young laticeps were nearly $3 \mathrm{~mm}$. longer from snout to vent than the young fasciatus. Although they supplied the same food to juveniles of both species the young laticeps grew much more rapidly than the young fasciatus.

\section{Carphophis amoena helenae (Kennicott) WORM SNAKE}

Description.-A small snake attaining a length of a foot or slightly more. Largest adult Ohio specimen ( $q$ ), 123/4 inches in length; smallest juvenile (possibly recently hatched), 4 inches. Head small, flattened and without a constriction at the neck. Eye small. One nasal; the nostril in the anterior half. Loreal long and narrow; no preocular. Internasals and prefrontals separate or fused.* Body subcylindrical and moderately stout. Tail short and tapering to a stout sharp tip.

\footnotetext{
* See paragraph headed "Affinities" on page 35.
} 
Dorsal scale rows 13 throughout the length of the body; the scales smooth. Upper labials 5 (4 on one side in a single specimen); lower labials 6 ( 5 and 7 in single instances). One postocular; temporals usually $1-2$, rarely 1-1 (the anterior temporal fused with the parietal in three cases). Ventrals in males 113 to 124 , average 118 ; in females 121 to 128 , average 124 . Subcaudals in males 30 to 38, average 35; in females 25 to 31 , average 27 . Anal plate divided.

Color above, including rostral, head and entire dorsal surface (except the first scale row) some shade of chestnut or pinkish brown. Color below, pink, including upper and lower labials, chin, throat, abdomen, under surface of tail, the first row and frequently a portion of the second row of scales. Preserved specimens fade to light brown above and yellow below. Newly hatched young are usually darker in color above than adults.

The scales are opalescent and the general appearance shiny. The body is translucent and if specimens are held before a strong light the lung and heart may be seen in movement.

Specimens examined, 60; specimens preserved, 56; specimens studied, 56.

Affinities.-Blanchard (1924a) separates Carphophis amoena helenae from Carphophis amoena amoena on the basis of the frequency with which the internasal and prefrontal plates are fused with one another. His studies show that in belenae $89 \%$ of the specimens have the plates fused and in amoena $97 \%$ have them separate. Of the 56 Ohio specimens studied, 40 , or $71 \%$ have each internasal fused with its corresponding prefrontal to form a single large scale on either side of the median line. In 11 specimens the internasals and prefrontals are entirely separate, in 3 they are separate on one side but fused on the other, and in 2 they are partially separated although appearing essentially as one scale. The Ohio specimens thus show a somewhat intermediate condition between amoena and helenae, but the material as a whole is much closer to the latter.

Range.-Central Illinois to southern Ohio and West Virginia and south to southeastern Louisiana, Mississippi and northwestern Alabama. In Ohio the worm snake has been collected only in the southern counties (see Map 6). Locality records are:

Adams County: 3 mi. W of Rarden (TZS 1072, 1163). Greene County: Yellow Springs (Morse, 1904). Hocking County: "Neotoma," Good Hope Twp. (Pl. 5, fig. 1); Salt Creek Twp. (AS; OSM 395.1, 407.1; TZS 977). LAwrencE CountY: Ironton (Smith, 1882). MeIGs CountY: (Morse, 1904); 2 mi. E of Bashan (OSM 394.1); Salem Twp. (TZS 1170). Monroe CoUnTY: Morton (USNM 8853). PIKE COUNTY: 6 mi. WSW of Bainbridge (TZS 770-1); Laurel Ridge, Sunfish Twp. (TZS 1076-7); 4 mi. E of Waverly (OSM 415.1-.2; TZS 1061-9). Ross Countr: Salt Creek near Londonderry (shed skin). Scióto CounTY: Near Friendship (TZS 1057):2 mi S of Henley (TZS 1879); $8 \mathrm{mi}$. SW of Otway (TZS 1883-4, 1922); 8 mi. SW of Portsmouth (OSM 76.1-.7; TZS 1138-45: $10 \mathrm{mi}$. SW of Portsmouth (TZS 1813-5, 1878); 12 mi. SW of Portsmouth (TZS 1806-12). Vinton County: 1 mi. W of Allensville (TZS 293). 


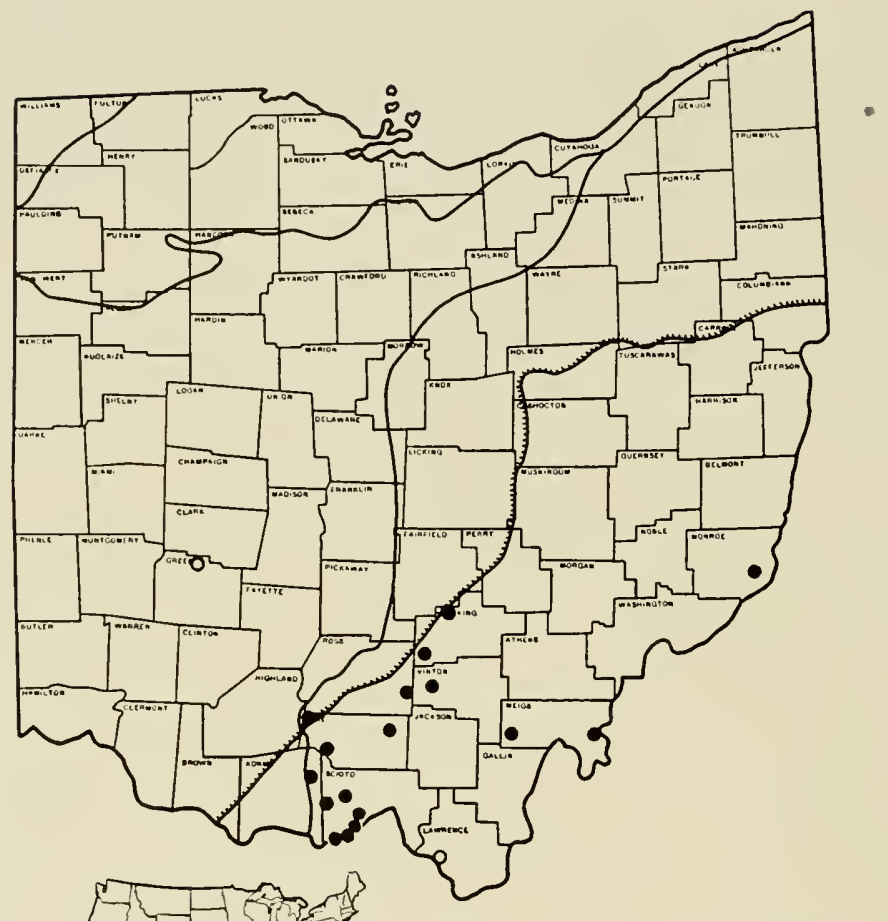

Map 6. Ohio locality records and general range of the Worm Snake, Carphophis amoena helenae.

Habitat and Habits.-The worm snake is a secretive serpent and is rarely seen abroad. Moist situations seem to be preferred and a majority of the specimens collected in the state were found in or near damp woods. Frequent hiding places were under flat stones, boards or decaying logs, or beneath the loosely adhering bark of the latter. Masses of decaying leaves or other vegetable detritus were also inhabited by worm snakes and no doubt they may occur under suitable cover on almost any part of the forest floor. Specimens suddenly exposed by removing their shelters were momentarily dazzled by the sudden brightness but almost immediately they sought cover, making their escape into a crevice or beneath some object. Agility sometimes was required to capture them, especially if they attempted to crawl down one of the insect burrows which often communicate with their retreats.

Specimens were found to be common on several hillsides in southern Ohio, particularly in Pike and Scioto Counties. Here the woods, largely oak and hickory, are relatively thin and often pastured, and the ground is liberally strewn with slabs of sandstone of diverse sizes and thicknesses. Several times systematic overturning of the latter revealed a half dozen or more specimens 
during a few minutes' hunt, but only rarely was more than one taken under any one rock.

Milk snakes often were found in the vicinity of colonies of worm snakes and are probably important enemies of the latter species; on one occasion a milk snake disgorged a worm snake shortly after being captured. The black king snake, ground snake, Storer's snake and the ring-necked snake were also obtained at one time or another with worm snakes. The ring-necked snake was uncommon where the worm snake was abundant and vice versa. In certain parts of Scioto County the present species appears to be the dominant woodland snake.

Most specimens were collected during May and a few were taken in April and early June; later in the season as the hills and woods became drier, the surface of the ground was apparently less favorable and worm snakes evidently retired to moister situations less accessible to the collector. Three individuals were taken in a decaying $\log$ in August; no others were found during the summer or fall months.

When a worm snake was held in the hand, the head and the stout pointed tail both sought crevices into which the snake could burrow its way. None of the many specimens examined attempted to bite.

What the worm snake eats is not well known. Captive specimens fed upon earthworms. Atkinson $(1901,147)$ found an earthworm in one, Holbrook (1842, III, 116) mentions insects and Ditmars $(1936,261)$ states that "the species feeds largely upon earthworms and the soft bodied grubs of insects."

The breeding habits of this species have been noted by Blanchard (1925b, 373-82) from observations made upon specimens secured in southern Indiana. During the early part of July, females collected by him deposited clutches of small white eggs varying in number from 2 to 5 . These were laid in the decayed wood provided; they hatched about two months later. "The eggs, upon deposition, were entirely separate." Measurements showed them to vary from 17 to $27.5 \mathrm{~mm}$. in length and from 7.5 to $9 \mathrm{~mm}$. in width. Upon hatching the young snakes were 87 to $105 \mathrm{~mm}$. (3.42 to 4.13 inches) long.

\section{Diadophis punctatus edwardsii (Merrem)}

\section{Ring-Necked SNAKe}

Description.-A small snake occasionally attaining a length of about a foot and a half. Largest adult Ohio specimen ( 9 ), 193/4 inches in length; smallest juvenile hatched in captivity, 45/8 inches (a specimen collected May 30, 1931 in Hocking County measured $4 \mathrm{1} / 2$ inches). Head small, flattened and but little distinct from neck. Eye small. Head plates normal. Two nasals, the nostril lateral and between them. Loreal present. Body slender and subcylindrical. Tail slender, moderately long and tapering to a point.

Dorsal scale rows normally 15 throughout the length, but 15-13, 15-14 and 15-17-15, respectively, in 3 individuals; the scales smooth. Upper labials 8, 
less often 7; lower labials 8, less commonly 7 and infrequently 9. Oculars 2-2 except in one specimen from Pike County which has the postoculars united to form a single scale on the left side. Temporals $1-1$, very rarely 2 in either place (in a few individuals one or more posterior upper labials, usually the next to the last, extend upward to meet the parietal, thus separating the two temporals or uniting with either). Ventrals in males 139 to 161 , average 151.2; in females 150 to 165 , average 157.8. Subcaudals in males 51 to 65 , average 54.8 ; in females 47 to 62 , average 52.1. Anal plate divided.

Color above, dark grey, bluish slate or black. A prominent yellow or orange-yellow ring, varying from 1 to 3 scales in width, crossing the neck above, and bordered anteriorly and posteriorly by a shade somewhat darker than the dorsal color. Under surface uniform yellow or orange except for a small dash of pigment, somewhat darker than the dorsal color, on the posterolateral tip of each ventral and subcaudal. A few scattered black dots on the ventral surface in some specimens, these tending to be arranged in a midventral row, particularly on the posterior portion of the belly. Labials and
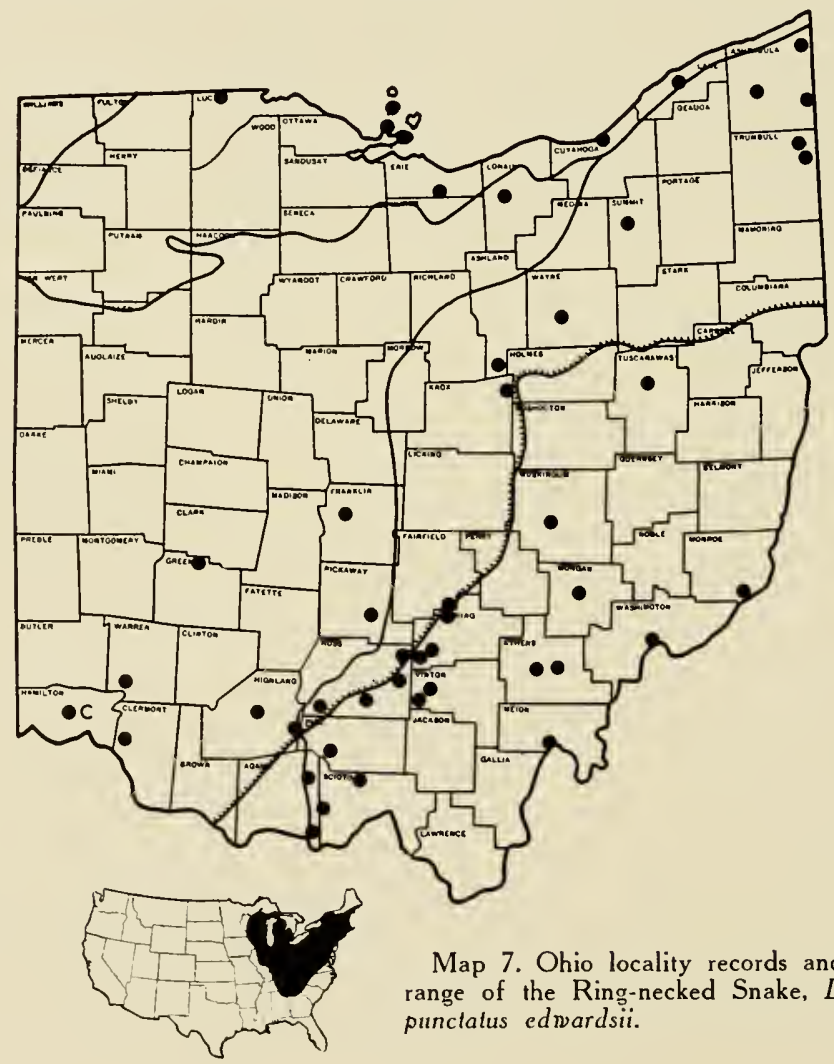

Map 7. Ohio locality records and general range of the Ring-necked Snake, Diadophis punctalus edwardsii. 
lower half of rostral yellowish, very rarely marked with a few black dots. Top of head somewhat darker than remainder of dorsal surface.

Juveniles similar to adults but frequently darker above. Many rural residents think the ring-necked snake is the young of the black racer.

Specimens examined, 149; specimens preserved, 111; specimens studied, 85.

Range.-The mountains of the Carolinas through the Appalachians northward to the northern peninsula of Michigan, Wisconsin, southern Canada and the Maritime Provinces.

Ring-necked snakes occur throughout a large part of Ohio and may range throughout the state, but the available records are all from the eastern and southern counties and those bordering Lake Erie (Map 7). Specimens appear to be rare in the heavily mined areas and especially in the hills which have been denuded of their timber for many years. In the western counties, which are largely devoted to agriculture, this species has not yet been taken. Possibly it may occur in the remaining wood patches, in stream valleys or in other favorable places in this area, but careful search has failed to reveal its presence. Whether it has always been rare or absent here, whether it has been reduced in numbers or exterminated by the destruction of its habitat, or whether the technique of the collectors has been at fault cannot be stated. Records are:

Adams County: Green Twp. (OSM 78.r); 3 mi. W of Rarden (TZS 107I). Ashland County: Clear Fork State Park, Hanover Twp. (TZS 2220). AshtaBula County: Monroe Twp. (OSM 215.1-2); Pymatuning Swamp near Andover (TZS 1027, 1646): Rock Creek (OSM 204.1). Athens CountY: Near Athens (OU); Canaan Twp. (TZS 1050-1). Clermont CounTy: (CSNH 198I); Union Twp. (CSNH 1402, 1555-6, 1718; TZS 1965). CuYahoga CounTY: Cleveland (CMNH; USNM 1899). ERIE CounTY: Near Village Creek, E of Milan (SHS); Fairfield County: Sugar Grove (OSM 2.1-2, 3.1-2, 183). Franklin County: Hayden's Falls, Norwich Twp. (OSM 471). CaReENE County: Yellow Springs (MCZ 746). Hamilton County: (Morse, 1904; CSNH 1973). Highland CounTY: 2 mi. S of Carmel (TZS 1499-501); near Hillsboro (TZS 1716-7). HockING Countr: Conkle's Hollow, E of Haynes (OSM 358); Clear Creek, Good Hope Twp. (OSM 79, 80.1, 172.1-.2, 419; TZS 297, 1058-9); Salt Creek Twp. (AS, OSM 300.1-.2; TZS 971-6). KNox County: Edlam, Greer P. O. (OSM 190.2-3). Lake County: Painesville (OSM 433.1). Loran County: Oberlin (OC). Lucas CountY: Sylvania (TZS 110, 1446). MeIgs CountY: Pomeroy (OSM 233.1). Monroe County: Jackson Twp. (TZS 484). Morgan County: Malta Twp. (OSM 373). Muskingum County: (CSNH 2009); Zanesville (OSM 474). OtTawa Countr: Catawba Island (BGSU, TZS 722, 1692); Danbury Twp. (TZS 1183-92); N. of Sandusky Bay (UMMZ 52070); Put-in-Bay (SL). PICKAWAY County: Circleville (OSM 255.3). Pike County: Laurel Ridge. Sunfish Twp. (TZS 1078-9). Ross CounTY: Bainbridge (BHFM 132); Colerain Twp. (TZS 298-300); Huntington Twp. (TZS 1821); Rattlesnake Knob, Harrison Twp. (TZS 301). Scioto County: Near Bear Creek, Morgan Twp. (TZS 1871); 8 mi. SW of Otway (TZS 1885-6). SUmmit CountY: Ira (OSM 77, 292). TRUmbull CounTY: Kinsman (USNM 60024); Vernon Twp. (TZS 334, 1012). Tuscarawas CounTY: Dover (CSNH 1976). Vinton County: I mi. W of Allensville (TZS 294-6); Harrison Twp. (TZS 980-2, 1166). WarReN CounTY: Foster (CSNH 1241). Washington CounTY: Harmar, W. Marietta (TZS 2010); Marietta (MC, USNM 7286). Wayne County: Miller's Pond, Wooster (WC). 
Habitat and Habits.-While the ring-necked snake is so abundant as to be probably the dominant woodland snake in many parts of Ohio, it is seldom seen. Specimens were uncovered by overturning flat stones, boards or logs, peeling the bark from decaying logs and stumps, moving slabs on old sawdust piles, raking through bark chips, heaps of leaves or piles of small stones, etc. As many as five were found at one time and on several occasions two or three were discovered under the same shelter. A dozen or more specimens were secured on some field trips but such success was rare and systematic search was often fruitless even in areas which appeared very favorable. It was unusual to find this snake, or any other, under objects which also sheltered any considerable number of ants or ground beetles.

The majority of specimens taken were beneath flat stones since this is the easiest cover to investigate. There was no apparent preference for certain types of rocks; individuals were as numerous and in as good condition under limestone as under sandstone or shale. In practically every case, however, the hiding place was moist and in or near woods. Since most of the level and less rugged parts of Ohio were long since lumbered, the hilly, wooded areas were the most productive; the snakes were found as often on the tops of the hills as on the slopes or in the valleys between them.

Specimens suddenly exposed to light sought to crawl under any nearby object even to the collector's shoes. Most were mild tempered when first caught although some would writhe about or force the depressed head between the fingers in an effort to escape. Occasionally one would strike and bite but the teeth were too small to do damage. The musk glands were usually copiously discharged during the excitement of capture; the fluid has a pungent and unpleasant odor.

Individuals were collected in every month from March to October inclusive, but most were obtained in May. The most productive period was from the time the snakes left hibernation in the early spring until the habitats became unfavorably dry during the summer.

The food of the ring-necked snake consists of cold-blooded animals including snakes, lizards, salamanders, frogs, insects and earthworms. Detailed records are: narrow-mouthed toad (Cope, 1900, 753); beetles and earthworms (Atkinson, 1901, 148); beetles, undetermined insect fragments, salamander (Surface, 1906, 173); green snake and red-bellied snake (Ditmars, 1936, 277); salamander (Blanchard, 1927, 286). Captive specimens ate earthworms and red-backed salamanders (Plethodon cinereus).

A fernale from Ashtabula County, measuring 193/4 inches in length, deposited six eggs June 22, 1932. These were adherent to one another, were in a single cluster and were laid in leaf mould and damp earth beneath a piece of bark in the snake's cage. They were white but stained yellow in places. Two of these eggs hatched August 14, 1932 (53 days after being laid), and the young were $43 / 4$ and $45 / 8$ inches in length, respectively.

Blanchard (1937a) has summarized his observations on 202 sets of eggs from northern Michigan. He found they were laid in moist (not wet) places, such as beneath the hard outer shell of rotten logs, and that the eggs in a set 
varied from 1 to 7 in number, but were most commonly 3 or 4 . Females laid in late June or very early July and showed a tendency to deposit their eggs in community nests; single logs were found containing as many as 48 and 55 eggs. Length of eggs varied from 18 to $43 \mathrm{~mm}$. and widths from 6 to 12.4 $\mathrm{mm}$. In a previous paper $(1930,10)$ Blanchard stated that the incubation period averaged 56 days and that newly hatched young varied from 105 to $143 \mathrm{~mm}$. (41/8 to $55 / 8$ inches) and averaged $124 \mathrm{~mm}$. (47/8 inches) in length.

\section{Heterodon contortrix (Linné)}

\section{Hog-Nosed Snake; Spreadhead; Puff Adder}

Description.-A stout bodied snake attaining a length of about three feet. Largest Ohio specimen ( 9 ), 39 inches; smallest juvenile, $611 / 16$ inches. Head medium and little distinct from neck. Rostral large, projected forward and upward and terminated by a bluntly rounded tip, directed backward from which is a keel-like ridge. Usually 1, rarely 2, small narrow scales (azygous) immediately posterior to the rostral, and separating the internasals entirely and the prefrontals partially. Normally one loreal but in two specimens there are 2 small scales arranged one above the other; in one individual the loreal is fused with the preoculars on the left side. Two nasals, the nostril entirely in the postnasal. Two large temporal scales bordering the last three upper labials and separated from the parietals by three rows of small scales. A series of 9 to 12 scales (plus the supraocular) completely encircling the eye, these taking the place of preoculars and postoculars and separating the upper labials from the orbit. Body stout; tail short.

Dorsal scale rows usually 25-23-21-19 and less often 27-25-23-21-19 (23-2119 in one specimen from Adams County and reduced posteriorly to 17 in a specimen from Pike County). Scales keeled except for the first one to three rows. Upper labials 8, rarely 7; lower labials 10, less often 9 or 11 . Ventrals in males 122 to 134 , average 129 ; in females 122 to 141 , average 134 . Subcaudals in males 47 to 57 , average 50 ; in females 40 to 52 , average 46 . Anal plate divided.

Ground color above, yellow, orange, red, brown, olive or dark grey. A vertebral series of 23 to 33 large dark blotches alternating with a lateral series of smaller dark blotches. Ground color usually brightest and richest between the blotches of the median series. Tail banded alternately with light and dark. Occasional specimens are uniform black or olive grey above with the markings absent or only faintly evident.

A dark band on the suture of the frontal and prefrontals and another wider and more or less interrupted band across the parietals and the posterior part of the frontal and supraoculars; a dark line from the eye to the angle of the mouth. A large dark elongate blotch on either side of the neck, normally with narrower extensions forward and upward to the ends of the band across the parietals. Belly in adults yellowish, greyish or pinkish with more or less conspicuous spots of greenish or grey; in juveniles the spots more confluent and giving to some a uniform black appearance on at least a part of the abdo- 
men. Throat and chin, and almost always the under side of tail, lighter than rest of the ventral surface.

Two enlarged teeth, one on either side, in rear of upper jaw. These solid; no evidence of poison glands, ducts, etc.

Specimens examined, 103; specimens preserved, 52; specimens studied, 23.

Range.-Massachusetts to Florida, westward to central Texas and eastern Montana. In Ohio the hog-nosed snake occurs in the northwestern and southern portions (Map 8). The correlation of range with habitat preferences is discussed below. Locality records are:

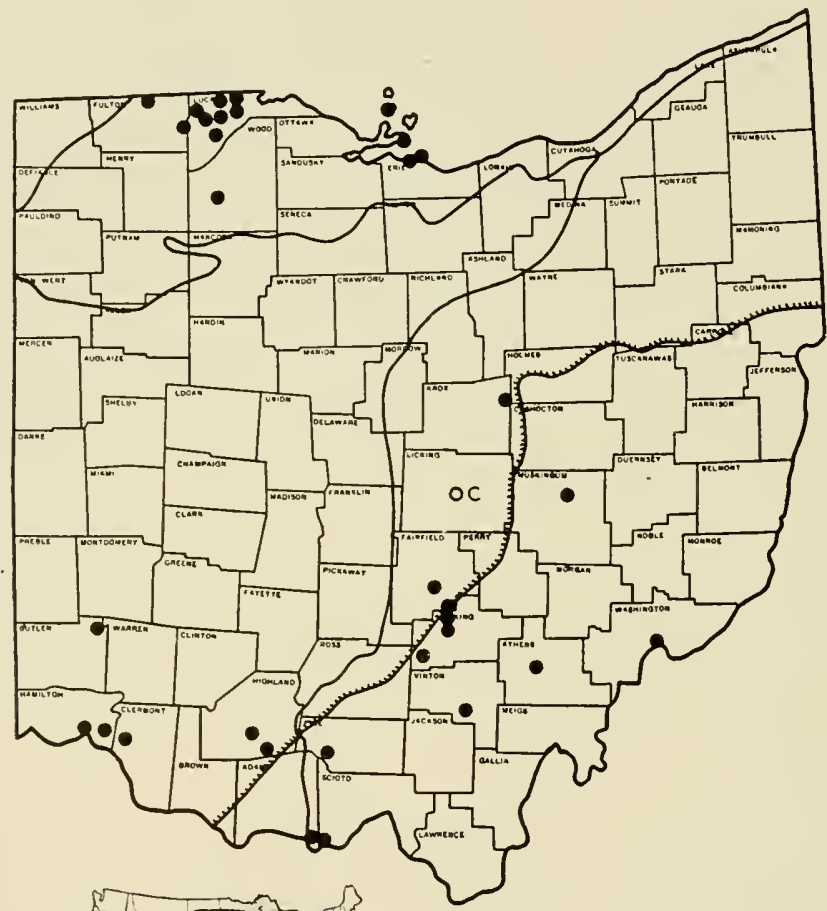

Map 8. Ohio locality records and general range of the Hog-nosed Snake, Heterodon contortrix.

Adams County: Green Twp. (OSM 81). Athens County: Near Athens (OU). Butler County: Poast Town (MU). Cleermont County: Union Twp. (CSNH 1407, 1411, 1557; TZS 1958). ERIE CountY: Cedar Point (BGSU; OSM 4-6; SHS; UMMZ 32852, 39!16): Sandusky (OSM 8; UMMZ 40941). FalRField County: Near Lancaster (OSM 375); Sugar Grove (OSM 7). Fulton County: Lyons (TZS 101); near Swanton (BGSU). Hamilton County: (Morse, 1904); Glendale, Cincinnati (CSNH 1484); Newtown (CSNH 1267). Highland CounTr: Near Belfast (TZS 764); Harrisburg, 5 mi. S of Hillsboro (TZS 748). 
Hocking County: Cantwell Cliffs, Laurel Twp. (OSM 362); Clear Creek, Good Hope Twp. (OSM 82); Salt Creek Twp. (AS). Knox CountY: Brinkhaven (OSM 366.2). Licking County: (Morse, 1904). Lucas County: Crissey (TZS 14); Holland (TZS 226-7, 956, 2284); Monclova (TZS 999); Spencer Twp. (BGSU); Springfield Twp. (OSM 244); Sylvania Twp. (TZS 105, 313); Toledo (TZS 102); Trilby. Muskingum County: Section 15, Salem Twp. (OSM 470). Ottawa County: Bay Point, Danbury Twp.; Put-in-Bay (SL). Pike County: Laurel Ridge, Sunfish Twp. (TZS 1443, 1942). Scютo CountY: Buena Vista (OSM 83). Vinton County: 2 mi. S of Dundas (DOR). Washington County: Marietta (MC; USNM 1180). Wood County: Section 20, Liberty Twp. (TZS 955).

Habitat and Habits.-The hog-nosed snake cannot be considered as abundant in the state. In some areas it is fairly common but its unusual behavior consistently causes uninformed and prejudiced persons to kill it. It probably will become less and less numerous in the state, at least in all but the wilder portions of its range.

In southern Ohio it occurs in most of the hilly counties and is particularly partial to the drier and more sandy districts. While a few specimens were taken in moist ravines, the majority were in dry open woods of either pine or deciduous dominance.

In northwestern Ohio the distribution, as indicated by the specimens taken, is more or less correlated with fossil and modern beaches. Thus west of Toledo this snake is fairly common in the sandy area locally known as the "Oak Openings" (see page 11). It is also found amid the dunes of a fossil beach near Portage, Wood County, and along Lake Erie on Bay Point in Ottawa County and Cedar Point in Erie County. It is apparently unknown in northeastern Ohio.

The field data indicate that the hog-nosed snake usually was found in the open, either on the prowl or sunning itself. However, a large specimen, about to shed its skin, was discovered hidden in the midst of a pile of stones on the top of a dry ridge in Pike County.

The most characteristic behavior of the hog-nosed snake is its threatening attitude and subsequent antics when disturbed in the field. Instead of attempting to escape, most specimens flatten the head and neck to twice or more the normal width. At the same time; they inflate the lung with air which they expel with a loud hiss. Some even strike, but always (apparently) with the mouth closed. When alarmed or annoyed sufficiently one may open its mouth widely, make a few convulsive movements, roll upon its back, wriggle a few times and then remain still. To all appearances, it is dead and it may be picked up, tossed about, hung over a fence or handled in a variety of ways without showing signs of life. If, however, it is placed upon the ground right side up it will roll over on its back, thus giving itself away! If it is let strictly alone for a time, it will raise its head and then turn over and crawl away.

One individual, instead of playing dead, varied the procedure by holding its head and neck in the air and its mouth wide open as it crawled slowly about. Most captive specimens refuse to perform after they have gone through their maneuvers once or twice. 
Behavior, such as that outlined above, is apt to be alarming to the novice and the belief is widespread that this harmless snake is poisonous. Common names carrying this implication are numerous and the writer has heard it called blow viper, sand adder, checkered adder, hissing viper, blow snake, puff adder, etc. Credulous persons even maintain that its breath is venomous. In "The World and the United States in Particular" by Jebediah Morse (published in 1793), we read the following concerning this snake: "Of the venomous serpents which infest this water (the islands and banks toward the west end of Lake Erie), the hissing snake is the most remarkable. It is about 18 inches long, small and speckled. When you approach it, it flattens itself in a moment, and its spots, which are of various colours, become visibly brighter through rage; at the same time it blows from its mouth, with great force, a subtile wind, said to be of a nauceous smell; and if drawn in with the breath of the unwary traveler, will infallably bring a decline, that in a few months must prove mortal. No remedy has as yet been found to counteract its baneful influence." This superstition is still widely prevalent.

Specimens were collected from April to October inclusive and there apparently was little seasonal fluctuation; they were taken about as many times in summer and fall as in the spring. Most of those found in September and October, however, were recently hatched juveniles. That these snakes leave hibernation during warm spells in the winter is attested by the fact that specimens were collected in Clermont County on January 24, 1933.

Although the hog-nosed snake was found in areas inhabited by a variety of reptiles it was most often associated with the box turtle and two amphibians, the American toad (Bufo americanus americanus) and Fowler's toad (Bufo fowleri). Freshly caught snakes disgorged toads of both species, and also leopard frogs (Rana pipiens) and green frogs ( $R$. clamitans). A specimen from Cedar Point, Erie County, had a nestling sparrow in its stomach. Captives showed a decided preference for toads although frogs were sometimes accepted. A small individual ate several crickets.

Two sets of eggs were laid in captivity by Ohio specimens at the Toledo Zoo. The first of these was from a female 33 inches in length collected in Sunfish Twp., Pike County, on May 29, 1932. It deposited 27 eggs June 19,1932 , which varied from 29 to 35 , average $32 \mathrm{~mm}$., in length, by 19 to 22 , average $20 \mathrm{~mm}$., in width. The second clutch of 12 eggs was from a female 231/4 inches in length (but with incomplete tail) collected May 27, 1934, at Holland, Lucas County; this set was laid July 1, 1934. Measurements were from 24 to 28 , average $26 \mathrm{~mm}$., in length and from 15 to 17 , average 15.8 mm., in width. A specimen 30 inches in length collected August, 1927, in Green Twp., Adams County, contained 7 well formed eggs.

Gloyd $(1932,403)$ records the hatching of 8 young, August 23 and 24, 1928 , sixty days after the eggs were laid by a female collected in Kansas. The lengths of the young varied from 168 to 203 , average $192 \mathrm{~mm}$. $(65 / 8$ to 8 , average $79 / 16$ inches). 


\section{Opheodrys aestivus (Linné) \\ Keeled Green SNake}

Description.-A very slender snake attaining a length of three feet. Largest adult Ohio specimens ( $\hat{o} \&$ \& $)$, 31T/2 inches; smallest juvenile, $81 / 16$ inches. Head narrow and slightly distinct from neck. Eye medium large; head plates normal. One nasal; the nostril lateral and centered in the nasal. Loreal present. Body very slender and subcylindrical but tapering somewhat at either end. Tail very long, whip-like, tapering gradually to a slim pointed tip and varying from $34.6 \%$ to $41.8 \%$, average $37.8 \%$, of the total length of the snake.

Dorsal scale rows 17-15; scales keeled except for the first one to three rows. Upper labials 7, sometimes 8, rarely 6; lower labials 8, sometimes 7 (6 on one side in one individual and 9 in another). Preoculars 1, occasionally 2; postoculars 2 ( 3 on one side in one specimen). Temporals $1-2$, occasionally 2-2. Ventrals 150 to 164 ; subcaudals 120 to 142 . Anal plate divided.

Color bright green above; yellowish, with a greenish tinge, below. The bright uniform green coloration of this snake and the smooth green snake have caused many persons to have the erroneous notion that both these innocuous serpents are venomous.

Specimens examined, 25; specimens preserved, 24; specimens studied, 21.

Range.-Southwestern Connecticut to Florida, west to northeastern New Mexico and north in the Mississippi Valley to southern Ohio, central Indiana, central Missouri and southeastern Kansas. The keeled green snake occurs in several of the southern counties of Ohio (Map 9). Locality records are:

Adams County: $2 \mathrm{mi}$. W of Buena Vista, Green Twp. (OSM 87); $1 \mathrm{mi}$. W of Lynx (DOR). Athens County: Between Athens and The Plains (OU). Clermont CountY: Union Twp. (CSNH 1140, 1146, 1186A-B, 1239-40, 1274, 1452, 1719; OSM 440; TZS 1684, 1990-2). Hamilton County: (Morse, 1904). Jackson County: Canter's Cave, Jackson Twp. (TZS 794). Lawrence County: Ironton (Smith, 1882). Meigs County: Portland (OSM 434.1); Salem Twp. (TZS 1194). Pike County: Coopersville (TZS 716). Scroto County: Portsmouth (OSM 207); Roosevelt Game Preserve, Nile Twp. (TZS 793); 2 mi. S of Rushtown (TZS 715); Shawnee Forest, Union Twp. (OSM 86).

Habitat and Habits.-The keeled green snake is not rare in certain parts of southern Ohio, and in Clermont and Scioto Counties it was taken frequently. It was found most commonly in hilly areas where it occurred in either deciduous or evergreen woods and in open meadows and prairies. Individuals were collected on the ground, on low pine and locust trees and on raspberry and blackberry vines; one was accidentally dislodged from a group of plants overhanging the cliff at Canter's Cave in Jackson County. Specimens were usually very difficult to detect unless they were in motion. The method suggested by Ditmars $(1907,323-4)$ of shaking bushes to get the snakes to move and thus reveal themselves was tried, but the enormous number of bushes in proportion to the few green snakes caused the experiment to be unsuccessful.

Although snakes of this species were usually mild-tempered, an occasional 


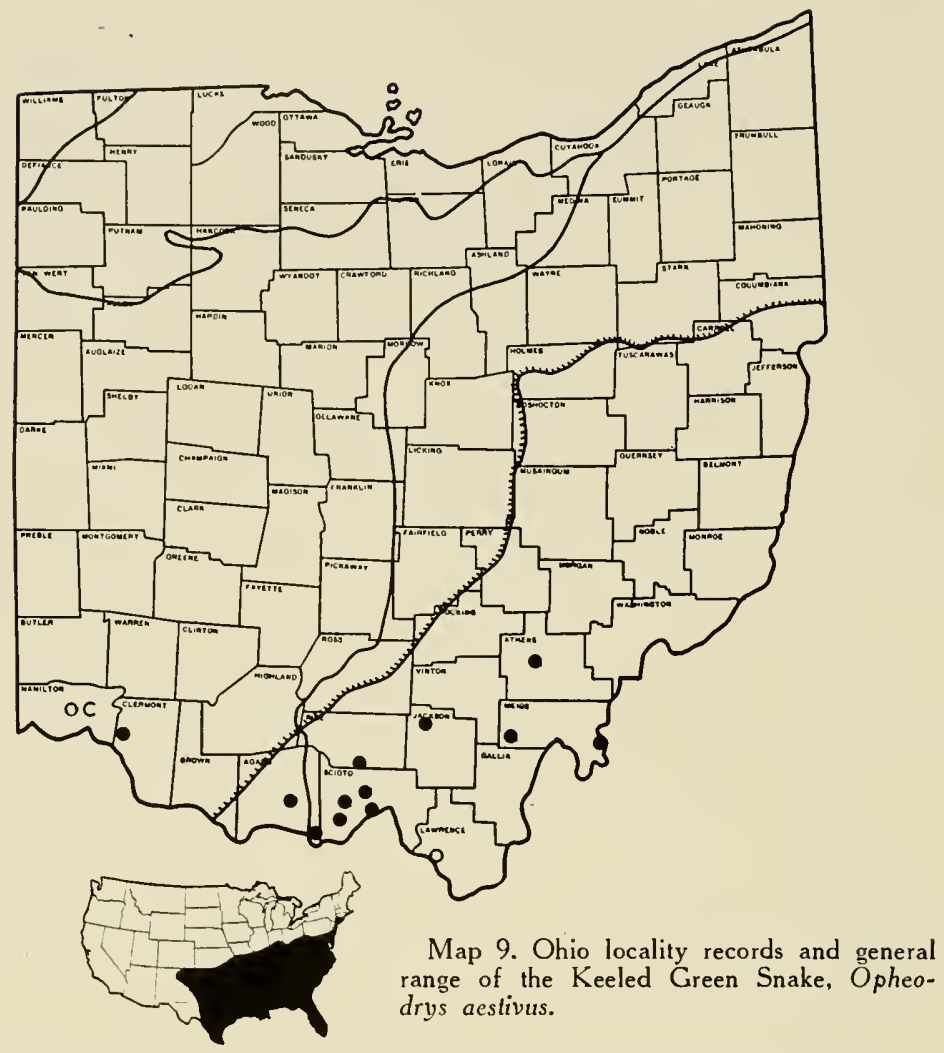

one struck repeatedly from a position in which the head and neck were looped backward and upward and the mouth was held open in readiness for the next advance. Specimens climb readily and were found more often in an arboreal habitat than not. The tail is somewhat prehensile.

Almost all of the keeled green snakes examined were collected in the summer and fall rather than in the spring; there is one record for April but none for May.

Records on the food of this snake include grasshoppers and crickets (Ditmars, 1936, 281); flies and other insects (Shaw, 1802, 551); insects (Holbrook, 1842, IV, 19 and Garman, 1892, 284). Captive specimens ate crickets and grasshoppers and several were collected on vines and other plants on which grasshoppers and other Orthoptera were present in abundance.

A female from Scioto County, 233/4 inches in length, laid 4 eggs July 20, 1928. These measured $31 \times 11,29 \times 10,30 \times 11$ and $30 \times 10 \mathrm{~mm}$. (Walker, 1931, 10). Another female $29 \mathrm{I} / 4$ inches in length, laid 4 eggs shortly after it was captured in Clermont County, July 2, 1932; three additional ones also were found in this specimen after it was preserved. The lengths of the eggs 
in this clutch varied from 23 to 29 , average $26 \mathrm{~mm}$.; widths from 10 to 11 , average $10.5 \mathrm{~mm}$. A female collected June 15, 1932 contained 5 unlaid eggs of slightly smaller size. The eggs of this species are capsule-shaped and have rather hard white shells.

\section{Opheodrys vernalis (Harlan)}

Smooth Green Snake; Grass Snake

Description.-A small, slender snake seldom exceeding a length of a foot and a half. Largest adult Ohio specimen ( $q$ ), 223/4 inches in length; smallest juvenile (probably recently hatched), 61/4 inches. Head small and only slightly distinct from neck. Eye medium; head plates normal. One nasal; the nostril lateral and in the center of the nasal. Loreal present (fused with the nasal on one side in a single specimen). Body slender, subcylindrical and tapering slightly at either end. Tail slender, tapering to a point and from $29.8 \%$ to $37.7 \%$ of the total length of the snake.

Dorsal scale rows 15; the scales smooth. Upper labials 7; lower labials usually 8 , rarely 7 or 6 . Preoculars 1 or 2 ; postoculars 2 (3 on one side in one specimen). Temporals 1-2. Ventrals 123 to 146; subcaudals 74 to 89 . Anal plate divided.

Color bright green above; whitish, with a distinct greenish yellow tinge, below. Newly hatched juveniles "dark olive-gray above, lighter on the sides, and pale grayish blue below" (Blanchard, 1933, 507).

The present species greatly resembles the last (keeled green snake) in color and general appearance. It may be readily distinguished, however, by its smooth scales, less attenuated form and the differences in scutellation.

Specimens examined, 22; specimens preserved, 22; specimens studied, 17.

Range.-Nova Scotia to southern Manitoba, south to Pennsylvania and West Virginia, and southwestward to Utah, New Mexico and northern Texas. The Ohio records for the smooth green snake are all in the glaciated part of the state (Map 10), but it is entirely possible that it may be found in some of the unglaciated southeastern counties as well. Detailed records follow:

Ashland County: Clearfork State Park near Loudonville (TZS 2011). Butler County: Monroe (USNM 10661-3). CRAWFord CountY: Brokensword (TZS 2281). ErIe County: (UMMZ 39115); Kimball (USNM 35687); Sandusky (OSM 12); $10 \mathrm{mi}$. S of Sandusky (SHS). FAYETTE County: Buena Vista (TZS 2044). Franklin County: Columbus (USNM 1472). Geauga County: Geauga Lake (CMNH). Hamilton County: (Morse, 1904); Newtown (CSNH). Hardin County: Patterson (TZS 1683). Lorain County: Oberlin (OC). Summit CounTY: Ira (OSM 13.1-.2, 84-5, 214, 265). Trumbulı. County: Vernon Twp. (TZS 444).

Habitat and Habits.- The smooth green snake appears to be a comparatively rare animal in Ohio. While it is recorded from a number of localities in the state, all but two are represented by single specimens. However, the late James S. Hine, of the Ohio State Museum, reported it to be common at Ira, Summit County.

So few of these snakes were collected that the habitat preferences in Ohio 


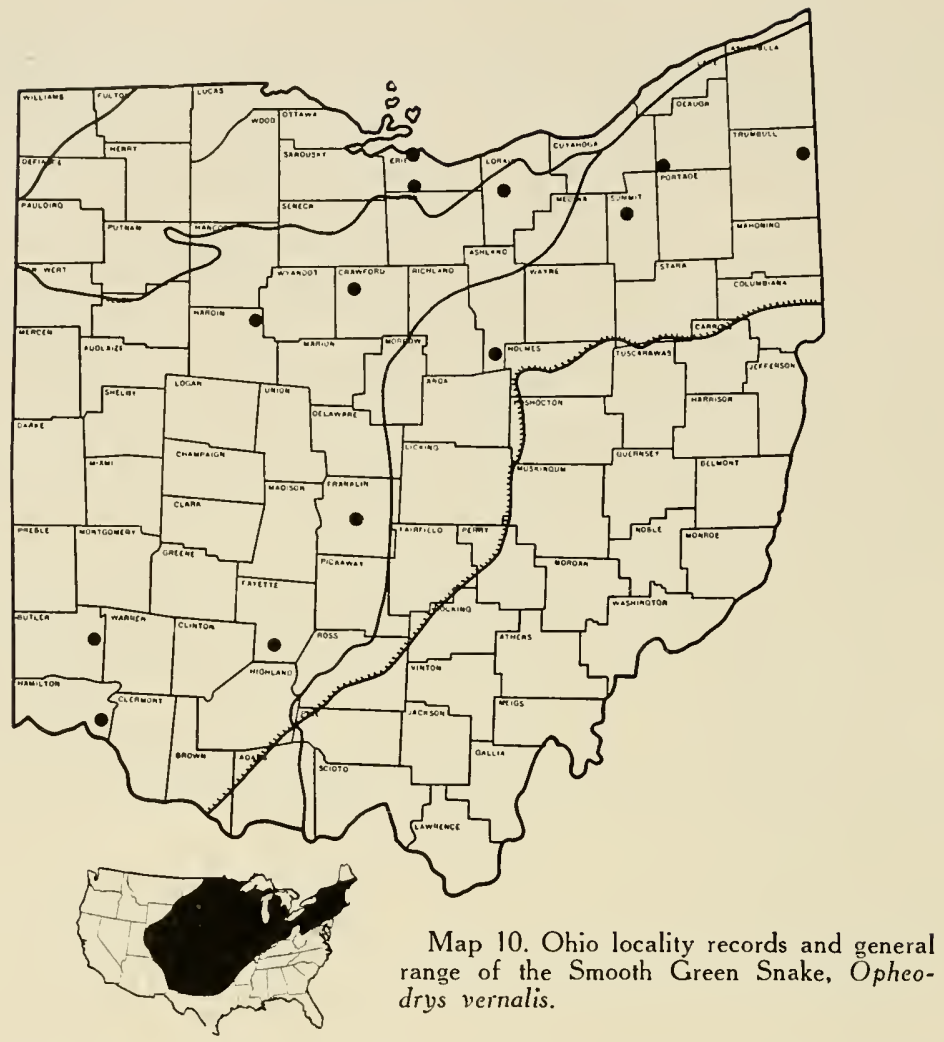

cannot be defined. One was found beneath a flat stone, another was crawling in a ditch and a third was sunning itself on a pile of cut grass. Specimens were reported as being seen on grape vines and rose bushes and in open grassy meadows. Only one smooth green snake was taken on a regular field trip. The others of recent date were turned in by farmers, correspondents and other interested persons, but all lacked adequate habitat notes. Collecting dates were scattered from April to September, inclusive. Most specimens were inoffensive, but one captive raised the forward portion of its body from the ground, held its mouth open and struck repeatedly when teased.

The food of this species as reported by Surface $(1906,165)$ includes snails, spiders and such insects as crickets, grasshoppers, Lepidoptera, measuring worm, red ants, ground beetles, etc. The same authority also records a striped salamander, but $73 \%$ of the total food he removed from the stomachs of specimens consisted of insects. Other records are grasshoppers (Atkinson, 1901, 148); insects (Ditmars 1936, 280). Blanchard $(1933,507)$ states that young green snakes were "observed to eat spiders, ant pupae, smooth, green lepidopterous larvae and grubs, and to refuse a pentatomid bug, ants, slugs, 
centipedes, earthworms and sow bugs." Captive specimens in the zoo ate crickets.

Blanchard (1933), who studied the eggs and young of this species, found that the number of eggs in a clutch varied from 3 to 11 and that 7 was the commonest number. He says, "the eggs are generally cylindrical, with bluntrounded ends. The shell, or membrane, is white and opaque, and unusually thin for a reptilian egg." His summary shows that the lengths of the eggs varied from 19.5 to $34.0 \mathrm{~mm}$. and widths from 8 to nearly $18 \mathrm{~mm}$. Laying dates were from July 24 to August 29, inclusive; hatching dates from August 5 to September 4, inclusive; the intervals from laying tc hatching varied from 4 to 23 days. His newly hatched snakes ranged from 101 to $166 \mathrm{~mm}$. (4 to $6 \mathrm{I} / 2$ inches) in length.

Dymond and Fry $(1932,102)$ report the finding of a clutch of 7 eggs in Ontario on August 1, 1931, and the discovery of pairs mating on August 18, 1931 and August 22, 1931.

A specimen from Ira, Summit County, Ohio, collected August 8, 1926 contained 7 eggs.

\section{Coluber constrictor constrictor Linné}

Black Racer; Black Snake

Description.-A large snake which may attain a length of six feet. Largest adult Ohio specimen ( $\hat{o}$ ), 591/4 inches; smallest newly hatched juvenile, 113/8 inches. Head medium and somewhat distinct from neck. Eye large. Cephalic plates normal. Nostrils large and between two nasals. Normally a single loreal, but in two or three instances this scale split in two horizontally. Body and tail slender, the latter whip-like and tapering to a point.

Dorsal scale rows normally $17-15$, but reduced in one specimen each from Guernsey and Highland Counties, to 14 and 13, respectively, on posterior part of body. Scales smooth. Upper labials 7, less often 8; lower labials 8 or 9 , rarely 10 . Oculars $2-2$, the lower preocular very small. Temporals 2-2-2, rarely 1 or 3 in any row. Ventrals 173 to 184 , average 178; subcaudals 85 to 101, average 93.8. Anal plate divided.

Color above, including the top of head, uniform black or blackish. Color below, usually uniform medium or dark grey, but inclining toward a deep olive grey in some specimens. Throat and chin whitish but more or less heavily marked posteriorly with blackish spots or blotches. Tip of snout, particularly the rostral, occasionally brownish.

Newly hatched juveniles bear a pattern of 52 to 65 , average 57.9, deep chestnut blotches (counting from the head to a point directly above the anus) on a light grey or blue grey ground. These blotches, which average 9 to 11 scales wide and 2 to 5 scales long, are edged with black and become smaller and less distinct posteriorly. A large number of blackish dots are sprinkled irregularly below these blotches on either side and across the belly. The ground color of the undersurface is whitish anteriorly to greyish posteriorly. The throat and chin are unspotted and the top of the head is marbled with 
grey, chestnut or black. As these snakes grow older the pattern becomes less distinct and the appearance of the entire upper surface becomes darker. At a length of about 18 inches it becomes difficult to count the blotches and at about 30 inches all trace of the juvenile patern has disappeared except for a few faint indications of the spots on the ventral surface.

Specimens examined, 66; specimens preserved, 55; specimens studied, 66. Range.-New England to Florida, west to central Ohio, southern Indiana and southern Illinois and to the Mississippi River south of its junction with the Ohio. In Ohio the black racer is found throughout the unglaciated part of the state and from thence northward through the easternmost tier of counties to Lake Erie, and west along the Ohio River to the Indiana border (Map 11). Locality records are:

Adams County: Lynx Prairie, near Lynx (TZS 1869). Athens County: Athens (TZS 1099). Belmont County: Warnock (TZS 488). Clermont County:

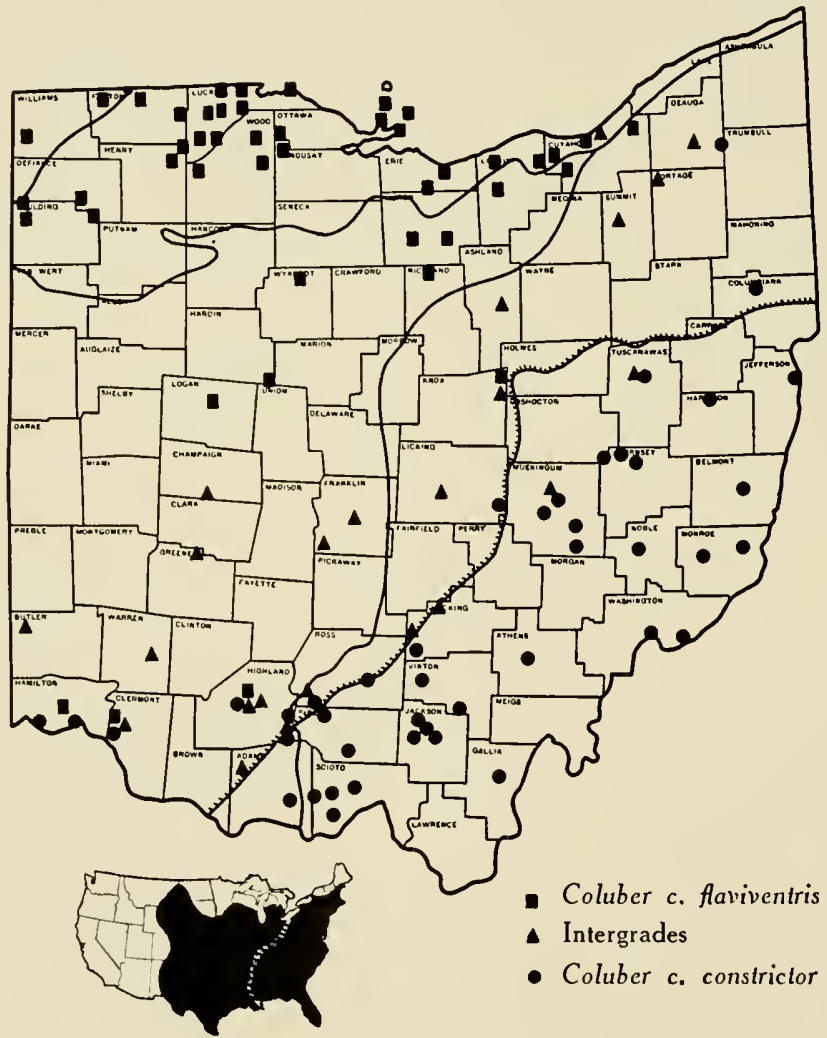

Map 11. Ohio locality records for the Black Racer, Coluber constrictor constrictor, the Blue Racer, Coluber constrictor flaviventris and intergrading specimens between these forms. The general ranges of constrictor and flaviventris are shown separated by a space which has been left especially wide for the sake of clearness. 
Union Twp. (CSNH 1200, 1403). Columbiana Countr: 3 mi. S of Salem (TZS 1610). Coshocton County: Near Linton Mills (TZS 1904). Gallia County: 1 mi. S of Evergreen (TZS 410). Geauga County: I mi. N of Bundysburg (TZS 1037). Guernsey County: North Salem (TZS 1905-7); Wheeling Twp. (TZS 865-6). Hamilton County: (CSNH 1974); Cincinnati (CSNH 1663); Fern Bank (CSNH II60). Harrison County: Scio (DOR). Highland County: N side of Ft. Hill, Brush Creek Twp. (TZS 571) ; Hillsboro (TZS 1652, 1745-6); Sinking Spring (TZS 572). Hocking County: Salt Creek Twp. (TZS 1083). Jackson CountY: Buckeye Creek, 4 mi. W of Jackson (TZS 304); Jackson; 5 mi. NW of Jackson (DOR); Rock Run, Liberty Twp. (OSM 414.1). Jefferson County: New Somerset, Toronto (OSM 271.2). Licking County: Flint Ridge. Hopewell Twp. (OSM 184.1). Monroe County: Near Cameron (CM 8409): 3 mi. IW of Woodsfield (TZS 2045). Muskingum County: Blue Rock Twp. (OSM 465-6); Salt Creek Twp.; Washington Twp.; Zanesville (OSM 472). Noble County: 2 mi. $\mathrm{N}$ of Caldwell (DOR). PIKE County: Greenbriar Ridge, Benton Twp. (TZS 570); 2 mi. S of Jasper (TZS 1822). Ross County: $21 / 2$ mi. S of Chillicothe (DOR); Paxton Twp. (OSM 413). Scioto Countr: $2 \mathrm{mi}$. S of Henley (TZS 1908-9); Nile Twp. (OSM 438.1); 8 mi. SW of Otway (TZS 1651); Roosevelt Game Preserve, Nile Twp. (OSM 240.1); Rush Twp. (OSM 379). Tuscarawas County: Dover (TZS 2285, 2295). Vinton County: $3 \mathrm{mi}$. W of Allensville (DOR) ; $3 \mathrm{mi}$. S of Dundas (DOR). WAsHington CountY: Marietta (MC; TZS 807-9; USNM 4439); Newport Twp. (TZS 487).

Specimens reported in the literature from Lancaster, Fairfield County, and London, Madison County, by Smith (1882) and Delaware County and Salt Creek by Yarrow (1882) appear to be no longer in existence and hence it cannot be determined whether they were identifiable as C. c. constrictor, C. c. flaviventris or intergrades between these two.

Intergrades.-Racers from a relatively narrow area extending in a diagonal direction across Ohio from Butler, Clermont and Highland Counties in the southwest, to Cuyahoga and Geauga Counties in the northeast (Map 11) cannot be definitely assigned to either Coluber constrictor constrictor or Coluber constrictor flaviventris. Such specimens are intergrades between these two subspecies.

Adult racers, typical of the two respective forms, show four major differences as are indicated in the following table:

TABLE 3

Characteristics of Adult Racers

\begin{tabular}{|c|c|}
\hline Coluber c. constrictor & Coluber c. Alaviventris \\
\hline 1. Upper surface uniform black & $\begin{array}{l}\text { 1. Upper surface uniform bluish black or } \\
\text { deep olive to light greenish or bluish } \\
\text { grey. }\end{array}$ \\
\hline 2. Under surface medium or dark grey. & $\begin{array}{l}\text { 2. Under surface greenish or bluish white } \\
\text { to yellowish. }\end{array}$ \\
\hline $\begin{array}{l}\text { 3. Throat and sometimes the chin more or } \\
\text { less heavily marked with dark spots or } \\
\text { blotches. }\end{array}$ & 3. Throat uniform white or cream. \\
\hline Idals 85 to $10 \mathrm{I}$, average 93.8 & 4. Subcaudals 82 to 96 , average 87 . \\
\hline
\end{tabular}

Many specimens from the intergrading area show various combinations of these characters. For example, one from western Hocking County is olivaceous black above and yellowish green below, but the chin and throat are 
heavily blotched and the subcaudals are 95 in number. Others, instead of showing characteristics of both subspecies in one individual, reveal conditions in which the colors, both above and below, may be intermediate or in which the throat may be partially spotted or the subcaudals may number somewhere between the respective averages. It should be remembered, however, that the last named character cannot be relied upon except when a series of specimens is available; a study of the statistics obtained from the examination of 17 intergrades from Ohio which have perfect tails, shows that the number of subcaudals in these specimens varies from 85 to 105, with an average of 91 .

Series of specimens from the same locality within the intergrading area show that intergrades and both constrictor and flaviventris may be encountered in the same territory, but outside of the zone of intergradation only constrictor or flaviventris have been found, depending in which part of Ohio the collector was working. Thus of the twelve and seven specimens available, respectively, from Union Twp., Clermont County, and the vicinity of Hillsboro, Highland County, there are 2 and 1,2 and 3, and 8 and 3 specimens each of flaviventris, constrictor and intergrades, respectively. Classification of individual specimens is largely a matter of personal judgment particularly when juveniles are involved. It has been the writer's general policy, however, to consider as an intergrade every specimen which did not exhibit all of the characters of constrictor, or of flaviventris.

Specimens of intergrades examined, 39; specimens preserved, 37; specimens studied, 39.

Ohio locality records for intergrading specimens are:

Adams County: Winchester (CSNH 1271). Ashland County: Jeromesville (TZS 2416). Butler County: Oxford (MU). Champaign County: Cedar Swamp, $5 \mathrm{mi}$. SSW of Urbana (TZS 1956; 2293). Clermont County: Union Twp. (CSNH 1136, 1141, 1181, 1275, 1404, 1406; TZS 1653). Cuyahoga County: Cleveland (WRU). Franklin County: Columbus (OSM 17.1-.2); Pleasant Twp. (OSM 371.1). Geauga County: Lake Kelso, Burton Twp. (TZS 1781). Greene County: Clifton Gorge, Miami Twp. (OSM 181). Highland County: 4 mi. S of Carmel (TZS 573); Hillsboro (TZS 1742); $1 \mathrm{mi}$. S of Hillsboro (TZS 1744); $3 \mathrm{mi}$. E of Hillsboro (TZS 175). Hocking CountY: (OSM 18.1-.2) ; 1/2 mi. E. of Laurelville (TZS 291); Neotoma, Good Hope Twp. (OSM 359, 411.1). Knox CountY: Brinkhaven (TZS 83). Licking County: Granville (OSM 297.1). Muskingum County: Washington Twp. (TZS 2415). Portage County: Solon Bog, Aurora Twp. (CMNH). Ross County: Big Round Top, Paint Twp. (CSNH 1869A-B). Summit County: Ira (OSM 260). Tuscarawas County: Dover (TZS 2294). Warren County: $1 \mathrm{mi}$. W of Ft. Ancient (TZS 949-50).

Habitat and Habits.-The black racer is a common snake in many parts of southern and eastern Ohio. It was not collected in numbers in any one place but at least one specimen was obtained on almost every field trip to the portion of the state in which it is found.

It occurs in a variety of habitats but appears to show some preference for dry and more or less open situations. However, specimens were taken in woods, in wet meadows and fields, about old buildings, near stone walls or loose rocks and in the vicinity of brush piles. Several were caught as they were crossing highways and one was collected as it was swimming in a flooded 
part of the Ohio and Erie Canal in Pike County. Most were in the open, either on the move or coiled in a sunny location, but a number, and especially young ones, were discovered hidden beneath such objects as stones, boards, logs, etc. While they are not habitually arboreal there are many authentic records of their presence in trees and bushes.

Many specimens sought shelter in a definite retreat. Thus one in Jackson County was disturbed from its resting place on top of a brush pile four times during a single afternoon, and each time it followed the same route to the same inaccessible spot beneath the pile. Many of those surprised in the open dashed for a particular hiding place, even though it was some distance away, and they had to pass other cover apparently as good enroute. On two occasions specimens raced toward and past the writer as they sought a certain refuge, even though adequate cover was available in almost every other direction.

Such an action as this might lead a nervous person to believe that the snake intended to attack, but no evidence was seen which would bear out the popular impression that racers chase human beings. Given a fair chance to escape these snakes made off with alacrity and with such speed that it took an alert and active collector to capture most of them.

The racer is a nervous and pugnacious snake when first caught and many individuals remain so as long as they are kept in captivity. Specimens strike and bite viciously and the sharp teeth are capable of producing scratches on an unprotected hand. They actively pursue their prey, occasionally with the mouth held open in readiness to seize the victim. The tail is vibrated rapidly when they are angered or alarmed.

A specimen sunning itself on a steep hillside in Guernsey County on a cool morning in April, 1932, crawled under a large slab of conglomerate. With the aid of an automobile jack the rock was raised and two racers and a pilot black snake were pulled from beneath it. Since the weather had been consistently cool it was presumed that these snakes had hibernated under the rock. All were in excellent condition. A group of farmers found 106 racers hibernating together in a woods near Bellville, Richland County, in February, 1932. These they slaughtered and hung up for display (Pl. 7, fig. 1).

The black racer is omnivorous. The numerous records on its food have been well summarized by Ortenburger $(1928,198-201)$. Included are insects, frogs, toads, snakes, lizards, birds, bird's eggs, and small mammals. The first and last of these constitute the largest percentage of the food; Surface (1906, 170 ) shows that, in the stomachs he examined, insects formed $28 \mathrm{I} / 2 \%$ of the whole, and mammals (mice, etc.) $37 \%$. Birds and eggs were taken so infrequently $(12 \%)$ when compared with the numbers of insects and destructive mammals, that the black racer should be considered as of economic value. Snakes are frequently eaten, and while they are usually of non-venomous species, Verrill $(1870,158)$ records an instance in which a copperhead was devoured. An Ohio specimen collected in Belmont County had a smaller black racer in its stomach and in the latter specimen were the remains of a caterpillar. Captives ate mice, young rats, sparrows, frogs, garter snakes and 
each other. The food was seized and engulfed without more ado unless there was a struggle, in which case the racer threw a loop of its body over the prey and pressed it firmly against the ground. Racers apparently are not constrictors.

The eggs of the black racer are white, sub-elliptical in shape and nonadherent to one another. They are covered with a tough skin which is well sprinkled with small particles about the size and color of salt grains. The eggs are deposited in the ground or in decaying vegetable matter such as logs, stumps or abandoned sawdust piles. Ditmars $(1936,194)$ states that this snake lays from one to two dozen eggs during June or July. A female slightly less than 5 feet in length deposited 8 eggs which he measured and found to be $17 / 8$ by $11 / 16$ inches. Young snakes, $83 / 4$ inches in length, hatched from these in 61 to 62 days after being laid.

\section{Coluber constrictor flaviventris Say}

Blue Racer

Description.-A large snake which may occasionally reach a length of six feet. Largest adult Ohio specimen (sex undetermined), 71 inches in length; smallest juvenile, $14 \mathrm{I} / 2$ inches. Head medium and somewhat distinct from neck. Eye large. Head plates normal. Normally one loreal, but split horizontally in two in one case. Nostril large and situated between the two nasals. Body and tail slender, the latter whip-like.

Dorsal scale rows $17-15$; the scales smooth. Upper labials usually 7 , occasionally 8 ; lower labials 9 , occasionally 8 and reduced to 7 on one side in a single specimen. Oculars $2-2$, the lower preocular very small. Temporals $2-2-2$, rarely 3 in any row. Ventrals 175 to 184 , average 180; subcaudals 82 to 96 , average 87 .* Anal plate divided

Color above, uniform but variable in shade, ranging from light bluish or light greenish blue in some specimens to dark olive or dark bluish black in others. Temporal region somewhat darker; more or less brown on the snout. Color below, uniform bluish white or greenish white to yellowish, becoming white or cream on the throat and chin, which color extends upward to the lower portions of the upper labials. Chin and throat not spotted or blotched.

Juveniles are similar to those of the black racer (Coluber constrictor constrictor) in color and pattern. Only four young Ohio specimens are available for examination in which the number of dorsal blotches can be counted, and these are 58, 58, 61 and 63, average 60 . In the blue racer the number of dorsal blotches averages higher than in the black racer as is shown by Ortenburger $(1928,175)$ in his review of the genus. Transformation to the adult coloration takes place at about the same size as in the black racer.

Specimens examined, 85; specimens preserved, 43; specimens studied, 85 .

* One male each from Maumee, Lucas County and Genoa, Sandusky County have the subcaudals 95 and 96 respectively. These specimens are from well within the geographical range of flaviventris, however, and in every other respect they are identical with this form. Excluding these two specimens, the highest number of subcaudals noted is 89 , and the average for the subspecies is 86 . 
Range.-The Rocky Mountains east to Michigan, central Ohio and to the Mississippi River south of its junction with the Ohio; north from the Rio Grande and the Gulf of Mexico to the Canadian border.

The range of this form in Ohio is through the western and north central counties (Map 11). Locality records are:

Clermont County: Union Twp. (CSNH 1243; TZS 1959). Cuyahoga CounTY: Cleveland (CMNH); East Rockport, near Berea, (MCZ 214); Mayfield (CMNH): North Olmsted (CMNH). Defiance County: $3 \mathrm{mi}$. SW of Defiance (TZS 1426). ERIE County: Berlin Heights; Cedar Point (Morse, 1904); Kelley's lsland (SHS; TZS 123); Milan (SHS). Fulton COUNTY: Near Fayette (TZS 827); Swanton (TZS 784); 7 mi. N of Wauseon. Hamiltun County: Cincinnati (MCZ 84). Hardin County: 3 mi. E of Mt. Victory. Henry County: Texas (DOR); NE corner of Washington Twp. Highland CounTY: I mi. N of Hillsboro (TZS 1743). Hu'ron County: Near Fitchville (TZS 1002); Greenfield Twp. (TZS 1309). Knox County: Edlam, Greer P.O., Jefferson Twp. (OSM 1901). Logan County: 6 mi. N of Bellefontaine (TZS 319). Lorain County: Amherst (OC); Oberlin (OC); North Ridgeville (CMNH). Lucas CounTY: Crissey; Holland (TZS 474, 1803); 5 mi. SW of Maumee (TZS 1975); Little Cedar Pt., Jerusalem Twp.; Sylvania Twp. (CMNH; TZS 377); Toledo (TZS 229); Washington Twp. (TZS 318); Whitehouse. OtTawa County: Catawba Island (TZS 1310); 1 mi. W of Genoa (TZS 473); Marblehead; Put-in-Bay. Paulding CounTY: Antwerp (OEE) ; 3 mi. N of Antwerp (OEE); Arthur (OSM 464). Richland CoUnTY: 2 mi. SW of Shilo (TZS 1195). SANDUSKY CountY: S of Genoa (TZS 2296); Woodville Twp. (TZS 1225). Williams County: 1 mi. SW Blakesley (TZS 320,762). Wood CounTY: Beaver Creek midway between Grand Rapids and Weston (TZS 375); Pemberville; Stony Ridge. WYANDOT CoUnTY: Near Tymochtee (OSM 238.1).

Habitat and Habits.-The habits of the blue racer are similar to those of the black racer. Both occur in much the same types of habitats, both are active snakes and the instinct to return to a specific refuge has been noted as frequently in both. The food, and the feeding habits are similar and so are the breeding habits. A pair of blue racers in mating position was discovered in Erie County on May 12, 1930. A clutch of 25 eggs was laid by a female, $51 / 2$ feet in length, from Lucas County on June 26, 1930. These were white, non-adherent to one another and were covered with small salt-like particles which formed a part of the shell. They measured 32 to 38 , average $34.5 \mathrm{~mm}$, in length and 18 to 23 , average $22 \mathrm{~mm}$., in width. All failed to hatch.

Three blue racers were found hibernating in a small hole about three feet underground near Swanton, Fulton County, November 20, 1931. Another had apparently hibernated with a massasauga near Crissey, Lucas County, during the winter of 1934-35. The blue racer should be considered as a beneficial snake and such wanton destruction as that illustrated in Pl. 7, fig. 1 is to be deplored.

\section{Elaphe obsoleta obsoleta (Say)}

Pilot Black Snake; Mountain Black Snake

Description.-A large snake attaining a length of seven or eight feet although averaging much less. Largest adult Ohio specimen ( $\hat{0}), 73$ inches in length; smallest newly hatched juvenile, 12 $\mathrm{x} / 4$ inches. Head medium and somewhat distinct from the neck. Head plates normal. The nostril lateral 
and between two nasals. Loreal present. Body slender in juveniles to medium stout in adults. Tail relatively short and terminated by a stout spine.

Dorsal scale row formula variable; normal minimum in Ohio specimens, 17; normal maximum, 25 or 27 , but 29 in one specimen from Licking County. Most frequent combinations: 27-25-23-21-19, 25-27-25-23-21-19-17, 25-23-2119-17 and 23-25-23-21-19-17, but other arrangements occur. First six to eleven rows of scales anteriorly, and first one to five rows posteriorly, smooth, the others weakly keeled; in many juveniles the keels so faint as to appear lacking. Upper labials 8 , rarely 7; lower labials 11 or 12 , rarely 13 or 14 . One preocular; 2 and occasionally 3 postoculars. Temporals 2 in first row and 3 or 4 in second row. Ventrals in males 221 to 239, average 232.9; in females 228 to 244 , average 237.6. Subcaudals in males 73 to 85 , average 81 ; in females 69 to 81 , average 73.8. Anal plate divided.

General color above, nearly uniform black or brownish black. In many specimens, however, a dorsal pattern of obsolete dark quadrate blotches may be discerned, this being most apparent in brownish specimens and least so, if at all, in black examples. In the lighter areas bordering the blotches the edges of many scales may appear yellowish, whitish or reddish in color and may encroach sufficiently upon the scales to bring out the pattern. Belly yellowish, and blotched or mottled with four alternating rows of dark squarish spots which become darker, denser and finally confluent posteriorly. Top of head uniform blackish; throat, chin and lower labials white; upper labials similar but often dusted with grey; sutures between labials dark.

In juveniles there is a well defined pattern of brownish or seal brown blotches on a grey ground. The dorsal blotches, 29 to 38 in number from head to anus, are about 4 to 8 scales long by 11 to 14 scales wide. Alternating with the dorsal series is a lateral series of blotches below which in turn is still another alternating series situated upon the first row or two of scales and the edges of the ventrals. In several specimens there are dark lateral extensions from the blotches in the neck region which collectively suggest a narrow lateral stripe on either side of the neck. This condition occasionally persists in the adults in which, despite the nearly uniform coloration, the stripe may be seen if the specimen is held in the proper light.

Belly yellowish with blotches better defined than in the adults; center of under side of tail light, edged with darker. As specimens grow older they acquire the uniform or nearly uniform dark appearance of the adult, but they may retain traces of the dorsal and lateral blotches throughout life. Juveniles greatly resemble the juveniles of Elaphe vulpina, even to the markings upon the head; young of the two species may be best distinguished from each other by the higher number of ventrals (221 to 244) in the pilot snake and the lower number (197 to 215 ) in the fox snake.

Specimens examined, 139; specimens preserved, 95; specimens studied, 51. Range.-Massachusetts to North Carolina and west to eastern Kansas.

The pilot black snake occurs throughout Ohio. It is most common in the 
southern and southeastern, and least so in the northern, counties (Map 12). Ohio locality records are as follows:

Adams County: Buzzard's Rock, Jefferson Twp. (DOR); 4 mi. E of Rome (DOR); West Union (OSM 406.1). Ashland County: 8 mi. N of Ashland (DOR). Ashtabula County: Eagleville (CMNH: TZS 2417). Athens Countr: $6 \mathrm{mi} \mathrm{N}$ of Athens (DOR); Nelsonville (OSM 20). Auglaize County: New Bremen (OSM 23). Butler County: Westchester (MU). Carroll County: Union Twp. (TZS 341). Clermont County: 2 mi. from Nicholsville (TZS 1654); Union Twp. (CSNH 1137, 1190, 1235 [albino], 1269, 1558, 1873; OSM 441). Columbiana County: Near Lisbon (DOR). Coshocton County: Ohio Canal, Oxford Twp. (TZS 1911). Cuyahoga County: Mayfield (CMNH). Erie County: Milan (SHS); Sandusky (UMMZ 31724). Franklin CountY: Columbus (OSM 34.1, 270). Gallia County: 1 mi. S of Cheshire (DOR). Geauga County: 1 mi. N. of Bundysburg (shed skin). Greene County: Spring Valley Twp.; Yellow Springs (Morse, 1904). Guernsey CountY: North Salem (TZS 1861); Wheeling Twp. (TZS 1306). Hamilton County: (CM 5128, 5133); Cincinnati (CSNH 1182); Hyde Park, Cincinnati (CSNH 1237); near New Baltimore (CSNH 1133). Hardin County: 6 mi. S of Kenton (DOR). Harrison County: Washington Twp. (OSM 261). Highland CounTY: $5 \mathrm{mi}$. S of Carmel (TZS 1611); Hillsboro (TZS 765, 1718-20); $6 \mathrm{mi}$. E of Hillsboro; N of Hillsboro (TZS 675). Hocking Coun-

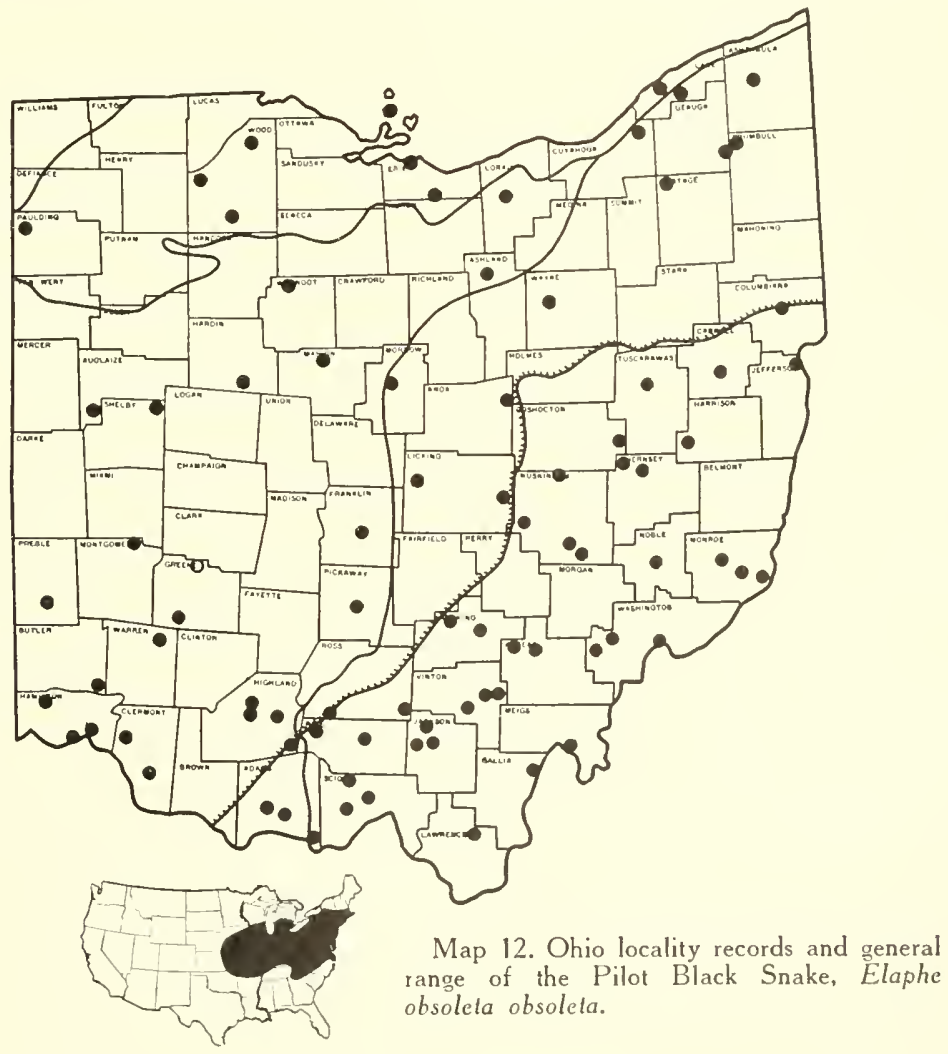


TY: Good Hope Twp. (OSM 355.1; TZS 1543-53); 2 mi. S of Logan. JAckson CountY: 4 mi NW of Jackson (DOR); Canter's Cave, Jackson Twp. (TZS 733); White's Gorge, Liberty Twp. (TZS 307). JefFerson CountY: Yellow Creek (TZS 1638). KNox County: Brinkhaven (TZS 176; OSM 366.4). Lake County: Mentor Marsh, Mentor Twp. (TZS 1410); 3 mi. S of Painesville (DOR).

Lawrence County: Near Arabia, Aid Twp. (TZS 505). Licking County: (Morse, 1904); Black Hand Gorge, Hanover Twp. (TZS 1910); Johnstown (OSM 356). Lorain County: Oberlin (OC). Marion County: $4 \mathrm{mi}$. $\mathrm{N}$ of Marion (DOR). Meigs County: Syracuse (DOR). Monroe County: Green Twp. (DOR); Ohio Twp. (DOR); $1 \mathrm{mi}$. N of Woodsfield (TZS 1304). MontgomerY County: Near Vandalia (Conant, 1930). Morrow County: Gilead Twp. (TZS 759). Muskingum County: Adams Mills (OSM 431.1); Blue Rock Twp. (OSM 467); Hopewell, Hopewell Twp. (TZS 2407); NE corner of Madison Twp. (TZS 1507); Philo (OSM 370.1-.3). Noble County: $3 \mathrm{mi}$. E of Caldwell (DOR). Ottawa County: Put-in-Bay (BGSU). Pauldinc County: Antwerp (OEE; TZS 1758). Pickaway County: Jackson Twp. (OSM 88). Pike County: $4 \mathrm{mi}$ W of Morgantown (TZS 674); $2 \mathrm{mi}$. N of Piketon (DOR). Portage CountY: Solon Bog, Aurora Twp. (CMNH). Preble County: Camden (OSM 228). Ross County: Paint Creek at Copperas Mt., Paxton Twp. (TZS 1100); $2 \mathrm{mi}$. E of Richmondale (DOR). Scioto County: $1 / 2$ mi. N of Rushtown (DOR); near Sedan (TZS 1444); Shawnee Forest, Union Twp. (OSM 232). Shelby County: Jackson Center (TZS 1039). Trumbull County: $11 / 2 \mathrm{mi}$. W of Mesopotamia (DOR). Tuscarawas County: Dover (CSNH 1875 A-B). Vinton County: Dundas (DOR); Knox Twp. (DOR); Near Prattsville (DOR). Warren CountY: Waynesville (CSNH $325 \mathrm{~A}-\mathrm{l}$ ). Washington CountY: Bartlett (USNM 50003dicephalous); Marietta (MC); Palmer Twp. Wayne County: Near Overton (WC). WoOd County: Beaver Creek midway between Grand Rapids and Weston (TZS 376); Cygnet (BGSU); Lime City (TZS 50). Wyandot CountY: Near Carey (TZS 679).

Habitat and Habits.-The pilot black snake, common in many parts of the state, occurs in a wide variety of habitats. Specific situations in which it was collected included river bottoms, abandoned canal beds, woods, open or wooded hillsides, ravines, cliffs, ledges and the vicinity of abandoned sawdust piles. Few were taken at any great distance from woods or thickets but rocky hillsides were also favored. A number of specimens, and especially those about to shed their skins or lay eggs, were found hidden beneath such objects as stones, logs, bark slabs, etc. On cool or very warm days specimens rarely were seen abroad. They were often arboreal and occasionally were found in trees at a considerable distance from the ground.

The pilot black snake is a slow moving animal when compared with the racers. While it can travel with a fair degree of speed, most specimens were caught with comparative ease unless shelter was available close by; a number remained motionless until they were grasped in the hand. This habit and the fact that it often crosses highways or suns itself upon them makes the pilot black snake an easy target for its human enemies. The frequency with which it is run over and the many which were found killed, even in the more remote areas, would indicate that it soon may become a rare snake in the state.

Most specimens showed fight when first caught. Many struck repeatedly from a position in which the neck was drawn backward in a graceful curve and the mouth was held open in readiness. Occasional specimens were phlegmatic and offered little or no resistance, but they were the exception. The 
tail was vibrated rapidly when the snake was alarmed or excited, and the musk glands exuded a fluid with an unpleasant odor. If a large, struggling example were allowed to coil about one's arm it would squeeze so tightly as to be uncomfortable and to interfere with circulation.

In many parts of its range the pilot black snake was found in association with the copperhead and timber rattlesnake. A superstition maintains that it "pilots" these venomous snakes to safety in time of danger. A pilot black snake unearthed in a sawdust pile with two copperheads was bitten near the middle of the body by one of the latter but there were no apparent ill effects. Specimens were collected from March to October with May as the leading month. There is only one record each for March and April, and the latter was a specimen found in hibernation with two racers.

The pilot black snake feeds almost exclusively upon mammals, birds and eggs, although Surface $(1906,160)$ records insects and the wood frog as well. Mammals eaten include red squirrels, chipmunks, shrews, weasels, opossum, house mice, meadow mice (Surface, loc. cit.); mice (Hay, 1892a, 503); cotton-tail rabbit (Ditmars 1936, 232); full grown red squirrel (Ditmars, 1929, 89). Birds recorded are robin, red-winged blackbird, sparrow and the eggs of chickens and wild birds (Surface, loc. cit.). The stomach of an Ohio specimen from Franklin County contained two juvenile meadow mice (Microtus) and a quail egg, and another from Athens County contained a whitefooted wood mouse (Peromyscus.) A specimen from Ottawa County had two flickers about three-fourths grown and two smaller birds in its stomach. Captives ate mice, rats, sparrows and eggs.

In subduing its prey the pilot black snake throws one or more coils of its body about its victim at the instant it seizes it in its mouth. The action is completed so rapidly as to be bewildering to the observer. Death comes through suffocation rather than by the crushing of bones with subsequent puncturing of vital organs. A six foot pilot snake easily can kill and swallow an average rat. The eggs of domestic poultry taken by large captives are swallowed a distance of a half foot or more where the muscles crush the shell with an audible sound. Usually the shell is swallowed but on two occasions it was disgorged.

This species is oviparous. A female $553 / 4$ inches in length, collected June 25, 1932, near Woodsfield, Monroe County, laid 12 eggs July 1, 1932. These were white, capsule-shaped and with smooth shells like thin, soft leather. At first they were coated with a moist substance, but after a few minutes' exposure to the air this dried and acted as an adhesive, fastening the eggs to one another. Within a few hours the shells hardened somewhat and turned slightly yellow. The lengths of the eggs varied from 41 to 50 , average $45.5 \mathrm{~mm}$; widths from 20 to 24 , average $21.3 \mathrm{~mm}$. Another female, $535 / 8$ inches in length, collected in Wyandot County June 5, 1930, died in captivity July 19, 1930. Dissection revealed the presence of 22 eggs which were nearly ready to be laid and which measured 38 to 48 , average $40.8 \mathrm{~mm}$., in length, and 21 to 24 , average $22 \mathrm{~mm}$., in width. 
The eggs are deposited in loose earth or damp sawdust (Surface, 1906, 159 ) and in manure piles (Hay, 1892b, 396). No doubt they may be laid in almost any situation which provides the requisite amounts of moisture and heat. Twelve eggs were found in an old manure pile in Muskingum County, August 25, 1931. One of these, preserved August 28, 1931, contained a well formed embryo, but the attached yolk equaled about half the bulk of the snake and the hemipenes were still everted. Eleven juveniles and the eggs from which they apparently had just hatched were dug from a large sawdust pile in Hocking County, September 11, 1932. The young snakes varied from $131 / 4$ to $141 / 4$, and averaged $137 / 8$ inches in length.

\section{Elaphe vulpina (Baird and Girard)}

\section{Fox Snake; Timber SNake}

Description.-A medium to large snake attaining a length in excess of five feet. Largest adult Ohio specimen ( $\hat{\delta}$ ), 621/4 inches; smallest newly hatched juvenile, $10 \mathrm{x} / 2$ inches. Head medium and somewhat distinct from the neck. Eye medium. Head plates normal; two nasals, the nostril lateral and between them; loreal present. Body moderately slender in juveniles to medium stout or even robust in adults. Tail short and stout and terminated by a sharp horny spine.

Dorsal scale rows most frequently $25-23-21$ or $23-25-23-21$, less often 27 . 25-23-21 or 25-27-25-23-21; reduced to 19 posteriorly in one specimen from Erie County. First six, seven or eight rows of scales anteriorly, and first one to six rows posteriorly, smooth; the others weakly keeled. Keels obsolete in very small juveniles. Upper labials 8 , rarely 7 or 9; lower labials 11, less frequently 10,12 or 9 , in the order given. One preocular ( 2 on the left side in a specimen from Erie County); 2 postoculars. Temporals 2, or occasionally 3, in the first row, and 3 or 4 in the second row. Ventrals in males 199 to 206 , average 202.3; in females 197 to 215 , average 208.6. Subcaudals in males 62 to 69 , average 65.8 ; in females 54 to 65 , average 57.2 .

Ground color above, yellowish to light brown, frequently finely stippled with brownish. From head to a point above the anus a median series of 28 to 39 chocolate to black dorsal blotches about 4,5 or 6 scales long by 10 to 15 scales wide, and separated from one another by about the length of two scales. Blotches usually subquadrate but often united with each other or contorted from the normal. A series of lateral blotches, on about the second to the seventh rows of scales inclusive, alternating with the vertebral series. Alternating in turn with this row is still another row occupying the first two or three rows of scales and the ends of the ventrals. Blotches continued on the tail but less distinct and presenting a banded effect posteriorly.

Head light brown or light reddish brown with a dark band running from the eye to the angle of the mouth and another downward from the eye to the mouth. Usually a transverse dark band along the suture formed by the prefrontals on one side and the supraoculars on the other. Frontal and parietals marked more or less with brown. Sutures between labials occasionally blackish. 
Abdomen yellowish, boldly marked with four alternating rows of dark blotches.

Juveniles paler than the adults and with the dorsal blotches narrowly edged with black or deep brown, an arrangement which occasionally persists in adult specimens.

Specimens examined, 140; specimens preserved, 63; specimens studied, 39.

Range.-Southern Minnesota, eastern Nebraska and eastern Missouri to northern Michigan, Ontario and western New York.

The fox snake has been taken in Ohio only in Lucas, Wood, Ottawa, Sandusky and Erie Counties, and is thus restricted to the vicinity of the marshes along the southwestern shore of Lake Erie (Map 13). To the east of this area the lake plain becomes a narrow strip which has its northern edge bounded by low cliffs along the lake. It is possible that in the few and relatively small marshes within this strip the fox snake may be found, but repeated search in the Mentor Marsh, Lake County, was unsuccessful. In Michigan it occurs in the area bordering Lake Erie (Ruthven, Thompson and Gaige, 1928,

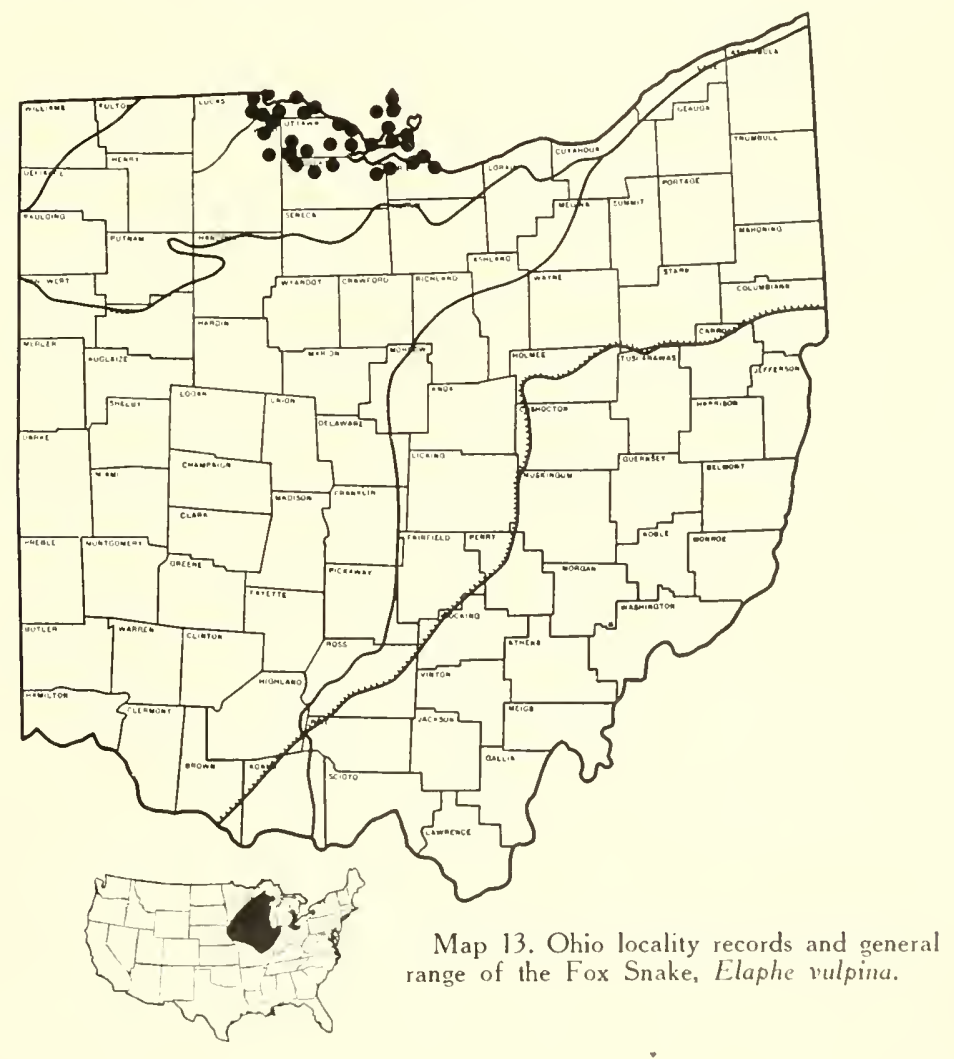


94) and in Ontario it has been taken along the lake as far east as Long Point, Norfolk County (Logier, 1931) which is north of Erie, Pennsylvania. There are also two specimens from near Buffalo, New York (ANSP 3779-80). Locality records are:

ErIe County: (UMMZ 31723; SHS); Castalia (OSM 28; UMMZ 62661-2); Cedar Point (OSM 29; UMMZ 34262); Sandusky (BU 1842; BGSU; FMNH 396; MCZ 19582-3; OSM 27.1-.2; UMMZ 31622-3, 32853-6, 32957, 41939; USNM 36968); 5 mi. E of Sandusky (DOR). Lake Erie, off Vermillion (UMMZ 82794). Lucas County: Alexis; Bono; Booth; Little Cedar Pt. Marsh, Jerusalem Twp. (USNM 92596-7); Point Place. $N$ of Toledo (CSNH 1506; TZS 80); Reno Beach. Jerusalem Twp.; East Toledo (OSM 442; TZS 1659); Toledo (UMMZ 68866). Ottawa County: Bay Point (DOR); Catawba Island (TZS 1960); Camp Perry; Clay Twp. (TZS 1223); Danbury (CMNH); Elmore (TZS 1165); Erie Twp. (TZS 1445); Genoa; Marblehead (TZS 1182); Middle Bass Island (SL); Oak Harbor; 5 mi. E of Oak Harbor (DOR); Port Clinton (TZS $998,1445) ; 8$ mi. S of Port Clinton (UMMZ 68711); Put-in-Bay (WC); Sandy Beach, Danbury Twp. (OSM 426); Touissant Creek, 4 mi. E of Bono; Rattlesnake Island (SHS); West Harbor, Danbury Twp. (BGSU). SAndusky County: 6 mi. $\mathrm{N}$ of Fremont; Near Genoa; Lindsey; Woodville (TZS 482); Townsend Twp. (OSM 208). Wood County: Lake Twp. (TZS 1224, 1912); Troy Twp. (TZS 483, 1181); Walbridge (TZS 1913); Ross Twp. (TZS 1509-15).

Habitat and Habits.--The fox snake is abundant in and near the extensive lake marshes from Toledo to east of Sandusky and it also occurs on the Lake Erie Islands. In the marshes it was taken among the reeds, on muskrat houses and on the nearby dikes and beaches. It often entered the water and appeared to be able to take care of itself in an aquatic environment. This was attested by two cases in which specimens were caught while swimming, respectively, several hundred yards and nearly a mile off shore in Lake Erie. It was also found in fields, along the streams which flow into the marshes and on the highways which traverse the area. At Catawba Isiand, Ottawa County, and on the islands it was taken in woods and on the cliffs. Most were discovered in the open, but a number were beneath rocks, boards and other shelter. One or two were in low bushes.

In general the fox snake is less aggressive and less prone to strike than the pilot black snake although an occasional specimen will give a good account of itself. Like the latter species it vibrates its tail rapidly when excited and if it is in dried leaves or other dead vegetation the noise of the tail striking against these is suggestive of that of the rattlesnake. The illusion is further heightened by the black and yellow markings which superficially resemble those of the timber rattlesnake, a species which has been taken with the fox snake at Catawba and on the islands. The reddish color of the head also causes it to be confused with the copperhead. As a result of these unfortunate similarities the fox snake is mistaken for a poisonous snake and killed as such, perhaps, as frequently as any other harmless serpent in the state.

Specimens were collected from April to October inclusive and numbers were taken in every month throughout the summer; the peak of abundance was in May and June. It is worthy of note that in the area where the fox snake is abundant only one pilot black snake was collected. The latter was 
taken on South Bass Island (Put-in-Bay), Ottawa County, which affords many habitats similar to those in which the pilot snake was found in other parts of the state.

Fox snakes feed upon mammals, birds and eggs. Freshly caught individuals disgorged mice (Microtus and Peromyscus), fledgling birds (probably red-winged blackbirds) and quail eggs. Captives ate mice, rats, sparrows and sparrows' eggs. Hay $(1892 a, 500)$ records a specimen which swallowed a half-grown rabbit. The food may not be restricted entirely to warm blooded vertebrates for Logier $(1931,233)$ states that a two foot specimen "disgorged a bundle of undigested earthworms."

In subduing struggling prey the fox snake throws one or more coils of its body about its victim and the more the latter resists the tighter the coils are drawn. Death results from suffocation; the snake usually examines its food with the tongue tips before swallowing it. Small items such as baby mice or small eggs are eaten without any attempt to use the coils; large eggs are crushed in the throat and the shells are either retained or disgorged. A specimen 52 inches in length collected on Rattlesnake Island, Ottawa County, in September, 1892, was coiled around a nest of hen's eggs from which it had driven the hen and eaten two eggs.

Several notes are available on the eggs of the fox snake. A female from Bono, Lucas County, 51 inches in length, deposited 15 eggs July 29, 1929. These were white, with firm leathery shells and were adherent to one another. They averaged $44 \mathrm{~mm}$. in length by $24 \mathrm{~mm}$. in width and weighed $1 / 2$ ounce each. The eggs were placed in damp sphagnum moss and three hatched 78 days later on October 19, 1929. Lengths of the young at hatching were $10 \mathrm{r} / 2$, $10 \% / 8$, and 11 inches, respectively. Two other females from East Toledo, Lucas County, laid eggs July 17, 1929. One of these, 49 inches in length, laid 17 eggs and the other, 50 inches in length, laid 15 eggs. Both lots failed to hatch. Another female, 45I/4 inches in length, from the same locality, died July 19, 1930, and was found to contain 11 eggs.

An unusually large female was secured on Little Cedar Point, Lucas County, June 24, 1933. This snake measured 59 inches in length and weighed two pounds, 11 ounces. During transportation a single egg was laid but was broken by the weight of the snake; the following day 28 additional eggs were deposited. These were obviously abnormal as the shells were very flabby and the eggs changed their shapes as they were rolled about. They measured roughly 40 to $50 \mathrm{~mm}$. in length by 20 to $30 \mathrm{~mm}$. in width. When they were opened they were found to contain a thick white fluid.

\section{Lampropeltis getulus nigra (Yarrow)}

Black King Snake

Description.-A medium to large snake attaining a length of four and a half feet or more. Largest adult Ohio specimen ( $\left.\sigma^{\prime}\right), 40 \mathrm{r} / 2$ inches in length; smallest newly hatched juvenile, $91 / 4$ inches. Head small, depressed, and but little distinct from neck. Eye medium small; cephalic plates normal. Two 
nasals; the nostril lateral and between the nasals. Loreal present. Body medium slender and varying but little in diameter throughout. Tail short and tipped with a spine.

Dorsal scale rows $19-21-19$ or $19-21-19-17$ and less often $21-19$; the formula 19-17 is exhibited in a single specimen from Scioto County. Scales smooth. Upper labials 7; lower labials 9, rarely 8. One preocular and 2 postoculars. Temporals 2, rarely 1 , in the first row; and 3, rarely 2 , in the second row. Ventrals in males 202 to 210 , average 205.7; in females 198 to 212, average 202.3. Subcaudals in males 46 to 54 , average 49.7 ; in females 41 to 49 , average 44.7. Anal plate single.

Ground color above, olivaceous black to black. Dorsal surface from tip of snout to tip of tail crossed by 71 to 95 rows of very small yellowish dots which fork and refork on the sides to impart an indistinct chain-like pattern. Throat, chin and labials yellowish; labial plates blackish along the sutures. Belly yellowish, heavily marked with squarish or irregular blackish blotches.

Specimens examined, 21; specimens preserved, 21; specimens studied, 20.

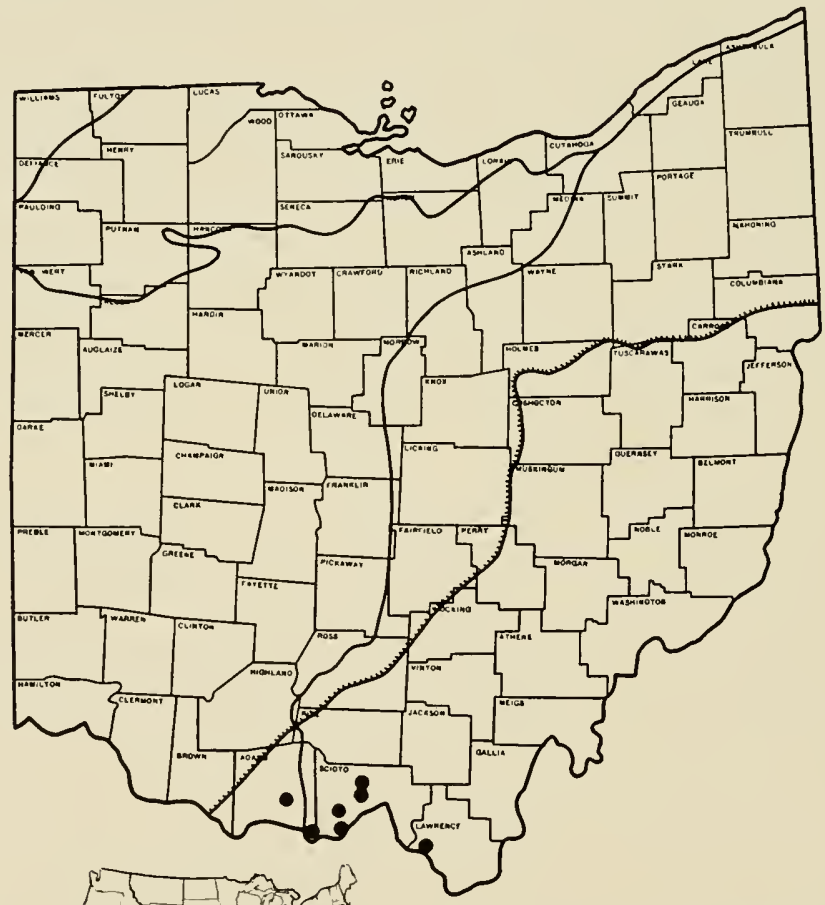

Map 14. Ohio locality records and general range of the Black King Snake, Lampropeltis getulus nigra. 
Range.-Eastern Illinois to southern Ohio and south to central Alabama. The black king snake barely enters the southern limits of the state (Map 14). Locality records are:

Adams County: Jefferson Twp. (OSM 468), Lynx Prairie, near Lynx (TZS 2401-5 - 4 hatched in captivity); Reck Run, Green Twp. (OSM 90). LAwrENCE County: Hanging Rock near lronton (OSM 31). Scioto CounTY: $10 \mathrm{mi}$. SW of Portsmouth (TZS 1943, 2000-7 -8 hatched in captivity); Roosevelt Game Preserve, Nile Twp. (OSM 429.1); Rushtown (OSM 357); 2 mi. N of Rushtown (TZS 1890); 2 mi. S of Rushtown (TZS 693).

Habitat and Habits.-The black king snake is rather rare in Ohio; only nine specimens were obtained in the field, and of these, three were found dead. Individuals were taken in the bottom lands of the Scioto and Ohio Rivers and in the adjacent hills. Two were dead on the road along the Scioto River near Rushtown and another was taken in a nearby comfield. One was discovered beneath a large slab of sandstone on a rocky pastured hillside directly above the Ohio River flood plain in Scioto County and another was on a dry rocky slope a few miles back in the hills. A specimen taken in a small dry prairie near Lynx, Adams County, was found crawling in the open shortly after noon May 29, 1933. Blatchley $(1899,545)$ writing on the reptiles of Vigo County, Indiana, states that this species "frequents rocky hillsides and the vicinity of streams." Blanchard $(1921,44)$ found a specimen in Tennessee, shortly after sunset, which was lying at full length along a road through farming country.

King snakes resisted capture at first by striking and biting and emitting a shatp hiss, but after being handled for a few minutes they became quiet and permitted close examination without show of fight. The only specimen which varied from this behavior remained netvous and erratic throughout the more than two years it was kept in captivity. Whenever recently hatched juveniles were disturbed they struck repeatedly to the accompaniment of a sharp hiss and the rapid vibration of their tails. Caged individuals showed a decided tendency to hide under objects introduced into their quarters.

The food of the king snake is varied; small mammals, birds and reptiles are included on its menu. Captives ate white mice, young rats, sparrows and the following snakes: Butler's garter snake, common garter snake, DeKay's snake, common water snake, and queen snake. Blatchley (loc cit.) records a specimen from Indiana which was found in the act of swallowing a gatter snake. Eggs, lizards and venomous snakes might be added to the list if the feeding habits of this form are (as would be expected) similar to those of its related subspecies, the eastern king snake (Lampropeltis getulus getulus) and Holbrook's king snake (Lampropeltis getulus holbrooki).

The black king snake is a constrictor. Large or struggling prey is encircled in one or more coils of the body which are pulled tightly until the victim is suffocated. Small or defenseless food is engulfed directly or is held beneath a coil of the body while being swallowed.

The king snakes in general appear to be immune to the venoms of the rattlesnakes and the moccasins (copperhead and cottonmouth). There ate numerous records in which the poisonous species were overcome and eaten 
even after biting king snakes repeatedly. Snakes of all species are usually seized by the head which, of course, lessens the victim's chance for resistance. Captive black king snakes were observed to stalk other snakes and refrain from grasping them until an opportunity was afforded to strike at the head.

Some observations on the eggs and young of the black king snake have been published recently (Conant, 1934c). A female 33 inches in length laid 10 eggs June 22, 1933, and another 353/4 inches in length deposited 9 eggs June 25,1933 . These were capsule-shaped except for a few which were pointed at one end; all were white at first but became yellowish in a few hours. The eggs of one clutch were all adherent to one another, but in the other clutch some were together and some were not, probably because the snake had moved while depositing them. Measurements varied in length from 28.1 to 47 $\mathrm{mm}$. and in width from 17.4 to $22.6 \mathrm{~mm}$., and the averages of the two clutches were respectively 31.4 by 18.5 and 41.5 by $21.6 \mathrm{~mm}$. Young, which hatched from 78 to 81 days after the eggs were laid, measured from $91 / 4$ to $103 / 4$ inches in length.

Lampropeltis triangulum triangulum (Lacépède)

Milk SNake; House SNake

Description.-A moderately slender, medium sized snake attaining a length of a yard or more. Largest adult Ohio specimen ( $)$ ), $43 \mathrm{r} / 2$ inches in length; smallest juvenile, probably recently hatched, $83 / 8$ inches. Head small, flattened and but little distinct from neck. Eye small; head plates normal. Two nasals; the nostril lateral and between them. A single loreal present. Body moderately slender and of approximately the same diameter throughout. Tail stout, tapering to a point and terminated normally by a short, stout spine.

Dorsal scale rows $21-19-17$ in the majority of specimens but occasionally 21-19; a maximum of 23 in one specimen from Lucas County. Scales smooth. Upper labials 7 (8 on one side in a specimen from Scioto County); lower labials usually 9 , occasionally 8 or 10 . One preocular and 2 postoculars. Temporals 2 in the first row, and 3, less often 2, in the second row. Ventrals in males 195 to 208, average 201.8; in females 197 to 210 , average 203.3. Subcaudals in males 46 to 53 , average 49.4 ; in females 42 to 48 , average 45.6 . Anal plate single.

Ground color some shade of grey, tan or light brown. There are five longitudinal series of dark blotches of which the ones of the median row are much the largest, being longer than broad and involving approximately 11 to 16 rows of scales transversely and 4 to 7 rows longitudinally. Alternating with the central series, and usually involving the 2 nd to the lower part of the 6th row of scales on either side, is another series of blotches, below which in turn is still another series involving the ends of the ventrals and the first 2 or 3 rows of scales. Blotches are brown, maroon or reddish brown to red and are bordered with black; juveniles are usually reddish but adults are browner. The blotches of the median series are much the brightest; the lowermost series is frequently dark grey or black. The blotches in the median series vary from 27 to 51 in number counting from the head to a point directly above the anus. 
The belly is white but marked with small squares of black. Across the posterior half of the prefrontals is a dark band and another extends from the eye to the angle of the mouth. A heart or V-shaped blotch of the ground color lies on the nape of the neck and another smaller one on the parietals; both are usually enclosed within dark extensions forward from the first dorsal blotch but there are many departures from this arrangement.

The largest specimen collected was taken in Troy Township, Wood County. It shows abnormalities in color in that both the ground color and blotches are darker than normal. The area between the median dorsal blotches is buff and stands out in marked contrast to the darker areas. The belly is salmon instead of white although anteriorly the ventral scutes show salmon bases and whitish ends.

Specimens examined, 156; specimens preserved, 97; specimens studied, 44.

Affinities.-Two milk snakes from Hughes, Butler County, which are preserved in the United States National Museum (No. 10084) have been identified by Blanchard $(1921,186)$ as Lampropeltis triangulum syspila. A

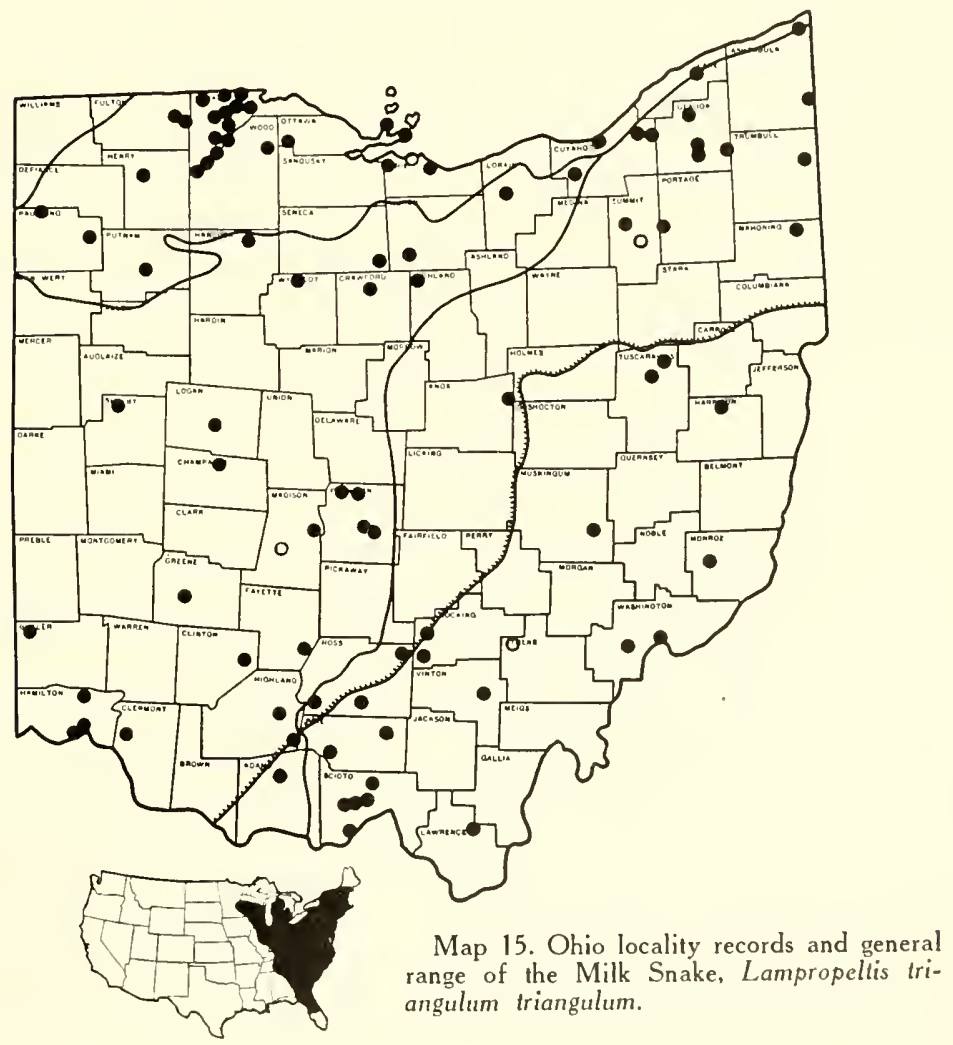


study shows that except for the fact that one has only 24 blotches in the median dorsal series, they fall within or close to the range of variation in triangulum in Ohio. Since aberrant specimens which strongly resemble syspila occur in many parts of the range of triangulum (Blanchard, 1921, 192), and since milk snakes from other parts of Butler County and the adjacent region are all clearly referable to triangulum it seems preferable to consider all Ohio specimens as of that race. Furthermore there is reason to believe that the specimens in question may not have come from Hughes (page 7). The range of syspila is west of Ohio. It is stated by Blanchard $(1925 \mathrm{a}, 28)$ to be "Southern Indiana to Minnesota, south to central Arkansas and west to central Kansas."

Range.-Eastern United States and southern Canada from Minnesota and Maine south to Florida. The milk snake occurs throughout the entire state of Ohio (Map 15). Locality records are:

Adams County: Lawshee, W of Peebles (OSM 299.1). Ashtabula County: Conneaut Creek, Conneaut Twp. (OSM 205.3); Pymatuning Swamp, near Andover (TZS 1032-4). Athens County: Nelsonville (Morse, 1904). Butler County: Dodge's Creek, $\mathrm{N}$ of Oxford (MU). Champaign County: $6 \mathrm{mi}$. $\mathrm{N}$ of Urbana (TZS 1881). Clemmont County: Union Twp. (CSNH 1175, 1451). Clinton County: Centerville, Lee's Creek P.O. (TZS 747). Crawford County: 4 mi. NW of Sulphur Springs (TZS 452). CuYahoga County: Chagrin Valley (CMNH); Cleveland (WRU); East Rockport, Berea, (MCZ 212); Mayfield (CMNH). ErIe CountY: Castalia (UMMZ 59793); Huron Twp. (SHS); Sandusky (Blanchard, 1921). Fayette County: Wayne Twp. (OSM 469). Franklin County: (OSM 33); Columbus (AS); Franklin County Infirmary, SE of Columbus (OSM 374): Grigg's Dam, near Dublin (OSM 404.1-.2); $N$ of Worthington (OSM 92). Fulton County: Swanton; $21 / 2 \mathrm{mi}$. NW of Swanton (TZS 69l). Geauga County: 2 mi. N of Bundysburg (DOR); Chardon; Lake Kelso, Burton Twp. (TZS 1332-4); South Bog, Burton Twp. (CMNH). Greene County: 3 mi. W of Xenia. Hamilton County: (CSNH 1982; Morse, 1904); Cincinnati (CSNH 1668); Eden Park, Cincinnati (CSNH 879); Glendale, Cincinnati (CSNH 1132). Hancock County: Cass Twp. (TZS 1945). Harrison County: Scio (BGSU). Henry County: Napoleon (TZS 99). Highland County: 5 mi. S of Carmel (TZS 1612); $6 \mathrm{mi}$. E of Hillsboro (TZS 257). Hocking County: Salt Creek Twp. (AS; OSM 246; TZS 1004-7); near South Perry (TZS 1164).

Huron County: Near Willard. Knox County: Brinkhaven (AS; OSM 366.3). Lake County: Perry, along Grand River (OSM 367). Lawrence County: Near Arabia, Aid Twp. (TZS 418). Logan County: (OSM 32); Bellefontaine (TZS 2292). Lorain County: Oberlin (OC). Lucas County: Crissey; Holland; Monclova; Maumee; 4 mi. N of Maumee (TZS 596); Richfield Center; Sylvania; Toledo (TZS 1047); Trilby; Waterville; Indianola Island above Waterville (TZS 1269) ; 6 mi. W of Toledo. Madison County: Jefferson Twp. (OSM 298); London (Morse, 1904). Mahoning County: Youngstown (CM 2057). Monroe County: $4 \mathrm{mi}$. W of Woodsfield (TZS 2008). Muskingum County: (CSNH 2011); near Chandlersville, Rich Hill Twp. (TZS 2408). Otrawa County: Catawba Island (TZS 1504, 1655); Genoa; Marblehead, Danbury Twp. (TZS 1193). Paulding CountY: $4 \mathrm{mi}$. NE of Antwerp (OEE); Charloe, Brown Twp. (OEE). PIKE CountY: Laurel Ridge, Sunfish Twp. (TZS 1081) ; $4 \mathrm{mi}$. E of IVaverly (TZS 1070). Portage County: Kent (NU 8, 11-12, 18). Putnam Ccunty: 3 mi. WSW of Ottawa (TZS 399). Richland County: Plymouth Twp. (TZS 1211-2). Ross County: Colerain Twp. (TZS 314); Huntington Twp. (TZS 647); Big Round Top, Paint Twp. (CSNH 1867). Scioro CounTy: 2 mi. S. of Henley (TZS 1880); $2 \mathrm{mi}$. N of Lucasville (DOR); $8 \mathrm{mi}$. SW of Portsmouth (TZS 1082); $1 \mathrm{mi}$. S 
of Rushtown (DOR); Shawnee Forest, Union Twp. (OSM 206). Seneca Countr: Venice Twp. (TZS 1001). Shelby County: Kettlersville (UMMZ 44337). Summit County: Akron (Morse, 1904); Ira (OSM 91, 93, 203, 212). Trumbull. County: Vernon Twp. (TZS 1013-4). Tuscarawas County: Zoarville (MC); Dover (TZS 2283). VINTON County: Near Prattsville (DOR). Wasilington County: Barlow Twp. (DOR); Marietta (MC). Wood County: Grand Rapids (TZS 98); Lemoyne; Perrysburg; Troy Twp. (TZS 1867). Wyandot CountY: Tymochtee Creek, $3 \mathrm{mi}$. NE of Crawford (TZS 285).

Habitat and Habits.-The milk snake is far from rare in Ohio. Despite its secretiveness it is numerous enough and sufficently conspicuous to be well known.

Nearly all the specimens collected during the present survey were found beneath boards, stones, pieces of discarded sheet-iron, tar paper, etc., or under the bark of rotting logs or stumps. One was found in a stump densely populated with ants. One or two were discovered sunning themselves in early spring, but the few others observed in the open were taken at night. It is probable that this species is more or less nocturnal, especially during hot weather.

The milk snake occupies a wide variety of habitats including woods, meadows and rocky hillsides. Even in well settled areas it occurs in waste land and it is found well within the city limits of some of the largest communities in the state. It occasionally enters farm lands, barns and other outbuildings where probably it is attracted by the presence of mice. Specimens discovered near stables are often falsely accused of extracting prodigious quantities of milk from cows. Persons who make such accusations fail to consider the small size of the snake and the fact that its mouth is equipped with sharp, hook-like teeth rather than sucking lips. No irrefutable proof has been produced to the effect that snakes ever extract milk from cows.

Specimens either remained motionless when first encountered, or crawled toward shelter. When once thoroughly disturbed they usually became pugnacious; they vibrated their tails rapidly and struck to the accompaniment of a short, sharp hiss. Captives and even freshly acquired individuals were usually quiet when handled, but they had an unpleasant habit of moving their heads parallel to a finger and then deliberately opening their mouths and sinking their teeth into the flesh without warning.

Specimens were collected from April to November inclusive with the greatest number being taken in May and June. A majority of those found in September and October were recently hatched young. Workmen grading the abandoned Miami and Erie Canal bed at Maumee, Lucas County, found two hibernating examples buried two or three feet in a clay bank on January 26, 1934.

The milk snake frequently was found in association with colonies of small secretive snakes and there is much evidence to indicate that it had been feeding on them. One disgorged a worm snake (page 37) and two had garter snakes in their stomachs. Another specimen seized and began swallowing a common swift which was placed in the same collecting sack with it. There are numerous similar records in the literature and it is probable that almost 
any snake or lizard, which is not too large or too active to be overpowered and swallowed, may be taken as food.

The most common item in the diet of the milk snake is mice. Surface $(1906,178)$ showed from his studies of this species that mice constituted $711 / 2 \%$ of the food and that the destructive meadow mouse (Microtus) alone made up $48 \mathrm{r} / 2 \%$ of the total. A specimen collected in Pike County, Ohio, disgorged two young mice of undetermined species. Other food includes birds $51 / 2 \%$, snakes $6 \%$, undetermined mammals $11 \%$, undetermined vertebrates $3 \%$, etc. (Surface, loc. cit.). From the above studies and those of various authors it is clearly shown that the milk snake is one of the most valuable snakes from the standpoint of human economics and certainly deserves protection.

Specimens ordinarily are not hardy as captives. At the Toledo Zoo only one out of many adults accepted food; it devoured 3 white mice which it disgorged the next day. Several juveniles, however, ate young snakes of other species. The milk snake has many of the same habits as the king snake and like the latter it is a constrictor and overcomes its prey in its coils.

The milk snake is oviparous. An individual 34 inches in length collected at Monclova, Lucas County, May 23, 1930, deposited 16 eggs in captivity during the night of June 28,1930 . These were white, oval and with smooth leathery shells; measurements averaged $30 \mathrm{~mm}$. in length by $16 \mathrm{~mm}$. in width. A group of 17 eggs (possibly laid by 2 females) was discovered under a bark slab on a decaying sawdust pile near Mansfield, Richland County, June 26, 1932. All were white except for 6 which were stained with blood; the entire set was adherent and the eggs were arranged roughly in two layers, one above the other. Measurements were from 25 to 35 , average $28.1 \mathrm{~mm}$., in length and from 17 to 20 , average $18.5 \mathrm{~mm}$., in width. All failed to hatch.

No juveniles were hatched in captivity but from the condition of the navel scar in several young collected in late summer or fall a number were judged to be but recently out of the egg. These varied from $83 / 8$ to $97 / 8$ inches in length.

\section{Natrix erythrogaster erythrogaster (Forster)}

\section{Red-Bellied Water SNake; Red-Belly}

Description.-A medium to large snake attaining a length of about four and a half feet. Largest adult Ohio specimen ( + ), $55 \mathrm{~T} / 2$ inches in length; smallest newly born juvenile, $85 / 8$ inches. Head medium and slightly wider than neck. Eye medium, but somewhat larger than in the common water snake. Head plates normal except that the two nasals are arranged in an oblique plane so that the nostril between them is directed both sideward and somewhat upward. Loreal present. Body slender in young to stout in adults. Tail slim to medium stout.

Dorsal scale rows usually $23-21-19-17$ or $21-23-21-19-17$, and less often 21-19-17, but occasionally exhibiting a maximum of 25 . Scales keeled. Upper labials 8 , rarely 7 ; lower labials $10,9,11$ or 8 , occurring less frequently in the 
order given. One preocular; usually 3, occasionally 4 and rarely 2 postoculars. Temporals usually 1-3; less often 1-2. Ventrals in males 149 to 156, average 151.8; in females from 149 to 157, average 153.5. Subcaudals in males 71 to 84, average 77; in females 64 to 74, average 67.4. Anal plate divided.

Adults uniform black or brownish black above. Belly uniform bright red or scarlet except for the antero-lateral portions of each ventral scute which are black or blackish. In many adult specimens this black area is so large as to cover the major portion of each ventral, thus resulting in a proportionate reduction of the area occupied by the red. This condition most noticeable posteriorly where occasionally the black areas form a mottled pattern. Throat and chin whitish. Labials reddish, but with the sutures between them dark red brown to black.

In juveniles there is a well defined pattern of dark (usually black) blotches on a reddish or brownish ground. The blotches of a middorsal series, from 31 to 42 in number from head to directly above the anus, are 3 or 4 scales long and 9 to 11 scales wide. Alternating with the dorsal series is a lateral series of smaller blotches 2 or 3 scales wide and 8 or 9 scales high, and which are situated from the 8 th or 9 th row of scales to the edges of the ventrals. The first 1 to 9 , average 3.7 , dorsal blotches are united with the lateral blotches to form dark crossbands or saddles, but this condition does not extend back as far, on the average, as in Natrix sipedon sipedon. The belly is pinkish, reddish or orange with the bases of the ventrals dark. Top of head dark; chin and labials similar to adults. The juvenile pattern gradually changes to the adult coloration as the snake grows older; in a specimen $331 / 2$ inches long from Blakesley, Williams County, which shows the uniform colors of the adult, the juvenile pattern can be made out faintly when the specimen is held in the proper light after shedding. (In preservatives the reddish areas quickly fade to yellow).

Specimens examined, 52; specimens preserved, 33; specimens studied, 40.

Range.-Southeastern Pennsylvania and the Carolinas to eastern Oklahoma and eastern Texas, and north in the Mississippi Valley to Illinois and Indiana; northwestern Ohio and extreme southern Michigan.

The red-bellied water snake has been collected in southern Michigan (Clark, 1903 and Clay, 1934) as well as in northwestern Chio (Map 16), but otherwise the nearest locality is southwestern Indiana (Blanchard, 1925b, 384). This snake was probably widespread through the intervening area at one time and probably still will be found in some localities. Many suitable habitats doubtless have been destroyed by the draining of ponds preliminary to agricultural activities. The red-bellied water snake probably reached northwestern Ohio from the southwest and it even might be suggested that the Wabash River valley served as the avenue of migration. Locality records are:

Hardin County: 3 mi. E of Mt. Victory (TZS 132, 386, 1662-80, 1690-1. 1748). Williams County: 1 mi. SW of Blakesley (OSM 443; TZS 374, 387-90. $1735,1858,1866)$. 


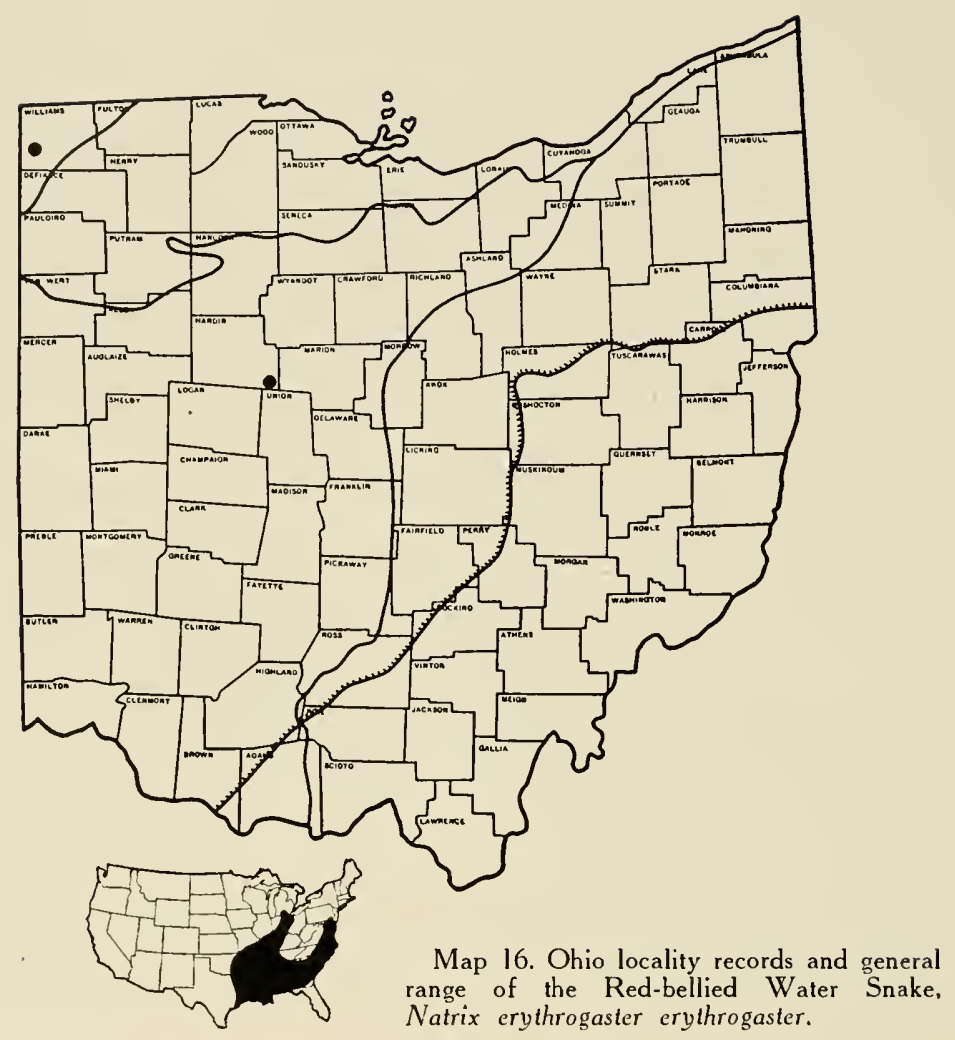

Habitat and Habits.-The red-bellied water snake is rare in Ohio but although it has been taken in only two restricted localities it appears to be well established in each. The conditions in both are similar. There are small woodland ponds, shallow in spring but frequently becoming dry in summer. Second growth woods border at least a portion of them, but open grassy meadows (devoted to grazing) are adjacent to or even surround the smaller ones. Cat tails rise in many and in the majority there is a profuse growth of the button-bush (Cephalanthus occidentalis L.).

As long as water remains in the ponds the red-bellied water snakes may be found in or near them, and often they may be seen sunning themselves on logs, tufts of grass or on the button-bushes. When the ponds become dry, however, the snakes wander about the meadows and woods where they have been taken as much as 200 yards or more from the nearest empty pond. They are difficult to find in midsummer, for besides the fact that they are scattered, the vegetation is high and forms an excellent cover for them.

Red-bellies are active and aggressive. They plunge into the water when approached and once alarmed they often remain motionless on the bottom 
where several were found by probing for them with the hands. They strike and bite viciously and their sharp teeth are capable of producing deep scratches or may be broken off in the captor's hand or glove. Some individuals flatten their bodies perceptibly when they are in striking position. The musk glands are used freely and the fluid, which is of a most unpleasant odor, is copiously discharged.

A number of species of snakes were found in association with the redbellied water snake and several of these are characteristic of the plains and prairies and have their ranges in Ohio essentially or exclusively in the glaciated portions of the state. Included are the blue racer, DeKay's snake, ribbon snake, Butler's garter snake, massasauga, and the common garter snake. Of special significance, however, is the fact that in both the Hardin County and Williams County localities the common water snake is uncommon, only two or three having been collected in each. While the latter species occurs in practically every body of water in Ohio and is universally abundant, its rarity in these two localities possibly may be explained by the fact that it finds other habitats more favorable than the dry conditions presented by these areas in midsummer.

Only one note is available on the natural food of the red-bellied water snake in Ohio. A specimen disgorged a leopard frog (Rana pipiens) when captured. There are a few records in the literature, however, and Ditmars $(1907,251)$ states that a specimen he collected in South Carolina "disgorged -eleven suckers, three sunfish and a crawfish"; Blanchard (19256, 384) records that an Indiana specimen disgorged seven large frog tadpoles and a larval salamander. It is probable that the food of specimens from the two Ohio localities may consist largely of amphibians and crayfish which are common in each. It is unlikely that fish occur in the ponds, for the latter, in addition to drying up in summer apparently have no direct connection with other bodies of water and no fish were seen in them. Captive snakes, however, throve on chopped fish and readily took frogs and toads of several species.

On May 7, 1932, much activity was noted in the colony of the red-bellied water snakes near Blakesley, Williams County. Many were swimming about in the water and one, evidently oblivious to the collector's presence, swam close enough to be caught easily. Mating activities were evidently in progress, for several parrs were found together; it was impossible to ascertain whether they were actually in coitu for they became alarmed and separated when approached. In the same locality, April 22, 1933, a pair was found mating and another male lay coiled nearby.

Three litters of young were born in captivity. A female 43 inches in length (but with part of the tail missing) collected near Mt. Victory, Hardin County, July 23, 1932, gave birth to 8 young September 30, 1932. Another female $437 / 8$ inches in length, taken in the Williams County locality, April 22, 1933 , bore a litter of 10 young, plus 4. dead, but well formed embryos, October 10, 1933. On October 14, 1933, a third female 483/4 inches in length, with the same collecting data, gave birth to 8 young plus 19 dead embryos, and also passed 3 infertile ova. Further evidence that the birth was abnormal is seen 
in the fact that several of the embryos were malformed and showed signs of having been dead for some time. Lengths of the living young from the three groups varied from $85 / 8$ to $103 / 8$ inches at birth. In each litter the largest specimen did not exceed the smallest by more than $11 / 8$ inches nor by less than $3 / 4$ inch. In the first group, which is the only one which can be considered as having had normal birth, the young varied from $91 / 4$ to $103 / 8$, average $97 / 8$, inches.

\section{Natrix kirtlandii (Kennicott)}

KirTLANd's SNAKE.

Description.-A small snake reaching a length of somewhat less than two feet. Largest adult Ohio specimen ( + ), 21 inches; smallest newly born juvenile, 5 inches. Head small and scarcely distinct from neck. Cephalic plates normal. Two nasals, the nostril lateral and largely in the prenasal. Loreal present. Body slender in juveniles to moderately stout in adults. Tail rather slender and terminating in a spine.

Dorsal scale rows normally $19-17$, but occasionally reduced to 17 for a short distance anteriorly or to 16,15 or even 14 posteriorly. Scales keeled. Upper labials 5 or 6 ; lower labials 7 , occasionally 8 , rarely 6 or 9 . Oculars 1-2, rarely 1-3. Temporals 1-2, rarely 1-1. Ventrals in males 123 to 135 , average 129; in females 125 to 136 , average 131. Subcaudals in males 57 to 69 , average 62; in females 50 to 61 , average 55 . Anal plate divided.

Ground color above, some shade of light brown or grey upon which are superimposed four longitudinal rows of subcircular black blotches. Those of the outer rows alternate with those of the inner and are somewhat the larger; they involve 2 or 3 scales longitudinally and from 4 to 7 scales transversely. The blotches of each inner row, which tend to become obsolete posteriorly, are situated on either side of the middorsal line and may either alternate with or lie opposite their partners of the other inner row. They involve 2 or 3 scales longitudinally and from 3 to 5 scales transversely. The number of blotches in each of the four rows is about the same; those in any one row, counting from the head to a point directly above the anus, are from 45 to 61 , average 53. Occasionally a series of small spots, which alternate with the blotches of the outer row, may be observed on the first row of scales and the tips of the ventrals. Among many of the smaller specimens all of these markings may be so obscure as to be seen only when the skin is stretched; adults are usually well patterned. The top of the head is black; the labials, chin and throat are cream or yellowish.

The belly is bright red or brick red in life but fades to yellow in preservatives. Near the end of each ventral scute is a conspicuous black spot giving the appearance, collectively, of two parallel longitudinal rows of spots. Frequently the belly between these rows may be marked with small irregular dark dots which sometimes may be quite numerous, especially posteriorly. The ends of the ventrals are dusted with grey.

Specimens examined, 155; specimens preserved, 116; specimens studied, 90. Range.-Central and northeastern Illinois, southern Michigan, Indiana, 
Ohio, Pennsylvania and New Jersey. In Ohio, Kirtland's snake probably occurs throughout the glaciated area (Map 17), for although records are lacking for the northeastern counties, this species is known in Pennsylvania. The few taken south of the glacial boundary were in or near small bogs or woodland ponds. The fact that these snakes appear to occur habitually in more or less moist, open situations and were not taken in deep woods, might indicate they were originally restricted to the wet prairie areas of the state. The habitats occupied in the cities of Toledo and Cincinnati probably are artificial but they appear to be highly favorable. Locality records are:

Auglaize County: Lake St. Mary's (OSM 444; TZS 244). Butler County: Oxford (MU). ERIE CounTY: Eastern part of Sandusky (MCZ 10011; SHS). Fairfield County: Sugar Grove (OSM 40, 94). Franklin County: Columbus (Smith, 1882). Hamilton County: (Morse, 1904); Cincinnati (CSNH 1453, 1632, 1664, 1717, 1721; OSM 458): Avondale. Cincinnati (CSNH 1435A-C. 1461, 1502; OSM 461); Clifton, Cincinnati (CSNH 1874A-C, 2017): Eden Park, Cincinnati (CSNH 852.1-.4, 875, 929); Glendale, Cincinnati (CSNH 1651). Hancock County: Cass Twp. (TZS 600). Highland County: Near Hillsboro (TZS 1721); 3 mi. S of Hillsboro (TZS 638-45). Hocking CountY: Salt Creek Twp. (OSM 393.1). Huron County: New London (OSM 39). Lucas County: East Toledo

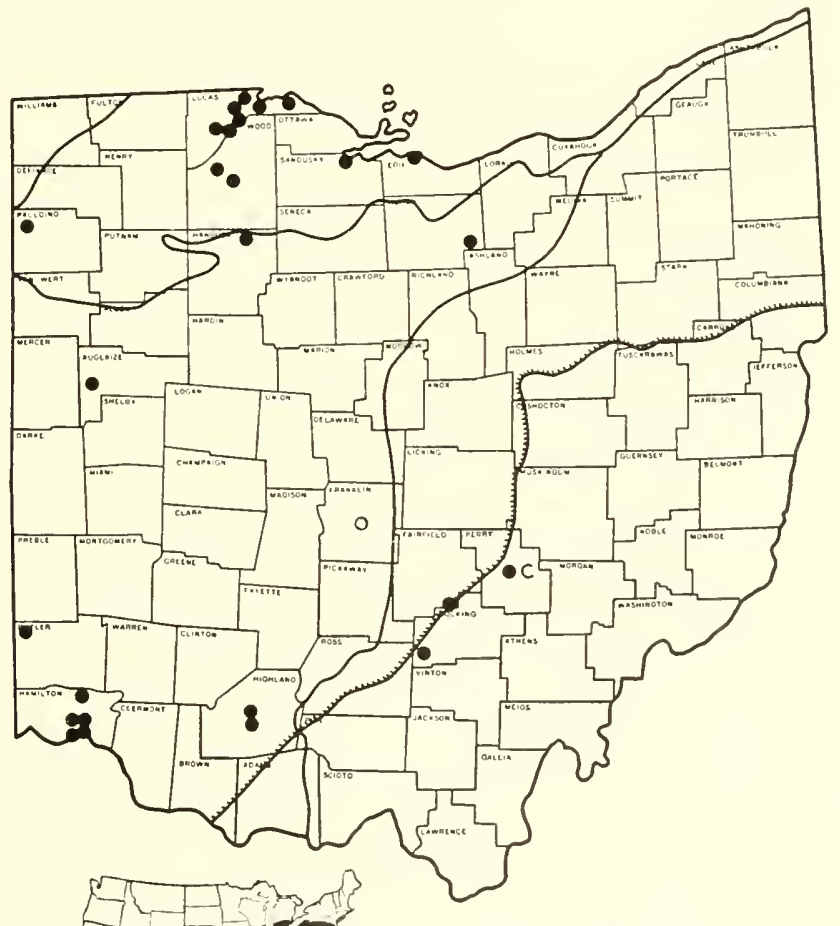

Map 17. Ohio locality records and general range of Kirtland's Water Snake, Natrix kirtlandii. 
(OSM 293; TZS 204-6, 1660, 1966); Maumee (TZS 1091); Monclova (BGSU; TZS 2388); Niles Woods, Jerusalem Twp. (TZS 1656); Toledo (ANSP 20601-2; TZS 9, 628-35, 1476; UMMZ 68879): Toledo-north end (TZS 2300); West Toledo (TZS 13); Toledo-near Toledo Zoological Park (CM 5278-80, 6677-8, 8088-95; TZS 33-5, 81, 92-7, 379-81, 914, 940, 1092-3, 1196-7, 1222, 1289-1290A, 1647, 1685, 1830, 2382-3, 2419). PAulding CountY: Maumee River at Antwerp (TZS 2418). Perry County: (OSM 38). Sandusky County: 6 mi. NNE of Fremont (TZS 1427). Wood County: Bowling Green (BGSU); Perrysburg (USNM 83449); Tontogany (TZS 396).

Habitat and Habits.-Considering Ohio as a whole it cannot be said that Kirtland's snake is a common species, but it is well established and abundant in at least two areas. These, unusual though it may seem, are in or near residential sections of the cities of Toledo and Cincinnati. Most of the other localities are represented only by single specimens.

Moist situations appear to be more or less a requisite, but Kirtland's snake is decidedly less aquatic than the other Ohio representatives of the genus Natrix. Only two or three specimens were found actually in water although several were in the vicinity of marshy meadows or small woodland pools and less often along streams. A few were discovered by raking through mud or soggy masses of grass and leaves. Almost all those found in early spring were covered with mud or clay, with which they had become coated during hibernation.

In Cincinnati these snakes occur on idle land and in several of the public parks, even ranging over the hillsides which often become decidedly dry in midsummer. In Toledo they are also found in the parks but the largest numbers were taken in a few acres of open fields and meadows immediately adjacent to the Toledo Zoological Park. The abandoned Miami and Erie Canal, the Toledo portion of which was drained in 1929, passed through this area. It is expected that the loss of the canal and the development of the boulevard which is to occupy its bed will have a considerable effect on this colony of Kirtland's snakes. The more aquatic species, the common water snake and queen snake, once common along the canal, disappeared shortly after it was drained.

A number of specimens were found in the open, particularly in the spring, but most were located under boards, stones, etc. A characteristic behavior was to flatten the body until it was almost ribbon-like in appearance. This action often was accompanied by a rigid immobility of the snake, which, in turn, was followed by a series of ineffectual strikes. Whether or not the mouth was opened during this maneuver was not determined, but none of the many handled made any attempt to bite. Given an opportunity to get away they actively did so and the habit of flattening the body, coupled with an erratic wriggling sometimes made them difficult to hold.

Kirtland's snake was collected in all the months of the year except November and December. The greatest number were taken in April and a graph showing seasonal distribution would have a peak two weeks to more than a month earlier than the majority of other species of snakes in the state. Common garter snakes, Butler's garter snakes, water snakes, queen snakes, DeKay's snakes and blue-tailed skinks were all found in association with Kirtland's snake at one time or another. 
Freshly captured specimens disgorged slugs and earthworms. In captivity they throve on the latter and occasionally would eat chopped fish. Ditmars $(1936,172)$ states, "It feeds upon small frogs and toads." None of the Kirtland's snakes taken in Ohio exhibited evidence of having eaten such prey, nor did captives show interest when frogs or toads were introduced into the cages with them. While small amphibians no doubt constitute a part of the diet of the present species it is believed that earthworms form the major portion. The prey is seized and swallowed as it struggles to escape.

A number of young were born in captivity. Six litters contained respectively $5,7,7,8,11$ and 11 individuals and the dates of birth ranged from August 4 to September 8 inclusive. Parturition in each female was completed within a few hours' time. The young were usually covered with a thin membrane through which they broke shortly after birth, but occasionally this was ruptured in advance and the snake and covering were extruded separately. The juveniles exhibited the habit of flattening their bodies immediately after being born and practically all shed their skins within 24 hours.

The length of females giving birth to young ranged from $145 / 8$ to $185 / 8$ inches. The larger ones had the larger litters except that one $171 / 2$ inches in length bore the smallest number (5) and her young averaged the smallest of any produced. Lengths of young varied from 5 to $65 / 8$ inches but in no one litter did the largest individual exceed the smallest by more than 3/4 inch.

\section{Natrix septemvittata (Say)}

\section{Queen Snake; Striped Water Snake}

Description.-A small snake which may attain a length of two and a half feet or more. Largest adult Ohio specimen ( $\%$ ), 33 inches; smallest newly born young, $73 / 4$ inches, but one collected at Toledo on August 18, 1930 measured $75 / 8$ inches. Head small, somewhat depressed and but little distinct from neck. Eye medium small. Head plates normal; a single loreal present. Two nasals, the nostril lateral and between them. Body slender in juveniles, stouter in aciults. Tail slender and tapering to a point.

Dorsal scale rows 19-17 in every specimen examined except one from Belmont County which has them 19-18. Scales keeled. Upper labials 7, rarely 6 or 8 ; lower labials 9 or 10 , rarely 8 or 11 . Oculars 2-2, rarely 1-2; temporals usually $1-2$ but occasionally 3 in the second row. Ventrals in males 138 to 154 , average 147.4 ; in females 139 to 153 , average 145.7. Subcaudals in males 72 to 79 , average 75.6; in females 64 to 72, average 68.0. Anal plate divided.

General color above, including the dorsal surface of the head, some shade of chocolate brown or chestnut. A light yellow stripe occupies the second and the upper half of the first row of scales and is continued forward on the head to include the upper labials and the lower parts of the rostral and lower postoculars. A narrow dark stripe may be seen on the middorsal row of scales and another occurs on the fifth (and also occasionally on the adjacent rows). These dark stripes may best be seen in young specimens; in the majority of adults they can be made out only with difficulty, if at all. 
The ends of the ventrals and the lower half of the first row of scales are brown, usually of a richer hue than the brown of the dorsal surface and, in contrast with the yellow lateral stripes and the yellow of the belly, stand out as two longitudinal dark stripes. Ground color of belly yellowish, superimposed upon which are two parallel rows of small brown or grey squarish blotches collectively extending the length of the adbomen and giving the appearance of two dark midventral stripes. Anteriorly these blotches unite to form a single line on the throat, while posteriorly they are apt to become confluent and may be represented solely by clouded or marbled areas, which condition is the usual one in large specimens. The under side of the tail is similar to the posterior portion of the belly. Chin and gulars are yellow.

To avoid confusing the queen snake with the garter snakes it should be remembered that the light middorsal stripe of the latter species is lacking in the queen snake. The double row of brown blotches on the belly is also characteristic of the queen snake.

Specimens examined, 257; specimens preserved, 176; specimens studied, 68.

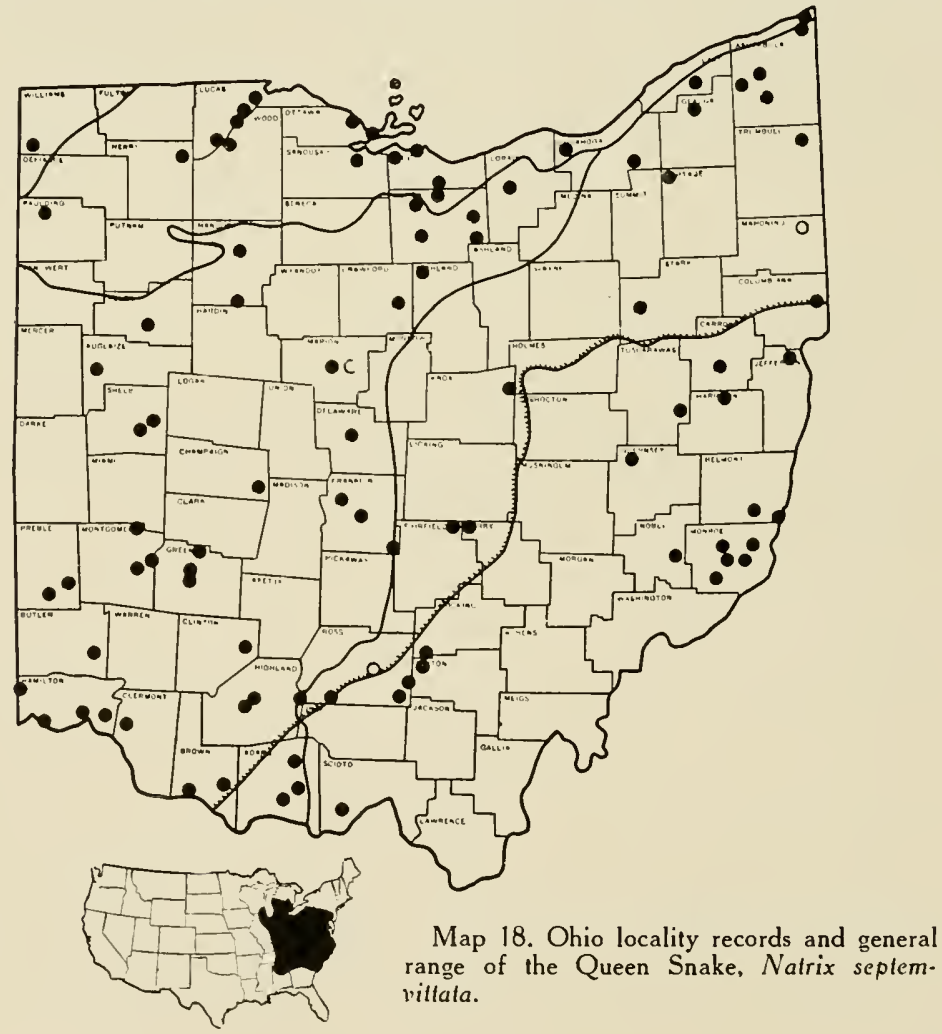


Range.-Pennsylvania to Wisconsin and south to South Carolina and central Alabama. Distribution in Ohio is general and the queen snake doubtless occurs in every county (Map 18). Specific localities are:

Adams County: Cedar Mills (OSM 248); Jefferson Twp. (TZS 719); Ohio Brush Creek at Buzzard's Rock, Tiffin Twp. (TZS 736-7); Peebles (TZS 2147). Allen County: Lima (USNM 21685). Ashtabula County: Conneaut (OSM 205.1); Conneaut Creek, near Conneaut (WC); Eagleville (CMNH); Farnham (TZS 1794); Rock Creek, Rome Twp. (TZS 1447-8); Trumbull (USNM 56049). Auglaize County: St. Mary's (ANSP 20603). Belmont County: Armstrong's Mills (TZS 1226-8); Captina Creek near Steinersville, Powhatan Point (TZS 1239-41). Brown County: 2 mi. W of Decatur (TZS 1914-7); White Oak Creek, $1 \mathrm{mi}$. N of Higginsport (TZS 1875-7). Butler County: Hughes (TZS 1957). Carroll County: Union Twp. (TZS 338). Champaign County: Mechanicsburg (OSM 99). Clermont County: Union Twp. (CSNH 1134, 1189, 1228; TZS 1415-25). Clinton County: Centerville, Lee's Creek P. O. (TZS 746). Columbiana County: Middleton Twp. (OSM 192). Crawford County: Sandusky River, $7 \mathrm{mi}$. E of Bucyrus (TZS 532). CuYahoga CountY: Dover Creek, Dover (USNM 40098); Furnace Run, near Bedford (NU 14). Delaware County: Delaware Twp. (OSM 289). ErIE County: (SHS; UMMZ 32847-9, 41942); Castalia (UMMZ 62659); Milan (UMMZ 31725-7); W of Milan (UMMZ 32958-60, 34257); Sandusky (OSM 49; UMMZ 31615-6, 32596, 32779, 40682-4, 41940). FAIRFIELD County: Buckeye Lake (OSM 98). Franklin County: (USNNi 25969-70); Columbus (Smith, 1882; OSM 47.1-.2); Hayden Falls, Norwich Twp. (OSM 287); near Lithopolis (OSM 225). Geauga County: Chardon (TZS 1786-8). Greene County: Oldtown (TZS 1894); 2 mi. N of Xenia; Yellow Springs (MCZ 741). Guernsey County: Kimbolton.

Hamilton County: (Morse, 1904; CM 5129); Duck Creek, Cincinnati (CSNH 201); Fernbank (CSNH 1059); Harrison (CSNH 1138); Newtown. Hancock County: Blanchard River, Findlay (USNM 21684); Near Williamstown (TZS 2268). Harrison County: Scio (TZS 339-40). Henry County: E of Texas (TZS 208-9). Highland County: (Smith, 1882; USNM 1381); Hillsboro; 15 mi. $\mathrm{E}$ of Hillsboro (TZS 568); Rocky Fork, $3 \mathrm{mi}$. SW of Hillsboro (TZS 560-1). Hocking County: Section 2, Salt Creek Twp. (TZS 986). Huron CountY: Clarksfield (USNM 40099); Huron River, Greenfield Twp. (TZS 1502); near Milan (SHS); Huron River, Monroeville (TZS 1563-72); New London. Jefferson County: Near Hammondsville (TZS 1560). Knox County: Brinkhaven. Lake County: Big Creek, Concord Twp. (TZS 1403-4). Lorain County: Oberlin (OC). Lucas County: Maumee (TZS 815); Toledo (TZS 134-5, 1360); Delaware Creek, Toledo (TZS 317); near Waterville (TZS 957). Mahoning CountY: Youngstown (Morse, 1904). Marion County: (CSNH 1763). Monroe County: Cranenest Fork, Center Twp. (TZS 491); Cranenest Fork, Green Twp. (TZS 1236-8); Sunfish Creek at Cameron (TZS 1246) ; Sunfish Creek, 2 mi. N of Woodsfield (TZS 1244-5); Washington Twp. (OSM 221). Montgomery County: (CSNH 2019); Dayton (USNM 13334-5); Harshman (UMMZ 46623-6); Sunderland Falls, Vandalia (CSNH 196). Nobl.e County: Stock Twp. (TZS 1249).

Ottawa Counry: Erie Twp. (TZS 1044); Port Clinton (TZS 492-3, 1998). Paulding County: South Creek, 3 mi. ENE of Antwerp (TZS 367-8). Perry County: Buckeye Lake (OSM 100). Portage County: Aurora Pond, Aurora Twp. (CMNH). Preble County: Aukerman Creek, 1 mi. NW of Gratis (TZS 942); Seven Mile Creek, Somers Twp. (TZS 1439). Richland County: Plymouth Twp. (TZS 1204-10). Ross County: Chillicothe (Morse, 1904); Paint Creek at Copperas Mt., Paxton Twp. (TZS 1105) ; Richmondale; Salt Creek, near Londonderry (TZS 1106-8). SANDUSky County: Green Creek, 6 mi. NE of Fremont (TZS 404). Scioto Counry: Roosevelt Game Preserve, Nile Twp. (AS). Shelby County: Miami River at Port Jefferson (TZS 1296); I mi. N of Sidney (TZS 1297). Stark County: Massillon (OSM 218.2). Trumbull County: Kinsman (TZS 1789-91). Tuscarawas County: Stillwater Creek, Mill Twp. (OSM 273.2). 
Vinron County: Pike Run, Eagle Twp. (TZS 979). Williams Counry: Stillwater River, near Edgerton Dam (UMMZ 63996). Wood CounTY: Opposite Maumee; opposite Waterville (TZS 915-8).

Habitat and Habits.-The queen snake is common and widely distributed in Ohio. It is decidedly aquatic and was not taken at any great distance from some body of water. It prefers slow moving or shallow rocky streams, but it also occurs about ponds, lakes, the abandoned canals and less often, perhaps, along the major rivers of the state. Specimens are often seen resting or sunning themselves upon logs, driftwood or trees overhanging the water into which they drop when approached. They are wary and some skill in stalking is usually necessary to catch them; some may be rushed successfully but the collector is as apt as not to get nothing but a bath for his trouble. Once in the water they dive to the bottom and usually attempt to secrete themselves in the mud or under any sheltering object. If the water is muddy or filled with aquatic vegetation there is little chance of seeing them again but in clear shallow places they can be followed and driven from one hiding place to another until caught.

A favorite shelter is under stones or logs which lie partially submerged along the water's edge. Rocky streams are often well populated and systematic overturning of the stones and detritus along these often revealed numerous queen snakes along with common water snakes, crayfish, small fishes and the larvae of aquatic insects. In this manner two collectors obtained 26 queen snakes in less than a half hour in the Huron River at Monroeville, Huron County, August 29, 1932.

A study of the records indicative of the relative abundance of the queen snake and the water snake (Natrix s. sipedon) shows that the latter is the more widely distributed in the state and was collected much more frequently than the former. In a number of streams, however, and especially those in many parts of southern and eastern Ohio the queen snake was found to outnumber the water snake two or three to one.

When a specimen is first captured the musk glands are freely used and the snake ordinarily struggles vigorously to escape. Some make no attempt to bite, but others strike repeatedly, although the teeth are too small to do more than break the skin.

Specimens were collected from April to October inclusive but there was little seasonal variation; they were taken as commonly in midsummer as in spring. At least two factors may contribute to this even distribution. First, the aquatic nature of the habitat provides more or less the same conditions throughout the season and even in cases of drought the snakes congregate about the remaining pools of water or work downstream to a more favored location. Second, in summer and early fall when the height and density of the vegetation makes collecting unproductive in most areas, the collector can wade stream beds and find aquatic reptiles in evidence.

No notes are available on hibernation but a specimen was found lying on the ice on the surface of a creek in Lucas County on January 18, 1931. After being warmed it appeared to be in good condition and in fact it lived in cap- 
tivity for several months. Whether it was actually frozen could not be determined for over an hour elapsed from the time the snake was caught until the writer saw it.

Queen snakes disgorged crayfish and small fish when captured. Atkinson (1901, 149) records crayfish as food and "also occasionally fish and small frogs." Surface $(1906,151)$ found crayfish in the stomachs of four specimens and a toad in another. It is doubtful as to whether the queen snake is active enough to catch the fast swimming food and game fish. Its small size precludes the taking of any but the smaller fish and like the common water snake much of its food is probably caught in land-locked pools, or consists of dead fish cast upon the shore. Judging from the many which disgorged crayfish this animal must constitute a considerable portion of its food. Captives fed rarely and then only on small crayfish.

A female $27 \mathrm{I} / 8$ inches in length from Toledo, Lucas County, gave birth io 11 young August 18,1930. These measured from $77 / 8$ to $8 \mathrm{~T} / 2$ inches in length. Another female 237/8 inches in length (but with part of the tail missing) collected August 6, 1932, in Union Twp., Clermont County, gave birth to 10 young August 20, 1932. These measured $73 / 4$ to $81 / 8$ inches in length, thus averaging slightly less than the litter mentioned above. Neither group exhibited the minimum size, however, for one taken in the field measured only $75 / 8$ inches.

\section{Natrix sipedon sipedon (Linné)}

\section{Common Water Snake; "Moccasin"}

Description.-A medium to moderately large snake attaining a length of four feet. Largest adult Ohio specimen ( $q$ ), $47 \mathrm{I} / 2$ inches in length; smallest newborn juvenile, $7 \mathrm{r} / 2$ inches. Head medium and slightly wider than neck. Eye medium in size. Cephalic plates normal excepting the two nasals which are in an oblique plane so that the nostril between them is directed both sideward and somewhat upward. Loreal present. Body slender in juveniles to stout in adults. Tail medium stout and tapering to a point; more slender in young.

Dorsal scale row formula variable; most usual groupings 23-21-19-17 and 21-23-21-19-17; less often 23-21-19 and still less often 23-25-23-21-19. (Even numbers appear occasionally and minimums of 18 and 16 are noted in a few instances. In a specimen from Ottawa County a maximum of 22 is recorded, and a maximum of 24 is seen in 5 specimens from scattered localities.) Dorsal scales keeled. Labials almost always 8 above and 10 below; rarely one more or one less. Oculars usually 1-3; rarely 2 in either place. Temporals 1.3 with occasionally 2 in the second row. Ventrals 135 to 149 , average 141.1. Subcaudals in males 68 to 78, average 73.3 ; in females 57 to 70 , average 62 . Anal plate usually divided but single in two specimens.

The dorsal surface is normally patterned with a median and lateral series of dark blotches, these being subquadrate in form and situated on a lighter ground. The coloration is extremely variable. The blotches in some specimens may be grey, pale brown or reddish, while in darker examples they may be 
deep grey, dark brown, reddish brown or black. The lighter specimens may have the blotches edged with a darker shade. The area between the markings varies from light $\tan$ or whitish to almost any shade of brown or grey. In many individuals the pattern may be less distinct posteriorly and in some adults the color of the ground may approach that of the blotches so closely as to present a nearly uniform dark appearance.

The blotches of the middorsal series, 26 to 43 in number from head to anus, are from 3 to 7 scales long and from 7 to 13 scales wide. The blotches of the lateral series, which alternate with those of the median series, are 2 or 3 scales wide and are situated from the 5th to 8th row of scales to the ends of the ventrals. The most anterior dorsal and lateral blotches unite to form dark crossbands or saddles, these averaging 10.6 in number, but frequently extending much farther back. In a single specimen from Geauga County the lateral blotches are alternated with the dorsal all the way forward to the head.

The belly normally is marked with numerous dark edged semicircles of

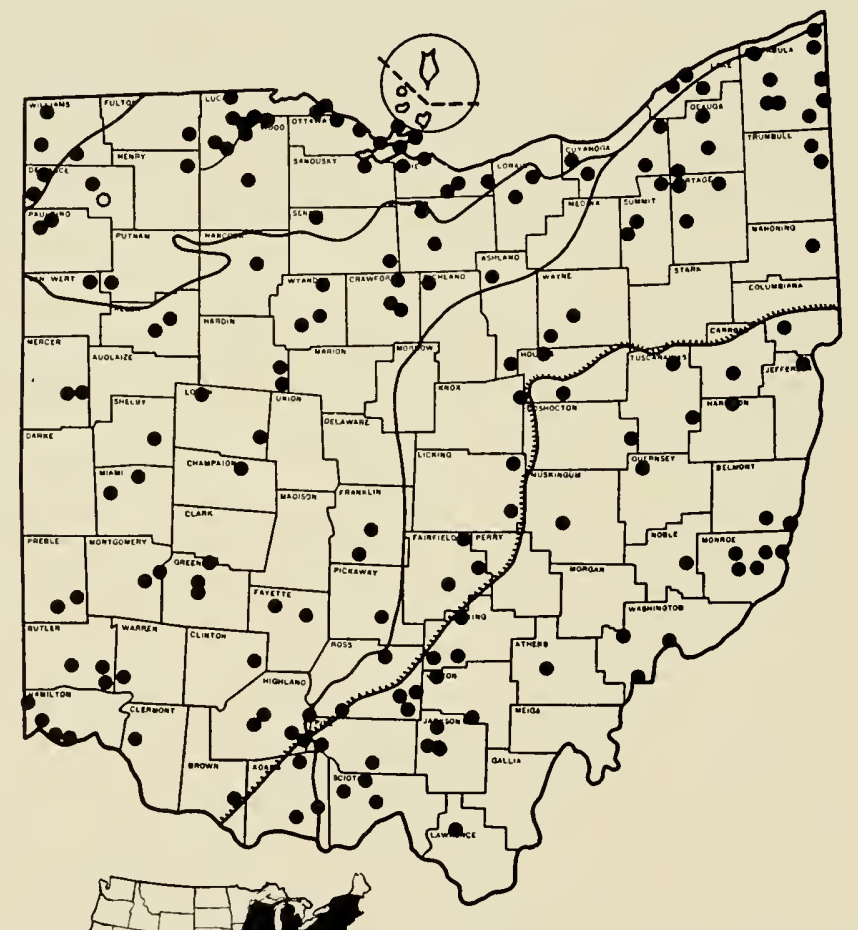

Map 19. Ohio locality records and general range of the Common Water Snake, Natrix sipedon sipedon. The area within the circle at the top of the map indicates the range of the Island Water Snake, Natrix sipedon insularum. 
greyish, brownish or reddish on a ground of yellowish or pale grey. Very frequently, however, these may be represented by more or less irregularly clouded, marbled or stippled areas, but in any event the markings become more numerous and often confluent posteriorly. In many specimens, and particularly in a majority of those from southern Ohio, there is a light midventral area of whitish or yellowish to orange or pinkish extending from the chin to or nearly to the anus. The top of the head is usually similar in color to the dorsal blotches. paler.

Juveniles are colored and patterned similarly to the adults but are usually

Specimens examined, 723; specimens preserved, 403; specimens studied, 167.

Range.-Southern Maine to Minnesota and Colorado, south to northern Alabama, Arkansas and Oklahoma. In Ohio the water snake doubtless occurs in every county (Map 19). Records are:

Adams Countr: Blue Creek (OSM 241); Ohio Brush Creek at Buzzard's Rock, Jefferson Twp. (TZS 739-40); Serpent Mound, Bratton Twp. (OSM 245). AlleN CountY: Sugar Creek, Lima (USNM 21690); 4 mi. NE of Lima (TZS 233). Ashland County: Clear Fork State Park, Hanover Twp. (TZS 2221); Savannah Lake, Clear Creek Twp. (TZS 1255). Asirtabula County: Eagleville (CMNH); Farnham; Geneva, Cowle's Creek (USNM 40093): Monroe Twp. (OSM 215.4); Pymatuning Creek, near Williamsfield (TZS 1020); Pymatuning Swamp, near Andover (TZS 1030-1); 3 mi. NE of Richmond Center; Rock Creek, Rome Twp. (TZS 1451); near Rome (TZS 1452). Athens County: Near Athens (OU). Belmont County: Armstrong's Mills (TZS 1229-30); Captina Creek, near Steinersville, Powhatan Point (TZS 1241A). Brown CounTY: 2 mi. W of Decatur (TZS 1918-20). Butler CoUNTY: Hughes; Timberman's Creek, 5 mi. from Hamilton (CSNH 209); Skinner's woods, near Westchester (TZS 281-2, 309, 393). CARroll County: Union Twp. (TZS 343). Champaign County: Kennard (TZS 1946-7). Clermont County: Union Twp. (CSNH II35A-C, 1227, 1236; TZS 1399-401). Clinton County: Near Centerville, Lee's Creek P. O. (TZS 673). Columbiana CounTY: Little Beaver Creek, S of Gavers, Wayne Twp. (TZS 344-6). Coshocton County: Ohio Canal, Oxford Twp. (TZS 1862). CRawford CounTy: Cranberry Twp. (TZS 994); Sandusky River, 7 mi. E of Bucyrus (TZS 454); Sandusky River, 3 mi. S of Sulphur Springs. CuYahoga Countr: East Rockport, Berea (MCZ 216); Furnace Run, near Bedford (NU 9); Mayfeld Twp. (TZS 538); North Olmsted (CMNH).

Defiance County: Defiance (Kirsch, 1895); Hicksville (FMNH 429); Ladd Lake, Milford Twp. (TZS 366); Section 31, Tiffin Twp. (TZS 1274). ERIE CounTY: (UMMZ 34255-6, 41941); Birmingham (OC); Castalia (SHS; UMMZ 62655-7); Milan (UMMZ 31722): Sandusky (SHS; UMMZ 31618-21, 31735-6, 32588-95, 32780, 32850-1, 32950-55, 40722-3, 40942); Old Woman Creek, Berlin Heights. FalRFIELD CounTY: Lancaster (TZS 504); Lieb's Island, Buckeye Lake (OSM 89); near Rushville (OSM 213). FAYETTE County: Near Bloomingburg (TZS 1994); Jeffersonville (OSM 126). FRANKLIN CoUnTY: (USNM 25964, 25971); Columbus (USNM 1107); Olentangy River, Columbus (OSM 45); Jackson Twp. (OSM 101). Fulton County: West Fork, Swan Creek, Swan Creek Twp. (TZS 517). Geauga CountY: Chardon (TZS 1783-4); Geauga Lake (TZS 539-40); Lake Kelso, Burton Twp. (TZS 821, 1335-8, 1780). Greene County: Oldtown; 2 mi. N of Xenia (TZS 2270-1); Yellow Springs (MCZ 791). GuerNSEY County: Wills Creek at Kimbolton (TZS 1256-7). Hamilton County: (Morse, 1904; CM 5131-2; CSNH 1993): Cleves (CSNH 1061); Delhi Twp.; Fern Bank (CSNH 1060A-B); Harrison (CSNH 1139A-B). HANCOCK CountY: Blanchard River, Marion Twp. (TZS 605). Hardin CounTY: Near Hepburn (TZS 1090); 
3 mi. E of Mt. Victory (TZS 1097, 1518-30A, 1999). Harrison CountY: Scio (BGSU). Henry County: Texas (TZS 1169); Washington Twp. Highland CounTY: 4 mi. SW of Carmel; Hillsboro; $15 \mathrm{mi}$. E of Hillsboro (TZS 569); Rocky Fork, $3 \mathrm{mi}$ SW of Hillsboro (TZS 548-59): 2 mi. $\mathrm{N}$ of Sinking Spring (TZS 562). Hocking County: Ash Cave, Benton Twp.; Clear Creek, Good Hope Twp. (OSM 382; TZS 289, 305); Salt Creek Twp. (AS; TZS 983-4). Holmes Countr: Killbuck Twp. (OSM 198); Odell Lake, Lakeville (TZS 2223). Huron CounTY: Huron River, Greenfield Twp. (TZS 1503); Huron River, Monroeville (TZS 1562). Jackson County: Near Canter's Cave, Jackson Twp. (TZS 738); Rock Run, Liberty Twp. (OSM 430.1; TZS 1616-37); White's Gulch, Liberty Twp. (TZS 1073-4). JefFerson County: Near Hammondsville (TZS 1559).

Knox County: Brinkhaven (AS; OSM 366.1). LAKe County: Big Creek, Concord Twp. (TZS 1402); Black Run Swamp, W of Fairport (TZS 1407); Mentor Marsh, Mentor Twp. (CMNH; TZS 543). Lawrence County: Dean Forest, Elizabeth Twp. (OSM 97.1-.2); Elizabeth Twp. (TZS 420). Lickinc CounTy: Flint Ridge, Hopewell Twp. (OSM 185); Wakatomika Creek, Fallsburg (OSM 418.1). Logan County: Pony lsland, Indian Lake (TZS 242-3, 271-2); $7 \mathrm{mi}$. N of North Lewisburg (TZS 563). LoralN County: Black Run, Elyria (USNM 40097); Oberlin (OC). Lucas CountY: Adams Twp.; Bono; Holland; Jerusalem Twp.; Maumee; Reno Beach; Sylvania (TZS 108); Delaware Creek, Toledo (TZS 283, 310, 315-6); Waterville (BCSU); Whitehouse. MAHONING County: Poland (USNM 1091). Mercer County: 1 mi. E of Montezuma (TZS 245); Montezuma (OEE) ; 3 mi. E of Montezuma (TZS 269-70). Miami CountY: Stillwater River, 11/2 mi. S of Covington (TZS 946); Greenville Creek, $11 / 2 \mathrm{mi}$. SW of Covington (TZS 945); Piquah (DOR). MonroE CounTY: Clarington (OSM 220) ; Cranenest Fork, Center Twp. (TZS 490); Cranenest Fork, Green Twp. (TZS 1231-5); Sunfish Creek at Cameron (TZS 1247); Sunfish Creek, 2 mi. N of Woodsfield (TZS 1242-3). Montgomeky County: Dayton (USNM 13336); Harshman (UMMZ 46633-7). Muskingum County: (CSNH 2010); Zanesville (OSM 473). Noble County: Stock Twp. (TZS 1248). Ottawa County: Bay Point (CMNH); $4 \mathrm{mi}$. E of Bono (TZS 321-2); Catawba Island (TZS 1340, 1342-8, 1350-9, 2365-76); Danbury Twp.; Erie Twp.; Marblehead; Marblehead Peninsula (USNM 35690-1); Mouse ls., Catawba lsland (TZS 2269); Near Port Clinton (TZS 648 . 67); Sandusky Bay. Paulding Countr: South Creek, $3 \mathrm{mi}$. ENE of Antwerp (TZS 384-5); 1 mi. S of Antwerp (OEE); Antwerp (Kirsch, 1895). PickawaY County: Hargus Run, Circleville (OSM 255.1-.2). PiKe County: Mifflin Twp. (TZS 547); 3 mi. S of Jasper. Portage County: Solon Bog, Aurora Twp. (CMNH); Twin Lakes, Franklin Twp. (NU 10); Hiram (NU 3). Preble CounTY: Aukerman Creek, $1 \mathrm{mi}$. NW of Gratis (TZS 943); Camden (OSM 228.1-.2); Seven Mile Creek, Somers Twp. (TZS 1395-8); Whitewater River, 1 mi. N of New Paris (TZS 948). Putnam County: Little Auglaize River. Ottoville (TZS 401). Richland County: (USNM 1064); Plymouth Twp. (TZS 1213-4). Ross County: 2 mi. SW of Kingston (TZS 978); Paint Creek at Copperas Mt.. Paxton Twp. (TZS 1102-4); Richmondale; Salt Creek near Londonderry (TZS 1109-31); Vauces. SANdusky County: $6 \mathrm{mi}$. NE of Fremont (TZS 407-8). Scioto County: Near Bear Creek, Morgan Twp. (TZS 1870); 2 mi. S of Rushtown (TZS 1533); Scioto Brush Creek, near Otway (TZS 1531-2, 1689). SENECA County: Liberty Twp. (OSM 243); Venice Twp. (TZS 1003, 1219). ShelbY County: 1 mi. NE of Sidney (TZS 1295). Summit County: Ira (OSM 95); Montrose (OSM); Twinsburg Twp. (TZS 622). Trumbull CountY: (USNM 56551-2) : Kinsman: Vernon Twp. (TZS 335). Tuscarawas County: Stillwater Creek, Mill Twp. (OSM 273.1); Zoarville (MC). VAN Wert Countr: Dog Creek, Jackson Twp. (TZS 400). Vinton County: Sec. 11, Eagle Twp. (TZS 985); Lake Alma, near Hamden. Warren County: (OSM 44-identified as Natrix fasciata fasciala L. by Morse, 1904); Mason (CSNH 1039). Washington Countr: Belpre Twp.; Marietta (MC); Palmer Twp. WAYNe CounTY: Near Craigton (TZS 2222); Miller's Pond, Wooster (WC); near Wooster (WC). Williams County: Bryan (DOR); 3/4 mi. SW of Blakesley (TZS 951, 1323); $3 \mathrm{mi}$. N of Blakesley 
(TZS 1760); Mud Lake, Northwest Twp. (TZS 1761). Wood County: Bowling Green; opposite Maumee; Rossford. Wyandot CountY: Mifflin Twp. (TZS 581); $2 \mathrm{mi}$. E of Upper Sandusky (TZS 1282); Tymochtee Twp. (TZS 582).

Habitat and Habits.-The water snake is one of the most widely distributed and certainly one of the most abundant snakes in Ohio. It was taken on practically every field trip and in many cases when collecting in general was poor, it was found in numbers. Almost every permanent body of water in the state is inhabited by it and it is frequently seen in streams which become dry in midsummer; it is absent, perhaps, only from streams heavily polluted with industrial waste.

Its association with water is quite marked. Even when specimens were found in such places as woods, rock piles, sawdust piles, in pubilic dumps and on cliffs, they were all within a short distance of the nearest pond or stream. Individuals, and especially young ones, traveled up small rills and ditches sometimes for considerable distances. They occasionally were found high up on the hills in unglaciated Ohio but even here they were almost invariably close to a spring or at least a trickle of water.

Water snakes are fond of basking, especially in early spring. They usually choose a stump, $\log$ or bush above or extending into the water and from which they can drop when they are alarmed. They are wary and are difficult to stalk; it is usually easier to get close to them from the water side of their resting place, either by wading or by approaching in a boat or canoe. Once in the water they either swim rapidly away or dive to the bottom to hide. They sometimes secrete themselves under the bank or log on which they were resting and if one probes for them with the hands they often can be located. They swim well and occasionally traverse sizable bodies of water.

Specimens hide under flat stones and logs lying at or near the water's edge, and systematic overturning of these often netted large collections. On dark cloudy days few individuals appear to be active and the great majority remain in concealment. Those which have just eaten or are about to shed their skins usually are found in hiding.

Water snakes are almost always aggressive when caught and the experienced collector wears leather gloves to protect his hands. They bite viciously and large ones are capable of producing deep scratches. Their pugnaciousness causes them to be known locally as "water moccasins," but the true venomous water moccasin (Agkistrodon piscivorus) of the southern states has not been found as far north as Ohio. Unlike the latter snake the water snake seldom stands its ground but instead usually flees from man. Some specimens flatten their bodies when they are alarmed. The sectetion from the musk glands is exuded profusely at the time of capture and since it is of a vile smelling odor it serves well as a weapon of defense.

Specimens were collected in every month from March to October, inclusive, but by far the greatest number was taken in May, June, and July. Owing to its abundance and widespread distribution, the water snake was found at one time or another in association with almost all of the other species of snakes known to occur in Ohio. 
The food of the water snake consists almost exclusively of cold-blooded animals. From the stomachs of specimens collected in the state the following animals were obtained: crayfish, minnows (Notropis), white crappie (Pomoxis annularis), catfish (Noturus flavus), bull frog (Rana catesbeiana), green frog (R. clamitans), leopard frog (R. pipiens), mud puppy (Necturus m. maculosus) and a small water snake of its own species. Fish probably constitute a large portion of the food but it is unusual for water snakes to catch the fast moving game fish. The snakes doubtless obtain many fish from pools in which the latter have become land-locked as a result of the fluctuating levels of the streams. It also appears that the snakes serve a useful purpose as scavengers by consuming dead fish which would otherwise rot and serve as breeding places for flies, etc. Surface $(1906,155)$ records mice and shrews as occasional food.

A pair of specimens was found in mating position April 19, 1931, on Pony Island, Indian Lake, Logan County. The male had its tail entwined about that of the female but it could not be determined whether they were actually in coitu. Young are born alive. A female $403 / 4$ inches in length, which was collected near Port Clinton, Ottawa County, August 20, 1931, gave birth to 19 young August 23, 1931. These varied from $8 \mathrm{I} / 4$ to 9 inches and averaged $85 / 8$ inches in length. Ditmars $(1936,164)$ records a litter of 44 young.

\section{Natrix sipedon insularum Conant and Clay}

\section{ISLAND WATER SNAKE}

Description.-A medium to moderately large snake attaining a length of well over three feet. Largest adult Ohio specimen ( $\$$ ), 40 inches in length; smallest newly born juvenile, $77 / 8$ inches. Head medium and slightly wider than neck. Eye medium in size. Head plates normal excepting the two nasals which lie in an oblique plane so that the nostril between them is directed both sideward and somewhat upward. Loreal present. Body slender in juveniles; stouter in adults. Tail medium stout and tapering to a point; more slender in young.

Dorsal scale row formula variable; scales most frequently 21-23-21-19-17, 23-21-19-17 and 23-21-19-18; occasionally a maximum of 25 and a minimum of 16. Dorsal scales keeled. Upper labials almost always 8 , but 7 in a few cases; lower labials almost always 10 but occasionally 9 or 11 ( 8 on one side in one specimen). Oculars usually 1-3; very rarely 2 preoculars, but often 2 postoculars. Temporals 1-3, often 1-2. Ventrals in males 141 to 151 , average 146.3; in females 137 to 152 , average 146 . Subcaudals in males 70 to 81 , average 75.4 ; in females 58 to 68 , average 63.2. Anal plate divided (single in one specimen).

In the most typical specimens of insularum the dorsal surface is uniform grey, greenish grey or brownish grey and the ventral surface is uniform white or yellowish white except for the bases of the ventrals which are often of the same color as the dorsum.

In some specimens there is a faint indication of a middorsal and lateral 
series of dark blotches but these markings are small and of a shade but slightly darker than the dorsal surface. In other specimens the pattern is more developed and somewhat darker, and is suggestive of that exhibired by the common water snake. However, along each side there is a grey patternless area from 4 to 10 rows of scales in width which imparts to the specimen a light grey lateral stripe.

The chin and throat are the same color as the ventral surface, and the top of the head the same as the dorsal. In many specimens there is a light midventral area of orange or pinkish which extends from the throat to the anus. Juveniles are uniform in coloration, or somewhat patterned as in the adults, but they are usually paler and often with the markings slightly better defined.

Specimens examined, 413; specimens preserved, 114; specimens studied, 229.

Intergrades.-Specimens from many of the Lake Erie islands show intergradation with Natrix sipedon sipedon by having patterns which are intermediate between the two forms. Random crossings from the mainland to the islands and from island to island must take place occasionally since the distances which separate the various bodies of land are not great. It is of significance, however, that the farther one gets from the mainland the less evidence there is of the influence of sipedon. The proportion of specimens of sipedon, intergrades and typical insularum have been worked out (Conant and Clay, 1936) and it has been shown that intergrades are common on such islands as Kelley's Island and Put-in-Bay, which lie close to the Ohio mainland, and rare on the more remote Pelee Island, Ontario, the type locality for the subspecies. Intergrades and more or less typical insularum occur rarely on the Catawba and Marblehead peninsulas, Ottawa County, Ohio. The procedure outlined by Dunn (1934) has been followed and the island populations as a whole are considered as insularum.

Range.-The islands in the western end of Lake Erie (Map 19). Ohio records are as follows:

ERIE County: Kelley's Island (TZS 103-4, 146-50, 182, 1926-31; USNM 40094). Ottawa County: Catawba Island (TZS 478, 1341, 1349); Green Island (TZS 137); Lakeside; Lost Ballast Island (OSM 96.1-.2); Middle Bass Island (TZS 2311-62); Put-in-Bay (OSM 41 -identified as Natrix fasciata erythrogaster Shaw by Morse, 1904; SL; TZS 1932; UMMZ 35852, 42811; USNM 40067-8, 40108, 40115, 40119); Rattlesnake Island (OC; FMNH 2544).

Habitat and Habits.-The island water snake is abundant on most of the islands of the Put-in-Bay Archipelago. Dozens of specimens were taken in a very short time on many occasions and three collectors obtained 234 of them in exactly four hours on June 1, 1935.

The islands are of limestone of a more or less porous nature and bogs and ponds are rare upon them. Most of the water snakes appear to be confined to the edges of the islands where there is an abundance of cliffs, ledges and piles of loose rocks. On these they prowl or sun themselves and under them they find an abundance of hiding places; sometimes a dozen or more were discovered under a single rock. Specimens surprised in the open attempted to 
crawl beneath various objects or dashed for the water where they swam either at the surface, or near the bottom in search of a loose rock under which to hide. Individuals were not often encountered on the sand and stony beaches, but they appeared to inhabit abandoned docks, and even those in use, almost as frequently as they did the rocky areas.

Specimens almost invariably struck and bit viciously when they were caught and the foul smelling fluid from the musk glands was copiously discharged.

Since it was necessary to depend upon the steamboats for transportation to and from the islands it was not possible to collect upon them except during the summer months. However, specimens were obtained from the last of May to the first of October, inclusive. Of other snakes, only the common garter snake was found with these water snakes in the field.

The food of the island water snake must consist largely of the dead and dying fish which are washed ashore. Twice specimens were seen eating dead fish in the field and several times fish were disgorged which appeared to have been dried by the sun before being engulfed. That the snakes render a useful service as scavengers in helping to clean up the large numbers of dead fish which litter the shores is obvious. Frogs were found to be rare along the shores of the islands, possibly as a result of the great abundance of the snakes. However, captive specimens did not touch frogs, which lived in cages with them for months at a time, although they ate fish with alacrity. Several times in the excitement of feeding, a frog was seized, but the snake almost immediately rejected it. From these very fragmentary observations it might be suggested that the island water snakes have lost some of the tolerance for the skin gland secretion of frogs which mainland water snakes appear to have.

The island water snake produces its young alive. A large female collected on Kelley's Island September 5, 1930, gave birth to 19 young which averaged $87 / 8$ inches in length. A female collected at Put-in-Bay, June 1, 1935, was bred in captivity February 22, 1936. On May 20, 1936, it gave birth to 10 young which varied in length from $81 / 4$ to $97 / 8$ inches. The female measured $37 \mathrm{r} / 8$ inches.

\section{Storeria dekayi (Holbrook)}

\section{DekaY's SNAKE}

Description.--A small snake attaining a length of somewhat more than a foot. Largest adult Ohio specimen ( 9 ), 16I/2 inches in length; smallest newly born juvenile, $33 / 4$ inches. Head small and somewhat distinct from neck; eye medium. Head plates normal. No loreal; two nasals, the nostril in the prenasal. Body slender in juveniles to medium stout in adults. Tail tapering gradually to a point.

Dorsal scale rows 17 in every specimen examined; the scales keeled. Labials $7-7$, very rarely 6 or 8 . Oculars usually $1-2$, less often $1-3$ and rarely 1-1. One anterior temporal; usually 2, less often 1 or 3 posterior temporals. Ventrals in males 120 to 129 , average 123.8 ; in females 124 to 134 , average 
129. Subcaudals in males 48 to 58 , average 52.9 ; in females 41 to 49 , average 45.3. Anal plate divided.

Color above, light yellowish grey or light brown to dark grey or dark brown and occasionally a deep reddish brown. A light middorsal band, slightly paler than the rest of the ground color, occupies the median 3 and halves of the adjacent rows of scales. The two scales on either side of this pale band are more deeply pigmented, and on these is a row of small blackish spots, more or less prominent and frequently with upward extensions which may unite with those of the opposite side to form narrow dark crossbands. Often another row of smaller blackish spots may be seen situated below and alternating with those of the upper row. In many specimens, however, all of these markings may be indistinct and may be made out only with difficulty, this being particularly true in the darkest individuals.

Belly pale yellowish, brownish or pinkish. Frequently the end of each ventral may bear one, or occasionally more, small black dots. Top of head somewhat darker than rest of ground color. A dark area extends downward from the eye and another from the anterior temporal to the commissure. Narrow dark blotches are situated on either side of the nape of the neck and these may unite across the dorsum to form a dark ring 2 or 3 scales posterior to the parietals.

Juveniles are similar in color to the adults, but average darker and have the pattern more obscure. At birth a conspicuous yellow band, 2 or $21 / 2$ scales wide, crosses the neck and occupies the area between the parietals and the above mentioned dark ring. The yellow soon darkens to become approximately the same shade as the rest of the dorsal surface.

Specimens examined, 412; specimens preserved, 138; specimens studied, 80.

Range.-From southern Maine west through the lower peninsula of Michigan to central Minnesota and central Kansas, and south, except peninsular Florida, to the Gulf of Mexico and along the coast to central Guatemala.

DeKay's snake occurs throughout most of glaciated Ohio (Map 20). Only one specimen was taken south of the glacial boundary and it was in a small marsh near Jimtown, Eagle Township, Vinton County (May 15, 1932). That this species will be taken in additional localities in the unglaciated plateau is quite probable. The prevalent well drained and dry hills are probably not favorable for it and it is more to be expected in the valleys or in the infrequent bogs within the area. Locality records are:

Allen County: Lima (Kirsch, 1895). Ashland County: $91 / 2 \mathrm{mi}$. N of Ashland (TZS 2458). Ashtabula County: Conneaut (OSM 205.2); Farnham; 2 mi. $\mathrm{E}$ of Kingsville (TZS 1038): Monroe Twp. (OSM 215.5-.7); Tinker's Hollow, Monroe Twp. (TZS 1023, A-B); Pymatuning Swamp, near Andover (TZS 328-9, 1458-61); 3 mi. NE of Richmond Center; Wayne Twp. (OSM 108.5); West Andover (TZS 1+62-4); Williamsfield (TZS 1022). Butler CountY: Monroe (USNM 10665-6). Champaign County: Kennard (OSM 447). Crawford County: 4 mi. NW of Sulphur Springs (TZS 449-50). Cuyahoga CountY: Cleveland (Baird and Girard, 1853); East Rockport, Berea (MCZ. 218); Solon (CMNH); western part of Cleveland (TZS 757). Defiance County: Defiance Twp. (TZS 847). Erie County: (UMMZ 34259-61); Cedaı Point (BGSU); Castalia (UMMZ 62658); Huron (OC; USNM 40095); Sandusky (SHS; UMMZ 32781-5). FAIRFIELD 
County: Buckeye Lake (OSM 104, 277). Franklin Countr: (OSM 52); Columbus (OSM 50.1-.3, 58.1, 105-6, 167, 391.1-.6; USNM 1957); $\mathrm{E}$ of Columbus (OSM 107); North Columbus (OSM 103). Geauga CountY: Chardon; Lake Kelso, Burton Twp. (TZS 822-5, 1336A). Greene County: Spring Valley. Hancock County: Cass Twp. (TZS 601-4, 610-19). Hardin Countr: 3 mi. E of Mt. Victory (TZS 594, 636, 694-5, 816). Henry County: Near Texas (TZS 1722-3). Highland County: (USNM 1947); $\mathrm{N}$ side of Ft. Hill, Brush Creek Twp. (TZS 567). Holmes County: (USNM 55940). Huron County: Richmond Twp. (TZS 1171-2). Lake County: Madison (USNM 6474). Lorain County: Oberlin (OC). Lucas County: Little Cedar Point, Jerusalem Twp.; Maumee (TZS 1731); Toledo (TZS 84, 203, 303); Pt. Place, Toledo (TZS 199, 1693); East Toledo; N. Toledo; Swan Creek, Toledo (TZS 947); Trilby; Waterville. Morrow CountY: Congress Twp. (shed skin); Ortawa County: Bay Point (OSM 186.2); Crane Creek, 3 mi. $E$ of Bono (TZS 867); Catawba Island; Port Clinton (TZS 302); Put-in-Bay (SL); Rattlesnake Island (TZS 91). Portage County: Aurora Twp. (CMNH; TZS 533); Hiram (NU 20); Freedom Station (CMNH); Kent (OSM 53-identified as Storeria occipito-maculata (Storer) by Morse, 1904). Putnam Countr: Cloverdale (Kirsch, 1895). Richland CountY: Plymouth Twp. (TZS 1303). Seneca County: Venice Twp. (TZS 993, 1054). Summit County: Barberton (OSM 290); Peninsula (NU 21). Trumbull County: Vernon Twp. (TZS 330-2, 1011). Union County: Paris Twp. (OSM 288). VInton County: Jimtown, Eagle Twp. (OSM 399.I). Wayne County: Creston (OC); Wooster (WC). Williams

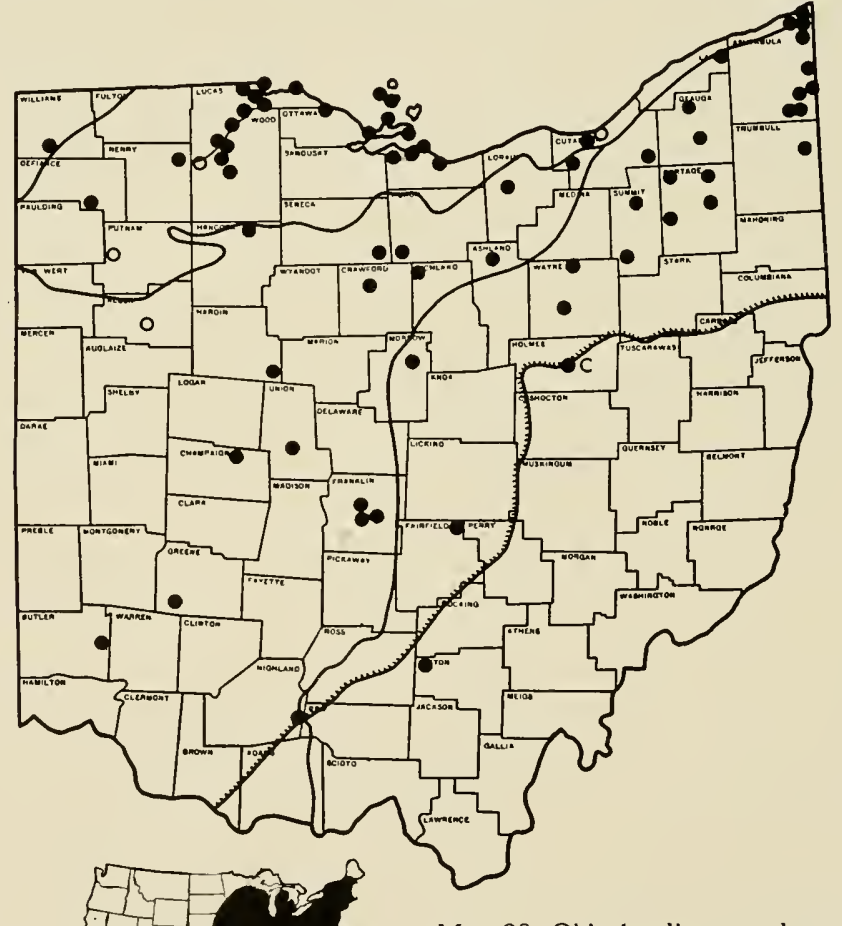

Map 20. Ohio locality records and general range of Dekay's Snake, Storeria dekayi. 
County: 4 mi. W of Bryan (TZS 1759). Wood County: W of Bowling Green (BGSU); Grand Rapids (Cope, 1900); Tontogany (TZS 395); opposite Waterville.

Habitat and Habits.-In many localities DeKay's snake is an abundant serpent. While it is common and well distributed in many parts of the state it is seldom seen abroad except in early spring. At this season, in common with other snakes, the breeding instinct appears to be paramount to every other and specimens may show practically none of their accustomed caution. Many were found moving about in open fields and by roadsides, and they were also discovered along shallow ditches into which they dove and swam away. Males were apparently the most active and in spring collections they outnumbered the females. In summer when the females were heavy with young this sex was taken more commonly and numerous collections made at that time of year showed the males to be in the minority.

Under ordinary circumstances DeKay's snake is a secretive serpent and a large majority of the specimens were taken in such favorite hiding places as under stones, boards and the bark of rotting logs. Moist woods, wet prairies and meadows, the environs of bogs and swamps, farmlands and city parks are included among the habitats occupied by this species. Moisture appears to be more or less a necessity and none were taken in actually dry situations. Their ability to keep well hidden is no doubt responsible for their abundance in many urban areas, even in small parcels of unoccupied land surrounded by human habitations.

A more inoffensive snake is difficult to imagine. None of the many collected attempted to bite and aside from the efforts to crawl away or wriggle from between the fingers the only defense activity was a tendency to flatten the body and use the musk glands. The flattening was not carried to such an extent as in Kirtland's snake, but the action helped to brighten the pattern by spreading the scales apart and revealing the skin between them. The secretion from the musk glands had a sweet odor which was not particularly unpleasant.

DeKay's snakes were collected every month in the year. November and December were lowest with three specimens each but April was by far the highest with over a third of the entire catch. October was second with slightly more than half as many as April, and May was third with somewhat less. A graph of the seasonal distribution would show a sharp peak for April with a drop in May, a tapering downward during the summer months and a second lesser peak in October. Specimens taken during the winter were out on warm days or were discovered in barns or houses. DeKay's snakes were found in one locality or another with all the other species of snakes known to occur over a considerable portion of glaciated Ohio.

The food consists largely of earthworms and slugs. A Hardin County specimen was discovered in the act of swallowing a small slug. It lay at length upon a weed some six inches from the ground and when it was picked up it disgorged another slug. The vegetation was wet and examination revealed that slugs were numerous in the immediate vicinity. Several others disgorged earthworms when captured. Surface $(1906,139)$ gives the food as slugs and snails $67 \%$, insect larvae $16 \%$ and earthworms $17 \%$. Captives fed well on earthworms. 
A pair of DeKay's snakes was found in mating position at Toledo, March 28,1931 , but they separated before it could be determined whether they were actually in union. A female $13 \mathrm{~T} / 8$ inches in length (but with part of tail missing) collected in Cass Twp., Hancock County, August 1, 1931, gave birth to 9 young August 4, 1931. These ranged in length from $33 / 4$ to $43 / 16$ inches. Several shed within a few hours after birth. That the number in a litter occasionally may be considerably greater is suggested by the fact that a specimen 14I/4 inches in length from Mt. Victory, Hardin County, collected July 6, 1931, contained 23 embryos. Another female 131/8 inches in length collected October, 1927, at Columbus, contained 24 eggs of large size which appeared to have been fertilized for only a short time. Such might be indicative of a late summer or early fall mating.

A female $12 \mathrm{r} / 4$ inches in length from Lucas County contained 3 embryos when examined upon its death July 27, 1931. These were well formed and the largest measured $33 / 8$ inches in length. Since the female had been in captivity for over a month and no evidence of young had been seen it was assumed that the 3 embryos constituted the entire complement.

\section{Storeria occipito-maculata (Storer)}

\section{Storer's Snake: Red-Bellied SNake}

Description.-A small snake attaining a length of about a foot. Largest adult Ohio specimen ( क ) ,121/8 inches in length; smallest newly born juvenile, $35 / 8$ inches. Head small, blunt and but slightly distinct from neck. Two nasals; nostril lateral and in the prenasal. No loreal. Body subcylindrical and tapering slightly at either end. Tail tapering to a point.

Dorsal scale rows 15 throughout the length of the body; the scales keeled. Upper labials 6, rarely 7; lower labials 7, rarely 8. Oculars 2-2; temporals $1-2$, occasionally $1-3$. Ventrals in males 121 to 131 , average 124.8; in females 123 to 131 , average 127 . Subcaudals in males 49 to 54 , average 51 ; in females 43 to 49 , average 46 . Anal plate divided.

The color above is light grey brown or chestnut brown to black. In all but the very darkest specimens four longitudinal stripes, slightly darker than the ground color, may be discerned. These occur on the first, and the sixth (or fifth and sixth) rows of scales. There are usually three yellowish spots immediately behind the head. These are obscure in some specimens, but in others they are so large as to be confluent and to give the appearance of a neck ring. The belly is uniformly red or pink; the edges of the ventrals are often dusted with grey in the lighter individuals and with black in the darker. Chin and labials are greyish.

In a melanistic specimen from the Pymatuning Swamp, near Andover, Ashtabula County, the general appearance both above and below is uniform black. The markings can be seen only upon close examination except for the occipital spots which are prominent and brownish orange in color.

Many juveniles are very dark in color.

Specimens examined, 47; specimens preserved, 43; specimens studied, 30. 
Range.-Central Maine to southern Manitoba, south to north central Florida and west to the Great Plains in Kansas and the Dakotas.

Storer's snake is common in Ohio only in the extreme northeastern portion, an area characterized by the many northern elements in its flora and fauna. Elsewhere in the state Storer's snake appears to be of local and rather infrequent occurrence (Map 21). Ohio locality records are:

Ashland County: Sullivan (CMNH). Ashtabula County: Eagleville (CMNH); 2 mi. E of Kingsville (TZS 1026); 2 mi. E of Monroe Center (TZS 961); Monroe Twp. (OSM 215.8-.11); Pymatuning Swamp. near Andover (OSM 392; TZS 1198-9, 1305, 1475, 1505, 1536-42, 1854); Williamsfield (TZS 1021). Fairfield County: Sugar Grove (OSM 54). Geauga County: Lake Kelso, Burton Twp. (TZS 1782); Burton (CSNH 2016). Hamilton County: (Morse, 1904). Hocking County: Salt Creek Twp. (OSM 246.2). Lake County: Madison (USNM 6473). Mahoning County: Near Garfield (DOR); Yellow Creek, Poland (USNM 2151). Portage County: Aurora Pond, Aurora Twp. (CMNH; TZS 749): Freedom Station (CMNH). Scloto County: $12 \mathrm{mi}$. SW of Portsmouth (TZS 1816); Roosevelt Game Preserve, Nile Twp. (TZS 1508); Shawnee Forest, Union Twp. (OSM 206.2). Trumbull County: Vernon Twp. (TZS 333).
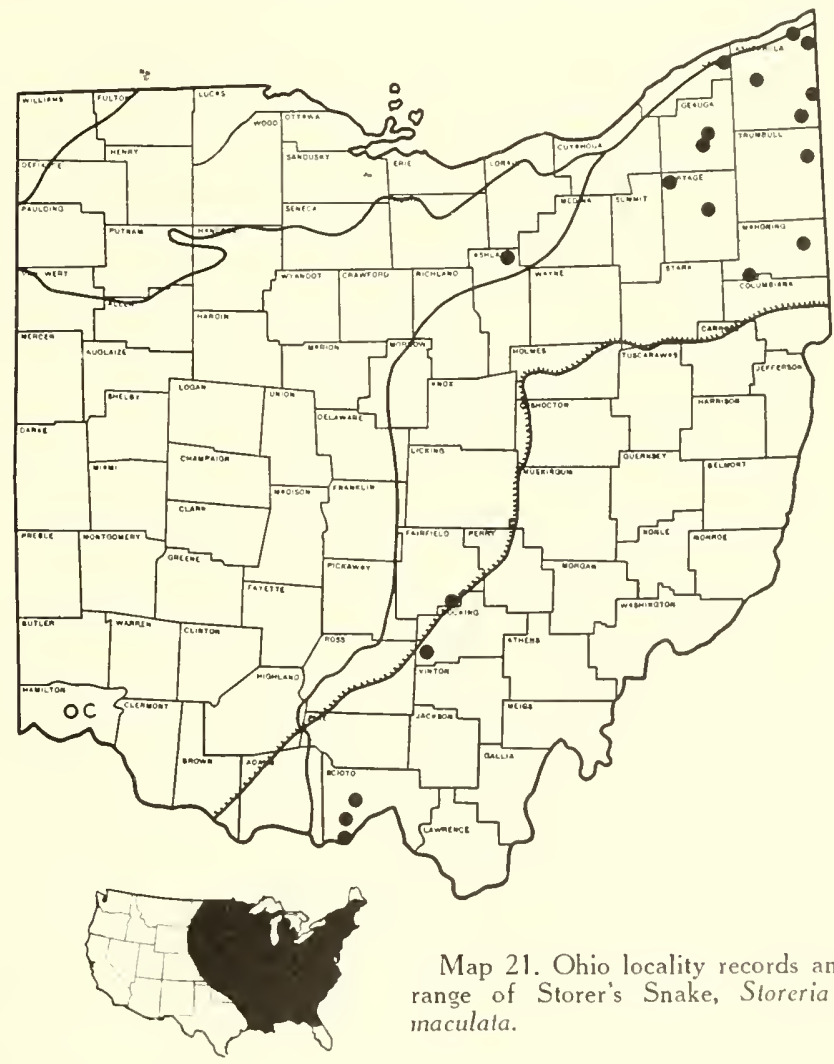

Map 21. Ohio locality records and general range of Storer's Snake, Storeria occipitomaculata. 
Habitat and Habits.-While Storer's snake was collected in a variety of habitats, all of the latter agreed in one thing - they exhibited a fair amount of moisture. Thus individuals were found in bogs, wet meadows, moist woods, in rotting sawdust piles, along roadside ditches and about abandoned farm buildings such as are so prevalent in Ashtabula County. They were highly secretive and practically all were discovered by overturning boards and stones or bursting open rotten logs.

All were inoffensive and while they exuded musk when handled, none attempted to bite. Collecting dates ranged from April to September, inclusive. In northeastern Ohio they often were found in association with DeKay's snakes and were taken at least once with each of the other common snakes of the region. In the southern part of the state other secretive species, such as the milk, worm and ring-necked snakes were collected at the same time as Storer's snakes and in similar habitats.

In the stomach of a red-tailed hawk collected at Freedom Station, Portage County, October 28, 1932, for the Cleveland Museum of Natural History, the remains of 15 small snakes were found. These were 7 Storer's snakes, 6 DeKay's snakes and 2 common garter snakes. Hawks and predatory mammals are doubtless frequent enemies of the smaller snakes.

The food of Storer's snake consists of slugs (Hay 1892a, 498; Surface, 1906, 137; Ditmars, 1936, 178), and earthworms and beetle larvae (Ditmars, loc. cit.). Captives have eaten earthworms.

A female $121 / 8$ inches in length collected August 20, 1932, in the Pymatuning Swamp, Ashtabula County, gave birth to 8 young August 23, 1932. These ranged in length from $35 / 8$ to 4 inches. Two females collected during July, 1929, in Monroe Twp., Ashtabula County, each contained 15 embryos. Blanchard (1937b, 161-2) summarizes his observations on 77 broods of young in northern Michigan. He found that the young varied in that region from 1 to 13 , average 7.18 , in number, and from 67 to $98 \mathrm{~mm}$., average $85.94 \mathrm{~mm}$., in length.

\section{Virginia valeriae valeriae Baird and Girard}

\section{Ground SNAKE}

Description.-A small snake which may attain a length of about a foot. Largest adult Ohio specimen ( $q$ ), 121/8 inches in length; smallest specimen $5 \mathrm{I} / 4$ inches. Head small and somewhat distinct from neck. Eye moderately small. Loreal long and narrow; no preocular. Two nasals; the nostril in the prenasal. Body subcylindrical and medium stout; tail short and tapering rapidly to a point.

A study of six of the seven known specimens from Ohio (all of which are preserved) reveals the following statistics: 


\begin{tabular}{|c|c|c|c|c|c|c|c|}
\hline $\begin{array}{l}\text { Scale } \\
\text { rows }\end{array}$ & $\begin{array}{l}\text { Upper } \\
\text { labials }\end{array}$ & $\begin{array}{c}\text { Lower } \\
\text { labials }\end{array}$ & $\begin{array}{l}\text { Post- } \\
\text { oculars }\end{array}$ & $\begin{array}{l}\text { Temp- } \\
\text { orals }\end{array}$ & $\begin{array}{c}\text { Vent- } \\
\text { rals }\end{array}$ & $\begin{array}{l}\text { Sub- } \\
\text { caudals }\end{array}$ & Sex \\
\hline 15 & 6 & 6 & 2 & $1-2$ & 118 & 32 & $\hat{o}$ \\
\hline 15 & 6 & 6 & 2,3 & $1-2$ & 125 & 27 & 무 \\
\hline 15 & 6 & 6 & 2 & $1-2,1$ & 121 & 25 & 우 \\
\hline 15 & 6 & 6 & 2 & $1-2$ & 122 & 27 & ㅇ \\
\hline 15 & 6 & 6 & 2 & $1-2$ & 121 & $23+$ & ㅇ \\
\hline 15 & 6 & 6 & 2,3 & 1.2 & 133 & 24 & q \\
\hline
\end{tabular}

The scales are smooth or with a few faint keels discernible on the posterior portion of the body. The anal plate is divided.

The color above is grey or brown, either uniform or marked with a number of small black dots. These, when present, are usually arranged in four rows, the median two of which lie a scale or two on either side of the middorsal row of scales. In some specimens each scale may be marked with a faint light line slightly suggestive of a keel when viewed from a little distance. Occa-

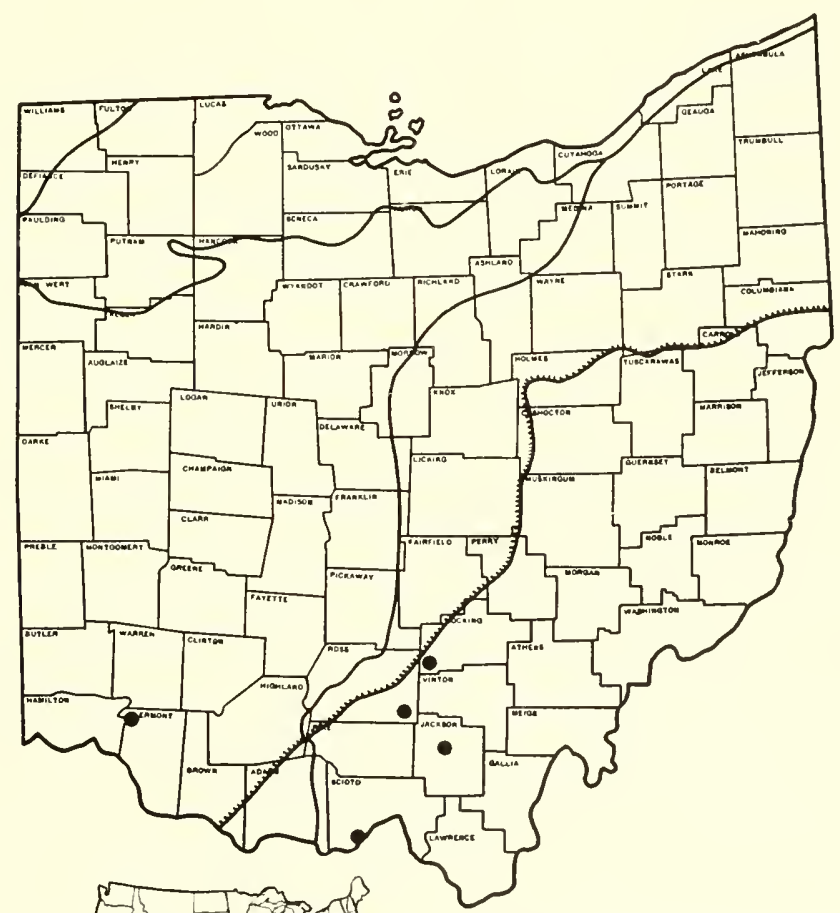

Map 22. Ohio locality records and general range of the Ground Snake, Virginia valeriae valeriae. 
sionally this may be so pronounced on the median row as to impart the appearance (collectively) of a narrow light dorsal stripe.

The entire under surface is uniformly whitish except for the tips of the ventrals which may be suffused with the dorsal color. Labials are whitish with the upper ones sometimes marked with a few black dots.

Range.-New Jersey to South Carolina and west to Tennessee and southern Ohio. This species has been taken in Ohio only in the southern part of the unglaciated plateau and in the till plains near the Ohio River (Map 22). Locality records are:

Clemmont County: near Miamiville (CSNH 2145). Hocking County: Salt Creek Twp. (AS; OSM 246.1; TZS 1000). JACKson CounTY: Jackson (CSNH 1643). Ross County: Richmondale (OSM 55). Scioto County: $8 \mathrm{mi}$. SW of Portsmouth (TZS 1137).

Habitat and Habits.-The small number of specimens of Virginia which were collected indicate it is one of the rarest of Ohio snakes. Those for which habitat notes are available were discovered under stones, except one found lying dead along a road. In Salt Creek Twp., Hocking County, two were taken under flat stones on open hillsides near woods. Another was under a large sandstone slab on a wooded hillside along the Ohio River in Scioto County. A worm snake found with the latter specimen crawled away rapidly while the Virginia, in contrast, remained motionless. It made no attempt to bite but when held by body and tail it pulled back its lips in such a way as to expose their inner surfaces and its teeth to view.

The food of this snake consists of worms and insect larvae (Ditmars, 1936, 180). Captives fed well upon earthworms. The young are born alive; Ditmars (loc. cit.) records the birth of 7 to a North Carolina specimen on August 15.

\section{Thamnophis butleri (Cope)}

\section{Butler's Garter SNake}

Description.-A small, slender to stout-bodied snake attaining a length of about a foot and a half to two feet. Largest adult Ohio specimen ( $q$ ), 25 inches in length; smallest newly born juvenile, 5 inches. Head small and but little distinct from neck. Eye medium in size. Head plates normal. Two nasals, the nostril lateral and between them. One loreal. Body stoutest in adult females; tail medium stout and tapering to a point. The tail in males $23 \%$ to $26.2 \%$, average $24.9 \%$ of the total length of the snake; in fernales $21.4 \%$ to $23.8 \%$, average $22.3 \%$.

Dorsal scale rows usually $19-17$, occasionally $17-19-17$ or $17-19-17-15$; the scales keeled. Upper labials 6 or 7, rarely 8; lower labials most often 8, occasionally 9 , rarely 7 or 10 . Oculars usually $1-3$, occasionally $1-2$ (1-1 in a single specimen from Toledo). One temporal in the first row; one large, or one large and one small in the second row. Ventrals in males 138 to 148 , average 142; in females 130 to 143 , average 137.5. Subcaudals in males 60 to 72 , average 66.5 ; in females 53 to 60 , average 56.6. Anal plate single. 
A pattern of three yellow stripes on an olive brown to deep brown (sometimes almost black) ground. A double alternating row of black spots in the ground color between the stripes, these obsolete in the majority of specimens, but readily apparent in others, especially when the skin is stretched. Ground color below the lateral stripes, the same shade or somewhat lighter than above them, and encroaching upon the ends of the ventrals. Top of head same color as dorsal body surface; usually a pair of small yellow spots near the common suture of the parietals. Dorsal stripe on the median and halves of the adjacent rows of scales; the lateral stripes on the third and adjacent portions of the second and fourth rows anteriorly and on the second and third rows posteriorly. Stripes yellow, the dorsal sometimes paler than the laterals; the latter occasionally orange. Chin, throat and labials yellowish. Belly pale greenish with a small black spot at either end of each ventral scute, these spots tending to widen laterally and sometimes becoming confluent with their partners on the anterior portion of the scutes.

Specimens examined, 436; specimens preserved, 91; specimens studied, 39.

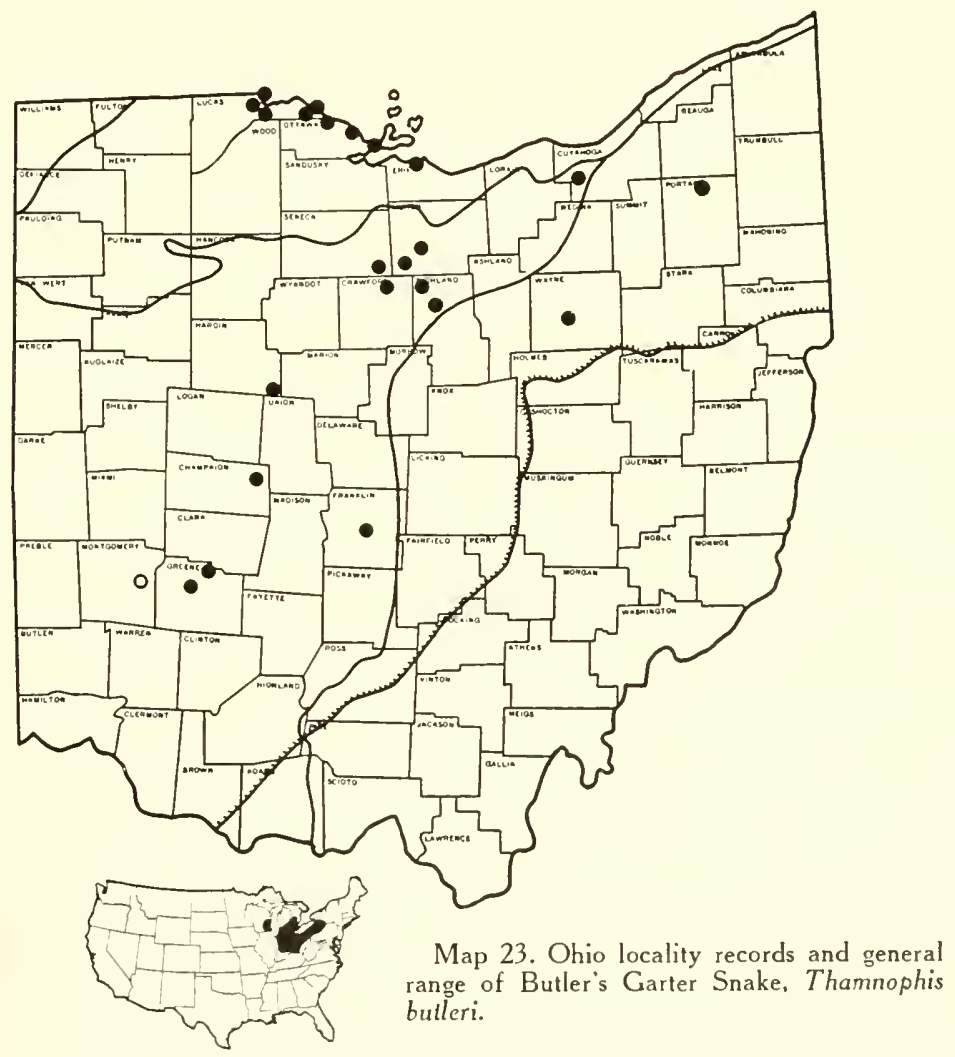


Range.--Extreme western New York and western Pennsylvania, through Ohio and Indiana to southern Michigan and Wisconsin.

Butler's garter snake has been collected only in the glaciated part of Ohio (Map 23). Its preference for moist or wet, more or less open habitats, as described below, would indicate that it is not apt to occur in unglaciated Ohio. The lack of records in the extreme western and the northeastern counties may be due to its rarity in those areas or the fact that collectors have not yet chanced upon any colonies. The records are:

Champaign County: Brush Lake, Rush Twp. (OSM 369). Crawford County: Cranberry Twp. (TZS 995-6, 1506). CuYahoca CountY: East Rockport, Berea (MCZ 219). ERIE CounTY: (SHS; UMMZ 41949); Sandusky (TZS 73-4; UMMZ 31612-4, 31713-4, 31717, 31719). FrankLin CountY: Columbus (OSM 56). Greene County: Clifton Corge, Miami Twp. (OSM 450.1-.5); $4 \mathrm{mi}$. N of Xenia (TZS 2299). Hardin CoUnTY: 3 mi. E of Mt. Victory (TZS 774). Huron CountY: Greenfield Twp. (TZS 1308); Richmond Twp. (OSM 424.1; TZS 1173-8). LuCAS CounTY: Bono; Reno Beach, Jerusalem Twp. (TZS 225, 1312); East Toledo; North Toledo (CSNH 1263; OSM 284.1-3, 285.1-.6; TZS 4-5, 178, 200, 213-24, 813-4. 849-61, 923); Pt. Place. Toledo (TZS 941). MontcomerY County: Dayton (Ruthven, 1908). Ottawa County: E of Bono (TZS 231, 897); Erie Twp. (TZS 944); Port Clinton. Portage CountY: Hiram (NU 19). RichLAND CountY: Jackson Twp. (TZS 1250): Plymouth Twp. (TZS 1202-3). SENECA County: Venice Twp. (TZS 996A-997, 1217-8). WAYNE CounTY: Wooster (WC).

Habitat and Habits.-Butler's garter snake is locally common and shows a tendency to form large colonies in favorable habitats. In certain parks and marsh lands in and near Toledo it was very abundant and as many as 62 were collected in a single day. Other sizable colonies were discovered at Bono, Lucas County, and the New Haven marsh which lies partially in Seneca, Huron, Crawford and Richland Counties. It was also common at Wooster, Wayne County, but all other localities were for the most part represented by only one or two specimens.

Open situations with more or less moisture appeared to be preferred. Individuals were taken along streams and ditches, in fields, meadows, pastures and along the edges of the extensive marshes at the western end of Lake Erie. Two very small ones were discovered beneath a small heap of grass washed ashore by the waves in Sandusky Bay.

Specimens were mild tempered and none of the many handled made any effort to bite. The secretion of the musk glands was found to have a sweet odor.

When crawling slowly, locomotion is similar to the sinuous movements often employed by other snakes, but when a specimen is excited and endeavors to travel with any speed, its progress is out of all proportion to the energy expended (see Ruthven, 1908, 90). The body is wriggled from side to side and movement in a forward direction is relatively slight. The action might be compared to that imparted to a rope, one end of which is shaken rapidly to the right and left.

Specimens were collected in every month except December. There was a decided peak of abundance in April, during which month over ten times as 
many were taken as in any other month. There was a minor peak in October which was the second most fruitful month of the year.

Butler's garter snake leaves hibernation in early spring and during each of the six years of observations at Toledo it first was found in numbers between March 24 and April 20; April 3 and 4 were about average dates. Breeding activities began immediately; a pair was found in coitu April 4, 1930 and on numerous occasions pairs placed together in cages early in April began courting at once. Reproductive instincts appeared paramount to all others at this time of year and specimens, which showed little concern for the observer, often were found prowling about. Males far outnumbered females in spring collections and the reverse was true in midsummer.

Almost every other species of snake known to be indigenous to glaciated Ohio was collected at one time or another in much the same habitat as Butler's garter snake. Most frequent associates were the common garter snake and DeKay's snake.

A number of newly captured individuals disgorged earthworms. Caged specimens throve on a diet of small frogs, earthworms and fish. Ruthven $(1911,268)$ records several leeches from the stomach of a specimen collected in Michigan.

Butler's garter snake is ovoviviparous. Three litters of young were born at the Toledo Zoo. A female 17 inches in length from Toledo was bred April 4, 1930, and gave birth to 5 young July 2, 1930; the newly born young averaged $6 \mathrm{I} / 4$ inches in length. A female from near Bono, Lucas County, 25 inches in length, bore 14 young July 28,1931, which varied from $61 / 2$ to $71 / 8$ inches in length. Another, 22I/4 inches in length, collected at Toledo, was bred March 23, 1934, and had 4 young, plus 4 dead (but well developed) embryos and two infertile ova July 3, 1934. Her living young ranged from $55 / 8$ to 6 inches in length. A specimen in the Ohio State Museum, 165/8 inches in length, collected near the Clifton Gorge, Greene County, on June 6, 1933, gave birth to four young, ranging from 5 to $55 / 8$ inches, on August 7, 1933. That the number in a litter may sometimes be greater is indicated by Ruthven $(1908,90)$ who states, "In the specimens examined the number of embryos is about twelve or fifteen."

\section{Thamnophis sauritus sauritus (Linné)}

\section{Ribbon SNake}

Description.-A slender snake attaining a length of two and a half feet or more. Largest adult Ohio specimen ( $q$ ), 28 inches in length; smallest newly born juvenile, 8 inches. Head small but distinct from neck. Eye large. Head plates normal. Two nasals, the nostril lateral and between them. One loreal. Body elongate; tail long and slim and varying from $28.5 \%$ to $33.4 \%$, average $30.4 \%$ of the total length.

Dorsal scale rows 19-17, the scales keeled. Upper labials 7, occasionally 8 ; lower labials 10 , occasionally 9 , rarely 8 or 11 . Oculars $1-3$, occasionally 1-4. Temporals 1 in the first row and 2, or occasionally 3, in the second row. 
Ventrals in males 160 to 173 , average 167 ; in females 157 to 171 , average 164.5. Subcaudals in males 109 to 125 , average 115; in females 95 to 119 , average 107. Anal plate single.

A pattern of a median and two lateral bright yellow stripes on a darker ground. Color above, including the head and the areas between and below the stripes, usually a uniform shade of brown - chocolate in some specimens to sepia, or even black, in others. Ground color below the lateral stripes, usually paler than above them, and extending upon the ends of the ventrals. Middorsal stripe on the median and halves of the adjacent rows of scales; lateral ones on the third and fourth rows. Stripes yellow, the dorsal occasionally with an orange tinge. A double row of dark spots, incompletely edged with yellow, between the dorsal and lateral stripes in some specimens. These usually most evident when the skin is stretched.

Labials, chin and lower postocular usually whitish and unmarked. A yellowish spot on the preoculars. Belly pale greenish and generally lacking the ventral spots found in the other Ohio species of Thamnophis. Young very slender and with the yellow stripes like fine golden lines.

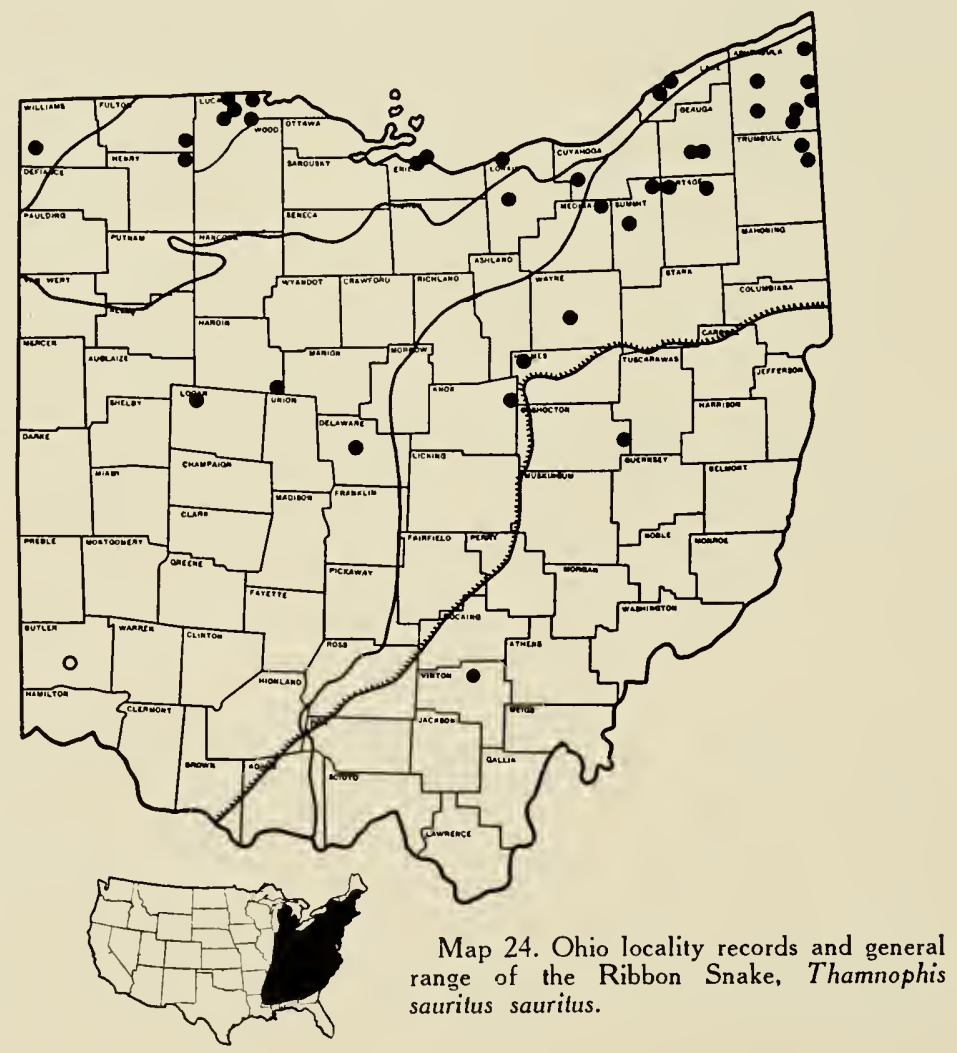


Specimens examined, 73; specimens preserved, 55; specimens studied, 43.

Range.-Michigan to Maine and south to Georgia, Alabama and Mississippi.

The ribbon snake is common in several localities in northern Ohio (Map 24). The well drained southern part of the state does not afford many suitable habitats. Of the specimens collected south of the glacial boundary one from Vinton County was beside a roadside ditch full of water. In Coshocton County two were seen and one collected along the abandoned, but still wellfilled, Ohio and Erie Canal. Locality records are:

Ashtabula County: Eagleville (CMNH); Monroe Twp. (OSM 215.3); Pymatuning Swamp, near Andover (TZS 327, 924, 1454-7); 3 mi. NE of Richmond Center; near Rome (TZS 1453); Lake Cardinal, Rome (CMNH); Wayne Twp. (OSM 108.4); West Andover (TZS 1796). Butler CountY: Hamilton (Morse, 1904). Coshocton County: Ohio Canal, Oxford Twp. (TZS 1863). Curahoga County: East Rockport, Berea (MCZ 213). Delaware County: Delaware Twp. (OSM 211). Erie County: Cedar Point (BGSU; SHS); Sandusky (MCZ 10533). Fulton Countr: West Fork, Swan Creek, Swan Creek Twp. (TZS 515). Geauga County: Lake Kelso, Burton Twp. (TZS 820); Punderson Pond, Newbury Twp. (OSM 363). Hardin County: 3 mi. E of Mt. Victory (TZS 76, 817). Henry County: Washington Twp. (TZS 1893). Holmes County: Washington Twp. (OSM 427.1). Knox County: Brinkhaven (OSM 169). Lake County: Black Run Swamp, W of Fairport (TZS 1408-9); Mentor Twp. (TZS 526). Logan CounTY: Indian Lake (OSM 405.1). Lorain County: Oak Point (OC); Oberlin (OC). Lucas CountY: Oak Openings, Holland (TZS 1, 528-31); Sylvania; Maumee River, Toledo (USNM 5451); W of Toledo (TZS 1095-6); Washington Twp. (TZS 210-2). Medina County: (Ruthven, 1908); Whipp's Ledge, Hinckley Twp. (OSM 115). Portage County: Aurora Pond, Aurora Twp. (CMNH); Hiram (NU 25). Summit County: Ira (OSM 116); Twinsburg Twp. (TZS 527). TRUmBUll County: Kinsman (TZS 1792-3); Vernon Twp. (TZS 1015). Vinton County: N of Creola (TZS 290). Wayne County: Highland Park, Wooster (WC). Williams County: I mi. SW of Blakesley (TZS 953, 1765).

Habitat and Habits.-The ribbon snake is widely distributed through northern Ohio and in a few localities was found to be abundant. It was markedly aquatic and few were seen far from some body of water; while only one or two were discovered actually in this medium they usually entered it at once if alarmed near it. On two occasions, however, individuals darted toward it and came to a complete stop at its edge. There they remained motionless until the collector approached when they went in without further hesitation.

Once in the water, ribbon snakes swam rapidly upon its surface and field notes indicate that none dived to the bottom as did many water snakes. Along large bodies of water the tendency was for them to skirt the shore and hide in any vegetation which might be present, but in small streams or ditches they swam to the opposite side where they rested until pursued. None were found in or along any of the larger streams or rivers of the state.

Bogs, small lakes or ponds and swampy regions formed the usual habitat but a number were also collected in districts subject to spring ponding and summer drought. A few were in moist woods. One was discovered in a bush several feet from the ground. 
The ribbon snake can crawl very quickly and its habit of entering water, if any be near, and its ability to thread its way rapidly through vegetation make it difficult to capture. Freshly caught individuals usually resisted by striking repeatedly but some were phlegmatic and made little attempt to escape; caged ones usually remained alert and nervous. The fluid from the musk glands, freely secreted when the snakes were first seized, had a sweet odor.

Ribbon snakes frequently were found in association with the common garter snake, DeKay's snake and the common water snake. Specimens were collected in every month from February to November inclusive.

The food consists of cold blooded prey with amphibians and fish apparently forming the greater portion. A specimen disgorged a wood frog (Rana sylvatica) in a collecting sack in the field and a few minutes later swallowed it again. A salamander (Desmognathus fuscus ochrophaeus) was found in the stomach of another. Insects are also eaten (Surface, 1906, 143) but it is possible that many of these were in the stomachs of the amphibians which the snakes devoured. Surface (loc. cit.) records earthworms, but repeated attempts to feed these to captive ribbon snakes met with no success. Zoo specimens thrived on chopped fish, tadpoles, small frogs, and occasional Plethodont salamanders.

A female collected in Lucas County during May, 1931, gave birth to 7 young, 3 of which were dead; the lengths varied from 8 to $8 \mathrm{r} / 2$ inches. Another female 27 inches in length, collected near Andover, Ashtabula County, May 26, 1934, bore 5 young, August 20, 1934. These varied from $85 / 8$ to $91 / 16$ and averaged $87 / 8$ inches in length. Ruthven $(1908,112)$ states that the embryos he found in ribbon snakes averaged about a dozen.

\section{Thamnophis sirtalis sirtalis (Linné)}

Common Garter Snake

Description.-A medium-sized snake attaining a length of a yard or more, but averaging one and one half to two and one half feet. Largest adult Ohio specimen (an unusually large female), 44 inches; smallest newly born juvenile, $6 \mathrm{~T} / 4$ inches. Head medium in size and distinct from neck; eye medium. Head plates normal. Two nasals; the nostril lateral and between them. One loreal. Body slender in juveniles to medium stout in adults. Tail medium slender and tapering to a point; in males $23 \%$ to $25 \%$, average $23.8 \%$ of the total length; in females $18 \%$ to $24 \%$, average $20.8 \%$.

Dorsal scale rows 19-17; the scales keeled. Upper labials 7, occasionally 8 , rarely 6. Lower labials 10 , occasionally 9 , rarely 8 or 11 . Oculars $1-3$, occasionally 1-4. Temporals $1-2$, occasionally $1-3$, and $1-1$ in 2 specimens. Ventrals in males 145 to 160 , average 153.7 ; in females 142 to 158 , average 149. Subcaudals in males 69 to 80 , average 73.8 ; in females 55 to 71 , average 63.4. Anal plate single.

The color and markings are variable. Normally there is a pattern of three light stripes on a darker ground; a dorsal stripe on the median and halves of 
the adjacent rows of scales and a lateral stripe on the second and third rows of scales. In many individuals the dorsal stripe may be lacking, in others the lateral stripes may so blend with the ground color below them as to appear to be nearly, if not quite obsolete.

The stripes are usually of some shade of yellow, but they may be greenish, bluish or brownish. The ground color between them varies from black, dark brown or greenish olive to light olive; the first row of scales is similar in color, but almost always lighter. A double row of dark spots, separated by lighter interspaces, may be seen between the stripes; in some specimens and especially in many of those from southern Ohio the spots are svell defined and prominent, but in others they may be faint or appear only when the skin is stretched. Occasionally the interspaces between the spots may be red.

Specimens examined, 788; specimens preserved, 312; specimens studied, 107.

Variation.-While common garter snakes exhibit a marked stability in scutellation their patterns and colors are so variable that distinct names have been proposed for several of the many phases. These often have been based upon individual variation, however, and two or more of the so called varieties may appear in a single litter of young.

An aberrant Ohio specimen, collected 2 miles SW of Upper Sandusky, Wyandot County, on July 18, 1931, merits some comment. This specimen, a female $253 / 8$ inches in length, shows a scutellation similar to the other common garter snakes from Ohio, but its lateral stripes are located upon the third and fourth rows of scales instead of the second and third. The dark spots, usually seen between the stripes are fairly well defined and there is a row of large black spots between the lateral stripes and the ventral scales. Spots, both above and below, encroach upon the lateral stripes which are further interrupted by small dark spots spaced upon them at more or less regular intervals. The sutures between the upper labials are heavily outlined with black and the entire general aspect of the snake is darker than normal.

Melanistic individuals were not uncommon in localities near the western end of Lake Erie. These snakes were uniform black throughout except for a few light markings on the chin and throat. Captive black females, bred in the wild, gave birth to young, some of which were melanistic and some normally patterned.

Range.-Nova Scotia to Florida, west to Minnesota, Missouri and eastern Texas and north to about the 52nd degree of latitude. The common garter snake occurs throughout Ohio (Map 25) but is not as abundant in unglaciated Ohio as in the less well drained parts of the state. Records are:

Adams County: Green Twp. (OSM 112-3); 3 mi. E of Rome (TZS 735). Allen County: Sugar Creek. Lima (USNM 21699-701). Ashland County: (USNM 56074); Savannah Lakes, Clear Creek Twp. Ashrabula County: Ashtabula Twp. (TZS 1035-6); Eagleville (CMNH); Geneva, Cowles Creek (USNM 21131); 2 mi. E of Kingsville (TZS 1025); Monroe Center (TZS 905): Tinker's Hollow, Monroe Twp. (TZS 1024); Pymatuning Swamp, near Andover (TZS 324-6, 786, 919-22, 1028-9); 3 mi. NE of Richmond Center; Rock Creek. Rome Twp. (OSM 204.2; TZS 1449-50); Wayne Twp. (OSM 108.1-.3); West Andover; Williamsfield (TZS 1019). Athens County: Athens (OU). Auglaize County: 


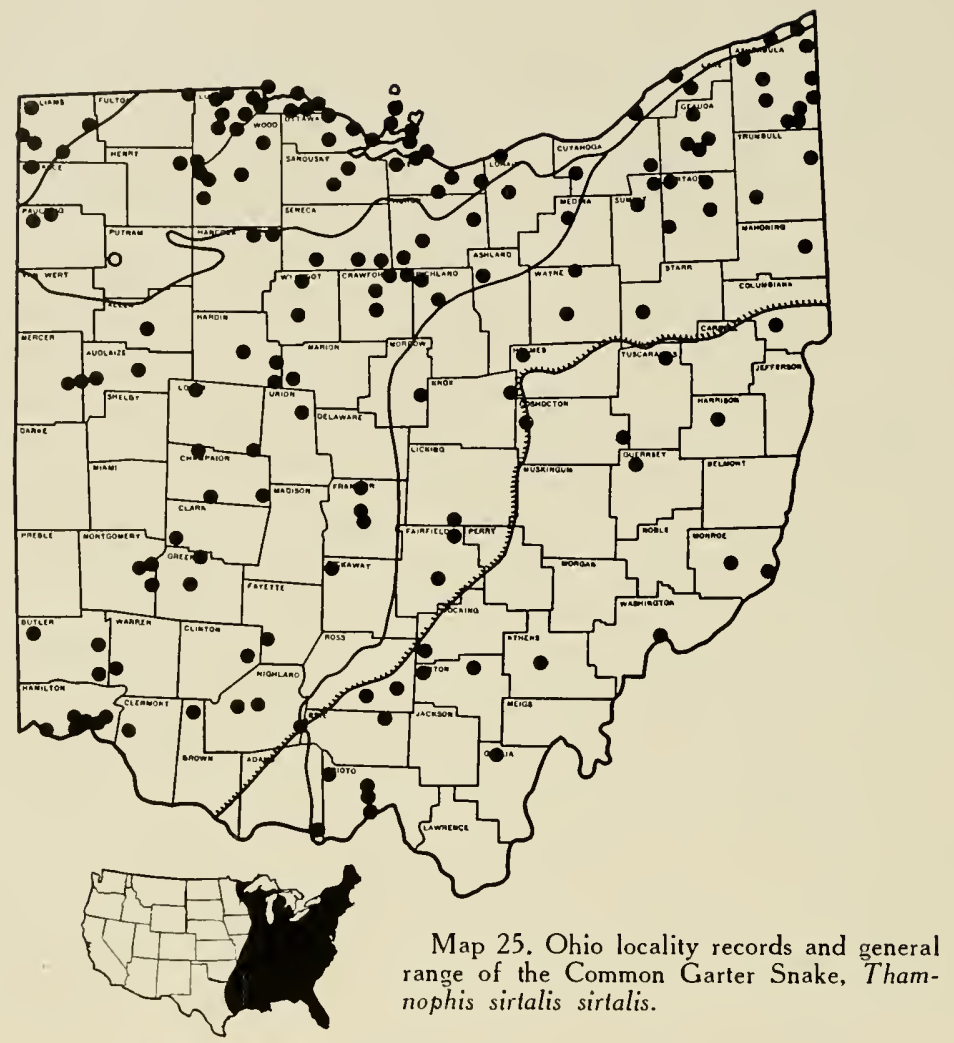

St. Mary's: 2 mi. E of Wapakoneta (TZS 235-6). Brown County: Near Fayetteville (DOR). Butler County: Monroe (USNM 10667); Near Oxford (MU); near Westchester (TZS 274-9). Champaign County: Cedar Swamp, 5 mi. SSW of Urbana (OSM 364); Mechanicsburg (TZS 565); Springhills (OSM 449). Clark County: Medway, Bethel Twp. (OSM 385.1). Clermont County: Union Twp. (CSNH 1187, 1230; TZS 1414). Clinton County: Centerville, Lee's Creek P.O. (TZS 744-5). Columbiana County: Little Beaver Creek, S of Gavers, Wayne Twp. (TZS 323). Coshocton Countr: W of Newcomerstown; near Walhonding (OSM 197). Crawford County: Auburn Twp.; Bucyrus Reservoir, Liberty Twp. (TZS 455); Cranberry Twp. (TZS 991); $4 \mathrm{mi}$. NW of Sulphur Springs (TZS 451). Cuyahoga County: East Rockport, Berea (MCZ 215); Euclid (CMNH); Solon (CMNH). Defiance County: Ladd Lake, Milford Twp. (TZS 365). Erie County: (UMMZ 34258-63, 41943-8); Berlin Heights; Birmingham (OC); Castalia (MCZ 7109-melanistic; UMMZ 62660); Cedar Point (OSM 59); Milan (SHS); Sandusky (UMMZ 31617, 31710-2; TZS 75): E of Sandusky (UMMZ 32961-6). Fairfield County: Lancaster (OSM 176, 202); Walnut Twp. (OSM 295). FayetTe County: $6 \mathrm{mi}$. NE of Centerville, Lee's Creek P. O. (TZS 676-7). Franklin County: (USNM 25967-8); Columbus (OSM 58.2, 109, I27, 175, 258; USNM 7800, 9254); North Columbus (OSM 60-1); Worthington (OSM 63).

Fulton County: Metamora (OSM 231). Gallia County: Vinton (OSM 452). Geauga County: Burton (TZS 868); Chardon (TZS 1785); Lake Kelso, Burton 
Twp. (TZS 818-9, 1337A-8A); Newbury Twp. (TZS 620). Greene County: 2 mi. N of Xenia (TZS 2272); Yellow Springs (MCZ 668). Guernsey CountY: Wills Creek at Kimbolton (DOR). Hamilton CountY: (CM 5130; CSNH 1979); Avondale, Cincinnati (CSNH I454); Eden Park. Cincinnati (CSNH); Hyde Park, Cincinnati (CSNH 974); Walnut Hills, Cincinnati (CSNH); Cincinnati (CSNH 914, 976; USNM 56073); Fernbank (CSNH 1058); Mariemont (CSNH 1425); Westwood (CSNH 130I). Hancock CountY: Cass Twp.; Washington Twp. (TZS 599). Hardin County: Near Hepburn (TZS 1089); Kenton (OSM 360-albino); $3 \mathrm{mi}$. E of Mt. Victory (OSM 380.1; TZS 280, 511, 1361-72A, 1373-84). HarRIson County: Stock Twp. (TZS 486). Henry County: Texas (TZS 256). Highland County: N side of Ft. Hill, Brush Creek Twp. (TZS 566) : near Hillsboro (TZS 17I5); 4 mi. W of Hillsboro (TZS 44l). HockIng County: Salt Creek Twp. (AS). Holmes County: Washington Twp. (DOR). Huron County: Greenfield Twp. (TZS 1311); Richmond Twp. (OSM 110-1; TZS 422): Vermillion River, Clarksfield (USNM 40107). Knox County: Brinkhaven (OSM 366.5-.6). Lake County: Big Creek, Concord Twp. (TZS 1405); Black Run Swamp, W of Fairport (TZS 1406). Licking County: Buckeye Lake, Union Twp. (OSM 177, 383.2); Union Twp. (OSM 294). Logan County: Near North Lewisburg (TZS 564); Pony Island, Indian Lake (TZS 240-1). LoRAin CountY: Oak Point (OC); Oberlin (OC). Lucas County: Bono (TZS 127-8); Cedar Point Marsh, Jerusalem Twp.; I mi. N of Curtice; opposite Grand Rapids; Holland; Maumee River, Maumee; Monclova; Reno Beach, Jerusalem Twp.; Silica; Springfield Twp. (OSM 244.2); Sylvania; Toledo (TZS 159-73-some melanistic, 259-68); Delaware Creek, Toledo (TZS 1046, 1048); North Toledo (TZS 8); Pt. Place, Toledo (TZS 1049). Mahoning County: (USNM 56071-2); Yellow Creek, near Poland (USNM 1004). Marion County: Bowling Green Twp. (TZS 608); Medina County: 3 mi. $\mathrm{N}$ of Medina (TZS 756). Mercer County: 3 mi. E of Montezuma (TZS 246-51); $6 \mathrm{mi}$. E of Montezuma.

Monroe County: Ohio Twp. (TZS 485); Cranenest Fork, Center Twp. (TZS 585). Montgomery County: (Ruthven, 1908); Beavertown (UMMZ 46473, 46484); Dayton (USNM 51177); Hoffman Prairie, Dayton (UMMZ 46513); Harshman (UMMZ 46475, 46485, 46488). Morrow County: Chesterville (OSM 173). Otrawa County: Bay Point (OSM 186.1); E of Bono (TZS 230); Catawba Island (OSM 372-melanistic; TZS 479-81); Erie Twp.; Lakeside; near Marblehead; Portage River, near Oak Harbor; Port Clinton (USNM 20542, 40077); Put-in-Bay (CAS 2645; SL). Paulding County: Antwerp (OEE; TZS 1763); Marie DeLarme Creek, Crane Twp. (TZS 1762). Pickaway County: Darby Twp. (OSM 384). Pike County: Omega (TZS 1060). Portage County: Aurora Pond, Aurora Twp. (CMNH; TZS 621); Freedom Station (CMNH); Hiram (NU 24); Kent (NU 15): Cuyahoga River, Kent (USNM 40091). Putnam CountY: Cloverdale (Morse, 1904). Richland County: Jackson Twp. (TZS 1251-4); Plymouth Twp. (TZS 1215-6). Ross County: Huntington Twp. (TZS 1133); Vauces, Sandusky County: near Fremont; Green Creek, 6 mi. NE of Fremont (TZS 405). Scioto County: Rarden (DOR); 2 mi. N of Rushtown (TZS 189i-2); I mi. S of Rushtown; West Portsmouth. SENECA County: $11 / 2 \mathrm{mi}$. S of Bloomville (TZS 287); Seneca Twp. (OSM 239); Venice Twp. (TZS 992, 1221). Stark CountY: Massillon (UMMZ). SUmmit County: Peninsula (NU' 22-3); Twinsburg Twp. TrumBULl CoUnTY: (USNM 55802); Leavittsburg (OSM 114); Vernon Twp. (TZS 336, 1016-7). Tuscarawas County: Zoarville (MC). Union County: Claibourne Twp. (TZS 512). Vinton County: I mi. $\mathrm{N}$ of Creola (TZS 734); Pike Run, Eagle Twp. (TZS 987). Warren County: Mason (CSNH 1008, 1040). WashIngton County: Marietta (MC). Wayne Countr: Creston (OC); Miller's Pond, Wooster (WC). Williams County: I mi. SW of Blakesley (TZS 954); 2 mi. W of Bryan (TZS 207); Mud Lake, Northwest Twp.; Tamarack Ditch, Florence Twp. (TZS 952); near West Unity. Wood CounTY: Bowling Green (BGSU); Grand Rapids (BGSU): Maumee River, Grand Rapids (USNM 21698); 31/2 mi. SE of Grand Rapids (TZS 1018); Milton Twp. (UMMZ 52069); Perrysburg; Stony Ridge. WYANDOT CountY: 3 mi. NE of Crawford (TZS 286); 2 mi. SW of Upper Sandusky (TZS 767). 
Habitat and Habits.-The common garter snake is one of the best known serpents of Ohio. In many localities it is decidedly abundant and, of all the snakes occurring in the state, it was collected in the greatest numbers.

It was found in a wider variety of habitats, perhaps, than any other Ohio serpent. Moist environments appeared most favorable and a majority of the specimens were taken in bogs, marshes, meadows, wet woods, pastures, along roadside and drainage ditches, etc. On the contrary, several were encountered in fields, so sear and dusty during the drought summers, as to look most uninviting.

Open land seemed preferable to woods and relatively few specimens were found in the latter. The destruction of the forests of the state no doubt has favored the garter snake and it is probably much more abundant now than it was in pre-pioneer days. Garter snakes thrive in close proximity to Man. As an example one can cite the many populous colonies found in parks and wastelands of the larger cities.

Specimens normally are terrestrial but a few were discovered in bushes and small trees, and one was fully eight feet from the ground.

During early spring when mating activities were at their height and before the vegetation had grown sufficiently to conceal them, garter snakes often were taken in numbers. The males collected at this season far outnumbered the females, since the former doubtless were more active in seeking mates. Three males, all attempting to mate with the same female at the same time, were discovered near Mt. Victory, Hardin County, April 2, 1932. Specimens were much less conspicuous later in the season, and like many other snakes they became more or less nocturnal during hot weather. Several were found abroad at night, and on very warm days it was unusual to see any unless one overturned stones, etc., in shaded places. Almost any object was chosen as a shelter and in addition to the usual boards, logs, etc., they were discovered under shocks of grain, tin cans, old mattresses, water melon rinds and a great variety of other junk. In fact, abandoned city dumps, overgrown with weeds, were often well populated with them. When alarmed near ditches or in boggy places garter snakes retreated to the water, but they were far from being as much at home in this element as the more aquatic water snakes.

The dispositions of individuals varied greatly. Most were mild mannered, and after the first wild efforts to escape they usually settled down and could be handled with impunity. However, many struck repeatedly when first caught, and free use was made of the musk glands. The habit of flattening the head and body in the assumption of a threatening attitude was often noted.

Garter snakes were taken in every month of the year, and twice on warm days in winter individuals were found sunning themselves only a few feet from snowdrifts, not yet dissipated by the brief thaw. Hibernation sites included rock crevices, burrows made by crayfish or other animals, masses of decaying vegetable matter, or almost any place sufficiently protected to remain unfrozen during the winter. Upon emerging in the spring from spots which were wet or muddy, specimens were often so coated with soil as to have their patterns entirely obscured. 
The food of the garter snake consists largely but not exclusively of cold blooded prey. A large portion of its diet is composed of frogs, toads, fish, earthworms and possibly insects. There are records of insects being found in the stomachs of garter snakes (Surface, 1906, 149), but it is usually difficult to determine whether these were taken voluntarily, or whether they were in the stomachs of amphibians the snake had eaten. The elytra of beetles often were found in the fecal matter of recently captured specimens, but the only definite observation in which an insect was taken concerned a large individual busily devouting a pile of earthworms. A grub of a scarabaeid beetle was introduced with a pair of forceps and readily was seized by the snake. The swallowing process was commenced but almost immediately the grub was rejected and the serpent proceeded to rub its mouth back and forth on the cage floor as though to rid itself of an unpleasant taste.

In the field, a specimen just collected disgorged a large toad (Bufo a. annericanus) and another disgorged a swamp tree frog (Pseudacris nigrita triseriata). That warm blooded animals are sometimes eaten is indicated by the fact that another in the field disgorged a mouse of undetermined species. Surface (loc. cit.) records a sparrow, and Ruthven $(1908,178)$ mentions a yellow warbler which was eaten at least a day after its death.

Captive garter snakes lived well on chopped fish and occasional earthworms and frogs. There was no attempt to kill live prey before eating it and it was swallowed as it struggled to escape.

The garter snake is a prolific animal. It is ovoviviparous and the number of young may be as many as 78 in a single litter (Ruthven, loc. cit.). Such a number is unusually high and the average is much lower. A female 37 inches in length collected at Fort Hill, Highland County, July 7, 1931, contained 39 embryos and another, 44 inches in length, collected along the Cranenest Fork, Center Township, Monroe County, June 28, 1931, contained 33 embryos.

Several Ohio females gave birth to young in the Toledo Zoo and litters of $14,16,22,27$ and 30 , respectively, appeared on dates ranging from July 3 to August 1, inclusive. Freshly caught specimens bred as soon as they were placed in cages early in April and, in addition to the group of three males and a female found breeding April 2, 1932, as mentioned above, two pairs were discovered in coitu near Andover, Ashtabula County, April 23, 1932. Newly born young measured from $6 \mathrm{~T} / 4$ to $77 / 8$ inches in length.

The fecundity of the garter snake and its ability to secrete itself doubtless are factors largely responsible for its ability to remain numerous in heavily populated areas.

\section{Agkistrodon mokasen mokasen Beauvois}

\section{COPPERHEAD}

Description.-A stout bodied snake of medium size which may attain a length of three and one half to four feet. Largest adult Ohio specimen ( 8 ), $391 / 2$ inches; smallest newly born juvenile, $81 / 2$ inches. Head large and triangular in shape, flat above and distinctly wider than neck. Eye medium 
and situated directly below the overhanging supraocular; pupil vertical and elliptical. Two nasals, the nostril largely in the prenasal. Loreal present and forming a part of the upper border of a deep facial pit. Rostral roughly bellshaped when viewed from in front and forming the terminus of the blunt snout. Parietals not large and marked with a dark spot near their common suture. Body stout; tail short (14.7\% to $17.1 \%$ in juveniles and $12.4 \%$ to $14.7 \%$ in adults) and terminating in a small stout spine.

Dorsal scale rows normally 23-21-19 but sometimes 25 or 24 for a short distance immediately behind the head; occasionally not reduced below 20 posteriorly; the formula 23-21 seen in two specimens. Scales keeled except for the first two rows. Upper labials 8 or 7, rarely 6; lower labials 9 or 10 , rarely 11 . Preoculars 3 , the lowermost very small; postoculars 3 , occasionally 2 or 4 . A subocular present. In about $75 \%$ of the specimens one or two (rarely three) small scales are interpolated between the scales bordering the eye and the upper labials. Ventrals are 148 to 157 , average 152. Anteriorly the subcaudals are single, posteriorly many are divided. The total number in males varies from 44 to 51 , average 47.5 ; in females from 40 to 47 , average 43.7. The number of divided scales in males varies from 1 to 19 , average 9.8 ; in females from 2 to 23 , average 11.2. The anal plate is single.

The pattern consists of a series of dark blotches on a lighter ground. When viewed from the side these appear roughly as isosceles or equilateral triangles bearing an upward extension at the apex which usually meets a similar extension from a blotch on the opposite side. Counting from the head to the middle of the tail, where they become indistinct, the total of such markings is found to be 15 to 21 , average 18.3. The upward extensions involve about 3 or 4 scales in a longitudinal direction at their narrowest point and the bases of the triangles involve 5 to 10 scales at their widest point.

The general coloration above is pinkish or reddish brown to chestnut, being darkest on the upper edges of the triangles and their extensions, less dark on their bases and centers and palest in the ground color between them. Very frequently small round or irregular dark areas are present between or within the markings. The darker specimens may be stippled with greyish dots, usually densest posteriorly. Top of head coppery red. Commissure margined with pinkish.

Belly yellowish or cream colored and marked laterally with dark subround blotches. The largest of these lie on the ends of the ventrals and the first row of scales, and are normally so arranged that there is one beneath the center of each triangle and another at the point where downward extensions of the sides of two adjacent triangles would cross. Occasionally specimens exhibit dark blotches lying midway between those just described.

Juveniles are similar to the adults but are paler and have the posterior portion of the tail yellow or greenish.

Specimens examined, 105; specimens preserved, 95; specimens studied, 59.

Range.-Massachusetts to northern Florida and westward through southern Ohio, Indiana and Illinois to east central Kansas, Oklahoma and eastern Texas. 
The range of the copperhead in Chio is essentially in the unglaciated part of the state (Map 26). Localities outside of this area are in or near the valleys of large streams flowing into the unglaciated counties, or in habitats similar in many respects to those in that part of the state. Baird and Girard $(1853,18)$ record two specimens in the National Museum from Cleveland sent to that institution by Dr. Kirtland. While copperheads may have occurred in the vicinity of that city, careful search in recent years has failed to reveal any. It is possible the specimens may have been erroneously credited to this locality. Locality records are:

Adams County: Green Twp. (OSM 120); Jefferson Twp. (DOR). Ashland County: Clear Fork State Park, Hanover Twp. (TZS 2282). ATHENS CounTY: Near Mineral (OU). Clermont County: Near Amelia (CSNH 1229); Union Twp. (CSNH 1238, 1405; TZS 1963). FaiRFIELd CounTY: Sugar Grove (OSM 71.1-.2). Hamilton County: (CSNH 235). Highland County: 2 mi. S of Carmel (TZS 1498); + mi. S of Carmel (TZS 678); 3 mi. S of Carmel (TZS 1734A-D); 5 mi. S of Carmel (TZS 1649); Fort Hill, Brush Creek Twp. (OSM 462; TZS 798, 2393-5). Hocking CounTY: (OSM 73); Good Hope Twp. (OSM 121.1-.2, 376, 419.2; TZS 1557-8); Salt Creek Twp. (TZS 1317, 1394). JACKSON CounTY: Rock Run, Liberty Twp. (OSM 414.2-3). KNox County: (Morse, 1904); Brink-

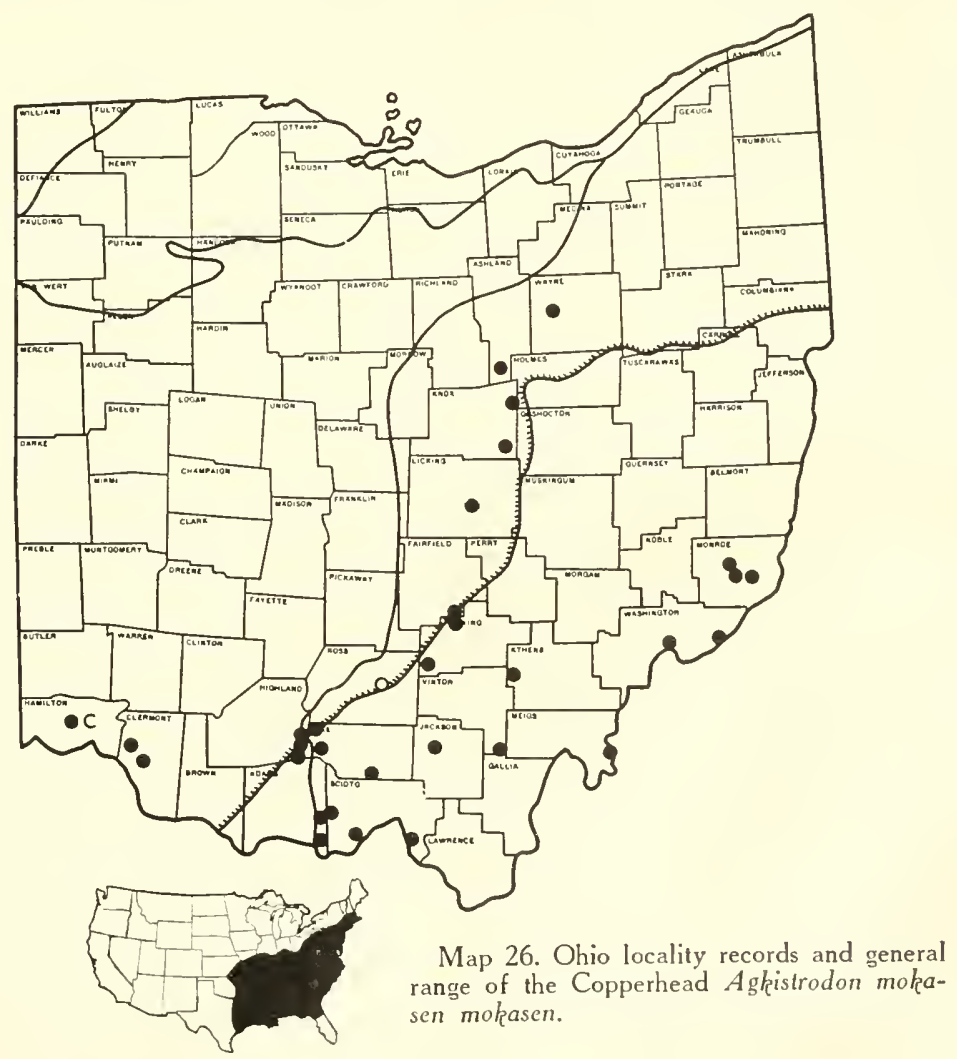


haven (OSM 365: TZS 82); Jackson Twp. (OSM 259). Licking CountY: Newark (OSM 454; TZS 2384). MEIGs County: Portland (OSM 437.1). Monroe CounTY: Center Twp. (TZS 503); Green Twp. (TZS 726-32, 792, 804, 1484-93); I mi. N of Woodsfield (TZS 1661). PIKE CountY: Mifflin Twp. (TZS 578); Perry Twp. (TZS 680-90, 797, 805; OSM 386) ; Beech Flats, Perry Twp. (TZS 806); Wakefield (DOR). Ross County: Chillicothe (Morse, 1904). Scioto Counry: Brush Creek Twp. (DOR): Franklin Furnace (TZS 2028); 2 mi. W of Friendship (DOR); $7 \mathrm{mi}$. SW of Otway (TZS 1639-45); $8 \mathrm{mi}$. SW of Otway (TZS 1496-7, 1650). Vinton County: Section 7, Wilkesville Twp. (TZS 1200). Washington CountY: Leith (CM 5167); Marietta (MC). WaYNe County: Near Overton (WC).

Habitat and Habits.- While it is not rare in some localities, the copperhead cannot be considered an abundant snake in Ohio.

Individuals were found in a variety of habitats and were apt to be encountered almost anywhere in unglaciated Ohio, even to well within the limits of the larger cities. They occurred in the valleys (sometimes along the streams) and ranged up the hillsides to their summits and out over the farm land or woods on the flat-topped hills. Sometimes they were in cleared open country and sometimes in heavy woods, but more often they were taken in scrubby second-growth or brush.

Specimens were rarely seen abroad save in early spring, and in midsummer they became distinctly nocturnal. Live ones were discovered on the roads at night and it was not unusual to observe freshly run-over ones on the highways in the early mornings. During daylight hours they secreted themselves beneath boards, stones, logs, etc., but one hiding place was so universally a favorite with them and so worthy of exploration that it is perhaps excusable to digress briefly to discuss it. Such was the sawdust and slab pile left to rot in the wake of the itinerant portable saw-mill.

Sawdust piles were not at all rare in many parts of southern Ohio. Over a mound of aging sawdust was usually scattered a profusion of thin bark slabs. Systematic overturning of these several times revealed copperheads to the collector. The snakes invariably attempted to escape by crawling under adjacent slabs or other cover and where the slabs were stacked or lying in a jumbled pile it sometimes was necessary to move the entire lot before the quarry could be secured. Such work, while arduous, was usually exciting for as the slabs were overturned and cast aside a glimpse might he had of a tail as a snake crawled under the next layer, and there was always a chance of discovering another in the midst of the pile.

Old and decaying sawdust piles are a favorite lurking place for many species of snakes and lizards. There is usually an abundance of hiding places under the close-fitting boards and bark, and the deep cracks, often in evidence in the pile itself, provide avenues through which the reptiles can penetrate far below the surface. Most sawdust piles are decidedly damp, at least below the outer layer, and even in the driest weather some moisture usually remains in them. This probably attracts snakes especially during the period prior to the shedding of their skins. While reptiles were not found in several of the large number of sawdust piles investigated in the course of the present survey, there were scarcely any in which the shed skin of at least one snake was not uncov. 
ered. The damp sawdust must be an excellent hatching medium for eggs, and ovoviviparous snakes may find the moist environment of advantage previous to the birth of their young. Three female copperheads found under a single bark slab in a sawdust pile in Monroe County each bore young a short time after they were collected.

Food, in the form of insects and rodents, is usually abundant and the warmth generated by the decaying of the sawdust must be still another inducement to reptiles. The interior of a pile in Scioto County, examined on a cool evening in early May, was so much warmer than the surrounding atmosphere that it actually steamed when it was exposed to the air. A copperhead found in it felt noticeably warm to the touch.

A large sawdust pile in Hocking County, which was covered with an interwoven mass of slabs, was systematically examined September 11, 1932. In it were found two juvenile copperheads, a swift, three young large-headed skinks, a common water snake and eleven pilot black snakes, the last apparently just emerged from eggs (see page 60). While no definite evidence was secured it is highly probable that snakes and lizards frequently hibernate in sawdust piles.

The habit of vibrating the tail when alarmed or excited is well developed in the copperhead. One, on a wooded hillside in Monroe County, would have been passed unnoticed but for the fact it vibrated its tail among dried leaves and attracted the attention of the collector. Most specimens, when first discovered, remained quiet or crawled away, but if they were once aroused or restrained they struck savagely and repeatedly.

As an example of how inoffensive a copperhead can be in the presence of human beings, the following case may be cited. A party of collectors stopped at a spring on a hillside in Hocking County, removed a wooden cover above the water, extracted a cup and filled it several times until all in the party were refreshed. During the act of replacing the cover a copperhead was discovered lying quietly on a rock immediately adjacent to the spring. The collectors' hands had several times been within striking distance of its head!

The copperhead is not the deep-dyed villain of popular imagination although there are numerous authentic cases in which unsuspecting persons were bitten by specimens they failed to see in advance. It remains so much in hiding that it seldom comes in contact with man and bites are infrequent. While it is decidedly dangerous and fatalities have occurred, it is not as deadly as some of the other venomous snakes, and the great majority of victims recover.

If one wears leather boots in areas where copperheads or other poisonous snakes are common, or protects his feet and legs in some other fashion, the chances of being bitten are slight. Care should be exercised where one places his hands and feet while in the field.

Copperheads were collected in Ohio from April to October inclusive but the greatest number was found from May to September. No "dens," such as those in which copperheads and other snakes are known to hibernate in other states, were discovered in Ohio during the course of the present work. 
The food of the copperhead is varied but consists chiefly of insects and small mammals (Surface, 1906, 188). This author also found a snake, sparrow and two salamanders in the stomachs of specimens he examined. A specimen in the Ohio State Museum from Licking County contained a half grown hairy-tailed mole (Parascalops breweri) it had swallowed tail first; one in the Carnegie Museum from Washington County had devoured a seventeenyear cicada which worked its way through the neck of the snake, causing the latter's death.

Captives ate mice and sparrows but none took frogs of the several species which were offered. Ditmars $(1936,334)$, however, states that "during the spring and fall it (the copperhead) is fond of frogs." Observations on specimens in the Toledo Zoo showed that large and active prey was bitten and released. After the venom had taken its effect the copperhead hunted its victim, usually examined it carefully with the tips of the tongue and then swallowed it head first. Smaller prey was bitten and held in the jaws, while such inoffensive victims as newly-born mice were engulfed without the fangs being used except in helping to work the food down the throat.

Copperheads bear living young. A female, 271/2 inches in length (but with the tail severed near the anus), collected in Perry Township, Pike County, August 27, 1931, gave birth to ten young September 3, 1931. These varied in length from $8 \mathrm{I} / 8$ to $93 / 16$ inches. Another female, 25 inches in length, taken June 27, 1931, in Green Township, Monroe County, bore six young September 10, 1931, which varied from $93 / 16$ to $93 / 4$ inches in length. The young of both groups shed their skins from 5 to 10 days after birth; both before and after shedding they were paler and greyer in color than the adults. A female from Brinkhaven, Knox County, in the Ohio State Museum contains ten large embryos.

Gloyd (1933) in his studies on the breeding habits and young of the copperhead gives the number in a litter as from 2 to 9 and the dates of birth as from August 9 to September 29 inclusive.

\section{Sistrurus catenatus catenatus (Rafinesque)}

\section{Massasauga; Swamp Rattler; Black Snapper}

Description.-A stout bodied snake which may attain a length of three feet. Largest adult Ohio specimen ( $\hat{o}), 30 \mathrm{r} / 2$ inches in length (exclusive of the rattle); smallest newly born juvenile, $75 / 8$ inches. Head broad, triangular in shape and distinct from the neck. Eye moderately small and lying directly below the overhanging supraocular; pupil elliptical. Head plates normal and occupying, collectively, a roughly oval area. Two nasals, the nostril largely in the postnasal. Two elongate preoculars, the upper in contact with the postnasal and the lower separated from the postnasal by a small rhomboidal or trapezoidal loreal. A deep pit in the loreal region. Postoculars 3 or 4 (rarely 5); a subocular present. Upper labials most often 12, less frequently 11 or 13 ; separated from the scales surrounding the orbit by a 
row of small scales. Lower labials 12 or 13 , rarely 14 . Body stout; tail short and stout and terminating in a jointed rattle.

Dorsal scale rows somewhat variable, but exhibiting a maximum most frequently of 25 (less often 26 or 27) and a minimum of 19 (occasionally 20, and 17 in one specimen from Hardin County); the most common formula is 25-23-21-19. The scales are keeled except for the first two rows which are smooth. Ventrals in males 132 to 142 , average 135.4; in females 136 to 144, average 140. Subcaudals undivided (except for a few just anterior to the rattle), and in males from 26 to 32, average 28.4; in females 20 to 26, average 23.1. Anal plate single.

Ground.color above, grey or brownish grey, conspicuously patterned with numerous brownish black or black subovate markings. The largest of these are arranged in a vertebral series of 21 to 35 (average 30.3) blotches, involving 3 to 6 scales longitudinally and 8 to 12 scales transversely. Below these are a number of smaller blotches most frequently distributed so that one lies directly below each one of the vertebral series and two are situated (one above the other) in positions alternating with the dorsal row. The variations are many, however, and the markings may occasionally be fused with one another.

The blotches are margined with black and the majority are still further surrounded with a narrow edging of whitish or yellowish. A pair of elongate blotches extend backward from the head and a broad dark band, edged narrowly above and more widely below with whitish, extends backward from the eye. The top of the head is largely dark but is crossed by a band of the ground color from eye to eye, and has light markings on the more posterior plates. Two divergent light lines extend downward from the pit to the mouth. The tail is patterned with 4 to 7 dark crossbands. The belly is black, irregularly marked with yellowish or whitish. Juveniles are similar but paler than adults and with the future rattle represented by a horny "button."

Melanistic specimens are found occasionally, which are uniformly jet black both above and below, except for a few light areas on the throat, chin and labials. On many such snakes, however, the pattern may be traced faintly when the specimen is held in the proper light, and it usually may be made out, even in the darkest individuals, if they have been preserved for any length of time.

The relative abundance of black and spotted specimens is of interest. Of fourteen collected near Mt. Victory, Hardin County, all adults were black and all juveniles spotted. Black females from this locality invariably gave birth to normally patterned young, and, according to farmers, spotted adults are rare or absent in the vicinity of Mt. Victory. In other localities black specimens were not common.

Specimens examined, 118; specimens preserved, 97; specimens studied, 62.

Range.-Southern peninsula of Michigan, southern Ontario and western New York, southwestward to eastern Kansas. The massasauga occurs over much of glaciated Ohio (Map 27). It is apparently rarer than formerly, 
especially in the northeastern counties. It probably will not be found in the unglaciated area. Locality records are:

Champaign County: Dallas Bog, $5 \mathrm{mi}$. SSW of Urbana (OSM 75.1-.8). Crawford County: Auburn Twp. (TZS 1180, 1465-9); Cranberry Twp. (TZS 990). Defiance County: Hicksville (FMNH 430-2, 438-9). Erie County: (FMNH 2552); $1 / 2 \mathrm{mi}$. W of Castalia (BGSU); Kimball (AMNH 4054). FaIRFIELD CountY: Buckeye Lake (OSM 119); Millersport, Walnut Twp. (OSM 174). Fayette Countr: 7 mi. NE of Centerville, Lee's Creek P. O. (TZS 1613-5). Franklin County: Columbus (USNM 546). Fulton County: Swanton (BGSU). Greene County: Fairfield. Hardin County: $3 \mathrm{mi}$. E of Mt. Victory (TZS 121, 378, 397-8, 800-3, 1307-all adults from this locality melanistic). HuroN CounTY: New Haven Marsh (BGSU, TZS 423-melanistic, 424-6, 1321-melanistic, 1322); New Haven Twp. (TZS 1179); Richmond Twp. (OSM 117-8-melanistic, 424.2); Mello Bog, Willard (CMNH). Licking CountY: Buckeye Lake, Union Twp. (OSM 291.1, 296, 383.1). Logan CountY: $7 \mathrm{mi}$. N of North Lewisburg (TZS 799); Pony Island, Indian Lake (TZS 308-melanistic). LoRAIN CounTY: Oberlin (OC). LuCAs County: Crissey (CSNH 1898); Holland (LMK 22947; OSM 378; TZS 158); N of Holland (TZS 1516); between Holland and Maumee (TZS 23-melanistic); 3 mi. W of Toledo (TZS 22, 459, 960); W. Toledo (TZS 117-8); near Silica (TZS 460); SW part of Spencer Twp. (BGSU); Trilby (LMK 22948);

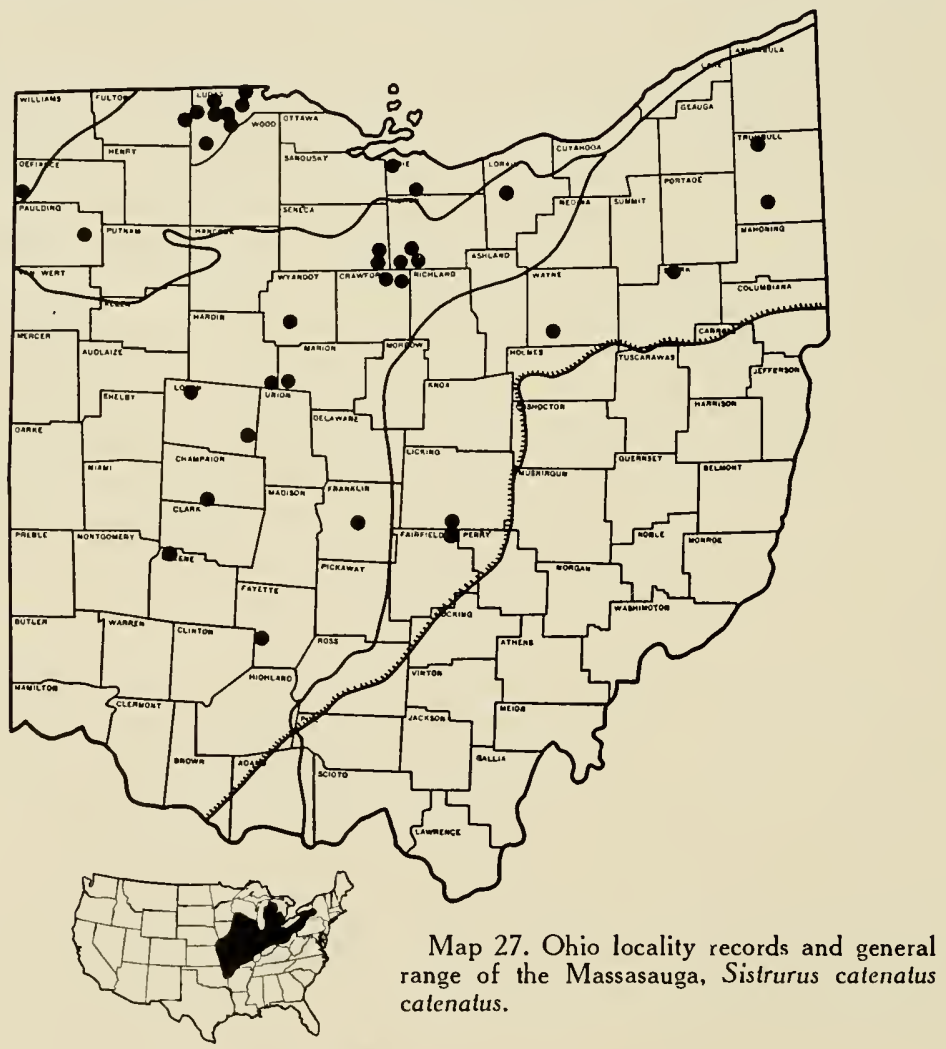


Whitehouse. Marion County: Bowling Creen Twp. (TZS 609-melanistic). Paulding County: Charloe, Brown Twp. (OEE) ; 7 mi. E of Paulding (OEE). Seneca County: Near Attica (TZS 772); Venice Twp. (TZS 989, 1220). Stark County: Near Hartville (OSM 439.1). Trumbull County: (USNM 545 probably originally melanistic); Bloomfield (TZS 2273-5); Warren (USNM 526, 543-4 probably originally melanistic). WAYNE COUNTY: Kauke, Franklin Twp. (TZS 394). Wyandot County: Miflin Twp. (TZS 597, 668-70).

Habitat and Habits.-While the massasauga is probably less abundant than formerly it is still a common snake in many parts of Ohio. In the New Haven Marsh, which lies partially in Seneca, Huron, Crawford and Richland Counties it is common enough so that specimens are frequently seen and cases of snake bite are not rare. Yet many natives of this area pay little attention to it. A family of Georgia "crackers" imported to work on the celery farms of the district, reported that a rattler crawled under the cement slab which served as a doorstep to their ramshackle home. When the slab was overturned five massasaugas were found hiding beneath it! The family showed little concern over the matter despite the fact that a dozen or so barefooted children played about the yard daily.

Near Mt. Victory in Hardin County the massasauga is also common. It apparently hibernates in and near the marshy remnants of a former swamp forest but spreads out over the surrounding farming country during the summer. It often hides under the shocks of grain and Charles L. Burris of Toledo, who formerly lived near Mt. Victory, is responsible for the statement that as many as 27 were discovered and killed during the harvesting of some 40 acres of wheat. Numbers are killed during threshing time each year.

That the massasauga is common in many places in Ohio is indicated by the several series of museum specimens from single localities, and by the fact that local residents in many different areas characterize it as abundant. The original habitat of the massasauga in the state was probably the scattered prairies of glaciated Ohio but agricultural activities have destroyed most of these. It appears to be confined, more or less, to the vicinity of bogs and matshes and other poorly drained areas, although it was not found in the most extensive marshes of the state-those lying along the shores of Lake Erie to the east of Toledo. Massasaugas must enter the water occasionally since at least two were discovered coiled upon tufts of grass entirely surrounded by shallow water.

Almost every specimen collected was more or less lethargic, made little or no attempt to bite and failed to sound its rattle. Several were nearly stepped upon but did not move. When once aroused they struck repeatedly but the rattle was seldom employed.

Several massasaugas were found under boards, pieces of tar paper, etc. A large number, however, were in the open. They were usually lying in a small compact coil and unless the day was hot they were in the sun.

Except in those areas where the massasauga is so abundant as to be a public menace, bites from it are rare. Despite its small size, however, it is a dangerous snake and should be treated with caution and respect. 
Specimens were collected in every month from April to November inclusive. More were taken in May than in any other month but the data show a fairly even distribution over the summer months. A specimen, apparently in hibernation, was accidentally discovered near Crissey, Lucas County, April 18, 1935. A blue racer (Coluber constrictor flaviventris) which was pursued by some farmers disappeared down a hole near a bush. In digging for this snake a large massasauga was unearthed among the roots some 18 inches below the surface in soil which was a mixture of sand and peat. Since the weather up to this time had been consistently cool, it was presumed the two snakes had hibernated in this place.

A large portion of the food consists of mice. An adult specimen in the Ohio Museum from Buckeye Lake, Licking County, had a very large meadow mouse (Microtus p. pennsylvanicus) in its stomach. Several individuals from the Mt. Victory locality disgorged mice shortly after they were captured and young ones had swallowed mice so large it must have taxed their abilities to the limit. Ditmars $(1936,345)$ states that his specimens "would take young birds, mice and frogs, and, like the copperhead snake, different kinds of food according to the seasons." Ruthven $(1911,270)$ states "Frogs were found in the stomachs of some of the individuals taken, and these probably form the bulk of the food." The same author also found two instances of snakes having been eaten (one a rattlesnake) and it appeared that they had been dead for some time before they were consumed. Captives in the zoo ate white mice which usually died within a very few minutes after being bitten. Following a brief inspection with the tongue tips they usually were swallowed head first.

Massasaugas bear living young. A female $207 / 8$ inches in length collected near Mt. Victory, July 6, 1931, gave birth to 7 young August 6, 1931. These varied from $83 / 4$ to $9 \mathrm{~T} / 4$ inches in length; all shed their skins within 48 hours after birth. Their fangs were well developed and at the age of 4 days two of them killed a mouse each, which had been placed in the cage to serve as food for the mother. The mice were removed for observation as soon as they were bitten. They were still alive several hours later but both were dead the following morning. Atkinson and Netting $(1927,42)$ indicate "that from five to nine young are produced late in July or eatly in August," but Swanson $(1933,37)$ gives the dates of birth as from August 15 to September 10. A specimen in the Northwestern University collection contained 12 embryos.

\section{Crotalus horridus horridus Linné}

\section{Timber Rattlesnake; Banded Rattlesnake}

Description.-The largest poisonous snake occurring in Ohio. Large adults average $31 / 2$ to 4 feet in length although a six foot specimen is on record (Ditmars, $(1936,367)$. Largest adult Ohio specimen ( $\hat{o}), 47$ inches in length, but there are authentic reports for Ohio individuals as large as 56 inches. The smallest newly born juvenile (possibly somewhat premature), $73 / 8$ inches. 
Head broad and flat and much wider than the neck. Eye medium and lying directly below the overhanging supraocular; pupil vertically elliptical. Top of head, with the exception of the supraocular, canthals and internasals, covered with small scales. Two nasals, the nostril in the postnasal. Loreals usually 2, rarely 1 . Usually' 1 canthal; occasionally 2 , rarely 3 or 4 . Three rows of scales separating the upper labials from the eye. Upper labials most often 14 , frequently 13 or 15 , rarely 12 or 16 . Lower labials usually 14,15 or 16 , often 17 , rarely 13,18 or 19 . A deep pit in the loreal region. Body stout; tail short and stout and terminating in a jointed rattle.

Dorsal scale rows most commonly 25-23-21-19, occasionally 23, and rarely 27 anteriorly; occasionally 18 posteriorly. Scales keeled. Ventrals in males 158 to 172 , average 166; in females 166 to 176 , average 169 . Subcaudals (single except for one or two anterior to the rattle in some specimens) in males from 21 to 25 , average 24 ; in females 19 to 22 , average 20 . Anal plate single.

There is a pattern of 18 to 27 (average 21) dark chevron-shaped crossbands on a lighter ground color. The crossbands, which originate on the first row of scales or the ends of the ventrals, are 2 to 6 scales in width and vary in color from tan to light olive brown or black. They frequently are outlined with a shade somewhat lighter than the adjacent ground color. The latter contains at least some yellow pigment, but may vary from a uniform light sulphur in some specimens to a grey brown or olive brown in others. Individuals with the lightest ground color have the lightest crossbands and vice versa. The darker coloration of many specimens appears to be due to a more or less extensive stippling of black uniformly distributed over the light and dark areas alike. The top of the head is yellow in light specimens and black in dark ones.

Occasionally, and especially on the anterior portion of the body, the ground color may cut off a small lateral portion of the crossbands from the main dorsal portion. A yellowish, brownish or russet stripe, occupying the middorsal row of scales and the 1 to 3 rows on either side, is strongly evident in many specimens but less so in others. It may or may not obscure or interrupt the crossbands. The tail is crossed by 3 or 4 dark crossbands in the lighter specimens but is uniform black in the darker. The belly varies from nearly uniform yellowish to heavily stippled with black. Newly born juveniles have the future rattle represented by a horny "button."

Specimens examined, 42; specimens preserved, 39; specimens studied, 36.

Range.-Southern Maine to northeastern Alabama, and southeastern Minnesota to northeastern Texas.

The timber rattlesnake occurs in Ohio on the peninsulas of Ottawa County and on some of the islands in Lake Erie. It is also found in the southern part of the unglaciated area (Map 28). Specific localities are:

Adams County: Green Twp. (OSM 123). Athens County: Mineral (OU). Jackson County: Near Vigo, but in Jackson Twp. (OSM 122). Ottawa County: Catawba Island (OSM 223.1-.2; SHS; TZS 796, 1703-11, 1972); Put-in-Bay (SHS; TZS 1977-89). Ross CounTY: S side of Pott's Hill, Paxton Twp. (TZS 
763). Scioto County: Nile Twp. (CSNH 1493); NE part of Nile Twp. (TZS $810) ; 8$ mi. SW of Otway (TZS 1738-40); Rocky Fork at Pink (OSM 410); Shawnee Forest, Union Twp. (OSM 124).

Habitat and Habits.-The timber rattlesnake appears to be much less common than formerly and must be considered as a comparatively rare snake in Ohio. According to reports of early travelers and settlers it was found frequently in the hilly southern counties, but the destruction of the forests and the constant persecution by man have caused its extirpation in all but a few areas. There is mention in historical accounts of a colony of considerable size in the rocky bluffs of the Scioto River just north of Columbus, but this has long since been destroyed by quarrying operations. More recent reports concern rattlers in the vicinity of Akron and Lancaster. Careful inquiry and search have failed to verify these, and while there are habitats suitable for timber rattlesnakes near each of these cities it is probable the reports are based upon the massasauga or upon the misidentification of some non-poisonous species. There are still colonies on the Catawba and Marblehead peninsulas of Ottawa County and on some of the Lake Erie islands, but all other recent records are from the southern part of unglaciated Ohio.

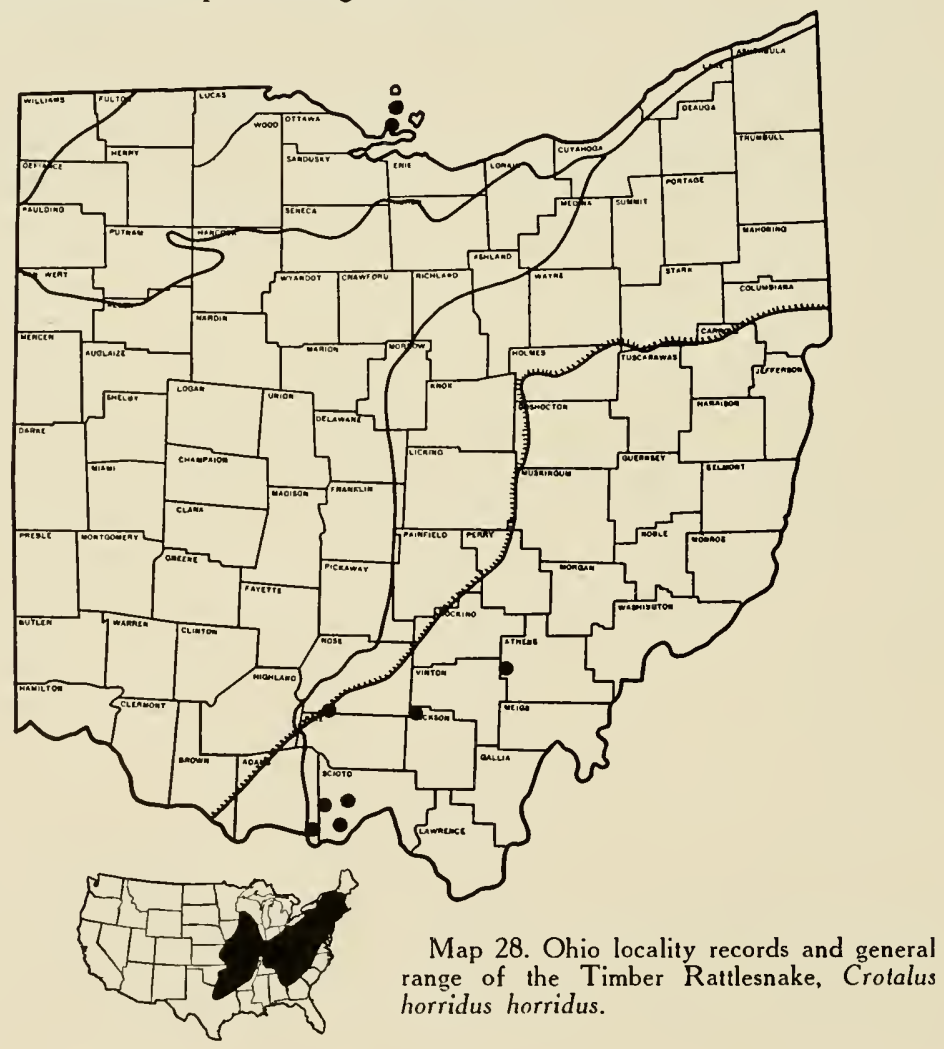


In Ottawa County rattlers are found in or near the rocky cliffs along Lake Erie, in caves and crevices in the limestone or in piles of rock assembled by the clearing of fields and the preparation of real estate developments. Despite the presence of large numbers of summer residents and picnickers in this area the rattlesnakes appear able to maintain themselves although they have obviously decreased in numbers in recent years. They spend much of the day in hiding and they forage at night. They are seldom seen in the open and it is probable that the colony would have been exterminated years ago had it not been for the abundance of hiding places in the rocks.

In southern Ohio some timber rattlers were taken in the vicinity of rocky cliffs, etc., but the favorite habitat appeared to be dry hillsides and hilltops which are covered, for the most part, with deciduous trees. In small clearings or "openings" in these woods huckleberries grow in abundance and rattlesnakes are occasionally found coiled under or between the bushes. The idea is prevalent among residents of parts of Scioto County that huckleberries and rattlesnakes are inseparable and any inquiry made in the vicinity concerning these snakes is apt to be answered by, "You have to wait 'til huckleberryin' time to ketch rattlers!"

No rattlesnake "dens" were discovered in the course of the field work and it is doubtful if rattlers are common enough in the state to form "dens" of any considerable size.

Field notes indicate that almost all specimens were quiet and made little attempt to bite or to rattle. Most crawled away when discovered but some remained coiled in their original positions until they were caught. One of the Catawba Island specimens was found in the early morning entering a rock pile within 50 yards of a summer cottage. Another was discovered under a large chunk of limestone not far from another cottage. Few specimens were seen on the roads and these apparently were run over at night. Individuals were collected from May to September inclusive.

While the timber rattlesnake, because of its large size, is the most dangerous snake in Ohio, its rarity, secretiveness and disposition are factors which tend to minimize its importance as an enemy of man. No records of persons being bitten by timber rattlers in Ohio were obtained during the course of the work although several cases of copperhead and massasauga bites are known.

The food of the timber rattlesnake consists largely, if not exclusively, of warm blooded prey. Surface $(1906,196-7)$ records such mammals as mice, rats, shrews, squirrels, etc., as constituting $94 \%$ of the food. In his diagram of the food of this species he indicates the remaining $6 \%$ as being composed of snakes but he fails to mention snakes in his itemized table. (Ditmars $(1936,369)$ states that "the food of the Banded Rattlesnake consists of warmblooded prey in the shape of small rabbits, squirrels, rats, mice and birds." Captives ate mice and sparrows.

A female from Catawba Island, $413 / 8$ inches in length, collected June 11, 1932, gave birth to 8 young September 15, 1932. These varied in length from $93 / 8$ to $97 / 8$ inches. Another female from Put-in-Bay, $417 / 8$ inches in 
length, collected June 4, 1933, gave birth to 12 young September 13, 1933. These ranged from $73 / 8$ to $81 / 2$ inches in length. Both females refused all food in captivity and both died a few days after the birth of the young. The appearance of the juveniles in each litter was such as to indicate that they were probably born a bit prematurely. Ditmars $(1936,370)$ gives the number in a brood as from 7 to 12 and the dates of birth as from September 6 to 18 inclusive.

\section{Sternotherus odoratus (Latreille)}

\section{Musk Turtle}

Description.-A small turtle attaining a carapace length of 5 inches or more. Largest adult Ohio specimen ( $\hat{o})$, had a shell 5 inches in length; smallest juvenile (probably recently hatched), $7 / 8$ inch. Carapace rigid and covered with horny plates. Shell relatively long and narrow and considerably arched, the highest point lying from $45 \%$ to $65 \%$ of the length back from the anterior margin. No outward flare of the shell at the edges of the carapace. Scutes smooth and slightly imbricate in the young. Juveniles with a prominent middorsal keel which gradually disappears with age. Nuchal small, occasionally much reduced and even wanting in one specimen. Costals and vertebrals normal. Marginals, including the nuchal, usually 23 (25 in a specimen from Hocking County and 22 and 21 respectively in two specimens from Athens County).

Plastron small and not nearly filling the opening of the carapace; rounded anteriorly and emarginate posteriorly. Posterior lobe rigid, anterior lobe movable on a hinge located between the pectoral and abdominal plates; hinge undeveloped in young. Plastral scutes of adults and many juveniles separated by areas of skin which are widest in adult males.

Head large, snout conical, tip of upper jaw not developed into a beak. Tail short and terminated by a blunt horny nail in adult males and with or without a sharp horny nail in females. Skin soft and covered with fleshy papillae; two to four elongate ones on the chin and two on the throat. Several long curved scales on the feet. Adult males with two zough patches of scales on the inner side of the hind legs near the knee and so arranged that the two patches on the same leg lie against each other when the legs are flexed.

Carapace some shade of dark brown, grey, olive brown or black and in the lighter specimens showing streaks or spots of a darker shade more or less irregularly arranged. Plastron yellowish brown, the borders of the scutes darker. Soft parts grey or olive grey mottled with yellowish. Two more or less well defined yellowish lines extending backward from the snout, one passing directly above the eye, the other below it. Lower margin of lower jaw bordered with yellow. Juveniles pigmented similarly to adults but usually darker and with the head markings more prominent.

Specimens are sometimes so overgrown with algae as to have the upper shell completely obscured, but when the skin of the scutes are shed this growth is lost with them. 
Specimens examined, 54; specimens preserved, 42; specimens studied, 20.

Range.-New England to Florida, west to Wisconsin, southeastern Kansas and eastern Texas. In Ohio the musk turtle is widely distributed and probably occurs in almost every part (Map 29). Locality records are as follows:

Ashland County: Long Lake, Lake Twp. (OSM 323). Athens County: Athens (TZS 1087, 1755-6). Champaign County: Mechanicsburg (OSM 408.1). Darke County: Versailles (OSM 229). Defance County: Defiance (Kirsch, 1895); Ladd Lake, Milford Twp. ("IZS 371). Erte CountY: Cedar Point (OSM 149.1-.2); Sandusky (Morse, 1904); Sandusky Bay (SHS). FrankLin CountY: (USNM 26038); Columbus (OSM 144); Georgesville (Morse, 1904). Geauga Countr: Fowler's Mill (CMNH); Geauga Lake (TZS 534-5). Hamilton County: Glendale (CSNH 1067). Henry County: Texas. Hocking County: Wolf's Basin, near Haydenville (TZS 1757, 1995-6). HoLmEs CounTY: Odell Lake, Lakeville (TZS 2226). Huron County: Richmond Twp. (OSM 138.1-2). Jackson CounTY: 3 mi. SE of Jackson (TZS 2153). Licking CounTY: Buckeye Lake (OSM 14I, 322, 324; WC). Logan County: Indian Lake (OSM 230). LuCas CountY: Maumee; Sylvania; Toledo (TZS 124, 284, 351). MERCER CounTY: I mi. S of Celina (TZS 252). Ottana County: Port Clinton. Portage County: Lake Brady, near Kent (OSM 188). Scloto County: Rushtown (TZS 1086); 2 mi. N of Rush-

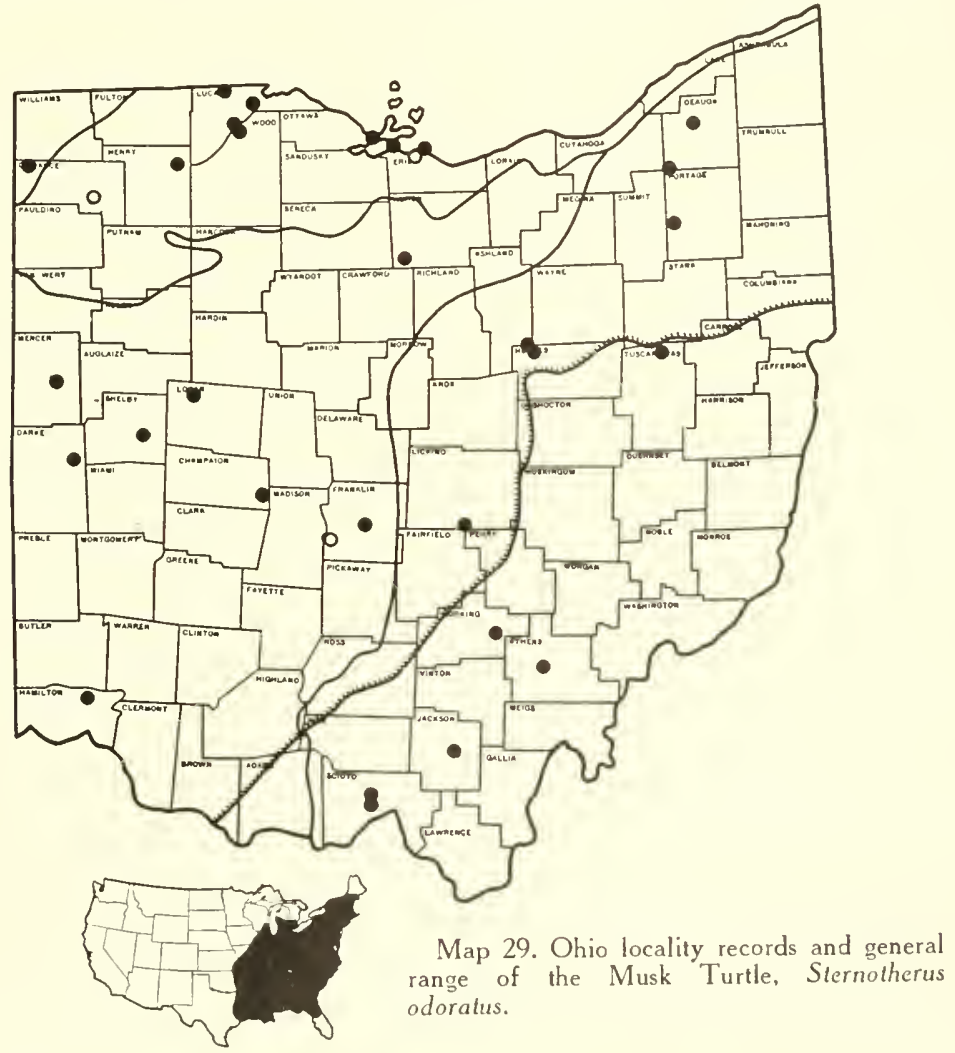


town (TZS 1826-7, 1888-9); 2 mi. S of Rushtown (TZS 2149). Shelby County: Tawawa Creek, near Sidney (OSM 321). Tuscarawas CountY: Zoar (OSM 445). Wood County: Perrysburg.

Habitat and Habits.-Judging from the comparatively few specimens collected on field trips it cannot be said that the musk turtle is generally abundant in Ohio. During the course of the survey not more than two ever were obtained in the same locality on the same day. Thomas and Trautman (1937), however, report the finding of a considerable number at Buckeye Lake (see p. 123), and it is known that musk turtles are common in some of the small lakes in southern Michigan not many miles north of the Ohio boundary.

The general absence of lakes and ponds throughout the greater part of Ohio influences the distribution of the musk turtle, probably to a considerable extent. It is difficult, however, to judge the relative abundance of any aquatic turtle, especially when the difficulties of collecting and the possibilities of overlooking specimens in deep or turbid waters are considered. Hence the musk turtle may be much more generally common than the field work indicated.

Individuals are decidedly aquatic. They seem to prefer quiet water and none were taken in fast moving streams. They were found in lakes and ponds, sluggish streams and in abandoned canals or ditches, the latter either clear or choked with aquatic vegetation. Most were collected on the bottom in shallow water, but, that they frequent greater depths was indicated by the fact that several surprised near shore did not hesitate to swim into deeper water. In addition specimens took the hooks of fishermen at a depth of several feet.

Only a few musk turtles were found out of water. One was discovered on a muddy bank secreted beneath a discarded piece of wallboard and two others were sunning at the edge of a pond. A few taken in the abandoned Ohio and Erie Canal in Scioto County were resting at the edges in a mass of vegetation in such a manner that only the centers of their carapaces were above water.

The normal gait in water is slow and specimens were seen walking about leisurely on the bottom. When alarmed, however, they swam with a fair amount of speed. Occasionally they were found buried in the mud under water, which latter measured a few inches to a foot or more in depth.

Musk turtles are usually bad tempered. They normally try to bite when handled, even after they have been in captivity for some time, but occasional ones become fairly tame. Care must be taken in holding a specimen lest the long and supple neck allow the sharp mandibles to come in contact with the hand. Wounds inflicted by them usually are superficial, however.

The name of this turtle is derived from the musky odor which is in evidence when a specimen is captured or teased. The odor arises from an orange or yellow fluid secreted by two glands lying beneath the border of the carapace on either side. One is located at the posterior end of the bridge, and the other about midway between the bridge and the anterior edge of the carapace. The locations may be recognized by the openings of the ducts leading 
from the glands, and which are often surrounded by a small raised lump of skin.

Specimens were collected in every month from March to October inclusive; the earliest record was March 3 (1933) and the latest October 20 (1929). That musk turtles sometimes hibernate in considerable aggregations is indicated by Thomas and Trautman (1937) who report finding an estimated 450 specimens in a canal north of Buckeye Lake, Licking County, on March 28, 1937.

During the collecting season musk turtles most frequently were found in association with snappers and painted turtles but they were also taken with most of the other species occurring in Ohio.

The food is varied but apparently is largely of an animal nature. Items which are too large to swallow are seized in the jaws while the legs push against the main mass until a piece is torn loose. Risley $(1933,700)$ states that "remains of fish, clams, snails, aquatic insects, and crabs, as well as much vegetable matter, such as buds of Elodea and other unidentified aquatic plants, have been found in their stomachs." Captives were observed to eat earthworms, crayfish, insects, such as grasshoppers, crickets, flies, etc., chopped meat, liver and fish. It is probable that the musk turtle consumes considerable carrion and hence is useful as a scavenger.

None of the specimens collected in Ohio were observed to lay eggs. They may dig their nests in decaying stumps (Newman, 1906, 148), in sand or in muskrat houses (Risley, 1933, $696 \& 699$ ) or in a variety of other places as described by Eigenmann $(1896,263)$, "The eggs are laid in the rotten wood in the tops of stumps standing in the margin of the lake (Turkey Lake, Indiana). The turtles were frequently found in the tops of these stumps, and some of their eggs wedged as far into the rotten wood as a finger could bore. Rotten logs removed some distance from the water are also favorable places for egg laying, and in a mucky place of small area at the edge of the lake 362 eggs were taken at one time." The same author goes on to say they "had deposited their eggs in the ground in depressions made by a cow while walking over the ground when it was soft. Still other eggs were found in bundles of rushes drifted together." Risley $(1933,699)$ has also noted the gregarious nesting habit and has recorded finds of 253, 196, 127 and 52 eggs at a time in single muskrat houses.

The latter author has summarized the breeding habits of this species. He states that "mating occurs in the spring between the approximate dates of April 1 and May 15" and that "it may also occur in the fall." He found that eggs of specimens from southern Michigan normally were laid from June 10 to July 5 and that in the laboratory the incubation period varied from 60 to 75 days. The number of eggs laid by single turtles varied from 2 to 7 but occasionally as few as 1 or as many as 9 were deposited. He gives the maximum length of eggs as from 24 to 31 , average $27.1 \mathrm{~mm}$., and the maximum diameters as from 14.2 to 17.0 , average $15.5 \mathrm{~mm}$. The eggs are white, elliptical in shape and have hard, rather brittle shells. Risley's newly hatched juveniles had the carapace from 19 to 25 , average $23 \mathrm{~mm}$. (3/4 to 1 inch) in 
length. That juveniles may be even smaller is shown by Babcock $(1919,360)$ who states that the "young when newly hatched, are $1 / 2$ inch long."

\section{Chelydra serpentina (Linné)}

\section{Snapping Turtle}

Description.-The largest turtle inhabiting the state. Some specimens attain a weight of 40 pounds and a shell length of 14 inches or more. Largest adult Ohio specimen (sex undetermined) had a carapace $135 / 16$ inches long; smallest newly hatched juvenile, 1 inch. Carapace rigid and covered with horny plates; subovate and sharply serrate behind. Shell smooth in large adults; smaller specimens rugose and with three well defined longitudinal keels, one median and two lateral. Keels tuberculate, the tubercles with radiating ridges which are directed forward and sideward. Scutes normal in number and arrangement; nuchal broad.

Plastron small, bridge narrow. Gulars most often fused with each other; anals absent or represented by a very small vestigial scale. Head large, flat above and with marked horny ridges. Snout rather pointed, both jaws hooked. Two small barbels at the anterior edge of the chin.

Tail long, tapering and with a median row of large horny tubercles on the dorsal side. Smaller tubercles on either side and smooth flat scales on the under surface. Skin with numerous warts and small scales, the latter largest on the limbs.

Carapace some shade of dark olive, brown or black. Head similar and frequently streaked and spotted with black in the lighter specimens. Under surface, including the chin, uniform blackish in very small individuals, marbled black and yellowish in small specimens and uniform dull yellow in adults. A yellow area in the center of the ventral side of each marginal in juveniles.

Specimens examined, 224; specimens preserved, 96; specimens studied, 33.

Range.-From the Atlantic coast to the Rocky Mountains and from Nova Scotia and southern Canada to the Gulf of Mexico; through Mexico and Central America to Costa Rica. The snapper is widely distributed in Ohio and undoubtedly occurs in every county (Map 30). Locality records are as follows:

Adams County: Cedar Mills (TZS 1898). Ashlland County: Ruggles Twp. (TZS 440). Ashtabula County: Kingsville, Conneaut Creek (USNM 51182); near North Kingsville (TZS 1799); Pymatuning Swamp, near Andover; 3 mi. NE of Richmond Center. Athens County: Near Chauncey (TZS 433). Auglaize CountY: S shore of Lake St. Mary's on boundary of Mercer and Auglaize Counties (TZS 253). Brown CountY: White Oak Creek, I mi. N of Higginsport (TZS 1874). Carroll County: Union Twp. (TZS 544). Clinton County: Near Centerville, Lee's Creek P. O. (TZS 671). Coshocton County: Ohio Canal, W of Newcomerstown (TZS 1859); Willowbrook, Virginia Twp. (OSM 456, 459). CRAWford CountY: Sandusky River, $3 \mathrm{mi}$. S of Sulphur Springs (TZS 468). Cuyalioga Countr: Chagrin Falls (C.MNH); 2 mi. SW of Chagrin Falls; Chagrin River, Mayfield Twp. (TZS 537). Defiance County: Auglaize River, Defiance (USNM 21561): near Florida; Ladd Lake, Milford Twp. (TZS 583). ERIE 
County: (UMMZ 41956, 41960); Sandusky (Morse, 1904; UMMZ 40720). Franklin County: (USNM 26039); Columbus (MCZ 1434; OSM 151); Scioto River below Columbus (OSM 304). Fulton CountY: West Fork. Swan Creek, Swan Creek Twp. (TZS 516). Gallia County: Springfield Twp. (TZS 413). Greene County: Yellow Springs (MCZ 1900). Guernsey Countr: Wheeling Twp. (TZS 1860). Hamilton County: (Morse, 1904); Ox-bow along Whitewater River, Whitewater Twp. (TZS 1961); near Whitewater (CSNH 1615). HANCOCK County: Cass Twp. (TZS 607). Hardin County: $3 \mathrm{mi}$. E of Mt. Victory. Harrison County: Scio (TZS 337). Henry County: Texas; NE corner of Washington Twp. Highland County: Near Hillsboro (TZS 743). Holmes County: Odell Lake, Lakeville (TZS 2227). Huron County: Peru Twp. Jackson County: 3 mi. SE of Jackson; Rock Run, Liberty Twp. (OSM 425.3). Jefr'erson CountY: Steubenville (OSM 256). Knox Countr: Brinkhaven (AS). LAKE County: Mentor Marsh, Mentor Twp. (TZS 536, 1411, 1470); 4 mi. E of Painesville (TZS 1440). Lawrence County: $5 \mathrm{mi}$. W of Ironton (CSNH 942); Creek near Proctorville; Storm's Creek, near Vesuvius Furnace (TZS 4II). LoGAN CounTY: Indian Lake (OSM 193); Pony Island, Indian Lake (TZS 239). Lorain CountY: Oberlin (OC); Lorain (OC). Lucas County: Bono; Holland; Maumee; Monclova; Ottawa Hills; Sylvania; Toledo (TZS 829-45); near Toledo (OSM 251); Miami and Erie Canal, Toledo (TZS 232); Maumee River, Toledo (TZS 627). Madison County: London (Morse, 1904). Mahoning Countr: (USNM 55582). Medina County: W of Medina (TZS 1040). Meigs County: Chester (TZS 412). Miami

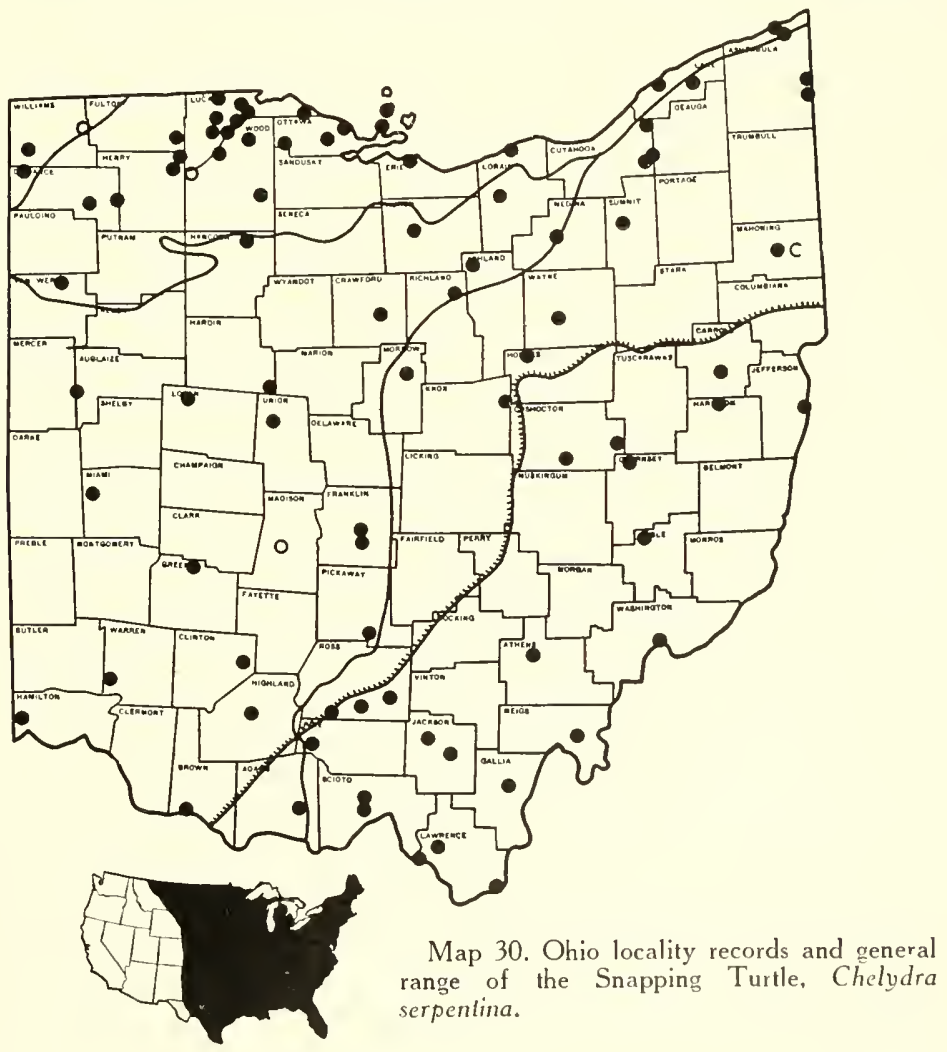


County: Greenville Creek, $11 / 2 \mathrm{mi}$. SW of Covington (TZS 938). Morrow CounTY: Congress Twp. Noble County: Buffalo Twp. (TZS 1261). OtTawa County: Catawba Island; Erie Twp.; near Genoa; Oak Harbor; Put-in-Bay (USNM 21125). PiCKAway County: Northern part of county (OSM 306); Pickaway Twp. (OSM 216.3). Pike County: Mifflin Twp. (TZS 575). Richland County: Black Fork, Shenandoah (TZS 472). Ross County: Huntington Twp. (TZS 1132); Paint Creek, Copperas Mt., Paxton Twp. (TZS 1101); Ox-bow of Scioto River at Vauces. Scioto County: Rushtown; 2 mi. N of Rushtown; 2 mi. S of Rushtown (TZS 1823-5). Summit County: Ira (OSM 305). Union County: York Twp. (DOR). Van Wert County: Town Creek, Hoaglin Twp. (TZS 584). Warren County: Mason (CSNH 1044). Washington County: Marietta (MC; TZS 497). Wayne County: Killbuck Creek, west of Wooster (TZS 469). Williams County: $1 \mathrm{mi}$. SW of Blakesley (TZS 373); West Unity (Kirsch, 1895). Wood County: Grand Rapids (Kirsch, 1895); Lime City; South Branch, Portage River (OSM 283); Maumee River, opposite Waterville.

Habitat and Habits.-The snapping turtle is one of the most abundant turtles in Ohio. It was not seen or found so frequently as the painted turtle but were it addicted to basking in the sun, and hence as conspicuous as the latter species, it probably would be found to equal or surpass it in numbers.

Almost any body of water large enough to keep it wet is a potential home for a snapper. Many juvenile and even medium sized individuals were found in rocky rills or ditches containing hardly enough water to wet their feet and plastrons. Others were completely buried in hard, caked mud in dry stream beds or ponds where they doubtless would have aestivated until the advent of rainy weather. The largest specimens, however, rarely were seen far from rivers, lakes, or other sizable bodies of water which had at least a fair degree of permanence.

A favorite habit of the snapper is to bury itself in mud in shallow water, covering all of its body save its eyes and nostrils. The depth of the water overlying the mud is often comparable with the length of the neck, for this member must be thrust upward occasionally so that the nostrils may have access to the air.

A trained collector often can find a snapper buried in such a way, merely by seeing the tip of its nose and its eyes, or by watching for the slight swirl of mud which appears in the water when it withdraws its head. Turtles resting in such places apparently lie in wait to seize any prey which may pass.

Other favorite hiding places are beneath stumps, roots or other objects which overhang the shore. Professional turtle collectors investigate such places with their bare hands, with a "sang froid" which startles the novice. Feeling for turtles with the hands or feet is popularly known as "noodeling" in many parts of Ohio.

The jaws of a snapping turtle are formidable weapons and are capable of doing considerable damage. In the younger specimens the mandibles are sharp and close fitting and make a neat, clean-cut bite, but in old ones they are usually dull and frequently notched or uneven. Once the jaws close upon an object it is difficult to pry them apart, hence any but very small snappers must be handled with great caution. The neck can reach back so far that it is unwise to grasp a specimen by the shell; the best method of carrying one is 
to seize it by the tail and hold it away from one's body. The head strikes with surprising quickness and doubtless the turtle may at times catch prey which is moving at a fairly rapid speed.

Snappers usually are pugnacious when first handled and some always remain so, no matter how long they are kept in captivity. Juveniles and occasional adults become tame, however, and may be handled with little more than a fair amount of caution. When first caught, specimens exude a fluid from their musk glands which has an unpleasant odor.

When a snapper is walking on land the shell is held clear of the ground. When one is at bay and prepared to strike, the posterior portion is usually elevated considerably more than the anterior. In striking from such a position the head is darted forward, the jaws close with a snap, the plastron thuds against the ground and the whole body may slide forward from the impetus of the blow.

Snappers are fair climbers and occasionally they ascend several feet up the trunks of trees inclined at a considerable angle with the surface of the water. They are not particularly given to basking, but on warm days in early spring they sometimes were found sunning themselves upon stumps, logs, etc., near the edge of the water.

Specimens were collected in every month except February. The seasonal distribution was found to be fairly even during the summer months; the peak of abundance, as indicated by the records, was in May. Snappers successfully hibernated in an outdoor pool at the Toledo Zoo; in each of many cases the site they selected was in water beneath a mass of leaves. Some individuals were completely submerged while others had the greater portion of their bodies above the surface of the water. Several were seen swimming slowly about under the ice in late fall.

Snapping turtles are largely carnivorous. They were observed eating insects, snails, slugs, crayfish, fish, frogs, salamanders, snakes, birds and mammals. That they occasionally take vegetable food is shown by the fact that captives ate lettuce and the core of an apple which fell into their tank. It is quite probable that a considerable portion of their food consists of carrion. They often were abundant in rivers polluted with garbage and other organic sewage.

Small prey is drawn into the mouth with a sudden gulp, as though it were sucked into a vacuum cleaner. Large animals, such as aquatic birds or mammals are seized in the jaws and held beneath the surface until they drown. There they are reduced to swallowable portions by the claws which tear off pieces as the animal is held. Captives live well on a diet of meat and fish, but they seem unable to swallow unless their heads are submerged in water.

Snappers are a distinct liability on muskrat farms, fish hatcheries, etc., where their voracious appetites are apt to make serious inroads upon the stock. It practically is impossible to exterminate them in marshes or other extensive 
bodies of water and if their destruction is desired in such places the usual procedure is to hunt and trap them continuously throughout the warmer weather. They are a valuable by-product of muskrat farms and the quantity caught and sold from some marshes is remarkably high. The snapper is an esteemed article of food and as such is of considerable economic importance.

Captive snapping turtles were seen mating under water a number of times. When in coitu the plastrons of both male and female were in parallel planes, with the plastron of the male pressed tightly against the carapace of the female. The male grasped his mate by hooking the claws of all four feet under the edge of her carapace and his tail was curled under hers in such a manner that his anal opening was turned upward to meet hers. He also pressed upon her snout with his chin so that it was necessary for her to keep her head withdrawn. In every case the actions and attitudes were very much the same. Sometimes in struggling, both sexes were seen to bite ineffectually at each other's forelegs. Males occasionally grasped males and one was observed to seize another male rear end foremost. The dates of mating records of these captive specimens include all the months from April to October and no season of particular activity was noted.

Snappers deposit their eggs in holes which they dig in sand, soil or vegetable debris. The excavation is funnel-shaped with the narrow part at the surface. Its depth and width depend upon the length of the hind legs which apparently are used exclusively in the digging process. Dirt is brought to the top by the sole of the foot, which is turned upward and rotated to the side to drop its load after it reaches the surface.

The eggs are deposited one at a time. After all are laid the hole is filled with the excavated dirt, and the excess of the latter is scattered about over the adjacent area so it often is difficult to determine the exact location of the eggs. The eggs are spherical in shape and are white, with one hemisphere pinkish. The shell is tough but rather brittle, and in appearance and bouncing qualities the eggs are quite similar to ping-pong balls. Captive snappers were observed digging and laying on June 29, 1932, and on June 15, 1934. Their eggs were about $11 / 8$ inches in diameter. Cahn $(1937,43)$ states that "from 20 to 30 eggs constitute a normal clutch" and that "the eggs measure about $33 \mathrm{~mm}$. on an average."

The young of two snapping turtles hatched the afternoon of September 27,1931 , in the private turtle yard of M. K. Murphy, of Toledo, Ohio. They totalled 41 in number but it was impossible to tell how many were in each group; all were almost exactly the same size except for one runty specimen. Their measurements averaged $1 \mathrm{~T} / 4$ inches in shell length and $1 \mathrm{~T} / 8$ inches in width. The nests from which they emerged were examined carefully and one was measured. The neck of the excavation was $11 / 2$ inches in diameter and $11 / 2$ inches in depth and the chamber below measured 6 inches in diameter and 5 inches in depth. The shells and four unhatched eggs were lying on the bottom as was also the dirt which fell in as the young climbed out. 


\section{Clemmys guttata (Schneider)}

Spotted Turtle

Description.-A small turtle. Largest adult Ohio specimen ( $\circ$ ), had a carapace 5 inches in length; smallest recently hatched juvenile, $11 / 8$ inches. Carapace rigid and covered with horny plates. Shell oval, relatively flat, widest somewhat posterior to the middle and with an outward flare in the region of the hind legs. No vertebral keel except for a slight one in the very young. Scutes smooth or with numerous subconcentric rings rising slightly one above the other, the latter condition especially evident in young adults. The highest part of the shell from $44 \%$ to $59 \%$ (males average $48.8 \%$, females $54.7 \%$ ) of the length back from the anterior edge of the carapace. Nuchal narrow, marginals 25, costals and vertebrals normal.

Plastron large and immovably attached to the carapace. Head moderately small; upper jaw notched. Tail moderate, longer in males than in females.

Carapace black or brownish black; each scute with one to several bright yellow or orange yellow circular spots, varying in the aggregate, in Ohio speci-

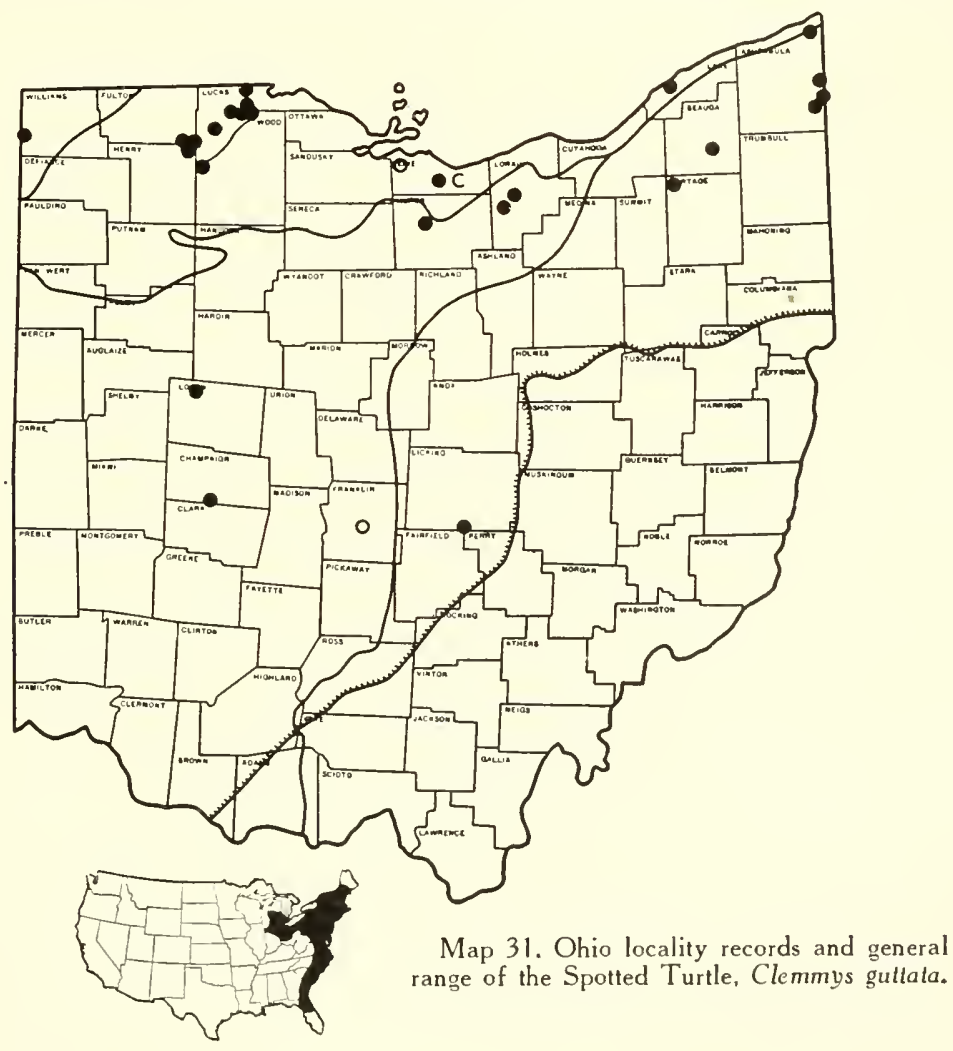


mens, from 14 to 114. Plastron black and yellow. In the only two very young specimens available from the state, the black covers the central $2 / 3$ of the plastron; in adults the black more or less surrounds a central yellowish area which may be so reduced as to produce an almost entirely black plastron. Head and neck black above and marked with a few small yellow or orange spots; a prominent blotch of orange or yellow somewhat behind and above the tympanum. Throat marbled with black and yellow.

Skin smooth or with small scales, the latter largest on the limbs. Dorsal surfaces of legs blackish with or without yellow spots; ventral surfaces yellowish.

Specimens examined, 191; specimens preserved, 53; specimens studied, 17.

Range.-Maine to northern Florida and west in the north to southern Michigan.

The spotted turtle has been found in many parts of glaciated Ohio, particularly in the more northern counties (Map 31). It has not been taken in the unglaciated part of the state, and the general absence of ponds and bogs in this area would indicate it will be found there, if at all, in only a few localities. Records for the state are as follows:

Ashtabula County: Andover (TZS 2385); Farnham (OSM 333); Pymatuning Swamp, near Andover (CSNH 1504; TZS 889-91, 1042, 1801); 3 mi. NE of Richmond Center (TZS 1800, 2236). Champaign County: Cedar Swamp, $5 \mathrm{mi}$. SSW of Urbana (OSM 131, 134, 180, 235, 237.2, 278, 331; TZS 358-9, 2228-33). Erie County: (UMMZ 41954-5); Castalia (Morse, 1904). Franklin County: Columbus (Morse, 1904). Fulton Countr: 2 mi. N of Colton; near Neapolis (OSM 242.1). Geauga County: Burton Twp. (OSM 455). Henry County: NE corner of Washington Twp. (TZS 1899). HUron CounTY: Peru Twp. (TZS 1802). Lake County: W end of Mentor Marsh, Mentor Twp. (TZS 541). Licking County: Buckeye Lake (OSM 130.1-.2, 132-3, 135, 136.1-.2, 171, 332). LogaN CountY: Pony Island, Indian Lake (TZS 255). LoRain CounTY: Camden Lake, $\mathrm{S}$ of Kipton (OC); Oberlin (OC). Lucas County: Adams Twp; $3 \mathrm{mi}$. W of Monclova (TZS 2157); Oak Openings, Holland (TZS 7); Oak Openings (OSM 201.2-3; TZS 228); Oak Openings, Springfield Twp.; West Toledo (CSNH 1503; TZS 1168); Washington Twp. Portage Counry: Solon Bog, Aurora Pond, Aurora Twp. (CMNH). Williams County: Tamarack Ditch, Section 31, Florence Twp. (TZS 958). Wood County: Grand Rapids.

Habitat and Habits.-Spotted turtles show a marked preference for shallow water. They were found in roadside ditches, small streams, bogs, tamarack swamps, wet meadows, and along the edges of small ponds and lakes, but were not seen in rivers or other sizable bodies of water. Nearly all those collected were in clear water, but whether they exhibited a dislike for turbid areas, or whether they were overlooked by the collectors in such places was not determined. On warm sunny days they frequently were seen resting or slowly walking about on the bottom in clear shallow water.

In early spring they often bask in the sun along the banks or upon such objects as logs or stumps protruding from the water. When alarmed they fall or walk in at once and swim to the bottom where they either remain motionless, burrow into the mud or crawl beneath sheltering objects. They are not particularly wary and the seasoned collector seldom has difficulty in capturing nearly all he may see. 
In a few favorable localities spotted turtles were found to be very common and as many as 28 were taken in the course of a few hours' search. Such well populated localities included the environs of the former Pymatuning Swamp near Andover, Ashtabula County, certain parts of the Oak Openings in Lucas, Henry and Fulton Counties, the arbor-vitae swamp south of Urbana in Champaign County, and the immediate vicinity of Buckeye Lake in Licking, Fairfield and Perry Counties. In several localities, which looked to one like excellent habitats for spotted turtles, repeated search failed to yield any specimens.

The seasonal distribution was found to be of more than usual interest. At least one specimen was taken in every month from February to November inclusive, but the great majority was obtained in the spring. Thus, of the 182 spotted turtles with collecting dates, 23 or $12 \%$ were found in March, 51 or $28 \%$ in April, and 90 or $49 \%$ in May. In no other month were more than 3 taken except in June when 6 were obtained.

Several factors doubtless contribute to this scarcity of specimens in summer. Ainong these are the lessened activity of the collectors during the warmer months of the year, the greater density of the vegetation, which more effectually conceals the turtles, and the possibility that certain habitats may become dry in midsummer and cause the turtles to aestivate. It also may be possible that they retire to deeper water in hot weather or remain in hiding during the day, or that, as Holbrook (1842, I, 83) says, they wander about on land in search of food. Whatever the factors may be, however, spotted turtles were sought in vain during the summer in localities where they were found abundantly in spring.

Spotted turtles were found in association with painted, snapping, Blanding's, box and musk turtles. They rarely attempted to bite when handled but drew in their heads and legs and hissed.

Specimens of this species are omnivorous. In the field they were observed to feed upon frogs, earthworms, grubs and the grass growing in a flooded meadow. Captives lived well on a diet of meat, fish and a small amount of lettuce, and in addition they were seen to devour snails, crayfish, carrot tops and spinach. They prefer to eat under water and usually take their food into this element before attempting to tear it into swallowable portions with the feet and jaws. However, at least two individuals were observed to seize meat and swallow it while resting at some distance from water.

Very little has been recorded on the breeding habits of this turtle. According to Babcock $(1919,398)$ the laying season (in New England) is from the 10 th to the 25th of June. Eggs of this turtle which he buried in the sand on June 16 hatched eighty-two days later on September 6. Babcock (loc. cit.) writes,

Two or three (rarely four) white, elliptical eggs (averaging $30 \times 17 \mathrm{~mm}$.) are deposited, the time of laying being in the late afternoon or evening. Copulation takes place in the water, the male grasping the female so tightly that it is possible to raise them both by lifting the former.

Two small recently hatched juveniles were collected in the field in Ohio. 
One of these was taken October 2, 1932, near Crissey, Lucas County, in a wet place, in an otherwise dry ditch, where the specimen was sunning in water about $\mathrm{I} / 4$ inch in depth. Its navel was soft and protruding; the carapace measured $11 / 8$ inches in length by 1 inch in width; the plastron $29 / 32$ inch in length and the depth of the shell $15 / 32$ inch. Another juvenile was found sunning itself on a steep bank about six inches above the water in a ditch in Washington Twp., Henry County, March 16, 1935. Its navel was healed but the scar was prominent and it is possible it may have hibernated in the nest and emerged in the spring. Its carapace measured $13 / 16$ inches by $1 \frac{1 / 16}{\text { inches }}$ and its depth was $7 / 16$ inch.

\section{Emys blandingii (Holbrook)}

\section{Blanding's Turtle}

Description.-Blanding's turtle attains a carapace length of 10 inches or more. Largest adult Ohio specimen ( $q$ ), had a shell $815 / 16$ inches in length; smallest newly hatched juvenile, $11 / 4$ inches. Carapace rigid and covered with horny plates; subovoid and flat above in adults; juveniles with a middorsal keel. Highest part of shell, in adults, from $45.7 \%$ to $58 \%$ of the distance back from the anterior margin; in juveniles as low as 30\%. A slight outward flare of the shell in the region of the legs. Scutes smooth or with subconcentric rings rising slightly one above the other, the latter condition most evident in young adults. Scutes somewhat imbricate in young. Nuchal narrow, marginals 25 , costals and vertebrals normal.

Plastron large and almost completely covering the soft parts. A transverse hinge between the pectoral and abdominal scutes, well developed in adults but lacking in the smallest specimens. Head large and flat above, upper jaw notched. Tail moderate, longer in males than in females. Skin covered with small scales, the latter largest on the limbs.

Ground color of carapace black, brownish black or grey and usually heavily marked with spots or streaks of yellow or pale olive. These markings numerous and averaging several dozen on each of the larger dorsal scutes. Plastron yellow with a blackish blotch on the postero-lateral portion of each scute. Top of head similar in color to carapace and more or less spotted with yellow or olivaceous dots. Chin and throat uniformly bright yellow.

Juveniles differ from adults in color and pattern. Newly hatched ones are uniform grey or grey brown with very little or no indication of the future spotting. The plastron is uniformly blackish except for a narrow edging of yellow. As specimens grow older and the areas originally occupied by the dorsal scutes are separated from each other by the new growth, light streaks appear in the new tissue and these eventually break up into the markings of the adult. Similarly the new growth of the plastron contains considerable yellow and the black eventually becomes confined to the postero-lateral part of each scute.

Specimens examined, 105; specimens prcscrved, 28; specimens studied, 16. Range.-Central Nebraska and Minnesota, east to southern Ontario and 
the south shore of Lake Erie as far east as Pennsylvania; New England and Long Island.

In Ohio, Blanding's turtle has been found in the counties bordering Lake Erie and those lying along and north of the Maumee River (Map 32). It is thus restricted to the lake plains, and to the till plains of the extreme northwest corner of the state. It is abundant in the Lake Erie marshes and especially in those which lie between Toledo and Sandusky. East of Sandusky, as the marshes become fewer and less extensive, and rocky cliffs line the shore, it is decidedly less common, except in such areas as the Mentor Marsh in Lake County. In the northwestern counties it is widely distributed.

In view of the large amount of collecting which was done throughout the state and the fact that no individuals were seen except in the area mentioned above, it appears probable that the record for Westerville, Franklin County, (OSM 189) is incorrect, or based upon an escaped specimen. Morse's record (1904) for Columbus is also open to the same doubt. Ohio locality records which appear to be authentic are:

Ashtabula County: Geneva (OSM 421.1-.2). Defiance County: Ladd Lake,

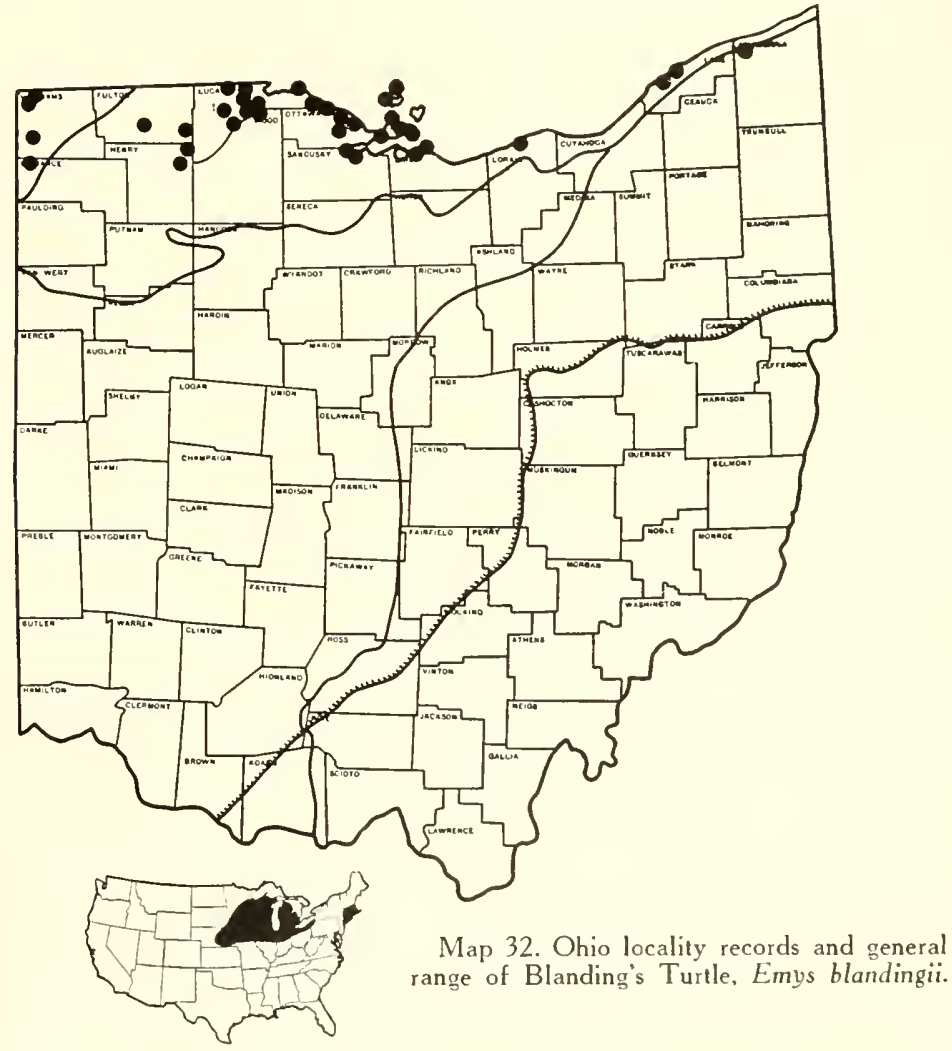


Milford Twp. (TZS 372, 1275). ERIE County: Cedar Point (OSM 150); Sandusky (Morse, 1904; UMMZ 31708, 32742, 40938); Venice (Babcock, 1919). Fulton County: Clinton Twp., W. of Wauseon (OSM 268); West Fork, Swan Creek, Swan Creek Twp. (TZS 518). Henry CountY: Bad Creek, Texas (TZS 363); NE corner Washington Twp. LAKE CounTY: Black Run Swamp. W. of Fairport (OSM 420.1); W. end of Mentor Marsh, Mentor Twp. (TZS 542). Lorain County: Lorain (OC). Lucas County: (OSM 201.8-.10); Bono (TZS 1094); Crane Creek on Ottawa Co. boundary; Holland; Little Cedar Point, Jerusalem Twp.; Maumee; Sylvania; Toledo (CSNH 1505; TZS 1903, 2046); Maumee River, Toledo; Swan Creek, Toledo; W. Toledo; Trilby. Otrawa County: Bay Point (OSM 328); 4 mi. E of Bono (TZS 312); Camp Perry; Catawba Island; Green Island (TZS 465); Middle Bass Island (SL); Oak Harbor; $1 \mathrm{mi}$. $\mathrm{E}$ of Pt. Clinton (DOR); Sandy Beach, Danbury Twp. (OSM 139); Toussaint Creek, Carroll Twp. SANDUSKY County: Mouth of Sandusky River (DOR); Muddy Creek, $6 \mathrm{mi}$. SW of Port Clinton. WILliams CounTY: 1 mi. S of Blakesley (TZS 364); Mud Lake, Northwest Twp.; Nettle Lake, Northwest Twp. Wood CountY: Maumee River, opposite Toledo.

Habitat and Habits.-Almost all the Blanding's turtles collected in Ohio were found in shallow water where, most often, they were discovered walking about on the bottom or swimming at the surface. When engaged in the latter activity their bright yellow throats stood out so vividly it sometimes was possible to identify them at a considerable distance. Occasionally they were found buried in mud, either beneath the water or in mud flats near a stream or pond.

In keeping with their preference for shallow water, Blanding's turtles seldom were seen anywhere except in such places as ditches, bogs, swamps, the marshy environs of lakes and the extensive marshes at the western end of Lake Erie. At least three, however, were collected on rocky islands in Lake Erie. Occasional individuals were seen prowling about on land but it was unusual for one to be more than a hundred yards from the nearest body of water.

Captives kept in fairly deep tanks did not thrive, even though there were ample places upon which they could climb to rest. In contrast, individuals lived for years in a shallow outdoor pool provided with gently sloping sides all around its perimeter.

Specimens are fond of sunning themselves, especially in spring. They were observed resting on muskrat houses, on the steep banks of the many dikes and ditches which traverse the lake marshes and also upon the stumps, logs and driftwood scattered about in the water. When disturbed they dove into the water at once and made their way to the bottom where they burrowed into the mud, hid under any shelter or swam rapidly away.

When seized they withdrew into their shells, hissed sharply and closed the movable lobes of the plastron as tightly as possible. They sometimes remained in this position for a considerable length of time. Usually no amount of teasing would induce them to bite; they made excellent pets and if supplied with plenty of food and the right environment they lived well in captivity.

Specimens were collected at the same time and in approximately the same 
places as all the other species of turtles known to occur in northern Ohio. At least one was taken in each month from January to October inclusive and the seasonal peak of abundance was found to be in May. A few were seen swimming under the ice several times in the late fall in a pool at the Toledo Zoo and numbers successfully hibernated in the same pool. Most selected places beneath masses of soggy leaves where they were either partially or completely submerged, but two of them spent the winter under wet leaves several feet from the water.

Blanding's turtles are omnivorous but the larger portion of their food is apparently of an animal nature. They were seen eating snails, crayfish, earthworms and fish and such items of carrion as dead fish and dead turtles. In captivity they took all of the above plus lettuce, meat and chopped fish. Their feeding habits and their small size, when compared to snappers, are such that they probably do very little damage on the many muskrat farms located within their range. Instead they furnish an additional source of revenue, in that large numbers are caught and sent to market.

Pairs were observed mating in captivity a number of times. In almost every detail, including the positions assumed, the use of the head and legs and the use of the tail, the matings were very similar to those of the snapping turtle as described under that species. Coupled pairs were always in the water but when lifted out they remained in coitu for some time unless they were treated roughly. The male organ was then withdrawn and they quickly separated. Males were actively pursuing females about the pool on a number of occasions. Although two or three matings were recorded during the summer, the majority were in March, April and early May.

Practically nothing is known about the nesting and egg-laying habits of Emys blandingii. However, Cahn $(1937,82)$ states,

The eggs number from 6 to 10 , though the ovaries of a large female will be found to contain hundreds of eggs of various sizes, these, of course, being the supply for future years. The eggs when laid are covered by a tough, white unglazed shell. The average size of eight eggs which composed the complement removed from the oviduct of a large female just about to lay is $36.6 \mathrm{~mm}$. by $25.2 \mathrm{~mm}$. The largest egg was $38 \mathrm{~mm}$. by $26 \mathrm{~mm}$.

A newly hatched juvenile, in which a fragment of the cord was still attached to the navel, was found September 3, 1930, on Green Island, Ottawa County, in Lake Erie. This specimen was making its way toward the water down a steep declivity between two masses of rock at one of the very few points on the cliff-rimmed shore up which its mother could have climbed to lay her eggs. Careful search in the vicinity failed to reveal the nest from which the young one emerged. Measurements of this specimen were: carapace length $11 / 4$ inches, carapace width $15 / 32$, plastron length $11 / 8$ inch, depth $17 / 32$ inch.

Another very small specimen was discovered floating near the shore in Ladd Lake, Milford Township, Defiance County, on May 16, 1931. It measured $17 / 16$ inch in carapace length and its navel appeared to be entirely healed. 


\section{Terrapene carolina (Linné)}

\section{Box Turtle; Dry-Land Turtle}

Description.-A small turtle attaining a carapace length of about 6 inches. Largest adult Ohio specimen ( $\hat{\sigma}$ ), had a shell $6 \mathrm{r} / 2$ inches in length; smallest newly hatched juvenile, $11 / 16$ inches. Carapace rigid and covered with horny plates; subovate, high and dome-like. Usually a decided outward flare (especially posteriorly) in the region of the legs. Highest part of carapace from $43 \%$ to $57 \%$ of the distance back from the anterior edge. Nuchal small or absent, other scutes normal. Juveniles with a median dorsal keel, traces of which usually may be seen even in the largest adults. Plastron large, completely filling the opening of the carapace and with a transverse hinge between the pectoral and abdominal scutes.

Head moderate, snout not protruding. Tip of upper mandible projected downward into a beak; lower mandible turned up in front. Tail short. Skin smooth or covered with scales, the latter largest on the limbs. Hind legs with 4 claws ( 3 in one specimen from Lucas County). Claws of hind limbs especially stout in adult males.

The color is brown and yellow both above and below and with either predominating. A wide variety of patterns is exhibited, streaks and convolutions being most numerous. Usually the same or similar arrangements of the markings are seen on each of the large plates of the carapace. The plastron is clouded or marbled with brown and yellow and often is without any definite pattern; occasional specimens may have the plastron nearly uniformly dark brown or black. The head is patterned with almost any combination of yellow, brown or olive. Males usually have red eyes. The skin is brown or yellow and the scales on the legs are of a somewhat different shade than the surrounding skin.

Four young box turtles which hatched in captivity September 29, 1934. and which were judged to exhibit a more or less typical juvenile appearance, may be described as follows: Carapace dark brown with a yellow spot in the center of each scute except the marginals. The spot, in each of the vertebrals, situated in the center of a strongly rounded prominence; these prominences collectively composing the keel. Entire carapace finely peppered with small protuberances which feel sandy to the touch. Plastron yellow but with the central half (in area) brownish black and with extensions of this color running out along the sutures between the plastral plates. Legs brownish black with a longitudinal orange stripe situated in such a position as to be prominently in evidence when the legs are partially withdrawn into the shell. Head brownish black with two small orange spots on the temples and another on the cheeks. Shell soft and with no sign of the plastral hinge. Chin mottled with orange and blackish.

Total specimens examined, 191; specimens preserved, 63; specimens studied, 32 .

Range.-Maine to Georgia and west to southern Michigan, Illinois and Tennessee. 
When the Ohio locality records are plotted upon a map they are seen to fall into two groups. One of these is in northwestern Ohio where the box turtle is found in the sandy "Oak Openings," on beaches, etc. The other group is widespread in southern Ohio (Map 33).

It appears that this turtle does not occur naturally in northeastern Ohio. It is unknown to the residents of that part of the state.

The constant transportation by human agency of all kinds of turtles, and especially the species of Terrapene, is such that it is becoming more and more difficult to determine the original ranges. In the course of the present work it was the policy to discount all records in which there seemed to be any doubt as to the origin of the specimen. Locality records for Ohio are:

Adams County: Cedar Mills (TZS 724); Lynx Prairie, near Lynx; 21/2 mi E of West Union. Athens County: Carthage Twp. (TZS 438); Dover Twp. (TZS 500). Brown County: (CSNH 1460); 4 mi. NW of Aberdeen; 2 mi. $\mathrm{N}$ of Georgetown (TZS 1897); Russellville (TZS 2148). Butler County: Westchester (MU). Champaign County: Cedar Swamp, $5 \mathrm{mi}$. SSW of Urbana (OSM 237.1). Clemmont County: Near Clermontville, Monroe Twp. (CSNH 1079);

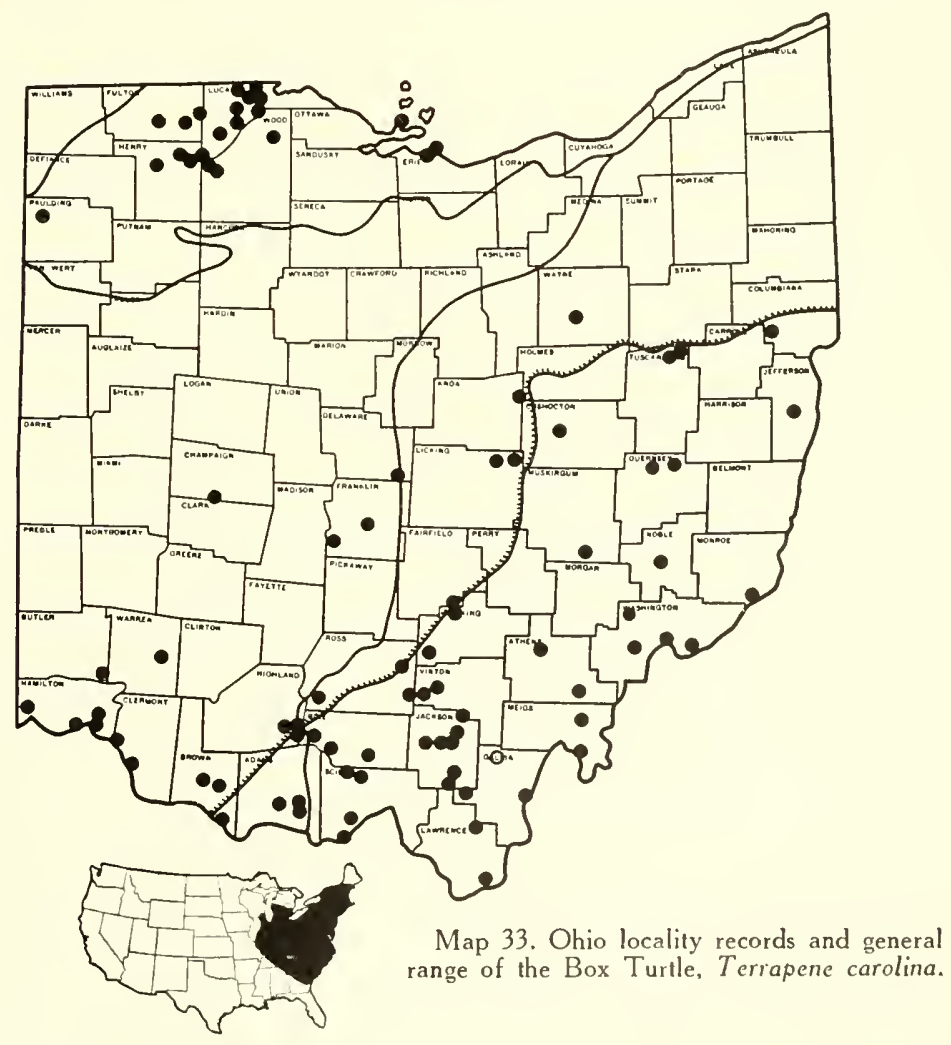


Along Ohio River, E of Hamilton Co. line (CSNH 1080). Columbiana County: Millport (CM 3208). Coshocton County: Warsaw (OSM 195.I). Delaware County: Harlem (OSM 334). ERIE County: (SHS; UMMZ 32869); Cedar Point (SHS); Sandusky (WRU). Fairfield County: Sugar Grove (OSM 280). FrankLiN County: Columbus (OSM 279); Georgesville (OSM 148). Fulton County: Delta (TZS 520); Swanton; Wauseon.

Gallia County: Blazer, Gallipolis; near Gallia; Gallipolis (OSM 266); Vinton (Morse, 1904). Guernsey County: North Salem (TZS 1265); Washington Twp. (OSM 264). Hamilton County: (Morse, 1904); Cincinnati (CSNH 359, 972); eastern part of Cincinnati (TZS 1962); Madisonville (CSNH 260); Whitewater Twp. Henry County: $N$ of Grand Rapids, along Henry-Lucas Co. line; near Liberty Center; Napoleon; Texas (TZS 445); Washington Twp. Highland County: Stultz Hill, $5 \mathrm{mi}$. S of Carmel (TZS 576); $4 \mathrm{mi}$. SW of Carmel; N side of Ft. Hill, Brush Creek Twp. (TZS 577). Hocking CountY: Clear Creek, Good Hope Twp. (OSM 137, 140; TZS 499); Salt Creek Twp. (TZS 1009). JACKson CountY: Jackson (OSM 276); Buckeye Creek, 4 mi. W of Jackson; 2 mi. E of Jackson; 2 mi. N of Oak Hill (DOR); Roads; Samsonville (DOR); White's Gorge, Liberty Twp. (TZS 352). JefFerson County: 8 mi. W of Steubenville (OSM 257). Knox County: Brinkhaven. Lawrence County: Near Arabia (TZS 431); Union Twp. (OSM 217.3). Licking County: Rocky Fork, Eden Twp. (OSM 225); Wakatomika Creek, Fallsburg (OSM 418.2). Lucas County: (OSM 201.1); Monclova; Oak Openings, Holland; Ottawa Hills; Sylvania; Delaware Creek, Toledo; $6 \mathrm{mi}$. W of Toledo; Trilby; I mi. N of Whitehouse. Meigs County: $3 \mathrm{mi}$. N of Chester (TZS 437); Sutton Twp. (TZS 436). Monroe County: Jackson Twp. (TZS 502). Muskingum County: Blue Rock Twp. (TZS 2387). Noble County: $3 \mathrm{mi}$. E of Caldwell. Ottawa County: Catawba Island (TZS 811). Paulding County: Antwerp (OEE). Pike County: Laurel Ridge, Sunfish Twp. (TZS 1085); Mifflin Twp. (TZS 646); 2 mi. N of Wakefield. Ross County: Big Round Top, Paint Twp.; Rattlesnake Knob, Harrison Twp. (TZS 353); Salt Creek, near Londonderry. Scioto CounTY: Near Bear Creek, Morgan Twp.; I mi. NW of Friendship (TZS 723); $21 / 2 \mathrm{mi}$. W of Friendship; $10 \mathrm{mi}$. SW of Portsmouth; near Sedan (TZS 1084). TUSCarawas County: Sandyville (CMNH); Zoar (TZS 2386). Vinton CounTY: I mi. W of Allensville (TZS 354); Harrison Twp.; Lake Alma, near Hamden. Warren CounTY: Ft. Ancient (OSM 457). Washington County: $2 \mathrm{mi}$. E of Barlow (TZS 501); Beverly; Marietta (MC); Newport Twp. (TZS 489). Wayne CountY: Wooster (WC). WoOd County: 31/2 mi. SE of Grand Rapids (TZS 1045); near Grand Rapids; Stony Ridge.

Habitat and Habits.-Box turtles are more habitually terrestrial than any other species of turtle in Ohio. They occur in a variety of habitats, however, and were found in such diverse places as dry sandy areas, on dry hillsides, in moist ravines, in thickets and woods, in cultivated fields and meadows and in bogs. Their terrestrial habits, which have earned for them the popular name of dry-land turtles, do not necessarily infer they are able to exist for indefinite periods without water or that they can disdain it entirely, as is frequently supposed. They can, and do, wander long distances from the nearest bodies of water, but in contrast, they may lie in mud or wet vegetation at the edge of a stream or pond for a week at a time. They even swim at times but their movements in water are clumsy and awkward.

In spring they are often found traveling about, but in hot dry weather they usually remain hidden beneath rotting logs, in masses of decaying leaves, etc. They sometimes stay secluded for many days at a time or they may venture out only during the early morning or at twilight. They appear to enjoy warm rains, and a sudden shower after a dry spell often causes them to 
leave their shelters. Several times collectors wandered through dry woods without seeing any reptiles, but during and after showers box turtles were much in evidence in the same woods. During several spring and summer trips to southern Ohio literally dozens of box turtles were seen on the roads during and after heavy rains. Experiments conducted in captivity on hot days showed that specimens almost always left their burrows when their enclosure was sprinkled with a hose.

Box turtles are deliberate in their movements. Their gait is slow and steady but they are capable of traveling considerable distances in a day. When thoroughly alarmed, however, occasional individuals will run off with a great scurrying. Despite their clumsy appearance they are fair climbers and they sometimes are found on hillsides so steep as to afford a very insecure footing for the collector.

When it is first approached in the field the usual procedure is for a specimen to emit a sharp hiss and to withdraw the head, tail and limbs into the shell. If it is touched the appendages are still further withdrawn and the movable lobes of the plastron are pressed firmly against the carapace. In some specimens the closure is so perfect it is impossible to insert such a small object as a broom straw between the shells. Very fat specimens are unable to retire completely within their bony armor and when the head and forelimbs are withdrawn the hind legs and tail protrude or vice versa. That this closing of the shell serves as a protection is indicated by the fact that several were found in which the shell, and particularly the flared portion at the edges of the carapace had been gnawed, possibly by such animals as dogs or raccoons.

Individuals were collected from April to October, inclusive, but there was a seasonal peak of abundance in May and June. One, preserved in the collection at Sandusky High School, was taken on New Year's Day, 1905, on Cedar Point in Erie County. Large numbers of specimens successfully hibernated at the Toledo Zoological Park. The enclosure in which they were kept was filled to a depth of a foot or more with leaves in the fall of the year. Into this mass the turtles burrowed and after the leaves had settled it was often possible to see the ends of the tunnels which they made in it. On warm days in fall, even until the first of December, occasional turtles were to be seen basking, but as the sun went down or the temperature dropped they retired from sight. The leaves were always moist and in every case, except one, the box turtles hibernated in or beneath them on the soil. The single exception was a large adult female which wintered in the water at the edge of a pond in precisely the same sort of situation selected by the more aquatic snappers, spotted, painted and Blanding's turtles. In the spring none of the hibernating box turtles came out until late March or early April.

Box turtles are omnivorous. They were observed to eat earthworms, grubs, crayfish, fish, frogs, salamanders, meat, lettuce, spinach, cabbage, blackberries, blueberries, bananas, tomatoes, several species of fungi, etc., and carrion, such as dead birds or amphibians. On one occasion two specimens were seen eating the contents of a duck egg which fell into their enclosure. Captives soon 
learn to expect food and will travel at a rapid pace toward the hand which proffers it to them. They often fight over the same morsel and engage in lengthy tug-of-wars over a stringy piece of meat, etc.

The mating of box turtles was observed on several occasions and was found to agree in practically every detail with that described by Cahn and Conder (1932). The male after a preliminary courtship, which appears to consist largely of pushing his shell against that of the female, inserts his legs between her carapace and plastron and hooks them about her legs. Once secured in this position he leans back upon the posterior edge of his carapace until his plastron is pointing upward at an obtuse angle with the ground. His tail is turned at such an angle that his anal opening is in contact with that of the female and the penis can be inserted readily. In all the cases seen, the male fell upon its back when the two sexes separated, but this may have been due to an effort to escape when the observer approached.

Three specimens were observed nesting the evening of June 15, 1934. Two began digging at twilight, the third about an hour after dark. In each case the procedure was much the same. The work was done entirely by the hind legs which excavated a funnel-shaped hole with a narrow neck at the surface of the ground and a wide portion below. It appeared that the depth, and diameter of the hole at its base, depended entirely upon the length of the hind legs and that the turtle continued to dig until it had reached its limit. Dirt was brought to the surface by the end of the stump-like foot which was rotated so that it pointed more or less upward as it was elevated. The dirt was deposited to the side after it reached the surface.

After the holes were completed the turtles rested for a few minutes and then emptied a surprisingly large quantity of water from their bladders into the excavation. Laying began a few minutes later. Eggs were deposited singly and fell to the bottom of the hole where the first one landed with a dull thud and subsequent ones struck the previously laid ones with a distinctly audible sound. The eggs, which were white and ellipsoidal, were deposited at from two to eleven minute intervals. After the last egg had been laid the turtle rested again for a few minutes. Then the loose dirt was shoved into the hole by the hind legs until it was filled. The shell was dragged back and forth over the nest and the immediate vicinity with such good effect that it was necessary to mark the location at once for fear of not being able to find it again. After a time the turtle left the spot and did not return. The first two specimens started to nest before they were discovered but they were watched for well over two hours. The third specimen required over four hours to complete her task from start to finish.

On September 29, 1934, four young emerged from one of the nests. They were on the surface of the ground when discovered during the afternoon and the shells and limbs of all were encrusted with dirt. Each bore an egg tooth which was situated midway between the nostrils and the beak, and which appeared as a small white cone-shaped object directed forward and of about the same shape and size as the small down-turned beak. The egg tooth of 3 disappeared the second day after hatching, but the other one's persisted for 
nearly a week. The navels of all were soft and a portion of the cord was attached. Average measurements at hatching were: carapace length 11/4 in., carapace width $13 / 32$ in., plastron length $15 / 32$ in., depth $5 / 8$ in.

The eggs in the other nests failed to hatch and on June 24, 1935, they were removed for examination. In each case the eggs still retained their normal shape but each had a hole in its shell and the interior was decayed and partially filled with earth. In two the skulls and other bones of well-developed embryos were found. One nest contained 4 eggs and the other 7 . In each case, including the nest from which the four young emerged, the bottom of the nest was nearly three inches below the surface of the ground.

Allard (1935) gives the number of eggs laid in a single nest as from 2 to 7 , average 4.2. The largest eggs he measured were $37 \times 22 ; 38 \times 22$ and $36 \times 21 \mathrm{~mm}$. and the smallest (laid with four larger ones) measured $16 \times 13$ $\mathrm{mm}$. His observations on 60 clutches of eggs showed the earliest date of laying to be June 4 (1933) and the latest July 13 (1932). The incubation period under natural conditions varied from 69 to 105 days.

Box turtles attain a considerable age. A large specimen collected by $\mathrm{M}$. K. Murphy, of Toledo, in Indiana in 1907, lived in captivity until the spring of 1931 and during this period it did not appear to grow in size. There are other records in which turtles were marked and then were recovered a number of years later. Finds of turtles with ancient dates upon their shells are frequently reported in the newspapers but it would appear well to discount all such unless the specimens can be accurately identified. The writer recalls having caught a turtle when he was a boy upon which he carved his initials and the date 1492 !

\section{Graptemys geographica (Le Sueur)}

\section{MAP TURTLE}

Description.-A medium to large turtle attaining a carapace length of ten inches or more. Adult females considerably larger than adult males. Largest Ohio female had a shell $81 / 4$ inches in length; largest male $43 / 8$ inches; smallest juvenile $13 / 8$ inches. Ditmars $(1936,408)$ records a female specimen from Sandusky $91 / 2$ inches in length. Carapace rigid and covered with horny plates; subovate, bluntly notched at the front and serrate at the rear margin. A distinct median keel, most evident and somewhat tuberculate in the young. Highest part of shell from $46.6 \%$ to $54.2 \%$ (males average $51.4 \%$; females $48.4 \%$ ) of the distance back from the anterior edge; juveniles average $38.7 \%$. Scutes smooth or with growth rings. Nuchal wedge-shaped and notched behind; other scutes normal. An outward flare may or may not be present in the region of the legs.

Plastron large and immovably fastened to the carapace. Plastron twice as long as wide, omitting the lateral portions of the pectorals and abdominals which are directed upward at an obtuse angle. Head large and swollen in adult females, considerably smaller in males. Tail short. Skin covered with small scales. Feet well webbed. 
Carapace olive or brownish green and patterned with numerous reticulating yellow lines which are most prominent in juveniles and nearly or quite obsolete in adults. Under surface of marginals yellowish with circular markings; bridge of plastron marbled with yellow and greenish grey. Plastron yellow, usually marked with grey along the sutures. Occasionally, and especially in juveniles, the ventral markings very bright and more or less expanded into whorls, curves, etc. Head greenish and streaked with numerous longitudinal yellow lines; a more or less triangular yellow blotch behind each eye. Soft parts greyish or greenish, streaked and mottled with yellow.

Juveniles similar to adults but with the markings more conspicuous.

Specimens examined, 94; specimens preserved, 59; specimens studied, 15.

Range.-Northeastern Texas and eastern Kansas to Iowa and southern Wisconsin, east to Lake Champlain, eastern Tennessee and southwestern Virginia.

In Ohio the map turtle is widely distributed (Map 34). It is common in the western half of the state but is distinctly less abundant in the eastern half. It appears to be more numerous in northeastern than in southeastern Ohio;

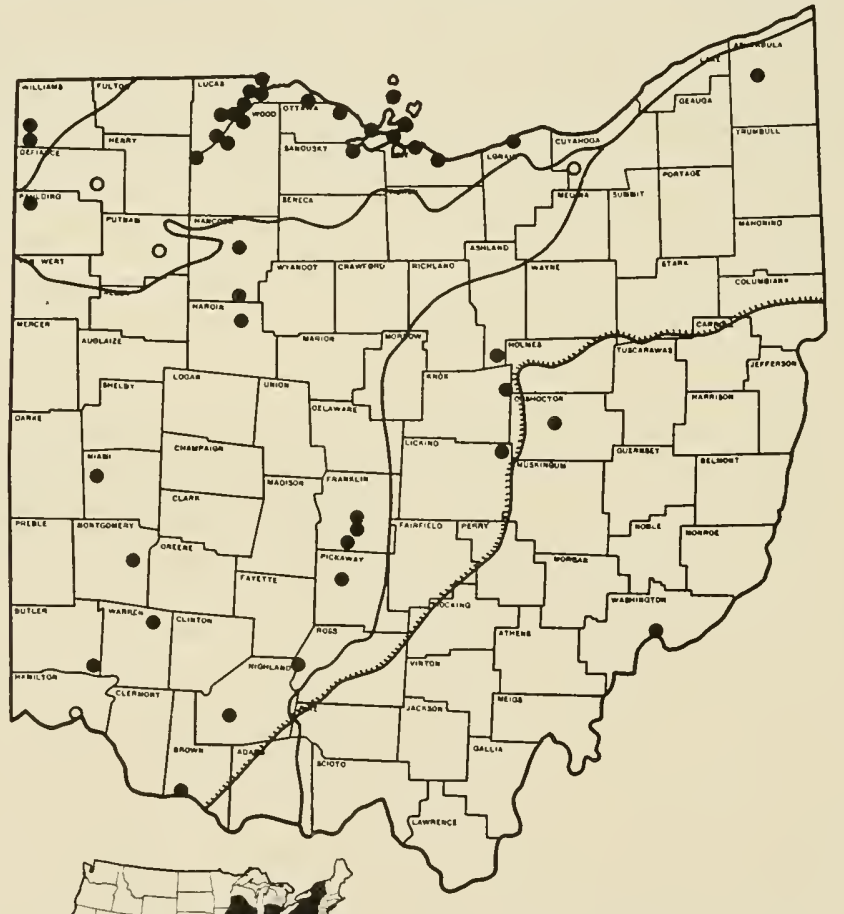

Map 34. Ohio locality records and general range of the Map Turtle, Graptemys geographica. 
there are only one or two records for each of these two areas but numbers were seen, although not collected, in the Grand River in Lake County. The only specimen seen in southeastern Ohio, besides the one recorded from Marietta, was in the abandoned Ohio and Erie Canal near Rushtown in Scioto County. Ohio locality records are:

Ashland County: Clear Fork State Park, Hanover Twp. (TZS 2286-7). Ashtabula County: Eagleville (CMNH). Brown County: Higginsport (OSM 402.1); White Oak Creek, I mi. N of Higginsport (TZS 1873). BUTLER CoUNTY: Westchester (TZS 362). Coshocton CoUnTY: Walhonding River (OSM 409). Cuyahoga County: Rockport, Berea (Morse, 1904). Defiance County: Defiance (Kirsch, 1895). Erie County: (UMMZ 32867); Huron (OC); Sandusky (Ditmars, 1907; OSM 146.1-2; UMMZ 40721; USNM 6719-22); Sandusky Bay (USNM 51187); Venice (Babcock, 1919). FrankLIN CoUnTY: (OSM 316; USNM 26040-1); Columbus (OSM 146.3); Jackson Twp. (OSM 236); Scioto River below Columbus (OSM 318). Hamilton Countr: Cincinnati (Morse, 1904); Ross Lake and Bloody Run (now Cincinnati) (McLain, 1899). Hancock CountY: Blanchard River, Findlay; Williamstown (TZS 2276). HardiN CounTY: Blanchard (USNM 21626). Highland CounTY: Pond near New Market (TZS 637). KNox CoUnTy: Brinkhaven (AS). Licking CounTY: Wakatomika Creek, Fallsburg (OSM 418.3). Lorain County: Lorain (OC). Lucas CountY: Bono; East Toledo; Maumee River, Maumee (TZS 430, 514); Miami and Erie Canal, Toledo (TZS 1969); Swan Creek, Monclova (TZS 1442); Pt. Place, Toledo (TZS 1944); Swan Creek, Toledo (OSM 199); Toledo (Smith, 1882; OSM 263.1); Maumee River, Waterville (TZS 1774). Miamı CountY: Greenville Creek, 11/2 mi. S of Covington (TZS 939). Montgomery CounTY: Stillwater Creek, Dayton (OSM 317). OTTAWA CoUNTY: Lakeside (USNM 51198); Port Clinton (TZS 306; USNM 51183); Put-in-Bay (USNM 21124); Terwilliger's Pond, Put-in-Bay (OSM 281; SL); Toussaint River. $10 \mathrm{mi}$. W of Port Clinton (USNM 21123). PAULding CounTY: Antwerp (Kirsch, 1895; OEE). Putnam County: Ottawa (Kirsch, 1895). Pickaway County: Big Darby Creek (OSM 319). Ross CounTY: Paint Creek, near Greenfield (CSNH 1868). SANDUSKY CoUNTY: Mouth of Sandusky River (USNM 51201). Warren County: Waynesville (CSNH 1507). Washington County: Marietta (USNM 7576). Williams CoUNTY: St. Joseph's River, near Blakesley (OSM 249; TZS 409); St. Joseph's River. Edgerton. Wood CounTY: Maumee River, Grand Rapids (USNM 21620); Maumee River near Perrysburg (OSM 200; USNM 51181); Maumee River, opposite Waterville (TZS 190).

Habitat and Habits.-The map turtle is one of the most difficult turtles to collect. It is extremely wary and is usually found in places where it is next to impossible to catch it. A favorite habitat is in the larger rivers. In these it appears to be equally at home in the deep parts as in the shallow, and when disturbed, it almost invariably heads to depths into which it is impossible for the collector to follow. It dives at the least alarm and swims under the water for a considerable distance and may or may not reappear upon the surface a few moments later. If it does come up, however, it is usually so far away as to be well out of reach of a landing net. It selects a basking place on a rock or log or other prominent situation in a stream from which it has a clear view of the surrounding territory. Almost any unusual noise or movement will send it scuttling into the water, and the slamming of an automobile door or the flight of a large bird overhead were observed to cause it to take alarm. It is nearly impossible to stalk large adults. Specimens often congregate in numbers and as many as ten were seen sunning upon a single log. If one dives into the water all the others within sight usually follow suit.

While the majority of map turtles collected in Ohio were found in the 
larger streams they were by no means confined to them. They are at home along the shores of Lake Erie and in such estuaries as the mouths of the rivers emptying into it and in Sandusky Bay. They occur in the large ditches in the extensive marshes along the lake, and along the shores of the Lake Erie islands. One was taken in a small pond on South Bass Island (Put-in-Bay). They are known to occur in lakes in Michigan and Indiana but none were found in Ohio lakes in the course of the present study.

Juveniles frequent shallower water than adults and consequently they were collected much more often. They were taken in patches of aquatic vegetation growing along rivers and also in the small temporary pools left by streams which overflowed their banks and then receded. One juvenile and one adult male were found buried in mud in shallow water.

Specimens were collected in every month from April to September inclusive. They were observed walking slowly about under the ice in a pool in the Toledo Zoo as late as the middle of December. Evermann and Clark (1920, 607 ) state that "the map turtle does not hibernate, but many, if not all of them keep walking about on the bottom of the lake (Maxinkuckee, Indiana) where they can be seen through the ice whenever it is clear. Throughout the winter of 1900-1901 they could be seen any day when the ice was not covered with snow." At least two specimens successfully hibernated in the Toledo Zoo pool in shallow water beneath soggy leaves.

Map turtles were several times taken in company with spiny soft-shelled turtles and they were also found commonly in the same bodies of water in which snappers and painted turtles were numerous.

The food includes crayfish, fish, aquatic insects, carrion and snails. The shells of the latter are crushed between the broad alveolar surfaces of the jaws. Captives were seen nibbling upon such greens as lettuce, spinach and beet tops on a few occasions and most of them readily accepted meat. They apparently are not averse to eating organic sewage and in certain of the larger rivers which are badly polluted with garbage, etc. they were found in abundance.

Newman $(1906,140-42)$ has reported in some detail upon the breeding habits of the map turtle. He writes:

Graptemys begins to lay very early in June, somewhat earlier than other species observed. The females are apt to wander some distance from the water for nesting, seeming to prefer soft, plowed soil or clear, dry sand away from the beaches. They wander about for hours in search of a suitable place for nesting. One specimen started five nests before she was satisfied with the condition of the soil. Two were rejected on account of the presence of stones and one because the sand caved in too readily. The other two appeared to me to be suitable in every way and I was unable to explain why she abandoned them.

If one expects to see the first stages of nest-making it behooves him to be astir before sunrise. Over half of the females found nesting were encountered before eight o'clock. They work slowly and seem to prefer the quiet hours of the day, probably because they are less likely to be disturbed.

Apart from the slowness and deliberateness of their movements, they work much after the fashion adopted by Aspidonectes (soft-shelled turtles), except that they never work the forefeet so as to secure a foothold.

The nests are of somewhat smaller dimensions and the flask-shaped expansion is more symmetrically placed, scarcely more bulged on one side than the other. Two 
layers of eggs are deposited in the flask-like expansion but the last two or three eggs are placed in the narrow neck, the uppermost egg being sometimes only about two inches from the surface.

It is difficult to frighten them away after they have once decided upon a nesting place. When surprised they stop work but soon resume it and continue it to the end, even while the observer is in plain view. The nest of Graptemys is a finished product, all traces of nest-making being obliterated. This is accomplished by dragging the smooth plastron back and forth across the small area that had been disturbed by nesting.

The eggs are ellipsoidal in shape, of a dull white color, and have a rather soft, easily indented shell. The number laid by one female at one time varies from eleven to fourteen.

The eggs hatch, as a rule, late in August or early in September, the young burrowing to the surface through the sand. When they emerge they are covered with sand that adheres for some time. Their instinct directs them unerringly toward the water and they frequently have to travel almost incredible distances before reaching the lake or tributary stream. On two occasions I have found recently hatched Graptemys, at a distance of about a quartes of a mile from the water, traveling steadily and in an approximately correct direction toward the lake. At the observed rate of progress they would reach the lake in about two days.

For some time I was greatly puzzled by the frequent discovery of newly hatched Graptemys during the months of May and June. Farmers in the vicinity frequently plowed up nests of eggs that were nearly ready to hatch.

These facts have been explained by the observation of occasional specimens nesting during the latter part of July. Eggs laid at that time would have only about five or six weeks of steadily warm weather, in which to develop, and would be retarded by the chilling of the ground in October. Thus the well advanced embryos must pass the winter in a condition of dormancy analogous to that observed in hibernating adults.

On no occasion have I caughi a female nesting whose carapace length was less than nineteen centimeters and whose age was less than fourteen years-according to the age record afforded by the annual growth ring on the scutes.

\section{Cahn $(1937,111)$ says:}

The number of eggs deposited varies from ten to sixteen, depending upon the size and age of the turtle, with twelve to fourteen by far the commonest number. They are white and elliptical, with a soft, leathery shell which may be very easily indented. They average $32 \mathrm{~mm}$. by $21 \mathrm{~mm}$.

\section{Chrysemys bellii marginata Agassiz \\ Painted Turtle}

Description.-A small turtle attaining a carapace length of about six inches. Largest adult Ohio specimen ( $q$ ), had a shell $6 \mathrm{r} / 4$ inches in length; smallest juvenile (probably recently hatched), 1 inch. Carapace rigid and covered with horny plates; subovate, depressed and smooth in adults, but with a slight ridge in the very smallest individuals. An outward flare in the region of the hind legs. Margin entire except for the nuchal and the adjacent marginals which may be notched or serrate anteriorly. Shell normally widest in the posterior half. Highest part of carapace $41 \%$ to $57 \%$ of the distance back from the anterior border; females showing a wider range of variation than males. Dorsal scutes normal, costals alternating with the vertebrals. Marginals 25 (26 in two specimens).

Plastron rigid and immovably attached to the carapace, well covering the soft parts and subtruncate at either end. Anterior edge of the gulars often 
slightly serrate and the antero-lateral corner of each gular sometimes thrust forward as a small protuberance.

Head medium in size and flat above. Upper jaw notched in front and with a small tooth-like projection on either side of the notch. Tail medium. Skin covered with small scales; the latter largest on the limbs. Claws of forefeet longer in males than in females.

Carapace olive, olive brown, brown or black. Costals and vertebrals narrowly outlined anteriorly with yellow or olive. A narrow, occasionally interrupted, red stripe running down the middle of the shell in most specimens. Marginals brightly patterned with red and black above and below. A bright red bar on the center of the lower side of each marginal; red markings more or less crescentic on upper surface; numerous small red areas scattered about the marginals.

The plastron is yellow with a dusky or black central blotch. In Ohio specimens this blotch exhibits a wide range in size and intensity. Normally it is elliptical and involves all of the plastral scutes. In some specimens, however, short extensions run outward along the sutures and the larger blotches usually include many irregular yellowish areas. In many the blotch may be very small or may be seen only posteriorly; in several specimens from the state it is entirely obsolete or but faintly discernible. The variability of the blotch is illustrated by 50 specimens collected in one day in the Black Run Swamp west of Fairport in Lake County. Of these, 20 had the blotch of average shape and size, 18 had it large and with some extensions along the sutures, 9 had it small, and in 3 no blotches could be seen.

The top of the head is deep olive to black and the throat is striped with yellow. A prominent yellow line extends backward from just below the eye and may or may not meet a similar line on the lower jaw. There is a short yellow streak behind the eye and a yellow spot on either side of the nape of the neck with backward extensions of yellow. The feet are black, striped with red, and the tail is similarly marked.

Specimens are frequently seen with the shell, especially the plastron, heavily incrusted with a reddish or blackish deposit which ordinarily may be chipped off with the thumb nail. In preservatives the natural reddish markings on the shell and soft parts fade to yellow.

Specimens examined, 586; specimens preserved, 152; specimens studied, 84.

Range.-North central New York and western Pennsylvania, west through southern Ontario, the lower peninsula of Michigan, Ohio, Indiana, northern Kentucky and southeastern Illinois.

No specimens of the eastern painted turtle, Chrysemys picta picta (Schneider), were found in Ohio nor were any hybrids between picta and marginata noted.

The painted turtle undoubtedly occurs in every county in the state (Map 35). Locality records are:

Ashland County: Ruggles Twp. (TZS 439); Savannah Lakes, Clear Creek 
Twp. (TZS 1268). Ashtabula County: Eagleville (CMNH); Kingsville, Conneaut Creek (USNM 51186); Monroe Twp. (OSM 282); Pymatuning Swamp. near Andover (TZS 892, 1041): Richmond Center (TZS 1797); 3 mi. NE of Richmond Center; near Rome (TZS 1472); Shenango River, Andover Tw'p. (TZS 1471); West Andover. Athens Countr: Athens (TZS 1754); near Chauncey (TZS 414). Auglaize County: S shore of Lake St. Mary's on boundary of Auglaize "and Mercer Counties (TZS 254). Belmont County: Speidel, Goshen Twp. (TZS 1267). Brown County: 2 mi. NW of Aberdeen (TZS 2150). Butler County: Rialto (MU). Carroll County: Union Twp. (TZS 348). Champaign County: 2 mi. W of West Liberty (TZS 1948). Clinton County: Near Centerville, Lee's Creek P.O. (TZS 672). Coshocton County: Ohio Canal, Oxford Twp.; Tuscarawas River, W of Newcomerstown; Warsaw (OSM 196). CRAwFord County: Bucyrus Reservoir, Liberty Twp. (TZS 457-8). CuYahoga County: $2 \mathrm{mi}$. SW of Chagrin Falls (TZS 521); Strongsville. Defiance Counry: Defiance Twp. (TZS 1273); near Florida; Ladd Lake, Milford Twp. (TZS 369-70). Erie County: (UMMZ 32868): Sandusky (Morse, 1904: UMMZ 31709, 40713-9); second creek E of Sandusky (SHS). Franklin COUNTY: (OSM 128; USNM 26037, 26042-3); Jackson Twp. (OSM 129.1-.3). Fulton County: Near Neapolis (OSM 242.2); West Fork, Swan Creek, Swan Creek Twp. (TZS 519). Callia County: Near Gallia (TZS 1828); Vinton (Morse, 1904). Geauga Countr: Geauga Lake (TZS 523); Lake Kelso, Burton Twp. (TZS 826). Greene County: Clifton (TZS 742). Guernsey County: Wheeling Twp. (TZS 864); Wills Creek

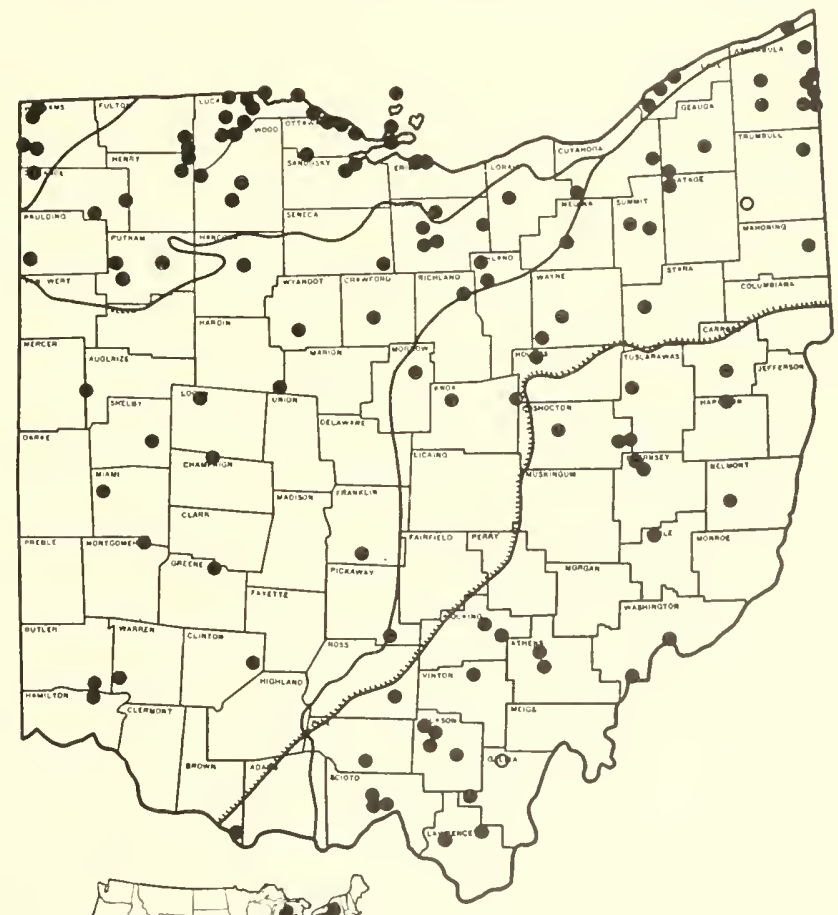

Map 35. Ohio locality records and general range of the Painted Turtle, Chrysemys bellii marginata. 
at Kimbolton (TZS 1272). Hamilton County: Glendale (CSNH 1053A-B). Hancock County: Blanchard River, Findlay (TZS 606). Hardin CountY: Hale Twp. (TZS 1298-9); 3 mi. E of Mt. Victory (TZS 1736). Harrison County: Scio (TZS 342). Henry County: Bad Creek, Texas (TZS 347); NE corner of Washington Twp. Hocking County: I mi. E of Haydenville (TZS 721); Logan (TZS 725). Holmes County: Odell Lake, Lakeville (TZS 2224-5). Huron County: Clarksfield, Vermillion River (USNM 21126); Greenfield Twp. (TZS 1481); Norwalk; North Fairfield (CM 3217); Peru Twp.

Jackson County: Buckeye Creek, 4 mi. W of Jackson (TZS 350); 3 mi. NW of Jackson (DOR); 3 mi. SE of Jackson; $5 \mathrm{mi} \mathrm{SE} \mathrm{of} \mathrm{Richmondale;} \mathrm{Rock} \mathrm{Run,}$ Liberty Twp. (OSM 425.1-.2). KNoX CountY: Brinkhaven (AS); Fredericktown (OSM 170). LAKE CounTY: Black Run Swamp, W of Fairport (OSM 187; TZS 1412-3, 1477-80); Mentor Marsh, Mentor Twp. (TZS 522, 525); Willoughby Twp. (TZS 524), Lawrence County: Elizabeth Twp. (TZS 432); Symmes Creek near Arabia (TZS 448). LoGAN CounTY: Indian Lake (OSM 194.1); Pony Island, Indian Lake (TZS 237-8). LoRaIN CountY: Oberlin (OC). LuCAs CountY: Bono; Delaware Creek, Toledo (TZS 192); Holland (TZS 191, 193-5); Little Cedar Point (TZS 1923); Maumee; Monclova; Oak Openings and Little Cedar Point (OSM 20l.4-.7); Ottawa Hills; Sylvania; Pt. Place, Toledo; Miami and Erie Canal, Toledo (TZS 6); Trilby. Mahoning Countr: Poland (USNM 7686); Yellow Creek, Poland (OSM 267). Medina Countr: Pond near Chippewa Lake (TZS 758). Mercer County: 6 mi. E of Montezuma (TZS 234). Miami County: Greenville Creek, 11/2 mi. SW of Covington (TZS 934-7). Montgomery CountY: Sunderland Falls, Vandalia (CSNH 342). Morrow County: Congress Twp. (TZS 456). Noble County: Buffalo Twp. (TZS 1262-4). Ottawa County: 4 mi. E of Bono; Catawba Island (TZS 477); Crane Creek; Elmore; Erie Twp.; North Bass Island (USNM 51206); $6 \mathrm{mi}$. E of Pt. Clinton (TZS 311); Toussaint Creek, Carroll Twp. Paulding County: Flatrock Creek, Benton Twp. (OSM 210). Pickaway County: Pickaway Twp. (OSM 216.1). PIKe County: Abandoned canal, $3 \mathrm{mi}$. S of Jasper (TZS 1896). Portage CountY: Solon Bog, Aurora Pond, Aurora Twp. (CMNH). Putnam CountY: Auglaize River, Jackson Twp.; Ottawa; Sugar Creek, Cloverdale (USNM 21615). Richland CounTY: Black Fork, Shenandoah (TZS 471). Ross CounTY: Liberty Twp. (TZS 1134-6); near Vauces. SANDUSKY County: $6 \mathrm{mi}$. NE of Fremont (TZS 406); mouth of Sandusky River. Scioto CountY: Near Rushtown (TZS 1895); 1 mi. S of Rushtown (TZS 127I); 2 mi. S of Rushtown; Scioto River tributary, Clay Twp. (OSM 252.1). SENECA CounTY: Venice Twp. (TZS 1010). Shelby County: $1 \mathrm{mi}$. NE of Sidney (TZS 1318). StaRk County: Massillon (OSM 218.1). Summit County: Ira (OSM 325); Silver Lake, near Cuyahoga Falls (USNM 51202). Trumbuli CountY: Kinsman (TZS 1798); Newton Falls (Morse, 1904). Tuscarawas CountY: E of Sugar Creek (TZS 357). Vinton County: N of Creola (TZS 349). WARREN CounTY: Mason (CSNH 1042-3). Washington County: Belpre Twp. (OSM 436.1); Marietta (TZS 498). WAYNE CounTY: Near Craigton; Killbuck Creek, W of Wooster (TZS 470). Williams CounTY: $1 \mathrm{mi}$. S of Blakesley (TZS 355-6, 402); Mud Lake, Northwest Twp. (TZS 1277); Nettle Lake, Northwest Twp. (OSM $250)$; St. Joseph's River, near Blakesley; Tamarack Ditch, Sec. 31, Florence Twp. (TZS 959). Wood County: Bowling Green; Maumee River, Grand Rapids (USNM 21600-3); Middle Branch, Portage River, Liberty Twp. (OSM 351). Wyandot County: Mifflin Twp. (TZS 580).

Habitat and Habits.-The painted turtle is doubtless the most conspicuous and the most frequently collected turtle in Ohio. It may be the most abundant species in the state, but it is possible that the more secretive snapper may exceed it in numbers.

Painted turtles are to be found in almost any locality in which there is sufficient permanent water to hide them and to supply them with food. Thus 
they were collected in such habitats as wet meadows, woodland pools, bogs, marshes, brooks, ditches, ponds, lakes, etc. They showed a distinct partiality for quiet, shallow water and rarely were found in rapidly moving streams or in the deeper parts of the larger lakes and rivers. They frequently remained close to masses of aquatic vegetation such as cabomba, chara, water lilies, pickerel weed, cat tails, etc. which grew along the shores of streams and ponds or in coves, ditches, etc. In such places the seasoned collector instinctively searches for them.

Painted turtles can withstand considerable organic pollution and several times they were taken in water which had a decidedly unpleasant odor. In water exhibiting marked pollution of an industrial source the only painted turtles collected were dead or dying.

Individuals are fond of basking and in localities in which they were numerous they sometimes were perched by the dozen upon muskrat houses, logs, etc. They usually dived in with alacrity when approached, but on cool days in early spring or late fall, when they were not so well warmed by the sun, they were more sluggish and could be more easily stalked or rushed by the collector. Likewise very small juveniles were much less wary, on the average, than adults.

Unless they were thoroughly alarmed, it was usual on warm, clear days for specimens to reappear at the surface near the spot where they dived in. By standing quietly in the water for a few minutes it often was possible to catch one or more of them when their heads appeared above the water, particularly if one was armed with a long-handled dip net. Individuals frequently secreted themselves in the vegetation or upon the bottom and it would appear thar they are most apt to do this on cool or cloudy days, towards evening, or when they are badly frightened. Specimens hiding in such places were often located by treading about in the water or by probing for them with the hands. Many were collected from boats and canoes and experience indicated that it was somewhat easier to approach them from the water side of the shore than from the land.

Many individuals bite when handled and their jaws often are so sharp that they can remove small clean-cut segments from the hand. They usually become very tame in captivity, however, and will readily come for food when the keeper appears with it.

Specimens were taken in every month of the year, and were collected in association with every other species of turtle known to occur in Ohio with the exception of the brown soft-shelled turtle. They were observed moving about under the ice in captivity. On February 21, 1931, eleven specimens were collected near Holland, Lucas County, several being obtained beneath a thin covering of ice. Another was taken January 31, 1931, in an open drainage ditch during a snow storm and while the thermometer registered just below freezing. Many specimens hibernated successfully in the Toledo Zoo pool in water and wet leaves. 
That turtles can exist under water, perhaps indefinitely, during cold weather is shown by the many records of finding them under ice. On the other hand painted turtles and those of other species taken in traps in summer die quickly or are in a weak condition when removed from the water. At least two factors doubtless contribute to these phenomena; first, the amount of oxygen dissolved in cold water is much greater than that in warm and hence more is available for buccal and cloacal respiration in winter; second, physiological activities are greater in warm weather than in cold and the necessity for oxygen is therefore increased.

Painted turtles are omnivorous. They will eat crayfish, earthworms, snails, insects and their larvae, fish, carrion - including dead birds, mice and turtles - and a variety of aquatic plants. In captivity they exhibit a fondness for meat and for almost all green vegetables. In all the numerous observations made upon them both in the field and in captivity they swallowed their food under, or at the surface of the water.

A pair was discovered in what was presumed to be a mating position April 19, 1931, along the shore of Indian Lake, in Logan County, but unfortunately they separated before any detailed observations could be made. None were seen in coitu in captivity but it is probable that pairing ordinarily occurs in early spring.

Nesting normally takes place in June. A specimen in the Toledo Zoo was observed digging its excavation and laying its eggs the evening of June 15, 1934. The work was begun at twilight and was carried out in much the same way as has been described for the nesting of the box turtle (page 140); the total time consumed was somewhat over two hours. The eggs, which were 5 in number, failed to hatch.

A female with a carapace $57 / 8$ inches long which had just deposited its eggs was discovered on the road at Cedar Point, Lucas County, June 17, 1933. It had dug through the hard surface and made its hole in the softer soil beneath. Its eggs were yellowish flesh in color and had rather brittle leathery shells which were easily indented by the fingers. They were more or less capsule shaped and several had a circular whitish area, about $10 \mathrm{~mm}$. in diameter upon their shells. The eggs, which were 8 in number, varied from 8.4 to 9.2 grams, average 8.7 grams in weight; and from 28 to 32 , average $30 \mathrm{~mm}$. in length and from 17 to 18 , average $17.5 \mathrm{~mm}$. in width.

A female collected on Little Cedar Point, June 8, 1935, was kept in a pail, and laid eggs intermittently from July 2 to July 11, until a total of seven had been deposited. Another female was discovered at Bono, Lucas County, in the act of statting her nest at twilight June 25, 1935.

Juveniles in which the navel scar was soft and large and which were judged to have been out of the egg only a short time were collected on a number of occasions. These measured an inch or slightly more in carapace length. 


\section{Pseudemys scripta troostii (Holbrook)}

\section{Cumberland Terrapin}

Description.-A medium to large turtle attaining a carapace length of ten inches. Largest adult Ohio specimen ( $q$ ), had a shell $91 / 2$ inches in length; smallest specimen, 2 inches. Carapace rigid and covered with horny plates; subovate, usually widest in the posterior half. Shell depressed (large females more domelike); a vertebral ridge present in juveniles but absent in adults. Costal and vertebral scutes normal, marginals 25; nuchal relatively wide in juveniles, narrower in adults. Carapace longitudinally rugose in large adults.

Plastron large, immovably attached to the carapace and well covering the soft parts; emarginate posteriorly, subtruncate anteriorly. Plastron about twice as long as wide, omitting the lateral ends of the pectorals and abdominals which are directed upward at an obtuse angle.

Head moderate in size, snout rather blunt; upper jaw slightly notched, lower jaw curved up in front. Feet well webbed, claws of forefeet in males very long. Tail of medium size. Skin covered with scales which are largest on the limbs.

Specimens of this species undergo a complex change of pattern as they grow older, this phenomenon being particularly marked in males. Small individuals are bright green with concentric yellowish and darker green markings which may be U-shaped, parallel or convoluted on the costals and vertebrals, and in the form of whorls on the upper and lower surfaces of the marginals. Normally, on each scute of the plastron, there is a blotch consisting of two black circular lines one within the other. Occasionally these markings on adjacent scutes may be confluent or there may be extra or imperfect ones on various parts of the plastron. The legs and head are streaked with yellow and green. A bright red band on either side of the head extends backward from the posterior corner of the eye. A yellow line extends backward from a point just below the eye and may or may not meet a similar line on the lower jaw. Another yellow line extends posteriorly from the symphysis of the jaw and forks on the chin. Bright yellow lines are present on the tail.

In all females and in young males the pattern is basically the same as the above. In the older specimens, however, the markings on the carapace are more differentiated and are yellow and olive, brown or black. On each costal scute there is usually a conspicuous transverse band of yellow flanked by lines of yellow and the darker color. The markings on the vertebrals are more or less longitudinal. On the plastron the blotches tend to become uniformly dark.

Adult males show decided tendencies toward melanism with a consequent suppression of the normal pattern. Black transverse bands first appear on the carapace (frequently on the sutures), these spreading and being joined by other darker areas until the upper surface, and more especially posteriorly, approaches uniform blackness. At the same time black or brown areas appear on the plastron, particularly along the median suture. These spread and be- 
come nearly uniform black or brown in occasional specimens. The soft parts become darker likewise and the bright markings eventually disappear, even to the red band upon the head which passes through a dull red stage before being completely obscured. Indications of melanism are also to be seen in adult females but not nearly to such a marked degree as in males.

Specimens examined, 13; specimens preserved, 6; specimens studied, 13.

Range.-From eastern Kansas, Iowa, northern Indiana and southern Ohio, south in the Mississippi Valley to southern Texas.

The Cumberland terrapin was taken in only two localities in Ohio (Map 36), viz.:-

Pickaway County: Pond in Scioto River bottom, Pickaway Twp. (OSM 216.2, 329). Ross County: Ox-bow of Scioto River at Vauces, Liberty Twp. (TZS 2288-2291).

Young specimens of troostii are sold by the thousands in pet stores and five and tens throughout Ohio. Many of these must be liberated annually and they may occasionally overwinter. However, this species does not appear

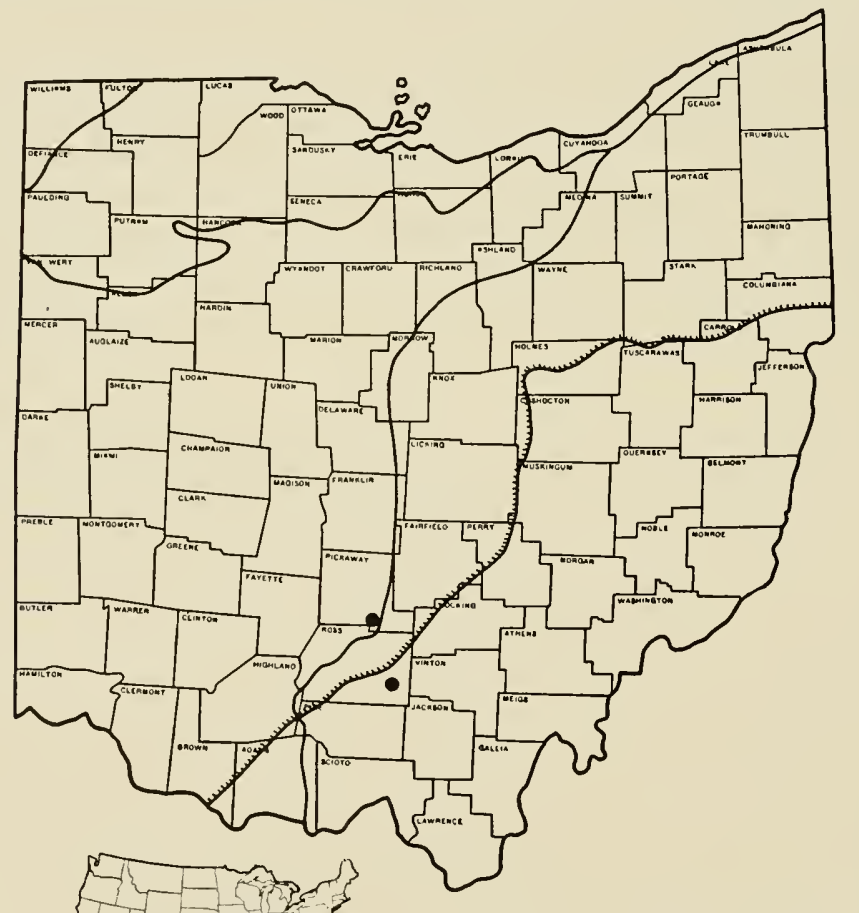

Map 36. Ohio locality records and general range of the Cumberland Terrapin, Pseu. demys scripta troostii. 
to have established itself anywhere in the state as the result of such accidental introductions. The two localities listed above are believed to be within the natural range of $P$. s. troostii.

Habitat and Habits.-Since so few specimens of the Cumberland terrapin were collected in the state, notes on habitats and habits are also few. Both Ohio localities, however, are old ox-bows of the Scioto River and it may be that this type of habitat is most favorable to this species within the state. The first specimen was taken in the Pickaway County locality August 10, 1929 , by Dr. Chas. F. Walker and the late James S. Hine, of the Ohio State Museum, and Milton B. Trautman, then of the Ohio Division of Conservation, while seining for fish. Another specimen was secured from a resident at the same place in May, 1930 (Walker, 1931, 12).

During the course of the many field trips of the present survey each of the ox-bows of the Scioto River was carefully searched at least once as was also the entire length of the abandoned Ohio and Erie Canal paralleling the river. On May 5, 1934, in the Ross County locality, which had been worked several times before, but with no success, no less than 11 specimens of the Cumberland terrapin were collected. The ox-bow at this point, normally several hundred yards long and several feet in depth, had shrunk as a result of the winter drought of 1933-34 to a few small puddles. In and near these the specimens were found, but only one, an adult male, was alive. The others had been dead for varying periods of time, some doubtless for just a few hours. The shells of three large adult fernales were in sufficiently good condition to preserve, but the smaller ones, including two juveniles about 2 inches in length, were badly decomposed. It was presumed that the combination of an unusually cold winter and lack of water (and hence food) was responsible for the decimation of the colony. The live male was found buried about three inches deep in dried mud near one of the remaining puddles.

Observations made by the writer on several hundred specimens at Reelfoot Lake in Tennessee indicate that this turtle is more at home in deep water than the painted turtle (represented by Chrysemys picta dorsalis (Agassiz) in this locality) and less so than the map turtle (represented by Graptemys pseudogeographica pseudogeographica (Gray). Specimens were caught in the coves and ditches and in the open lake (Reelfoot), but juveniles were seen only in vegetation or in mud in shallow water. In early spring young and old alike frequented the shallow water near shore which was more readily warmed by the sun.

Captives fed upon meat, fish, crayfish, earthworms, carrion, lettuce, spinach, beet tops and a variety of other greens.

Courtship behavior was observed in the zoo pools a number of times. Males would swim toward a female from any angle and then turn to face her and extend the forelegs directly toward her head. From this position the long claws were vibrated rapidly several times while the male swam with his hind legs in such a way as to keep himself directly facing the female. The actual vibrating lasted only a second or so but the process was repeated con- 
tinuously, sometimes for nearly an hour. Occasionally as high as five males would extend their court to a single female at the same time but she did not appear at any time to take the slightest note of them, except to retract her head momentarily when they approached too closely. Taylor (1933) recently has published similar observations.

Cahn (1937, 167-8) gives the best account of the nesting and egg-laying habits of this turtle. He says that it nests in clear sandy areas not far from the water and usually during the last two weeks of June and the first one in July. He found that the number of eggs in a clutch varied (depending upon the size and age of the female) from 6 to 23 , with an average of 15 to 18 ; in size they averaged $37 \times 22 \mathrm{~mm}$.

\section{Amyda mutica (Le Sueur) \\ Brown Soft-Shelled Turtle}

Description.-A large turtle attaining a carapace length of fourteen inches; females reach a considerably greater size than males. Largest adult Ohio female had a shell 9 inches in length; largest male, 61/2 inches; smallest juvenile, probably recently hatched, $13 / 8$ inches. Carapace leathery and without horny plates, oval in outline and nearly as broad as long; margin entire. Shell rounded but quite flat; juveniles with a slight vertebral ridge. Shell smooth and with no tubercles present upon it. Carapace thrust well backward, extending considerably beyond the plastron posteriorly, but not reaching farther forward than the plastron anteriorly. Plastron relatively small, covering the soft parts anteriorly but leaving the hind legs and tail exposed.

Head moderately small, narrow and terminating in a prolonged and flexible snout. Mandibles covered with fleshy lips. Nostrils represented by two circular holes. Tail stout and considerably longer in males than in females; anal opening near tip. Skin smooth; a few scales on the limbs. Feet well webbed; five digits on each foot but only the first three bear claws.

Carapace olive grey or olive brown, marked with numerous dots or short streaks of a shade but little darker than the ground color. Shell with a narrow yellowish or brownish marginal band bordered interiorly with a clouded line of dark grey. Large females mottled with areas of various shades of greyish or brownish olive.

Plastron uniform white or yellow. Head olive grey, sometimes faintly dotted with darker. A yellow line, bordered with blackish or grey, extends from or near the snout back through the eye to the neck. Throat yellowish. Lips uniform yellow or clouded with grey.

Feet uniform olive grey, or stippled or clouded with a darker shade. Under side of legs and tail whitish or yellowish.

Juveniles similar to adults but paler and with the canthus rostralis considerably more pronounced. 
This and the following species are very similar and are apt to be confused. The best characters for separating Amyda mutica from Amyda spinifera are, in the former, the lack of spines and tubercles on the carapace, lack of a nasal septum with ridges projecting into the nostrils, lack of a mottled pattern on the feet, and in the younger specimens and males, the carapace marked with dots and streaks instead of circular spots.

Specimens examined, 19; specimens preserved, 17; specimens studied, 16.

Range.-Texas, Oklahoma and Kansas, east in the Mississippi River and its tributaries to southern Ohio; north to South Dakota and Minnesota.

The brown soft-shelled turtle has been collected in Ohio only in the Scioto, Muskingum and Ohio Rivers, although it doubtless occurs in other large rivers in the southern part of the state (Map 37). Kirsch $(1895,333)$ records Amyda mutica from a number of localities in northwestern Ohio, but it is evident that he confused this species with $A$. spinifera which latter is abundant in that part of the state. All of the specimens of Amyda from Ohio in the collection of the U.S. National Museum are definitely spinifera, including those collected by Kirsch. Locality records are:

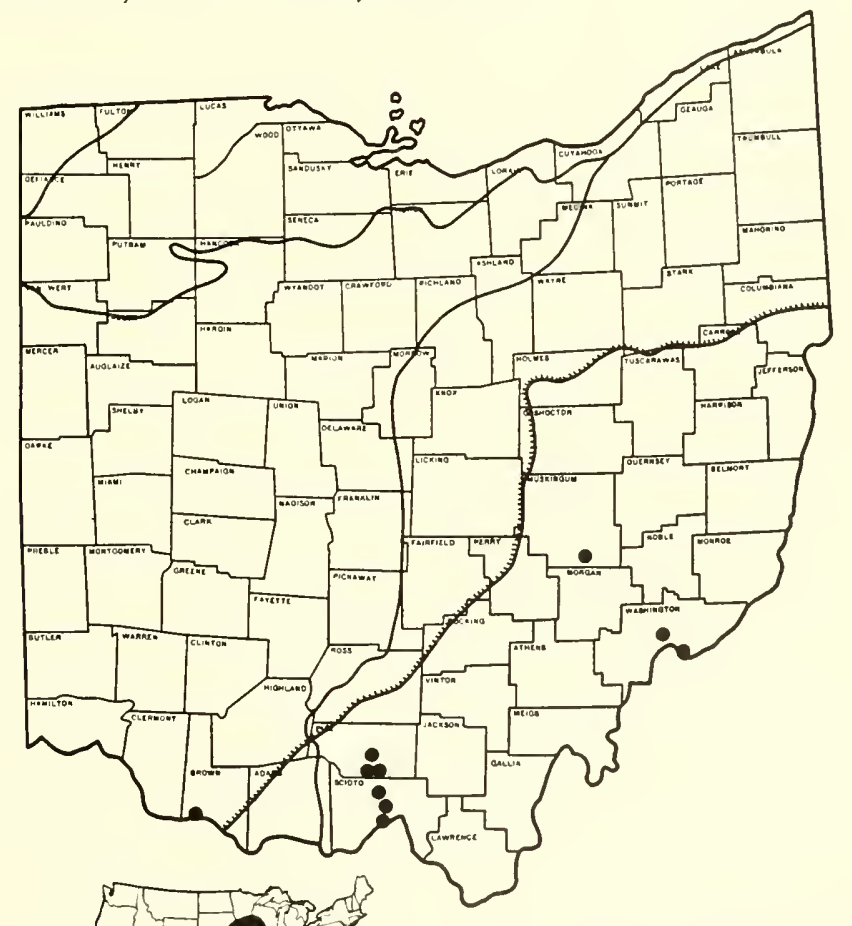

Map 37. Ohio locality records and general range of the Brown Soft-Shelled Turtle. Amyda mutica. 
Brown County: Mouth of White Oak Creek, Higginsport (OSM 272). Muskincum County: Near Gaysport (OSM 142). Pike County: Scioto River, Camp Creek Twp. (OSM 353.1-.5; TZS 509); Scioto River, Newton Twp. (TZS 1688); Scioto River, Scioto Twp. (OSM 274.1-3). Scioto County: Scioto River, Clay Twp. (OSM 252.2); Scioto River, Portsmouth (TZS 1573); Scioto River, 3 mi. N of Rushtown (TZS 1088). Washington County: Dam No. 2, Muskingum River, northern edge of Marietta (OSM 253.1); Ohio River, $4 \mathrm{mi}$. SE of Marietta (MC).

Habitat and Habits.-The majority of Ohio specimens of the brown softshelled turtle were taken in seines by the Ohio Division of Conservation incidental to the making of fish collections. The few which were collected by hand were either at rest on the bottom in shallow water, or were buried in sand or gravel bars in a few inches of water near the shore. Like the spiny soft-shelled turtle they appear to hide themselves in such places, and only the head shows as they wait for prey to pass. In no case were they found buried in water deeper than the length of their necks; these they stretched upward for air until the nostrils protruded above the surface.

Too few were seen to determine whether they bask in the sun as the spiny soft-shelled turtles occasionally do. Specimens can swim well and can run upon land with surprising rapidity.

In the lower portion of the Scioto River it appears that the present species is abundant while spinifera is almost entirely absent. The two species were taken at the same time in the same net, but the comparatively few observations indicate that where one is common the other is rare. Map turtles were also obtained in association with specimens of the present species.

Captives ate meat, fish, crayfish, earthworms and insects.

Muller (1921) records observations on the nesting habits of this species as seen on an island in the Mississippi River near Fairfield, Iowa. He writes:

In this locality the egg laying season covers the last half of June and the early part of July. In building her nest, the female selects a spot with an unobstructed view of the open water, and from ten to sixty feet inland. Here she scoops out a hole in the sand, about five inches in diameter, and ten inches deep, using her forepaws in the operation, and piling up the loose sand around the hole. The necessary conditions for incubation are sufficient dampness so that the sand will just cling together, and absence of clayey or earthy matter which might cause the sand to pack and thus prevent the escape of the young. Often in her search of proper conditions the female will dig three or four holes before laying her eggs. A suitable nest being dug, the turtle assumes a position with her hind feet down the hole, and dropping her eggs into her hind paws, arranges them neatly upon the floor of the nest. The hole is then filled in with the sand removed from it, the hind feet being used.

The number of eggs laid varies with the size of the turtle. Eight nests contained respectively $12,13,4,22,21,16,26,33$ eggs.- The average annual lay of a female would be around twenty-two. The finished nest appears as a small crater of sand, about a foot in diameter, or, where the surface is covered with pebbles, as a circular area of clear sand. The temperature of the nests is quite constant-about $90^{\circ} \mathrm{F}$.

As the embryo grow's the calcareous part of the shell becomes very much cracked and the shell membrane, yielding to pressure from within, stretches until the egg becomes approximately $2.39 \mathrm{~cm}$. in diameter. The carapace is folded down around the young turtle and the arms are extended in front of the head. The forepaws are thrust through the shell first in hatching, and this opening enlarged to allow egress for 
the rest of the body. Although the young have an egg-tooth below the flexible proboscis it does not seem to be used in escape from the eggs, and is dropped a week after hatching.

Muller found that the young were nearly circular and his measurements of the carapace lengths of five newly hatched ones varied from $13 / 8$ to $17 / 16$ inches. His observations showed that the eggs in the nests on the island hatched from July 31 through early August and that the incubation period under favorable conditions was from 70 to 75 days.

According to Cahn (1937, 183) the eggs are round and white and are smaller but very similar to those of Amyda spinifera. He found that the average size of 116 eggs was $22.6 \mathrm{~mm}$.

\section{Amyda spinifera (Le Sueur)}

\section{Spiny Soft-Shelled Turtle}

Description.-A large turtle attaining a carapace length of fourteen or fifteen inches; females reach a considerably greater size than males. Largest adult Ohio specimen ( $q$ ), measured $14 \mathrm{I} / 2$ inches in (shell) length; largest male, 61/2 inches; smallest juvenile, probably recently hatched, 111/16 inches.

Carapace leathery and without horny plates. Outline oval and not much longer than wide; margin entire. Shell rounded but nearly flat; juveniles with a slight vertebral ridge. Anterior margin of carapace studded with numerous more or less prominent tubercles. The entire upper shell, in males, covered with small tubercles which in the larger specimens feel like sandpaper. In large females these tubercles usually are very fine and often confined to the anterior and posterior ends of the shell. Carapace thrust well backward so that its anterior end extends no farther forward than the anterior end of the plastron; posteriorly it extends much farther backward than the plastron. Plastron leathery and relatively small, well covering the soft parts anteriorly but leaving the hind legs and tail exposed.

Head moderately small, narrow and tapering to a prolonged and flexible snout. Mandibles covered with fleshy lips. Nostrils divided by a septum from which a narrow ridge, running back into the nasal passage, projects into each nostril. Tail stout, the anus neat the tip. Tail protruding beyond the carapace in adult males, scarcely reaching the edge in adult females. Skin smooth; a few scales on the limbs. Feet well webbed; five digits on each foot but only the first three bearing claws.

Carapace olive grey, marked with numerous circular black spots which are largest toward the center of the shell. Margin with a narrow yellowish band bordered interiorly by a nearly continuous black line. In large females the circular markings break up and the pattern consists of mottled areas of various shades of olive green, brown or grey. The writer has seen no adult males in which the circular spots were not present.

Plastron uniform white or yellow. Edges of underside of carapace occasionally streaked or spotted with blackish. Head olive grey, dotted or streaked with black. A yellow line, bordered with blackish, extends backward from the snout through the eye to the neck. Lips yellow, spotted with grey or olive. 
Feet heavily dotted, streaked or mottled with yellowish and olive grey or black. A broad yellow band, bordered with black, on either side of the tail. Under surface of legs and tail yellow.

Juveniles similar to adults but paler and with the markings occasionally somewhat indistinct. Canthus rostralis most pronounced in very small specimens.

Specimens examined, 71; specimens preserved, 41; specimens studied, 26.

Range.-Mississippi River and tributaries, west to Colorado and Montana, east through the drainage systems of Lake Erie, Lake Ontario and the St. Lawrence River to Vermont.

The spiny soft-shelled turtle is widely distributed in Ohio although it appears to be rather less abundant in the eastern counties than in the western ones (Map 38). Locality records follow:

Ashland County: Long Lake, Lake Twp. (OSM 143). Auglaize County: Pusheta Creek, W of Wapakoneta (TZS 360). Brown CounTY: White Oak Creek, $1 \mathrm{mi}$. N of Higginsport (TZS 1872, 2151-2). Champaign County: Mad River, $4 \mathrm{mi}$. SW of Urbana (TZS 1949). ERIE Countr: Huron (OC); Sandusky (Morse,

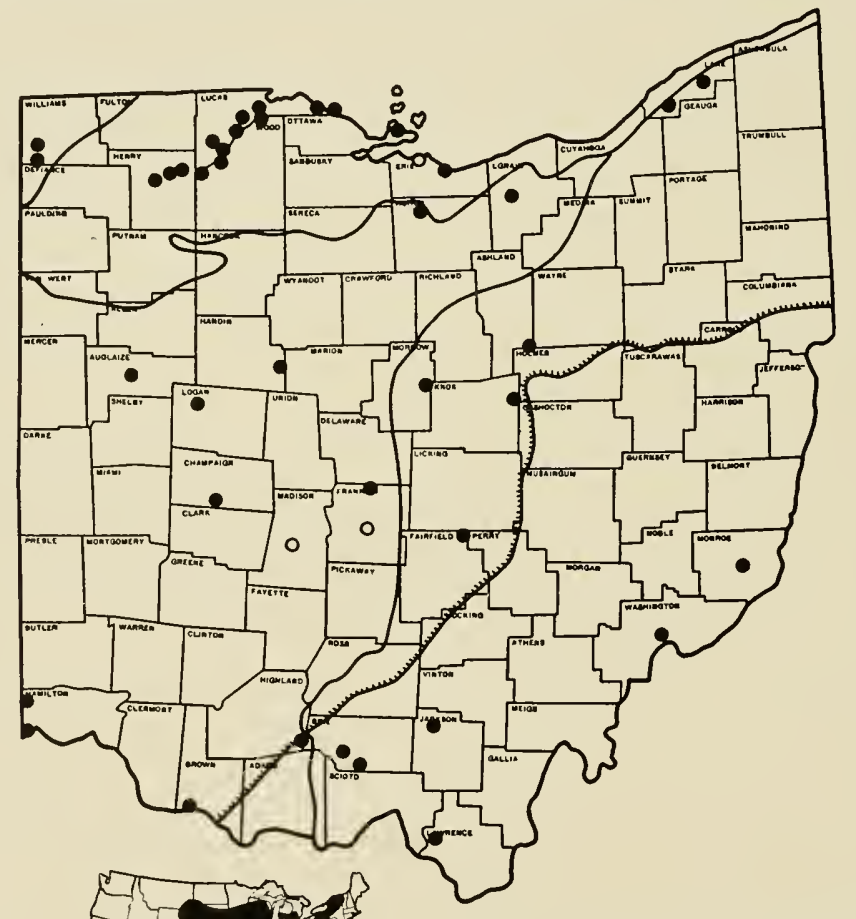

Map 38. Ohio locality records and general range of the Spiny Soft-Shelled Turtle. Amyda spinifera. 
1904). Fairfield County: Buckeye Lake (WC). Franklin County: (USNM 26290); Alum Creek, Westerville (OSM 254); Columbus (Morse, 1904). HamiltoN County: Harrison (CSNH 1188); mouth of Miami River (OSM 352.1-.2). Hardin County: Near Hepburn (TZS 1730). Henry County: Maumee River, E of Napoleon; Maumee River, near Texas (TZS 1483); Maumee River, 3 mi. W of Texas. Highland County: Little Brush Creek, 2 mi. N of Sinking Spring (TZS 574). Huron Countr: Huron River, near Monroeville (SHS). JacKson County: Small stream near Canter's Cave, Jackson Twp. (TZS 720). KNox County: Brinkhaven (AS). LAKE CounTY: East branch Chagrin River, Kirtland (CMNH); Grand River, 4 mi. E of Painesville (TZS 1441). Lawrence County: Pine Creek, Elizabeth Twp. (TZS 421, 506-7, 1749). Logan County: Miami River, near Indian Lake (OSM 428). Lorain CountY: Oberlin (OC). LuCAs CountY: Lake Erie at Reno Beach, Jerusalem Twp.; Lake Erie, 1/2 mi. offshore from mouth of Crane Creek; Maumee River at Maumee (TZS 428-9); Maumee River, Toledo (TZS 1940); Swan Creek, W of Toledo; near Waterville; Swan Creek near Whitehouse. Madison County: London (Morse, 1904). Monroe County: Cranenest Fork, Green Twp. (TZS 1266). Morrow County: Kokosing River, Franklin Twp. (TZS 508). OtTawa County: East Harbor, Catawba Island (TZS 2277). PIKE CountY: Chenoweth Fork, Sunfish Twp. (TZS 1053); Scioto River, Camp Creek Twp. (OSM 353.6). Washington County: Dam No. 2, Muskingum River, northern outskirts of Marietta (OSM 253.2). Williams CountY: $1 \mathrm{mi}$. S of Blakesley (TZS 361); St. Joseph River, near Blakesley; Edgerton (USNM 21567-8). Wood CountY: Grand Rapids (TZS 1968); Grassy Creek, Rossford; Haskins (TZS 595); Maumee River opposite Toledo.

Habitat and Habits.- The spiny soft-shelled turtle is probably more essentially a river turtle than any of the other species in the state. It is true that it was found in smaller streams and in lakes but it is in the larger rivers that it is most abundant. It is equally at home in deep or in shallow water and its excellent swimming abilities make it difficult to catch in either. It seldom leaves the water except to nest and to bask occasionally upon a log or rock inaccessible to the collector. Sometimes specimens crawl out on the steep clay banks of streams where they rest head downward in position to slide into the water on an instant's notice. They can travel rapidly on land and when surprised they make for the water with considerable speed.

Soft-shelled turtles frequently bury themselves in mud or sand in shallow water. When a specimen is placed on such a bottom it moves its shell rapidly from side to side and in a few moments disappears from sight. When it is covered completely it remains still for a short time but soon thrusts out its head to have a look around. The depth of the water in which it buries itself appears to be gauged by the length of the neck, which is extended upward occasionally to allow the nostrils to reach the surface of the water. Numbers of soft-shelled turtles were collected by carefully inspecting mud and sand bars. Watch was kept for slight swirls or disturbances on the bottom which were caused by a turtle withdrawing its head. Such places were investigated by hand as were any depressions or raised places which appeared at all foreign to the general appearance of the bar.

Soft-shelled turtles are difficult animals to hold. Their round, flat shells make it hard to get a good grip on them and the strong claws are capable of producing deep scratches if the hands are not kept out of the way. Despite the fleshy lips which more or less conceal the cutting edges of the jaws, the latter are weapons which are to be carefully avoided. 
Specimens were collected in every month from March to October inclusive but the greatest numbers were taken in May and June. A single specimen was secured in the Maumee River opposite Toledo in December, 1929. None successfully hibernated in the zoo pool and it would appear that the masses of wet leaves provided in this place were not a suitable winter environment for soft-shelled turtles.

Individuals were obtained in company with map, painted and snapping turtles and also once or twice with the brown soft-shelled turtle.

Captive specimens ate a great variety of food including crayfish, worms, insects, snails, fish, meat, etc., but none were observed to take vegetable matter. Surface $(1908,123)$, however, writes:

We take this opportunity to record the fact that we have found the soft-shelled turtle feeding upon grains of corn obtained in or near the ponds which they inhabit. A specimen examined by us in Ohio some years ago contained both the yellow and red field corn, to the extent of almost as much corn as would be produced upon two average ears of this plant.

The soft-shelled turtle is much esteemed as an article of food and, like the snapper, numbers of the present species find their way into the Ohio markets. Professional turtle collectors take them by "noodeling," in traps, nets or on set lines.

On two occasions pairs of specimens were seen in positions which indicated mating but neither time were they actually in coitu. The male had his forefeet placed upon the back of the female in such a way that his hindfeet were beyond the posterior border of her shell and his tail could be turned so that its ventral surface met hers.

The eggs are spherical in shape. Their shells are hard and remind one of a ping-pong ball and they even bounce somewhat similarly when they are dropped on a hard surface. A group of 21 eggs from a large female collected in Wampler's Lake, Michigan, June 18, 1934, were white to pale pinkish brown in color with a single white "polar cap" varying from $1 / 16$ to nearly $1 / 2$ of the surface of the egg. The greatest diameter of the eggs of this clutch varied from 25.8 to $29 \mathrm{~mm}$. and averaged $27 \mathrm{~mm}$.; the least diameter varied from 24 to $27.8 \mathrm{~mm}$., and averaged $25.6 \mathrm{~mm}$. Cahn, writing on the turtles of Illinois $(1937,193)$ gives the number of eggs in a complement as 9 to 25 , average 18. He found that the average diameter of the 217 eggs he examined was $28.3 \mathrm{~mm}$.

Newman (1906) describes the nesting of a specimen as follows:

A warm sunshiny day. Place: the 'old road' about ten feet from the water's edge and concealed from view on one side by tall grass. A large female Aspidonectes (Amyda) has just escaped from the grass and is commencing to nest. No time is lost in selecting a spot. She scratches out footholds for the forefeet and begins to excavate with the hindfeet, using right and left alternately with a circular gouging movement. As the hole becomes deeper it is generally necessary for her to give a more nearly perpendicular thrust with the hindfeet.

In less than forty minutes the nest is completed and she has commenced to lay her eggs, letting the tail down into the narrow hole as far as possible. After depositing several eggs she arranges them with the hindfeet and then rakes in some earth previously wet with water from the accessory bladders. The earth is gently packed in 
before any more eggs are laid. The remainder of the eggs are deposited and the hole is filled up with earth and tramped down quite firmly with the knuckles of the hind feet, right and left feet being used alternately. This treading movement continues for some minutes and seems to be quite thorough. Although not in any way disturbed, the tortoise left without attempting to cover up the traces of the scratching feet, and anyone who is familiar with the appearance of the tortoise nest would have no diffculty in detecting this one.- The nest was examined and found to be flask-shaped with a narrow neck only an inch and a half in diameter. The depth of the nest was a trifle over six inches and the diameter at the bottom about three inches. The nest contained eighteen rather large spherical eggs of a delicate pink color and with a very thin, brittle shell.

The same author states that mating takes place during April or May and the nesting season is from the middle of June to the middle of July. He also states that the character of the soil selected for the nest is immaterial and records nests which were excavated in hard clay, in a rock pile, among the roots of a tree and on a sandy beach.

It is probable that the eggs hatch in the early fall, but some, as in the case of other species of turtles, do not hatch until spring.

\section{Glossary}

For the convenience of persons who are not familiar with certain of the terms used in the text a glossary is here included. Reference also should be made to the plates illustrating features of scutellation. Such words as dorsal, longitudinal, serrate, anus and others widely used in zoology are purposely omitted; the novice will find definitions of these terms in any good dictionary.

ô-Male.

ㅇ-Female.

AвDOMinal.-One of the fourth pair of scutes on the plastron of turtles.

AdPRESSED.-The fore and hind limbs of lizards stretched at full length toward each other and pressed against and parallel to the sides of the body.

Alveolar.-The masticatory surface of the jaws in tuitles.

ANAL.- The most posterior plate or one of a pair of the most posterior plates on the plastron in turtles.

Anal Plate.-The scale lying just in front of the anus in snakes, sometimes a single large scale (anal plate single), sometimes divided obliquely into two scales (anal plate divided).

ANGLE OF JAw.-The point of juncture of the two jaws.

Auricular.- Of or pertaining to the ear.

Azycous.-Single, i.e., not paired. Said of the median dorsal scale posterior to the rostral in Heterodon contortrix.

BARBEL.-A small fleshy filament on the chin or throat of a turtle.

BRIDGE.-The portion of the shell joining the plastron to the carapace in turtles.

Butron.-The horny caudal appendage of newly born rattlesnakes.

Canthal.-A small plate on the rim of the snout (in Crotalus) between the internasals and supraoculars.

Canthus Rostralis. - The angle of the head from the tip of the snout to the eye.

CARAPACE.-The upper shell in turtles.

Cephalic Plates.-The large scales on the head.

Costal.-One of the large scutes lying in the row between the marginals and the vertebrals in the carapace of turtles. 
FAcial Pit.-The opening on the side of the head, between and below the eye and the nostril, in the rattlesnakes, the copperheads and their allies.

FEMORAL.--One of the fifth pair of scutes of the plastron of turtles.

Femoral Pores.-A row of large pores on the ventral side of the thigh in some lizards.

Frontal.- The large scale on the top of the head between the supra-oculars in snakes and many lizards.

Glaciated.-Covered at some time by a glacier. Said of northern and western Ohio.

GulaR.- The most anterior plate or one of a pair of the most anterior plates on the plastron of turtles.

Gulars.-The scales of the throat.

HINGE.-A transverse joint on the plastron of some turtles.

Humeral.-One of the second pair of scutes on the plastron of turtles.

INTERNASAL.-One of a pair of scales between the nasals in snakes and many lizards.

KEEL.-A median longitudinal ridge en a scale, or a median longitudinal ridge on the carapace of a turtle.

LABIALS, LOWER.-A row of scales bordering the lower jaw on each side and separated from the row on the opposite side at the anterior tip of the jaw by a scale called the mental.

LABIALS, UPPER.-A row of scales bordering the upper jaw on each side and separated from the row on the opposite side at the anterior point of the head by the rostral plate.

LOREAL.-A small scale lying between the nasal scale and the preoculars.

Marginal Scutes.-The scales around the margin of the carapace in turtles.

NaSAL. - The scale in which the nostril lies. "One nasal" signifies that the nostril lies in or near the center of one large scale and "two nasals" signifies that the nostril lies between two squarish scales or largely in one of them. When two nasals are present they are known as the prenasal (anterior nasal) and postnasal (posterior nasal) respectively.

Nuchal. - A small plate at the center of the anterior end of the carapace in turtles and which is included in counting the series of marginals.

Oviparous.-Producing young by means of eggs which hatch some time after extrusion from the body.

Ovoviviparous.-Producing young by means of eggs which hatch either in the body of the parent or shortly after extrusion.

PAPILla.-A small pimple-like projection.

Parietal.-One of a pair of large plates on the posterior dorsal surface of the head.

Pectoral.-One of the third pair of scutes on the plastron of turtles.

Prt.-See facial pit.

Plastron.-The lower shell in turtles.

Postocular.-One or more small scales directly behind the eye.

Prefrontal.- One of a pair of scales on the dorsal surface of the head anterior to the frontal.

Preocular.-One or more scales directly in front of the eye. If the scale in this position is much longer than high, it is called the loreal, in which case the preocular is absent.

RATTLE.- The dermal structure on the tail of rattlesnakes.

Rostral.- The large scale at the end of the snout.

Rows of Scales.-The lines of dorsal scales counted obliquely. The position of lateral stripes is determined by counting obliquely upward from the lowermost row of dorsal scales on each side.

SADDLES.-Saddle-shaped blotches. 
SCUTE.-A large scale. Synonymous with plate.

SePtum.-A partition.

SuBCAUDALs.-Large scales on the under side of the tail in snakes, usually in two series (divided), but in some snakes in only a single series (entire).

Subocular.-The scale directly below the eye.

Supraocular.-The large scale above each eye in snakes. In lizards there may be several supraoculars of small size.

Temporals. - The scales on the side of the head behind the postoculars, and between the parietals and the upper labials.

TUBERCLE.-A small knob-like prominence.

Unglaciated, - Not covered by a glacier. Said of southeastern Ohio.

VENTRALs.-In snakes the large scales on the lower surface of the body between the head and the anal plate.

Vertebral.- One of the large scales of the median dorsal row on the carapace of turtles.

\section{BIBL.IOGR.APHY *}

Agassiz, Louls. 1857-Contributions to the natural history of the United States of America. Little, Brown and Co., vol. II, pp. 45I-643, pls. I-XXVII.

Allard, H. A. 1935-The natural history of the box turtle. Scient. Monthly, Oct., 1935, pp. 325-38.

Atkinson, D. A. 1901-The reptiles of Allegheny County, Pennsylvania. Ann. Carnegie Mus., vol. I, pp. 145-57.

Atrinson, D. A. And M. Graham Netting. 1927-The distribution and habits of the massasauga. Bull. Antivenin Inst. Amer., vol. I, no. 2, pp. 40-4, figs. 8-9.

Babcock. Harold L. 1919-Turtles of New England. Mem. Boston Soc. Nat. Hist., vol. 8 , no. 3 , pp. 325-431, pls. 17-32.

Baird, S. F. and C. Girard. 1853-Catalogue of North American reptiles in the museum of the Smithsonian Institution. Part I.-Serpents. Smithson. Inst., pp. i-xvi $+1-172$.

Barbour, Thomas. 1934-Reptiles and amphibians: Their habits and adaptations. Revised edition. Houghton, Mifflin Co., pp. i-xx + 1-129, figs. 1-142.

Bishop, Sherman C. and F. J. W. Schmidt. 1931-The painted turtles of the genus Chrysemys. Field Mus. Nat. Hist., Publ. 293, Zool. Ser., vol. XVIII, no. 4 , pp. 123-39, figs. 1-27.

Blanchard, Frank N. 1920-A synopsis of the king snakes: Genus Lampropeltis Fitzinger. Occ. Pap. Mus. Zool., Univ. Mich., no. 87, pp. 1-7.

1921-A revision of the king snakes: Genus Lampropeltis. U. S. Nat. Mus., Bull. 114, pp. i-vi + 1-260, figs. I-78.

1923-The snakes of the genus Virginia. Pap. Mich. Acad. Sci., Arts and Lett., vol. III, pp. 343-65, figs. 10-15.

1924-The forms of Carphophis. Pap. Mich. Acad. Sci., Arts and Lett., vol. IV, pp. 527-30.

1925a-A key to the snakes of the United States, Canada and Lower California. Pap. Mich. Acad. Sci., Arts and Lett., vol. IV, pt. II, pp. i-xiii + I-65, figs. 1-78.

* Including references used in the text and references to Ohio reptiles. 
1925b-A collection of amphibians and reptiles from southern Indiana and adjacent Kentucky. Pap. Mich. Acad. Sci., Arts and Lett., vol. V, pp. 367-88, pls. 22-3.

1927-Eggs and young of the eastern ring-neck snake, Diadophis punctatus edwardsii. Pap. Mich. Acad. Sci., Arts and Lett., vol. VII, pp. 279-92, pls. 13-9.

1930 - Further studies of the eggs and young of the eastern ring-neck snake, Diadophis punctatus edwardsii. Bull. Antivenin Inst. Amer. vol. IV, no. I, pp. 4-10, figs. 1-7.

1933-Eggs and young of the smooth green snake, Liopeltis vernalis (Harlan). Pap. Mich. Acad. Sci., Arts and Lett., vol. XVII, pp. 493-508, figs. 51-7, tab. I, pls. LI-LVI.

1937,a-Eggs and natural nests of the eastern ring-neck snakes, Diadophis punctatus edwardsii. Pap. Mich. Acad. Sci., Arts and Lett., vol. XXII, pp. 521-32, pls. LIII-LVII.

1937b-Data on the natural history of the red-bellied snake, Storeria occipitomaculata (Storer), in northern Michigan. Copeia, 1937 (3), pp. 151-62, figs. 1-4, tables 1-6.

Blatchley, W. S. 1899-Notes on the batrachians and reptiles of Vigo County, Indiana. 24th Ann. Rep. Dept. Geol. Nat. Res. Indiana, pp. 537-52.

Boulenger, George Albert. 1889-Catalogue of the chelonians, rhynchocephalians and crocodiles in the British Museum. Pp. i-x + 1-3II, pls. I-VI, figs. 1-73.

Burt, Charles E. 1931-A study of the Teiid lizards of the genus Cnemidophorus with special reference to their phylogenetic relationships. U. S. Nat. Mus. Bull. 154, pp. i-viii + 1-283, figs. 1-38.

Butler. Amos W. 1892-Contributions to Indiana herpetology No. 3. Journ. Cincinnati Soc. Nat. Hist., vol. XIV, pp. 169-79.

Cahn, Alvin R. 1937-The turtles of Illinois. Ill. Biol. Mono.. vol. XVI, nos. 1-2, pp. 1-218, pls. 1-31, text figs. 1-15, tables 1-20, maps 1-20.

Cahn, Alvin R. and Evert Conder. 1932-Mating of the box turtles. Copeia 1932 (2), pp. 86-9.

CARR, A. F., Jr. 1937-The status of Pseudemys scripta and Pseudemys troostii. Herpetologica, vol. 1, no, 3, pp. 74-7, pl. VII.

Clark, Hubert Lyman. 1903-The water snakes of southern Michigan. Amer. Nat., vol. XXXVII, no. 433, pp. 1-23.

CLAY, WILliam M. 1934-Rediscovery of the red-bellied water snake, Natrix sipedon erythrogaster (Forster), in Michigan. Copeia, 1934 (2), pp. 95-6.

Conant, Roger. 1930—Field notes of a collecting trip. Bull. Antivenin Inst. Amer., vol. IV, no. 3, pp. 60-4.

1932-A key for the identification of the reptiles of Ohio. Toledo Zool. Soc., pp. 1-6.

1934a-The red-bellied water snake, Natrix sipedon erythrogaster (Forster), in Ohio. Ohio Journ. Sci., vol. XXXIV, no. 1, pp. 21-30, pls. I-II.

-1934b-Guide to the reptile house in the Toledo Zoological park, Toledo Zool. Soc., pp. 1-24, 16 figs.

1934c-Observations on the eggs and young of the black king snake, Lampropeltis getulus nigra (Yarrow). Copeia, 1934 (4), pp. 188-9.

Conant, Roger and William M. Clay. 1937-A new subspecies of water snake from islands in Lake Erie. Occ. Pap. Univ. Mich. Mus. Zool., no. 346, pp. 1-9, pls. I-III. 
Conant, Roger and R. Marlin Perkins. 1931-This mite question. Bull. Antivenin Inst. Amer., vol. $V$, no. 2, pp. 36-9.

COPE, EDward Drinker. 1900-The crocodilians, lizards and snakes of North America. Rept. U. S. Nat. Mus. for 1898, pp. 153-1294, figs. 1-347, pls. 1-36.

Ditmars, Raymond L. 1907-The reptile book. Doubleday, Page, pp. i-xxxii + 1-472, pls. I-CXXXVI.

1929-Serpents of the eastern states. Bull. N. Y. Zool. Soc., vol. XXXII, no. 3, pp. 82-120, figs. 1-33, pl. I.

1936 - The reptiles of North America. Doubleday, Doran pp. i-xvi $+1-476$, pls. 1-135.

DUnN, E. R. 1934-Systematic procedure in herpetology. Copeia, 1934 (4), pp. $167-72$.

Dury, Charles. 1910a-Young snakes taking refuge in the mother's mouth in time of danger. Journ. Cincinnati Soc. Nat. Hist. vol. XXI, no. 2, pp. 68-72. 1910b-Ibid., p. 73.

Dury, Ralph. 1932a-Notes on copperhead, Agkistrodon mokasen (Beauvois). Proc. Jun. Soc. Nat. Sci., vol. 3, no. 2, pp. 19-20.

$1932 \mathrm{~b}-$ Recent acquisitions to the department of herpetology. Proc. Jun. Soc. Nat. Sci., vol. 3, no. 2, pp. 26-8.

1934-Snakes of the Cincinnati region. Zool. Soc. Cincinnati, Quarterly, vol. I, no. 1, pp. 7-12.

Dymond J. R. AND F. E. J. Fry. 1932-Notes on the breeding habits of the green snake (Liopeltis vernalis). Copeia, 1932 (2), p. 102.

Eigenmann, C. H. 1896-The inhabitants of Turkey Lake: Testudinata. Proc. Ind. Acad. Sci., pp. 262-4.

Evermann, Barton Warren and Howard Walton Clark. 1920-Lake Maxinkuckee: A physical and biological survey; the reptiles and amphibians. State of Indiana, Dept. of Conserv., Publ. 7, vol. I, pp. 580-644, 3 figs.

ForCE, EDITH R. 1930-The amphibians and reptiles of Tulsa County, Oklahoma, and vicinity. Copeia, 1930 (2), pp. 25-39.

Gadow, Hans. 1901-Amphibia and reptiles. Macmillan \& Co., pp. i-xiii + 1-668, figs. $\mid-181$.

Garman, H. 1892-A synopsis of the reptiles and amphibians of Illinois. Bull. Illinois State Lab. Nat. Hist., vol. III, art. XIII, pp. 215-385, pls. IX-XV.

Gloyd, Howard K. 1928-The amphibians and reptiles of Franklin County, Kansas. Trans. Kansas Acad. Sci., vol. 31, pp. 115-41.

- 1932_-The herpetological fauna of the Pigeon Lake region. Miami County, Kansas. Pap. Mich. Acad. Sri., Arts and Lett., vol. XV, pp. 389-409, map 3, pls. XXX-XXXII.

1934-Studies on the breeding habits and young of the copperhead. Agkistrodon mokasen Beauvois. Pap. Mich. Acad. Ści. Arts and Lett., vol. XIX, pp. 587-604, figs. 18-9, pls. LXXVII-LXXIX.

1935-The cane-brake rattlesnake. Copeia, 1935 (4), pp. 175-8.

Gloyd, Howard K. and Roger Conant. 1934-The broad-banded copperhead: A new sub-species of Agkistrodon mokasen. Occ. Pap. Mus. Zool., Univ., Mich., no. 283 , pp. $1-5$, pl. I. 
Grant, Chapman. 1935-Secondary sexual differences and notes on the mud turtle, Kinosternon subrubrum, in northern Indiana. Amer. Midland Nat., vol. 16, no. 5, pp. 798-800.

Hay, Oliver Perry. 1892a-The batrachians and reptiles of the state of Indiana. Ann. Rept. Indiana Dept. Geol. and Nat. Resources, vol. 17, pp. 412-602, pls. 1-3.

$1892 \mathrm{~b}-$ On the breeding habits, eggs, and young of certain snakes. Proc. U. S. Nat. Mus., vol. XV, pp. 385-97.

HiNE, JAs. S. 1911-Beneficial habits of snakes, toads and related animals. Extens. Bull. Agric. College (Ohio State), Vol. VI, No. 7, pp. 1-16.

Holbrook, John Edwards. 1842-North American herpetology. J. Dobson, Phila., vols. I-V.

KIRSCH, PhILIP H. 1895-A report upon investigations in the Maumee River basin during the summer of 1893. Bull. U. S. Fish Comm., art. 20, pp. 315-37.

Kirtland, Jared P. 1838-Reptiles (of Ohio). Geol. Surv. Ohio, 2nd Ann. Rept., Pp. 158, 167, 188-9.

KLAUBer, LAurence M. 1936-A key to the rattlesnakes with summary of characteristics. Trans. San Diego Scc. Nat. Hist., vol. VIII, no. 20, pp. 185-276, figs. 1-112.

KRAATZ, WaLter C. 1921-A preliminary survey of the macro-fauna of Mirror Lake on the Ohio State University campus. Ohio Journ. Sci., vol. XXI, no. 5, pp. 137-84.

Logier, E. B. S. 1931-A faunal investigation of Long Point and vicinity, Norfolk County, Ontario. The amphibians and reptiles of Long Point. Trans. Royal Canadian Inst., vol. XVIII, pt. I, pp. 229-36.

McLain, R. B. 1899-Notes on a collection of reptiles, made by Mr. C. J. Pierson, at Fort Smith, Arkansas, with remarks on other eastern reptiles. Privately printed, Wheeling, W. Va., pp. 1-5.

Morse, Max. 1901-Ohio reptiles in the Ohio State University zoological museum. Ohio Natur., vol. 1, no. 8, pp. 126-8.

1902a-Variations in the water snake. Ohio Natur., vol. II, no. 3, pp. 183-7, pl. 13.

1902b-The range of the fox snake. Science, vol. XV, no. 391, p. 1035.

1903-Ohio reptiles and batrachians. Ohio Natur., vol. III, no. 3, pp. 360-1.

1904--Batrachians and reptiles of Ohio. Proc. Ohio State Acad. Sci., vol. IV, pt. 3, Spec. Pap. no. 9, pp. 95-144, pls. I-II.

Muller, J. F. 1921-Notes on the habits of the soft-shelled turtle-Amyda mutica. Amer. Midland Nat., vol. VII, no. 6, pp. 180-4.

Myers, George S. 1926-A synopsis for the identification of the amphibians and reptiles of Indiana. Proc. Ind. Acad. Sci., vol. 34, pp. 277-94, 1 fig.

1927-Notes on Indiana amphibians and reptiles. Proc. Ind. Acad. Sci., vol. 36, pp. 337-40.

Netring, M. Graham. 1927-Muhlenberg's turtle in western Pennsylvania. Ann. Carnegie Mus., vol. XVII, nos. 3-4, pp. 403-8, pl. XXXVI.

Newman, H. H. 1906-The habits of certain tortoises. Journ. Comp. Neurol. and Psychol., vol. XVI, no. 2, pp. 126-52.

Noble, G. K. AND E. R. MAson. 1933-Experiments on the brooding habits of the lizards Eumeces and Ophisaurus. Amer. Mus. Novitates, no. 619, pp. 1-29. figs. 1-6. 
Ortenburger, A. I. 1928-The whip snakes and racers. Univ. Mich. Studies, Memoirs Univ. Mich. Mus., vol. 1, pp. i-xviii + 1-247, figs. 1-64, pls. I-XXXVI.

Peattie, Roderick. 1923-Geography of Ohio. Geol. Surv. Ohio, 4th Ser., Bull. 27, pp. i-vi + 1-137, figs. 1-28.

Piatt, Jean. 1931-Herpetological report of Morgan County, Indiana. Proc. Ind. Acad. Sci., vol. 40, pp. 361-8.

Ridgeway, Robert. 1912 - Color standards and color nomenclature. Publ. by author. pp. i-iv + 1-44, pls. I-LIII.

Risley, PaUl. L. 1933-Observations on the natural history of the common musk turtle, Sternotherus odoratus (Latreille). Pap. Mich. Acad. Sci., Arts and Lett. vol. XV11, pp. 685-711, figs. 78-9.

Ruthuen, Alexander G. 1908 - Variations and genetic relationships of the garter snakes. U. S. Nat. Mus., Bull. 61, pp. i-xii + 1-201, figs. 1-82, pl. 1.

1911-A biological survey of the sand dune region on the south shore of Saginaw Bay: Amphibians and reptiles. Mich. Geol. and Biol, Surv., Pub. 4, Biol. Ser. 2, pp. 257-72.

Ruthuen, Alexander G., Crystal Thompson and Helen T. Gaige. 1928-The herpetology of Michigan. Mich. Handbook Ser., Univ. Mich. Mus., no. 3, pp. $\mathrm{i}-\mathrm{x}+1-229$, figs. 1-52, pls. 1-XIX.

Schmidt, Karl P. ANd Walter L. Necker. 1935-Amphibians and reptiles of the Chicago region. Bull. Chicago Acad. Sci., vol. 5, no. 4, pp. 57-77.

1936-.The scientific name of the American smooth green snake. Herpetologica, vol. 1, no. 2, pp. 63-4.

Shaw, George. 1802-General zoology or systematic natural history. G. Kearsley, London, vol. 111, pt. 1, pp. i-vi + 1-615, pls. 1-140.

SIEBENROCK, F. 1909-Synopsis der rezenten schildkröten, mit berücksichtigung der in historischer zeit ausgestorbenen arten. Zool. Jahrbücher, Suppl. X. Heft. 3, pp. $427-618$.

Smith, W. H. 1882-Report on the reptiles and amphibians of Ohio. Rept. Geol. Surv. Ohio, IV, pp. 629-734, figs. 1-8.

Stejneger, Leonhard. 1893-The poisonous snakes of North America. Rept. U. S. Nat. Mus., pp. 337-487, figs. 1-70, pls. 1-19.

1934-Scincus lateralis Say, preoccupied. Copeia, 1934 (4), p. 182.

Stejneger, Leonhard and Thomas Barbour. 1933-A check list of North American amphibians and reptiles. Third edition. Harvard Univ. Press. Cambridge. pp. i-xiv $+1-185$.

Stupka, Arthur. 1933-A lizard new to Ohio. Copeia, 1933 (1), p. 43.

Surface, H. A. 1906-The serpents of Pennsylvania. Zool. Bull., Div. Zool., Penna. State Dept. Agric., vol. IV, nos. 4 and 5, pp. 113-208, figs. 4-23, pls. XIV-XLII.

1907-The lizards of Pennsylvania. Ibid., vol. V, no. 8, pp. 233-264, figs. 26-28, pls. XXX-XXXIII.

1908-First report on the economic features of turtles of Pennsylvania. Ibid., vol. VI, nos. 4 \& 5, pp. 105-96, figs. 1-16, pls. IV-XII.

Swanson, Paul L. 1933-The size of Sistrurus catenatus catenatus at birth. Copeia, 1933 (1). P. 37.

Talbert, Margaret E. 1933-An albino pilot black-snake. Proc. Jun. Soc. Nat. Sci., vol. 3, no. 2, p. 19. 
TAYlor, Edward H. 1932a-Eumeces inexpectatus: A new American lizard of the family Scincidae. Bull. Univ. Kansas, vol. XXXIII, no. 10, pp. 251-6I, pls. XVII-XVIII.

1932b-Eumeces laticeps: A neglected species of skink. lbid., pp. 263-71, pls. XIX-XX.

1933-Observations on the courtship of turtles. Ibid., vol XXXIV, no. 5, pp. 269-71.

1935-A taxonomic study of the cosmopolitan scincoid lizards of the genus Eumeces. Unịv. Kans. Sci. Bull., vol. XXIII, no. 1, pp. 1-643, figs. 1-84, pls. I-XLIII.

Thomas, Edward S. and Milton B. Trautman. 1937-Segregated hibernation of Sternotherus odoratus (Latreille). Copeia, 1937 (4), p. 231.

Trautman, Milton B. 1931-List of turtles of Ohio. Ohio Dept. Agric., Bur. Sci. Research, bull. 53, 1 p.

Verrill, A. E. 1870-Natural history miscellany. Amer. Nat., vol. 4, pp. 1-671.

Viosca, Percy, JR. 1933-The Pseudemys troostii-elegans complex, a case of sexual dimorphism. Copeia, 1933 (4), pp. 208-10.

Walker, Charles F. 1931-Notes on reptiles in the collection of the Ohio State Museum. Copeia, 1931 (1), pp. 9-13.

Weller, W. H. 1930a-On a recent occurrence of the blue-tailed skink in Hamilton County (Ohio), Proc. Jun. Soc. Nat. Hist., vol. 1, nos. 5 and 6. 1930b-Micrurus fulvins (fulvius) in Ohio. Ibid., vol. I, nos. 10 and 11.

YARROW, H. C. 1882-Check list of North American reptilia and batrachia. Bull. U. S. N. M. 24 , pp. 1-249.

\section{First Aid in Case of Snake Bite}

A thorough knowledge of what to do in case of snake bite is something which everyone who spends much time in the woods or fields should acquire. Many accidents with venomous snakes occur at such times and places that the proper application of first aid measures may mean the difference between life and death.

Snake poison is a colorless or yellow fluid secreted by glands at the sides of the snake's head. By means of hollow fangs it is injected into the body of the victim. Venoms vary in composition but those from snakes of the same species are very much alike. Those of the three venomous snakes in Ohio are sufficiently similar so that the same type of first aid treatment may be applied to all.

Treatment, briefly outlined, resolves itself into three essential steps. These are:-

1. Use of Tourniquet. A tourniquet should be applied to the bitten limb a few inches above the bite but it should not be drawn too tightly. Recent investigation has shown that the poison travels most rapidly through the 
lymph system and that the tourniquet only needs to be snug enough to impede the lymph flow. Adjusting the ligature so that a finger can be forced between it and the skin will give some idea of how tightly it should be pulled. If it is too tight there is danger of seriously interfering with the flow of the larger and deeper blood vessels.

2. Incision. An incision should be made connecting the fang punctures, and again at right angles to the first cut, with a sharp, sterile instrument. The incision should be made as deeply as the fangs have penetrated $-1 / 2$ inch in the case of a large copperhead or massasauga and somewhat deeper for a large timber rattlesnake. If the limb becomes greatly swollen it may be necessary to make similar incisions in the most affected areas. Care must be taken when cutting not to sever a blood vessel or to injure a bone.

3. Suction. Considerable amounts of venom can be removed by applying suction at the site of the incisions. This may be accomplished either with the mouth or by means of one of the numerous types of suction devices now included as part of modern snake bite kits. Suction should be continued for 20 minutes out of every hour and in the most severe cases it may be necessary to continue it for 15 or 20 hours.

It is essential to keep the patient as quiet as possible. Some feeling of confidence may be instilled by knowledge of the fact that the death rate without any treatment is only $15 \%$ and that with proper energetic first aid measures it can be consistently reduced to $11 / 2 \%$. The use of stimulants, particularly alcoholic ones, should be avoided. Such remedies as kerosene, urine, potassium permanganate and the entrails of chickens have long been proven useless and even dangerous.

The services of a competent physician should be secured in every case of poisonous snake bite; the use of serum is perhaps best left in the physician's hands.

It is difficult to establish rules for the identification of poisonous snakes. However, the three in Ohio have the following characteristics in common and may be distinguished by them from all the harmless snakes in the state. (1) They all possess a deep facial pit between the eye and the nostril. (2) The pupils of their eyes are vertically elliptical. (3) The subcaudals are in a single row, at least anteriorly.

The above characters can scarcely be used in the field for they require too close examination of the subject. The rattle will serve to identify adults of the two species of rattlesnakes; newly born individuals have only a horny "button" to represent the future appendage. However, in the field the rattle itself may be hidden from view. It is best to learn to recognize the individual species by study so that they may be identified at once. Without question the poisonous snakes are the most dangerous wild vertebrates still forming a part of the fauna of Ohio. 


\section{Suggestions for Collecting}

Care must be exercised when one comes in contact with the poisonous snakes. Skilled persons are able to catch them by means of a snake hook or noose but this is not recommended for anyone who has not had experience.

For study collections rattlesnakes and copperheads are best killed and preserved at once. A pistol or small calibre shot-gun loaded with very fine shot is useful for this purpose, and in the case of many lizards and aquatic reptiles some sort of fire-arm is indispensable. Harmless snakes may be seized in the hand although the larger ones are capable of biting hard enough to produce scratches; a pair of heavy leather gauntlets is a good protection. The lizards of the state are too small to do much damage but care must be used in grasping them lest the tail become detached. Turtles may be held by the shells, except snappers, which are best carried by the tail.

Formalin and a hypodermic needle should be taken in the field to preserve specimens which are collected dead. Live material is best carried in a sack. Flour, sugar or salt bags which have been stitched around the edge by a sewing machine are quite satisfactory. Burlap bags and other sacks of coarse weave should not be used as snakes and lizards sometimes force their way through the meshes, especially if they are wet.

Specimens should never be left in air tight containers nor should bags of them be left in the sun. Under ordinary circumstances they survive best under cool, damp conditions.

Most lizards and turtles are discovered while they are active and in the open but the majority of snakes are usually found hidden beneath rocks. boards, etc. Hence much collecting consists of overturning such objects. Favorite habitats and places in which the various species of reptiles have been found are mentioned under the discussions of each individual species.

\section{Instructions for Preserving Reptiles}

Preserved collections of reptiles are indispensable for making scientific records and are very useful for purposes of identification and teaching. Materials for permanently preparing specimens are inexpensive and the amount of effort required is not great.

Snakes and lizards are most satisfactorily killed by chloroforming or by drowning. This may be accomplished by placing them in a bottle, can or sack, excluding all air and immersing them in tepid water. It is paradoxical that water snakes are among the quickest and easiest to drown and pit vipers are among the hardest. Turtles also may be killed by drowning but more rapid results are obtained by injecting them with a small amount of ether.

Reptiles are best preserved as alcoholics. To prevent internal decay and eventual spoilage specimens should be injected with $6 \%$ formalin or $70 \%$ grain alcohol by means of a hypodermic syringe. Injection should be made 
at a number of points along the body and, in the case of snakes, in the tail as well. In the event that no syringe is available the ventral surface of snakes or lizards may be opened by means of a fine pair of scissors or small knife. Short slits about an inch or so in length and at about one or two inch intervals are sufficient; such openings permit the preserving fluid to penetrate to the internal organs.

After a specimen has been killed and injected it should be placed in a shallow vessel containing $6 \%$ formalin. Care must be exercised at this point, however, to pose the specimen in the position which it is clesired for it to assume permanently. Snakes are best coiled in a bottle with a wide bottom and wide top such as an ordinary mason jar. Lizards are best posed in a straight line unless they are exceptionally large when they may be coiled like the snakes. Turtles should have their limbs and heads pulled out of the shells sufficiently far so that they can be seen and studied.

For permanent storage of smal! specimens, mason jars or wide-mouthed bottles with close fitting ground glass stoppers are most satisfactory. When rubber jar rings are used they must be inspected and replaced periodically. Ground glass stoppers may be coated with vaseline before they are inserted. For the larger snakes and turtles larger containers are necessary. Gallon pickle or mayonnaise jars are useful for all but the largest specimens although it is often difficult to make the lids of such vessels fit tightly. When large material is to be stored special earthenware crocks or metal containers are necessary. These can be secured from most biological supply houses. For permanent storage 70'; alcohol is best, especially if the material is to be iemoved occasionally for study. In cases in which alcohol is not available $6 \%$ formalin may be substituted. Before specimens are transferred from formalin to alcohol they should be rinsed carefully in water. Storage is best made in dark, or even light-tight rooms or closets, as specimens fade in color very rapidly if they are exposed to strong light.

Specimens are worth little unless they are properly tagged. Labels should be tied directly to specimens and to prevent tearing or loss they should be of pure tin, parchment or some other resistant substance Linen thread is most satisfactory for tying. Tags are usually attached to one of the hind feet in turtles. In snakes they are tied around the body a few inches back of the lead but care must be taken not to pull the thread too tightly or the scales will be injured. In lizards the tag is tied around the body just anteriorly to the hind legs.

A number should be stamped or placed in some other unalterable way upon each tag. Record of the numbers may be kept in a notetook or catalogue in which also is entered all pertinent data. These should always include the name of the species, the exact locality in which it was collected, the name of the collector and the date. Such other items as the date of preservation, notes on habitat and record in captivity should be added if they are known. Data may be written directly upon the tags attached to the specimens, but even if this is done a number should be used and an additional record kept. 

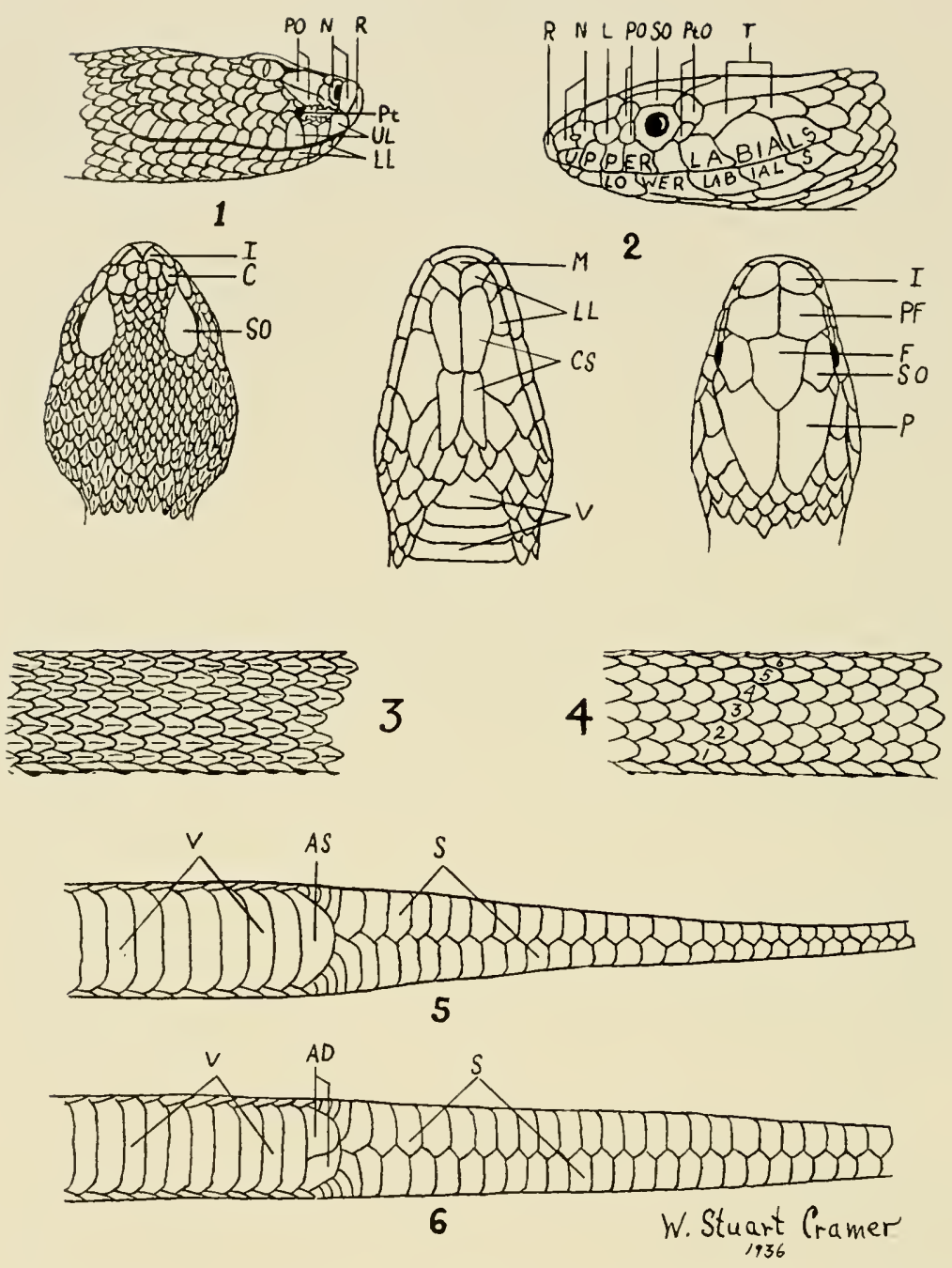

Plate 1. Fig. I. Head of venomous snake (Crotalidae), lateral and dorsal view. Fig. 2. Head of non-poisonous snake (Colubridae), lateral, ventral and dorsal view. Fig. 3. Section of body showing keeled scales. Fig. 4 . Section of body showing smoo:h scales and scale rows. Fig. 5. Ventral surface showing rapidly tapering tail as seen in female snakes. Fig. 6. Ventral surface showing slowly tapering tail as seen in male snakes.

AD-Anal plate divided. AS - Anal plate single. C-Canthal. CS-Chin shields. F-Frontal. I-Internasal. L-Loreal. LL-Lower labials. M-Mental. N-Nasal. P-Parietal. PF-Prefrontal. PO-Preocular. Pt.-Pit. PiO-_Postocular. R-Rostral. S-Subcaudals. SO-Supraocular. T-Temporal. UL-Upper labials. V-Ventrals. 

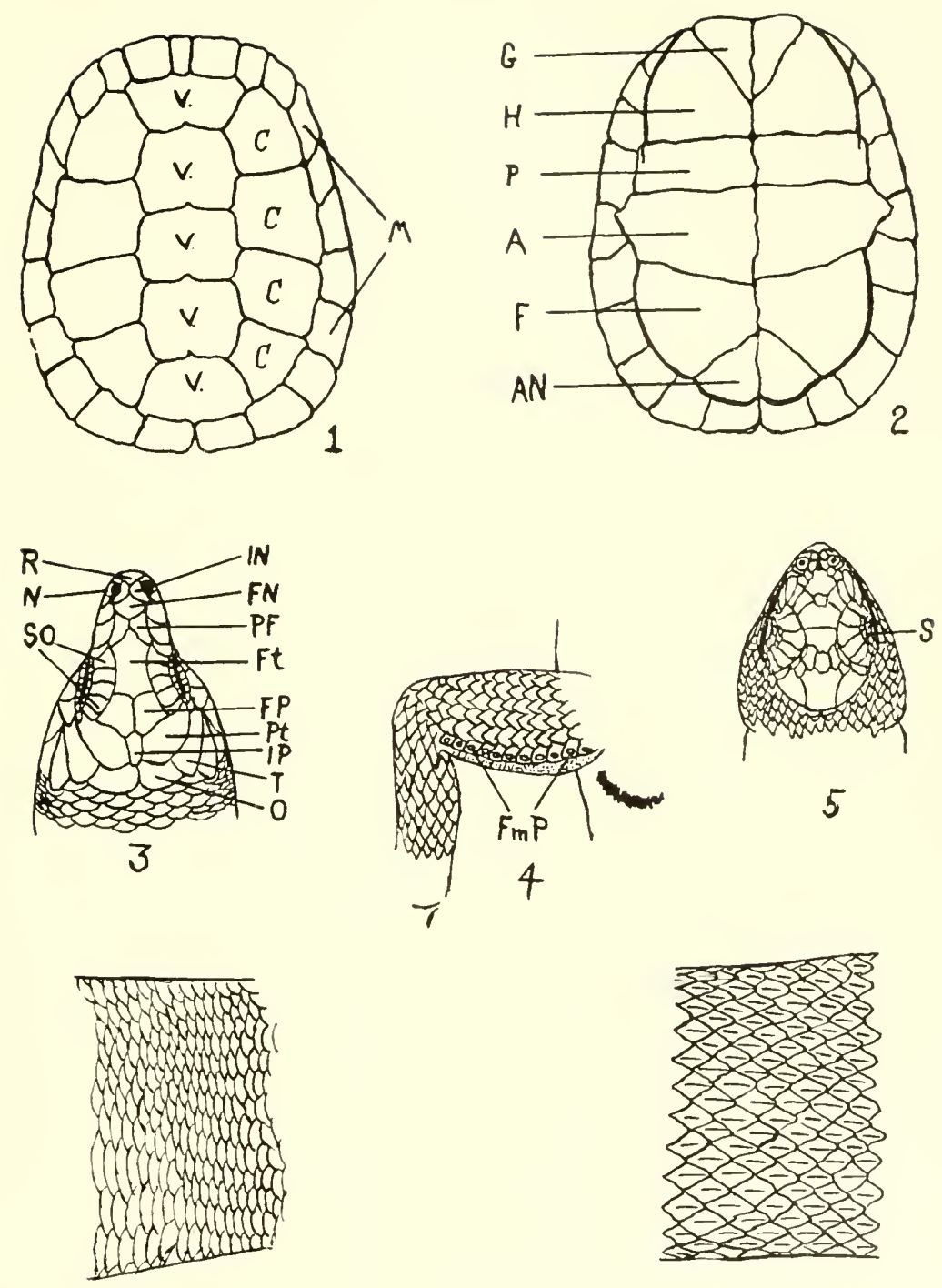

6
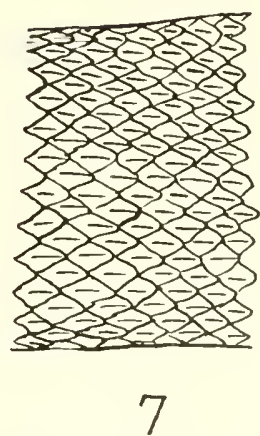

Plate 2. Fig. 1. Carapace of turtle. Fig. 2. Plastron of turtle. Fig. 3. Head of lizard (Eumeces). Fig. 4. Ventral view of leg of Sceloporiss. Fig. 5. Head of lizard (Sceloporus). Fig. 6. Section of dorsal surface of lizard showing smooth scales. Fig. 7. Section of dorsal surface of lizard showing keeled scales.

A-Abdominal. AN-Anal. C-Costal. F-Femoral. FmP-Femoral pores. FN-Fronto-nasal. FP-Frcnto-parietal. Ft.-Frontal. G-Cular. H-Humeral. INInternasal. IP-Interparietal. M-Marginals. N-Nasal. O-Occipial. P-Pectoral. PF-Prefrontal. Pt-Parietal. R--Rostral. S-Supercilia ies. SO-Supracculars. T-Temporal. V-Vertebral. 


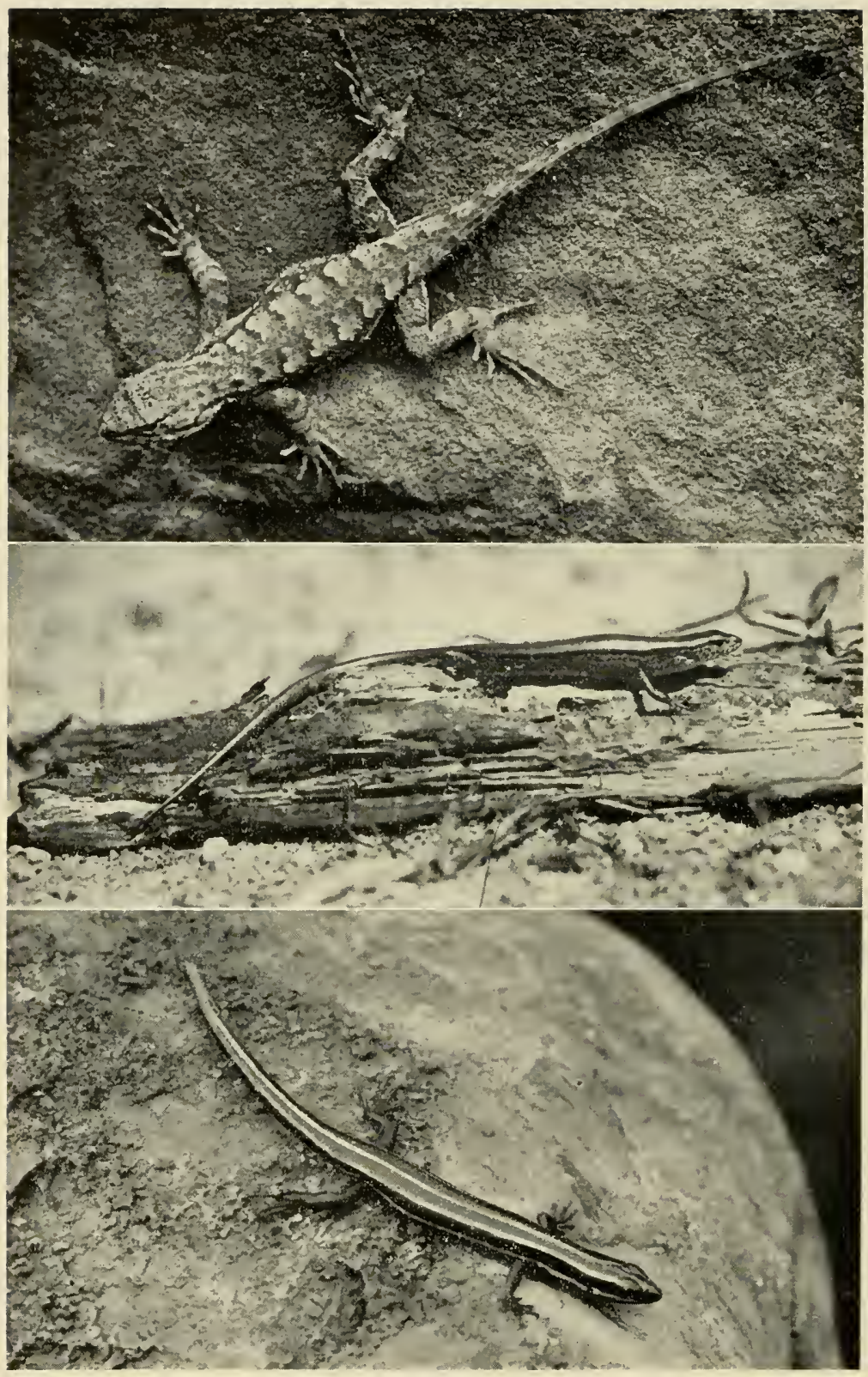

Plate 3. Fig. 1. Swift, Sceloporus undu!atus, "Neotoma," Good Hope Twp., Hocking County. Length about 6 inches. Photo by Edward S. Thomas. Fig. 2. Brownbacked Skink, Leiolopisma unicolor. Specimen from Florida. Length 37/8 inches. Photo by Mark Mosney, Jr. Fig. 3. Blue-tailed Skink, Eumeces fascictus. "Neotoma," Good Hope Twp., Hocking County, May, 1927. Young specimen abcut $\equiv 1 / 2$ inchss in length. Photo by Edward S. Thomas. 


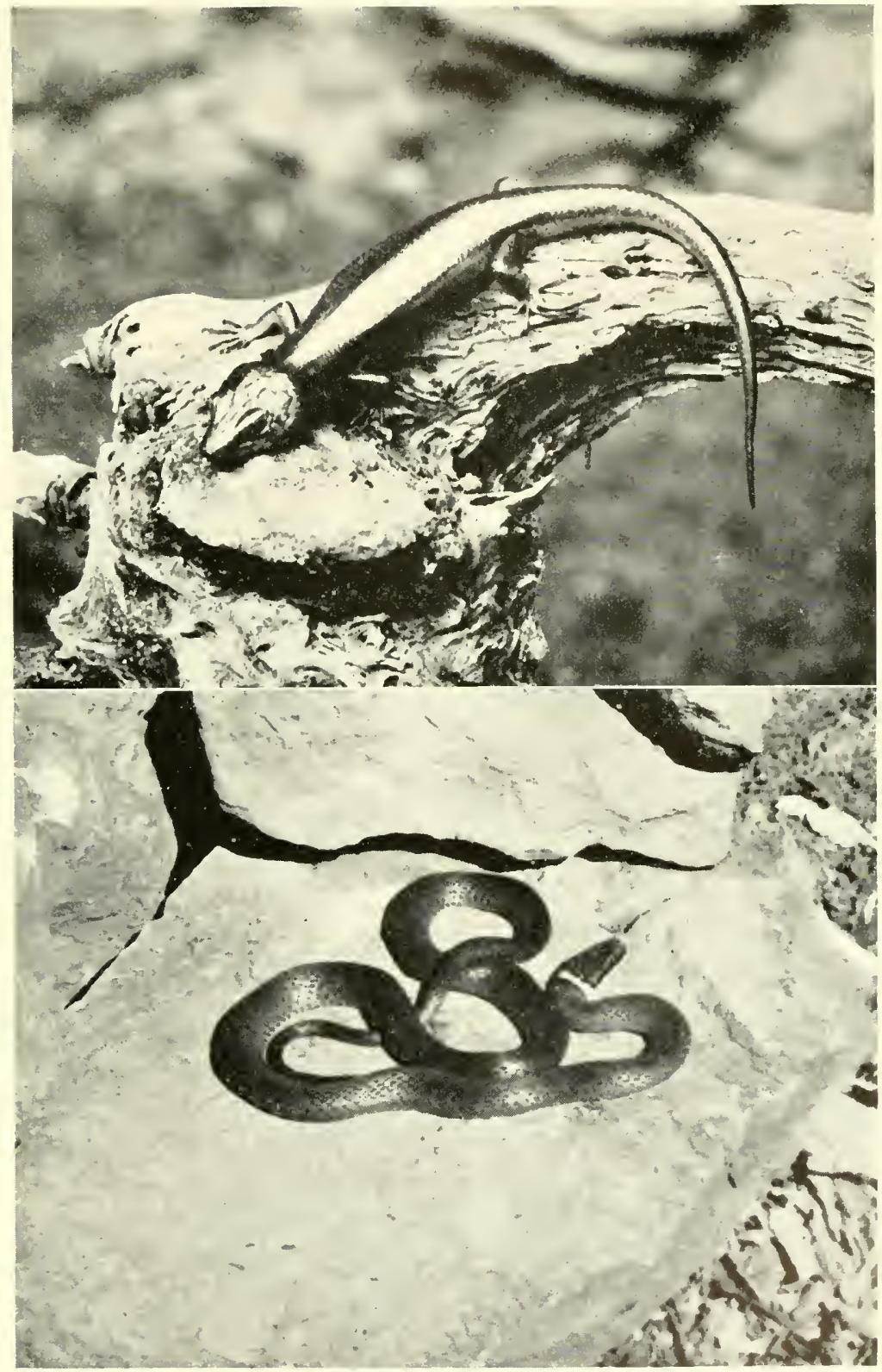

Plate 4. Fig. I. Large-Headed Skink, Eumeces laliceps. Adult male from southern Missouri. Length about 8 inches. Photo taken at the St. Louis Zoo by R. Conant. Fig. 2. Ring-necked Snake, Diadophis pinctatus edwardsii. Pymatuning Swamp near Andover, Ashtabula County, May 21, 1932. Length 193/4 inches. Photo by L. D. Hielt. 


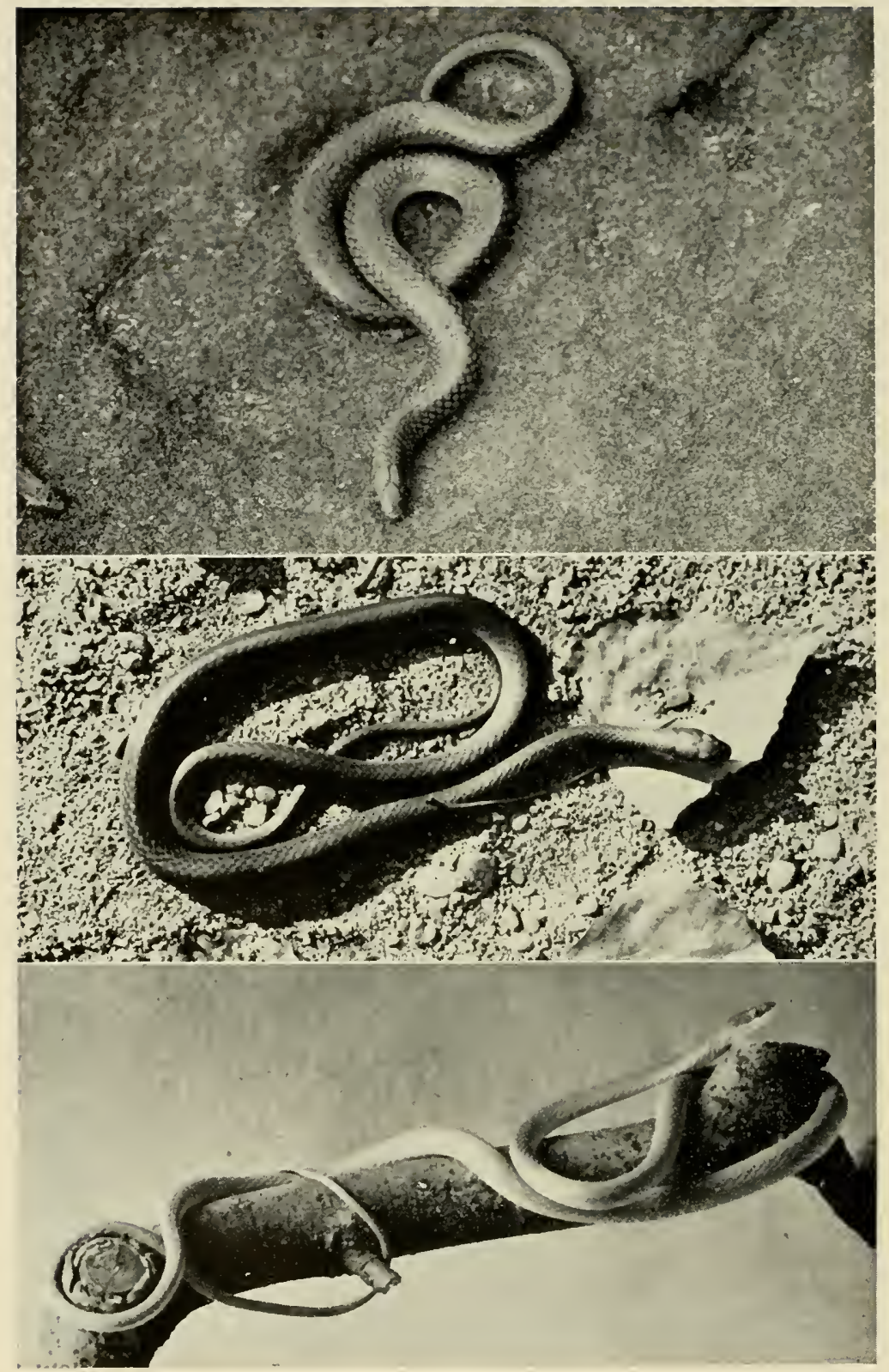

Plate 5. Fig. 1. Worm Snake, Carphophis amoena helenae. "Neotoma," Good Hope Twp., Hocking County, May, 1925. Length about 10 inches. Photo by Edward S. Thomas. Fig. 2. Smooth Green Snake, Opheodrys vernalis. Patterson, Hardin County, September 1, 1932. Length 191/4 inches. Photo by L. D. Hiett. Fig. 3. Keeled Green Snake, Opheodrys aestivus. Portland, Meigs County, August 31, 1932. Length $291 / 2$ inches. Photo by Edward S. Thomas. 


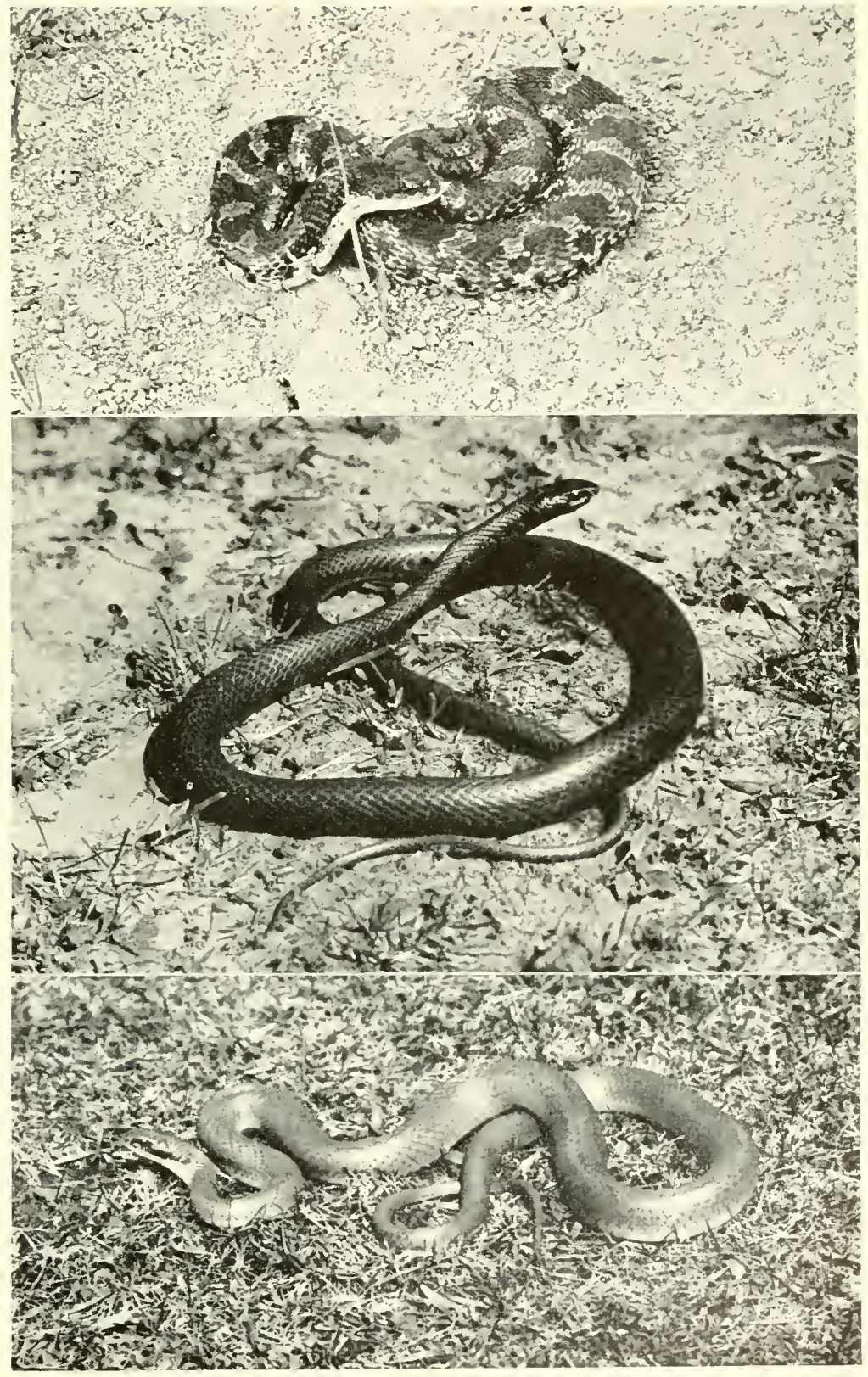

Plate 6. Fig. 1. Hog-nosed Snake, Heterodon contortrix. Creen Tw?.. Adams County, August, 1927. Length 30 inches. Photo by Edward S. Thomas. Fig. 2. Black Racer, Coluber constrictor constrictor. Near Linton Mills, Coshocten County. May 20. 1933. Length 591/4 inches. Photo by R. Conant. Fig. 3. Blue Racer, Coluber const.ictor fariventris. Near Sylvania, Lucas County. April 2, 1933. Length abcut 4 feet. Phots by L. D. Hiett. 


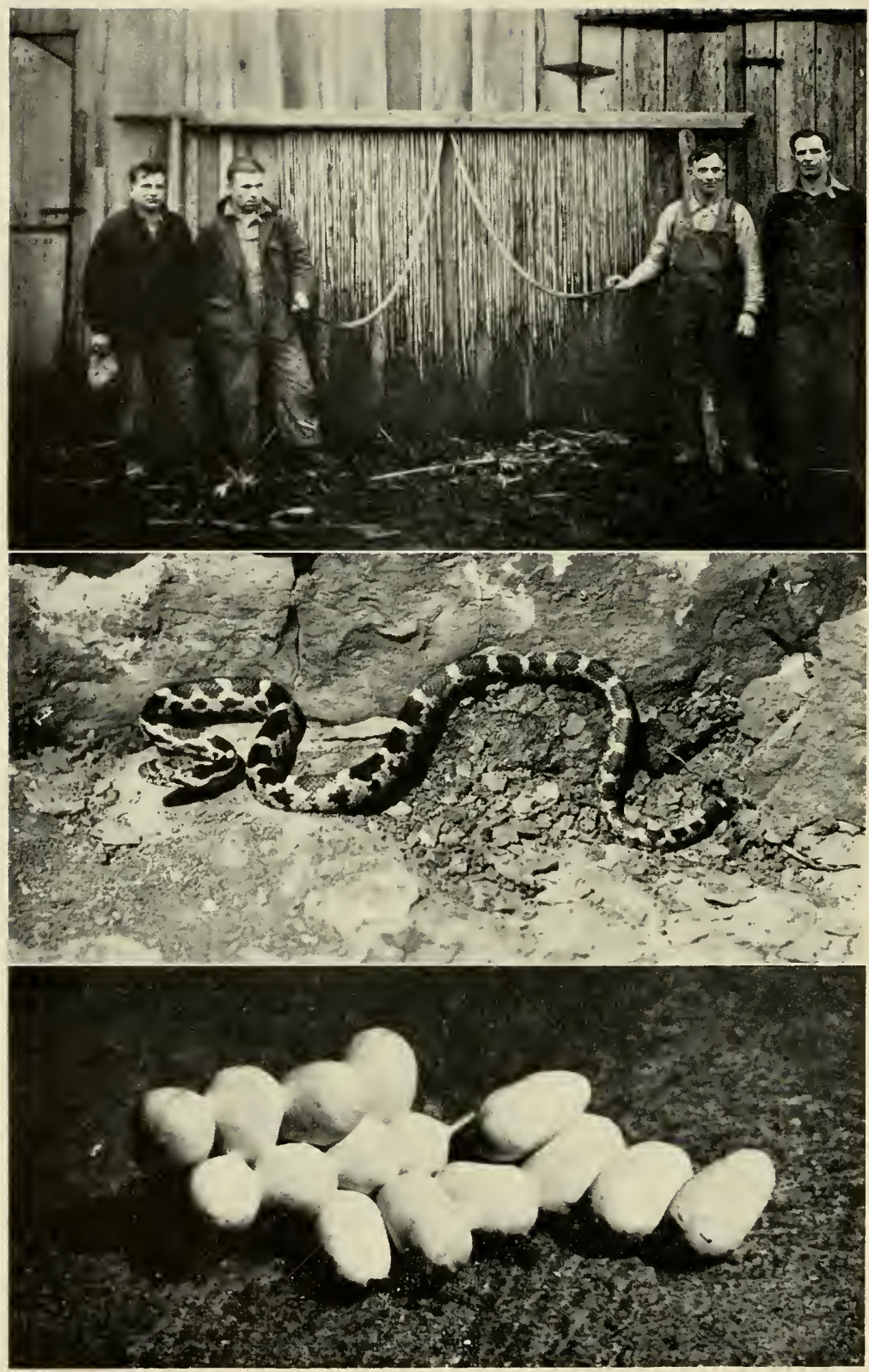

Plate 7. Fig. 1. Racers, Coluber. A group of 106 racers slaughtered by farmers near Bellville, Richland County, February, 1932. The potential value of these snakes, in point of numbers of rats and mice they might destroy, is incalculabe. Fig. 2. Pilot Black Snake, Elaphe obsoleta obsoleta (juvenile). Gilead Twp.. Morrow County, Jun 13,1931 . Length 127/8 inches. Photo by R. Conant. Fig. 3. Eggs of Fox Snake, Elaphe vulpina. Laid in captivity July 17, 1930, by a female 4 feet in length collocted near Port Clinton, Ottawa County. Weight of clutch $71 / 2$ ounces. Photo by R. Conant. 

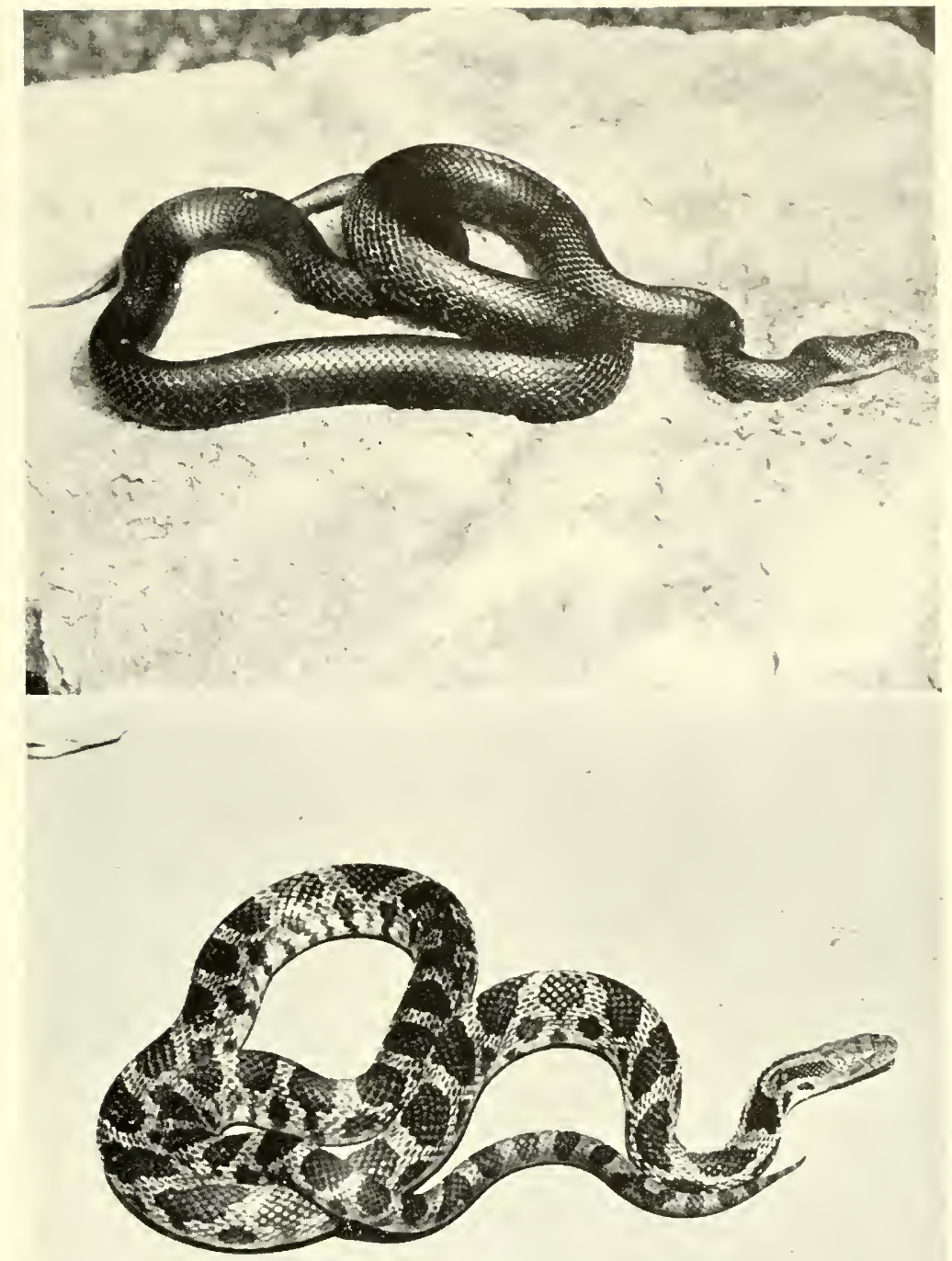

Plate 8. Fig. 1. Pilot Black Snake, Elaphe obsoleta obsoleta. Ohio Canal. Oxford Twp.. Coshocton County, May 20, 1933. Length about 5 feet. Photo by R. Conant. Fig. 2. Fox Snake, Elaphe vulpina. Lithle Cedar Point, Lucas County, Ohio, June 18, 1938. Length 56 inches. Phoo by Mark Mooney, Jr. 


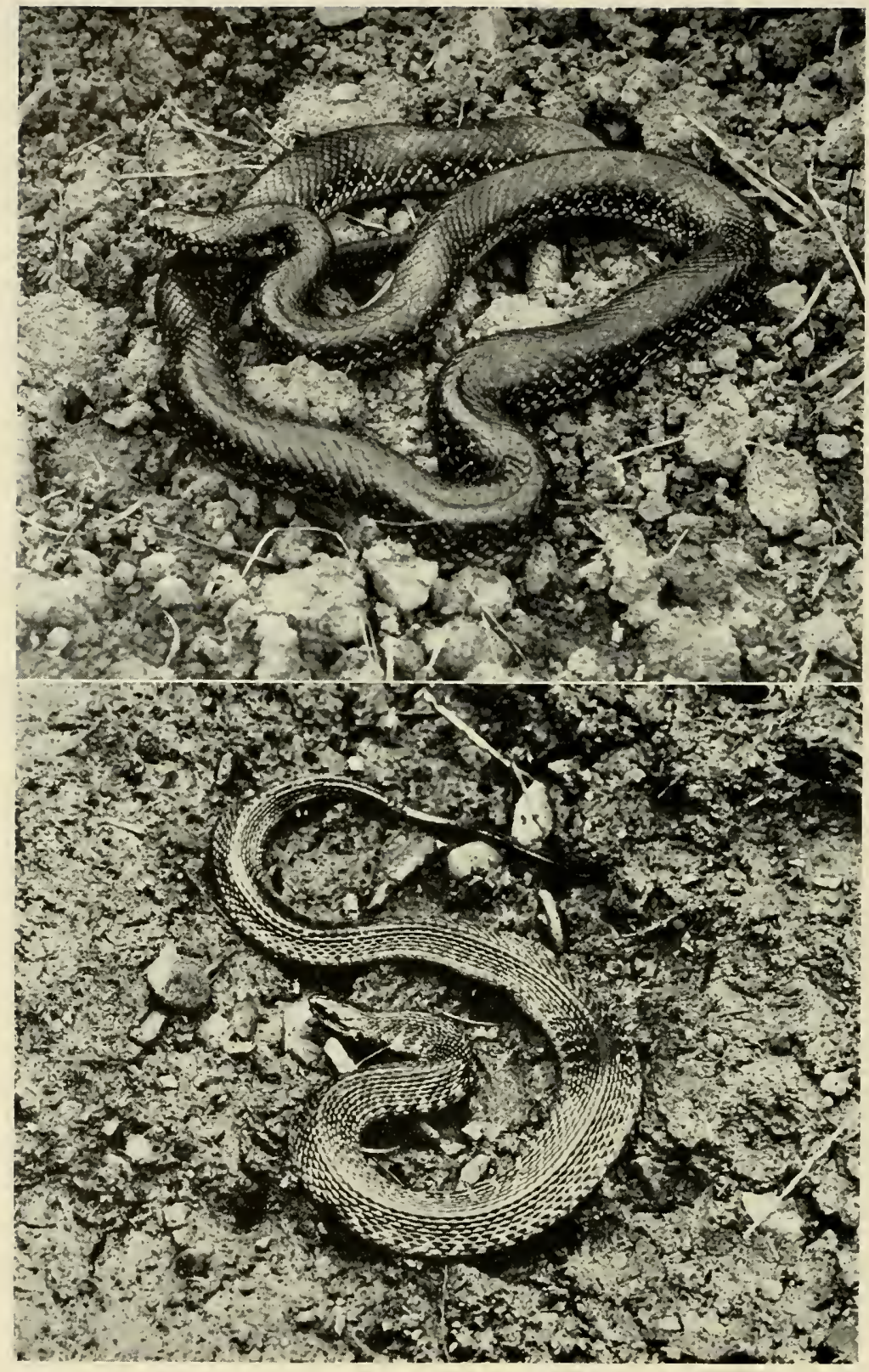

Plate 9. Fig. 1. Black King Snake, Lamoropeltis getulus nigra. Rrck Run, W of Buena Vista, Green Twp., Adams County, April 24, 1927. Length 38 inches. Photo by Edward S. Thomas. Fig. 2. Kirtland's Water Snake, Natrix kirtlandii. Sugar Grove, Fairfield County, February 21, 1926. Length 151/2 inches. Photo by Edward S. Thomas. 

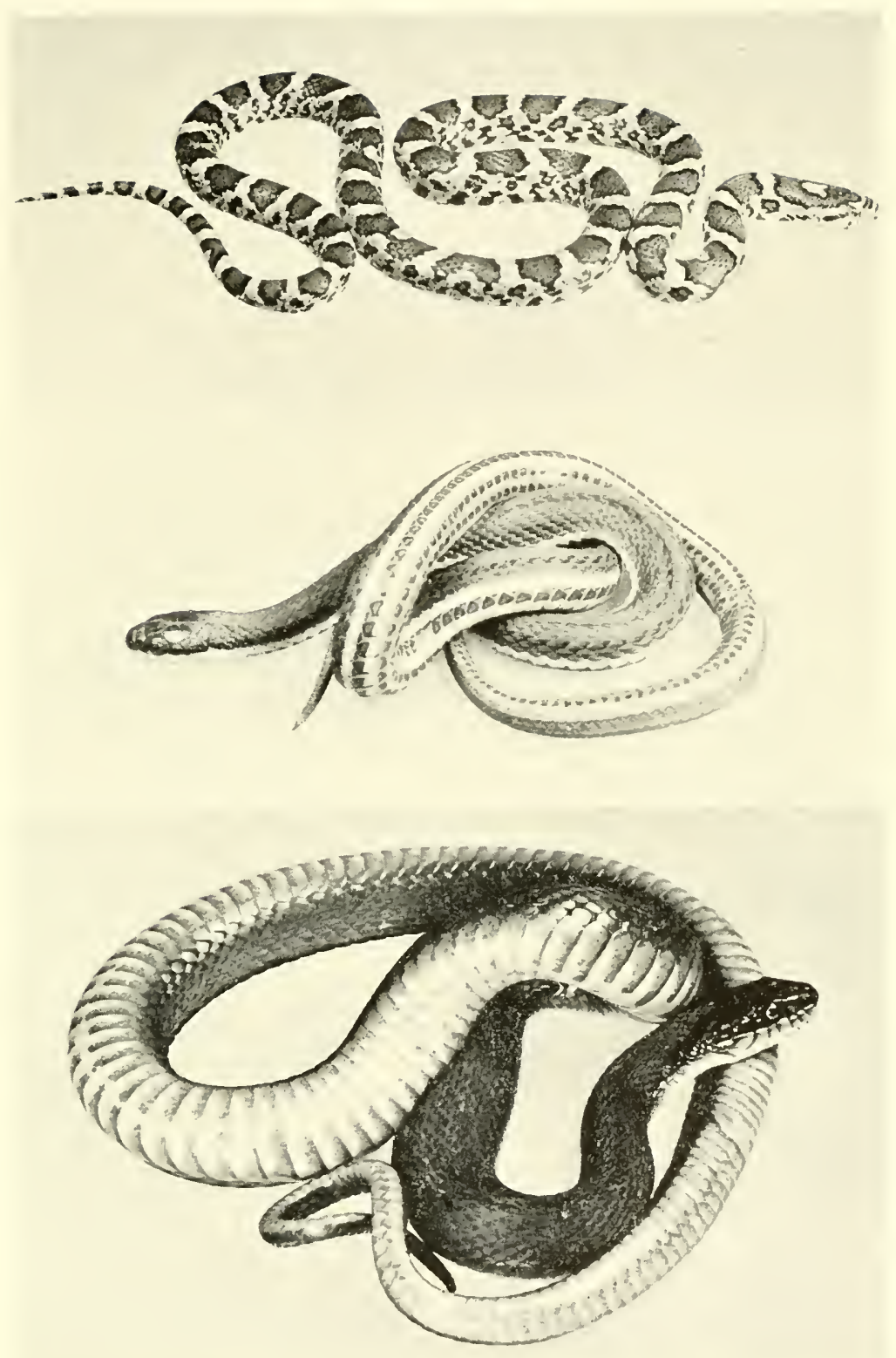

Plate 10. Fig. 1. Milk Snake, Lampropeltis triangulum triangulum. Length about 30 inches. Photo by H. K. Gloyd. Fig. 2. Queen Snake, Natrix septemittata. Huron River at Monroeville, Huron County. August 29. 1932. Length about 2 feet. Photo by H. K. Gloyd. Fig. 3. Red-bellied Water Snake, Natrix erythrogaster erythrogaster. One mile SW of Blakesley, Williams County, April 22, 1933. Length about 42 inches. Photo by H. K. Gloyd. 

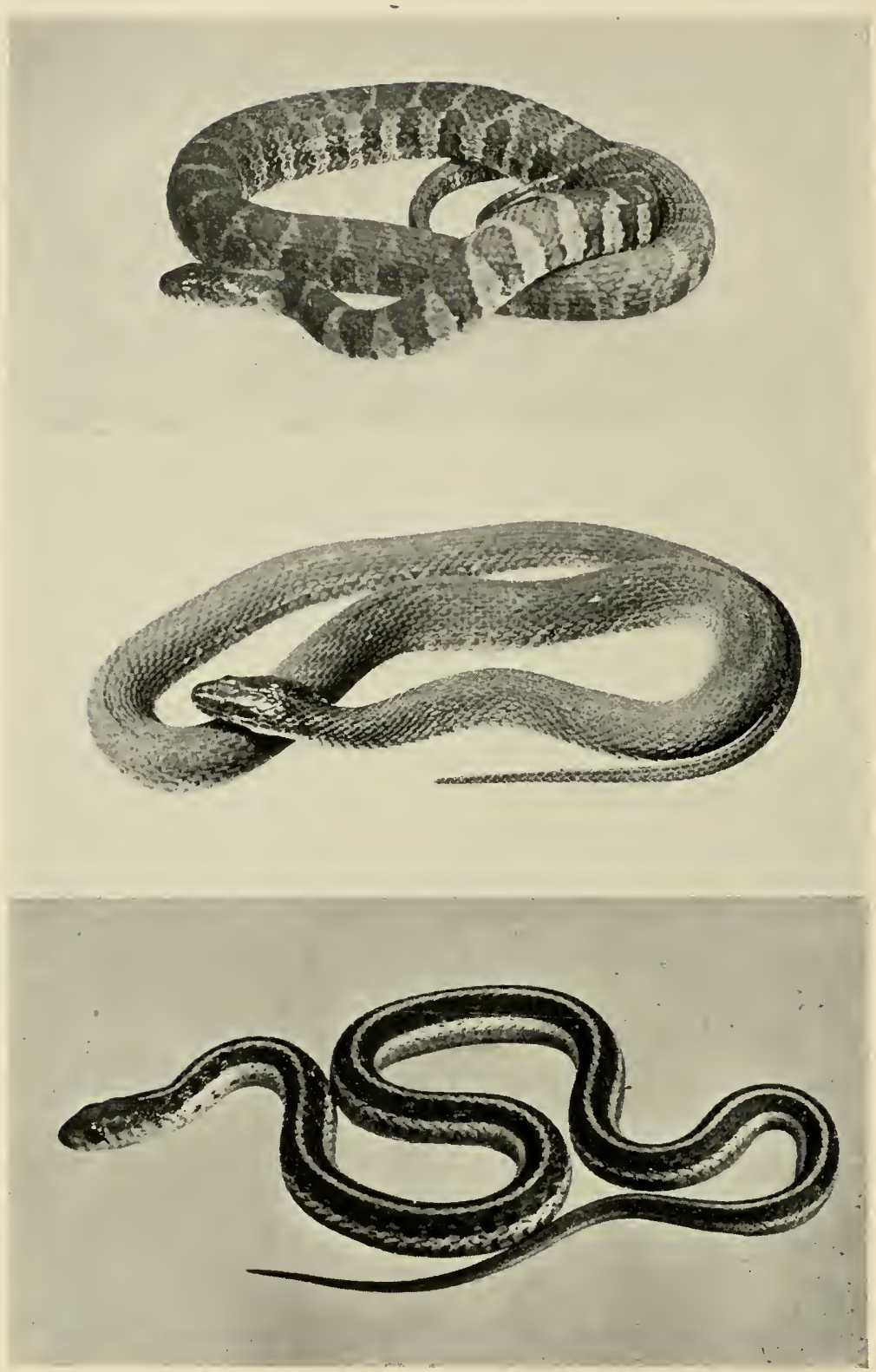

Plate 11. Fig. 1. Common Water Snake, Natrix sipedon sipedon. Ann Arbor, Michigan. Length about 30 inches. Photo by Wm. M. Clay. Fig. 2. Island Water Snake, Natrix sipedon insularum. Put-in-Bay, Ottawa Ccun:y, June 1, 1935. Length about 30 inches. Photo by Wm. M. Clay. Fig. 3. Common Garter Snake, Thamnophis sirlalis sirtalis. Length about 24 inches. Photo by H. K. Gloyd. 


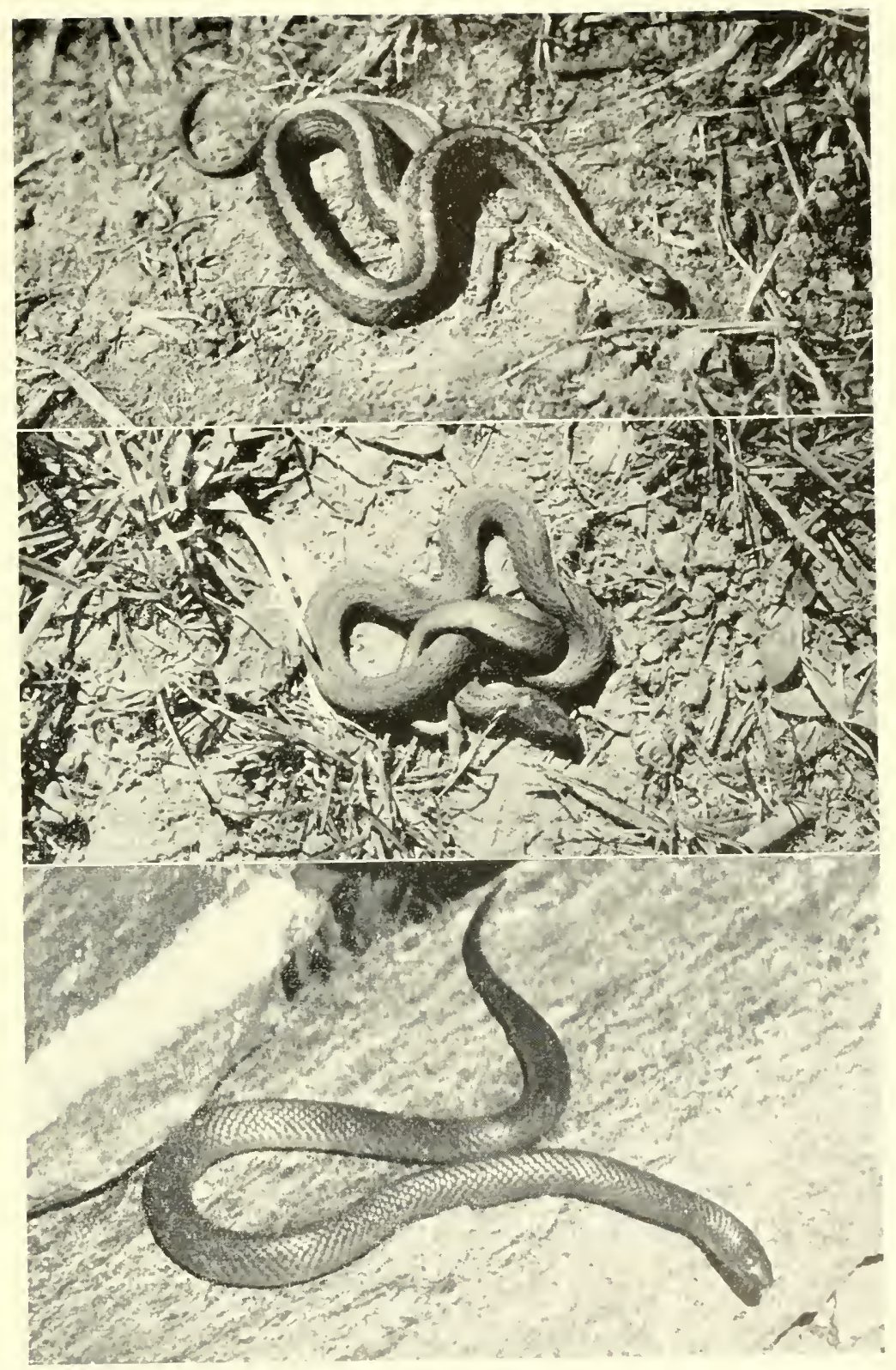

Plate 12 Fio. I. Dekay's Snake, Storeria dekavi. Cass Twp.. Hancock County, August 1, 1931. Length abcut 12 inches. Photo by R. Conant. Fig. 2. Storer's Snake, Storcria occipito-maculata. Two miles $E$ of Monroe Center. Ashtabula County, Afril 23, 1932. Length 10 inches. Photo by F. R. Flickinger. Fig. 3. Ground Snake, I'irginia valeriae valeriae. Six miles NNE of Elverson, Pennsylvania, May, 1936. Length $8 \frac{1}{2}$ inches. Photo by Mark Mconey. Jr. 


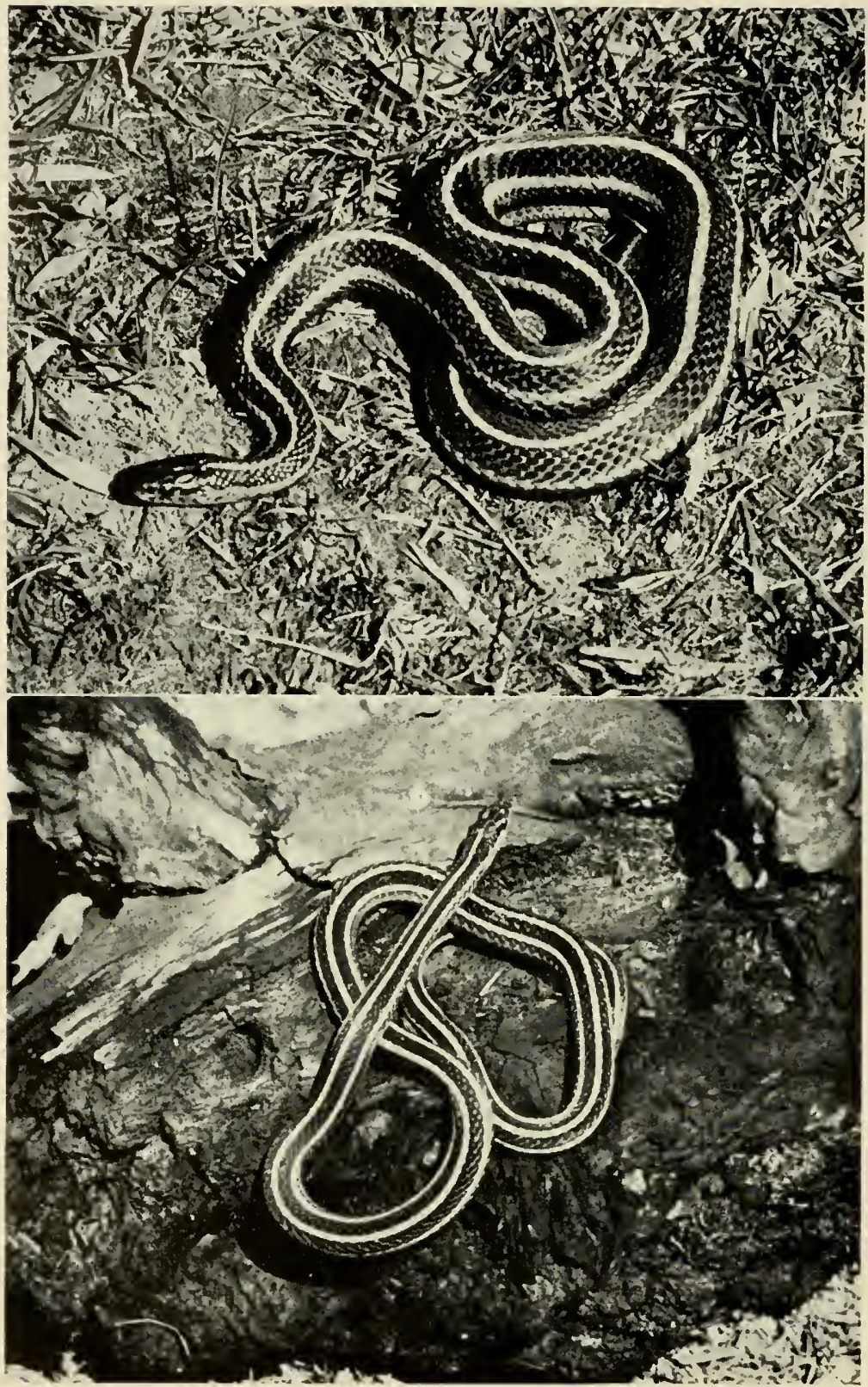

Plate 13. Fig. I. Butler's Garter Snake, Thamnophis butleri. Bono, Lucas County, May 26, 1932. Length 22 inches. Photo by L. D. Hiett. Fig. 2. Ribbon Snake, Thamnophis sauritus sauritus. Oak Openings, near Holland, Lucas County. April 12. 1931. Length 28 inches. Photo by L. D. Hiett. 

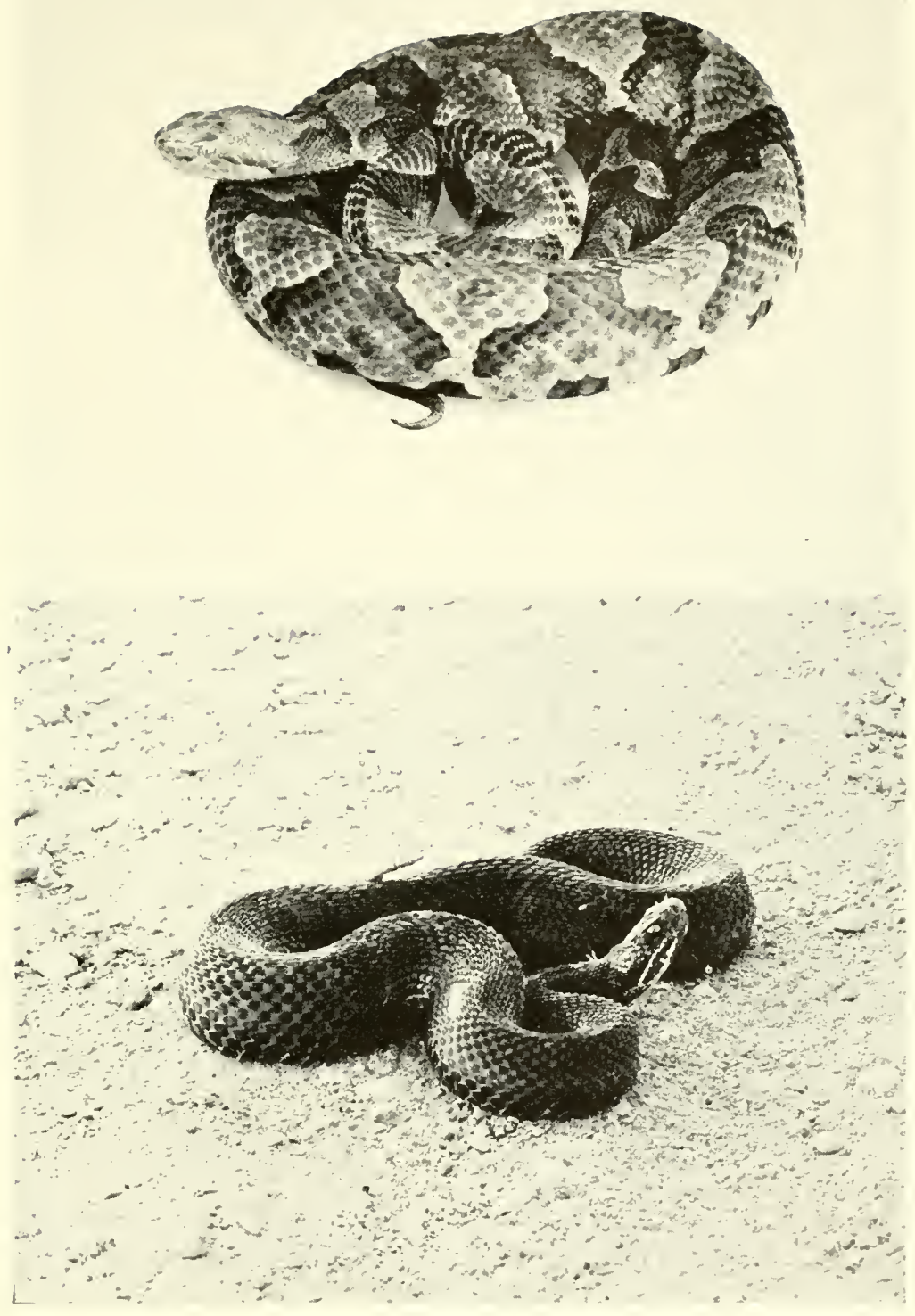

Plate 14. Fig. I. Copperhead, Agkistrodon mokasen mokasen. Mifflin Twp.. Pike County, July 9, 1931. Length 27 inches. Photo by H. K. Gloyd. Fig. 2. Massasauga, Sistrurus catenatus catenatus (melinistic specimen). Willard Bog, Richmend Twp., Huron County. August 7, 1927. Leng:h 211/2 inches. Photo by Edward S. Thomas. 

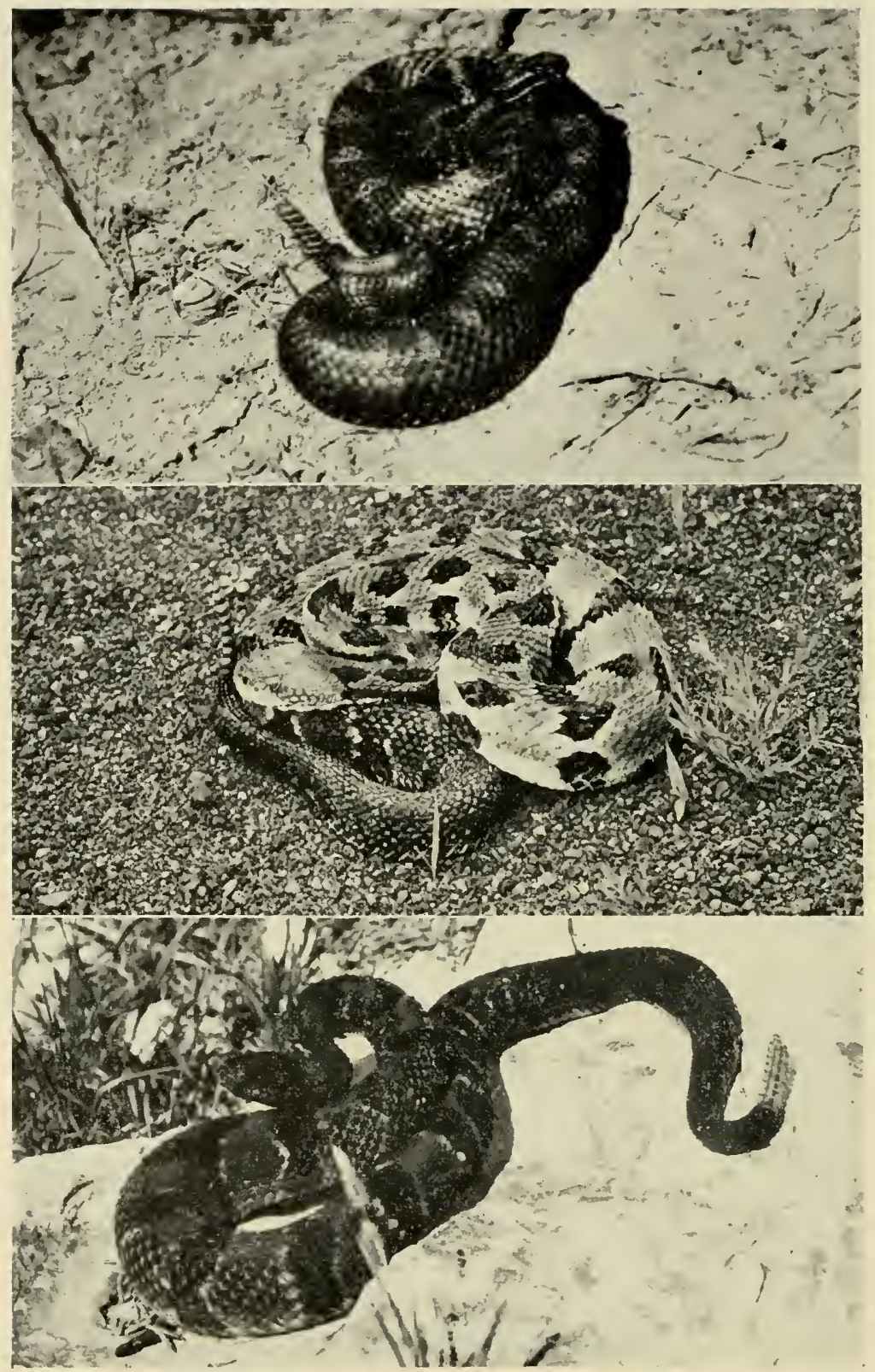

Plate 15. Fig. 1. Massaszuga, Sistrurus catenatus catenatus. Near Holland, Lucas County, April 20, 1930. Length about 30 inches. Phcto by R. Ccnant. Fig. 2. Timber Rattlesnake, Crotal is horridus horridus (yellow phase). Shawnee Forest, Union Twp., Scioto County, July 9, 1928. Length $403 / 4$ inches. Photo by Edward S. Thomas. Fig. 3. Timber Ratllesnake, Crotalus horridus horridus (dark phase). Paxten Twp., Ross County, July 3, 1931. Lengih 47 inches. Photo by R. Conant. 

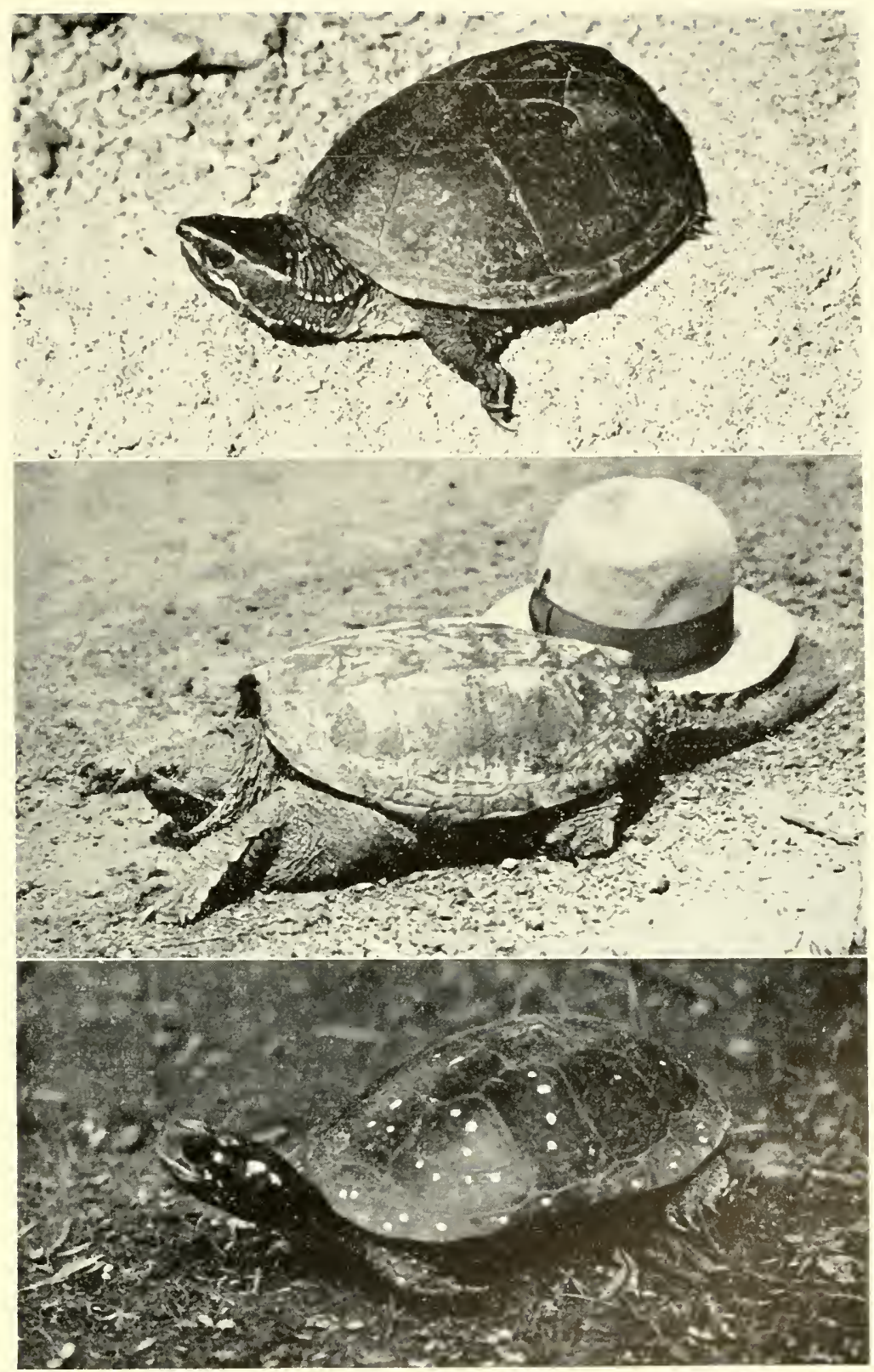

Plate 16. Fig. 1. Musk Turtle, Sternotherus odoratus. Philadelphia, Pennsylvania. Length of carapace $41 / 2$ inches. Photo by Mark Muoney. Jr. Fig. 2. Snzpping Tu-tle, Chelydra serpentina. Catawba Island, Ottawa County, June 21. 1931. Weight 20 pounds. Photo by L. D. Hiett. Fig. 3. Spotted Turtle, Clemmys guttata. Aźams Twp., Lucas County, May, 1932. Length of carapace about $41 / 4$ inches. Photo by L. D. Hiett. 


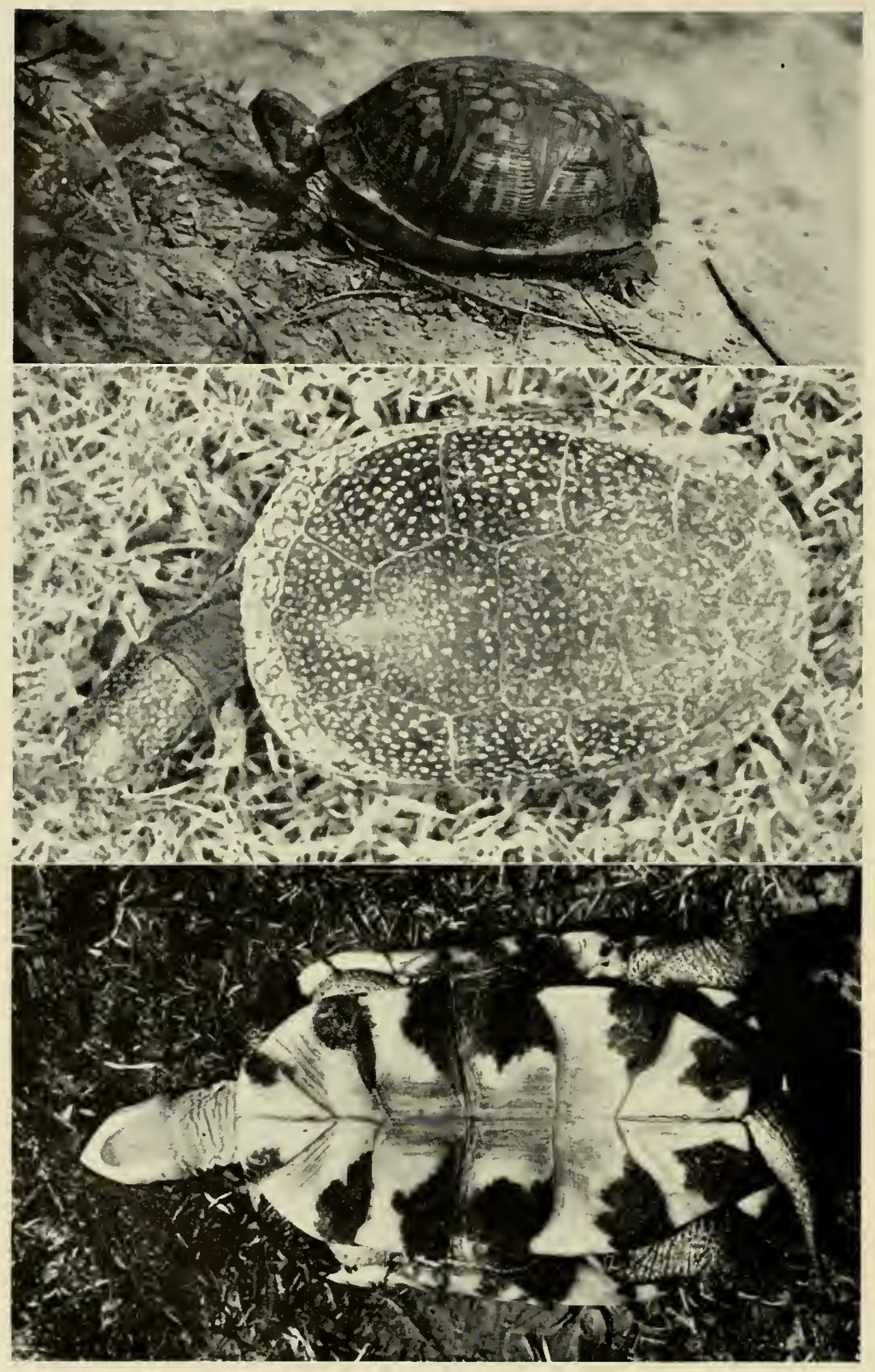

Plate 17. Fig. I. Box Turtle, Terrapene carolina. Beverly, Washingten County, September 4, 1925. Length of carapace about 6 inches. Photo by Edwa.d S. Thomas. Figs. 2 and 3. Blanding's Tuitle, Emys blandingii (dorsal and ventral views). One mile S of Blakesley. Williams County, May 7, 1932. Length of carapace $81 / 2$ inches. Photos by L. D. Hiett. 


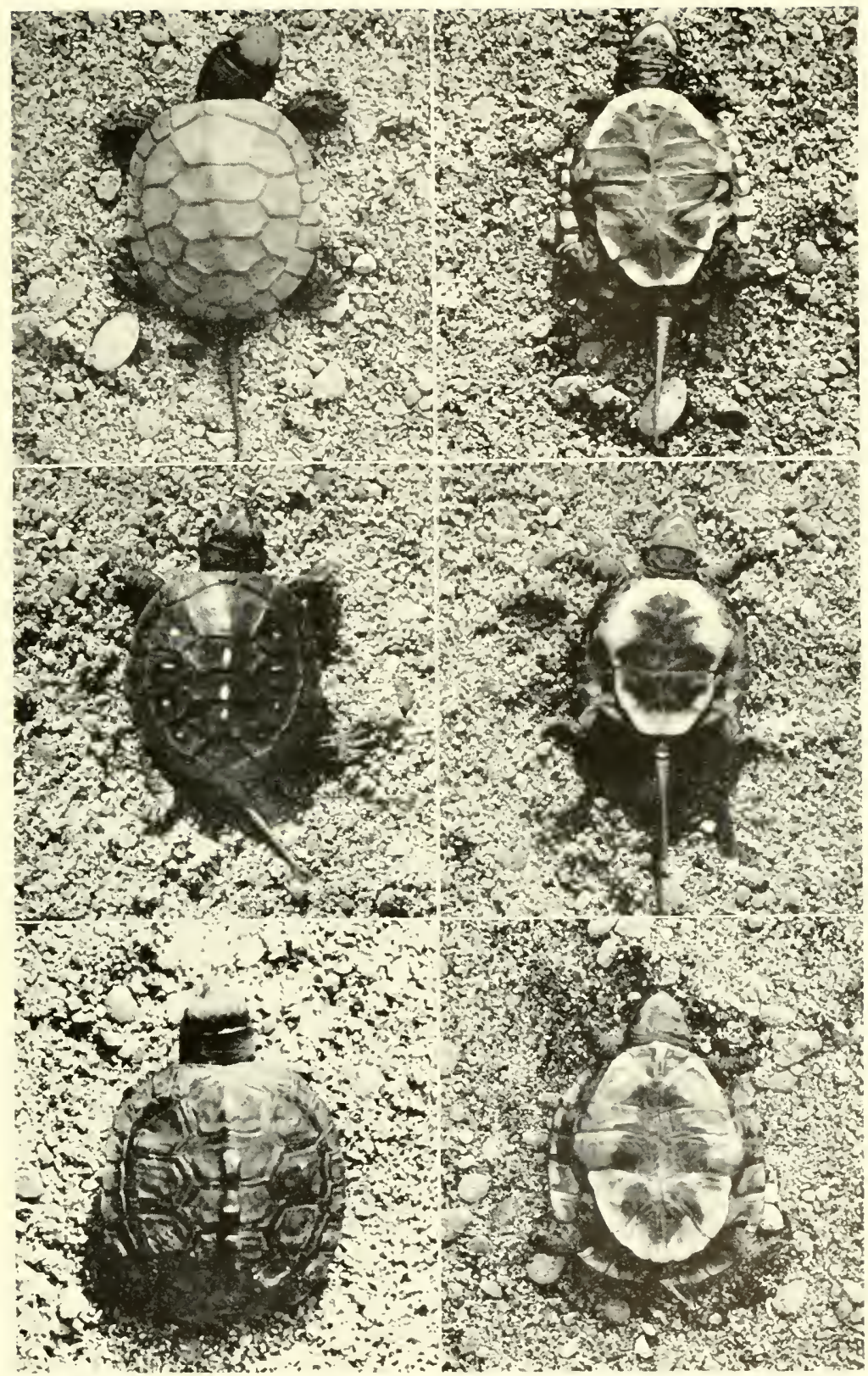

Plate 18. Figs. I and 2. Blanding's Turtle, Emys blandingii (dorsal and ventral views of juvenile). Near Trilby, Lucas County, October 4, 1932. Length of carapace $11 / 4$ inches. Photos by L. D. Hiett. Figs. 3 and t. Spotted Turtle. Clemmys guttata (dorsal and ventral views of juvenile). Oak Openings, Springfield Twp., Lucas Cotnty, October 2, 1932. Length of carapace 1332 inches. Photos by L. D. Hiett. Figs. 5 and 6. Box Turtle, Terrapene carolina (dorsal and ventral views of juvenile). Trilby, Lucas County, October 26, 1932. Length of carapace 13/8 inches. Photos by L. D. Hiett. 


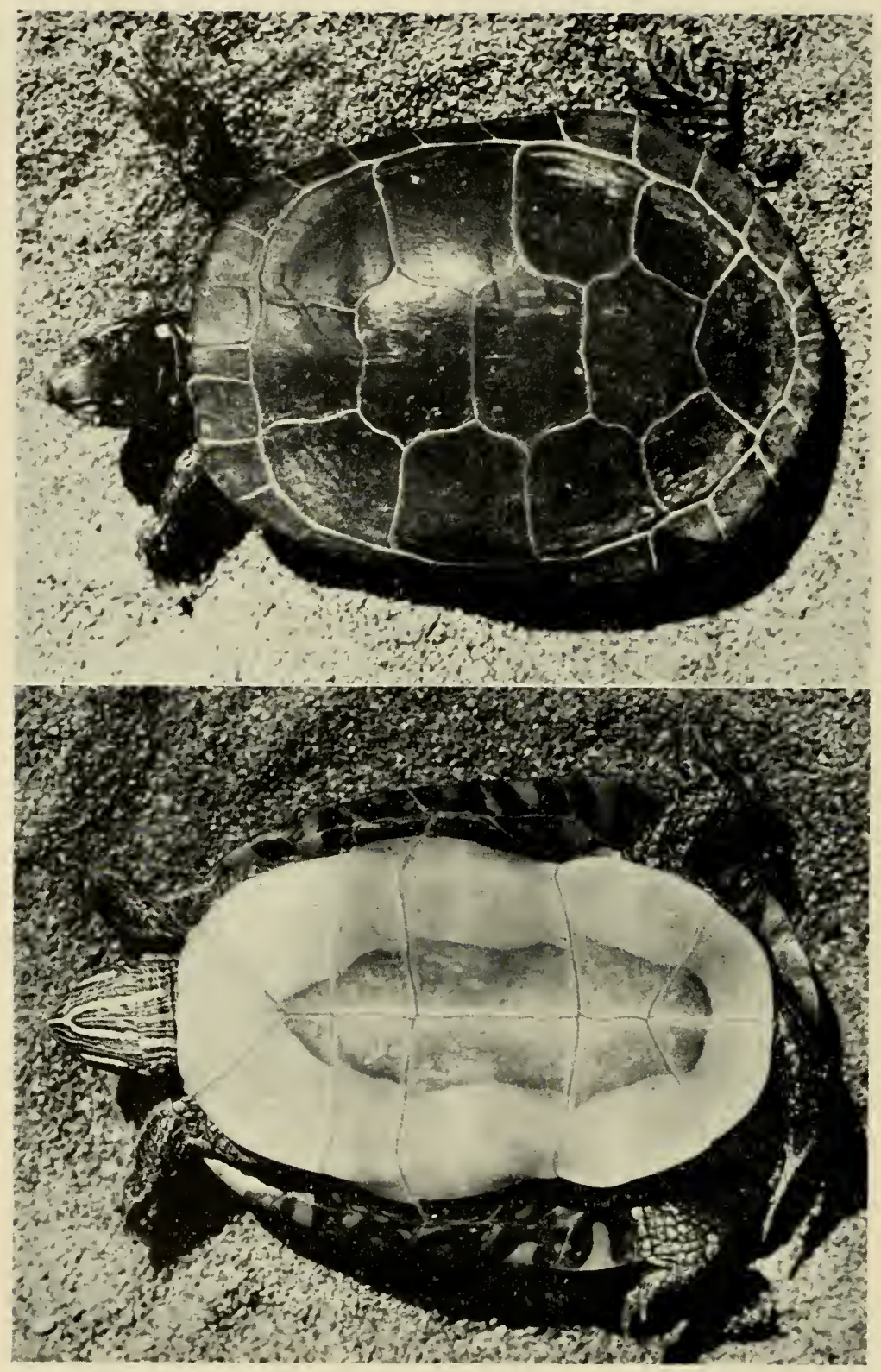

Plate 19. Figs. I and 2. Painted Turtle, Chrysemys bellii marginata (dorsal and ventral views). Toledo, Lucas County. April, 1928. Length of carapace about 51/2 inches. Photos by L. D. Hiett. 


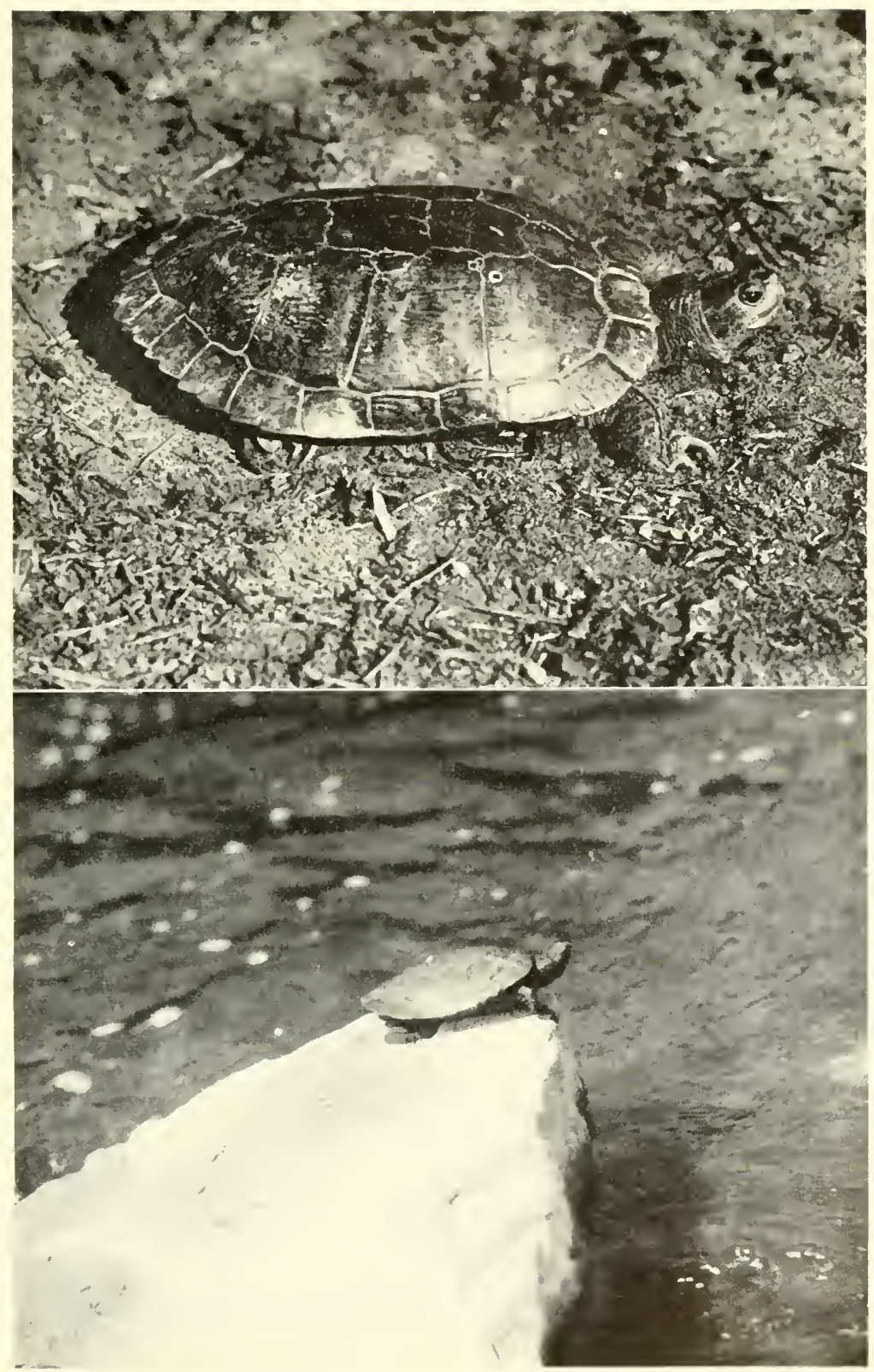

Plate 20. Fig. 1. Cumberland Terrapin, Pseudemys scripla troostii (adult mâle). Near Vauces, Ross County, May 5, 1934. Carapace length $81 / 2$ inches. Photo by R. Conant. Fig. 2. Map Turtle, Graptemys geographica. Specimen resting on a rock in the Maumee River, near Waterville, Lucas County, summer, 1931. Length of carapace about 5 inches. Photo by R. Conant. 


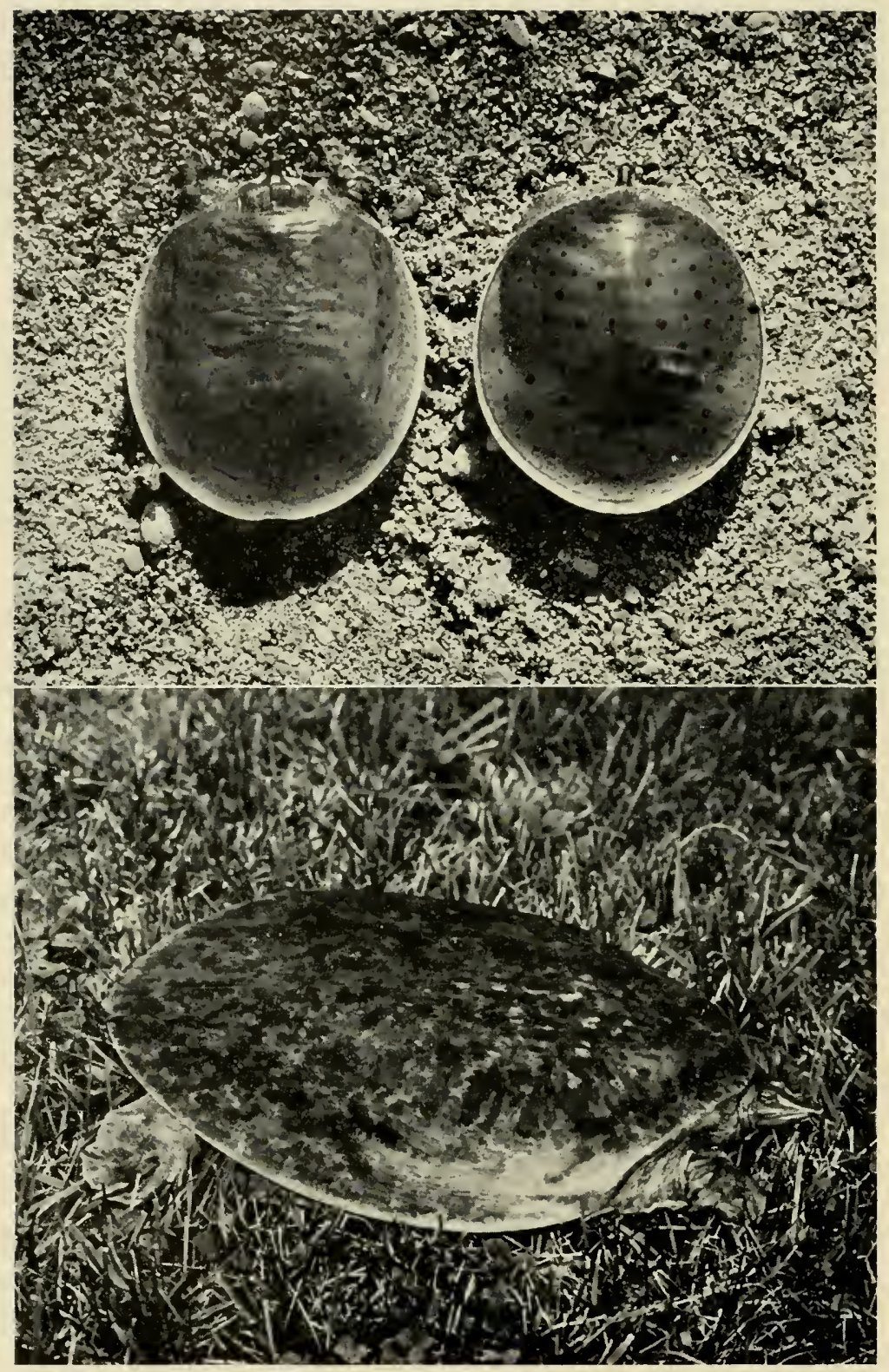

Plate 21. Fig. 1. Juvenile Soft-Shelled Turtles. Left-Amyda mutica. Scioto River, Newton Twp., Pike County, September 10, 1932. Carapace length 15/8 inches. Right-Amyda spinifera. Swan Creek near Whitehouse, Lucas County, May 19, 1932. Carapace length $17 / 16$ inches. Photo by L. D. Hiett. Fig. 2. Brown Soft-shelled Turtle, Amyda mutica (adult female). Mouth of White Oak Creek, Brown County; August 17, 1930. Length of carapace 9 inches. Photo by Edward S. Thomas. 


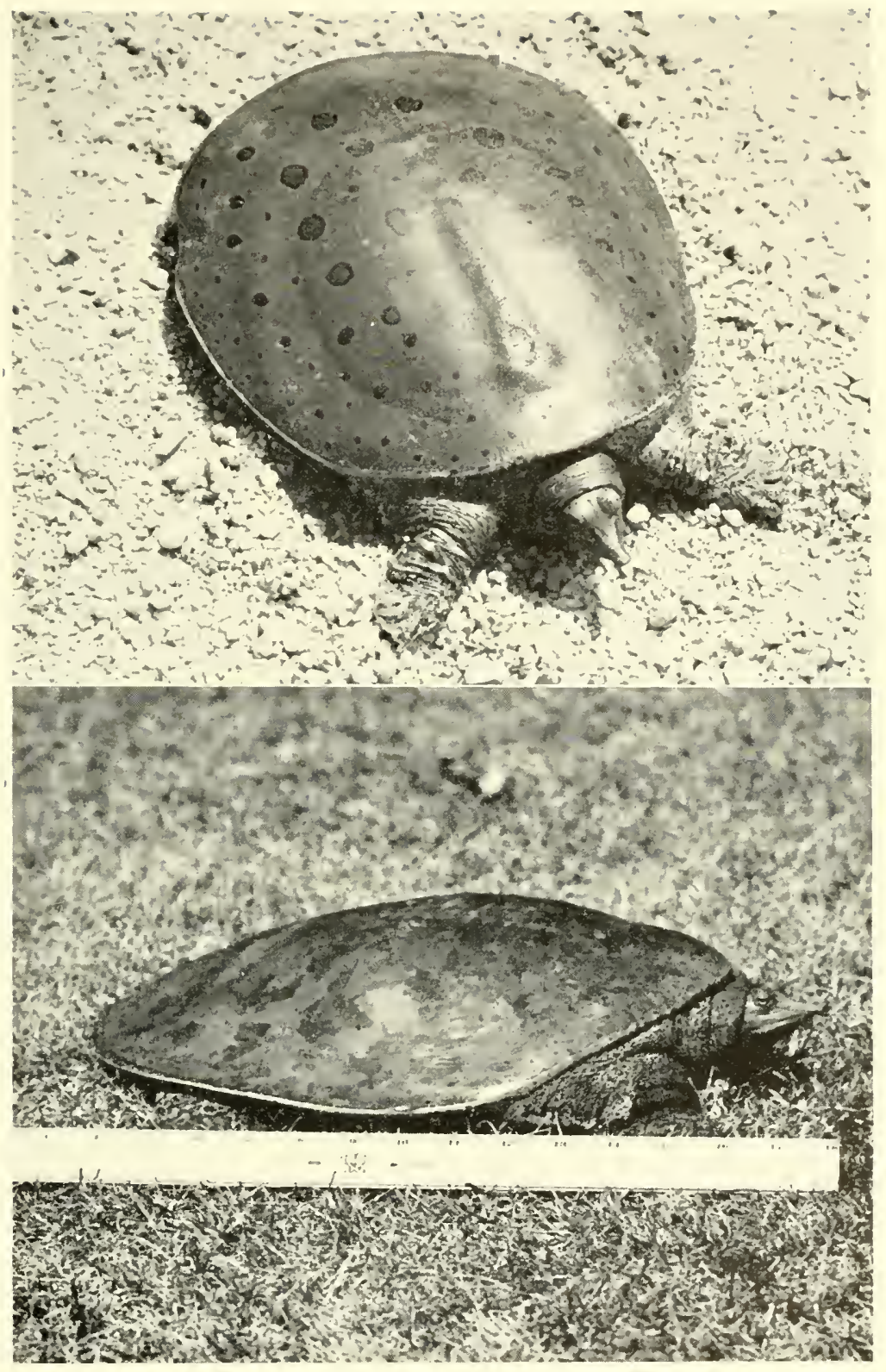

Plate 22. Fig. 1. Spiny Soft-shelled Turtle, Amuda spinifera (adult male). Specimen from southern Michigan. Length of carapace $63 / 4$ inches. Phots by Mark Mooney, Jr. Fig. 2. Spiny Soft-shelled Turtle, Amyda spinifera (adult female). Maumee River at Toledo, Lucas County, August, 1932. Length of carapace $1+1 / 2$ inches. Photo by L. D. Hiett. 

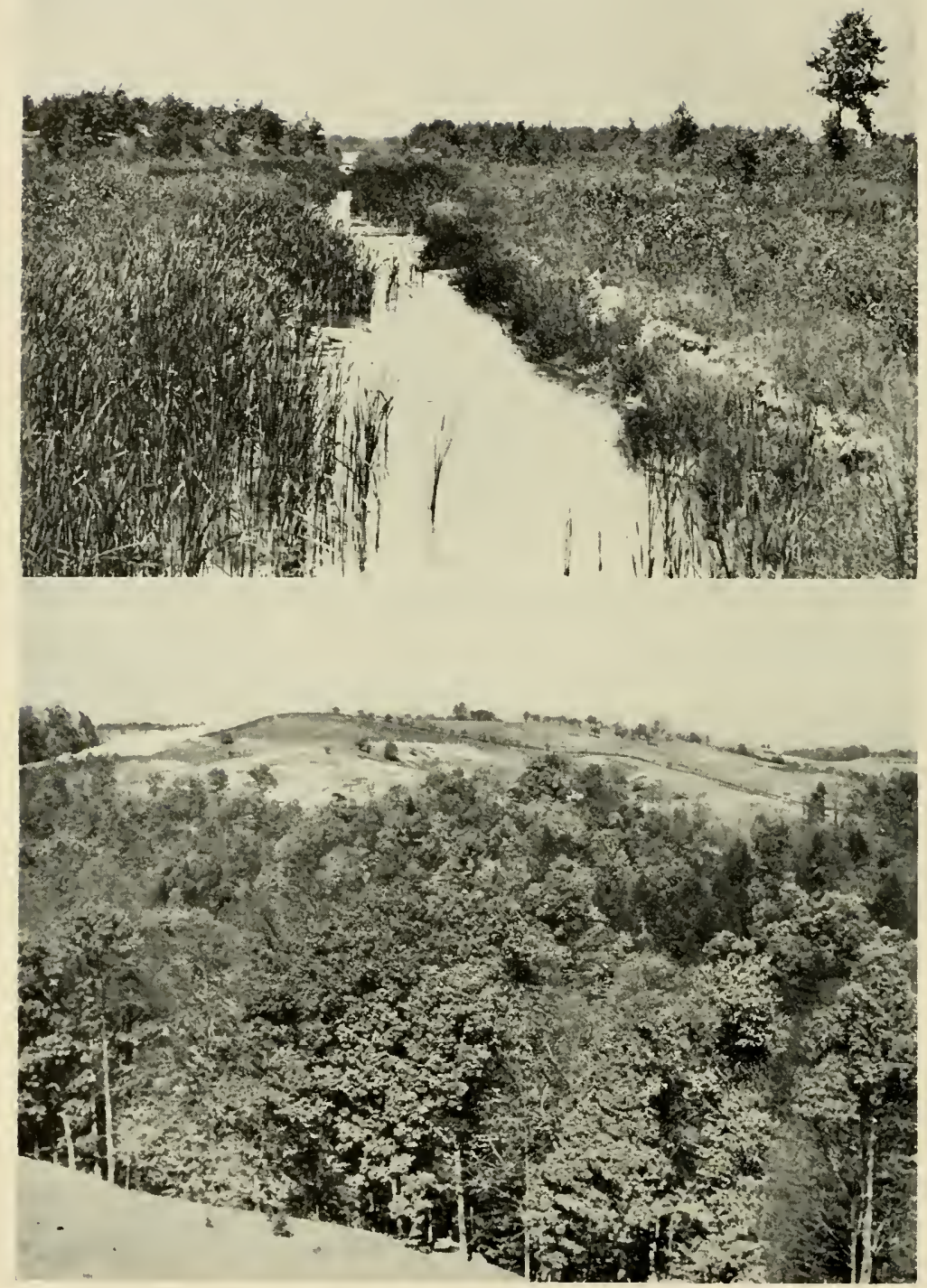

Plate 23. Fig. I. Oak Openings, Lucas County. Habitat of Heterodon contortrix, Thamnophis sauritus sauritus, Sistrurus catenatus catenatus and Terrapene carolina. Photo by Edward S. Thomas. Fig. 2. Hills near Beverly, Washington County. Habitat of such forms as Sceloporus undulalus, Diadophis punctalus edwardsii, Coluber constrictor constrictor, Elaphe obsoleta obsoleta and Terrapene carolina. Photo by Edward S. Thomas. 

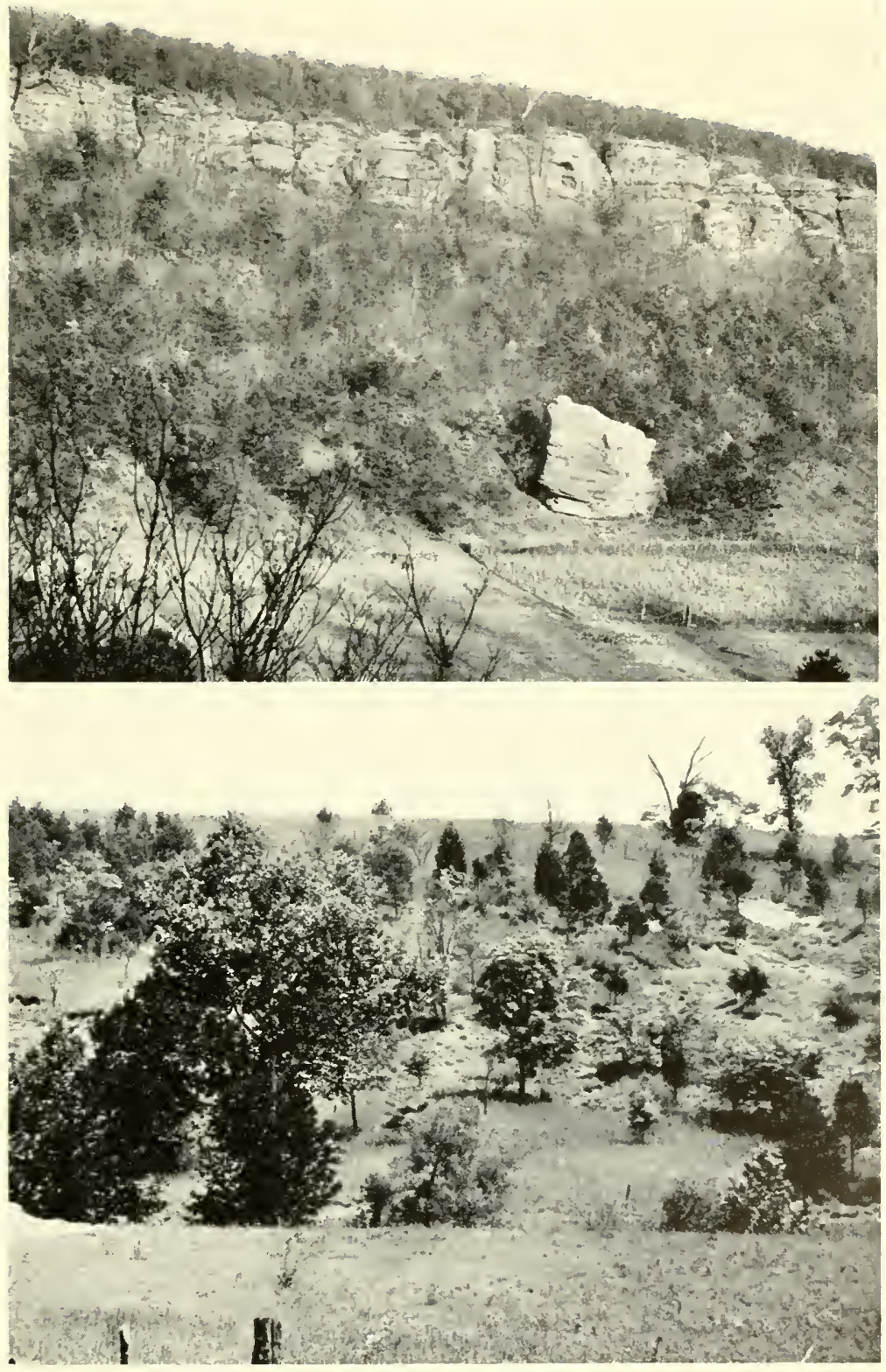

Plate 24. Fig. 1. Cliffs and Hillside at "Neotoma," Good Hope Twp., Hocking County. Habitat of Sceloporus undulatus, Eumeces laliceps, Heterodon contortrix, Coluber constrictor constrictor, Elaphe obsoleta obsoleta, Aghistrodon mokasen moleasen and Terrapene carolina. Photo by Edward S. Thomas. Fig. 2. Cedar Opening. Locust Grove, Adams County. Hibitat of Sceloporus undulaius and Opheod ys cestivus. Photo by Edward S. Thomas. 


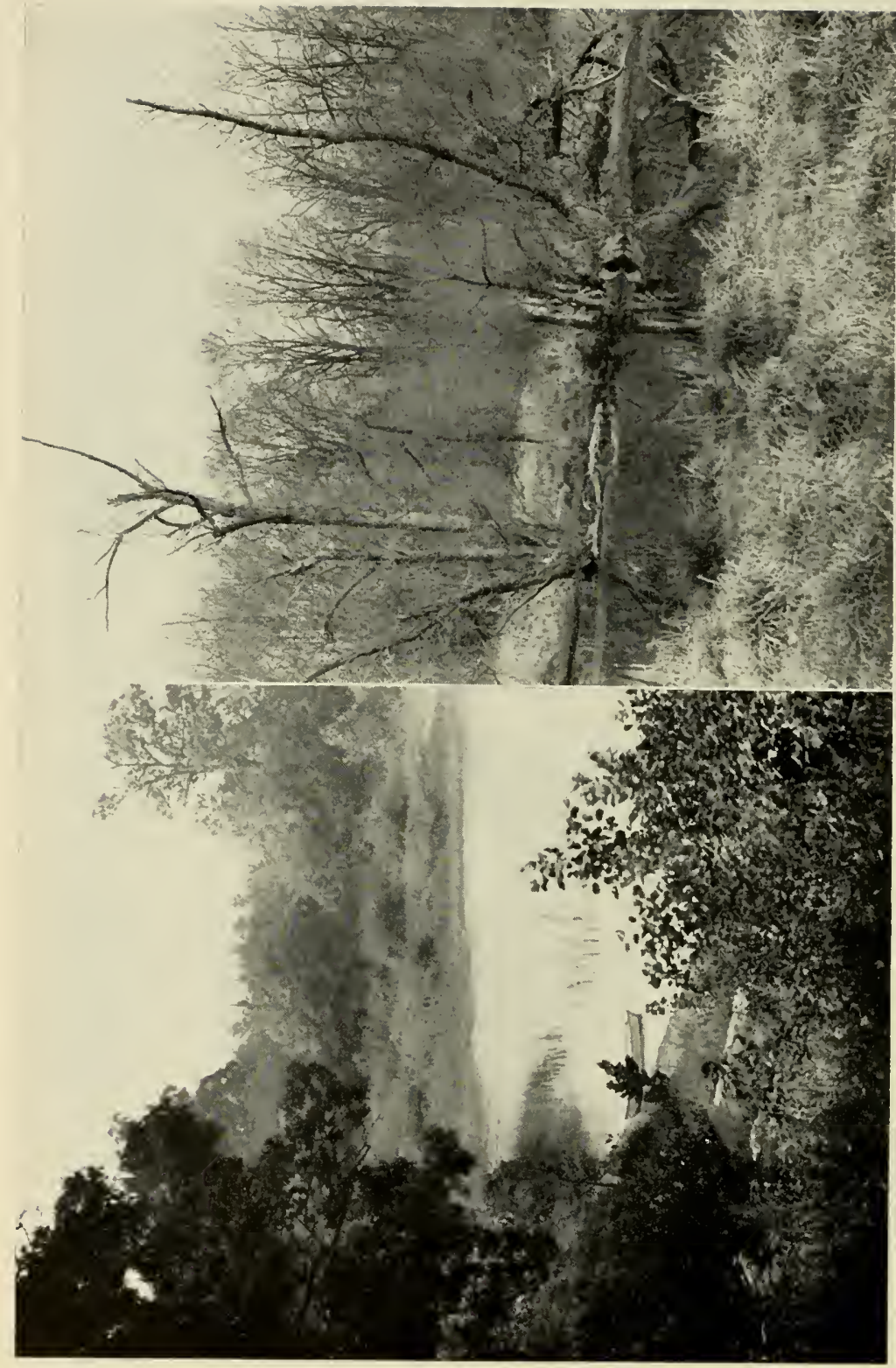

ป

등

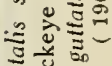

.

n

艺政

हे

ह 3

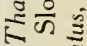

宅

고용

药

$E$.

近

के

๖

文F

ธें

ㅎํㅇ

产 $\frac{\pi}{\frac{\pi}{5}}$

$\therefore>\hat{5}$

5ㅇํㅇ

运.

要

을

.

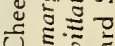

$\dot{d}:=\hat{\Xi}$

i ธ

$\sum^{\pi} \infty$

ข $\overrightarrow{\mathrm{E}}$

픈

- $2<\frac{2}{2}$

Eणั

巳一正.

- $\stackrel{0}{\approx}$

计专

กิร

岁定

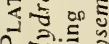

2. 


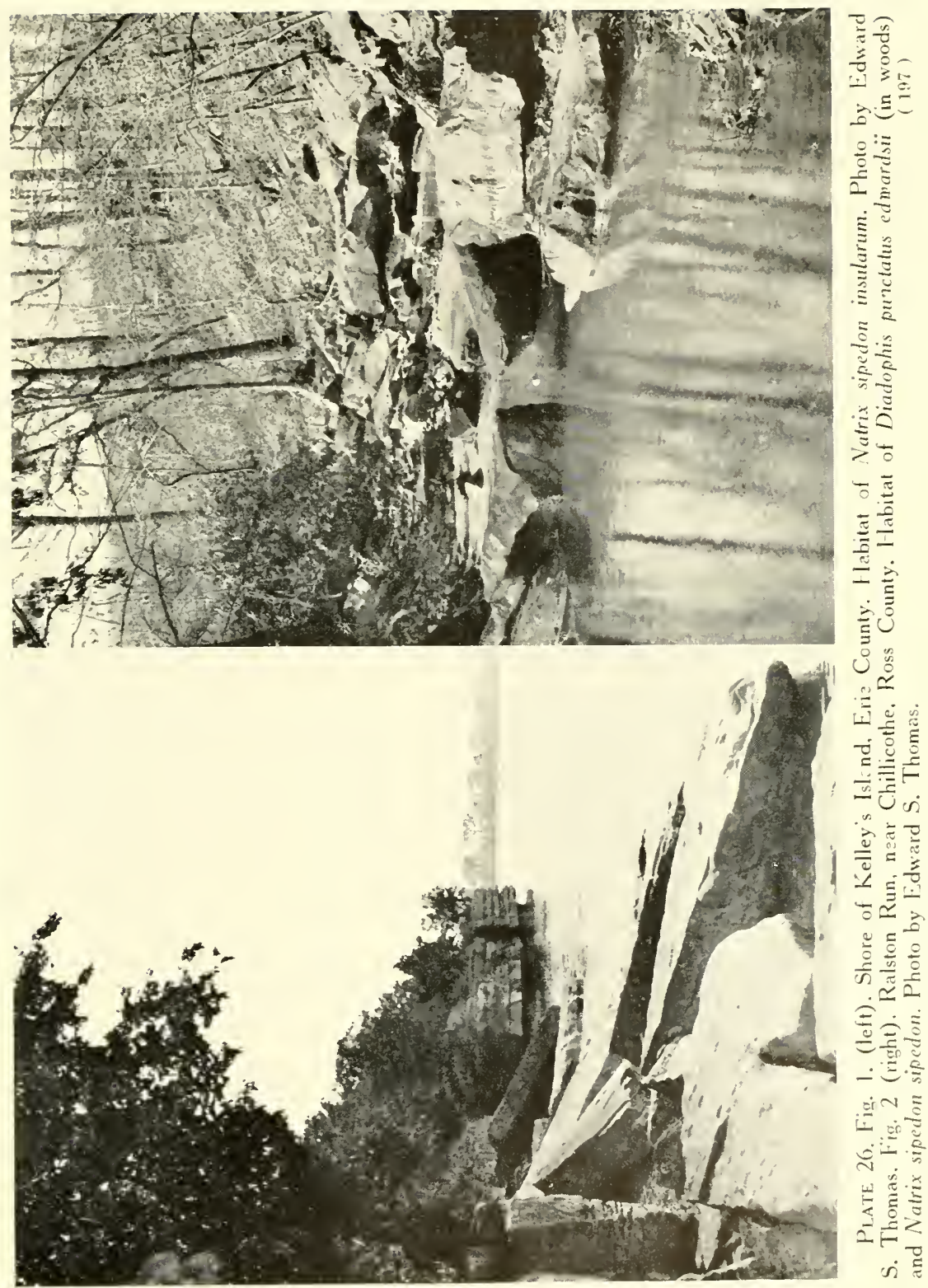





\section{Revisionary Addenda}

(Based upon Material and Data Accumulated Since 1938) 

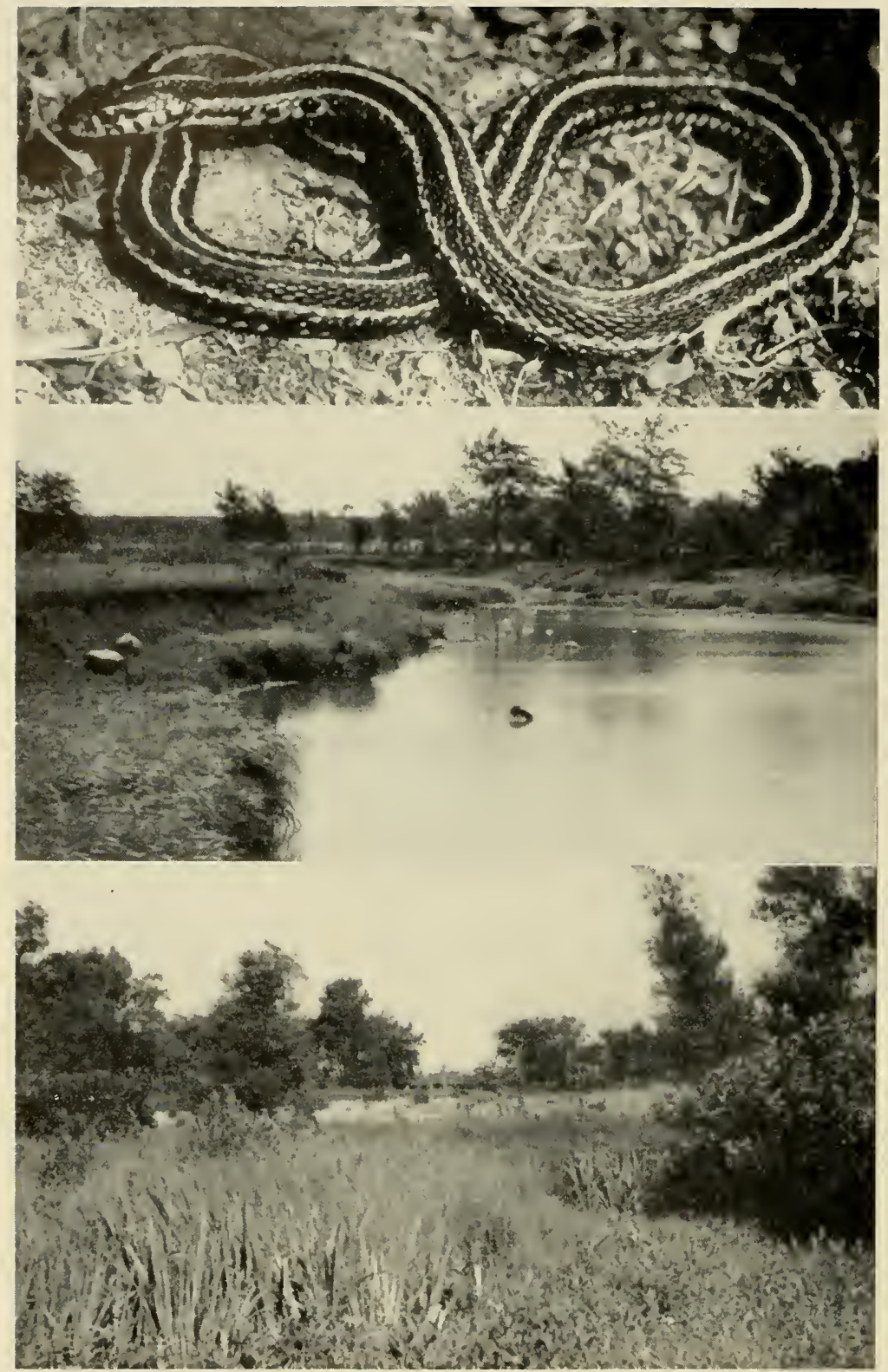

Plate 27. Fig. 1. Prairie Garter Snake, Thamnophis radix radix. Maricn Twp., Marion County, April 12, 1942. Length 233/4 inches (part of tail missing). Fig. 2. The Little Scioto River in Section 5. Marion Twp., Marion County. Fig. 3. A swale occupying an old uxbow of the Scioto River, Greencamp Twp., Marion County. Photos by Edward S. Thomas. 


\section{REVISIONARY ADDENDA}

\section{Introduction}

If ever I felt like an arm-chair naturalist, it has been during the preparation of these revisionary addenda for the Reptiles of Obio. Since my departure from the Buckeye State in 1935. I have returned for visits on only a few ocrasions, and most of my personal field work of recent years has been confined to the South and to the Atlantic Coastal Plain. Although I have kept more or less in touch with Ohio herpetology, a very large part of the data herewith presented is based upon the published works of others, on notes that have been very graciously turned over to me, and upon the many specimens that have been captured, preserved, and added to museum and personal collections. My role has been merely that of compiler, and I could not have undertaken it without the hearty cooperation of the many friends and colleagues to whom I acknowledge my indebtedness on pages 205 and 206.

When Dr. John D. Mizelle, editor of The American Midland Naturalist, netified me of his intention to reprint the Ohio reptile report, I urged him to include additional information. So much field work has been done and so many noteworthy records have been accumulated during the past decade, that it seemed a shame not to summarize them. This Dr. Mizelle has kindly permitted, and the information that follows may be considered as supplemental to what was published originally in 1938 and which has been reprinted on the preceding pages.

Circumstances have prevented me from journeying to Ohio to examine all the specimens that have beer added to collections in recent years, but the vast majority of them have been borrowed and examined in detail. Hence, any errors in identification may be blamed upon me. In those instances wherein I have not seen the specimens myself, the persons who have checked or published upon them are mentioned. In the cases of the more common species it has seemed superfluous to attempt making additional scale counts, but the rarer forms have been studied in detail, and so have all specimens of Opheodrys vernalis, Coluber constrictor, and Storeria dekayi, each of which species has intergrading populations in Ohio. Items of general interest (among all species) have been recorded and are noted in the text; these include measurements of very large or very small specimens, comments upon aberrant colorations or patterns, data that support or contradict premises propounded in the original edition, etc.

Ohio specimens have found their way into a number of museums and private collections besides those mentioned on pages 2 and 3, and a few completely new collections have been created. The following list is chiefly supplemental, but it also includes those institutions that now use a different combination of initials to designate their specimens than they did in 1938:

(CA)-Chicago Academy of Sciences, Chicago, Illinois-formerly CAS. (CNHM) -Chicago Natural History Museum, Chicago, Illinois-formerly FMNH. 
(CZP) - Cleveland Zoological Park, Cleveland, Ohio.

(DPLM) - Dayton Public Library Museun, Dayton, Ohio.

(FR) - Forest Riscn, Columbus, Ohio.

(FWB)-Forest W. Buchanan, Amsterdam, Ohio.

(GF) - George S. Fichter, Reily, Ohio.

(HTG) - Herschel T. Gier, Manhattan, Kansas.

(ISC) - Iowa State College, Ames, Iowa.

(KSU) - Kent State University, Kent, Ohio.

(OUVC) - Ohio University Vertebrate Collection. Athens, Ohio-formerly OU.

(OWU) - Ohio Wesleyan University, Delaware, Ohio.

(ROMZ) - Royal Ontario Museum of Zoology, Toronto, Cntario.

(TMS) - Toledo Museum of Science, Toledo, Ohio-formerly TZS.

(UC) - University of Cincinnati, Cincinnati, Ohio.

(WED) - William E. Duellman, Dayton, Ohio.

An effort has been made to see all material added to collections up to and including December 31, 1948. Some few 1949 records (chiefly for the rarer spccies) have been admitt:d to the lists, however. I have not examined the reptiles from the Lake Erie archipelago which are preserved at the Strn= I, ahoratory, Put-in-Bay. Many of these were collected by Dr. Charles F. Walker who is preparing a revicw of the herpetofauna of the islands.

New material is available from almost all parts of the state, but there is a really imposing increment of new records from southeastern and southwestern Ohio. The Messrs. Seibert, Gier, and Mittleman (see section on acknowledgements) and their students and colleagues have added many specimens from Athens, Jackson, Vinton, and adjacent counties to the collection at Ohio University, in Athens. Wood, Duellman, Walter, and their associates from Dayton, plus Danicl and Fichter, working in Butler and ncarby counties, have (collectively) given us, for the first time, some conception of the abundance and distribution of reptiles in the southwestern section of Ohio. This is an area in which I personall $y$ did relatively little field work and where collecting, except in aquatic habitats, often is quite discouraging.

Much field work remains to be done in Ohio, especially on the subjects of behavior and life histories. Many ranges no doubt will be extended, but it is necessary to point out that such a great amount of matcrial of the more common species is now available in museums that it would seem unnecessary to collect more specimens in quantities. Selective, rather than mass, collecting should be practiced in the future. Conservation is imperative if certain of our reptiles are to survive the broadening impact of civilization. One species, Natrix erythrogaster, already may be gone from Ohio.

In so far as possible, a definite style has ben followed in presenting the new information about each species. In general, there is first a discussion of taxonomic changes (if any have taken place), and then mention of alterations in the general range of the species or subspecies. This is followed by a list of new Ohio lecality records and comments upon range extensions within the state. Notes are presented upon habitats, habits, scutellation, size, etc; the rarer species (obviously those about which least is known) are treated most fully.

Some comment should be made about ventral and subcaudal counts among the snakes. In the original edition (as mentioned on page 17), the anal 
plate in each specimen was included as a ventral and the spine at the tip of the tail was included as a subcaudal. This is not standard practice. In the making of counts upon recently collected serpents (and in older specimens that have been restudied), these extra scales have been omittel, and all references to the atdominal and subcaudal scutes ucon the pages that follow are in accordanc? with generally accepted precedure. It should be borne in inind that the statistics for ventrals and subcaudals in the first edition of this report (pages 1 to 197, inclusive) are all high by one unit. Thus, a ventral count given as 212 actually should be 211; a subcaudal count of 77 should be 76 , etc.

The "mean," where stated in the following pages, is the arithmetic mean as defined by Simpson and Roe $(1939,85)$, and it is the equivalent of "average" as used in the original printing of the Reptiles of Obio.

Completely new distribution maps have been pripared. Information recently published by the Geological Survey of Ohio has necessitated a partial redrawing of the base map.* On this, the physiographic boundaries have been altered to conform with those shown on Maps 1 and 2 in the Geology of WVater in Obio (Stout, Ver Steeg, and Lamb, 1943). Most of the changes are relatively minor, but the line indicating the Allegheny Front Escarpment (the eastern bo:der of tha Till Plains and the Blue Grass Region) has been moved eastward and it no longer appears as a relatively smooth curve (see maps on pages 269 to 279); this alteration results in an increase in the area cccupied by the Till Plains and a corresponding decrease in the Glaciated Allegheny Plateau. The teach ridge of Lake Maumee, after running northward for a short distance into Michigan, is now known to loop scuthward into Fulton County, thes slightly reducing the territory occupied by the Lake Plains. The glacial boundary, which has been worked out with greater accuracy, has been shifted slightly farther north and west in numercus places.

Stout and Lamb (1938) have described a new physiographic boundary, the Flushing Escarpmont, which may or may not have some effact upon the distribution of reptiles in Ohio. It is represented by an irregular lire extending southward from Columbiana County to Monroe County, and it has been drawn upon only theee maps, those showing lecality records for Sceloporus undulatus byacinthinus, Opheodrys vema!ss, and Agkistrodon contortrix mokeson. In the cases of Sceloporus and Opheodrys there are records lying eastward of this escarpment, and these are at some consid rable distances from the nearest othar Ohio reco:d's for the same species.t In the case of Agkistrodom. several recosts fall close to (and on both sid's) of the line. Future collecting may tend to fill in gaps in the Ohio ranges of these three species, but the present status of cur knowledge of their cistribution indicates that this physiographic foature may cossibly be of some sionificance. The Flushing Escarpment, accor'ing to Stout and Lamb (op. cit.), marks the boundary of an "old

* Acknowledgement is gratefully made to the George F. Cram Company, of Indianapolis, for permission to use its outline map of Ohio as the base upen which to develop the many dist"ibution mass accompanying this report.

$\dagger$ The general distribution pattern of Pscudacris brachyphone in Ohio (IValter. 1946. fig. 20) is similar in many respects to that of Scelnporus undulatus hyacinthinus. 
water divide separating major streams of Teays time ... [that $]$ is readily traced by the change in elevation of the ridge summits and by the difference of contour pattern." The area east of the Escarpment "has wider ridges, less direct relief, fewer small streams, and in general more uniformity" than the area to the west.

Upon the revised and up to date base map, the locality records (both old and new) have been plotted for each spccies of reptile indigenous to Ohio. As heretofore, solid circles represent specimens that I have examined personally; hollow circles indicate records from the literature or from competent observers with whom I have been in correspondence. For the sake of simplicity in printing and so they will be handily accessible, the new maps are grouped at the end of the addenda. No attempt has been made to bring the general range maps up to date; changes involving them, as mentioned above, are noted in the text.

Scores of new lakes and ponds have teen created in Ohio during the past decade by the damming of creeks and rivers. These water conservation projects are of benefit to certain aquatic reptiles, but they are a headache to anyone attempting to prepare distribution maps. The names of many of these new bodies of water do not appear on charts or topographical sheets, and, in some instances, I finally have had to give up in my attempts to find them. Hence, a few locality records have had to be omitted.

Three specimens of extra-limital species deserve special attention:

(1) The Ohio State Museum has acquired another glass lizard, Ophisaurus ventralis (OSM 547), contributed from Mt. Vernon, in Knox County. It is accompanied by data that reads, "Killed by John Gilbert during the Civil War." There is, of course, the strong possibility that this reptile was obtained in the South and was taken to Ohio during or after the war betwcen the states.

(2) The Cincinnati Society of Natural History has another coral snake, Micrurus fulvius (CSNH 2650), that was caught in the Price Hill section of Cincianati. This, according to Dury, is in a well-inhabited section of the city. He states that the snake was found by two five-year-old childten, it was placed in a mayonnaise jar (where it died), and was taken to the Cincinnati Museum by high school students, one of whom was a brother of one of the children. Dury solicited the help of the local newspapers in an effort to determine whether the specimen might have escaped from captivity. No information on the subject was forthcoming, possibly because the owner did not wish to admit possession of such a dangerous serpent. The finding of this snake is of special interest in view of the fact that coral snakes have twice previously been reported from the general region (see p. 8). An isolated colcny of Micrurus may occur in the Ohio Valley, but I prefer to take the more conservative view of considering the recently-acquired specimen as having been transported to Cincinnati by human agency. Such things do happen, for a coral snake appeared a few years ago in Philadelphia, Pennsylvania. Two boys brought a live one to the Philadelphia Zoo which they had found in a crowded section of the city. Investigation showed that it had been imported from the South in a basket of string beans! There is additional evidence to strengthen the 
theory of accidental introduction; the specimen found at Cincinnati years ago is identifiable as Micrurus fulvius fulvius whereas the recent one is Micrurus fulvius tenere.

(3) A nood turtle, added to the Ohio State Museum collection early in 1949, seemed to indicnte that Clemmys insculpta had, at long last, be?n added to the fauna of the state. It is a large male with a carapace $199 \mathrm{~mm}$. in length. The collecting data are "Hudson, Summit County. by Dr. Raymond C. Rush, December, 1948, or January, 1949." The donor stated that another had been given to him the previous fall, but it had later escaped. However, he also stated that he has done field work (mostly in mollusca) in the vicinity of Hudson for sixty years and has never seen the species there until the two turtles were found recently. He is convinced that they were brought into the area by someone.

Students of Ohio herpetology are referred to the excellent report on the frogs and toads of the state by Dr. Charles F. Walker. This was published in 1946 by the Ohio State Archaeological and Historical Society and may be secured for one dollar by writing to the Ohio State Museum, Columbus 10. A companion volume on the salamanders is in preparation.

\section{ACKNOWLEDGEMENTS}

A large share of the credit for this report should he given to Dr. Edward $S$. Thomas, Curator of Natural History at the Ohio State Museum. This revision might not have been attempted without his urging, and most assuredly, it would be far less elaborate and complete had it not been for his constant interest and stimulating commonts. He has repeatedly taken time cut from his own heavy schedule of activities to look up information for me or to lend advice on critical points.

A number of young naturalists have been particularly active in Ohio during the past decade, and they, collectively, have added considerably to our knowledge of the reptiles inhabiting the state. They have turned up many rare specimens, have been responsible for innumerable range extensions, and one of them must be cretiled with add:n? a species to the known fauna of Ohio. lt was D1. Robert L. Rausch, formerly of Marion, but now with the U. S. Public Health Service, at Anchorage, A'aska, who Iroved that Thamnophis radix is indigencus to our area. Also, among this group of ycung men, I am especially indebted to John Thornton Wood, formerly of Dayton, but now with the Virginia Fisheries Laboratories, Yorktown, Virginia; he has contributed much original data. William E. Duellman, of Dayton, and Robert H. Mattlin, cf the Cleveland Zoological Park, have been exceptionally cooperative and generous in supplyin information based on their own field work. Charles A. Triplehorn, of Bluffton, and Joseph H. Camin, of Columbus, have been exceedingly helpful in many ways and have spent much time and effort both in the field and in the laboratory on my behalf. Richard M. Johnson, of Delaware, who has been particularly fortunate in finding rarities in southern Ohio, has sent me many nots. George S. Fichter, of Reily. and Ha old J. Walter, of Dayton, must be thanked for numerous favors. Paul M. Daniel, of Oxford, besides doing collecting in extreme southwestern Ohio, has been quite succor fu' in ferreting out museum specimens for me that might otherwise have been overlooked. Credit for adding many excellent records should be given to three former residents of the state. These are Iohn H. Hughes, with the U. S. Public Health Service in Washirgten: Myron B. Mittleman, of Larchmont. New York; and Dr. H. T. Cier, of Kansas State College. Dr. Gier has very generously supplied me with notes and records made while he was at Ohio University.

The custodians of many reptile collections in Ohio must be thanked for preparing I-rts and shipping their specimens to me for examination. Among them are: Milten B. Trautman, of the Stone Laboratory, Put-in-Bay; Leo J. Higgins, of the Toledo 
Museum of Science; Dr. Henri C. Seibert, of Ohio University; C. A. Barker, of the Dayton Public Library Museum; Dr. Arthur B. Williams, of the Cleveland Museum of Natural History; Dr. William A. Dreyer, of the University of Cincinnati; and Dr. N. T. Matiox, formerly of Miami University, but now with the University of Puerto Rico.

Forest Buchanan, of Amsterdam, Dr. Ralph W. Dexter, of Kent State University, Dr. H. R. Eggleston, of Marietta College, and Seymour Van Gundy, of Whitehouse, have sent me a number of interesting specimens or useful data, or both. B. E. Leete, of the Ohio Division of Forestry (at Chillicothe), has furnished me with detailed maps showing localities where he has encountered copperheads and timber rattlers. P. H. William Bachmann, of Brooklyn, New York, has aided considerably by helping to assemble recoids from the literature.

A number of old friends, who had a part in the preparation of data for the original cdition of this report, have helped again, and it is particularly pleasant to ackn swledge their assistance. They are: Ralph Dury, Karl H. Maslowski, and Woodrow Goodpaster, all of Cincinnati; Louis W. Campbell, of Toledo; O. E. Ehrhart, of Antwerp; William F. Rof'tar, of Port Clinton; and E. L. Wickliff, Chief, Fish Management Section, Ohio Department of Natural Resources, Columbus.

For the loan of specimens from their respective institutions, for data on species or groups wit'n which they are particularly familiar, and for many other favors, I am indebted to: Dr. M. Graham Netting and Dr. Grace L. Orton, of the Carnegie Museum; Dr. Doris M. Cochran, of the United States National Museum; Dr. Norman E. Hartweg and Dr. Charles F. Walker, of the Museum of Zoology, University of Michigan; Dr. Archie F. Carr, Jr., and Dr. Arnold B. Grobman, of the University of Florida; Dr. Howard K. Gloyd, of the Chicago Academy of Sciences; Charles M. Bogert, of the American Museum of Natural History; Karl P. Schmidt and Clifford H. Pope, of the Chicago Natural History Museum; E. B. S. Logier, of the Royal Ontario Museum of Zoology; Dr. Orlando Park, of Northwestern University; Dr. A. H. Wright and Miss Kay Kapp, of Conell University; W. Lesliz Burger, of the University of Illinois; Carl F. Kauffeld, of the Staten Island Zoo; Dr. Sherman A. Minton. Jr., of the Indiana University Medical Center; and Dr. Themas H. Langlois, of the Stcne Laboratory.

R. E. Lamborn, Assistant State Geologist, and Miss Ethel S. Dean, Secretary, respectively, of the Ohio Divisicn of Geological Survey, have supplied helpful information, and Mr. Lamborn has checked the physiographic boundaries on my new base map.

The names of many of the perscns listed above appear in the text of this revision, some of them frequintly. Informaticn credied to them is chiefly from unpublished data, but reference to their papers is made (by the use of dates keyed to the list starting on [rage 265 ) in all cases where they have made contributions to the literatu e.

The Messrs. Thomas, Schmidt, Netinz, Wood, Duellman, Triplehorn, Johnson, and Mattlin and Dr. Orton kindly undertook a reading of the manuscript, and to them I extend my sincerc thanks for their many suggestions and criticisms.

My wife, Isabelle Hunt Conant, has executed much of the mechanical work of readying this report for the press, and she has been my constant and devoted heiper during the tedious checking and double-checking which is an inevitable part of a work of this sort.

\section{Sceloporus undulatus hyacinthinus (Green) \\ Northern Fence Lizard}

(Page 22; maps 2 and 39; plate 3, fig. 1)

Sweeping changes in the classification of the swifts of the undulatus group have been proposed by Hobart M. Smith (1938). He recognizes seven subspecies and shows that the name Sceloporus undu!atus undulatus should be restricted to a southern race that cccurs from eastern Louisiana to southern South Carolina and southward to the Gulf and the northern half of Florida. 
This subspecies is characterized by its large dorsal scales; they rarely excced 37 in number (counting from the last of the head scales to a point opposite the posterior border of the thighs). The form byacinthinus (the one that occurs in Ohio) has smaller scales that usually exhibit a count in excess of 37; it ranges from southeastern New York and New Jersey south to South Carolina, and west to Kansas, Oklahoma, and Texas. Thus the inset map on page 23 indicates the app:oximate distribution of both undulatus and hyacinthimus; the two races intergrade where their ranges come together. For the use of the name byacinthinus see Smith (1948). New Ohio records are:

Adams County: (SL 438-9); Beaver Pond, 31,2 mi. FSE of Peeb es (UC 25). Athens County: Athens (OUVC 574); Buchtel (OUYC 2436); Carbondale (OUVC 2204); Rainbow Lake, Alexander Twp. (OUVC 383); Waterloo State Forest (OUVC 2369, 2433). Brown County: 5 mi. E of Ripley (WED 304.5). Hocking County: Old Man's Cave (WED 12). Holmes County: NW' Richland Twp. (OSM 518). Jackson County: (OSM 5C9; OUVC 312); Blocmfield Twp. (OSM 5C8.1); Jackson (OUVC 1268A-C); Jackson Twp. (OUVC 571); Liberty Twp. (OSM 861.1-2): Rock Run area, Liberty Twp. (OSM 5C8.2). Jeffep oN County: Amsterdam (OUVC 1284); Steubenville (OUVC 332); near Yellow Cree.s (CU 2567). Muskingum County: Duncan Falls (OSM 477). P1KE County: Pike State Forest (DPLM 163-6.42, 187.42, 251-62.44, 264-5.44, 584-6.44. 604.74: IVED 7-11, 179); $1 \mathrm{mi}$. S of Piketon (OUVC 24l1). Ross Countr: (OSM 654); 2 mi. SE of Bainbridge (DPLM 263.44); Harrison Two. (OSM 717); Tar Hollow, Harrison Twp., near Hocking Co. line (UMMZ 98025A-C); 1 mi. W of Vigo (OSM 513.1-2). Scioto County: (OSM 512.1-2): Roosevelt Game Preserve (OSM 619); Shawnee State Forest (WED 13, 185-6). Vinton County: 2 mi. S of Lake Hope (HTG); Old Hope Funnace, Lake Hope (OUVC 2211): Zaleski State Park (WED 6).

The specimen from Beaver Pond, Adams County (UC 26) apparently is the largest Sceloporus undulatus byacinthinus on record. It is a very stoutbodied female measuring $197 \mathrm{~mm}$. in total length; the head-body length is 84 mm., which exceeds Smith's $(1946,222)$ largest specimen by $5 \mathrm{~mm}$.

Wood advises me that he had several swifts from Pike County which deposited eggs in captivity. One female laid eight on July 30, 1940, and two others produced six and eight eggs, respectively, on July 3, 1942; these were non-adherent, papery-shelled. and whitish in coloration, and they ranged from $\mathrm{I} / 2$ to $5 / 8$ of an inch in their long dimensions. Wood found a single ego of this species near the top of a shale outcropping in Tobacco Barn Hollow, Pike County, on August 2, 1940. The egg was shaded from direct sunlight beneath a tiny ledge, but it had apparently been deposited in the open. It contained a well-developed embryo. The first young of the year (in 1942) were noted on September 1 .

\section{Lygosoma laterale (Say) \\ Brown-BACKED SKINK \\ (Page 26; maps 3 and 40 ; plate 3, fig. 2)}

The generic name of this lizard has been the subject of much argument. Some herpetologists would use Leiolopisma, but others believe that Leiolopisma is merely a subgenus of the wide-ranging genus Lygosoma. The latter students follow Malcolm A. Smith (1937) who, based upon his wide knowledge of the reptiles of southern Asia, has come closer to providing us with a revision 
of these lizards than anyone else. Using Lygosoma also has the advantage of showing relationship between the few American and the very many Old World skinks of this group. Mittleman's proposal (1950) of the generic name Scincella has the merit of bringing all the New World forms under a single head, but his conclusions were based upon a study of only a small segment of the genus Lygosoma as a whole. Until someone undertakes an exhaustive review of this difficult group, the name Scincella may best be employed at the sutgeneric level, i.e., Lygosoma (Scincella) laterale. For use of the name laterale instead of unicolor see Harper (1942).

Hobart Smith (1946, map 25) shows that this lizard ranges well westward into Oklahoma and to central Texas. The small inset map appearing on page 27 should be altered accordingly.

Several brown-backed skinks have been collected in the state during the past decade, and these serve to prove that the species, although se.dom see's and possibly uncommon, is quite definitely a part of the fauna of Ohio. Only a single spscimen (from Hocking County-sce page 26) was available for study in 1938. The new records are:

Scioto County: Nile Twp. (OSM 866) ; Roosevelt Game Preserve (OSM 903); Bear Lake, Roosevelt Game Preserve (OSM 548); Shawnee State Forest (CSNH2 spec.). In addition, the Cincinnati Museum has a specimen (CSNH 2654) from near Rome (Stout P. O.), Adams County, that, because it had been temporarily mislaid. was not available for examination while this revisionary manuscript was being prepared.

Johnson has encountered four of the e kirks in the field. At Baar Laks, on September 10,1942, he found a very small specimen at the edge of the spillway from the dam. The adjacent terrain consisted of an open grassy area with a rather sparse oak-hickory woods near-by. He found two others on April 23, 1949, by overturning stones that were piled up in a row between two overgrown fields in the Shawnee Forest. Young sycamore and elm trees were growing in the line of stones and the adjacent fiolds w:re covered with a mixture of thue grass, blackberries, sumac, and goldenred. Second grewth (oak and hickory) was at one end of the stone pile. Johnson also took a hatchling in the Rcosevelt Game Preserve on Ottober 16. 1949; it was under a stone in an o'd field at the base of an oak-hickory hillside.

Goodpaster obtained his two specimens (CSNH) in the Shawnce Forest late in the season-on September 23 and October 15, 1948. One was beneath a pile of stones alongside a spring; just above the spring was a heavy growth of oak and mavle and iust below was a small open field. The other skink was under a board. Ants had been working there, and the lizard was found abou: six inches below the surface of the ground in one of the insects' burrows. Goo'paster believes that this reptile was seeking a place to hibernat; the weather was cold. Undergrowth, in the form of weeds and briars. was abundant close ry, and not far awav there was timber.

According to Dury and Goodpaster, who collaborated in catching it, the skink from Adams County was found during May, 1946, near sandstone cliffs about a mile from the Ohio River. The exact locality was "a very dry southwest hillside along the edge of rather heavy timber, tut the hillside itself was covered with bushes and briars, and a rather heavy coating of dead leaves from 
the larger oaks and maples just about covered the ground." This specimen was moving when first noticed.

These notes on the habitats in which this skink has been found in Ohio all have one thing in common. In each case the lizard was in or near an open area at the edge of a woods.

The specimens from the Roosevelt Game Preserve (OSM 548 and 903) are both very small; the head-body lengths are $21 \mathrm{~mm}$. and $25 \mathrm{~mm}$., and the total lengths are $50 \mathrm{~mm}$. and $58 \mathrm{~mm}$. respectively, but part of the tail is missing in the shorter lizard. The largest individuals (OSM 866 and CSNH) have head-body lengths of $43 \mathrm{~mm}$. and $40 \mathrm{~mm}$., and total lengths of $106 \mathrm{~mm}$. and $118 \mathrm{~mm}$., respectively. The longest Ohio Lygosoma, therefore, measurcs about $45 / 8$ inches.

In ali six specimens studied (including the one from Hocking County) there are 26 rows of scales at midbody. The lower labials are 6 in every case; the upper labials number 7, except that two specimens have only 6 of these scales on one side of the head.

\section{Eumeces fasciatus (Linnaeus)} Blue-TAiled SKink

(Page 28; maps 4 and 41 ; plate 3, fig. 3)

Foutren counits may be added to the list. New records are:

Adams County: Green Twp. (SL 996-7); Smoky Creek (CMNH 66). Allen County: $2 \mathrm{mi}$. N of Bluffton (OSM 751). Ashtabula Countr: (OSM 679); Dorset Twp. (CMNH 322, 328). Butler County: Reily (GF): Roily Twp. (OSM 642). Chimpa:gn County: Cedar Swamp, 5 mi. SSW of Urbana (DPLM 170-5.42; osm 7h1). Clemmont County: (OUVC 869; Sl 437). Cuyahoga County: North Chagrin Reservation (CMNH 135). DaRKE CounTy: 3 mi. E of Greenville (WED 325-7). Delaware County: Butler's Swamp. $10 \mathrm{mi}$. E of Delaivare (OSM? 651). Hardin County: 3 mi. 上 of Mt. Victory (OSM 583). Highland Countr: Fort Hill (OSM 860). Hock Ng County: Clear Creek, Good Hope Twp. (OSM 432). Jackson County: Liberty Twp. (OSM 585). Logan Countr: East side of Indian Lake (WED 16-25, 312,334,364). PAulding Countr: 2 mi. SE of Antwerp (OEE); 3 mi. W of Antwerp (OEE). PIKE County: S of Buchanan, Pebble Twp. (OSM 550); Pike State Forest (DPLM 167-9.42, 587.4t: WED 26, 180). Portage County: Atwater Twip. and S of Kent (Dexter, 1944). Preble Countr: West Elkton (MU 22). Ross Countr: I mi. W of Vigo (OSM 533). Scioto County: Shawnee State Forest (WED 182). Shelby County: 3 mi. SSE of Sidney (WED 214). Trumbull County: 2 mi. W of Johnston (CM 19066); North Bristol (NU 26-7). Union Countr: Near Magnetic Springs (OSM 576); 5 mi. S of Marysville (OSM 581.1-2, 582.1-8, 668.1-6). VInTON Countr: Brown Twp. (OUVC 2387. 2419-22); $2 \mathrm{mi}$. E of Lake Hope (OUVC 2385); $6 \mathrm{mi}$. NE of Lcndenteriy (TMS 2473); Zaleski Forest (HTG-2 spec.). Warren Countr: Fo:t Ancient (OSM 738; UC 28; WED 328). Wrandot Countr: Near Eden Twp. School (OSM 690).

An inspection of map 41 will show that Eumeces fascialus is conspicuously absent frcm a large block of counties in the unglaciated part of eastern Ohio. In view of the considerable amount of field work that has now been done, this species must be at least raze or highly localized in southeastc:n Ohio, if it lives there at all.

In south central Oh:o however, fasciatus occurs in a great many lecalities 
south of the glacial boundary. This section of the state, from Ross and Hock. ing counties southward to the Ohio River, possesses a particularly rich reptilian fauna. Many species here reach their notthernmost limit (at least in Ohio), among them being Lygosoma laterale, Lampropeltis g. nigra, Haldea $v$. valeriae, etc. The timber rattlesnake has survived here in some numbrrs, and Storeria o. occipitomaculata is not rare, although it is found elsewhere in Ohio only in distant parts of the state. A wide variety of habitats and extensive forested areas no doubt contribute to the richness of the region.

Eumeces fasciatus may have crossed the glacial bounc'ary and entered south central Oh:o by making use of "filled" valleys in much the sarze manner as is postulated for Natrix kirtlandii, Storeria dekayi, and Thamnophis sauritus. (See the discussions concerning these species on the pages that follow.) This skink is partial to moist habitats such as are found in filled valleys, and from the field notes available, it appears to avoid the well-drained hil's that characterize much of the region.

The general range map (page 29) nceds some slight alterations. Florida should be eliminated completely, and the cark area should be extended northward to Lake George in New York. Goin (1940) points out thai all ex stirg Flot:da recosds for this lizard are open to question; Hamilton (1947) reports the species from near Hague, New York.

My data now include detailed scale counts for ninety-three Ohio specimens of fasciatus. These may be summarized as follows:

Scale Rows-26 (in 2 specimens); 27 (in 4); 28 (in 32); 29 (in 20); and 30 (in 33); one additional lizard from Toledo, Lucas County, has 32 scale rows and another from Clermont County has 33.

Supralabials -A count of 4 supralabials (preceding the subocular labial) occurs 156 times (allowing two for each lizard, one left and one right) and a count of 5 cccurs 30 times; in twelve specimens there are 4 labials on one side of the head and 5 on the other; in nine specimens the count is 5 on both sides. The last nine skinks are from widely scattercd localities - Butler, Franklin, Hardin, Lucas, Union, and Vinton counties.

Postlabials - There are two posilabial scales in 87 of the 93 specimens and another has one large postlabial (on one side of the head) which is apparciatly the result of fusion of the two smaller scales. Only five lizards may be said to have aberrant counts; three of these have two postlabials on one side of the head and one on the other; another snecimen has two on one side and three on the other. Only a single specimen (from Fo:t Ancient, Warren County) has a single postlabial en both sides of the head.

Scale rows in excess of 30 , counts of 5 supralabials, and a sinole enlarged postlabial scale are all characteristics that are usually associated with specimens of Eumeces laticeps. A glance at the above ficures will show, of course, that there is some overlapping and that a few individuals of fasciatus bear counts that might be diagnostic of laticeps. None of them, however, have complete combinations of the characters of laticeps. For example. the fasciatus from Lucas County with 32 scale rows has only four supralabia's and it has two 
cnlarged postlabial scales. Skinks with five supralabials may have only 28 scale rows, etc. In attempting to identify Ohio specimens of Eumeces, one should check carefully on all three characteristics-supralabials, postlabials, and scale rows at midbody. These, combined with size (laticeps attains much greater dimensions than fasciatus), should make the identification of fasciatus comparatively easy (see Table 4, page 212). Among all the counts, the postlabials are most constant and, hence, the most reliable. These normally appear as two scales, one directly atove the other, but in some specimens they may be somewhat misshapen or somewhat out of position. The postlabials usually are considerably larger than the small scales above and posterior to them. Often a Icns is necessary to see them adequately, especially in the case of juvenile specimens. The statement on page 28 that $10^{\prime} r$ of the postlabials are abnormal refers to shape and position-not to the number of them.

Most of the new specimens that are accompanied by collecting data were t $\mathrm{k} \times n$ in moist surroundings - at swamp edges or in rotting logs or stumps, damp sawdust piles, lakeside habitats, etc. Dexter (1944) mentions encountering one in a Larix-Vaccinium-Chamaedaphne bog. Rausch found a fasciatus in Union County on July 5, 1942, that was brocding $15 \mathrm{eggs}$, and Duellman obtaincd one in Logan County on July 21, 1946, that was brcoding a clutch of 17 eggs. Duellman further reports that a medium-sized skink of this species was promptly eaten by a racer (Coluber c. constrictor) that was placed in the collecting sack with it.

\section{Eumeces laticeps (Schncider) \\ LARGE-HEAdEd Skink \\ (Page 32: maps 5 and 42; plate 4, fig. 1)}

Several more of these skinks have been obtained during the past decade. but only one new county (Montgomery) may be added to the list. The recends are:

Athens County: Athens (OUvC 2163). Clemmont County: (SL 434-6). Hamilton County: Riverside, Cincinnati (UC 25). Hocking Countr: "Neotoma," Good Hope Twp. (OSM 584, 703, 825.1-2). Montgomery Countr: Sunderland Falls, Butler Twp. (WED 400)

The general range (inset map on page 33) should be slightly expanded to include the Del-Mar-Va Peninsula; there are records for the eastern shore of Maryland.

Scale counts upon twenty-four Ohio specimens of laiceps may be summarized as follows:

Scale Row's-30 (in 12 specimens); 31 (in 4); 32 (in 7); and 33 (in 1).

SupraI.ABIALs - A count of 5 supralabials (preceding the subocular labial) occurs 34 times (allowing two for each lizard, one left and one right) and a count of 4 occurs 14 times; in six specimens there are 5 labials on one side of the head and 4 on the other; in four specimens the count is 4 on both sides.

Postrabials - There is only a single enlarged postlabial scale on each side of the head in 17 of these 24 skinks. In other specimens the ac are two small, 
a large and a small, or two large postlabials; these occur in various combinations and sometimes there is the normal single enlarged postlabial on one side of the head and one of the variations on the other side. The frequincy of each type of scutellation is: 1 enlarged scale (34 times); 1 large and one small ( 3 times); 2 small (7 times); and 2 enlarged scales (4 times).

An analysis of the above statistics w:ll show that specimens of laticeps occasionally exhibit characteristics that are more frequently associated with fasciatus. But in no case c'oes any large-headed skink have more than one of the characteristics of fasciatus. Two specimens of laticeps have two enlarged postlabial scales on each side of the head, but each of these skinks has 5 supralabials and the scale rows at midbody are 32 and 33, respectively. Specimens with 4 supralabials on each side of the head have only a single postlabial, etc.

TABLE 4

Characteristics of Ohio Eumeces

\begin{tabular}{|c|c|c|c|c|c|}
\hline Species & $\begin{array}{l}\text { Scale } \\
\text { Rows }\end{array}$ & $\begin{array}{l}\text { Supra- } \\
\text { labials }\end{array}$ & Postlabials & Size & Habitat \\
\hline $\begin{array}{l}\text { Eumeces } \\
\text { laticeps }\end{array}$ & $\begin{array}{l}30 \text { to } 33 \\
\text { (never } \\
\text { less than } \\
30 \text { ) }\end{array}$ & $\begin{array}{c}\text { Usually } \\
5\end{array}$ & $\begin{array}{l}\text { A single enlarged } \\
\text { s c a l e or two } \\
\text { small ones; rare- } \\
\text { ly t } w \text { o enlarged } \\
\text { scales. }\end{array}$ & $\begin{array}{l}\text { Grows to large } \\
\text { s iz e; maximum } \\
\text { Ohio specimen is } \\
91 / 2^{\prime \prime}(241 \mathrm{~mm} .) \\
\text { long. }\end{array}$ & $\begin{array}{l}\text { Largely arbore- } \\
\text { al; in trees, on } \\
\text { cliffs. P refers } \\
\text { fairly dry condi- } \\
\text { tions. In southern } \\
\text { Ohio only. }\end{array}$ \\
\hline $\begin{array}{l}\text { Eumeces } \\
\text { fasciatus }\end{array}$ & $\begin{array}{l}26 \text { to } 30 \\
\text { (very } \\
\text { rarely } \\
\text { more than } \\
30 \text { ) }\end{array}$ & $\begin{array}{c}\text { Usually } \\
+\end{array}$ & $\begin{array}{l}\text { Almost invaria- } \\
\text { bly two enlarged } \\
\text { scales, one direct- } \\
\text { ly above the } \\
\text { other. }\end{array}$ & $\begin{array}{l}\text { La rges t Ohio } \\
\text { specimen is } 71 / 2^{\prime \prime} \\
(190 \mathrm{~mm} .) \text { long. }\end{array}$ & $\begin{array}{l}\text { Largely terrestri- } \\
\text { al; in s } \mathrm{tumps} \text {, } \\
\text { logs, under logs } \\
\text { and stones. Pre- } \\
\text { fers moist condi- } \\
\text { tions. Only liz- } \\
\text { a rd in northern } \\
\text { Ohio. }\end{array}$ \\
\hline
\end{tabular}

Table 4 should prove helpful in distinguishing between these two confusing skinks. Juveniles sometimes are difficult to diagnose, and occasionally it may be necessary to check on other characters besides those discussed above. Smith's Handbook of Lizards (1946) should be consulted for details. The possibility also should be borne in mind that the two species, laticeps and fasciatus, may occasionally hybridize, in which case some of the offspring might be expected to show characteristics of both parents.

Several of the recently-acquired specimens of laticeps are large, but they do not quite equal the dimensions of the longest individual previously recorded. The one from Montgomery County is a hatchling with a head-body length of $33 \mathrm{~mm}$. It was collected by Walter in the moist, wooded ravine about one-quarter of a mile downstream from Sunderland Falls. The specimen was beneath the loosely adhering bark of a nearly horizcntal tree trunk approximately two and one-half feet in diameter. Walter, in describing the 
habitat, states, "The trunk was between the creek and a mucky, black seepage area. The woods here and along the creek might be considered 'moist,' and the entire valley is well shaded by tall trees. Much of the undergrowth is paw-paw (Asimina). The steep sides of the valley seem well-drained and quite dry, however."

\section{Carphophis amoenus helenae (Kennicott) \\ Central Worm Snake \\ (Page 34; maps 6 and 43; plate 5, fig. 1)}

New records for this small secretive snake are:

Adams County: Buzzard's Roost Rock, Jefferson Twp. (UMMZ 95934); Green Twp. (SL 418); 3 mi. S of Locust Grove (OSM 759); Smoky Creek, Green Twp. (UMMZ 95932). Athens County: Buffalo Beat, near Buchtel (OUYC 2174); Stroud's Run, 3 mi. NE of Athens (OUVC 1869). Fatrfield Cocntr: "Wahkeena," Berne Twp. (OSM 831). Highland County: I mi. SW of Cynthiana (OSM 515). Hocking County: "Neotoma," Good Hope Twp. (OSM 7 742, 746, 832, 863.1-2). Mergs Countr: 4 mi. SW of Darwin (OUVC 605). Montgomeri County: Northiidge, Harrison Twp. (DPLM 65.44). Pike County: Old Baldy, Greenbrier Ridge (DPLM 15-7.72); Pike Lake (DPLM); Pike State Forest (WED 28, 136-7, 184. 311,357); Richardson and Egyptian Hollows (USNM 128923). Ross CountY: Tar Hollow State Forest (WED 188). Scioto County: Friendship (SL 464); Shawne? State Forest (WED 190, 205, 261). ViNton Countr: Lake Hope (OUVC 2062). Washington County: Litle Hocking (OUVC 2417); 5 mi. NIW of Marietta (OSM 864).

As may be seen by comparing maps 6 and 43, most of these new records fall well within the distributional pattern previously plotted. The new localities for Athens and Washington counties help to bridge the gap between the previous concentration of collecting stations and the lone record from Monroe County. Walker, however, has called my attention to the possibility that this easternmost Ohio locality may be in error. It is based upon a specimen in the National Museum (USNM 8853) that was catalogued on March 29, 1877, and credited as having come from Morton, Ohio. A. H. Tuttle is recorded as the collector. Smith included Carphophis in his Report on the Reptiles and Amphibians of Ohio (1882, 699) "upon the authority of Dr. J. M. Wheaton, of Columbus, [who informed him] that some years ago a specimen was captured by Prof. Tuttle, at Ironton, on the bank of the Ohio River. The animal was sent to the Smithsonian Institution. ..." Since Professor Tuttle's specimen doubtless was accompanied by data written in longhand, it is highly conceivable that his "Ironton" was inadvertently changed to "Morton." The National Museum no longer has the correspondence pertaining to this matter, so it cannot be proved irrefutably that a mistake was made. Nonetheless, the Monroe County record should be questioned. Evidence of the presence of Carphophis in that county eventually may be found; there are now two records for the neighboring county to the west (Washington), although both of them are from west of the Muskingum River. The Carnegie Museum has "reports" for the worm snake from Greene County, Pennsylvania, and from Marion County, West Virginia, both of which are relatively near Morton, Ohio. The same institution has specimens from Calhoun, Gilmer, and Lewis counties, West Virginia, which are at no great distance from the Ohio River. It is of 
interest to note, however, that the Pennsylvania and West Virginia populations of Carphophis belong to the subspecies amoenus. Dr. Orton, at my request, has checked the Carnegie Museum's specimons (5 and 53, respectively) from those two states, and all but one of them have the prefrontals and internasals completely separated (as in typical amoenus). The exception is CM 6919 from Nicholas County, in central West Virginia, which has the two scales partially fused on one side of the head. The "Morton," Ohio snake is a typical helenae.

The single specimen from near Dayton, in Montgomery County (DPLM 65.44), is of special interest for two reasons. It is the only Carphophis extant from southwestern Ohio and it helps to confirm Morse's (1904) published record for Yellow Springs, Greene County. No other worm snakes have besn found in that section of the state despite the fact that the Dayton area has been intensively worked in recent years. Harold J. Walter has supplied the following details concerning the capture of the specimen: "I was tearing at the edges of a stump about 2 feet in diameter and about 3 feet high, and, although it was largely riddled with insect tunnels internally, it was quite dry and hard and I exerted quite an effort in pulling pieces loose; the specimen came tumbling out as I tore a chunk from the upper edge of the stump. The locality was on a high, sloping hill and was in a fairly dense woods ... that is on one of a series of steep hills traversed by ravines and small streams which rise on the higher, nearly flat land to the north. Trees have apparently been cut here from time to time, and the hill upon which the snake was taken was open and grassy in places with scattered stumps and logs in various stages of decay. These I was systematically tearing apart when I fourd the specimen."

A colony of Carphophis apparently is well established in the marl prairie north of Castalia, in Erie County. The conservative way to exp'ain this snake's presence in the extreme northern part of the state and at such a long distance from all other records, is to presume that it was accidently introduced by human agency. Worm snakes are so secretive that it is not difficult to imagine several specimens (or perhaps only a single female with ripening egos) being carried in the "balled" roots of nursery stock or other vegetation to a new locality where habitat conditions are suitable for a colony to develop and thrive. The University of Michigan has a specimen from near Castalia (UMMZ 95933); there are others in the collection at the Stone Laboratory, at Put-in-Bay, and upon which Walker is planning to report in the near future.

The worm snake from near Marietta (OSM 864) was being swallowed by a racer (Coluber c. constrictor) when it was first seen. The two snakes were in an old apole orchard in the uplands not far from the west bank of the Muskingum River.

Including the fifty-six worm snakes that were reported upon in the first edition, there are now ninety-one individuals from Ohio available for study* An analysis of these shows that the prefrontals and internasals are separate in 32 instances (allowing two counts, one left and one right, for each snake), they are completely fused in 143 instances, and are partly fused (although

* Excluding specimens from Castalia. 
appearing essentially as but a single scale) in 7 instances. The last-mentioned condition occurs in only five specimens. If all scales in the last two categori-s are considered as being "fused" (the chief diagnostic characteristic of the subspecies helenae), then this condition exists in 82.4 ' $;$ of the instances. In sixty-seven $\left(73.6^{\prime} i\right.$ ) of the specimens the scales are completely fused on both sides of the head.

\title{
Diadophis punctatus ednardsii (Merrem)
}

\author{
Northern Ring-Necked Snake \\ (Page 37; maps 7 and tt; plate $t$, fig. 2)
}

New records for Diadophis are:

Adams County: Green Twp. (SL 419). Ashland County: Mohican State Park ( $S L$ 46-). Athlns Counzy: Athens (OUVC 2462); 7 mi. SE of Athens (OUVC 1378): Buchtel (OUYC 2210). Buti.er County: Reily (Fichter, 1947) Carroll County: Near Amsterdam, Loudon Twp. (FIWB). Clermont County: (SL 449-1). Geauga County: South Bog. Burton (CMNH 69). Hamilton County: Mt. Airy Park, Cincinnati (UC 14A-B). Hocking County: Cantwell Cliffs (WED 30): Cedar Falls (SL 348-9); Good Hope Twp. (OSM 570.1-2. 571.1-4. 828); Old Man's Cave (WED 29, 187): Salt Creek. W of Ash Cave (OUVC 1852): Salt Creek. Woodyeard Hollow, Benton Twp. (OUYC 1826); Salt Creek Twp. (OSM 338). Jacison County: Liberty Twp. (OUVC 1252. 1269); Scioto Twp. (OUVC 346). Lawrence County: Southern Decatur Twp. (UMMZ 95971). Miami CounTY: Ludlow Falls (DPLM 66-7.4t). Montgomery County: Germantown Dam, German Twp. (DPLM 24l-2.4t); Sunderland Falls (WED 251). Ottawa Countr: Near Port Clinton (OSM 678.1-2). Pickaway County: Pickaway Twp. (OSM 718). PiKe CounTy: (DPLM 188-9.42, 228.42); S of Buchanan. Pebble Trip. (OSM 760): Egyptian Hollow (DPLM 368.4t, 606.44); Old Baldy (DPLM 90.44): Pike Lake (DPLM 84.44, 89.44, 386.44, 602-3.44, 644-6.44); Pike State Forest (WED 31-4); Richardson and Egyptian Hollows (USNM 128922): 12 mi. E of Sinking Springs (WED 35-6). Preble Countr: 2 mi. S of Camden (MU 13-14). Ross County: Higby (OSM 835.1-2). Scioto County: Nile Twp. (OSM 644.12); Roosevelt Game Preserve, Nile Twp. (OSM 895.1-3; UMMZ 98739A-B): Shawnee State Forest (WED 259). Stark County: Canton (OSM 879). Summit County: Northfield Twp. (CZP 14). Vinton County: Brown Twp. (OUVC 113. 2423-4); Lake Hope (OUVC 2374): 2 mi. S of Lake Hope (HTG); Zeleski State Forest (OUVC 1861, 1865). Warren County: Ft. Ancient, Washingtor Twp. (OSM 650; WED 203). WAsHincton CountY: (OSM 677). Wood has also seen a specimen from near Bellbrook, Greene County. Van Gundy has obtained evidence indicating that ringnecks still cccur near Sylvania, Lucas County; he found one dead on the road near there during the summer of 1947 and another during 1948.

Nine new counties are represented above and four of them lie in extreme southwestern Ohio, an area from which records have heretofore becn relatively few. Habitat notes on specimens recently collected in that part of the state may be summarized as follows: Almost all were taken in or near wooded ravines and all were hiding beneath rocks, under the bark of decaying logs, bark slabs, ctc. One, found in a pasture, was under a flat stene in a rock pile in an open sunny area; in this case a stream bank, covered with mixed "h?rdwoods," was near-by.

Four ring-necked snakes from scattered localities in unglaciatrd Ohio have an unusually large number of black spots on the ventral scutes; these markings are arranged in a more or less continuous row and are about as large and 
as numerous as in many examples of Diadophis punctatus punctatus from the Southeastern States. Some of them also have a fcw dark flecks on their chins. None of these specimens, however, has an interrupted neck ring and the sum of the ventrals and subcaudals in every case is well in excess of 190 (as in typical edwardsii). These snakes may be considered as being aberrant since they constitute only a very small segment of the Ohio population of Diadophis as a whole.

Wood reports that he found a female in Pike County with two eggs (presumably hers) "beneath a flat stone on a steeply-sloped hillside." She remained with the eggs, which were somewhat collapsed but uninjured; the maximum lengths were 32 and $34.5 \mathrm{~mm}$., respectively. Wood also states that, "during other collecting work on top of Greenbrier Ridge, Pike County, in September, 1944, I took apart a flat-stone building foundation, and in the process counted fragments of the shells of 90 Diadophis eggs. The central depression in this foundation was permanently moist, and it provided a breeding and egg deposition site for Ambystoma opacum during the months of October and November of the several years this area was observed."

A juvenile from Vinton County (OUVC 113) measures only $111 \mathrm{~mm}$. ( $43 / 8$ inches) in length and is hence the smallest ring-necked snake on record from Ohio.

\section{Heterodon platyrhinos platyrhinos (Latreille) \\ EAstern Hog-Nosed SNAKe \\ (Pag= 41 ; maps 8 and 45; plate 6, fig. 1)}

Cogent arguments have been advanced by Klauber $(1948,7)$ to prove that the specific name contortrix should be applied to the copperhead rather than to the hog-nosed snake (see page 253 for details). Thus the next oldest name, platyrhinos, must be assigned to Heterodon.

There is a rather poorly-defined subspecies, Heterodon p. browni, that occurs in southern Florida and for which allowance should be made upon the general range map (page 42). In browni there are fewer than 20 light crossbars on the body and the small (azygous) scale between the internasals is usually lacking. New Ohio records for hog-nosed snakes are:

Athens County: Athens (OUVC 381, 1236); 1 mi. SE of Athens (OUVC 1245); Buchtel (HTG). Butler County: Reily Twp. (OSM 499, 689); Tallawanda Creek, Oxford (MU 24). Clemmont County: (SL 433); Stcnelick Creek, near Owensville (CM 2395I). Fairfield County: (OSM 519). Hocking County: Cedar Falls (WED 181); “Neotoma," Cood Hope Twp. (OSM 591, 833.1-2 - all melanistic). Jackson County: (OUVC 313); Coal Twp. (OUVC 1855); Jackson Twp. (OUVC 563); Milton Twp. (OUVC 822). Licking County: Black Hand Gorge (OSM 498); Granville (OSM 497, 740). Lucas CountY: Oak Openings (SL 802). Montgomery County: 3 mi. W of Germantown (DPLM 92.42): Germantown Dam (DPLM 88. $42,93.42,301.42,303.42$ ). Muskingum County: Zanesville (OSM 756). Paulding County: $11 / 2$ mi. SW of Charloe, Brown Twp. (OEE). PIKE County: Old Baldy (DPLM 385.44-melanistic); Pike lake (DPLM 687.44-melanistic); Lake White (OUVC 1856). Ross CountY: SW of Bainbridge (OSM 881); 3 mi. SW of Bainbridge (DPLM 647.44-melanistic). Wood reports specimens from Nelsonville, Athens County, and from Germantown, Montgomery County. Rofkar states that the hog-nosed snake, once not uncommon in his vicinity, "has not been seen on Catawba "Island," Ottawa County, for years." 
All of these records fit the distributional pattern previously plotted (see map 8) with the possible exception of the specimen from Paulding County. Ehrhart states, however, that there are a number of small sandy areas in that county, including the locality near Charloe. The beach ridge of former Lake Whittlesey passes through Paulding County, and the small "pockets" of sand probably were deposited by stream action after the waters of the lake had receded. Here may be another instance of Heterodon finding a suitable habitat in or near fossil beaches (see p. 43).

Several hog-nosed snakes exhibiting a jet black dorsum, comolctely without pattern, have been collected recently in Pike, Ross, and Hocking counties. Some of these were taken in the same localities where normally-patterned specimens have been found, but the melanistic ones, in most instances, have been comparative rarities. Wood reports, however, that, in his field experience in Pike and Ross counties, he encountered about the same number of black individuals as spotted ones.

A series of four large dark specimens in the collection of the Dayton Public Library Museum shows some interesting variations. The biggsst of the lot (DPLM 88.42 from Montgomery County) is a female measuring 914 $\mathrm{mm}$. (approx. $36 \mathrm{in.)}$ in length that shows strong evidences of pattern even though its general appearance is quite dark. The other three snakes (DPLM 687.44, of, $830 \mathrm{~mm} . ; 385.44$, ot, $710 \mathrm{~mm} . ; 647.44$, क, $645 \mathrm{~mm}$.) are completely melanistic above, but their bellies are brownish- or yellowish-grey clouded with a somewhat darker color. The underside of the tarl in platyrhinos normally is distinctly lighter in coloration than the belly, but in the larger male and in the female the under surface of the tail is black; in the smaller male it is light yellow with a few dark spots. In the large partly. patterned specimen (DPLM 88.42), the underside of the tail is pink but heavilv marked with dark grey; the ground color is lighter than the belly whereas the markings are distinctly darker. Attention should be called to the fact that these melanistic snakes are quite different from the a!most uniformlycolored specimens that ate found in several Ohio localities, notably in the "Oak Openings" west of Toledo. The latter are nearly plain olive grev (in life), but the dark bands extending backward from the had to the sidas of the neck are almost always in evidence.

A melanistic female from Hocking County (OSM 833.1), measuring $695 \mathrm{~mm}$. in length and which was collected on May 15, 1948, laid 23 eggs on June 25 th or 26 th, 1948. Another, well-patterned female from Ross County (OSM 881), measuring $808 \mathrm{~mm}$. and collected May 7, 1949, laid 9 eggs on July 11, 1949. This is an unusually small number for so large a snake; actually it does not represent the full complement, for there are several fairly large eggs still present in the body cavity of the preserved specimen.

\section{Opheodrys aestivus (Linnaeus) \\ Keeled Green Snake \\ (Page 45; maps 9 and 46; plate 5, fig. 3)}

Two more counties may be added to the list. New Ohio tecords are:

Adams County: Mineral Springs (OSM 615). Athens County: The Plains 
(OUVC 120). Clermont County: Near Glen Este (CM 23957-9); Union Twp. (SL 462). Gallia County: Cheshire Twp. (OSM 683). Hamlton County: Green Twp.. 3 mi. NW of Cincinnati city limits (UMMZ 98643). Jackson CountY: (OUVC 133): Jackson (OUVC 1270); Jackson Twp. (OSM 516); Liberty Twp. (OSM 517). Lawrence County: Olive Furnace, along highway \#75 (OSM 514); $2 \mathrm{mi}$. W of Miller (OUVC 469.1-2, 2058.1-2). PIKE County: Pike State Forest (W'ED 313, 355); Richardson Hollow (DPLM 98.44, 630.44). Ross CountY: Higby (OSM 836). Sc1oto County: Nile Twp. (OSM 769); Shawnze State Forest, Nile Twp. (OSM 883).

In addition to these, Gier reports a keeled green snake from 2 miles east of Athens, Athens County, and two from 5 or 6 miles west of Gallipolis, Gallia County. The Toledo Museum of Science has a specimen (TMS 2462) that was found at Walbridge, Wood County, near the Toledo Airport in May, 1938. Higgins says that he views this record "with great suspicion, since it was found in a railroad yard near some box cars." Here, in all probability, is another case of a southern snake being transported far north of its range in produce, lumber, or some other commodity.

Grobman (1941, 13) points out that the ranges of Opheodrys aestivus and Opheodrys vernalis are complementary, the former being a lowland and southern form and the latter an upland and northern one. He quotes Netting as stating that "in West Virginia aestivus is found in the valleys and vernalis in the mountains." The ranges of the two species of green snakes are almost mutually exclusive in Ohio, but there is some overlapping in the vicinity of Cincinnati. In wooded ravines in Clermont County, aestivus is commonly found in trees and bushes. The recently collected aestivus from Green Twp., Hamilton County (UMMZ 98643), was found dead on the road; there was a truck garden on one side of the road but no evidence of any woodland habitats near-by. The only smooth green snake from the Cincinnati region was taken, according to Dury, in the valley of the Little Miami River. Morse (1904) reported vernalis from Hamilton County, but his specimen is no longer extant. Future collecting may make it fossible to show that the two species are ecologically, if not geographically, isolated in extreme southwestern Ohio, but the data at hand are too meagre to warrant any general statements upon this subject.

One of the snakes from Jackson Countv (OUVC 133) was obtained very late in the season-or December 14, 1936. Hughes, who caught it, says it "was found out of hibernation on a warm day."

Twenty-two additional specimens of Opheodrys aestivus have been collected in the past several years: thus, the number of individuals upon which scale counts are now available has been slightly more than doubled. Statistics for all forty-three ( 23 males and 20 females) may be summarized as follows: Upper labials--7 occurs seventy-two times, 8 eleven times, and 6 three times. Lower labials - 8 occurs seventy times, 7 nine times, 9 four times, and 6 three times. Preoculars-normally 1 , but 2 on both sides of the head in three snakes. Postoculars - normally 2, but 3 on one side of the head in two specimens and 1 on both sides in two others. Anterior temporals-normally 1, but 2 on one side of the head in two snakes and 2 on both sides in another. Posterior temporals-normally 2 , but 1 on one side in one snake and on both sides 
in another. Ventrals in males, 149 to 157 , mean 152.1; in females, 148 to 163 , mean 155.0. Subcaudals in males (17 specimens), 119 to 141 , mean 130.6; in females (19 specimcins), 119 to 135, mean 124.2.

A specimen trom Gallia County (OSM 683-a female) measures 810 mm. (317/8 inches) in length and is thus slightly longer than the largest destivus previously reported from Ohio.

\section{Opheodrys vernalis vernalis (Harlan) \\ Eastern Grass Snake \\ (Page 77; maps 10 and 77 ; plate 5, fig. 2)}

Grobman, in his review of variation in the smooth-scaled green snake (1941), split this species into two races-Opheodrys $v$. vernalis of "the original eastern torest" and a new subspecies, $O, \gamma$. blanchardi, of "the more western prairies and plains area." He based his distinction tetween the two upon the number of ventral scutes, vernalis having lower counts (less than 131 in males and less than 140 in females) than blanchardi. On his distribution map (op. cit., 38), he indicates records for vernalis in northeastern Ohio and from Columbus, and records for blanchardi from a few scattered places in the western part of the state. The localities for the two races, when plotted, were found to fall upon opposite sides of a "line connecting eastward prairie extensions after Transeau (1935) and Shantz and Zon (1924)."

Obviously Grobman prepared his map and based his conclusions on studie; made upon the species Opheodrys vernalis as a whole. Only a $\mathrm{few}_{\mathrm{w}}$ Ohio specimens were available to him and most of them lacked detailed habitat data. Approximately twice as many grass snakes are now at hand, and. although they bear out his contention that both subspecies ozcur in Ohio, they also make it clear that the two forms are not quite so neatly separat-d geographically as his map indicates. The subject of intergradation is discussad under the section on Opheodrys $v$. blanchardi (page 221).

Grobman's publication enables one to define the range of vernalis much more accurately than was possible previously. This race is now known to cccur from New Brunswick, Canada, to northern New Jersey, and westward through southern Ontario, New York, Pennsylvania, northeastern Ohio, Michigan, and most of Wisconsin to northern Minnesota; to the south, vernalis is found in the mountains of West Virginia and western Maryland; there are also records from the George Washington National Forest, in Virginia, and from Madison County, North Carolina. This snake is an "upland form" that apparently may be expected only at relatively high latitudes or altitudes.

Ohio records for Opheodrys vernalis vernalis (including scme of the specimens listed on page 47) are as follows:

Ashland County: Mohican State Park, near Loudonville (SL 485: TMS 2011). Carroll County: Near Amsterdam, Loudon Twp. (FWB; OUVC 823). CuYarioga County: Brecksville Reservation (CZP 22-3); Chagrin Falls (CMNH 47); Independence (CZP 3); South Park (CZP 15). Geauga County: Geauga Lake (CMNH +6). Jefferson County: Springfield Twp., near Ansterdam (FWB). Lorain County: Oberlin (OC). Medina County: Medina (TMS 2464-5). Por- 
tage County: Kent (KSU-7 specs.); Ravenna (Dexter, 1948). Summit County: Ira (OSM 13.1-2, 84-5, 214, 265). Trumbull Countr: Vernen Twp. (TMS 444).

The grass snakes from Carroll and Jefferson counties are the first from south of the glacial boundary. Buchanan, the collector, states that he found them in open, grassy situations such as orchards and pasture fields. He also says that smooth green snakes are not at all rare in the vicinity of Amsterdam; his students bring two to five of them to the Amsterdam High School each year. This serpent is widely distributed in western Pennsylvania, and the Carnegie Museum has a specimen from Ohio County, West Virginia. Hence, it is not particularly surprising to find it in this part of unglaciated Ohio.

The increment of new records indicates that vernalis must be common in many localities in the northeastern part of the state. Dexter (1944 ard 1948) found it to be abundant near Kent, Portage County. One of his specimens was taken along the bank of the Cuyahoga River. Several were collected on the campus of Kent State University, including three that were found in hibernation on December 5, 1945, while workmen were moving a pile of cinders. One of these was a juvenile measuring just 6 inches in length, the smallest recorded from Ohio. A female, found on the campus on July 22, 1947, laid six eggs over a period of two days and another egg was found in the specimen after it was preserved; this snake measured $467 \mathrm{~mm}$. (slightly under $18 \mathrm{~T} / 2 \mathrm{in}$.) in length when I examined it in 1949.

Scale counts upon twenty-seven grass snakes (including those reported upon in 1938) are now at hand from northeastern Ohio. Among these the ventral counts are: 120 to 128 , mean 124.0 , in seventeen males; and 127 to 137, mean 132.6 in ten females. Thus, all fall below the maximum counts for vernalis (see above).

\section{Opheodrys vernalis blanchardi Grobman \\ Western Grass Snake}

(Map 47)

This subspecies, described by Grobman in 1941, is a plains and prairie form in which the ventral counts are 131 or more in males and 140 or more in females. It ranges from western Ohio to north central Utah; northward it extends through southwestern Minnesota and the Dakotas into extreme southern Manitoba; in the West it occurs in many parts of Colorado and south. ward through New Mexico almost to the Mexican border. After carefully sifting all the records, Grobman was unable to find proof that the grass snake is indigenous to Montana. Texas, Oklahoma, or Arkansas. Hence, proper adiustment should be made to eliminate these states from the general range map on page 48. Many specimens of Opheodrys aestivus have been reportein the literature as $O$. vernalis. The southern limit of the range of blanchardi, from Ohio to eastern Karsas, apparently coincidcs with the southe:nmost limit of Pleistocene glaciation.

Only a very few snakes of this form have been found in Ohio. Specimens that definitely may be assigned to this race are from the following localities: 
Butler County: Monioe (USNM 10661-3). Fayctte County: Buena Vista (TMS 2044). Hamilton County: Newtown (CSNH).

These localities are all in the extreme southwestern part of the state. It is quite possible, however, that future collecting may demonstrate that blanchardi is widely distributed through a large part of western Ohio.

Among the five snakes listed above, the ventral counts are 131 and 132 in the two males and 144, 145 and 145 in the three females. Both males are from Butler County; one has 92 subcaudals and the other has 99, but the scales in the latter snake are somewhat irregular, hence, this is probably an abnormally high figure. The greatest number of subcaudals recorded among Ohio specimens of vernalis is 88 ; this count occurs in three males.

At the present time only forty-three grass snakes from Ohio are available for study. Twenty-eight of these can be assigned to vernalis and five to blanchardi. The remaining ten specimens - all from the central part of the statemay or may not be members of an intergrading population. They constitute but a meagre sample on which to base conclusions, and the matter is further complicated by the fact that there is only a single character-the ventral count --to use in distinguishing between subspecies. (In Coluber, by way of contrast, there are four characteristics [Table 3, p. 51] that help to separate flavi. ventris from constrictor.) The area of intergradation tentatively indicated on Map 47 is little more than guesswork; it has been drawn to include only those localities from which the specimens suggest an overlap in the matter of ventrals. Thus, snakes from Erie and Crawford counties (in the eastern part of the stippled area) have the high counts of blanchardi, and snakes from Hardin, Wyandot, Marion, and Franklin counties have the lower counts of vernalis. Locality records for this part of Ohio are:

Crawford County: Broken Sword (TMS 2281). ERIE County: (UMMZ 39115); Kimball (USNM 35687); Sandhill (CNHM 2554): Sandusky (OSM 12); $10 \mathrm{mi}$. S of Sandusky (SHS). Franklin County: Columbus (USNM 1472). Hardin County: Patterson (TMS 1683). Marion County: Morral (OSM 818). Wyandot County: Upper Sandusky (OSM 725).

Rausch advises me that he collected a few smooth green snakes in Marion Twp., Marion County, but these unfortunately were not preserved.

When, and if, numbers of specimens become available from central and Western Ohio, it will be of interest to see where intergradation takes place between vernalis and blanchardi. Possibly there may be a relatively broad area occupied by an intergrading pooulation. Eventually it may be demonstrated, however, that the two forms show considerable overlapping. with blanchardi being confined more or less to prairie habitats and with vernalis occurring near-by in localities where forests once were present. Most of Ohio was originally forested, but the western half of the state, in pre-pioneer days, included a large number of prairie "islands," some of them quite extensive in area. These, which formed part of the Prairie Peninsula, have been mapped in some detail by Transeau (1935, fig. 1). The intensive agricultural activities conducted by mankind have vastly altered the original habitats, but some of the prairies still survive (at least in part) as relicts. If the Ohio records for grass snakes with high (blanchardi) ventral counts were to be plotted on Transeau's map, several of them would fall directly upon prairie "islands," 
but a number of others would not. Ccnversely, the large majority of localities for specimens with low (vernalis) counts would fall upon spots that once were wooled. The almost complete lack of habitat data makes correlations difficult. Certainly naturalists who collect any smooth green snakes in Ohio in the future should make every effort to obtain complete and detailed ecolcgical notes on the localities in which they find them.

The destruction of the prairie areas may partially account for the scarcity of records for blanchardi. Many other plants and animals that apparently entercd Ohio from the western prairies after the rctreat of the ice in postPleistocene times, survive today only in isolated swales, along railroad rights of way, or in other localities that have been little disturted by main. Thamnophis radix in Ohio is an excellent example of a prairie-relict form; Opheodrys vernalis blanchardi possibly may be another.

\section{Coluber constrictor constrictor Linnaeus}

\section{Black Racer}

(Page 49; maps 11 and 48; plate 6, fig. 2)

Dunn and Wood (1939) have discribed a Floridian su'species (priapus) on the basis of hemipenial characters in male specimens. Living individua!s of that race have reddish eyes, and juveniles (in life) also may be dstinguished by the general reddish tone of their markings (Conant, 1942, 194). The range of the form has not been accurately defined, but it evidently occurs throughout most of Florida; the general range map on page 50 requires alteration accordingly.

Attention should be called to the fact that the Ohio racers listed on pages $50,51,52$ and 55 were identified solely on the basis of morphological characters, and each individual snake was designated as Coluber constrictor constrictor, Coluber constrictor flaviventris, or an intergrade between them. Hence, in some instances, all three were listed as occurring together in the same lccality. This method of studying intergradation between subspecies, which often has resulted in confusion in the past, is falling more and more into disfavor. In accordance with the "new systernatics," names should be applied to populations and not to individual animals. Intergrading pozulaticns may be assigned a combination of the names of the two subspacies involved, in this case Coluber constrictor constrictor X flaviventris. All racers occurring within the stippled area (map 48) should be so designated. They are members of a (presumably) freely interbreeding population that may proz'uze individual; morphologically indistinguishable from specimens of either constrictor or flavirentris, or may produce snakes combining the characteristics of both these subspecies. The area of intergradation can only be approximated, for it obviously would require large series of specimens from a great many lecalities to outline it with any degree of accuracy; the ranges indicated upon th? map are based upon the material now available.

New recorc's for Coluber constrictor constrictor are:

Adams County: $5 \mathrm{mi}$. SW of Manchester (CM 17557); Near Stouts (WED 201). Athens County: Athens (OUVC 376, 880-1, 2063, 2367); $6 \mathrm{mi}$. W of Athens (OUVC 1372); Lodi Twp., $7 \mathrm{mi}$. SE of Athens (OUVC 1377); SE of 
Nelsonville (OUVC 1854); Waterloo Forest (OUVC 1265); Sec. 29, Waterloo Twp. (OUVC 2435). Carroll County: Near Amsterdam (OUVC 825A-B, 826). Hocking County: Near Gibisonville (WWED 3+2). JACkson Countr: Jackson (OUVC 347, 1267); Jackson Twp. (OUVC 600). Jefferson County: Bergholz (FWB). Ross Countr: Vigo (OSM 685). Scioto County: Rooseve't Game Preserve, Nile Twp. (OSM 884); Shawnee State Forest (OSM 885; IWED 45, 253).

Lawrence E. Hicks caught a racer 5 miles northwest of Marietta, Washington County, as it was in the process of swallowing a worm snake (Car. phophis).

A hatchling from Athens County (OUVC 880) measures $275 \mathrm{~mm}$. (approximately $107 / 8$ inches) in length and is hence the smallest racer from the state.

Since the number of subcaudal scales is of diagnostic importance, this characteristic has been re-evaluated upon the basis of the three populations: (a) Coluber c. constrictor from eastern and southeastern Ohio; (b) Coluber c. flaviventris from the northwestern third of the state; and (c) the intergrading population, which lies between them. (Many individual snakes from the central portion of Ohio were identified in the first edition of this report either as constricior or as flaviventris; among the statistics below, all snakes from the intergrading area are considered as intergrades despite their morphological resemblance to either of the two subspecies.) The means and extremes for subcaudals in the three populations, based upon all available Ohio material with complete tails, are as follows:

Coluber c. constrictor (29 specimens) - 85 to 102, mean 93.6.

Coluber c. constrictor X flapiventris (52 specimens) $-8+$ to 105 , mea. 90.4 .

Coluber c. Alaviventris (2t specimens) - 81 to 96 , mean 87.0.

Recent collecting has considerably increased the number of juvenile specimens available for study. Dorsal blotch counts made upon these, from the head to a point directly above the anus, may be summarized as follows:

Coluber c. constrictor ( 9 specimens) -54 to 66, mean 59.0.

Coluber c. constrictor X flaviventris (17 specimens) -52 to 72 , mean 60.0 .

Coluber c. flaviventris ( 5 specimens) -58 to 66 , mean 61.2.

Ortenburger, in his monograph on North American whip snakes and racers (1928), states that juveniles of flaviventris (p. 180) have 65 to 80 dorsal saddles "present between head and anterior third of tail" and that juveniles of constrictor have 50 to 65 (p. 196). From the statistics summarized above, it is obvious that the number of markings upon the young is of no diagnostic value insofar as Ohio specimens are concerned.

New records for the intergrading population are:

Butler County: Hamilton (OSM 531); Relly (Fichte", 19-17); Reily Twp. (OSM 688). Brown Countr: $1 / 2 \mathrm{mi}$. $\mathrm{N}$ of Greenbush (WED 5!); $1 \mathrm{mi}$. SW of Sardinia (WED 391). Clermont County: Goshen Station (UC 1); Stonelick Creek, near Owensville (CM 23952-3). Clinton County: Blanchester (UC 17); Wilmington (UC 2; USNM 118319). Greene County: Bellbrook (DPLM 1.48). H:gilland County: Belfast (DPLM 123.42). Hocking County: Near Cartwell's Cliff, Lau el Twp. (UMMZ 89893); Near Rockbridge (SL 166). KNox CountY: $1 \mathrm{mi}$. E of Centerburg (CM 19385). Lake Counts: Near Painesville (OSM 877). Montcomery County: Butler Twp. (DPLM 72.45); Dayton (Wood and Duellman, 1947b) : Englewood Dam. Randolph Twp. (WED 46-7); Germantown Dam (DPLM 
$3 r$. 42) ; Jefferson Twp. (DPLM 221.42, 223.42); Northridge, Harrison Twp. (Wcod and Duellman, 1947b); Van Buren Twp. (DPLM-2 specs.; WED 53); Washington Twp. (DPLM 222.42). Pike County: Pilie State Forest (DPLM 629.44, 669.44; WED 48, 50). Preble County: Camp Myron Kahn, 2 mi. S of Camden (MU 8). Ross Countr: 1/2 mi. S of Adelphi (WED 2C4); Potts Hill, Paxton Twp. (OSM 908). Warren County: 1 mi. W of Waynesville (WED 52).

One of the specimens from Wilmington, Clinton County (UC 2-a large male) has an undivided anal plate.

As is commonly the case when two forms are known to intergrade, individuals found well within the range of one race may show characteristics of the other race. I have already mentioned two specimens of flaviventris with high subcaudal counts (page 54, footnote). Two or three quite dark racers have been collected in northwestern Ohio, and a few rather bluish specimens have turned up in the eastern and southeastern counties. In many cases, howevei, not too much reliance can be placed upon color, for methods of preservation vary and fading often occurs. Likewise, living individuals exhibit changes; snakes preparing to shed are apt to be of a lighter coloration than usual. Only those racers that have recently passed through ecdysis may be said to exhibit diagnostic hues.

\section{Coluber constrictor flaviventris Say}

\section{Blue RACER}

(Page 54; maps 11 and 48; plate 6, fig. 3)

Racers from extreme southern Texas are characterized by (a) the consistently greenish coloration of the adults and (b) by the fact that the markings of the young consist chiefly of small dark spots which, on the anterior part of the body, fuse sufficiently to suggest narrow dark crossbars. Snakes of this population are now designated as Coluber constrictor stejnegerianus (Cope) and the general range map (page 50) should be altered to make allowance for them. Attention also should be called to an interesting population of racers that occu's from western Louisiana into Texas and Arkansas. Snakes from this region are irregularly marked with prominent white or yellow spots; the name Coluber constrictor anthicus (Cope) is available for them.

New records for blue racers in Ohio are:

Defiance County: Sec. 35, Defiance Twp. (OSM 819). Hardin County: (TMS 2467-8) $11 \mathrm{mi}$. E of Mt. Victory (OSM 753): $3 \mathrm{mi}$. E of Mt. Victory (OSM 559). Ingan CounTY: East side of Indian Lake (WED 49); south side of Indian Lake (Duellman, 1947). LuCAS CounTY: (TMS 2474); Sylvania (OSM 446). Miaml County: $11 / 2$ mi. S of West Milton (DPLM 6.43). Paulding County: 5 mi. NE of Antwerp (OSM 684). Preble CountY: Eat:n (DPLM 195.42).

Considerable comment upon flaviventris and its intergradation with constrictor has been made under the heading of the black racer (p. 222, et seq.).

\section{Elaphe obsoleta obsoleta (Say)}

\section{Pilot Black Snake}

(Page 55; maps 12 and 49; plate 7, fig. 2 and plate 8, fig. 1)

New records for this species are as follows:

Atiens County: (OUVC 349-50, 1264); 1 mi. E of Athens (OUVC 2238); $3 \mathrm{mi}$. SW of Athens (OUVC 1276); The Plains (OUVC 1330). Butler CountY: 
Oxford (Fichter, 1947); 4 mi. $\mathrm{N}$ of Oxford (MU 2); Reily (GF). Carroll CounTY: Near Amsterdam, Loudon Twp. (OUVC 828). Champalgn County: (OSM 495). Clermont Countr: Near Glen Este (CM 23956); Near Owensville, Stonelick Creek (CM 23954). Columblana County: Elk Run Twp. (OSM 423). Coshocton County: $10 \mathrm{mi}$. E of Coshocton (OSM 820.1-2). Darke County: Washington Twp. (OSM 686.1-2). Delaware County: Camp Lazarus, $3 \mathrm{mi}$. S of Stratford (FR); Kilbourne (OSM 659). Franklin CountY: Flint (OSM 396); Indian Run, near Dublin (OSM 826); Madison Twp. (OSM 739). Creene CounTY: Bellbrook (USNM 128918); Xenia (DPLM 194.42). Hamilton County: (SI_ 443,467 ). Highland County: I mi. E of Rainsboro (WED 56). Hocking CounTY: Ash Cave (HTG); Crane Hollow, 3 mi. S of Gibisonville (WED 350). Hurow LoUniY: 1 mi. S of New London (OSM 496). Jackson County: Jackson Twp. (OUVC 572); Scioto Twp. (OUVC 1266). Logan County: East side of Indian lake (Duellman, 1947). Montgomery Countr: Dayton (DPLM); Jefferson Twp. (DPLM 120.42); 2 mi. S of Taylorsville Dam (DPLM 10.43); also the fo lowing localities reported by Wood and Duellman (1947b) - Cricket Holler B.S.A. Camp and Shaker Pond, Butler Twp.; Northridge, Harrison Twp.; Pinnacle Road, Miami Twp.; and Hills and Dales Park, Van Buren Twp. Pike Countr: Pike State Forest (WED 55); Richardson and Egyptian Hollows (USNM 128919). PREBle County: 21/2 mi. S of Gratis (DPLM 2.48). Ross County: Vigo (OSM 687). Sc1ото County: Near Friendship (SL 463); Sec. 19, Madison Twp. (OSM 904). VInton County: Zaleski (OUVC 2173). Warren County: Ft. Ancient (UC 15: WE.D 200). Washington County: $6 \mathrm{mi}$. SW of Marietla (OUVC 1369). Wyandot County: Upper Sandusky (OSM 726). Kauffeld reports a specimen from 3 miles southwest of Winterset, Guernsey County.

A considerable number of juveniles is now available for study. Among forty-eight of these (including a few subadults in which the pattern is still well evident) the number of dorsal blotches, from the head to a point directly above the anus, varies from 29 to 40 with a mean of 34.6 . The specimen from Preble County (DPLM 2.48) is the smallest recorded for Ohio; it measures $287 \mathrm{~mm}$. (11 5/16 in.) in total length.

An adult female, $4 \mathrm{ft} .11$ in. in length (OSM 739 from Franklin County), was shot in a tree twenty feet from the ground as it was robbing the nest of a red-headed woodpecker on July 9, 1936.

Most Ohio specimens of Elaphe o. obsoleta, in comparison with those from the East (a iarge number from Pennsylvania. New Jersey, and the DelMar-Va Peninsula have passed through my hands in recent years), are decidedly brownish in coloration. Ohio pilot snakes, especially those from the southwestern counties, are also likely to retain strong traces of th = juvenile pattern even after they have reached relatively large size. Adult eastern specimens tend to be jet black and to have the pattern obsolete or lacking entirely.

\section{Elaphe vulpina gloydi Conant}

\section{EASTERN FoX SNAKE}

(Page 60; maps 13 and 50; plate 7, fig. 3 and plate 8, fig. 2)

Studies made upon a series of more than 200 specimens from all parts of the range have shown that the fox snake is separable into two subspecies (Conant, 1940), chicfly on the basis of the size and number of dorsal blotches (mean 34 in gloydi and 41 in vulpina). The eastern form occurs in Ohio near the western end of Lake Erie; it also is found (in Michioan ant On. tario) in the general vicinity of Lakes Erie and St. Clair and S a g n $\mathbf{n}^{-} \mathbf{w}$ and 
Georgian Bays. There is a dubicus record from "near Buffalo, Ncw York." The approximate range of the western subspecies, Elaphe vulpina vulpina (Baird and Girard), is indicated by the large dark area on Map 13, but, in addition, vulpina is now known from extreme eastern Nebraska and extreme southeastern South Dakota. New Ohio records for the fox snake are:

Erie County: Margaretta Twp. (AMNH 49901); Sandusky (AMNH 3502; BU 1842). Lucas Countr: Little Cedar Point, Jerusalem Twp. (ANSP 21650 [the type specimen]; ANSP 21651 [allotype]; ANSP 21652-61; CA 6935; ISC 7 [all para-topotypes]; OSM 575; CM 20631-9); Toledo (OUVC 1218). OTtawa County: Bay Point (CMNH 156); Catawba Island (OSM 675); 5 mi. E of Port Clinton (UMMZ 98526); South Bass Island (UMMZ 95974).

Three large females from Little Cedar Point, Lucas County, deposited eggs at the Philadelphia Zoo on July 20, 21 and 23, 1938, respectively. Data on these have been published (Conart and Downs, 1940, 38), but the extr=mes and means are noted in the following table:

TABLE 5

Eggs and Young of Elaphe vulpina gloydi

\begin{tabular}{|c|c|c|c|c|}
\hline Clutch & No. of Eggs & Length & Width & Weight \\
\hline I & $\begin{array}{l}14 \text { (11 adherent } \\
\text { in a sing le } \\
\text { cluster) }\end{array}$ & $\begin{array}{l}36 \text { to } 47 \mathrm{~mm} . \\
\text { (mean } 41.9 \mathrm{~mm} .)\end{array}$ & $\begin{array}{l}2 t \text { to } 27 \mathrm{~mm} . \\
\text { (mean } 24.6 \mathrm{~mm} \text {.) }\end{array}$ & $\overline{(\text { mean } 14.75} \mathrm{g})$. \\
\hline II & $\begin{array}{l}11 \text { (5 adherent } \\
\text { in a cluster) }\end{array}$ & $\begin{array}{l}38 \text { to } 58.5 \mathrm{~mm} \text {. } \\
\text { (mean } 47.75 \mathrm{~mm} \text { ) }\end{array}$ & $\begin{array}{l}22 \text { to } 26 \mathrm{~mm} \text {. } \\
\text { (mean } 24.2 \mathrm{~mm} \text {.) }\end{array}$ & $\overline{(\text { mean } 17.5}$ g.) \\
\hline III & 21 & $\begin{array}{l}29 \text { to } 47 \mathrm{~mm} . \\
\text { (mean } 40.7 \mathrm{~mm} \text {.) }\end{array}$ & $\begin{array}{l}23 \text { to } 27 \mathrm{~mm} \text {. } \\
\text { (mean } 25.4 \mathrm{~mm} \text {.) }\end{array}$ & $\begin{array}{l}13 \text { to } 20 \mathrm{~g} \text {. } \\
\text { (mean } 15.4 \text { g.) }\end{array}$ \\
\hline
\end{tabular}

Five of the eggs of clutch II hatched in September, 1938. The mean length of the babies was $321 \mathrm{~mm}$. (125/8 inches) and the mean weight 14 grams.

Mattlin (1948) has reported upon a clutch of 20 eggs deposited on August 5, 1947, by a female gloydi from the same locality. Ten of his eggs remained in good condition and began hatching on September 18; the means for 7 young were $294 \mathrm{~mm}$. (115/8 inches) and 11.7 grams. 'Two of Mattlin's eggs, when opened, were found to contain fully-deve! isped, but badly deformed, snakelets.

\section{Lampropeltis getulus nigra (Yarrow)}

\section{Black King Snake}

(Page 63; maps 14 and 51; plate 9. fig. 1)

The black king snake may now be recorded from a fourth county (Jackson), which extends the range slightly farther north. New records are:

Jackson County: Liberty Twp. (OUVC 314, 1851); Rock Run, Liberty Twp. IOSM 593); Scioto Twp. (OSM 755). Scıto County: Shawnee State Forest (WED 1+1). Johnson also has obtained specimens from several other localities in Scioto County: 2t/2 mi. SE of Henley. Union Twp.; 3 mi. SW of Portsmouth, Washington Twp.; in and near the Roosevelt Game Preserve. Nile Twp.; and S of Rushtown, Rush Twp. 
So many king snakes have now been obtained from Scioto County (west of the Scioto River) that the species can almost be designated as common in that portion of the state.

Some additional habitat notes are available for this interesting Ohio snake. The two specimens in the Ohio University Vertebrate Collection were taken in or near the open marshy "meadow" below White's Gulch; one of them was plowed out of the ground (May 20, 1940). Rausch obtained two in the Rock Run area, borh in rather derse wordland: one was encountered when a slab pile was torn apart and the other "was found one morning lying in a dirt road." Duellman secured his specimen in the Shawnee State Forest as it was crossing a road flanked by a grove of pines. Johnson has encountered king srakes (many of them DOR) in a variety of habitats which may be summarized as follows: In weeds along state highway; at the edge of blue glass pastures; in or near cultivated fields; ncar woods; along a stream; and under a rock at roadside.

Four of the five new museum specimens are males. Scale counts made upon them (and upon the single female) fall well within the ranges of variation indicated on page 64, except for the ventral counts in males. There, in a total of fourteen specimens (including those previously available for study) vary from 199 to 214 , and have a mean of 205.9 .

A specimen $98 \mathrm{~cm}$. in length and weighing 224 grams devoured a milk: snake (Lampropeltis d. triangulum) measuring $82 \mathrm{~cm}$. and weighing 105 grams on the day of the king snake's capture. 1949.

A gravid female, collected on May 30, 1949, laid eleven eggs on June 21,

\section{Lampropeltis doliata triangulum (Lacépède) \\ Eastern Milk Snake \\ (Page 66; maps 15 and 52; plate 10, fig. I)}

Klauber $(1948,10)$ has presented evidence for reinstating the Linnaean name (Coluber doliatus) which was long in use for the memters of the milk snake group. For detailed arguments concerning this taxonomic change. Klauber's paper should be consulted, but the essence of his reasoning is as follows: He believes that doliatus, contrary to Stejneger $(1918,99)$, is identifiable and that the name is applicable to the scarlet king snake (formerly Lampropeltis elapsoides). Thus, the latter form becomes Lampropeltis doliata doliata, and the various taces of milk snakes fall in line as subspecies. Recently it has been demcnstrated that doliata is subspecifically related to triangulum through temporalis, the coastal plain race (Conant, 1943b).

It is now known that the eastern milk snake does not occur so far to the southeast as is indicated on the inset map (page 67). Old records from the southern coastal plain and piedmont have proved to be in error, and it can be shown that triangulum, in the South, is apparently confined to the mountains (Conant, op. cit.). Below Maryland the range should be amended to extend 
only as far eastward as western Virginia, western Ncrth Carolina, and extre.ne northcastern Georgia. From southeastern Pennsylvania and southern New Jersev to the vicinity of Washington, D. C., triangulum intergrades with temporalis, a race characterized by a "collar" across the nape of the neck and by large dorsal blotches that extend downward to the ends of the ventral scutes (at least on the forward part of the body). The range of temporalis embrace; the Del-Mar-Va-Penınsula and part of mainland Virginia. New Ohio records for triangulum are:

Allen County: Blufftcn (OSM 727); 2 mi. N of Bluffton (OSM 821). Athens County: Angel Ridge, near Shade, Lodi Twp. (OUVC 2454); $10 \mathrm{mi}$. SW of Athens (OUVC 1244). Butler County: (OSM 530); Oxford (MU 3). Clemmont County: (SL 461); Stonelick Creek, near Owensville (CM 23955). Clinton County: Clarksville (UC 18). Delaware County: Near Radnor (OSM 658). Fairfield County: Baltimore (OSM 546-albino). Franklin County: Columbus (OSM 34.1-2, 596). Greene County: 2 mi. W of Osborn (DPLM $11.43,610.44) ; 3$ mi. NW of Yellow Springs (USNM 128921). Hamilton CounTY: California (CM 23960); Cincinnati (ROMZ 5996); Sedamsville (CSNH 2609 -albino). Hancock County: North of Mt. Cory (OSM 671). Hardin County: Mt. Victory (OSM 502). Hocking County: "Neotema," Good Hope Twp. (OSM 597). Jackson County: Jackson (OUVC 336). Lawrence County: Chesapeake (CM 17568). Logan County: Indian Lake (Duellman, 1947). Miami County: l_udlow Falls (DPLM 1II-2.44); 11/2 mi. S of West Milion (DPLM 93.44). Montgomery County: East Dayton (Wood and Duellman, 1947b); Englewood Dam, Randolph Twp. (DPLM 196.42; WED 58-9); Madison Twp. (DPLM 305.42); Van Buren Twp. (DPLM 32.47). Ottawa Countr: Marblehead (CA 5591); near Port Clinton (OSM 693). PIKE County: Pike State Forest (DPLM 96.42, 141.42, 309.42, 605.44; WED 61); $12 \mathrm{mi}$. E of Sinking Springs (WED 62); Tcbacco Barn Hollow (USNM 128920). Putnam County: I mi. E of Pandora (OSM 692.1-6). Scloto County: Shawnee State Forest (WED 189). Stark County: Sec. 12, near Hartville, Lake Twp. (CA 58n8). Warren County: $11 / 2$ mi. SSE of Roachester (WED 223). Washington CountY: Muskingum River, Marietta (OUVC 603).

Since I ampropeltis doliata syspila, a related subspecies, occurs in southern Indiana, the patterns of all new specimens from southwestern Ohio were care. fully checked. All of these are identifiable as triangulum. The number of dorsal blotches (among thirteen specimens) varies from 37 to 58, man 47.3; the snake with the fewest number (from Oxford, Butler County) has a welldeveloped "V" on its neck and two rows of lateral blotches on each side of the body-both triangulum characteristics. Among seven specimens from Pike and Scioto counties (from much farther east and in unglaciated O'io) the number of blotches averages even lcss-38 to 49 and with a mean of 44 . The maximum for syspila (Blanchard, 1921, 23) is 35. In making these counts I have followed the unorthodox methed of Blanchard who calculated the total number from head to tip of tail. This renders snakes with incomplete tails useless for statistical purposes.

Wood has a record in his notes of a specimen from the Engleweod Dam, Montgomery County (DPLM 196.42), that had a maximum of 23 scale rows. This same snake devoured thre z juvenile copperheads that were temporarily houscd with it, and it deposited 26 eggs in caprivity during the first week of July, 1940. 


\section{Natrix erythrogaster neglecta Conant \\ Northern Copperbelly \\ (Page 70; maps 16 and 53; plate 10, fig. 3)}

Recent studies have indicated that Natrix erythrogaster is readily separable into four geographic races, the most northerly of which (neglecta) occurs in Ohio (Conant, 1949). This form has been recorded from south central Michigan, Hardin and Williams counties, Ohio, and fron several localities in Indiana southwestward to near the mouth of the Wabash River. The inset map (page 72) shows the approximate ranges of three of the four subspicies: (1) neglecta (characterized by a black or dark brown dorsum and a bright red belly); (2) flavigaster (greenish grey above, yellow below), from southeaster $\Omega$ Missouri and western Tennessee south through Arkansas, Mississippi, and Louisiana to the Gulf; and (3) erythrogaster (reddish brown above, salmon below), of the Southeast. The fourth race, transversa, occurs from Kansas south through Oklahoma and Texas into Mexico. The subspecie; erythrogaster does not range so far north in the East as the map indicates; the Pennsylvania records have been shown to be in error, and, according to our present knowledge, the northernmost station for it is in the southern part of the DolMar-Va Peninsula (Conant, 19.43c). New Ohio records are:

Hardin County: $3 \mathrm{mi}$. E of Mt. Victory (AMNH 68695 [the type specimen]; AMNH $68596-8$; OSM 505, 605, 67t). Williams County: I mi. SW of B'akesley (ANSP 2587I).

The status of the copperbelly in Ohio at present is highly precarious. Mattlin reported more than a decade ago that the ponds near Blakesley had been emptied by a "honeycomb" of drainage pipes, and Triplehorn has recently told me that the current intensive agricultural activities in the Hardin County locality will probably destroy the habitat there. This, neglecta already may be gone from the only two places in Ohio from which actual specimens are available. There is a possibility, however, that eventually it may be found in other localities, especially in the western part of the state. Shortly before I left Ohio in 1935, I heard several rumors about "red-bellied black snakes" along roadside ditches in the northenstcrn corner of Henry County, but opportunity was lacking to investigate them thoroughly. Thomas has had reports about the former prevalence of the red-bellied water snake in Van Wert County and at Indian Lake. Ehrhart has henrd tales about its occurrence in Paulding County, and Clarence F. Clark, of St. Marys, states that he saw a specimen in Nettle Creek, Williams County, as recentlv as the summer of 1948. Robert Goslin recalls having killed and skirned one many years ago that was takcn along Pleasant Run which formerly drained a boreal relict bog in the Hocking River bottoms. The species may once have occurred even farther east. Zeisberger, a Moravian missionary, described what may have been a copperbelly from Gnadenhutten. Tuscarawas Counzy, in the 1790's (Hulbert and Schwarze, 1910, 70). All such "reports" are of interest, but in consideration of the ease with which dark individuals of Natrix s. sipedon may be confused with neglecta, only those records which are supported by actual specimens can be accepted. 


\author{
Natrix kirtlandii (Kennicott) \\ KIRTI AND's Water SNAKE \\ (Page 74; maps 17 and 54; plate 9, fig. 2)
}

Far from being the rarity it once seemed, evidence is still accumulating to prove that Natrix kirtlandii is widely distributed in western Ohio. No new centers of concentrated aburdance (like those at Toledo and Cincinnati) have been discovered, but records are now at hand from eleven additional counties, eight of which lie wholly, and one almost entirely, within the till plains of western Ohio. Wood and Duellman (1947a) have published upon localities from the Miami Valley. New records are:

Allen County: 2 mi. N of Bluffion (OSM 708.1-2, 822). Butler County: Oxford (GF). Champaign County: Near Kennard (OSM 745). Clark County: Crystal Lake (DPLM). Clermont Counry: Goshen (CSNH 2657). Darke County: Near Greenville (WED 409). Er!E County: Sandusky (AMNH 3370). Greene County: Xenia (Wood \& Duellman, 1947a). Hamilton County: (SL 442); Cincinnati (CM 24115-7; CSNH 194, 1591, 2032; SL 781-2); Clifton, Cincinnati (CSNH 1632.1-2, 2164.1-25, 2346.I-2); Coy Field, Cincinnati (UC 5A-D); Mt. Airy, Cincinnati (CM 20630); Mt. Washington, Cincinnati (AMNH 65514-9); Westwood, Cincinnati (CM 20603-10). Jackson Countr: Whites Gulch, Liberty Twp. (HTG; OUVC 345). Logan County: East Side, Indian Lake (WED 63. 66); Liberty Twp. (OSM 486, 529). Lucas County: Toledo (CA 5283; CM 2061I-29; CMNH 82; CU 3504a-b; UMMZ 96992). Marion County: Sec. 5. Maricn Twp. (OSM 534). Montgomery County: Dayton (DPLM; WED 64-5). Paulding County: 3 mi. NE of Antwerp (OSM 501). Wood Counry: Maumee River, opposite Waterville (CA 5284-5). Gier advises me that one of Dr. Eggleston's students collected a specimen of hirtlandii in Squaw Hollow, just west of Marietta. Washington County. This snake was subsequently lost.

In all probability kirtlandii will turn up in numerous other localities in western Ohio, but its secretive natuie and marked preference for prairie or prairie-like habitats make it difficult to find. The marl bog near Kennard, Champaign County, for example, has been visited by naturalists for many years, but kirtlandii was not discovered there until July 2, 1947. Th: species also is likely to be found in eastern Ohio, for it has long been knewn from western Pennsylvania which it may have reached through the eastward exten. sion of the prairie peninsula (see Transean, 1935, and Schmidt, 1938).

Among recently collected material, most interest probably should focus upon the snak's from southeastern Ohio. Natrix kirtlandii has previously been reported from unglaciated Ohio (Fairfield and Hocking counties-page 75 ), but specimens are now also available from another place within the borders of the same physiographic province-along the stream below White's Gulch in Jackson County. Attention should be called to the fact, however, that the localities in all three of these counties are on the floors of filled vallevs, silts to considerable depths having been deposited when the valleys were dammed by glaciers to the north and west. Thomas has pointed out to me that conditions in these localities are not typical of the unglaciated plateau and that the areas in question resemble those of certain parts of glaciated Ohio. The filled valleys, for example, contain many boggy and marshy spots, habitats that are notably lacking elsewhere in the southeastern part of the state. 
I have recently summariced data on the species Natrix kirtlandii as a whole (Conant, 1943a), basing it in large part upon Ohio material. This paper"Studies on North American Wates Snakes-I: Natrix kirtlandii (Kennicott)"-may be consulted for additional information on habits, habitats, general distribution, etc. Incidentally, the inset map on page 75 should be amended to show the main part of the range terminating in western Pennsylvania (Westmoreland County). There are two old, and probably questionable, records (Trenton, New Jersey, and Delaware County, Pennsylvania) from much farther east, but kirtlandii apparently does not range clear across the Keystone Staie.

Wood and Duellman (op. cit.) report that some of their spzcimens bit the collectors' hands at the time of capture, an experience that I have not had. My former failure to keep caged adults alive over winter has been overcome by freezing quantities of earthworms in iate fall. These, when fresh!y thawed, have been readily accepted by the snakes. Many zoo curators and other persons are now taking advantage of "deep-freeze" methods to provide an offseason supply of worms, insects, frogs, lizards, baby snakes, and other perishables as food for captive specimens.

\section{Natrix septemvittata (Say) \\ Queen Snake}

(Page 77; maps 18 and 55; plate 10, fig. 2)

The many rew records from all parts of Ohio add proof of the fact that Natrix septemvittata is one of the most abundant and widespread snakes in the state. Ten new counties may be added. Records are:

Allen Countr: 2 mi. N of Blufton (OSM 695, 705). Ashtabula County: Cnnneaut (CU 3816-6 specs.). Brown CountY: Georgetown (UC 13); $8 \mathrm{mi}$. N of Georgetown (USNM 129016-27); Owl Creek, 4 mi. S of Decatur (WED 281); Saltlick Creek, Chasetown (WED 269-71); Straight Creek, 3 mi. E of Georgetown (WED 272-9, 376); Straight Creek, $6 \mathrm{mi}$. S of Georgetown (WED 76); White Oak Creek, New Hope (WED 239-40, 285-99, 379-81). Butler County: Oxford (Fichter, 1947); Reily (GF). Carroll County: Near Amsterdam (OUVC 1287). Champaign County: Kiser Lake (WED 245); Mad River at West Liberty (UMMZ 89891); l mi. W of Springhills (WED 85, 243). Clark Countr: Mad River, near Medway (WED 80-4); 1 mi. W of Springfield (WED 310). Clermont County: Clover Lick Creek, 2 mi. $\mathrm{N}$ of Bethel (WED 389-90); near Goshen (WED 217-9. 236-7); Twelve-mile Creek, S of Batavia (WED 228-30); Union Twp. (OUVC 1222). Clinton County: (DPL.M 651-3.44); Anderson's Fork (DrLM 381-2.44); S of Westboro (IVED 283-4, 384-6). Cuyahoga County: Chagrin Falls (UMMZ 96912). DaRke County: (USNM 128964): Greenvi'le Creek, 5 mi. W of Greenville (Wood, 1949). Defiance County: Defiance (OSM 696); l mi. SW of Defiance (OSM 752.1-3). Frankin County: Big Walnut Creek, Hamilton Twp. (OSM 839); near Brice and Fairfield Co. line, Madison Twp. (OSM 494); Columbus (OUVC 2073A-B). Greene Countr: Clifton Gorge (DPLM 356.44; OSM 694); Little Sugar Creek, Bellbrook (WED 67); Osborn (DPLM 388.44). Hamilton Countr: Mt. Washington, Cincinnati (CM 23961, 24118); Rapid Run, Delhi Twp. (UC 7). Hancock Countr: Findlay (CM $22604-$ 5). Hardin Countr: Panther Creek, I mi. N of Mt. Victory (WED 7l); Wildcat Creek (OSM 544); Wildcat Creek, near Mt. Victory (OSM 610). Hockinc CounTY: Conkle's Hollow (WED 341). Huron County: Monroeville (AMNH 64+41). Logan County: I mi. N of Huntsville (WED 68); Indian Lake (Duellman, 1947); 
21/2 mi. SE of Indian Lake (WED 73-4); Liberty Twp. (OSM 507). MARION County: Olentangy River, Richland Twp. (OSM 611). Miamı County: (USNM 129031); near Covington (WED 372); Ludlow Falls (DPLM 612-21.44; WED 72. 324; USNM 129028-30); Stillwater River, I mi. N of Montgomery Co. line (Wood, 1949). Montcomery County: (USNM 128999-129012); Centerville (WED 176, 194-6, 300); Dayton (DPLM 112.42, 17.43, 101.44); SE of Dayton (DPLM 319.44); Englewood Dam, Randolph Twp. (DPLM-25 specs.; WED 69 70, 86: USNM 128974-98); Germantown Dam, German Twp. (Wood \& Duel'man, 1947b) ; Northridge (DPLM 53-68.45; USNM 128971-3); Taylorsville Dam, Butler Twp. (DPLM 569.44, 572-80.44; USNM 128965-70); Wolf Creek, Harrison Twp. (DPLM 632.44). Paulding County: Antwerp (OEE-4 specs.). Preble CounTY: 1 mi. E of Camden (USNM 129015); 2 mi. S of Camden (MU 6-7, 15); Gratis (USNM 129013-4). Scioto County: Roosevelt Game Preserve (WED 75). Seneca County: I mi. N of Bloomville (CZP 2). Shelby County: Mill Creek, 2 mi. NE of Lockington (WED 249). Summit County: Northfield Twp. (CZP 1). Vinton County: Salt Creek at Hocking County line (OUVC 1858A-B). W W County: Fort Ancient (UMMZ 96913-4); $11 / 2 \mathrm{mi}$. SSE of Roachester (WED 2212): $1 \mathrm{mi}$. W of Waynesville (WED 77-9); $5 \mathrm{mi}$. SW of Waynesville (WED 303). Washington County: Marietta (OUVC 602).

Records are still lacking from a small block of southern counties (Athens, Meigs, Jackson, Gallia, etc.). Both Mittleman and Gier, who did much field work in that part of Ohio, failed to find septemvittata there. The specics probably will turn up eventually, but some explanation for its apparent scarcity may be found in the nature of the streams of the region. Evidently one (or more) of the optimum conditions outlined by Wood (see below) is missing in these counties. The absence of records from Pike County is also surprising in view of the intensive field work done there during the past decade.

Several papers on Natrix septemvittata in Ohio have been published during the past few years (Wood, 1944; Triplehorn, 1949; Wood, 1949; and Wood and Duellman, 1950). Coilectively, these authors have presented so much data, in the form of field and laboratory observations and statistical summarizations, that the queen snake is now certainly one of the best studied reptiles in the state. Their respective publications must be consulted for details, but the bulk of the following paragraphs constitute an abstract of the more important facts contained therein.

Wood's 1949 contribution is concerned with the results of his field work in southwestern Ohio from 1940 to 1947 during which time more than 1,000 specimens passed through his hands. He points out that, in some parts of the Miami Valley, septemvittata is extremely abundant, even in certain of the larger rivers. He believes that three conditions must be met if an area is to support a large population of queen snakes. These are:

1. A permanent water area, either running or still, in which the water remains at or above 65 degrees Fahrenheit during most of the active season of Natrix seplemvillata;

2. An abundance of cover, usually in the form of flat rocks lying partly in the water, partly on the bank; and

3. An abundance of crayfish (gerus Cambarus).

During the hot summer months all specimens were found in the water or beneath rocks; in early spring and late fall queen snakes were often seen sun- 
ning on objects overhanging the water; very few sepiemvittata were encountered at night during any season of the year.

Wood states further that crayfish are the chief focd item, and he bases this conclusion upon the examination of stomach contents, observations upon material disgorged by freshly-captured specimens, and a sifting of the literature that has been published on this species. Most of the crayfish caten, he believes, are engulfed shortly after they have passed through ecdys:s; some are taken dead, as carrion. In either condition the prey would be help!ess. Queen snakes probably do not often seize large active crayfish which would be capable of inflicting considerable damage. Specimens of septemvittats with missing eyes or scarred heads and necks are rarely found.

Duellman, who has also done much field work in the southwestern part of Ohio, states (in a letter to $\mathrm{me}$ ), "From all observations here in the Miami Valley, we have found the only food taken by the queen snake is crayfish. These are always found to have been swallowed tail first."

Wood (op. cit.) reports, however, that he observed a large female septem. vittata disgorge a 5-inch catfish. My statement (p. 81) that "Queen snakes disgorged crayfish and small fish when captured," included several instances of these crustaceans having been eaten, but only one in which a fish was involved. Wood believes these to be the only valid records of fish-eating by this spacies. Probably other instances have been recorded, but it is clear, both from the studies of Wood and Duellman and from reports published on septemvittata in other states, that this snake is a negligible predator insofar as fishes are concerned and a quite important predator of crayfish.

Triplehorn (1949) has reported upon an exceptionally large female that was collected along the Auglaize River, at Defiance, on June 18, 1946. This snake measured $922 \mathrm{~mm}$. (361/4 in.) in length-a new maximum record for the species. It contained 23 embryos, an exceptionally large number.

Wood (op. cit.) presents data on the number of young or embryos for several additional Ohio queen snakes. These, when added to Triplehorn's report (and to mine, see p. 81 ), give us records for seven females; the number of their offspring varied from 10 to 23 and averaged 13.4. Mattlin states that some very young specimens in his possession fed upon earthworms.

Borh Wood and Duellman have secured considerable data suggesting that the queen snake in some localisies may aggregate in large numbers prior to hibernation. Wood (1944) reported upon a group taken along the Miami River about five miles upstream from Dayton. Nearly fifty specimens were found basking in the late afternoon sun on October 27, 1940, in denud d saplings growing in a mud bank. Thirty-two were collected; these varied in size and included many large adults, but no young of the year were among them. In commenting further about aggregations of queen srakes, Wood (1949) mentions the finding of 125 specimens in less than one hour along White Oal Creek, 3 miles north of Georgetown, Brown County, on September 22, 1946. Twenty-four of these snakes were beneath a single rock. This large collection was made by Dueliman and two companions. Duellman says that most of the specimens were under rocks that also had water beneath them; a few were 
swimming in the stream; one or two were basking on the bank. Most were of "good" size; not more than six were juveniles. Other sizable collections of queen snakes were taken along the same stream-about 40 on October 4, 1947; 15 on March 25, 1948; and more than 25 on September 9, 1948.

The above notes may or may not indicate that Natrix septemvittata assembles in groups for hibernation as do snakes of other species. Quite probably it does, but it would be of interest to know whether anything else may have been involved, such as a high concentration of crayfish. As mentioned on page 80, another collector and I obtained twenty-six specimens under rocks along the Huron River, at Monroeville, on August 29, 1932. The weather was quite warm and it probably was too early in the season for impending hibernation to be a factor. I believe that we might have doubled or even tripled our catch cn that day if the necessary effort had been expended.

The paper by Wood and Duellman (1949) is concerned with size and scutellation as revealed by a study of 188 individuals from the southwestern counties, chiefly Brown and Montgomery. Their scale counts are quite similar to those reported upon page 77 , but the range of variation is greater, because of the larger population sample. Their largest specimens were females, and that sex averaged mure than two inches longer than males. They present a histogram showing that juveniles fall into two size groups: young of the year, measuring from 166 to $255 \mathrm{~mm}$., and snakes that are presumably in their secund year, measuring from 286 to $375 \mathrm{~mm}$.

\section{Natrix sipedon sipedon (Linnaeus) \\ Northern Water SNake \\ (Page 81; maps 19 and 56; plate 11, fig. 1)}

This abundant water snake is well represented in recent collections, and large series of specimens from virtually all parts of the state are now available for study. A few individuals from the most southwestern counties have wellseparated dorsal markings, low dorsal blotch counte, and a tendency for the dark "half-moons" on the belly to be in pairs. These are characteristics of Natiix sipedon pleuralis which subspecies Mittleman $(1947,481)$ has reported from south central Indiana (northward as far as Brown, Monroe, and Owen counties). Studies in which I am currently engaged upon Nouth American Natrix may eventually demonstrate that the water snakes occurring in southwestern Ohio are members of an intergrading population between sipedcn and pleuralis. From the evidence currently at hand, however, the influence of pleuralis appears to be slight in Ohio, and, for the sake of expediency, all water snakes (of this species) from the state may be considered for the present as Natrix sipedon sipedon. New Ohio records are:

Adams County: Peach Mountain. Meigs Twp. (UC 10). Allen County: Richland Twp. (OSM 840, 845); Riley Creek, Bluffton (OSM 711); Riley Creek, $\mathrm{S}$ of Bluffton (OSM 749). Athens County: Athens (OUVC 121, 342); $6 \mathrm{mi}$. SW of Athens (OUVC 830): Beaumont (OUVC 2323). Brown County: Center Point (WED 301-2); $8 \mathrm{mi}$. N of Georgetown (USNM 129C44-55); $1 \mathrm{mi}$. SW of Georgetown (WED 383); NW of St. Martin (WED 107): Saltlick Creek, Chase- 
town (WED 268); Straight Creek, 3 mi. E of Georgetown (WED 280, 377-8); Straight Creek, 6 mi. S of Georgetown (WED 108-12); White Oak Creek, Newhope (WED 24l, 382). Butler County: Bull Run, Oxford (MU I); Reily (GF). Champaign County: I mi. W of Springhills (WED 242). Clark County: I mi. W of Springfield (WED 309). CLERmont County: Cloverlick Creek, $2 \mathrm{mi}$. $\mathrm{N}$ of Bethel (WED 388); Goshen (WED 220, 238): $11 / 2$ mi. NW of Owensville (WED 233-5); Twelve-mile Creek, S of Batavia (WED 231-2). Clinton County: (DPLM 648.44); Anderson"s Fork (DPLM 383.44); S of Westboro (WED 387). Darke County: (USNM 128059-62). Defiance County: Auglaize River, I mi. SW of Defiance (OSM 748.1-2); Lost Creek (UMMZ 84714). FayetTe County: (UC 4). Franklin County: Black Lick Creek, Madison Twp. (SL 995); Alum Creek, Mifflin Twp. (OSM 645). Greene Countr: Anderson's Fork (DPLM 379.44); Beaver Creek, near Alpha (WED 98); Bellbrook (WED 177); Caesar Creek (DPLM 570.44); Glen Helen, Yellow Springs (WED 257-8). HamiltoN County: Mt. Healthy (CSNH 2633). Hardin Countr: 3 mi. E of Mt. Victory (OSM 869; WED 101, 113). Highland County: Buford (UC 8). Hocking County: Ash Cave (WED 347); Cedar Falls (OUVC 2389); Clear Creek at Hocking River, Good Hope Twp. (WED 349); near Old Man's Cave (CM 2l682); South Bloomingville (WED 343); 4 mi. S of South Bloomingville (HTG-4 specs.). JACKSON COUNTY: (OUVC 134); Jackson Twp. (OUVC 569-70). JefFErson County: Amsterdam (OUVC 827, 829). Lawrence County: Union Twp. (OUVC 1859). Logan County: 21/2 mi. SE of Indian Lake (WED 102); Mad River, southern Liberty Twp. (UMMZ 84715). Lucas CounTY: Little Cedar Point (OSM 609). Marion Countr: I mi. S of Marseilles (UMMZ 98773). Miami County: Ludlow Falls (DPLM 609.44; WED 104); West Milton (WED 323). Montgomery County: Dayion (DPLM 82.42, 318.44; UMMZ 95358-7 specs.); Englewood Dam, Randolph Twp. (DPLM-27 specs.; WED 99-100, 103, 193; USNM 129032-5); Northridge (DPLM 69-71.45); Taylorsville Dam, Butler Twp. (DPLM 514.44, 568.44; USNM 129036-43): Wolf Creek, Dayton (DPLM 363.44). Ottawa County: Catawba Island (OSM 899): Marblehead (UMMZ 97057-2 specs.). Pine County: Pike Lake (DPLM 248-50.44); Pike State Forest (WED 106). Preble Countr: I mi. E of Camden (USNM 129056-7); Camp Myron Kahn, 2 mi. S of Camden (MU 4-5, 16); Gratis (USNM 129058). Ross County: 5 mi. SSE of Greenfield (WED 197). Scioto CoUnty: Bear Creek, Morgan Twp. (SL 732); Roosevelt Game Preserve (UMMZ 98024). Shelby Countr: Brush Creek, 23/. mi. SSW of Sidney (WED 246-8); east end of Loramie Lake (WED 244). Vinton Countr: Raccoon Creek, Vinton Twp. (OUVC 573). WaRREN COUNTY: 11/2 mi. SSE of Roachester (WED 224-6).

A specimen collected at Fort Ancient, Warren County, by Walter on May 4, 1941, disgorged a larval salamander at the time of its capture. Duellman reports the birth of twenty young to a female from 3 miles east of Mt. Victory, Hardin County; the mother, which measured 321/2 inches in length, was caught on July 28, 1946. The young, born on September 3, 1946, varied from 8 to $91 / 4$ inches and averaged $85 / 8$ inches.

Sportsmen's organizations and magazines, many state fish departments, and so-called conservation groups have long ard loudly advccated the destruction of the water snake, basing their arguments upon the assumption that the fewer predators there are the more fish there will be for the angler. Recent research tends to refute this theory and to indicate, paradoxically, that Natrix may play an important role in providing better fishing.

Lagler and Salyer (1947) have reported upon the stomach contents of a large series of Natrix s. sipedon collected in Michigan. Fish constituted by far the greater part of the food, but the large majority of water snakes collected 
along natural waters had consumed forage fishes; game and pan fishes made up only a small percentage of the total. Among 106 specimens of sipedon taken along Michigan trout streams, only 7 snakes $(6.6 \%)$ had eaten trout and all of these were small. Lagler and Salyer, in summarizing their findings, state, "Any widespread control [of water snakes] on natural waters... cannot be warranted biologically at this time. We are in general agreement, however, with the opinion of several workers . . . that reduction of populations at fish-cultural stations is requisite and justifiable."

The thought-provoking paper of Trembley (1948) on fishing conditions in Pocono Mountain lakes (Pennsylvania) is recommended as "must" reading for anyone who deplores the ruthless miainer in which all predators have been persecuted for decades. Trembley points out that numerous ponds and lakes that provided excellent fishing ten to twenty-five years ago are no longer fished, hut their waters now support "very high populations of stunted fish, especially small yellow perch." He further states, "All evidence in this area seems to point to the conclusion that intensive removal of predators, especially those that take small size fish, has been carried to the point of producing a serious state of unbalance in the lakes. In the absence of predation, the large breeding stock of lake fishes has produced enormous hordes of young destined never to grow to full size. In the face of competition induced by overpopulation these young bccome stunted and worthless to the fisherman."

In suggesting a remedy for the situation, Trembley says, "Of the avian. teptilian, and mammalian fish predators . . the common watersnake, Natrix sipedon, may offer the quickest solution of the overpopulation problem. It increases rapidly if given protection. ... It is a local, non-migratory animal and therefore does not have to run the gamut of guns and other dangers over a migration route of several thousand miles. It produces no valuable coat, like the mammalian fish eaters. If given protection, it seems to be capable of doing a good job of thinning out overabundant populations of small fish. If it ever becomes too abundant for the best interests of the lake, which is very doubtful, its numbers can very easily be reduced. Surprisingly enough, watersnakes may add to the game fish supply of the lake since they catch more nongame than game species and turn their food into young snakes which are caught easily and eaten greedily by large bass and pickerel."

Water snakes have virtually disappeared from many of the waters of Pennsylvania, in which state the Fish Commission has long advocated the extermination of Natrix. "Junior Conservationist" badges are still being awarded by the Commission to youngsters who show proof of having killed ten or more water snakes.

It is encouraging to learn that certain other states are taking a more tolerant view and that they are willing to accept the findings of research workers even in the face of blind prejudice to the contrary. The role of the predator in nature is now well known, but the problem of convincing the lay public that the ugly, often-pugnacious "water moccasin" is not only harmless but actually useful, is one that offers no easy solution. 


\section{Natrix sipedon insularum Conant and Clay \\ Lake ERIE Water SNake \\ (Page 86; maps 19 and 56; plate 11, fig. 2)}

Among the new Ohic records for insularum are the following:

Ottawa County: Fisher's Pond, Middle Bass Island (ROMZ 5732): Gibraltar Island, Put-in-Bay (CM 19038; ROMZ 5730); Green Island (OSM 850.1-32); North Bass Island (CA 6020); South Bass Island (CA 5248; OSM 612-3, 834.1-4, $851.1-24,852.1-23,853.1-20,854.1-16,855.1-17,856.1-11,857.1-30,858.1-7,859.1$ 16; ROMZ 5549).

The extraordinary abundance of this snake on many of the is!ands in Lake Eric has bcen repeatedly demonstrated. A large catch, made on South Bass Island on June 1, 1935, has already been described (page 87), and several other collectors have obtained specimens in numbers on the same and on other islands. Trautman, who has been resident in the archipelago for ten years, advises me, however, that insularum is now far less common on the inhabited islards than formerly. On small, outlying islands, where it is more or less free from human predation, this subspecies appears to be holding its own.

Thomas (1949) reported on a large fopulation that he encountered on Middle Island, Ontario, which lies just north of the Ohio boundary and which has had no human residents since about 1933. His visit was made on Augus: 30,1945 , and a great number of large water snakes were seen sunning or lying in the shade of shrubbery on limestone ledges running along the north shore of the island. Juveniles were conspicuous by their absence. A party of seven persons visited the same island on April 30, 1949. and they succeeded in cap. turing 600 snakes during the course of the day. Of these, about 200 were Thamnophis s. sirtalis (including two melanistic individuals), five were Storeria dekayi, and the remainder werc insularum. Triplehorn, who was a member of the party, states, "During the morning few specimens were seen ranging or sunning, and, although we collected between 200 and 300 snakes before noon, we got fewer than two dozen juveniles. In the afternoon we began to see the water snakes sunning themselves, but not along the water as we had expected. They were all about fifteen to twenty yards from the water's edge, and many were far inland. Early in the afternoon we came across an old well which was banked rather deeply with limestone. From this small area (about 5 feet square) we pulled 90 snakes, all but about two dozen of which were juvenile insularım, probably of last year's litters."

Only two specimens were collected during Thomas' visit to Middle Island, but both were exceptionally large; one measured 49 inches in length and the other was $503 / 4$ inches. Not only is the latter snake the largest insu! arum on record, but it also contained the amazingly high number of 57 embryos. The other snake had 25 embryos. The Ohio Snake Museum collection has recently been augmented by skins, embryos, etc. representing ten litters of insularum from South Bass Island; the young in these number 6. 10, 15, 15, 16, 19, 22, 23, 29, and 31, respectively.

The extraordinary amount of variation that occurs in the dorsal and ventral 
markings of insularum is attracting the attention of several students, and we soon may have detailed statistics available upon the populations from several of the islands.

\section{Storeria dekayi dekayi $\mathrm{X}$ wrightorum \\ DEKAY's SNAKE \\ (Pags 88; maps 20 and 57; plate 12, fig. 1)}

Trapido (1944) divided Storeria dekayi into a half dezen subspecies, three of which occur in the United States. These latter, with thcir approximate ranges (as defined by Trapido) are as follows: (1) $S$. $d$. dekayi-the Northeast, from eastern Ohio and Virginia eastward and northward to Maine and southeastern Quebec; (2) S. d. wrightorum-the Midwest and South, from southern Wisconsin to Louisiana and eastward (in the south) to South Carolina, Georgia, and the Florida panhandle; and (3) S.d. texana-southern Minnesota to southern Texas. On his distribution map (loc. cit., p. 54), Trapido shows broad areas of intergradation between the adjacent races; the western half of Ohio is marked to indicate intergradation between dekayi and wrightorum.

In attempting to evaluate Trapido's conclusions, two important facts must be borne in mind. First, he saw only a meagre sixteen specimens from Ohio, half of which he listed as dekayi and half as wrightorum. Obviously, he either ignored or overlooked the many snakes of this species in the collections at the Toledo Zoo and the Ohio State Museum. Second, each individual specimen is identified in his text as either dekayi or wrightorum without regard to geographical distribution. No intergrades are designated nor is an intergrading population defincd. (See comments upon the "new systematics" on page 222.) He lists $S$. $d$. dekayi from as far west as Lucas County, Ohio, although his map indicates that this form does not extend farther westward than the center of the state. (T'rapido also lists $S$. $d$. wrightorum from western Pennsylvania and east central West Virginia, cven though the localitie; in those states are one hundred and fifty miles farther east than the area of intergradation between dekayi and wrightorum shown on his map )

It is rather apparent that Storeria dekayi (in Ohio at least) is in need of further study.

In describing wrightorum, Trapido distinguished it from the subspeciss dekayi on the basis of two characters: (1) the dorsal spots, which normally are present in dekayi, are fused across the center of the back in wrightorum to form short crossbars; and (2) the sum of the ventrals and subcaudals is 176 or more in wrightorum and 175 or less in dekayi.

I have recently examined (or re-examined) one hundred and thirty-six Ohio specimens, checking carefully upon these two characters. Some of the snakes, of course, are of littie or no value for this purpose. Those with truncated tails are useless for making the necissary scale counts, and several juveniles, plus a few adults that have heen badly stained by formalin, have the dorsal pattern quite obscure. In some, one character could be determined but not the other. In order to check upon the relative abundance of the charac- 
teristics of the two :aces, the following scheme was devised: A snake with the sum of the ventrals and subcaudals equaling or exceeding 176 and which also had numerous crossbars, was considered to have two factors for wrightorum. One with 175 or fewer scales and few or no crossbars was considered to have two factors for dekayi. Snakes on which only one character could be determined (specimens with incomplete tails, for example) were classified as having cne factor for the one subspecies or the other. A number of individuals exhibited one of the characters of dekayi and one of wrightorum; such snakes were considered as having one factor for each.

There is so much variation in dorsal patterns among Ohio specimens that I arbitrarily set the figure 10 for distinguishing the subspecific characters. Snakes with 10 or more well-defined crossbars were credited with a wrightoru $n$ factor; others with a dekayi one.

Among 46 specimens from northeastern Ohio (Ashtabula, Carro'l, Cuyahoga, Geauga, Portage, Stark, Summit, and Trumbull counties) there are 67 factors for dekayi and 17 for wrightorum. The percentage is thus 79.8 in favor of dekayi. However, factors are involved and not snakes! Among the 46 specimens, only $25(54.3 \%)$ bear both characters of dekayi. Theez snakes have both the characters of wrightormm; all the others combine characters of both races, or they either have incomplete tails or obscured patterns. One of the snakes, from the former Pymatuning Swamp on the eastern border of Ohio, has 181 scales beneath the body and almost as many crossbars on its back as the type specimen of wrightorum (Trapido, op. cit., figs. 38 and 44 ).

Among 59 specimens from northwestern Ohio (from Erie, Huron, Crawford, and Marion counties westward to the Indiana line) the:e are 68 $(61.3 \%)$ factors for dekayi and 43 for wrightorum. But among these snakes only $23(39 \%)$ exhibit both of the characters of dekayi; 11 have both those of wrightorum. Ameng 13 specimens from Franklin County thre ar? 4 with both characters of dekayi and only 1 that shows both those of wrightorum. From elsewhere in the state the available population samples are too small to be significant. In Ohio, as a wholc, only 43.4\%\% of the 136 snakes studied can be identified as dekayi and only 11.8 \%, as wrightorum.

If all specimens with incomplete trils, obscure patterns, or both are eliminated, then there remain 109 snakes with characteristics distributed as follows: $59(54.1 \%)$ with two factors for dekayi; $16(14.7 \%)$ with two factors for wrightorum; and $34\left(31.2^{\%}\right)$ with one factor for each. Among the 109 snakes the factor totals are $152(69.7 \%)$ for dekayi and $66(30.3 \%)$ for wrightorum.

From the above it is clear that Ohio is inhabited hy a mixed population. Some specimens are morphologically identifiable as dekayi and some as wrightorum, but many are intermediate. In none of the samples tested is one race in a majority of 3 to 1 , the ratio that most herpetologists accept as the criterion of subspecific distinctness. The influence of dekayi is dominant throughout the state, although it is strongest in northeastern Ohio. But the characteristics of wrightorum become proportionately more numerous in the western counties. 
On the basis of our present knowledge, the population of this snzke in Ohio is an intergrading one, and it should bear the designation Storeria dekayi dekayi $\mathrm{X}$ wrightorum. How far the intergrading area extends into adjacent states is something that can be determined only by careful examination of many large series of specimens. One could wish for a much larger Ohio sample, but dekayi is such a common species in many localities that naturalists have paid little attention to it. Also there is the fact that specimens are small, and makirig scale counts upon them is tedious work. As a result, relatively few have been preserved. New Ohio records are:

Allen County: Bluffion (OSM 724). Ashtabula County: Dorsel Twp. (CMNH 323-5, 327); 5 mi. N of Geneva (Trapido, 1944). Carroll County: Sec. 20, Lee Twp. (FWB). Clermont County: Near Goshen (CSNH 2418); Goshen Station (UC 16). Cuyahoga County: Case College Campus, Cleveland (CMNH 127). Defiance County: $1 \mathrm{mi}$. SW of Defiance (OSM 699.1-2); Defiance Twp. (OSM 844). Delaware County: (OSM 657). Erie County: (UMMZ 95962AD, 95963); Huron Twp. (CNHM 2545). Franklin County: Alum Creek (OSM 905, 907); Columbus (OSM 390, 823, 843); near Columbus (ROMZ 3761). Greene County: Huffman Prairie Marsh (DPLM 110.42). Huron County: (UMMZ 95964). Lucas County: Jerusalem Twp. (SL 892); Little Cedar Point (OSM 700.1-2); Toledo (CA 5276). Madison CounTY: 9 mi. S of Londen (OSM 623). Marion County: Sec. 6, Greencamp Twp. (OSM 624); Rail's Corner, Greencamp Twp. (OSM 669.1-3). Montgomery County: Belmont, Dayton (DPLM 77.44; WED 134); Dayton (DPLM 310.42); Dayton, Mad River Twp. (WED 143); Oakwood, Van Buren Twp. (Wood and Duellman, 1947h). OtTawa County: South Bass Island (CM 9485; UMMZ 95965A-B, 95966-70). Paulding County: 3 mi. NE of Antwerp (OEE-2 specs.). Scioto County: Portsmouth (OSM 910); Shawnee Forest, Nile Twp. (OSM 506). Stark County: (CA 5843-50); Canton (OSM 880). Vinton County: Coalmont Hollow, 2 mi. N of Zaleski (OUVC 1835). Wayne County: Brown's Lake Bog, Clinton Twp. (OSM 643).

Among the new records are a few additional localities from relatively short distances south and east of the glacial boundary. There is evidence to indicate that most, if not all, of these lie in filled valleys where habitat conditicns are similar to those in the till plains and the glaciated plateau area and considerably different from those that prevail throughout the uplands of the unglaciated Allegheny plateau as a whole. Comment upon such valleys is included in the discussions on Natrix kirtlandii (p. 230) and Thamnophis s. sauritus (p. 249), both of which snakes have distributions in Ohio that are similar in some respects tc. that of Storeria dekayi.

Field notes accompanying specimens of dekayi that were taken in the unglaciated part of the state are incorporated in the paragraphs that follow.

Carroll County: Buchaisan, who has supplied the data below on the geology of the region near his home, has seen a specimen from the Specht Marsh (in the northeastern part of Washington Twp.), which is a poorly drained area in the valley now occupied by Still Fork Creek. This valley is the bed of a lake that was created when the glacial front advanced southward to Big Sandy Creek and dammed the streams of the region. Silts and glacial debris subsequently filled the valley of Big Sandy Creek to a depth of 200 feet and the other valleys to a lesser degree (but with silt only). Both the ribbon snake and the spotted turtle also occur in the Specht Marsh. They and Stor- 
eria dekayı may have entered the area from the north, crossing the glacial boundary but finding habitat conditions not greatly different from those prevailing in glaciated tetritory. All three species, the two snakes and the turt!e, are known from many localities in northeastern Ohio but from very few in the unglaciated region. Buchanan also has seen several DeKay's snakes from the extreme eastern part of Loudon Township and there is a specimen in his collection from Lee Township. These localities lie east of the Flushing Escarpment. Storeria dekayi may have crossed this physiographic boundary, but it also is possible that it entered the region of Amsterdam from the northeast by way of the filled valley of the Ohio, thence westward up the valley of Yellow Creek. Opheodrys $v$. vernalis may or may not have followed the same route.

Scioto County: Jolnson found a specimen (OSM 910) at Portsmouth on January 13,1950, "as it was crawling from beneath a board at the upper limit of debris deposited by high water on the flood wall on the west side of town." This locality is in a filled preglacial valley. The same collector also obtained a specimen of dekayi on the Roosevelt Game Preserve bineath a stone at roadside. The Ohio State Museum has one of these srakes from the Shawnee Forest (OSM 506).

Vinton County: Gier and Mittleman collected a specimen (OUVC 1835 ) uider a small log in "a marshy hollow" between Zaleski and Lake Hope. The snake previously reported from Jimtown (p. 89) was taken in a small marsh. Both habitats in this county are similar to those that are found in poorly-drained portions of filled valleys that lie fairly close to the glacial boundary.

We cannot be sure that Storeria dekayi, Natrix kirtlandii, Thamnobhis sauritus, Clemmys guttata, and Eumeces fasciatus (and perhaps also Opheo. drys vernalis) have used filled valleys as a means of expanding their ranges into unglaciated Ohio, but there are indications that they may have done so. At least they have found suitable habitats in the relatively moist portions of such valleys, and they appear to be rare or absent in the surrounding hills. One can but wish that a great deal more material were available and that extremely detailed habitat notes were at hand for every individual specimen.

\section{Storeria occipitomaculata occipitomaculata (Storer)}

Red-Bellied SNAKe

(Page 92; maps 21 and 58; plate 12, fig. 2)

Trapido (1944) has described a new subspecies of this snake-Storeria occipitomaculata obscura, from northern Florida and the coastal plain of Gcorgia. In this form the three light occipital spots are coalesced into a ring crossing the neck, the top and sides of the head are chiefly black, and the ventral and subcaudal counts average somewhat different than in the typical form. The general range map (page 93) should be amended to allow for obscura in the Southeast; the western limit for occipitomaculata has not been adequately defined and some revision in this direction may eventually be necessary. Trapido's map (op. cit., p. 20) leaves much to be desired. New Ohio records are: 
Cuyahoga County: Brecksville (CMNH 16). Defiance County: $1 \mathrm{mi}$. SW of Defiance (OSM 702, 744, 837, 838.1-5). Geauga CountY: Troy Twp. (OSM 701). Pike County: Pike State Forest (WED 135, 356). Scioto County: Near Friendship (SL 465); Nile Twp. (OSM 676); Roosevelt Game Preserve (OSM 66I); Turkey Creek, Nile Twp. (OSM 648); Union Twp. (OSM 710).

I have checked the specimen that Trapido (op. cit., p. 32) listed from Columbus (ANSP 6463). It is obvious from the catalogue entry that there has been an error of some sort, and, in addition, the snake possesses certain characteristics which indicate that it may be an intergrade between occipitomaculata and obscura. No state name follows the "Columbus" (in the Academy catalogue), and possibly the snake may have come from Columbus, Georgia. In any event it should be removed from the Ohio list. The occipitomaculata (USNM 10089) reported by Trapido (loc. cit.) from Hughes, Butler County, also may not be from Ohio; this specimen is one of a series of serpents that probably were collected farth $r$ west. (See discussion under Diadophis punctatus arnyi on page 7.)

Among the new records, the snakes from near Defiance are of the greatest interest. All other Ohio lecalities for occipitomaculata (that are backed by specimens and unquestionable data) are concentrated in the northeastern and south central porticns of the state, and it is surprising, to say the least, to discover this species in the laka plains and well within the area formerly occupied by the "Great Black Swamp." Triplehorn (1948) has reported upon the finding of two specimens a mile southwest of the city of Defiance. One was obtained on July 7, 1946, "in open oak-hickory woodland at the top of a dry ravine," and the other was taken near-by on July 16, 1947, as it crawled "across a path in a large clump of hazelnut bushes." More recently (August 5, 1948), Triplehorn obtained a third snake of this species in the same locality. It gave birth to five young on August 23, 1948; three were virtually plain black above and each had a relatively broad area of red down its belly; the other two juveniles were albinos.

It is possible, of course, that the Defiance County colony of occipitomaculata has become established through human agency. The locality is at a Boy Scout camp, and many boys keep snakes as pets, some of which escape or are liberated in improper places. On the other hand, the red-bellied snake is widespread in Michigan and there are records from the southern part of that state. It is conceivable that this colony may be a relict outpost of the Michigan population. Physiographically, extreme northwestern Ohio is similar to southeastern Michigan. A belt of small lakes and tamarack hogs extends southward into Indiana and into the corner of Ohio as far as Ladd Lake in northern Defiance County. A number of important tributaries of the Maumee River, such as the Tiffin River, have their headwaters in Michigen, and they may have provided migration routes for this species. In support of this supposition is also the fact that specimens from Defiance County and from southeastern Michigan exhihit similarities in certain scale counts that are slightly at variance with counts made on red-bellied snakes from eastern and souther:1 Ohio.

The scutellation is of interest in two respects. First, there is only a single 
posterior temporal in each of the three larger snakes from Defiance County and in one juvenile (the other four have two each), whereas all other Ohio specimens have either two or thrce postericr temporals. Second. the ventra! counts are quite low, varying from 118 to 123 ; with a mean of 119.8 (in the three adults the counts are 119,119 and 120); only one other Ohio specimen has fewcr than $120(119)$, and the mean for all the rest of the Ohis material (38 specimens) is 125.2 .

For comparative purposes, Hartweg has very kindly furnished me with scale counts for nine occipitomaculata from Oakland, Livingston, and Washtenaw counties in southern Michigan. Among these the ventrals vary from 113 to 131 (mean 122.7); two specimets have only one posterior temposal on each side of the head and another has one on one side and two cn the other. The population samples from both southern Michigan and Defiance County, Ohio, are too small to permit definite conclusions, but they are similar in that individuals from both groups have single posterior temporals ard the ventrals average less than in the populations inhabiting eastern ard southern Ohio.

Two females, one from Gaauga County and one from Pike County, have only 39 subcaudals, a lower number than has previously been recorded from Ohio.

Gosner (1942) has reported "lip curling" in this species similar to that which I have described for Haldea (=Virginia) on page 96.

\section{Haldea valeriae valeriae (Baird and Girard) \\ Eastern Ground Snake \\ (Page 94; maps 22 and 59; plate 12, fig. 3)}

Stejneger and Barbour, in the fourth edition of their check list (1939), combined into a single genus the species of snakes previously known as Potamophis striatulus and Virginia valeriae. These they assigned to Haldea of Baird and Girard $(1853,122)$, evidently giving that gereric designation preference over Virginia of the same authors (loc, cit., 127) on the basis of page priority. Hence the ground snake is now known as Haldea valeriae valeriae.

This diminutive serpent evidently is not particularly rare in some parts of southern Ohio. Two more counties may be added to the !ist, and several additional specimens have been collected in Scioto County. New records are:

Adams County: Smoky Creek, near Rome (CSNH 2651 A-B). Pike Countr: (DPLM 153.42): Pike Lake (DPLM 588.44); Pike State Forest (WED 405). Scioto Countr: Bear Lake, Shawnee State Forest (WED 252): Roosevelt Game Preserve (OSM 541, 662, 902.1-2): Shawnee State Forest, Nile Twp. (OSM 865; OWU).

Johnson has been successful in finding a number of Haldea in Ohio, and the following data are summarized from habitat notes made upon elcven sp:cimens that he encountered in the Shawnee State Forest and on the Roosevelt Game Preserve. Three were fcund dead on the road in the early morning; the road in each case was flanked by woods. One other specimen was in the 
open; it was seen in midafternoon crawling over the edge of a rock. In this instance Johnson says, "There had beer. light sprinkles intermittently th:oughout the day and the surface of the ground was wet; oak and pine covered the surrounding slopes." All his other ground snakes were found under various objects; six were beneath stones and one had hidden itself under an old cement sack. Of these seven specimens, three were in abandoned fields, one was in cleared bottom lands, one was in a roadside ditch, and the other two were along a road that had oak forest on one side and the immature swamp forest of a flood plain on the other.

Wood has notes on the habitat situations in which three specimens of Haldea were taken at the junction of Richardson and Egyptian Hollows in Pike County. These were found under a slate slab in an open meadow, under a flat stone in a temporarily dry creek through a wooded area. and in a small building in a Boy Scour camp.

The information that follows is based upon eight male and ten female specimens of Haldea from Ohic (including those for which data are tahulated on page 95): The scale rows are 15 in every instance except one (see below). The labials (both upper and lower) are 6 in all, except that there are 7 infralabials on one side of the head in one fernale. The postoculars, usually 2 , are 3 on one side of the head in three females and one male, and 3 on both sides in one male and one female. There is invariably a single anterior temporal; the posterior temporals, usually 2 , are reduced to a single scale on one side of the head in one female and one male, and to a single scale on both sides in two males and one female. Ventrals in the males vary from 115 to 121, mean 116.9; in the females from 120 to 132, mean 123.2. Subca!ndals in the males vary from 31 to 38 , mean 35.6; in the females (9 specimens) from 23 to 31 , mean 26.6 .

The two snakes from Adams County are both juveniles; one of these has an undivided anal plate and both have a large percentage of the dorsal scales keeled, even well forward on the body. All other specimens either have all smooth scales or there are keels only on the hindmost part of the body. One of the above-mentioned juveniles measures $125 \mathrm{~mm}$. (slightly less than 5 inches) in length, and it is hence somewhat shorter than the smallest individual previously recorded from the state.

A specimen from Pike County (WED 405) exhibits two anomalies in scutellation. Counts of 13 and 14 rows can be made upon the anterior fourth of the body; the reduction is caused by the fusing of the 2nd and 3rd rows of dorsal scales, this occurring farther forward on the right side of the body than on the left. Also the posterior pari of the loreal is cut off on each side of the head to form a small preocular. This snake is a female measuring 218 $\mathrm{mm}$. in length and it contains four large eggs; it was collected on June 26, 1949.

A female from Scioto County (OSM 865), measuring $222 \mathrm{~mm}$. in length (collected on June 16, 1949, but preserved some time later), has five ripening eggs in its abdominal cavity. In each of them an embryo is clearly visible. 


\title{
Thamnophis butleri (Cope)
}

\author{
Butler's Garter Snake \\ (Page 96; maps 23 and 60; plate 13. fig. 1)
}

Three papers have appeared during the past few years on the taxonomic status of Thamnophis butleri.

In the first of these, Albert G. Smith (1945) reviewed the butleri complex and concluded that two species are involved. The easternmost population, inhabiting northwestern Pennsylvania and southwestern New York, he referred to Thamnophis brachystoma (Cope); specimens from the rest of the range (see map on page 97) he considered as butleri. Smith pointed out that in brachystoma the maximum number of dorsal scale rows is almost invariably 17 and the upper labials are normally 6; the corresponding counts in butleri are 19 and 7 . In a later paper (1949) Smith reviewed these two snakes again, but this time he reduced them to subspacific status and considered them both to be races of 7 hannophis radix.

Certain obvious errors in Smith's data and conclusions (in his 1949 contribution) led to the preparation of a third paper (Conant, 1950) on the status of Thamnophis butleri. In this I have attempted to show that there is no proof of intergradation between radix and butleri; the two forms occur together both in Ohio and in southeastern Wisconsin. There also is no evidence of intergradation between butleri and brachystoma. Smith pointed out (1945, 151) that there is a gap between the ranges of these two snakes. The gap actually is greater than he supposed, for an error has come to light recently for which I have only myseif to blame. During the preparation of the original manuscript for the Reptiles of Obio, I insisted on examining all material myself, but, at the moment of going to press, I accepted a few records that were sent to me by a herpetological colleague. Unfortunately, he mistcok a specimen of Thamnophis s. sauritus (NU 19) for butleri. This was from Hiram, Portage County. Hence the easternmost Ohio lozality (map 23) must be eliminated.

In my opinion, butleri is entitled to full specific status and so is brachystoma.

Thomas (in Conant, Thomas, and Rausch. 1945) has made some interesting comments upon the past and present distribution of butleri. He expresses the opinion that this snake "may be considered as a relict of a former climate, since it exists in isolated colonies throughout most of its range." It is an endemic species of the eastern part of the Prairie Peninsula, and, as Thomas indicates, it probably persisted throughout Wisconsin times beyond the periphery of the ice sheet whence it may have moved into the glaciated portions of the Prairie Peninsula scon after the retreat of the ice.

The range of butleri (stated on p. 98) should be amended to include solithwestern Ontario (Logier, 1939); New York and Pennsylvania, of course, should be deleted. New Ohio records are:

Erie County: Sandusky (ANSP 16948-51). Falrfield County: Black Lick Woods, on border of Franklin Co. (OSM 628). Logan County: (OSM 540); West 
Liberty (OSM 673). Lucas County: Buckeye Marsh, Toledo (WED 345). MarION County: (OSM 704); Sec. 7, Marion Twp. (OSM 627). Otrawa County: Near Port Clinton (OSM 672.1-3). County not Stated: Buckeye Lake (OUVC $1853,2245 \mathrm{~A}-\mathrm{C})$.

The specimen from the Buckeye Marsh, Lucas County (WED 345), exhibits two abnormalities that should be recorded. There are only 5 upper labials and the maximum number of scale rows is 21 . The last two supralabials are fused to form one large scale on each side of the head. There are 19 dorsal scales in the neck region, but, somewhat farther back on the body, counts of 21 may be made for a short distance. In other respects the specimen is a typical butleri. It is a female, $470 \mathrm{~mm}$. in length, and it contains several well-developed embryos.

An unusually large specimen is worth mentioning even though it is from outside the borders of the state. A female butleri was collected early in 1942 at Detroit, Michigan, by Wilbur Auffenberg and later sent to the Philadelphia Zoo; it measured $27 \mathrm{r} / 4$ inches (694 mm.) which, I believe, is the maximum known length for the species.

\section{Thamnophis radix radix (Baird and Girard) Prairie Garter Snake \\ (Map 61 ; plate 27, fig. 1)}

We have learned only recently that this snake is a part of the Ohio fauna. A detailed account concerning it has been published, however (Conant, Thomas, and Rausch, 1945), and much of the information below, including all the passages in quotation marks, has been abstracted from that paper. Since there was no discussion concerning radix in the original edition of this report, and so that this garter snake may be accorded equa! treatment with the ether reptiles indigenous to the state, the review that follows is in considerable detail. Fourteen Ohio specimens of radix have been found, all from Marion and Wyandot counties. Nine of these ( 3 males and 6 females) are preserved, and scale counts and measurements for them have already been tabulated (op. cit., 62). All statistical data below are based upon these same nine specimens.

Description.-A medium-sized snake that occasionally may exceed a yard in length. The largest preserved one (a female in which part of the tail is missing) measures almost 30 inches, but Rausch obtained another in Marion County that he estimated at nearly a meter (393/8 inches). As is the case among other members of the genus Thamnoph:s, females attain greater dimensions, both in length and girth, than males. The largest Ohio male is $20 \mathrm{r} / \mathrm{s}$ inches long. No juveniles are available for study.

Head medium in size but clearly distinct from the neck; eye medium. Head plates normal. Two nasals; the nostril lateral and between them. One loreal. Body slender in young specimens, but becoming somewhat robust in large females. Tail medium slender and tapering to a point. Among three males the tail is $23.7 \%, 24.4 \%$, and $25.2 \%$ of the total length; among three females the figures are $21.2 \%, 21.6 \%$, and $22.0 \%$.

Dorsal scale rows 19-21-19-17 or 21-19-17; the scales keeled. Upper labials 
7 in five specimens and 8 in four; lower labials 10. Oculars 1-3, except in one snake which has 2 postoculars on one side of the head. Temporals 1-2, except that two snakes have 3 in the posterior row on one side of the head. Ventrals in males 154 to 15.9, mean 156; in females 149 to 155, mean 151.8. Subcaucals in males 75 and 76 , mean 75.3 ; in (three) females 64 to 66 , mean 65 . Anal plate single.

This snake is conspicuously patterned with three light longitudinal stripes on a darker ground color. The murkings and coloration are as follows:

"Middorsal stripe bright orange yellow, occupying the median row of scales and adjoining fractions of the adjacent tows. Lateral stripe bright vellow; situated on scale rows 3 and 4. Dorsal ground color dark chocolate brown. A double row of round black spots on each side of body between the stripes, these approximately 1 to $1 \mathrm{I} / 2$ scales in length and about 2 to $21 / 2$ scales in height; the spots often run together and thus obscure the ground color. A row of similar dark spots between the lateral stripe and the ventrals.

"Top of head and occipital region black or very dark brown, except for a pair of bright yellow parietal spots. Lower labials, chin, and throat uniform pale yellow; sutures between lower labials edged with black in some specimens. Upper labials yellow, their posterior edges broadly bordered with black, expe. cially toward the rear of the head. There are yellow or yeilowish areas on the nasals, preoculars, and lower postoculars.

"Belly light grcenish grey, each ventral with a conspicuous black spot at each end; sutures between the veritrals often irregularly bordered with black. There is a tendency in some specimens for spots on adjacent ventrals to run together. Similar, but indistinct, markirgs on the under side cf the tail.'

Key Characters.--Persons using the key for identification (pp. 19-22) will find that radix will check out to section 9 (p. 20). It differs from all other Ohio garter snakes, however, in having a maximum of 21 scale rows (all the others normally have 19); both radix and Thamnophis s. sauritus have the light lateral stripes on the 3 rd and 4 th scale rows, but radix has a shorter tail $-26 \%$ or less of the total length in comparison with $28 \%$ or more in sauritus. It should also be borne in mind that radix has a relativelv large and wide head which is quite different in shape from the narrow head of sauritus and the noticeably small head of butleri.

Range.-Eastern Iowa, northeastern Missouri, Wisconsin, Illinois, and the dune region of northwestern Indiana; farther east radix occurs in disjunct colonies in Indiana and north-central Ohio. To the west it intergrades with Thamnophis radix haydenii (see Smith, 1949). The Ohio records are:

Marion Countr: Sec. 26, Bigg Island Twp. (OSM 535); Sec. 33, Grand Prairie Twp.; Greencamp Twp. (ANSP 24735); Sec. 6. Greencamp Twp. (OSM 536, 538): western and southwestern edges of Marion; west of Marion: Sec. 5. Marion Twp. (OSM 539); Sec. 7. Marion Twp. (OSM 537); Clark's Bridga (over the Scicto River), Montgomery Twp. WYANDOT County: Sec. 7. Pitt Twp. (OSM 670); Sec. 9. Pitt Twp. (OSM 667); 2 mi. SW of Upper Sandusky (TMS 767).

Habitat and Habits.- Thomas has visited most of the localities in which radix has been taken in Ohio, carefully noting habitat conditions and record- 
ing data periinent to the ecology of this interesting snake. These he has summarized in considerable detail (of. cit., 63-5). In part, he states, "It is of considerable interest to note that this population of a western species, a great number of miles to the east of any previously known station, should occur in what was once the most extensive single wet prairie area in Ohio. It also is noteworthy that this snake has been able to survive drastic alteration of its former habitat. The original prairie, now some of the most productive farm land in the state, has been almost completely destroyed by cultivation and grazing, and the former prairie vegetation is at present limited to remnants along the roadsides and railroad rights of way and to a few restricted swales which have proved difficult to drain.

"The specimens from the immediate vicinity of Marion were take:1 along railroads, particularly the New York Central System. The rights of way of these are paralleled by broad shallow ditches which, having never been plowed or grazed, support a luxuriant growth of prairie vegetation, probably not differing greatly from that which prevailed originally."

Thomas also reports radix from cultivated fields, beneath a shock of oats, near the grassy margin of a small artificial pond in the midst of a field, in or rear shallow prairie swales, ox-bows, etc. In summary he says, "All of the foregoing localities are in the midst of a typical, flat, wet prairie country with deep, black soils and sluggish mud-bottomed streams. Few of the specimens of radix, however, were captured in typical prairie land. It will be noted, rather, that all were in, or close to, prairie swales or streams. This was also true of the Montgomery Township specimen, which was found on the bank of the Scioto River. No evidence of prairie habitat was noted in the vicinity, but the river at this place has all the aspects of a typical prairie stream; it is deep and sluggish, with few riffles and with mud banks and bottom.

"The presence of this western snake in the prairies of Ohio, so far east of any other known colony, would seem to constitute one of the most remarkable examples of prairie relict yet recorded. There is always the possibility, of course, that it may have been introduced by human means in historic times, but this seems unlikely. Its very wide distribution throughout the prairie area of western Marion and southern Wyandot counties would indicat? that the species has been established in the region for a long time."

Of the several specimens found alive in the state, some were in the open, sometimes on the prowl, but others were hidden beneath various objects. Dates of collection ranged from March to September, inclusive. "Almost all flattened their bodies considerably when they were alarmed or handled, and most of them struck and attempted to bite repeatedly. Those kept captive ate live earthworms, frogs, minnows, and chopped fish."

Pope $(1944,208)$ states that the number of young in a litter may vary from 6 to 40, and that the average is 20. Among forty-two new-born babies (representing three broods from the Chicago area) length measurements varied from $63 / 8$ to $71 / 4$ inches. The young are torn in August or September. 


\title{
Thamnophis sauritus sauritus (Linnaeus)
}

\author{
Eastern Ribion Snake \\ (Page 99; maps 24 and 62; plate 13, fig. 2)
}

Klauber $(1948,8)$ has pointed out that Linnaeus undoubtedly had a ribbon snake at hand when he assigned the Coluber Sirtalis in the 10th edition $(1758,222)$ of his Systema Naturae. Therefore the ribbon snake, according to the rules of priority, would have to be known as Thamnophis sirtalis and the next earliest name (Co!uber ordinatus Linnaeus-1766) wou!d have to be applied to the eastern garter snake. Such a shift could only result in boundless confusion. The name sirtalis has been associated with the garter snake for nearly two centuries and is so deeply entrenched in the literature and in museum collections, that transferring it to the ribbon snake would make it completely valueless; sirtalis would have no meaning and would have to be coupled with the phrase "formerly sauritus" whenever it was used. In o:der to avoid such a regrettable situation, an appeal has been made (Schmidt and Conant. 1950) to the International Commission on Zoclogical Nomenclature requesting that the rules be suspended and that sirtalis be continu?d for the garter snake and sauritus for the ribbon snake.

Only a few ribbon snakes have been collected in Ohio in recent years, but the new records, when added to the old ones, suggest some interesting inferences concerning the past and present distribution of this semi-aquatic garter snake in Ohio. The new records are:

Carroll County: Sec. 12, Washington Twp. (FWB). Geauga County: I mi. E of Chardon (OSM 728). Guernsey County: Valley of Salt Fork, Jefferson Twp. (OSM 510). Hardin County: 3 mi. E of Mt. Victory (OSM 636, 757). Jackson County: Liberly Twp. (OSM 758). Portage County: Hiram (NU 19). Summit County: Near Kent (HTG). Wrandot County: Pitt Twp. (OSM 709). County not Stated: Buckeye Lake (OUVC 1321). It also is reported from $3 \mathrm{mi}$. IV of Antwerp, Paulding County, by Ehrhart, and from near Lake Hope, Vinton County, by Gier.

When all of these localities are added to those previously plotted (see map 62), thrce things are at once apparent: (1) The ribbon snake (as stated en page 101) is widely distributed through northern Ohio, especially in the lake and bog region of the notheastern counties; (2) there are four additional, scattered localities from the unglaciated area; and (3) the species is conspicuously absent from southwestern Ohio.

In commenting upon habitats within the unglaciated plateau, Thomas has pointed out to me that the region has "many filled vallevs harboring bogs and swamps with strong boreal aspects ... [and] none of these localities is many miles from the glacial front." Of the ribbon snakes recently taken in this area, orily twe are accompanied by detailed habitat notes. The one from Vinton Courty was found alongside i trail through oak woods in the Zaleski Forest about a mile southwest of the Lake Hope dam; there was a small stream and sphaonum bog near-by. Buchanan. in commenting upon the specimen from Carroll County, states that "in the valley of Still Fork Creek, which stretches from Mechanicstown to Minerva, where it hits Big Sandy Creek, the 
ribbon snake is abundant in all marshy and swampy places." Sevcral tributaries of Sandy Creek flow southward from glaciated territory, and they probably serve as readily accessible migration routes across the glacial boundary.

At the time when the Reptiles of Ohio first went to press, the absence of records from the till plains of the southwestern counties might have been attributed to inadequate field work. But this could not be claimed today. The region recently has been intensively collected by several of the younger herpetologists, working out of Dayton and Oxford, and not a single ribbon snake has been encountered. The sole record for the entire area is the one published by Morse (1904) for Hamilton, Butler County. Unfortunately, his specimen is no longer extant and its idertity cannot be checked. One might speculate upon whether Thamnophis sauritus has always been missing or whether the drainage ditch, followed by the plow, has destroyed its habitat. Certainly in southwestern Ohio this snake is now absent, extremely rare, or highly local in its distribution. It might be pointed out that much of this area lies within the province of the Illinoiar and early Wisconsin drift, which, in the absence of boreal habitats and perhaps in other ways, may offer less favorable conditions for this species than the late Wisconsin drift farther north.

Evidence of the ribbon snake's former great abundance in part of northwestern Ohio is contributed by Ehrhart who, writing about Paulding County where he has long been resident, states, "When I was a boy we lived about $31 / 2$ miles west of Antwerp, about seven years after they had blown up the 'Six-mile Reservoir' and drained the Black Swamp. We cleared up some of that swampland and it was alive with snakes, mostly garter, spotted water, and ribbon snakes, with the last by far the most common. Since then I haven't seen a single ribbon until about ten years ago [circa 1938], and then I had my hands on one in the east part of the county, but it got away."

Here, in Paulding County, is indication of a profound change effected as a result of mankind's activities. Possibly intensive human utilization of the land in southwestern $\mathrm{O}$ hio may have produced results of a similar nature.

\section{Thamnophis sirtalis sirtalis (Linnaeus) \\ Eastern Gartfri Snake \\ (Page 102: maps 25 and 63; plate 11, fig. 3)}

Comment has already been made (p. 249) on the proposal to shift the scientific names of the garter snakes.

New Ohio records for this species are as follows:

Adams County: Green Twp. (SL 417). Allen County: Bluffton (OSM 723); $1 \mathrm{mi}$. NW of Bluffion (OSM 722): $2 \mathrm{mi}$. NW of Bluffton (OSM 707). AsHTabula Countr: Dorset (CMNH 326); 5 mi. N of Geneva (CM 14034-6). Athens County: Athens (OUVC 1328, 2368); 1 mi. E of Athens (OUVC 2259); $3 \mathrm{mi}$. $\mathrm{E}$ of Athens (OUVC 2322); 6 mi. W of Athens (OUVC 1329). Auglaize CounTY: Sec. 3, St. Mary's Twp. (UMMZ 98026). Butler CounTY: Hamilton (OSM 532); New Miami (MU 17); Oxford (MU 11); Reily (GF). Carroll County: Amsterdam (OUVC 1285-6). Champaicn County: Mad River at West Liberty (UMMZ 89892). Clinton County: (DPLM 649-50.44). CuYahoca County: Cleveland (CMNH 129). Darke County: (USNM 128924); Liberty Twp. (OSM 
706). Defiance County: I mi. SW of Defiance (OSM 750). FayetTe County: Washington Cours House (IVED 192). Franklin County: Alum Creek, Columbus (OSM 906); Columbus (OSM 754, 827, 862.1-4I). Greene County: Glen Helen, Yellow Springs (WED 256): near Orton Pool (DPLM 655.4t); 6 mi. W of Yellow Springs (USNM 128926). Hamilton County: Coy Field, Cincinnati (UC 9A-B); Clifton, Cincinnati (CSNIH 2659-albino); Delhi (UC 6A-B). HARdiN County: 3 mi. E of Mt. Victory (WED 140). Hocking County: 2 mi. NIV of Gibisonville (IWED 351). JACKson CounTY: (HTG -3 specs.; OUVC 130, 568): Jackson Twp. (OUVC 354, 359, 361, 363-4. 567). Logan County: East side of Indian Lake (WED 139. 148); 2 mi. S of Indian Lake (WED 370); Pony Island. Indian Lake (WED 145). Lucas Countr: (UMMZ 83829); Little Cedar Point (OSM 545, 639.6 646.1-2 -all melanistic; OSM 646.3-4); Toledo (CA 5288-9-both melanistic). Miarion County: Western part of Marion (OSM 638). Miami CounTY: Near Covington (WED 371); Ludlow Falls (DPLM 7.43; WED 158); near West Milton (USNM 128925). Montgomery County: Dayton (DPLM 113-6.42, $218-20.42,245-55.42,4.43,6.43,14.43,88.44,371-2.44,670-86.44$; WED 147; USNM 128931-63): north of Dayton (DPLM 71.44); Englewood Dam, Randolph Twp. (DPLM 83.42, 124.42, 210.42, 407.44, 640-3.44, 656.44; WED 138, 172; USNM 128927-30); Miami River at Northridge (DPLM 72-4.45); Oakwood, Van Buren Twp. (Wood \& Duellman, 1947b). Otrawa County: Winous Point. Bay Twp. (UMMZ 95972A-B, 95973-all melanistic). PiCKawaY CountY: Jackson Twp. (OSM 824); $11 / 2$ mi. NW of Laurelvilla (IWED 339). PIKE Countr: Morgantown (WED 175). Preble County: Near Camden (MU 18); West Elkton (MU 23). Scioto County: Nile Twp. (OSM 770). Shelby County: Sidney (WED 202). UNION COUNTY: 3 mi. S of Mt. Victory (WED 114). VINTON County: Lake Hope (OUVC 2373). Warren County: I mi. W of Waynesville (WED 282). Wood County: I mi. N of West Millgrove (UMMZ 98772). WYandut County: Pitt Twp. (OSM 543.1-4). County not Stated: Buckeye Lake (OUVC 1322, 1825).

The "aberrant" specimen (TZS 767) reported upon page 103 is actually identifiable as Thamnophis radix, and it was the only individual of its species that was available from Ohio when the original report was published. The error resulted chieflv from two causes--failure to record the maximum number of scale rows (the snake has 21 , but was listed in my notes as having 19) and the fact that radix was totally unexpected so far east of its (then) known range. The locality for $2 \mathrm{mi}$. SW of Upper Sandusky, Wyandot County, should be deleted from both the list and the distribution map.

Although the presence of 21 rows of scales is one of the chief diagnostic characteristics of radix, there is at lease one specimen of sirtalis from Ohio (UC 6A from Delhi, Hamilton County) that has a maximum of that number. This is a relarively large specimen in which the dorsal scale formula is 21-19. 17 ; counts of 21 can be made upon the anterior third of the body. There is some dark pigment on the lower labials and considerable on the upper ones, but this appears to be an "overflow" from the head-it is not distributed as in radix. The paired dark spots on the belly in the Delhi snake are negligible, and the lateral light stripes are situated upon the second and third rews of scales. Counts have been made upon only a few recently-collected garter snakes; hence, there may be others exhibiting maxima of 21 scale rows. The presence of such aherrant snakes in otherwise normal populations illustrates one of the difficulties encountered in attempting to construct keys for the identification of specimens, and, conversely, the futility of expecting such keys to work in the case of every individual reptile. 
The great variability in pattern and coloration that exists among garter snakes of this species has been summed up in the descriptive matter (see page 103) that was compiled from studies made upon more than one hundred specimens from all parts of Ohio. The same description could have been prepared equally well from a group of forty-one specimens (OSM 862) that recently were collected in a single locality and all at approximately the same time. These were taken by E. S. Thomas and Robart Goslin on Marih 25th and 26th, 1949, as the snakes were "coming out of hibernation in a restricter area on a hillside in Columbus." This presumably (genetically) homogeneous population sample includes snakes that are boldly spotted and some that have such markings obscure or absent. Some are conspicuously strip:d, and some are not. The colors vary through the entire gamut previously recorded. None, however, even temotely approaches the almost uniform black coloration that appears frequently in specimens from some of the counties bordering Lake Erie. The group of forty-one snakes is composed chiefly of adults of average dimensions, but several small ones, including young of the year, are among them; none are of large size.

Blanchard and Blanchard (1941), after conducting breeding experiments among melanistic and normally-patterned sirtalis, were able to present evidence indicating that "the inheritance of melanism with several specimens from Toledo is inherited in simple Mendelian fashion (the factor for black being recessive)..." They also secured data tending to show that fall matings were successful; females captured in the autumn, and kept away from males, produced young at the usual time during the following summer. Since the appearance of their paper, however, several persons have published notes offering proof that sperm (in other species at least) may remain viable for one or more years. Hence the Blanchard snakes may have mated even earlier than supposed.

Mattlin and Wood have each published a note upon a large litter of Thamnophis s. sirtalis. Mattlin (1948b) recorded a female from near Cleveland that measured $960 \mathrm{~mm}$. (373/4 in.) and which produced 51 living young and 13 infertile ova on August 23, 1947. Among ten of the juveniles the lengths varied from $179 \mathrm{~mm}$. to $195 \mathrm{~mm}$. (mean $187.2 \mathrm{~mm}$.) ; weights varied from 2 to 2.5 grams. Wood (1945) obtained 57 young on August 6, 1940, from a female from Pike County that measured $914 \mathrm{~mm}$. (36 in.) in length; fifty-two of these varied from $169 \mathrm{~mm}$. to $203 \mathrm{~mm}$. (mean $188.4 \mathrm{~mm}$.). Wood also states (in correspondence) that an unusually large garter snake from Pike County contained 75 embryes, another from Montgomery County contained 30, and still another (from the latter county) gave bitth to 23 young on July 24, 1940.

Lagler and Salyer (1945), reporting upon specimens of sirtalis collected along natural waters in Michigan, found that these snakes had eaten mostly earthworms, frogs, and toads; fishes constituted only $6.2 \%$ of the food by volume. In the vicinity of fish-rearing stations, however, trout amounted to $403 \%$. Thus garter snakes, which are largely terrestrial near wild waters, show a marked tendency to become aquatic with the increased availability of fish at rearing stations 
A common garter srake was found in the stomach of a red-shouldered hawk that was shot in Montgomery County.

Wood advises me that J. M. Miller found a "hibernating ball" of garter snakes in a hole two feet in depth in the levee along the old channel at Daytor. The date was January 8, 1944. Of the seventeen snakes entwined together, twelve were males and five were females. An aggregation of sixteen specimens (thirteen fermales and three males) was discovered in the foundation of an abandoned house in an uncultivated field in Dayton on April 27, 1940. The snakes were found by H. J. Walter and J. H. Martin "in a ball 7 inches in diameter in a depression in loose earth beneath one of the steps of a rotten staircase."

\section{Agkistrodon contortrix mokeson (Daudin) \\ NorThern COPPERHEAd \\ (Page 107; maps 26 and 64; plate 14, fig. 1)}

The copperhead has been the subject of much study and considerable nomenclatorial juggling during the past several years. Four subspecies are now recognized; the range of two of these is indicated by the solid dark portion of the irsế map on page 109. A southern race, characterized by its pale coloration and the nartowness of its dark crossbands, occurs from southeastern Virginia southwestward through the coastal plain and piedmont of the Carolinas and Georgia into extreme northern Florida; from there it ranges west to castern Texas and north through the Mississippi Embayment to southern Illi. nois. The northern copperhead occurs in the remainder of the dark section of the map, but its range should be extended somewhat to the northwest to include new records from extreme southeastern Inwa and extreme southeastern. Nebraska.

The name mokasen of Beauvois, used in the first edition of the Reptiles of Ohio, has been shown by Gloyd and Conant $(1943,149)$ to he unidentifiable; mokeson, of Daudin, as the next oldest name, is applicable to the northern copperhead. The use of contortrix for the species as a whole is based upon the arguments of Klauber $(1948,7)$ who believes that the Linnaean Boa contortrix is applicable to the copperhead and not to the hog-nosed snake, as was maintained by Stejneger and Barbour throughout the five editions of their Check List of North American Amphibians and Reptiles. Since the specimen described by Linnaeus was from "Carolina," the southern copperhead should he known as Agkistrodon contortrix contortrix.

New Ohio records are:

Adams Countr: Near Stouts (WED 207). Athens County: 6 mi. SW of Athens (OUVC 852); Buffalo Beat, near Buchtel (OUVC 382). Fairfield CounTY: Berne Twp. (OSM 487); Sugar Grove (OSM 712.1-9). Hamilron County: Riverside, Cincinnati (CSNH 2655). Hocking County: Clear Creek (OSM 774). Jefferson County: I mi. S of Bergholz (FWB-2 specs.). Pike County: Old Baldy (DPLM 380.44); 1 mi. NE of Pike Lake (DPLM 104-5.42); Pike State Forest (DPLM 98.42, 100.42, 103.42, 208-18.43, 99.44; WED 149-51, 154); Wildcat Holler (DPLM 622.44, 654.44). Ross County: Harrison Twp. (OSM 715.13); I mi. W of Vigo (OSM 486). Scıто CountY: Near Haverhill (AMNH 
65172); 3 mi. N of Rarden (OSM 900): Shawnee State Forest (WED 254). ViNton County: S of Lake Hope (OUVC 1864); Zaleski State Forest (OSM 490; OUVC 1834).

The following reporis (from Buchanan, Gier, and Leete) may be added to the list: Athens Countr: Athens; Stroud's Run, 3 mi. NE of Athens. Hocking CounTY: Conkle's Hollow. JefFerson County: The valleys of Brush Creek and Yellow Creek from the vicinity of Bergholz to the Ohio River. PIKE County: Benton Twp. (Camp Pike). Ross County: Chillicothe; Colerain Twp. (Pine Lake in Tar Hollow Forest); Franklin Twp. (Stoney Creek in Scioto Trail Forest). Scioto County: Union Twp. (Copperhead Tower in Shawnee State Forest).

The copperheads from Jefferson County furnish a notable, but not unexpected, extension of range. This snake probably is locally common throughout most of unglaciated Ohio, although it is interesting to note that all the known records in the extreme eastern part of the state are from close to or east of th? Flushing Escarpment.

Among the specimens collected recently there are several that are exceptionally dark in coloration. A male from Pike County (DPLM 105.42), that measures $890 \mathrm{~mm}$. in length, is heavily stippled with grcy and brown and is one of the darkest snakes of this species I have ever examined.

\section{Sistrurus catenatus catenatus (Rafinesque)}

\section{EAstern Massasauga}

(Page 112; maps 27 and 65; plate 14, fig. 2 and plate 15, fig. 1)

Evans and Gloyd (1949) have shown that catenatus and its western subspecies, tergeminus, intergrade in Missouri and that the species does not occur in the Ozarkian uplift. Hence the general range map (page 114) should be amended to show catenatus terminating in north central Missouri instead of in eastern Kansas and Oklahoma. New Ohio records are:

Ashtabula County: Lake Cardinal (CMNH 43); Rome Twp. (CMNH 54-5, 154; CZP 4). Cuyahoga County: $12 \mathrm{mi}$. SW of Cleveland (TMS 2463, 2466). Fayette County: Western Concord Twp. (OSM 641.1-16). Greene County: Huffman Dam, Bath Twp. (WED 440). Hardin County: 3 mi. E of Mt. Victory (OSM 620, 621.1-3; SL 486-7). Huron County: Willard (CMNH 140-5). Lucas County: Oak Openings, west of Toledo (SL 993). Montgomery County: Riverside (DPLM 631.44). Paulding County: Near Charloe (OSM 492). Portage County: Atwater Twp. (Dexter, 1944). Trumbull County: North Bristol (NU 7). Wyandot County: Sec. 9, Pitt Twp. (OSM 542).

Among the above specimens, CMNH 54, 141, 143, 144; OSM 621.1-3; SL 486-7; and TMS 2466 are either melanistic or so dark and with so little evidence of pattern that they may have been melanistic in life. The mother of OSM 620 (a juvcnile born in captivity) is said to have been black also. Several of these snakes, it will be noted, are from 3 miles east of Mt. Victory. Many more rattlers have been collected there during the past decade (Rausch and Camin, for example, caught thirteen in a single afternoon), but it is still possible to state that all adults taken in that locality have been black and all juveniles spotted (see page 113).

In at least two areas where the massasauga formerly was abundant it may soon disappear altogether. The New Haven Marsh (see page 115), accord- 
ing to Mattlin, "is under intense cultivation, and a collecting trip to the area in May, 1948, proved a failure so far as rattlers were concerned. Interrogation of some twenty-five field hands brought to light the startling fact that only two rattlers had been encountered up to the time of my visit. I might add that field mice were everywhere in abundance."

Concerning the Mt. Victory locality, Mattlin adds that this spot "is being heavily cultivated and the remnants of the swamp forest have been drained." When Triplehorn last visited Mt. Victory (late in 1947) bulldozers were at work ripping up large sections of the massasaugas' habitat in that region.

A sizable colony of these rattlers has recently been discovered in Rome Twp., Ashtabula County. Both the Cleveland Museum and the Cleveland Zoo have obtained specimens from there (eight were received at the Zos during the past two years). Dr. Williams describes the locality as follows:

"The vicinity of Rome is, generally speaking, the basin of the Grand Rive: Valley. This basin is really an extension of the Lake Plain southward, reaching back to the vicinity of Niles, a distance of about 40 miles from Lake Erie. It is from 8 to 12 miles in width and stands only 150 to 350 feet above lake level. It has been said that if the blanket of glacial drift were removed from its surface, much of it would be at Lake Erie level (573' above sea level). This accounts for large areas of marsh lands in the basin, and for the generally muddy character of the river water. . . This should give the setting for the habitat of the massasaugas, which are not uncommon in the marshy parts of the basin."

Wood advises me that he examined a small massasauga $(268 \mathrm{~mm}$. in length) from the Huffman Dam area, in Greene County, which had eaten a snake. Only the tail remained undigested and an accurate identification was impossible. Wood believes, however, that it probably was Storeria dekayi.

\section{Crotalus horridus horridus Linnaeus}

Timber Rattlesnake

(Page 116; maps 28 and 66; plate 15, figs. 2-3)

Judging from numerous reports and records, the timber rattlesnake may be considerably less rare in the state than was indicated by the data available when the first edition of this report was being prepared. Numbers of specimens have turned up in some of the southernmost counties-in the wilder areas and in the state parks and forests. A number of accidents have occurred and there have been some fatalities as the result of rattlesnake bite. New records that are backed by preserved specimens are as follows:

Ross County: Harrison Twp. (OUVC 1863); Tar Hollow, Harrison Twp. (OSM 714); Tar Hollow State Park (OSM 566). Scioto County: (OSM 716); Pond Run (OSM 488); Shawnee State Forest (WED 159). Vinton Countr: Sec. 7. Eagle Twp. (OSM 489): Zaleski State Forest (OUVC 1866A-B).

In addition, there are the following reports supplied by competent ebservers (chiefly Thomes, Leete, and Gier) or obtained from newspaper accounts that pictured the snakes or reported fatalities: Hocking Countr: Salt Creek Tw.p. (along Salt Creek just north of Pine Cottage School). Ross County: Colerain Twp. (Pine Lake. 
Tar Hollow Forest); Franklin Twp. (Scioto Trail Forest, Snake Hol'ow, and Stony Creek, about 9 mi. S of Chillicothe); Harrison Twp. (Piny Run, near Rattlesnake Knob and Tar Hollow Forest); Jefferson Twp. (I mi. E of Richmondale); Paxton Twp. (Pott's Hill at Pike County line). Scioto County: Brush Creek Twp. (head of Bear Creek); Nile Twp. (Panorama Trail in Shawnee Forest); Union Twp. (head of Pine Creek and in Pine Run, I mi. S of state highway \#73). Vinton County: Brown Twp. (Lake Hope).

Gier says that "there were approximately 60 rattlers reported killed by the C.C.C. in Zaleski Forest during path construction and other improvements from 1936 to 1939, inclusive." Gier believes that Crotalus is "at least rare" in both Athens and Meigs counties where he has done much collecting. Regarding northern Ohio, Mattlin states that "there seems to be very little fluctuation in the number of timber rattlers reported from Ottawa County on the Catawba and Marblehead peninsulas, two or three being found every year." Rofkar, who lives in the region, believes that the rattlesnake population has not changed to any appreciable degree during the past twenty years.

The secretiveness of this snake, despite its large size, may well be responsible for its seeming rarity. A combination of nocturnal habits (at least in hot weather) and a marked propensity for remaining close to rock piles, crevices, or other places affording immediate shelter, enable timber rattlers to kecp well out of man's way. Where they occur they may be far more abundant than has been realized. This has been demonstrated in the Zaleski Forest where large numbers of men, engaged in brushing operations day after day, managed to encounter a sizable number of the snakes. Casual search through the region probably would have netted but a few rattlers, even under optimum collecting conditions.

The Hocking County State Park district, with its rugged, well-forested terrain, its picturesque cliffs and valleys, and its spectacular rock-shelter caves, has been visited by naturalists more frequently than almost ary other part of the state. Yet there are no reports of rattlers from the region. Furthermore, Thomas has been unable to secure evidence from older residents of the area that rattlesnakes ever occurred there. He believes that the absence of the species may be explained by the failure of the massive formations of the Black Hand sandstone to provide suitable hibernation sites for Crotalus. In the process of weathering, no talus cones develop, such as are characteristic of so many other types of sedimentary rocks. On the other hand, therc are wellauthenticated reports of the species in extreme southwestern Hocking Countv, along the col of Salt Creek. Here, the Cuyahoga Formation provides quite a different habitat. The layers of thin-bedded, fine-grained, resistant sandstones of this formation, alternating with friable shales, result in extensive talus slopes of sandstone slabs.

\section{Sternotherus odoratus (Latreille)}

\section{Musk Turtle}

(Page 120; meps 29 and 67; plate 16, fig. 1)

More evidence has accumulated to indicate that the musk turtle is vastly more abundant in Ohio than the records might suggest. The report by 
Thomas and Trautman (1937) of finding approximately 450 specimens near Buckeye Lake has already heen mentioned (page 123). Wood has furnished information on another large aggregation of Sternotherus. He states, "I examined 75 specimens collected by H. J. Walter from Eastwood Pond, east of Dayton, that were obtained in the spring of 1942 during a period of unusually dry weather, when the water level in the ponds fell to only a few inches and 'noodling' was very successful."

New Ohio records for Stemotherus are:

Allen Countr: Diller's Quarry, 21/2 mi. WNW of Bluffton (OSM 747). Athens County: Margaret's Creek (OUVC 116). Auglaize Countr: Forly-acre Pond, 3 mi. N of St. Marys (UMMZ 98023). Butler Count?: Fairfield Twp. (OSM 666.1-2). Clark County: Crystal Lake (IVED 368). FayetTe County: North Fork, Paint Creek, Marion Twp. (SL 573); Paint Creek at state route \#70, Union Twp. (OSM 735): Washington Court House (WED 163). Jackson CounTY: Black Fork Creek, Jefferson Twp. (OUVC 119); Jackson (OUVC 1381). Madison County: lefferson Twp. (OSM 765). Montgomery County: Dayton (DPLM 316-7.44, 375.44, 787.44, 840-51.44, 853.44, 856-68.44, 875.44, 880-87.44; WED 162); Southeast of Dayton (DPLM 316-7.44); Englewood Dam, Randolph Twp. (Wood \& Duellman. 1947b). Stark County: Myer's Lake, 1/2 mi. W of Canton (OUVC 2391). Summit Countr: Hower Lake, Coventry Twp. (OSM 733). Vinton County: Lake Alma (OUVC 126, 128-9).

The large majority of the specimens reported above and on pages 121 and 122 were taken by hand or by dip-net, wher. the turtles were basking or prow!ing in shallow water, or when the females were ashore during the nesting, seasen. Since Sternotherus odoratus is so markedly aquatic, the few individuals thus obtained are scarcely indicative of the actual abundance of the species. Extensive trapping in the ponds and streams of Ohio probably would prove that the musk turtle is one of the most common reptiles in the state. On several recent accasions, while trapping in New Jersev and Delaware and using the terhnique outlined by Lagler (1943b), I have caught more musk turtles in a single twenty-four hour period than I collected in six years of tramping about in the Buckeye State. The Ohio laws ctipulatz that no traps with meshes less than four inches in diameter may be used; such traps permit small turtles, including all specimens of Sternotherus, to escape. I tried repeatedly to obtain a special permit to use a small-meshed $n \in t$ while I lived in Ohio, but the laws at that time made no provision for scientific collecting. Fortunately this situation recently has been remedied by an act of the General Assembly (approved May 17, 1947) that provides for the issuance of permit; to properly arcredited persons.

It is quite possible that a systematic trapping campaign would result in adding the mud turtle, Kinosternon subrubrum subrubrum, to the fauna of Ohio.

Lagler (1941) has presented data on a number of fall matings which he observed in Michigan. This substantiates Risley's supposition that copulation might take place during the autumn months (see page 123) as well as in spring. 


\section{Chelydra serpentina serpentina (Linnaeus) \\ Snapping TuRTle \\ (Page 124; maps 30 and 68; plate 16, fig. 2)}

It is now generally conceded that there is more than one subspicies of snapper. Chelydra s. osceola, of peninsular Florida, is a weakly defined race in which there are four chin barbels instead of the usual two and in which the vertebral plates of the carapace are widened. Eventually the tropical snappers may be considered conspecific with the wide-ranging North American form, but specimens from Latin America are still scarce in collections.

A slight alteration in the general range map (page 125) must be made to allow for osceola in Florida. New Ohio records are:

Allen County: Riley Creek, Bluftion (OSM 713). Butlen Countr: Reily (Fichter, 1947). Clermont County: Ohio River, 1 mi. NW of New Richmond (OSM 743). Defiance County: I mi. SW of Defiance (OSM 729). FayetTe County: Paint Creek at state route \#70, Union Twp. (OSM 737). Highland County: $1 \mathrm{mi}$. W of Rainsboro (WED 206). Hocking County: Laurel Twp. (UMMZ 89989). Jackson County: Jackson (OUVC 561). Logan CounTY: Indian Lake (WED 164); 6 mi. S of Indian Lake (WED 369). MontgomerY County: Dayton (DPLM 125.42); Wolf Creek, Madison Twp. (Wood \& Duellman, 1947b). Paulding County: Antwerp (OEE). Portage County: Kent, Ravenna, and Windham (Dexter, 1948). Preble County: Camp Myron Kahn, 2 mi. S of Camden (MU 12). Stark County: (CA 5823). Tuscarawas County: Near Gnadenhutten (OSM 842). Williams County: West Branch, St. Joseph River, Sec. 8, Bridgewater Twp. (SL 780).

These records are few in number for such a common and $\mathrm{n}$ idespread turtle, but they reflect the teluctance of collectors to catch and carry heavy specimens and of museum curators to devote large containers to such material. Virtually all the specimens listed above are juveniles. Snappers usually ate not easy to find and to capture by hand, however. Here is another turtle that is most easily acquired by trapping.

Lagler (1943a) has surnmarized the feeding habits of the snapper, basing his conclusions upon an examination of the contents of stomachs and colons removed from 281 specimens collected in lakes and streams of Michigan. In the stomachs, the composition by volume was: game and pan fishes $34.2 \%$; carrion $19.6 \%$; vegetable matter $36.2 \%$; invertebrates made up the bulk of the remainder. In the colons, vegetable matter accounted for $69.2 \%$ of the total, and the leaves and petioles of aquatic plants had been eaten by three out of every four individuals. Lagler, after studying the effects of snapper predation, its biotic importance in natural waters, its value as a scavenger, and its use as human food, recommends the conservation of this turtle except in "those watets where special investigation proves $[\mathrm{it}]$ to be undesirable."

\section{Clemmys guttata (Schneider)}

\section{Spotted Turtle}

(Page 129; maps 31 and 69; plate 16, fig. 3 and plate 18, figs. 3 and 4)

Relatively few spotted turtles have been collected in the past dicade, and only three counties may be added to the list of those from which the species has been reported. New records are as follows: 
Carroll County: Specht Marsh, Sec. 12, Washington Twp. (FWB). ChamFAIGN CountY: Cedar Swamp, $5 \mathrm{mi}$. SSW of Urbana (DPLM 95.42; OSM 511; UC; WED 31-22); Kiser Lake (DPLM). Erie County: 1.3 mi. NNW of Castalia (OSM 681). Geauga Counity: Fern Lake, Burton Twp. (SL 778). Greene County: Trebein, along tributary of Little Miami River (USNM I29C65). Licking County: Cranberry Island, Buckeye Lake (OUYC 1324). Logan County: I mi W' of West Liberty (OSM 680). Ricilland County: Plymouth (SL 681).

The Carroll County specimen is the first from unglaciat:d Ohio. Clemmys guttata is one of several species that are common and widespread in the northeastern counties and which probably crossed the glacial boundary by making use of the drainage system of Sandy Creek.

In the interests of conservation it should be pointed out that there is now a considerable number of spotted turtles in museum collections from the cedar swamp in Champaign County. Clemmys is an interesting element in the fauna of this relict boreal bog, and it would seem needless to deplete the popu. lation furthei in this locality.

There is a useful secondary sex character in this species that is helpful in distinguishing males from females. In adult males the horny portion of both jaws is almost completely covered with dark grey pigment; in females the jaws are light yellow. Pope $(1939,86)$ has summarized the sexual differences of spotted turtles.

One of the specimens from Champaign County (OSM 511) is the sma!lest on record from the state. Its carapace measures $25.5 \mathrm{~mm}$. (1 inch) in length.

\section{Emys blandingii (Holbrook) \\ Blanding's Turtle}

(Page 132: maps 32 and 70; plate 17. figs. 2 and 3 and plate 18, figs. 1 and 2)

New records for Blanding's Turtle are:

Allen County: Riley Creek at Bluftion (OSM 849). Defiance County: Along St. Joseph's River, Milford Twp. (OEE). Lucas County: Jerusalem Twp. (UMMZ 86036).

The record from Allen County may be open to question. Riley Creek is part of the Maumee drainage system, but all other localities in northwestern Ohio are either fron the Maumee River or north of it. Further collecting south of the master stream may eventually confirm the Bluffton record, but the possibility must not be overlooked that OSM 849 may be an escaped or liberated curtle.

In addition to the above, the Ohio Statc Museum has acquired another specimen (OSM 731) from Westerville, Franklin County. This one and OSM 189 (see page 133) are both large adults. Their presence in contral Ohio, so far from all other records in the state, could be most easily accounted for by assuming that they were released there by human agency. This apparently has been the case. Camin, who has made inquiry at Otterbein College (situated at Westerville), advises me that, "Otterbein's Biology Department has been buying fifty to one hundred turtles of miscellaneous species every autumn for several years. . . They are used in zoology and comparative anatomy courses during the fall and winter, and the surplus, a dozen or so 
and often including Emys blandingii, are released in the spring each year. This ought to explain the recovery of Blanding's turtle at Westerville."

W/ood reports that two large adults were found in the Dayton area in 1944. These also had probably been liberated by someone. At least one biological supply company makes a practice of selling specimens of Emys blandingii to schools, colleges, and research centers in all parts of the country.

Ehrhart states that the specimen from Defiance County was taken "in a muskrat den above the water line."

\section{Terrapene carolina carolina (Linnaeus)}

Eastern Box Turtie

(Page 136; maps 33 and 71; plate 17, fig. 1 and plate 18, figs. 5 and 6)

Herpetologists are now generally agreed that all of the box turtles of the eastern United States are races of the same species, hence the use of a trinomial for the Ohio population. At least two of the other subspecies, triunguis and bauri, are known to intergrade with carolina. New Ohio tecords are:

Adams County: Manchester (SL 416); 31/2 mi. W of Rome (WED 265). Athens County: Sec. 23, Canaan Twp. (OUVC 2449). Brown County: Ash Ridge (UMMZ 84329); 1 mi. SW of Georgetown (WED 374) ; 3 mi. SE of Macon (WED 264). Butler County: Reily (GF). GReene County: Bryan State Park (DPLM 111.42). Highland County: $12 \mathrm{mi}$. W of Hillsboro (SL 386). Hockinc CountY: "Neotoma," Good Hope Twp. (OSM 734; SL 779); I mi. SE of South Bloomingville (WED 338). JACKSON CoUNTY: Jackson (OUVC 564-6. 1382-3). LoGan County: 2 mi. NE of West Liberty (OSM 719). Montgomery County: Germantown Dam, German Twp. (Wood and Duellman, 1947b); Hills and Dales Park. Van Buren Twp. (Wood and Duellman, 1947b); Northridge (DPLM 473.44); Harrison Twp. (Wood and Duellman, 1947b). P1KE CounTY: 11/2 mi. S of Nipgen, Benton Twp. (OSM 720). Scioto CountY: Buena Vista (WED 266). ViNToN CountY: Near Oreton (OSM 841). WarRen County: Lebanon (UC).

In addition to the above, the Cleveland Museum has a box turtle (CMNH 168) from the "Cleveland Region," and Dexter (1948) has reported upon a male Terrapene that was found near Twin Lakes, Portage County. These two specimens are of special interest in view of my comment (page 137) that "this turtle does not occur naturally in northeastern Ohio."

For additional information on this subject I have appealed to Mattlin, who, in his capacity as curator of reptiles at the Cleveland Zoo, is the constant recipient of specimens collected in the northeastern counties. He states, "Th? fact that box turtles are intentionally or fortuitously released is graphically illustrated by the fact that I have received one thrce-toed box turtle and on: Baur's box turtle, both of which were collected in the Cleveland area. I know that numcrous common box turtles are being released in the Cleveland Metropolitan Parks every year, and it is possible that the species may become indigenous to this section in years to come. To date I can find nothing to indicate that the common box turtle is breeding in northeastern Ohio. Your original statement in the Reptiles of Ohio still holds true."

Substantiating Mattlin's comments is the fact that staff members of the Cleveland Museum, who have done extensive field work in the northeastern 
counties, have failed to find this species except under circumstances which would indicate that escaped specimens were involved. Until it can be proved that breeding colonics are established in that part of the state, it probably is wisest to view with suspicion any box turtles which may be found there. Strictly speaking, some of the records that I have admitted to the lists may be based upon turtles that were introduced by human agency, but there is no way in which to prove the matter-one way or the other. It is quite definite, however, that Terrapene is widespread in southern Ohio, especially in the unglaciated region, and that it is well established in the Oak Openings of Lucas, Fulton, and Henry counties. Doubtless it is native to many parts of the state, and most of the records indicated may be considered as valid Wc shall never know the exact natural ranges of many of our turtles, thanks to mankind's propensity for carrying these reptiles about and releasing them wherever it suits his fancy.

\section{Graptemys geographica (Le Sueur) \\ Map Turtle: \\ (Page 141: maps 34 and 72; plate 20, fig. 2)}

Graptemys geographica continues to be a relatively elusive reptile, and most of the new records for it are concentrated in areas where naturalists have been especially active during the past decade. Most map turtles ssem to b3 taken incidental to othar field activities or are acquired when they are brought by fishermen (and others) to zoos or museums for identification. Graptenys does not resnond well to baits used in traps (Lagler, 1943b, 24), but some are caught occasionally during seining operations for fish. Just as is the case with Sternotherus, the map turtie is probably far more abundant in Ohio than the available data would indicate. New records are:

Athens County: Near Fisher, Alexander Twp. (OUVC 1868). Franklin CouNTY: Blacklick Creek (OSM 721); Big Darby Creek, Pleasant Twp. (OSM 682). Hancock Countr: Blanchard River, at Findlay (OSM 848). Montgomery CounTY: Murlin Heights, Butler Twp. (Wood and Duellman, 1947b); Dayton (Wood and Duellman, 1947b); Wolf Creek, Madison Twp. (Wood and Duellman, 1947b). Portage County: Dollar Lake, near Twin Lakes (Dexter, 1948). Ross County: Scioto River, at Higby Bridge, Jefferson Twp. (SL 1001). Tuscarawas Countr: Tuscarawas River, 2 mi. below Gnadenhutten (OSM 867). Williams CounTy: Fish Creek, St. Joseph Twp. (SL 699-700). Gier reports that, while he was stationed at Ohio University, he received several map turtles that were taken in "fish nets" by Lee Roach; these were from the East Branch of Shade Creek, in Section 16, Orange Twp., Mleigs County. Wood has examined map turtles from the following additional localities: DARKE CoUnTY: Greenville Creek, $5 \mathrm{mi}$. E of Greenville. Greene Countr: Little Beaver Creck, at Alpha; Little Miami River, at Grinnell's Mill. Ross CounTy: Paint Creek, near Seven Caves.

Wood also has sent me information on a large female specimen that was caught during 1940 in the Stillwater River, in Montgomery County, just below the Miami County line. This turtle, now a mounted skeletal exhibit in the Dayton Public Library Museum, had a carapace that measured 105/8 inches. Hence, it is the largest of its species yet to be recorded from Ohio. Ehrhart has acquired a hatchling from Antwerp, Paulding County, that measures 336 
mm. (approx. 1-5/32 inches) in carapace length; this is slightly shorter than the smallest one previously reported (page 141).

\section{Chrysenys picta marginata Agassiz \\ Central Painted Turtle}

(Page 145; maps 35 and 73: plate 19, figs. 1 and 2)

It is now generally agrecd that the genus Chrysemys is monotypic and that there are four well-differentiated races of a single species. The Ohio form, marginata, intergrades with the subspecies bellii to the west (in eastern Illinois and southeastern Wisconsin) and with the subspecies dorsalis in southern Illinois. Intergradation with picta, the eastern form, occurs through a wide area, but there is some difference of opinion as to just where one subspecies stops and the other begins. Apparently marginata occurs eastward at least to the Hudson Valley and to east central Pennsylvania. The New England population, in general, may be considered as intermediate, and there is even some evidence of the influence of marginata southward in the Atlantic coastal plain at least to the Del-Mar-Va Peninsula. The range of this form is approximated by the inset map on page 147. New Ohio records are:

Athens County: Athens (OUVC 557); $6 \mathrm{mi}$. SW of Athens (OUVC 2053). Butler County: Reily (Fichter, 1947). Darke County: West of Greenville (WED 165). Defiance County: Sec. 35, Defiance Twp. (OSM 846). FalRfield Counry: Indianola Lake (OUVC 2051). FayetTE County: Paint Creek at state route \#70, Union Twp. (OSM 736); Washington Court House (WED 166). HaMILton County: Mt. Healthy (UC); near Shaker Village, Crosby Twp. (OSM 732.1-3). Hardin Countr: Near Mit. Victory (OSM 829). Jackson County: Black Fork Creek (OUVC 122); Jackson (OUVC 559); Jackson Twp. (OUVC 560). Lake County: Painesville (OUVC 1562). Logan County: Indian Lake (WED 167-9, 171); 21/2 mi. SE of Indian Lake (WED 173-4, 178). MaHoning County: 2 mi. SE of Berlin Center (CM 19071). Montgomery County: Dayton IDPLM 87.44, 315.44, 788-809.44, 811-828.44, 830-3.44; WED 170; USNM 129063); Englewood Dam, Randolph Twp. (DPLM 430.44); Northridge, Harrison Twp. (Wood and Duellman, 1947b). Ottawa County: Portage River, near Oak Harbor (SL 388). Paulding County: Antwerp (OEE). Pickaway County: 2 mi. W of Circleville (WED 183). Ross County: Willow Branch Camp (DPLM). Stark County: (CA 5821-2). Trumbull Countr: 2 mi. W of Johnston (CM 19070). Warren County: Lebanon (UC). Gier reports two localities from Meigs County-Orange Twp. and Breezy Lake, in Rutland Twp.

The relative size of the dark plastral blotch among fifty specimens from Lake County has been discussed on page 146. Among a group of thirty-two painted turtles recently collected near the opposite corner of the state (Dayton, Montgomery County), 25 had blotches of average size, 3 had largs ones, 3 had small ones, and a single specimen was unmarked. Although a few of these turtles had dark extensions running out from the central blot:h along the sutures between the plastral scutes, such extensions were in no casa prominent.

The recent widespread practice of building dams and creating lakes for reservoir or recreation purposes should be a boon for Chrysemys and other turtles that thrive in lacustrine habitats. This is especially true in unglaciated Ohio where natural ponds and bogs are few in number. 


\title{
Pseudemys scripta elegans (Wied)
}

\author{
Mississippi Valley Terrapin \\ (Page 151; maps 36 and 74; plate 20, fig. 1)
}

Dr. Archie F. Carr, Jr., one of the principal students of the genus Psewdemys, advises me that Ohio specimens of this group should now he designated as Pseudemys scripta elegans. Recent studies have shown that the name troostii, formerly applied to all the populations inhabiting the Mississippi and certain adjacent drainage systems, should be restricted to the turtles of a relatively small area in the higher stream region of eastern Tennessee. The distribution of elegans, as understoed at present, is approximatcd upun the inset map on page 152--except as follows: (1) The dark area should be extended eastward to the area of intergradation with troostii in central Tennessez and to western Georgia and Florida where elegans intergrades with Pseudemys scripta scripta; (2) the range should be extended somewhat farther southwest in Texas where irtergradation cccurs between tegans and the subspacies gaigene; and (3) Nebraska should be omitted there apparently are no valid records from that state (Hudson, 1942, 99).

No data are available upon the present status of the colonies previously reported from Pickaway and Ross counties. Nor are there any new records that may be considered as authentic. A few juveniles have been reported from scattcred localities, but all are st:spected of having been captives that were liberated by weil-meaning owners. This, of course, is the turtle that is vended in vast numbers by pet stores and five-and-tens. It is possible that the species might succeed in establishing itself in one or more localities in Ohio if specimens were turned loose in places where suitable food, hibernating sites, etc. are available. This apparently has happened recently in Michigan, for Edgren (1948) has presented evidence to show that troostii (=elegans) has become resident in Muskegon and Oceana counties (of that state), obviously as the result of introducion by human beings. (These counties border on Lake Michigan about half way up the Lower Peninsula.) Unless groups of adults are found or breeding populations can be demonstrated. however, it is best to discount or distegard new Ohio "records."

Cagle (1950) has published an excellent summary of his studies on the life history of elegans (under the name troostii).

\section{Amyda mutica (Le Sueur) \\ Brown Soft-Shelled Turtle \\ (Page 154; maps 37 and 75; plate 21, figs. 1 and 2)}

There are only four new records and reports for this turtle, but two of them are from far up the Muskingum Valley, and they thus extend the range considerably northward in Ohio. The species is now known to occur farther east than had been generally realized, and the dark area on the inset map should be extended to include central western Pennsylvania. There is a sp-cimen in the Museum of Comparative Zoology (MCZ 1911) from the Alle- 
gheny River at Foxburg, Clarion County, Pennsylvania, and upon which Netting (1944) has reported. New Ohio records are:

Scloto County: Scioto River, Rush Twp. (SL 459). Tuscarawas County: Tuscarawas River, 2 mi. below Gnadenhutten (OSM 868); near Winfield (MCZ 12205). Wood reports this species from Pike Lake, Pike County.

On page 156 of this volume there is a quotation from Muller (1921) in which it is stated that a female Amyda mutica excavated her nest with her "forepaws." Pope $(1939,321)$ believes that Muller is in error, inasmuch as all other turtles, in so far as is known, dig their nests with their hind limbs. I heartily agree with Pupe.

\section{Amyda spinifera spinifera (Le Sueur)}

\section{Siny Soft-Shelled Turtle}

(Page 157; maps 38 and 76; plate 21, fig. 1 and plate 22, figs. 1 and 2)

Three subspecies of Amyda spinifera are currently recognized (Conant and Goin, 1948). The race that occurs in Ohio (spinifera) ranges from Lakes George and Champlain westward through the St. Lawrence and Great Lakes drainage systems to southern Michigan and thence to west central Wisconsin; southward it is found in Ohio and Mississippi drainages from western Pennsylvania and eastern Tennessee west to the Mississippi River. Through in broad zone bordering the latter, spinifera intergrades with hartwegi, a race that ranges westward to Montana, Wyoming, and the Oklahoma panhandle; hart. wegi is characterized by the small size of the circular markings (ocelli) on the carapace which may be reduced to mere dots and specks. The third subspecies, aspera, is found in the Southeast; in it there are two or more broken dark lines bordering the rear margin of the carapace, and the pestocular and postlabial light lines usually meet on the side of the head. From the above it is obvious that the general range shown on page 158 is no longer of much value. New Ohio records are:

Ashland County: Black Fork, Sec. 27, Green Twp. (SL 389). Athens CounTY: Hocking River, near Athens (ITG); near Fisher, Alexander Twp. (OUVC 2052-9 specs.). Butler County: Oxford (MU). Coshocton County: Walhonding River, below Dam \#6 (SL 460). Deflance County: Auglaize River, Shawnee Scout Camp, Defiance Twp. (OSM 730). Greene County: Huffman Dam (DPLM 139.42). Medina County: Hinckley Lake (CZP). Montgomery County: Mad River, Dayton (Wood and Duellman, 1947b) : Miami River, Dayton (DPLM 86.44, 376.44); Stillwater River, Dayton (WED 199). VINTON County: Lake Hope (OUVC 1867). Warren County: Fort Ancient (UC). Williams County: West Branch, St. Joseph River, Sec. 8, Bridgewater Twp. (SL 787).

The following localities, some reported by Wood and others by Gier, may be added in the list: Jackson County: Jackson Lake. Meics County: Shade River, below Darwin. Miamı County: Miami River, above Troy. Ross County: Paint Creek, near Bainbridge. Vinton County: Lake Alma.

Wood saw a number of these turtles on a gravel bar in the Miami River below the Main Street Bridge. right in the heart of Dayton. Seven of them, including two large ones with carapaces each about a foot in length, were lying along the edge of the bar during midafternoon on June 8, 1944, all apparently cblivious to the traffic passing above them. An eighth turtle hovered off the 
edge of the bar, its head and neck above water. When Wood dropped a pebble from the bridge only one of the lot took alarm. All proved to be extremely wary when an attempt was made to approach them by foot along the bar.

Trautman reports that he saw a concentration of upwards of fifty of these turtle; along the West Branch of the St. Joseph River, in Williams Countv, on May 21, 1941.

\section{SUPPLEMEN'TARY REFERENCIS}

(Chiefly those published since 1938, but including some others that are mentioned in the revisionary text.)

Blanchard, Frank N. and Frieda Cobb Blanchard 1941 The inheritance of melanism in the garter snake Thamnophis sirtalis sirlalis (1 innaeus), and some evidence of effective autumn mating. Pap. Michigan Acad. Sci., Arts, Lett., vol. XXVI, pp. 177.192.

CAgle. Fred R. 1950- The life history of the slider turtle. Pseudemys scripta troostii (1 lolbrool:). Ecol. Mono., vol. 20, no. 1, pp. 31-54, figs. 1-18.

Conant, Roger 1938a-The reptiles of Ohio. Amer. Midl. Nat., vol. 20, no. I, pp. 1-200, pls. 1-26, maps 1-38.

1938b-On the seasonal occurrence of reptiles in Lucas County, Ohin. Ierpetologica, vol. 1, pp. 137-144, figs. 1-2.

1940-A new subspecies of the fox snake, Elaphe mulpina Baird and Girard. Ibid., vol. 2, no. I. pp. 1-14, pl. I, fig. 1, map I.

1942-Notes on the young of three recently described snakes, with comments upon their relationships. Bull. Chicago Acad. Sci., vol. 6, no. 10, pp. 193-200. 1943a-Studies on North American water snakes I: Natrix kirtlandii (Kennicott). Amer. Midl. Nat., vol. 29, no. 2, pp. 313-341, figs. 1-2, pl. 1, map.

1943b-The milk snakes of the Atlantic coastal plain. Proc. New England Zool. Club, vol. XXII, pp. 3-24, pls. II-IV', map.

1943c-Natrix erythrogaster erythrogaster in the northeasteın pait of its range. Herpetologica, vol. 2, no. 5, pp. 83-6.

-1949 - Two new races of Natrix erythrogaster. Copeia, pp. 1-15, pl. 1.

1950-On the taxonomic status of Thamnophis butleri (Cope). Bull. Chicago Acad. Sci., vol. 9, no. 4, pp. 71-77.

- ANd William Bridges 1939-What snake is that? Appleton-Century, pp. i$\mathrm{x}, \mathrm{1}-163$, pls. 1-32.

And Alexander Downs, Jr. 1940-Miscellaneous notes on the eggs and young of reptiles. Zoologica, vol. XXV, part 1, pp. 33-48.

ANd Coleman J. Goin 1948-A new subspecies of soft-shelled turtle from the central United States, with comments on the application of the name Amvda. Occ. Pap. Mus. Zool., Univ. Michigan, no. 510, pp. 1-23, pls. [-II.

_- Edward S. Thomas, and Robert L. Rausch 1945-The plains garter snake, Thamnophis radix, in Ohio. Copeia, pp. 61-8, pls. I-II, map 1.

Dexter, Ralph W. 1944-New records of reptiles from Portage County, Ohio. Ibid., p. 252.

-1948-More records of reptiles from Portage County, Ohio. Ibid., p. 139.

Duellman, William E. 1947-Herpetological records from Logan County, Ohio. lbid., p. 208.

Dunn, Emmett Reid and Gilbert Congdon Wood 1939-Notes on eastern snakes of the genus Coluber. Notulae Naturae, no. 5, pp. 1-4, 1 fig.

Edgren, Richard A., Jr. 1948 Some additional notes on Michigan Pseudemys. Nat. Hist. Misc., no. 22, pp. 1-2. 
Evans, Philip D. and Howard K. Gloyd 1948-The subspecies of the massasauga. Sistrurus catenalus, in Missouri. Bull. Chicago Acad. Sci., vol. 8, no. 9; pp. 225-232, pl. I.

Fichter, George S. 1947-Preliminary list of the reptiles of Butler County, Ohio. Herpetologica, vol. 4, pp. 71-73.

Gloyd, Howard KaY 1940-The rattlesnakes, genera Sistrurus and Crotalus. Chicago Acad. Sci., Special Publ. no. 4, pp. i-viii, 1-270, pls. 1-31, figs. 1-10, maps $1-22$.

- And Roger Conant 1943-A synopsis of the American forms of Aghistrodon (copperheads and moccasins). Bull. Chicago Acad. Sci., vol. 7, no. 2, pp. 147 70, figs. 1-16, maps 1-2, tab. I.

Goin, Coleman J. 1940-Does Eumeces fasciatus (Linnaeus) occur in Florida? Copeia, p. 52.

Gosner, Kenneth L. 1942--Lip curling of the red-bellied snake. Ibid., pp. 181-2.

Grobman, Arnold B. 1941-A contribution to the knowledge of variaticn in Opheodrys vernalis (Harlar), with the description of a new subspecies. Misc. Publ., Mus. Zool., Univ. Michigan, no. 50, pp. 1-38, figs. 1-2, map 1.

Hamilton, William J., Jr 1947-Eumeces fascialus in northern New York. Copeia, p. 64.

Harper. Franc:s 1942-The status of Scincus lateralis Say. Ibid., p. 180.

Hudson, Georce E. 1942-The amphibians and reptiles of Nebraska. Nebraska Conserv. Bull., no. 24, pp. 1-146, pls. 1-XX, maps 1-32.

Hulbert, Archer Butler and Nathaniel Schwarze 1910-David Zeisberger's history of the noithern American Indians. Ohio Archaeol. Hist. Publ., vol. XIX, pp. 1-189.

Klauber, L. M. 1948 - Some misapplications of the Linnaean names applied to American snakes. Copeia, pp. 1-14.

Lagler, Karl F. 1941-Fall mating and courtship of the musk turtie. Ibid., p. 268. 1943a-Focd habits and economic relations of the turtles of Michigan with special reference to fish management. Amer. Midl. Nat., vol. 29, no. 2, pp. 257-312, figs. $1-9$. 1943b-Methods of collecting freshwater turtles. Copeia, pp. 21-25, fig. I.

- AND J. ClARK SALYER, II. 1945-Influence of availability on the feecing habits of the common garter snake. Ibid., pp. 159-162.

1947-Food and habits of the common watersnake. Natrix s. sipedon, in Michigan. Páp. Michigan Acad. Sci., Arts, Lett., vol. XXXI, pp. 169-180.

Linnaei, Caroli 1758 Systema naturae, editio decima, tomus 1, pp. 1-823. -1766-Ibid., editio ducdecima, tomus I, pp. 1-532.

Logier, E. B. Shelley 1939-Butler's garter snake, Thamnophis butleri, in Ontario. Copeia, pp. 20-23.

Mattlin, Robert H. 1948a-Observations on the eggs and young of the eastern fox snake. Herpetologica, vol. 4, pp. 115-116, I fig. 1948b-A large litter of Thamnophis s. sirtalis. Ibid., vol. 4, p. 149.

Mittleman, M. B. 1947-Miscellaneous notes on Indiana amphibians and reptiles. Amer. Midl. Nat., vol. 38, no. 2, pp. 466-484, figs. 1-3.

1950-The generic status of Scincus lateralis Say, 1823. Herpetologica, vol. 6. pp. $17-20$.

Netting, Morris Graham 1944-The spineless soft-shelled turtle, Amyda mulica (Le Sueur), in Pennsylvania. Ann. Carnegie Mus., vol. XXX, art. VIII, pp. 85-88.

Pope, Clifford Hillhouse 1937-Snakes alive. Viking Press, pp. i-xii, 1-238, figs. $1-28,65$ photos.

-1939-Turtles of the United States and Canada. Alfred A. Knopf, pp. ixviii, 1-343, pls. 1.99 .

1944-Amphibians and reptiles of the Chicago area. Chicago Nat. Hist. Mus., pp. 1-275, pls. 1-12, text figs. 1-50. 
Raney, Edward C. AND Robcrt M. Roecker 1947-Food and growth of two species of water snakes from western New Y'ork. Copeia. pp. 171-74, fig. 1.

Schmidt, KarL PAtTerson 1938 Herpetological evidence for the postglacial eastward extension of the steppe in North America. Ecology, vol. 19, no. 3, pp. $396-407$.

and Roger Conant 1950- The names of the common North American garter snake and ribbon snake. Copeia, p. 58.

ANd D. Dwight Davis 1941 -Field book of snakes of the United States and Canada. G. P. Putnam's Sons, pp. i-xiii, 1-365, pls. 1-34, text figs. 1-103.

Shantz, H. L. and Raphael Zon $192+$-Natural vegetation. Allas Amer. Agric., pp. $1-29$.

Simpson, George Gaylord and Anne Roe 1939-Quantitative zoology. McGrawHill Book Co., lric., pp. i-xviii, 1-414, figs. 1-52.

Smith, Albert G. 1945- The status of Thamnophis butleri Cope, and a redescription of Thamnophis brachystoma (Cope). Proc. Biol. Soc. Washington, vol. 58, pp. $1+7-5+$.

1949-The subspecies of the plains garter snake, Thamnophis radix. Bull. Chicago Acad. Sci., vol. 8. no. 14, pp. 285-360, fig. 1.

Smith. Hobart M. 1938 -Remarks on the status of the subspecies of Sceloporus undulatus, with descriptions of new species and subspecies of the undulatus group. Occ. Pap., Mus. Zool., Univ. Michigan, no. 387, pp. 1-17, tab. 1-11, 1 map.

1946-Handbook of lizards: Lizards of the United States and Canada. Comstock Publ. Co., pp. i-xxi, 1-557, pls. 1-135, figs. 1-136, maps 1-41.

1948 - The scientific name of the common northern fence lizard. Nat. Hist. Misc., no. 24, pp. $1-2$.

Smith, Malcolm A. 1937-A review of the genus Lygosoma (Scincidae: Reptilia) and its allies. Rec. Indian Mus., vol. XXXIX, pp. 213-234, figs. 1-5.

Stejneger, Leonhard 1918-Nomenclatorial notes on milk snakes. Proc. Biol. Sic. Washington, vol. 31, p. 99.

- and Thomas Barbour 1939-A check list of North American amphibians and reptiles. Harvard Univ. Press, ed. 4, pp. i-xvi, 1-207.

1943-A checklist of North American amphibians and reptiles. Bull. Mus. Comp. Zool., vol. XCllI, no. 1, pp. i-xix, 1-260, ed. 5.

Stout, W:Lber AND G. F. Lamb 1938-Physiographic features of southeastern Ohio. Ohio Journ. Sci., vol. XXXVIIl, no. 2, pp. 49-83, 9 figs.

- Karl Ver Steeg and G. F. Lamb 1943-Geology of water in Ohio. Geol. Surv. Ohio, th Ser., Bull. 4t, pp. 1-694, maps 1-8.

Thomas, Edward S. 1949-A population of Lake Erie island water snakes. Copeia. p. 76.

Transeau, Edgar Nelson 1935-The prairie peninsula, Ecology, vol. 16, no. 3, pp. 423-37, figs. 1-28.

Trapido, Harold 1944 - The snakes of the genus Storeria. Amer. Midl. Nat., vol. 31, no. 1, pp. 1-84, figs. 1-60 (plus fig. 1), maps 1-3.

Trembley, Francis J. 1948-The effect of predation on the fish population of Pocono Mountain lakes. Proc. Pennsylvania Acad. Sci., vol. XXII, pp. 44-49.

Triplehorn, Charles A. 1948-Storeria occipitomaculala in northwestern Ohio. Copeia, p. 133.

1949-A large specimen and a high embryo count for the queen snake. Ihid., p. 76.

Walker, Charles F. 1946-The amphibians of Ohio. Part 1-The frogs and toads (order Salientia). Ohio State Mus., Sci. Bull., vol. I, no. 3, pp. 1-109, figs. 1-28, pls. $1-14$.

Wood, John Thornton 1944 Fall aggregation of the queen snake. Copeia, p. 253. 1945-Variation in length of newly-born garter snakes. Ihid., p. 118. 
1949-Observations on Natrix seplemvillata (Say) in southwestern Ohio. Amer. Midl. Nat., vol. 42 , no. 3, pp. $7+4-50$.

and William Edward Duellman 1947a-Range extension of Natrix kirllandii in Ohio. Herpetologica, vol. 3, p. 151.

1947b-Preliminary herpetological survey of Montgomery County, Ohio. Ibid., vol. 4, pp. 3-6.

1950 Size and scutellation in Natrix septemvittala (Say) in southwestern Ohio. Amer. Midl. Nat., vol. 43, no. 1, pp. 173-8. 


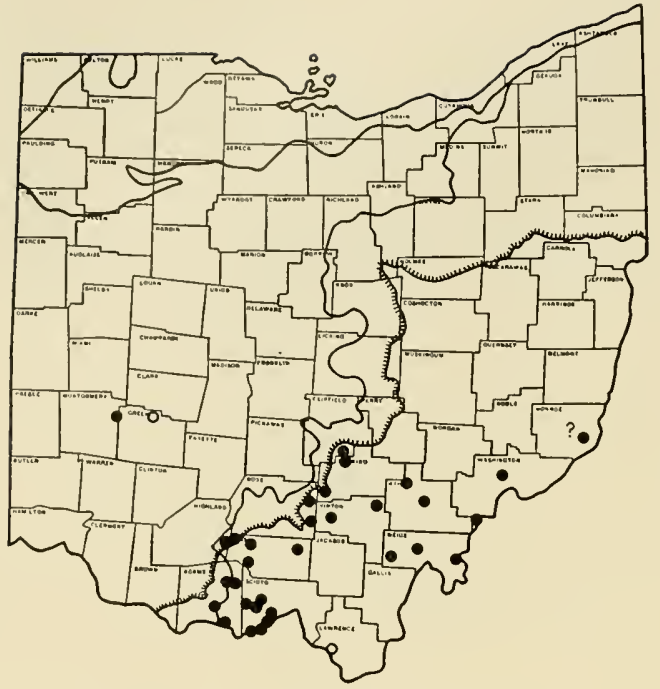

Map 43. Central Worm Snake, Car. phophis amoenus helenae (pp. 213-215).

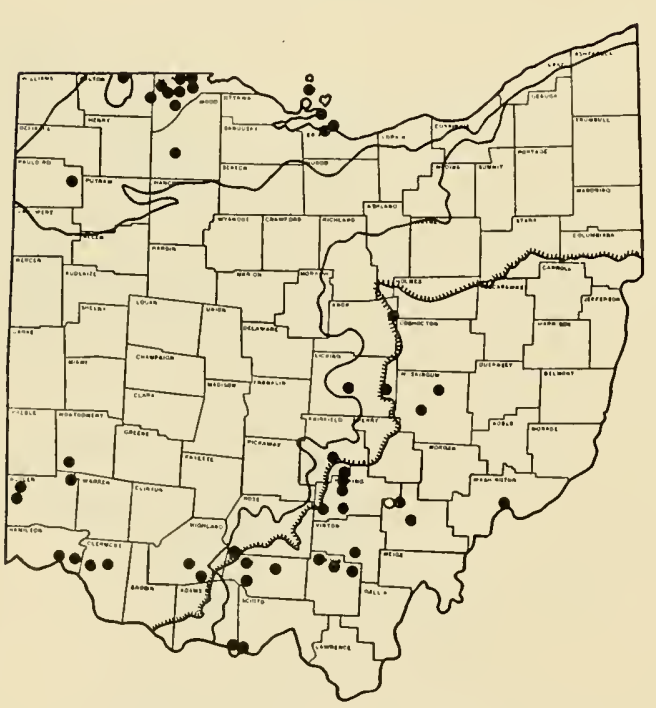

Map 45. Eastern Hog-nosed Snake. Heterodon platyrhinos platyrhinos ( $\mathrm{pp}$. 216-217).

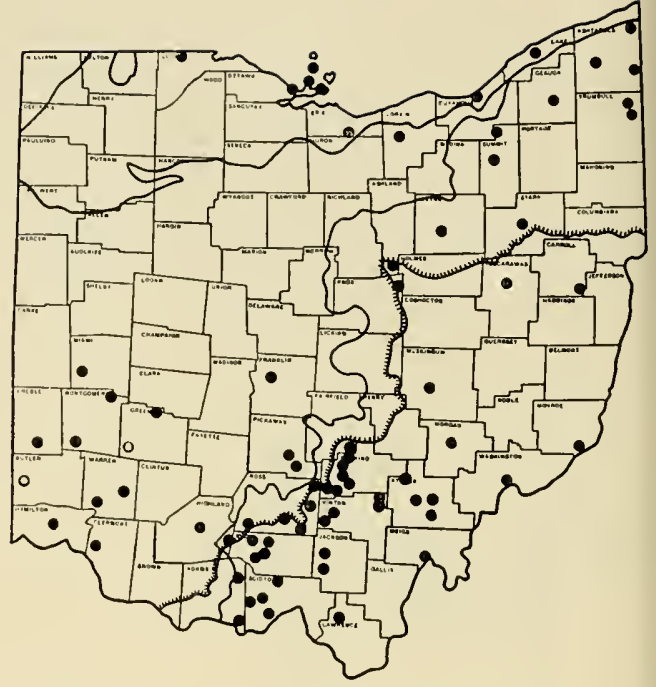

Map 4f. Northern Ring-necked Snake, Diadophis puncialus edwardsii (pp. 215 216).

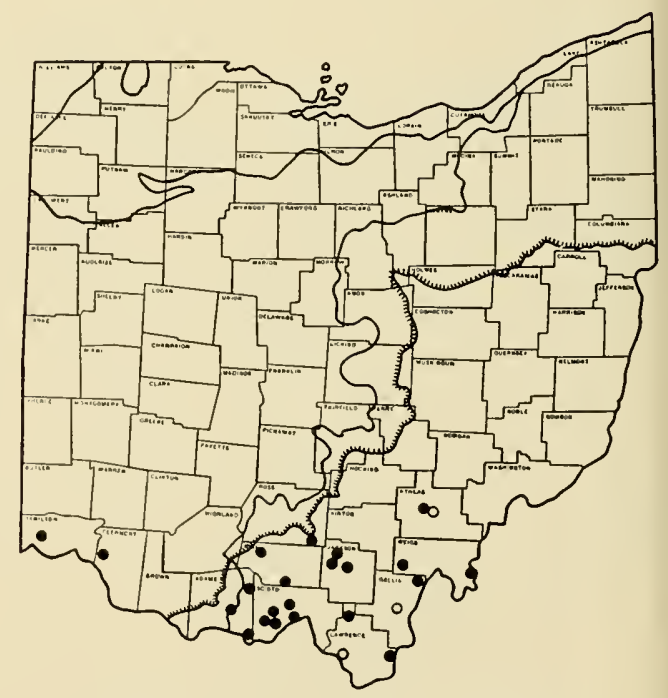

Map 46. Keeled Green Snake, Opheodrys aestivus (pp. 217-219). 

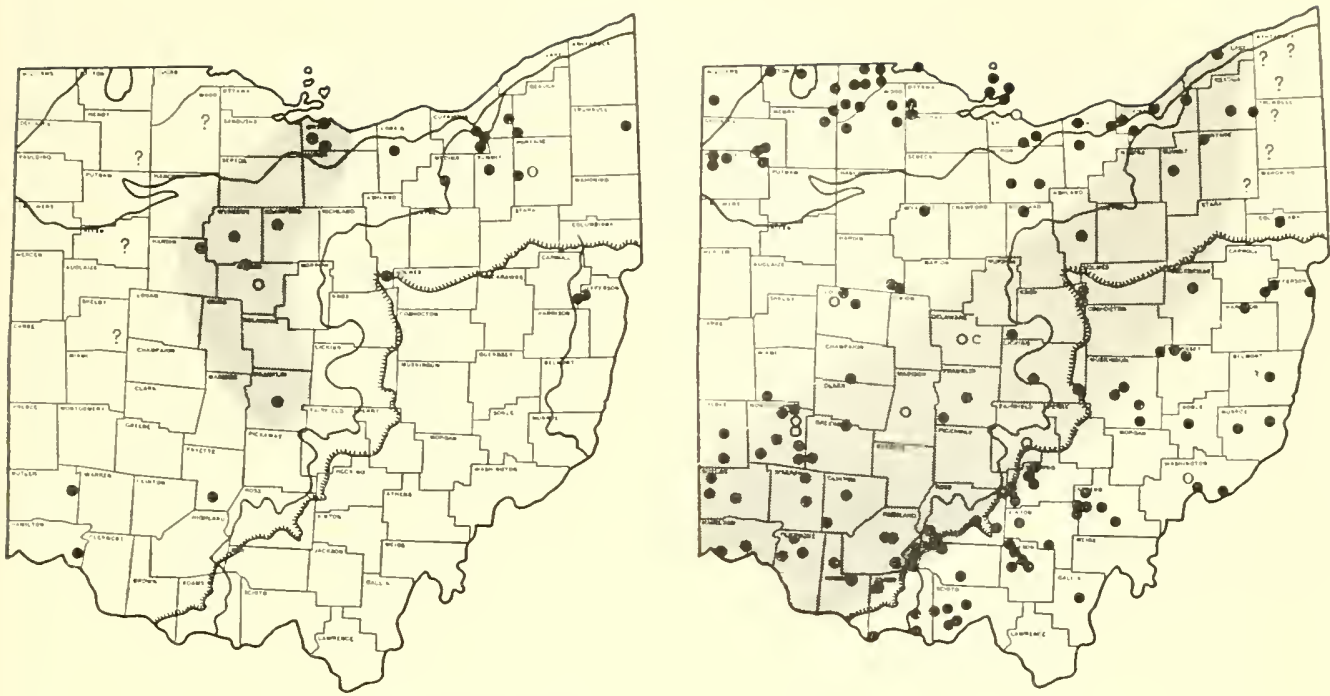

Map 47. Grass Snakes. The symbols in northeastern Ohio indirate localities for the Eastern Grass Snake, Opheodrys rernalis vernalis. The spots in the three southwestern ccunties mark loca'ities for the Western Grass Snake, Opheodrys vernalis hlanchardi. Specimens from within the stippled area are members of an intergrading population, Opheodrys vernolis vernalis $X$ blanchardi. This population may extend farther westwerd than indicated, or it may be that future collecting will demonstrate the presence of hlanchardi in the northwestern couaties. Grass snakes must be at least rare or highly localized in that portion of the state. Agricultural activities have obliterated or greatly altered the original habitats. (See pp. 219-222.)

Man 48 Racers. The symbols in southeastern Ohio indicate loc ilities for the Black Racer, Coluber constrictor constrictor: those in northwesterr. Ohio mark localities for the Blue Racer, Colut r constrictor flaviventris. Specimens from within the stippled area are members of an intergrading population, Coluber constrictor constrictor X flaviventris. The limit of the intergrading area cannot be defined in the extreme northeastern part of Ohio because of the paucity of material from that part of the state. (See pp. 222-224.) 
Plate 32

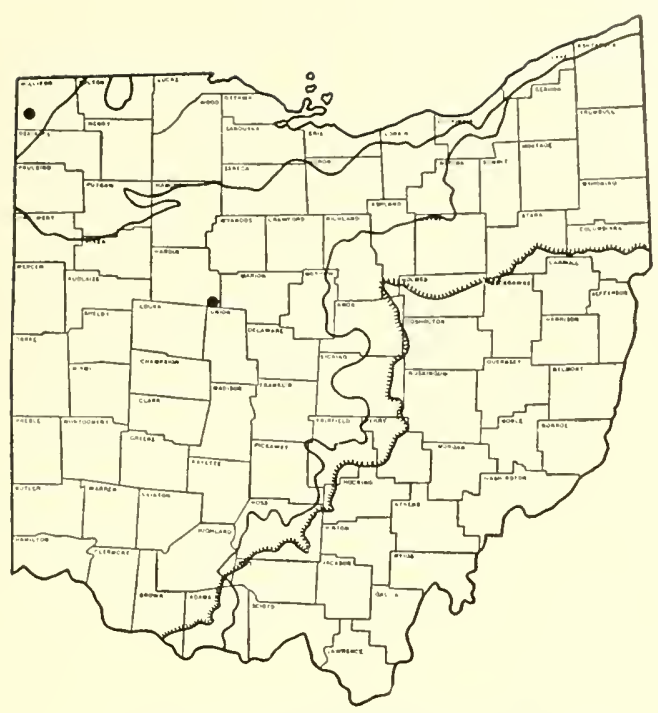

Map 53. Northern Copperbelly, Natix erythrogaster neglecta (p. 229).

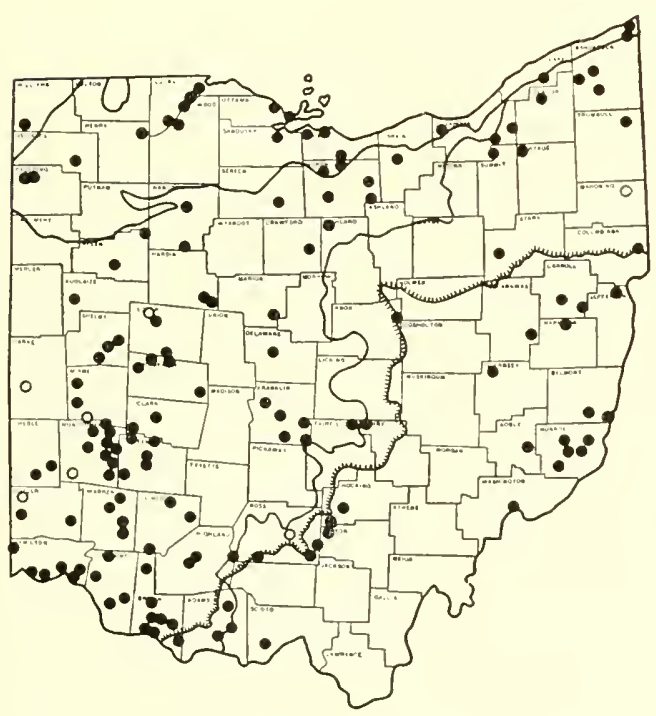

Map 55. Queen Snake, Natrix septemvittata (pp. 231-23-1).

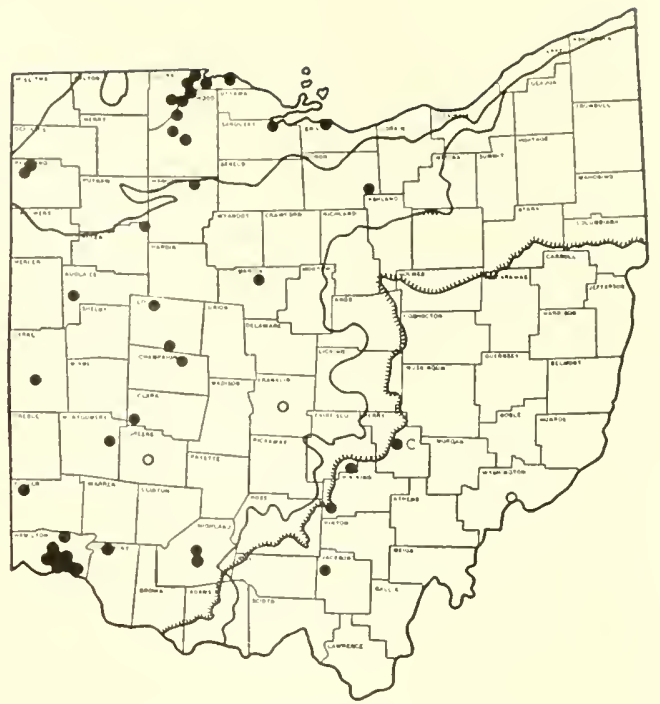

Map 54. Kirland's Water Snake, Natrix hirtlandii (pp. 230-231).

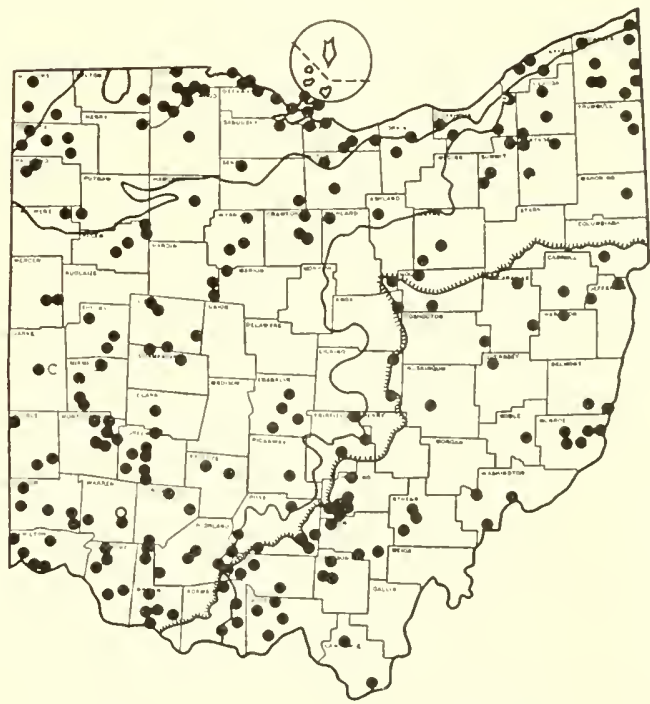

Map 56. Northern Water Snake, Natrix sipedon sipedon (pp. 234-236). The area within the circle at the top of the map indicates the approximate range of the Lake Erie Water Snake, Natrix sipedon insularum (pp. 237-238). 


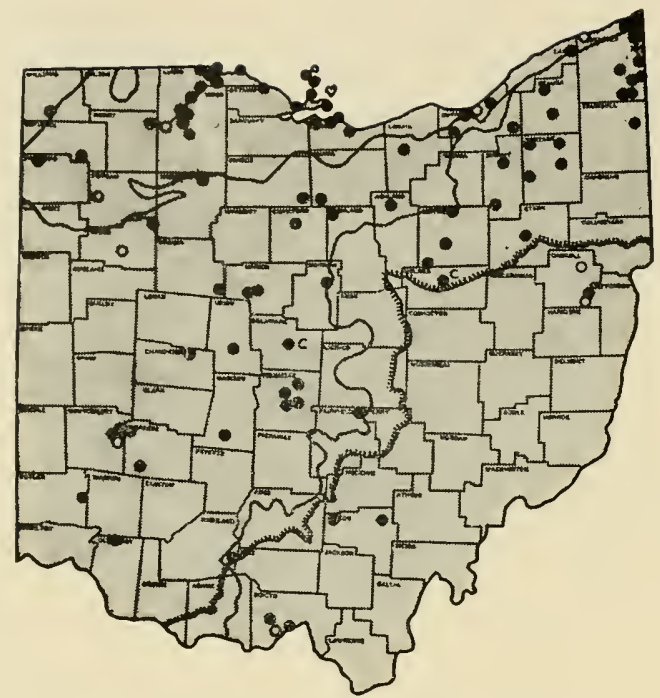

Map 57. Dekay's Snake. The snakes of this species occurring in Ohio constitute en intergrading population, Storeria dehayi dekayi X wrightorum. (See pp. 238-241.)

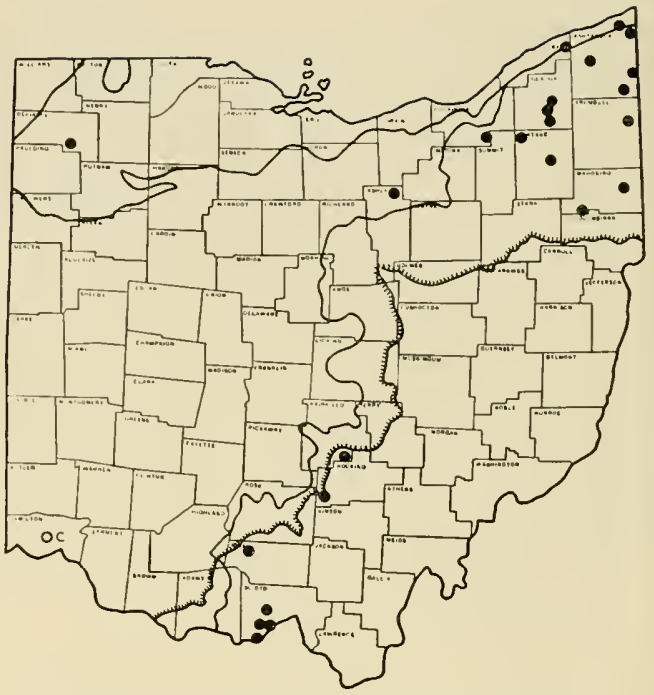

Map 58. Red-bellied Snake, Storer.a occipitomaculata occipitomaculata (pp. 241-243).

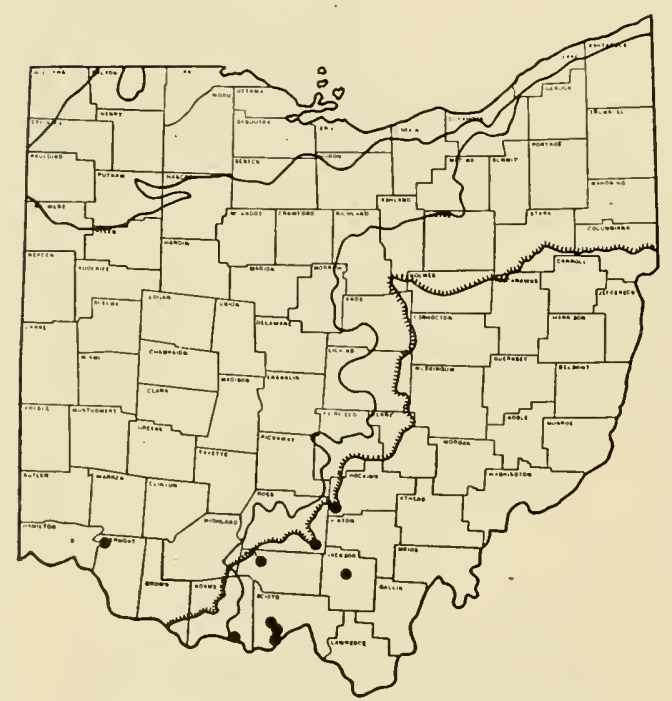

Map 59. Eastern Ground Snake, Haldea valeriae valeriae (pp. 243-244).

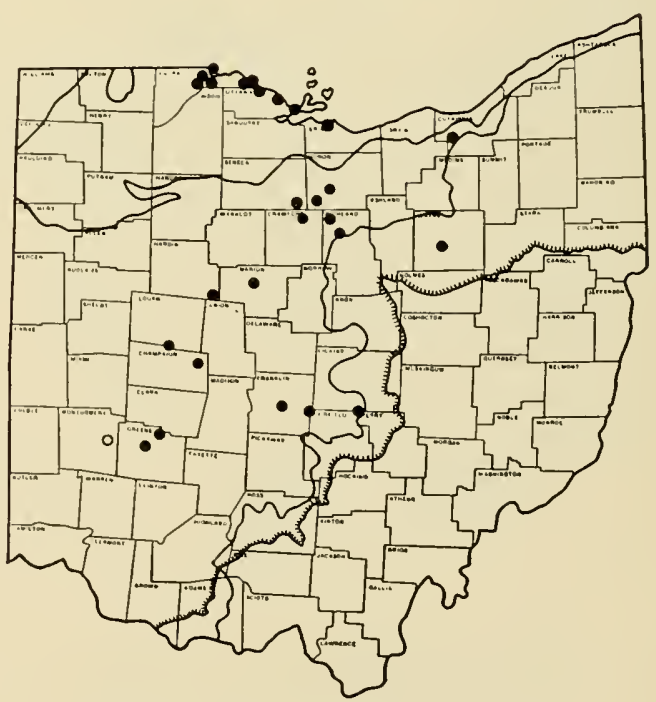

Map 60. Butler's Garter Snake, Thamnophis butleri (pp. 245-246). 
Plate 34

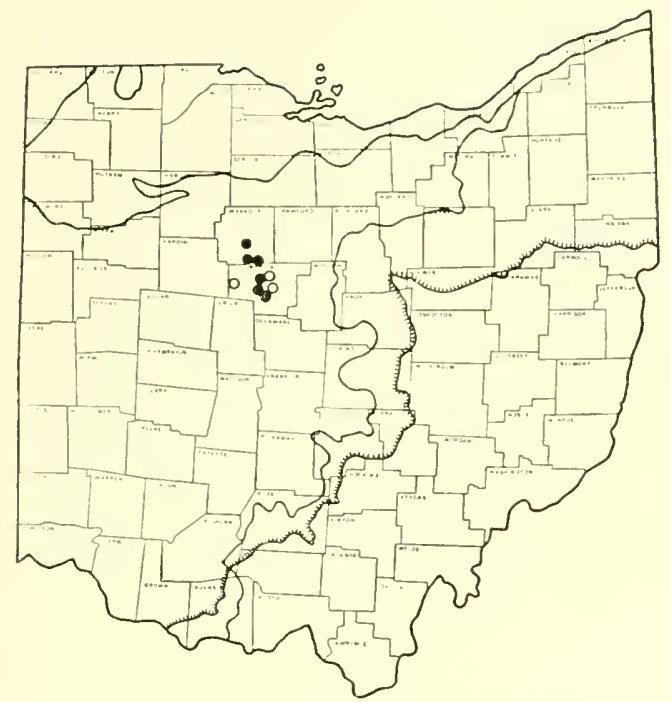

Map 61. Prairie Garter Snake, Thamnophis radix radix (pp. 246-248).

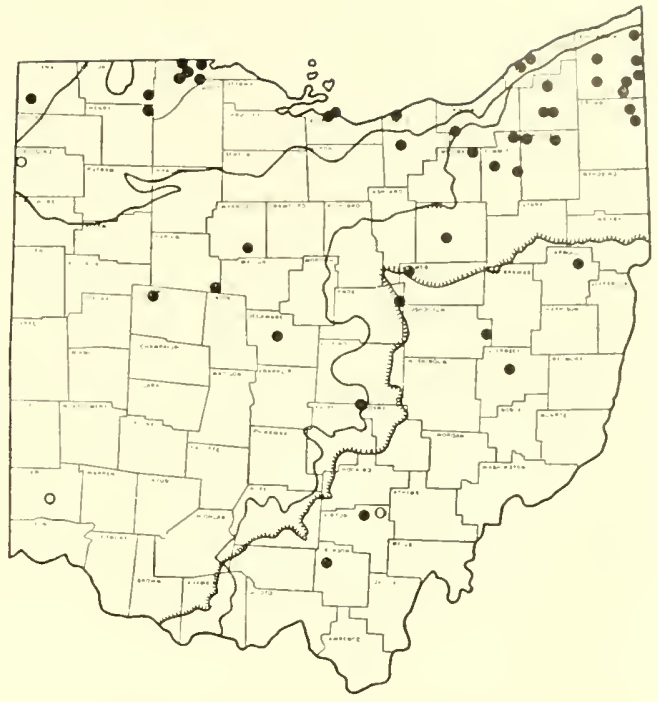

Map 62. Eastern Ribb n Snake, Thamnophis sauritus sauritus (pp. 2ł9-250).

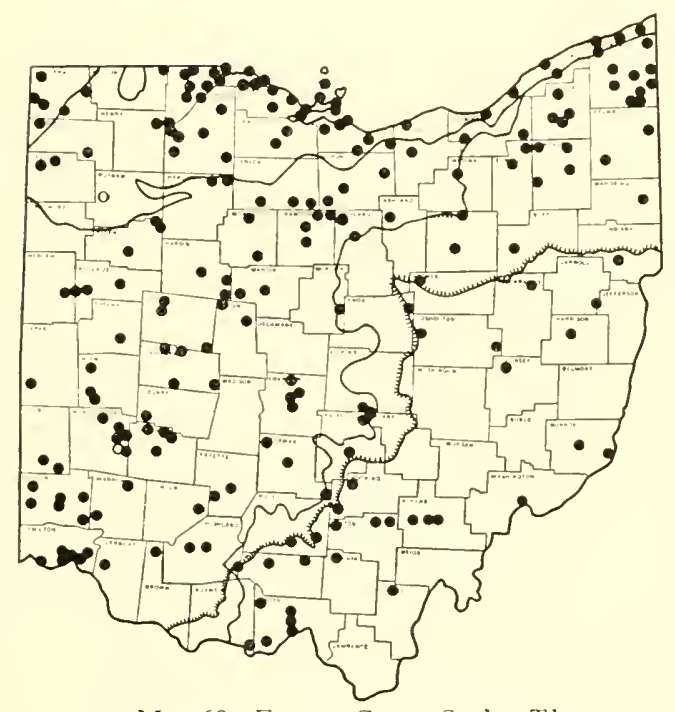

Map 63. Eastern Garter Snake, Thamnophis sirlalis sirlalis (pp. 250-253).

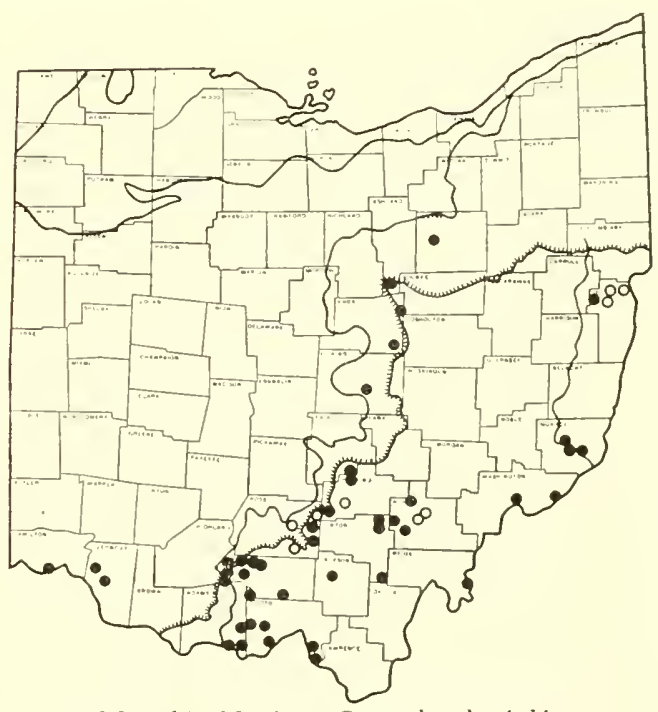

Map 64. Northern Copperhead, Aghistrodon contortrix mokeson (pp. 253-25t). 


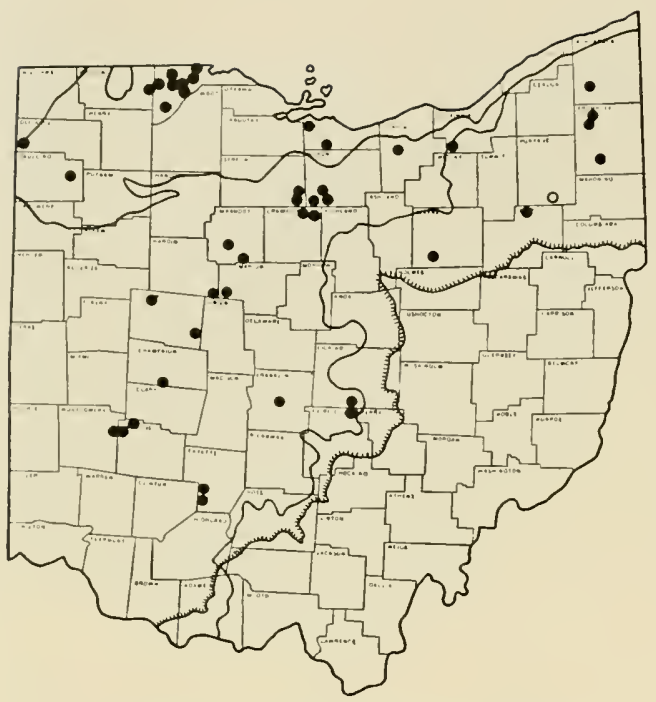

Map 65. Eastern Massasauga, Sistrurus calenatus catenalus (pp. 254-255).

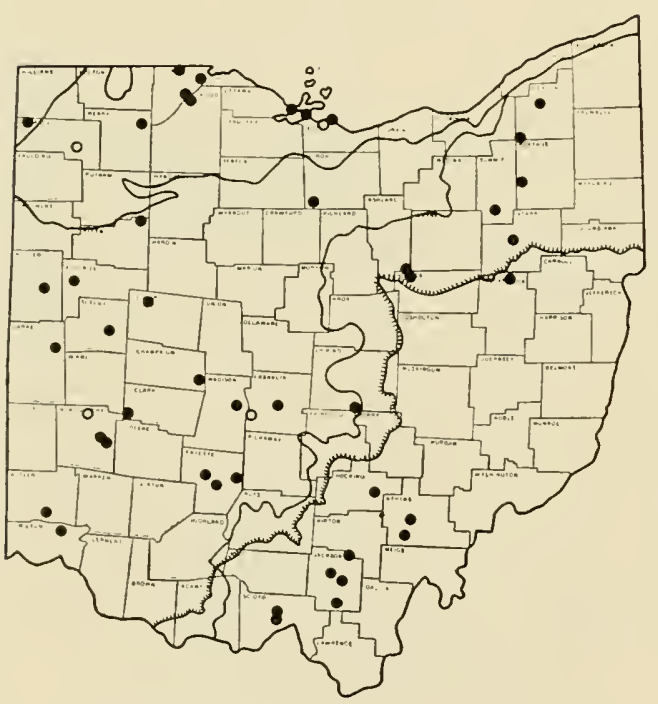

Map 67. Musk Turtle, Sternotherus odoralus (pp. 256-257).

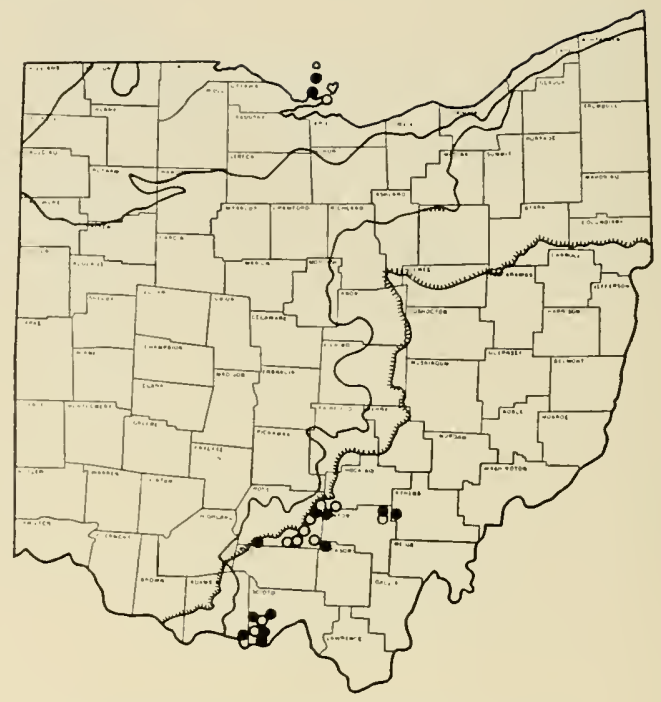

Map 66. Timber Rattlesnake, Crolalus horridus horridus (pp. 255-256).

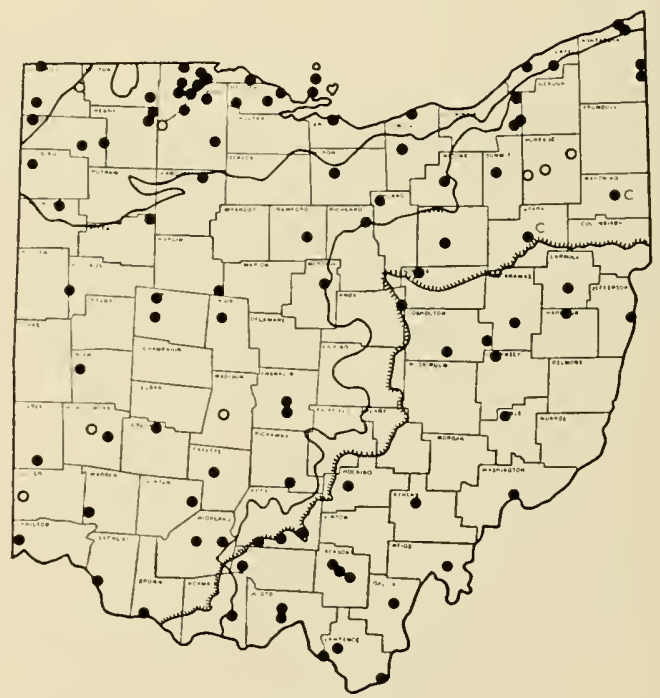

Map 68. Snapping Turtle, Chelydra serpentina serpentina (p. 258). 


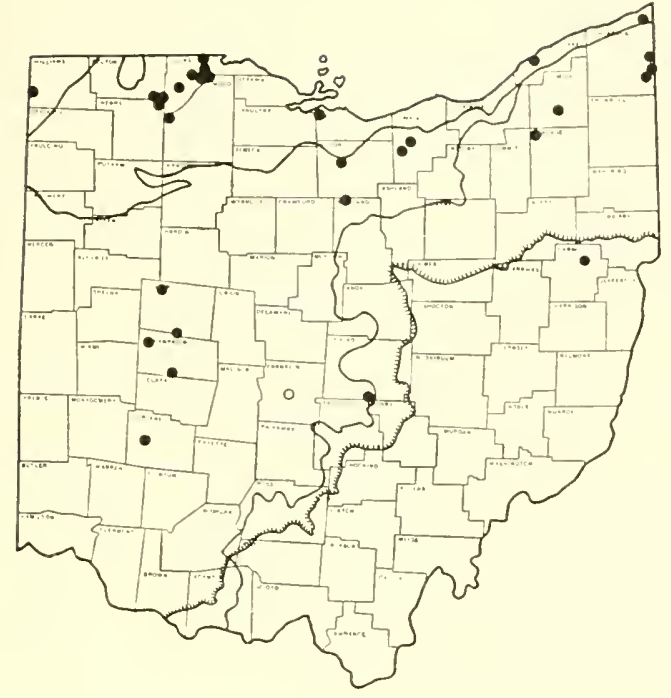

Map 69. Spotted Turtle, Clemmus guttata (pp. 258-259).

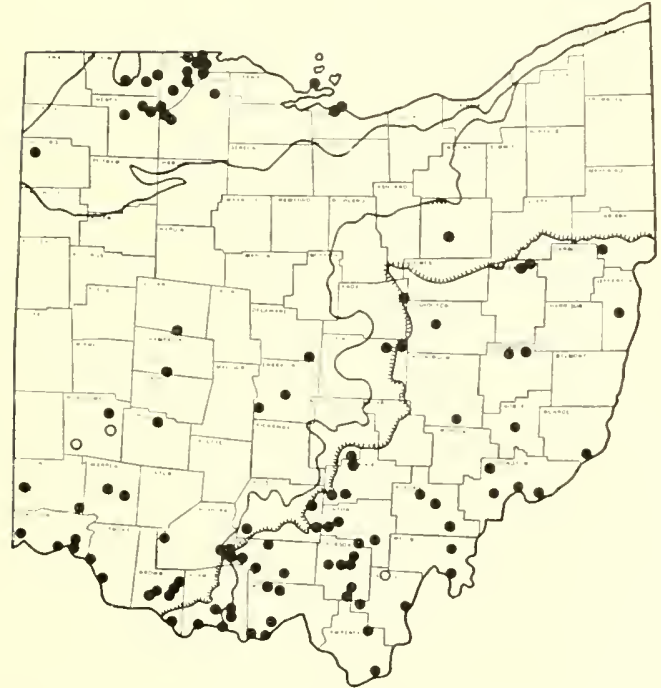

Map 71. Eastern Box Turtle, Terrapene carolina carolina (pp. 260-261).

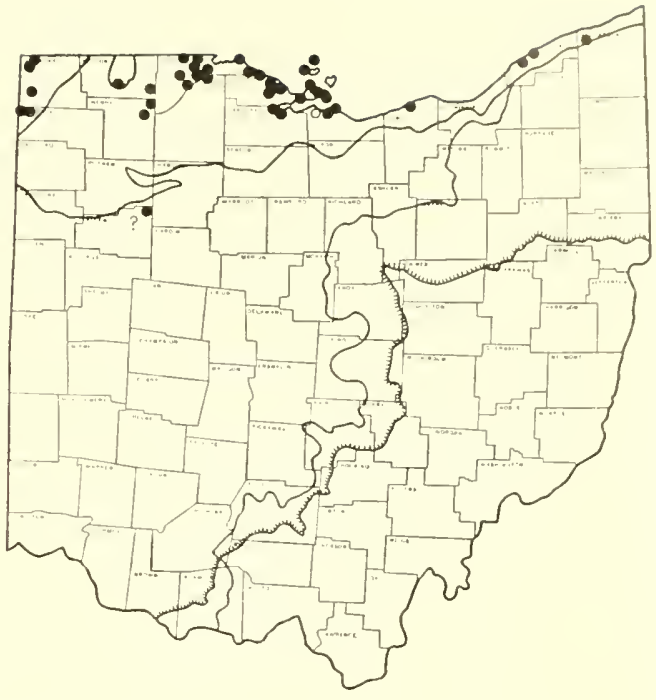

Map 70. Blanding's Turtle, Emus blandingii (pp. 259-260).

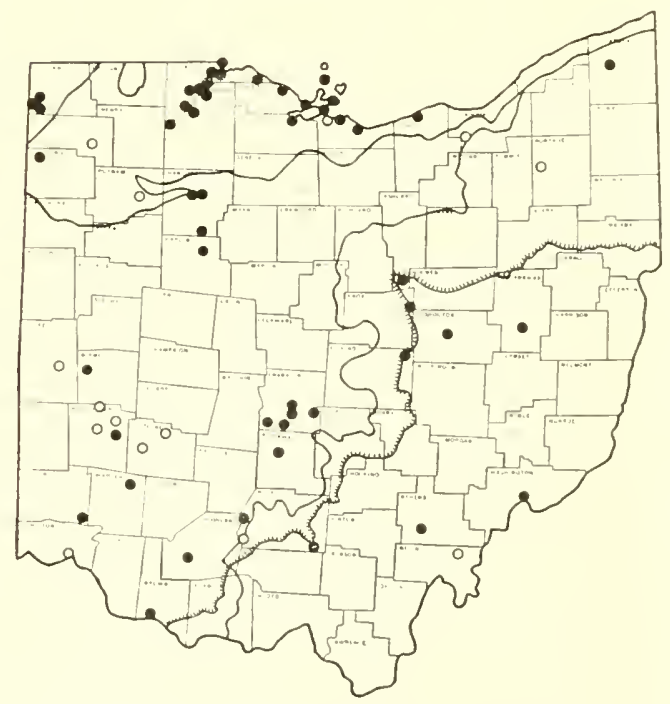

Map 72. Map Turtle, Craptemus geographica (pp. 261-262). 


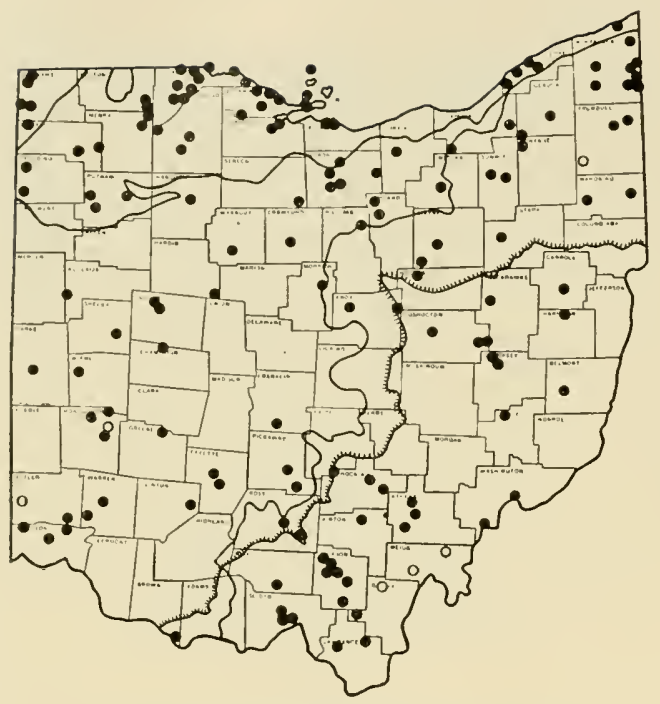

Map 73. Central Painted Turtle, Chrysemys picta marginata (p. 262).

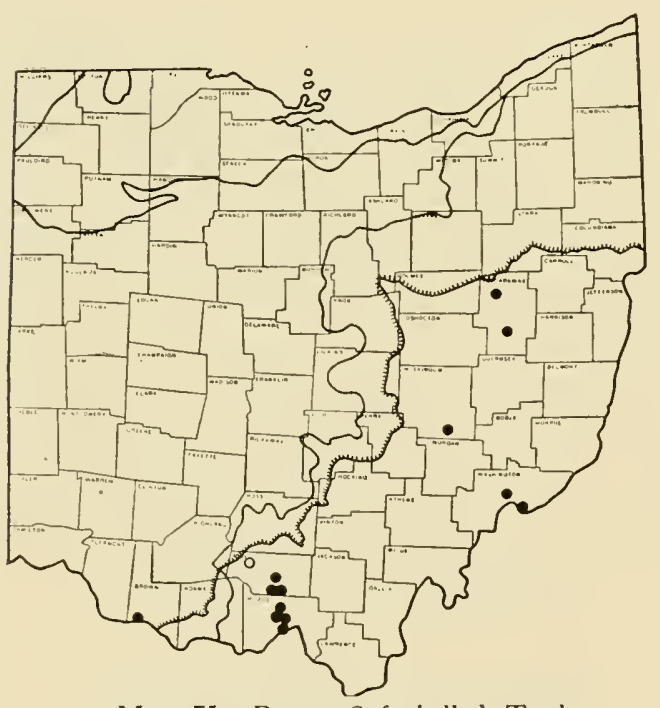

Map 75. Brown Soft-shelled Turtle, Amyda mutica (pp. 263-264).

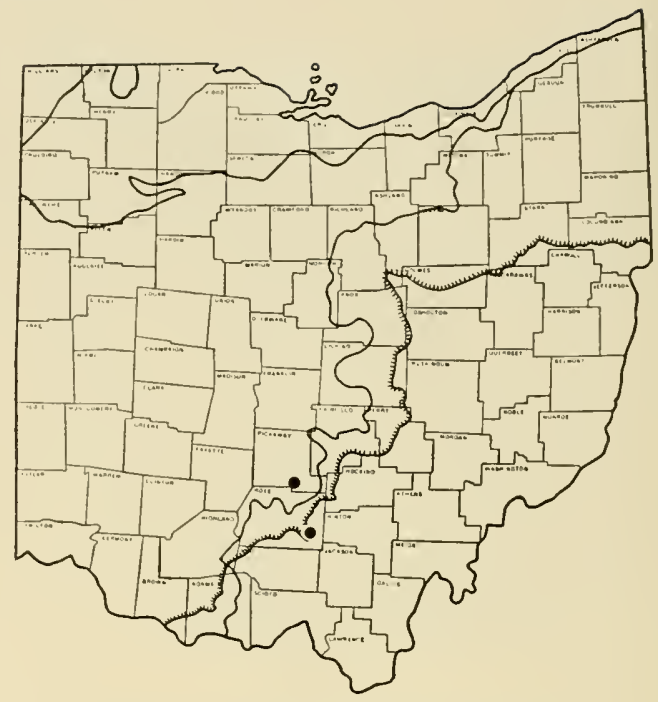

Map 74. Mississippi Valley Terrapin,

Pseudemys scripta elegans (p. 263).

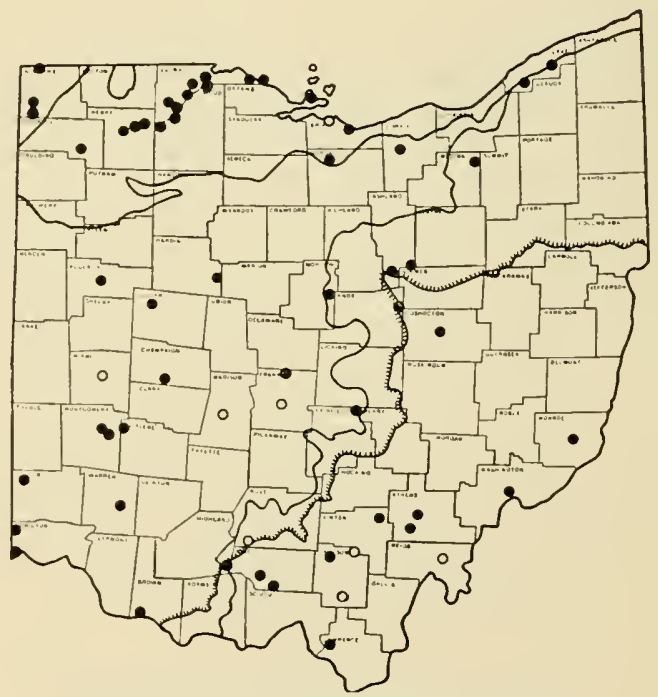

Map 76. Spiny Soft-shelled Turtle, Amyda spinifera spinifera (pp. 26ł-265). 


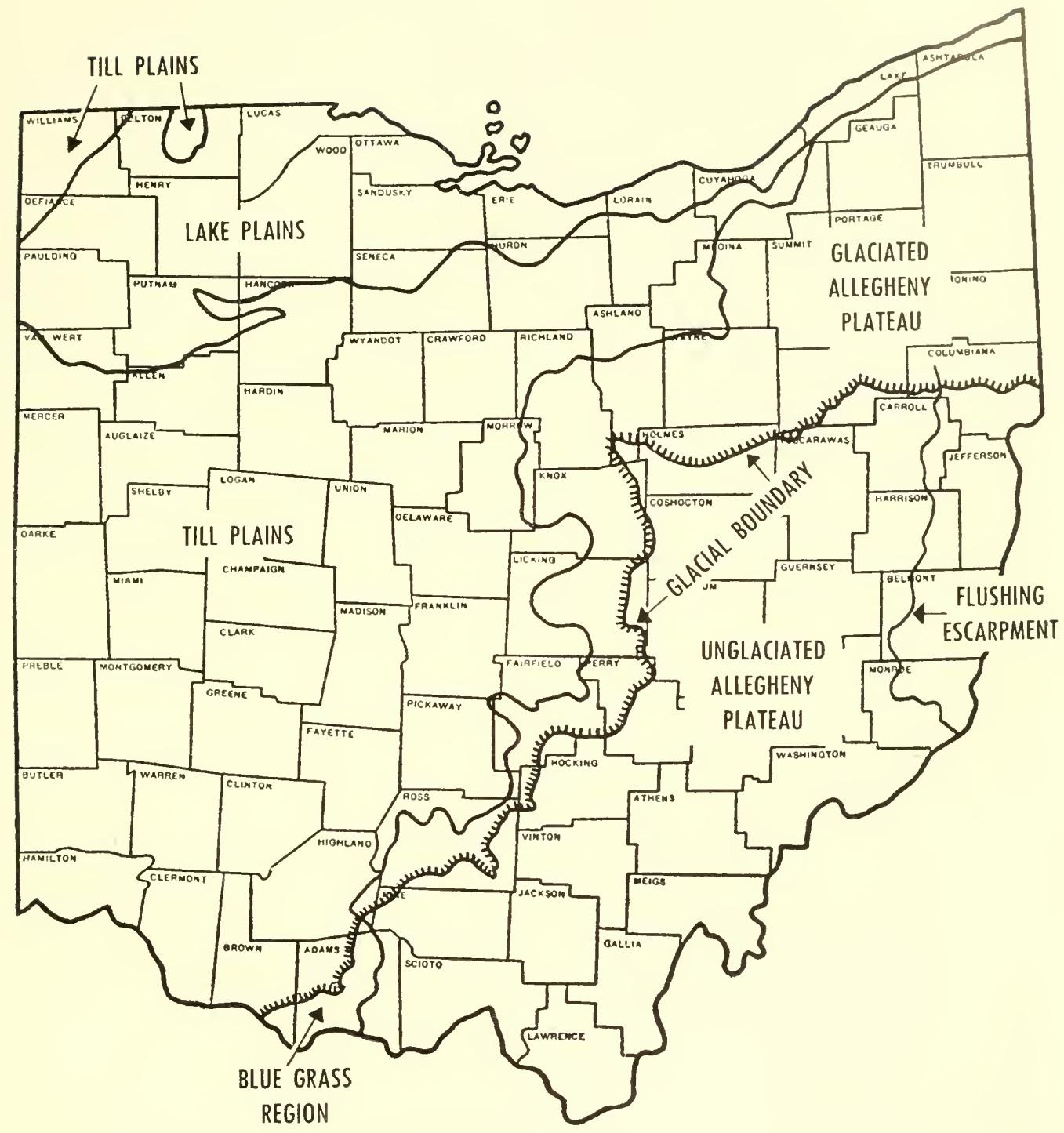

Map 77. The Physiographic Areas of Ohio (after Peattie, but amended to confo:m with Maps 1 and 2 in the "Geology of Water in Ohio," by Stout, Ver Steeg, and Lamb, 19+3). The Lake Plains are characteristically level and are bounded by old beach lines marking the maximum extent of Lake Maumee in postglacial times. Low rolling hills cover much of the Till Plains area, which is termnated on the east by the eastern limit of the Upper Devonian shales. The Allegheny Plateau is more deeply dissected. especially in the unglaciated portion, and the bedrock is chiefly sandstone, shale, and conglomerate. The western half of the state rests upon the limestone of the Cincinnati geanticline. The Blue Grass Region is the only extensive limestone country in the state that escaped olaciation. The Glacial Boundary and the Flushing Escarpment are indicated. 


\section{INDEX*}

Ackuowledgements $3,203,205$

Addenda, Revisionary 201

Additional Species

Aglistrodon contortrix contortrix

253

Aghistrodon contortrix mokeson $203,253,(275)$

Aglistrodon mokasen mokasen $5,9,12,13$,

15, 16, 21, 107, (109) 185, 195, 253 Aghistrodon piscivorus

Allegheny Front Escarpment 203

Alligator mississipiensis

Ambystoma opacum 6

Amvda .216

Amvda mutica 21

16, 21, 154, (155), 192, 263, (278)

Amyda spinifera .............. 6, 15, 21, 155 ,

157. (158), 192, 193, 264, (278)

Amyda spinifcra aspera

Amyda spinifera hartwegi

Arny's Ring-necked Snake

Aspidonectes

264

7

144,160

Banded Rattlesnake

Banded Water Snake

116

Bibliography

Black Racer

$21,49,(50), 55,177,178,222$, (271)

Black Snake

Black Snake, Mountain

55

Black Snake, Pilot ….....20, 53, 55, (57),

$62,63,111,178,179,224,(272)$

Black Snapper

Blanding's Turtle $11,22,131$,

132, (133), 139, 188, 189, 259, (277)

Blue Grass Regicn $(10), 15,16,203,(279)$

Blue Racer $21,(50)$, $54,73,116,177,178,224,(271)$

Blue-tailed Skink

25, 28, (29), 34, 76, 174, 209, (269)

Boa contortrix

Box Turtle 22, 44,

131, 136, (137), 188, 189, 260, (277)

Brown-backed Skink $19,26,(27), 174,207,(269)$
20

Brown Snakes

Brown Soft-shelled Turtle …__..........21, 149, 154, (155), 163, 192, 263, (278)

Bufo americanus americanus ........4, 107

Bufo fowleri ...............................................

Bull Frog ......................................................... 86

Bull Snake
Butler's Garter Snake 20 , $65,73,76,96,(97), 184,245,(274)$

Carphophis amocna amocna

Carphophis amoena helenae $5,12,13,14,15,21,34,(36), 176$

Carphophis amocnus helenae ..213, (270)

Cemophora coccinea

Central Painted Turtle

Central Worm Snake 262, (278)

213, (270)

Chelydra serpentina 6,15 , $22,124,(125), 187,196,258,(276)$

Chelydra serpentina osceola

Chelydra serpentina serpentina

$258, \quad(276)$

Chelydridae

Chrysemys bellii marginata $6,15,22,145,(147), 190,196$

Chrysemys picta bellii

Chrysemys picta dorsalis ...-.-.....153, 262

Chrysemys picta marginata ....262, (278)

Chrysemys picta picta .............146, 262

Clemmys gutlata …...6, 12, 15, 22, 129, (129), 187, 189, 196, 241, 258, (277)

Clemmys insculpta $8,13,205$

Clemmys muhlenbergii 8,13

Cnemidophorus sexlineatus sexlineatus 7

Coal Skink

Collections Examined 2. 201

Coluber constrictor 201

Coluber constrictor anthicus ..................224

Coluber constriclor constrictor ................ 5 , $12,14,15,21,49,(50), 54,177,178$, 194, 195, 211, 214, 221, 222, (271)

Coluber constrictor flaviventris $5,11,15,(50), 51$, $52,54,116,177,221,222,224,(271)$

Coluber constrictor stejnegerianus .......224

Coluber dolialus ................................227

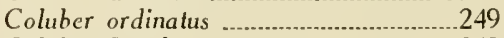

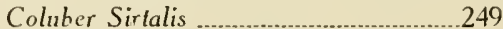

Colubridae

Copperhead $21,25,59,65,107,(109), 116$, $119,162,169,170,185,253,(275)$

Coral Snake 8,204

Cottonmouth 65

Crotalidae

Crotalus horridus horridus $6,9,11,14,15,16$,

$21,116,(118), 161,186,255,(276)$

Cumberland Terrapin $22,151,(152), 191$

* Page numbers in bold face indicate main references, in italics illustrations, and numbers in parentheses refer to distribution maps. 
DeKay's Snake $20,65,73,76$, 88, (90), 94, 99, 102, 183, 238, (27-1 )

Desmognathus fuscus ochrophaeus ........102

Diadophis punctatus armi 7. $2 \div 2$

Diadophis punclatus edwardsii $5,11,15,21$, 37, (38), 175, 194, 197, 215, (270) Diamond-backed Water Snake .......... 8

Diapsida

Discussion of Species ......................... 22

Distribution of Ohio Reptiles ............. 15

Doubtful Records

Diy Land Turtle 136

Eastern Box Turtle 260, (277)

Easiern Fox Snake 225. (272)

Eastern Garter Snake 250, (275)

Eastern Grass Snake 219, (271)

Eastern Ground Snake 243, (274)

Eastern Hog-nosed Snake 216. (270)

Eastern King Snake

Eastern Massasauga

Eastern Milk Snake …….... 65 254, (276) 227, (272)

Eastern Painted Turtle

Eastern Ribbon Snake $1+6,262$ 249. (275)

Elaphe

Elaphe obsoleta obsoleta ...5, 15, 29, 55, (57), 178, 179, 194. 195, 224, (272)

Elaphe vulpina $.5,11,15,20,56,60,(61), 178,179$

Elaphe vulpina gloydi 225, (272)

Elaphe vulpina vulpina $6,11,12,15$

Emus blandingii $22,132,(133), 188,189,259,(277)$
Eumeces anthracinus ............. Eumeces anthractus $5,9.15,19,28,(29)$, $32,34,174,209,212,241,(269)$

Eumeces inexpectalus

Eumeces laticeps $5,9,12,14,15,19,25,29,31$, 32, (33), 175, 195, 210, 211 , (269) Eurycea bislineata bislineata ............... 26

False Map Turtle …………………....... 8

Fence Lizard ......................................... 22

First Aid in Case of Snake Bite _..... 168

Flushing Escarpment …........203. (279)

Fox Snake $20,56,60,(61), 178,179,225,(272)$

Garter Snake, Butler's $65,73,76,96,(97), 184,245,(27 t)$

Garter Snake, Common $20,65,69,73,76,78,88$ $94,99,102,(104), 182,250,(275)$ Garter Snake, Prairie ....200, 246, (275) Garter Snakes ……..................20, 30, 78 Geography of Ohio 9. 203
Glaciated Allegheny Plateau

$(10), 13,15,203,(279)$

Glass Lizard.......................... 7, 204

Glass Snake …………………........ 7

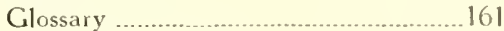

Gopherus agassizii ………..................... 6

Graptemus geographica …………. 6 $15,22,141,(1+2), 191,261,(277)$

Graptemys pseudogeographica pseudogeographica ….............................. 8, 153

Grass Snake .......................47, 219, 220

Green Frog ..................................4, 86

Green Snake …................................ 40

Green Snake, Keeled $20,45,(46), 176,217,(270)$

Green Snake, Smooth $21,47,(48), 176,2 i 8,219,(271)$

Green $\mathbb{W}$ ater Snake

Ground Snake $20,21,37,94,(95), 183,243,(274)$

Haldea valeriae valcriae 210, 243, (274) Heterodon conlortrix ............ $5,11,12,13$, 15, 20, 41, (42), 161, 177, 194, 195 Heterodon platurhinos browni .............216 Heterodon platurhinos platurhinos

$216, \quad(270)$

Hog-nosed Snake

$$
\text { 20, 41, (42) 177, 216, (270) }
$$

Holbrook's King Snake ….................. 65

House Snake ....................................... 66

Iguanidae .............................................. 5

Instructions for Preserving Reptiles ....170

Introduction ……........................ 201

Island Water Snake 21. (82), 86, 182, 237, (273)

Kceled Green Snake $20,45,(46), 176,217,(270)$

Key to the Reptiles of Ohio ............... 19

King Snake, Black

$21,37,63,(64), 180,226,(272)$

King Snake, Holbrook's ...................... 65

King Snake, Prairie ............................ 7

King Snakes _........................... 21, 70

Kinosternidae …................................. 6

Kinosternon sutrubrum subrubrum 8, 257

Kirtland's Water Snake $20,74,(75), 91,180,230$. (273)

Lake Erie $\mathbb{W}^{\prime}$ ater Snake ....... 237, (273)

Lake Plains Region 9. (10), 15, 203, (279)

Lampropellis ......................................... 21

Lampropeltis calligaster ...................... 7

Lampropeltis doliata doliata …............227

Lampropeltis doliata syspila …............228

Lampropeltis doliata temporalis ..227, 228 
Lampropeltis doliata triangulum

227. (272)

Lampropeltis elapsoides ........................227

Lampropeltis gefulus getuless

Lampropeltis getulus holbrooki

Lampropeltis getulus nigra ..............5, 14, $21,63,(64), 180,210,226,(272)$

Lampropeltis triangulum syspila ........7.67

Lampropeltis triangulum triangulum $5,11,15,21,66,(67), 181$

Large-headed Skink

$25,30,32,(33), 111,175,211$, (269)

Leiolopisma

Leiolopisma laterale

Leiolopisma unicolor $5,9,14,15,19,26,(27), 174$

Leopard Frog $44,73,86$

Lined Snake

Liopeltis

Lygosoma laterale $207,210,(269)$

Map Turtle

22,141

$(142), 153,156,163,191,261,(277)$

Map Turtle, False

Massasauga ...21, 31, 55, 73, 112, (114).

$118,119,169,185,186,254,(276)$

Micrurus fulvius fulvius .....-...-8, 205

Micrurus fulvius tenere …_-_-_...-...-205

Milk Snake ...

$31,37,66,(67), 94,181,227,(272)$

Milk Snake, Red

Mississippi Valley Terrapin ....263, (278)

Moccasin 65,81

Mountain Black Snake ....................... 55

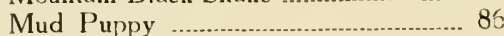

Mud Turtle

Muhlenberg's Turtle _..................... 8

Musk Turtle

$22,120,(121), 131,187,256,(276)$

Natrix

20,76

Natrix cyclopion cyclopion ….............7, 8

Natrix erythrogaster 202, 229

Natrix erythrogaster erythrogaster $5,9,12,15,20,21,70,(72), 181$

Natrix ervithrogaster flavigaster ..........229

Natrix erythrogaster neglecta 229, (273)

Natrix erythrogaster transversa _.........229

Natrix leirllandii _....... $5,13,15,20,74$, (75), $180,210,230,240,241,(273)$

Natrix rhombifera

Natrix septemviltata
$20,77, \quad(78), 181,196,231$,

Nalrix sipedon fasciala

Natrix sipedon insularum ...........5, 9, 11. $15,21,(82), 86,182,197,237,(273)$

Natrix sipedon pleuralis .234

Nairix sipedon sipedon $5,8,9,12,15,20,71,80,81,(82)$,
$87,182,196,197,229,234,(273)$

Necturts maculosus maculosus

Northern Copperbelly 229, (273)

Northern Copperhead ..........253, (275)

Northern Fence Lizard ..........206, (269)

Northern Ring-necked Snake 215, (270)

Northern Water Snake

234

Opheodrys aestivus ........ 5, 12, 14, 15, 20 , 45, (46), 176, 195, 217, 220, (270) Opheodrys vernalis .........5, 9, 15, 21, 47, (48), 176, 201, 203, 218, 241, (271) Opheodrys vernalis blanchardi $219,220,(271)$

Opheodrys vernalis vernalis 219, 241, (271)

Ophisaurus ventralis 7,204

Painted Turtle $22,123,126,131,139,144$, 145, (147), 153,167, 190, 262, (278)

Painted Turtle, Eastern …...-.........146, 262

Phrynosoma cornutum …...................... 6

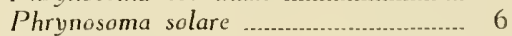

Physiography of Ohio -......... 9, (10), 203

Pilot Black Snake …..20, 53, 55, (57), $62,63,111,178,179,224,(272)$

Pine Lizard .............. 22

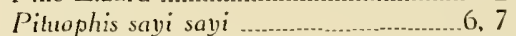

Plethodon cinereus _._._............................

Potamophis striatulus _..__..___._. 243

Prairie Carter Snake --.200, 246, (275)

Prairie King Snake 7
16

Presentation of Species ............... 16

Previous State Reports _..._......... 4

Pseudacris brachyphona _________._._. 203

Pseudacris nigrila triseriata ..._-_-__-..-107

Pseudemys elegans

Pseudemys scripla 9. 263

Pseude mys scripla elegans .......263, (278)

Pseudemys scripta gaigeae ..._-_..-...-263

Psendemys scripla troostii $6,9,12,15,22,151,(152), 191,263$

Pseudemys troostii ......................... 9

Puff Adder _..__ 41

Python molurus biviltatus ................... 6

Queen Snake $20,65,76,77,(78), 181,231,(273)$

Racers 178, (271)

Rana catesbeiana ...................-............. 86

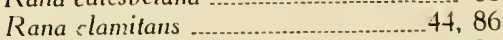

Raila pipiens $44,73,86$

Rana sylvatica 102

Rat Snake 20,21

Rattlesnake, Band zd 
Rattlcsnake, Timber $21,59,116,(118), 186,255,(276)$

Rattlesnakes $65,161,162,170$

Red-backed Salamander

Red-bellied Snake ....40, 92, 241, (27t)

Red-bellied Water Snake $20,21,31,70,(72), 181,229,(273)$

Red Belly

Red Milk Snake ………………... 7

Reptilia

Ribbon Snake 20, 73, 99, (100), 184, 249, (275)

Ring-necked Snake $21,25,37,(38), 94,175,215,(270)$

Ring-necked Snake, Ainy's

Sauria 5,19

Scale Counts $16,17,202,203$

Scarlet Snake

Sceloporus undulatus ......5, 12, 13, 14, 15, $16,19,22,(23), 174,194,195,205$ Sccloporus undulatus huacinthus

Scincella 203. 206. (269)

Scincidae 208

Scincus lateralis 5,19

Scincus quinquelinealus

Scorpion

Scutellation of Reptiles 28,32

Serpentes 172, 173

Sistrurus catenatus catenatus 5. 19

$6,12,15,21,112$ (114), 185, 186, 194, 196, 254, (276)

Sistrurus cotenatus tergeminus … ...........254

Six-lined Lizard

Skink, Blue-tailed

$25,28,(29), 34.76,174,209,(269)$

Skink, Brown-backed $19,26,(27), 174,207,(269)$

Skink, Large-headed ...................... 19. $25,30,32,(33), 111,175,211,(269)$

Skinks 19

Smcoth Green Snake

$9,21,47,(48), 176,218,219,(271)$

Snapping Turtle $22,123,124,(125), 131$ $135,139,14,160,187,258,(276)$ Soft-shelled Turt'e, Brown ............ 21, $149,154,(155), 160,192,263,(278)$ Soft-shelled Turtle, Spiny …......21, $14+1$. 156, 157, (158), 19?, 193, 264, (278) Soft-shelled Turtl-s Spiny Soft-shelled Turtle …...........21, 144, $156,157,(158), 192,193,264,(278)$ Spotted Turtle 22 129, (129), 139, 187, 189, 258, (277) Spreadhead Squamata 5. 19
Sternotherus odoratus .................. 6, 15, $22,120,(121), 187,256,261,(276)$ Storeria 8,20 Storeria detavi $\quad 5,15$, 20, 88, (90), 183, 201, 210,237, 255 Storeria dekayi dekavi $\mathrm{X}$ wrightorum 238, (274)

Storeria deleayi texana .....................2238

Storeria dekavi mrightorum ...............238

Storcria occipito-maculata _.......... 5, 12,

$13,15,20,92,(93), 183,241,(274)$

Storeria occipitomaculata obscura 241, 242

Storeria occipitomaculata occipito-

macilata $210,241,(274)$

Storer's Srake $20,37,92,(93), 183,241,(274)$

Striped Water Snake .................... 77

Suggestions for Col'ecting _.................. 170

Supplementary References .................265

Swamp Rattler …............................. 112

Swamp Tree-Froz …………............. 107

Swift

$19,22,(23), 30,31,34,69,111,174$

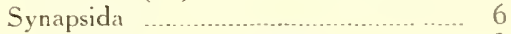

Systematic List of Reptiles .................. 5

Terrapene carolina ...6, 11, 15, 22, 136. (137), 188, 189, 194, 195, 260, (277)

Terrapene carolina bauri …................260

Terrapene carolina carolina ..260, (277)

Terrapene carolina triunguis ..............260

Testudinata ....................................... 19

Testudinidae …................................... 6

Thamnophis brachystoma ……… 245

Thamnophis butleri .......... 5, 13. 15. $20,30,96,(97), 184,245,247,(274)$

Thamnophis radix havdenii ..............247

Thamnophis radix radix $200,222,245,246,251,(275)$

Thamnophis sauritus sauritus $5,15,20,30,99,(100), 184,194$, $210,240,241,245,247,249,(275)$

Thamnophis sirtalis sirtalis

$5,15,20,30,102$, $(104), 182,196,237,249,250,(275)$

Till Plains Region $(10), 11,15,203,(279)$

Timber Rattlesnake ….......21, 59, 116, (118), 169, 170, 186, 210, 255, (276) Timber Snake ...................................6 60 Trionychidae …….................................. 6 Tropidoclonion lineatum ………..... 7, 8 Two-lined Salamander …....................... 26

Unglaciated Allegheny Plateau (10), 14, 15, (279)

Use of Names

Virginia valeriae valeriac .................. 5. 12. $14,15,20,21,94,(95), 183,243$ 
Water Moccasin 85,236

Water Snake, Banded

Water Snake, Common $20,65,73,76,80,81,(82), 87$ $101,102,106,111,182,234,(273)$

Water Snake, Diamond-backed

Water Snake, Green

Water Snake, Island $21,(82), 86,182,237,(273)$
Water Snake, Kirtland's

$20,74,(75), 91,180,230,(273)$

Water Snake, Red-bellied $20,21,31,70,(72), 181,229$, (273)

Western Grass Snake ..............220, (271)

Wood Frog 102

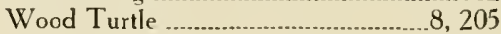

Worm Snake 21 ,

34, (36), 69, 94, 96, 176, 213, (270) 





